\title{
The petrogenesis of mid-Cretaceous continental intraplate volcanism in Marlborough, New Zealand, during the break-up of Gondwana
}

Alexander Joseph McCoy-West

A thesis submitted in partial fulfilment of the requirements for the degree of Masters of Science with Honours in Geology

School of Geography, Environment and Earth Sciences,

Victoria University of Wellington

2009 


\section{FRONTISPIECE}

The pessimist sees difficulty in every opportunity. The optimist sees the opportunity in every difficulty.

Winston Churchill

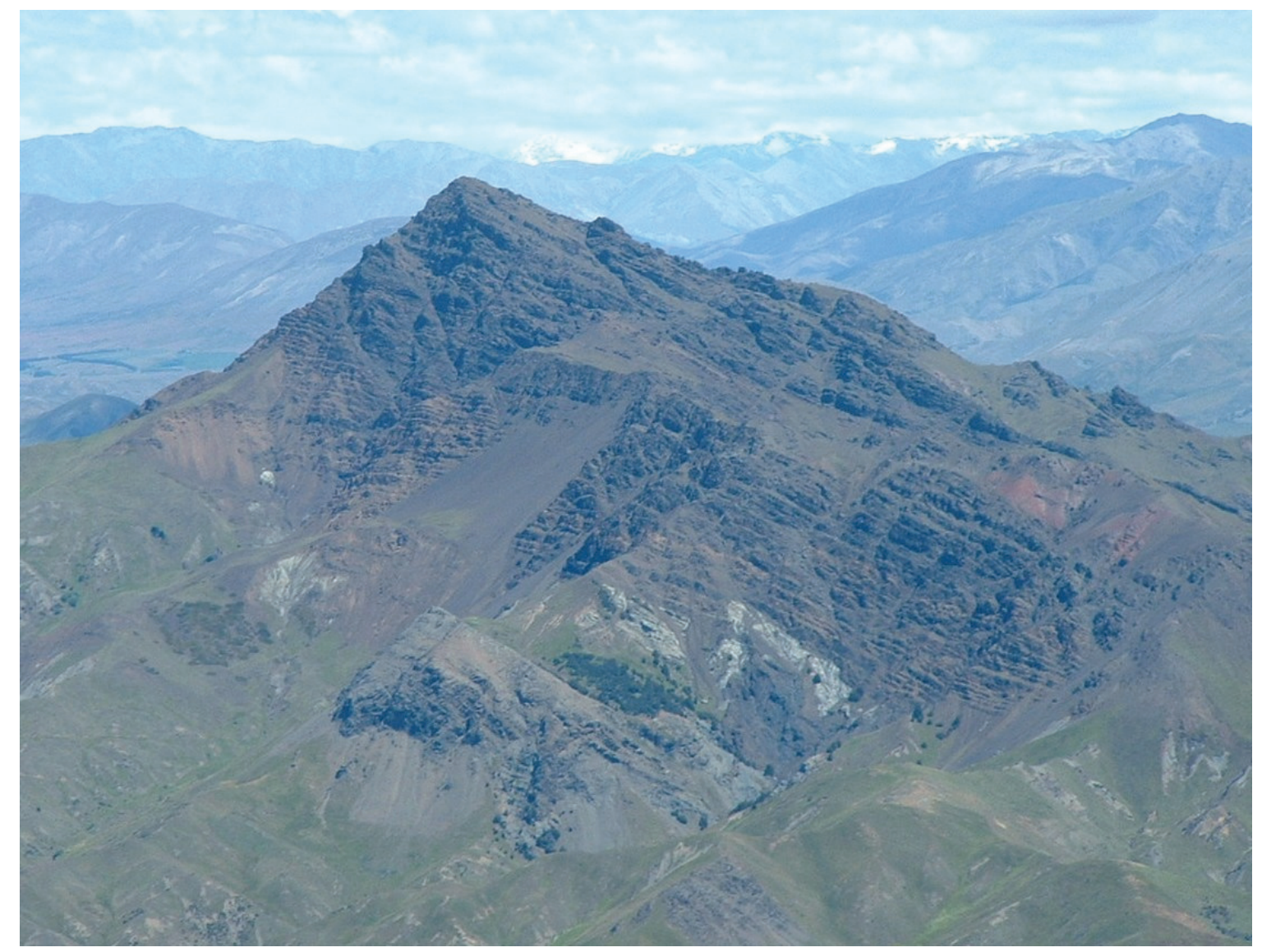

Plate 1: The summit of Mount Lookout (1814 m) comprises a westward dipping sequence of over $300 \mathrm{~m}$ of terrestrial lava flows. 


\section{ABSTRACT}

The Lookout Volcanics are the remnants of an extensive sheet of mid-Cretaceous (ca. $96 \mathrm{Ma}$ ) continental intraplate volcanic rocks erupted just prior to the rifting of New Zealand from Gondwana. Preserved in a fault angle depression bounded by the Awatere Fault located in Marlborough, South Island, New Zealand, the volcanic rocks cover an area of ca. $50 \mathrm{~km}^{2}$ with exposed thicknesses up to $1000 \mathrm{~m}$. On the basis of stratigraphic evidence the dominantly terrestrial lavas flows are inferred to have erupted from dykes of a coeval radial dyke swarm. A detailed sampling of the lava flows of the Lookout Volcanics has been undertaken with a ca. $700 \mathrm{~m}$ composite stratigraphic section being constructed, largely based on a continuous sequence of lava flows outcropping in Middlehurst Stream. New $\mathrm{Rb}-\mathrm{Sr}$ age constraints for the Lookout Volcanics $(97.6 \pm 3.4 \mathrm{Ma})$ and Blue Mountain Igneous Complex $(97.1 \pm 0.7$ $\mathrm{Ma})$ are consistent with previous radiometric dates of plutonic complexes in the Central Marlborough Igneous Complex, and suggest a rapid accumulation of volcanic material from ca. 98-96 Ma during the initial extension of proto-New Zealand.

The predominantly mafic and alkaline samples include basalt, picrobasalt, basanite, trachybasalt and basaltic trachyandesite rock types. No samples represent primary magmas with all samples having undergone fractionation (or accumulation) of olivine + clinopyroxene \pm plagioclase $\pm \mathrm{Fe}$-Ti oxides. Initial Sr-Nd-Hf-Pb isotopic variations $\left({ }^{87} \mathrm{Sr} /{ }^{86} \mathrm{Sr}=0.7030-0.7039 ;{ }^{143} \mathrm{Nd} /{ }^{144} \mathrm{Nd}=0.51272-0.51264 ;{ }^{176} \mathrm{Hf} /{ }^{177} \mathrm{Hf}=\right.$ $\left.0.28283-0.28278 ;{ }^{206} \mathrm{~Pb} /{ }^{204} \mathrm{~Pb}=20.32-18.82\right)$ reflect mixing between melts of a HIMUlike mantle component with up to $25-30 \%$ of an Early Cretaceous upper crustal component.

Oxygen isotope ratios determined by laser fluorination analysis from 6 lava flows yielded $\delta^{18} \mathrm{O}=4.7-5.0 \%$ or olivine, $4.8-5.4 \%$ in clinopyroxene cores, $3.9-5.5 \%$ o in clinopyroxene rims. Average olivine (4.8\%o) and clinopyroxene core $(5.1 \%$ o) values are $0.4-0.5 \%$ o lower than those of average mantle peridotite but comparable to those of HIMU OIB, and are consistent with New Zealand intraplate magmas being generated by a low $\delta^{18} \mathrm{O}$ mantle. However, oxygen isotopic disequilibrium between clinopyroxene cores and rims $\left(\Delta^{18} \mathrm{O}=-1.4\right.$ to +0.3$)$ records the overprinting of this signature by crustal processes. Negative disequilibrium between clinopyroxene rims and cores in primitive samples suggests these phenocrysts grew in a shallow crustal magma chamber with an active meteoric water system. The effects of crustal assimilation can also be observed with clinopyroxene phenocrysts from the most evolved sample exhibiting coupled elevated $\delta^{18} \mathrm{O}$ and ${ }^{87} \mathrm{Sr} /{ }^{86} \mathrm{Sr}$.

Variations in incompatible trace element ratios are consistent with the Lookout Volcanics being the small degree (2-5\%) partial melts of an amphibole-bearing garnet pyroxenite. Furthermore, the elevated $\mathrm{NiO}$ contents of olivine phenocrysts are consistent with melting of a pyroxenitic mantle source. The presence of residual amphibole constrains melting to the hydrous subcontinental lithospheric mantle. The Lookout Volcanics and coeval plutonic complexes are the oldest occurrences of HIMU magmatism in Zealandia. This source was generated by small degree silicate melts from recycled oceanic lithosphere that metasomatised the base of the subcontinental lithospheric mantle beneath East Gondwana over 200 Ma ago. 


\section{TABLE OF CONTENTS}

Title Page ..........................................................

Frontispiece .........................................................

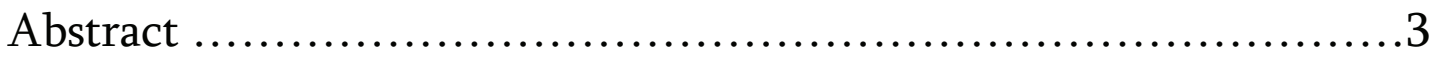

Table of Contents ............................................. 4

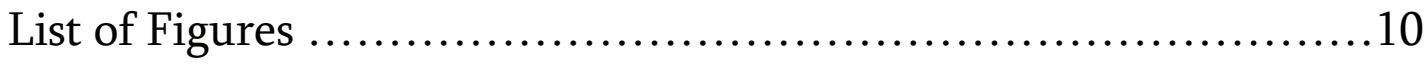

List of Tables .....................................................13

List of Plates ...................................................... 16

List of Acronyms ................................................ 17

Acknowledgements ...............................................18

CHAPTER 1: Introduction ...................................... 19

CHAPTER 2: Field Geology ...................................57

CHAPTER 3: Petrology \& Mineral Chemistry .......................84

CHAPTER 4: Petrogenesis of the Lookout Volcanics..................140

CHAPTER 5: Geochronology.................................... 197

CHAPTER 6: Synthesis \& Conclusions ...........................207

References .................................................217

APPENDIX 1: Analytical Techniques ..............................234

APPENDIX 2: Sample Information ............................272

APPENDIX 3: EPMA Data.....................................284

APPENDIX 4: Comparative Olivine Data ........................312

APPENDIX 5: Chemical \& Isotopic Data ..........................327 


\section{CHAPTER 1: INTRODUCTION}

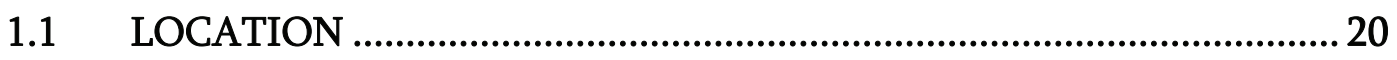

1.2 PHYSIOGRAPHY AND CLIMATE ......................................................... 20

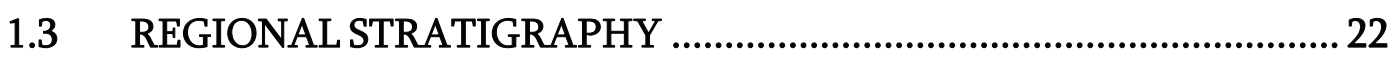

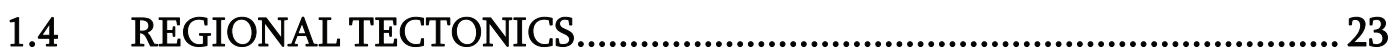

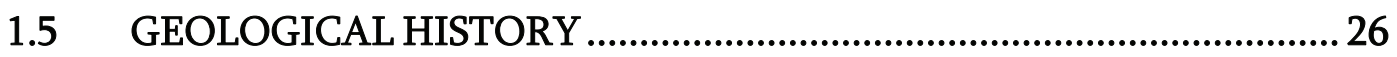

1.5.1 Mid-Cretaceous extension of proto-New Zealand ...................................... 26

1.5.2 Mechanisms for New Zealand-Gondwana rifting ..................................... 27

1.5.3 Mid-Cretaceous regression and volcanism ............................................. 35

1.5.4 Post Ngaterian transgressive marine sedimentation ................................ 35

1.5.5 Miocene-Recent uplift of the Kaikoura Ranges......................................... 36

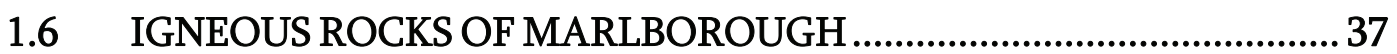

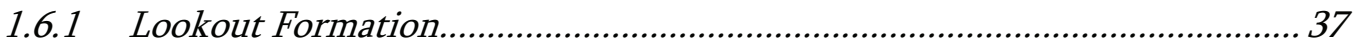

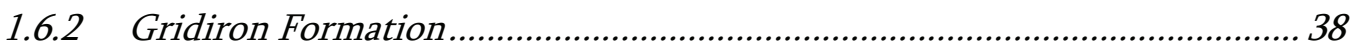

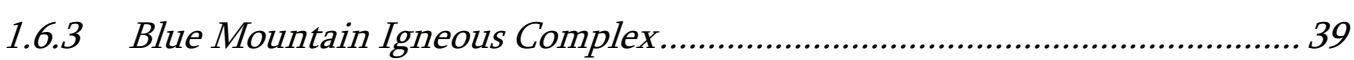

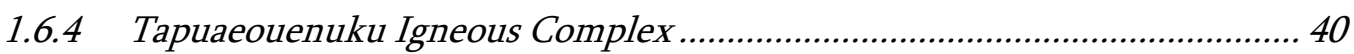

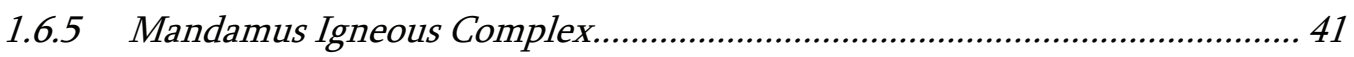

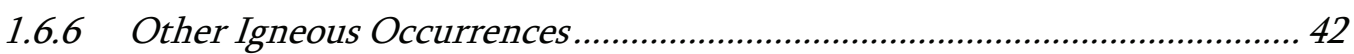

1.7 INTRAPLATE VOLCANISM IN NEW ZEALAND .................................... 43

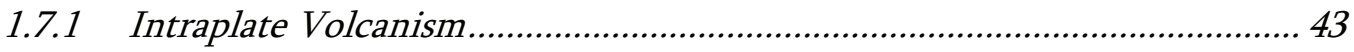

1.7.2 Central Marlborough Igneous Province .................................................... 46

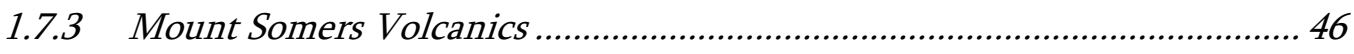

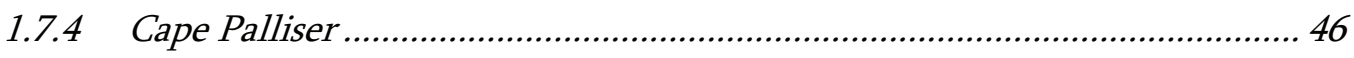

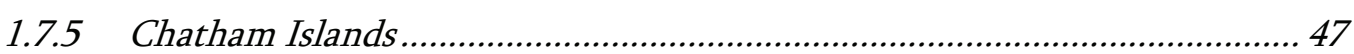

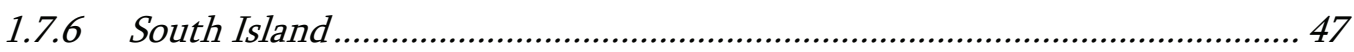

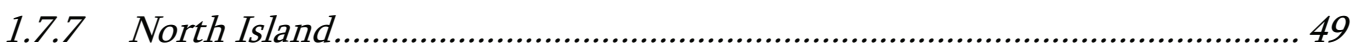

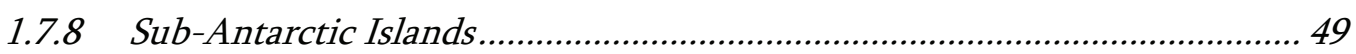

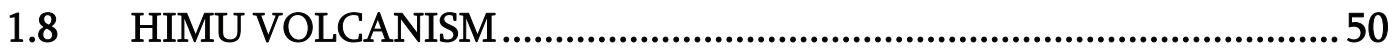

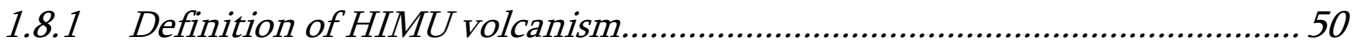

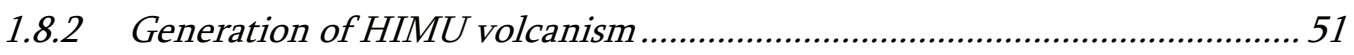

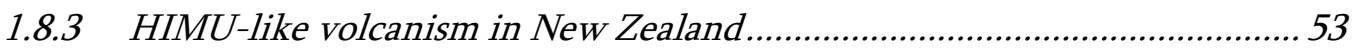

1.9 OBJECTIVES AND OUTLINE OF THIS STUDY ……………………...... 54

CHAPTER 2: FIELD GEOLOGY \& SAMPLING

2.1 INTRODUCTION..................................................................... 58

$2.2 \quad$ FIELD METHODS ................................................................. 58 


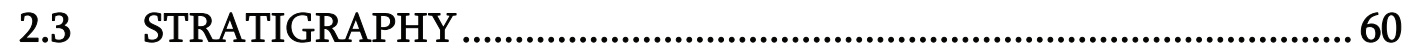

2.3.1 Pahau Terrane (Torlesse Supergroup).............................................................. 60

2.3.2 Gladstone Formation............................................................................................. 60

2.3.3 Winterton Formation................................................................................ 60

2.3.4 Lookout Volcanics ............................................................................................. 61

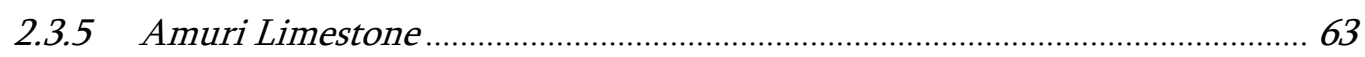

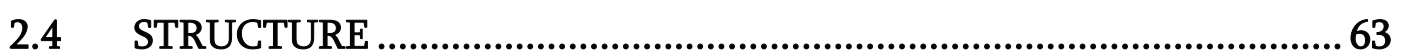

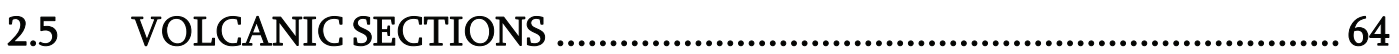

2.5.1 Section A (Awatere River) …………………………………………………... 64

2.5.2 Section B (Middlehurst)................................................................................... 66

2.5.3 Section $C$ (Winterton-Awatere) …………………………………………...... 66

2.5.4 Section D (Dykes) ........................................................................................ 72

2.5.5 Section E (Faulted) .............................................................................. 72

2.5.6 Section F (Middlehurst Stream) ........................................................................ 75

2.5.7 Section G (Lookout) ............................................................................... 77

2.5.8 Section H (Castle River) .............................................................................

2.6 COMPOSITE VOLCANIC STRATIGRAPHY ............................................. 80

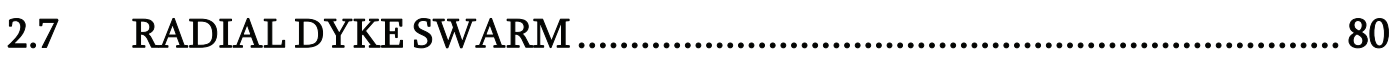

\section{CHAPTER 3: PETROGRAPHY \& MINERAL CHEMISTRY}

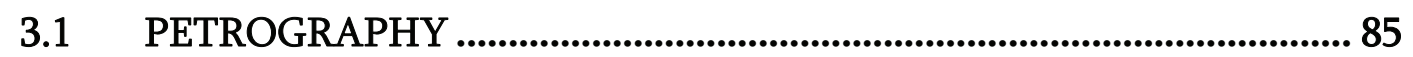

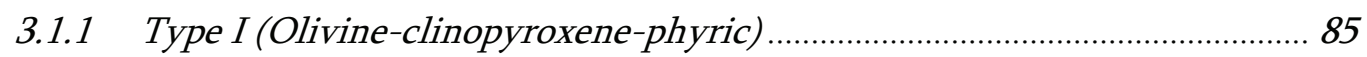

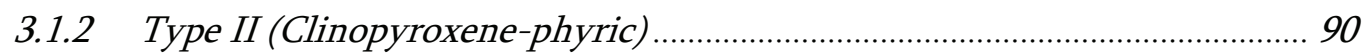

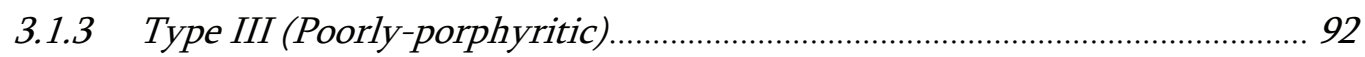

3.1.4 Type IV (Sparsely porphyritic or aphyric) (................................................... 94

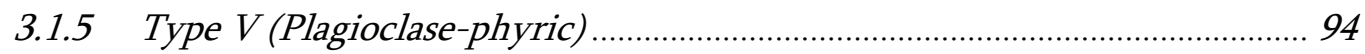

3.1.6 Type VI (Honeycombed plagioclase)........................................................... 96

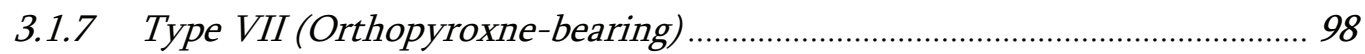

3.2 MINERAL CHEMISTRY ………………………............................... 99

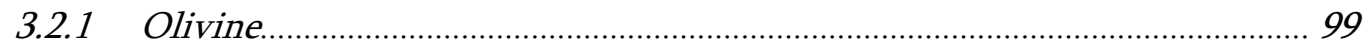

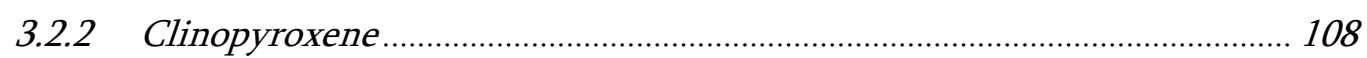

3.2.3 Orthopyroxene

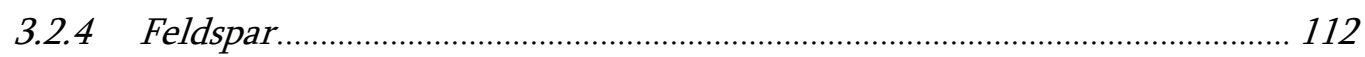

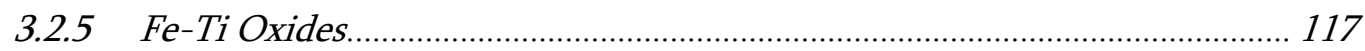

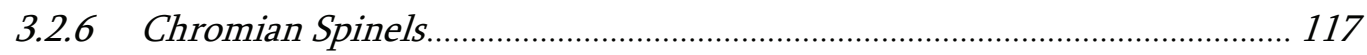


3.3 IMPLICATIONS OF MINERAL CHEMISTRY DATA ......................... 121

3.3.1 Magmatic evolution as recorded by phenocrysts ....................................... 121

3.3.2 Pyroxenitic contributions to the mantle source............................................ 124

3.3.3 Ca in olivine strongly controlled by melt composition................................. 131

3.3.4 Chromian spinel as a petrogenetic indicator................................................ 133

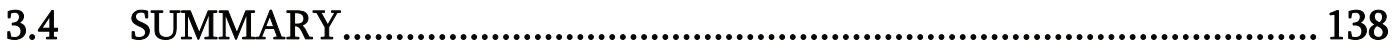

\section{CHAPTER 4: PETROGENESIS OF THE LOOKOUT VOLCANICS}

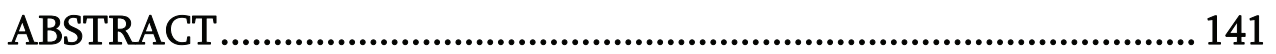

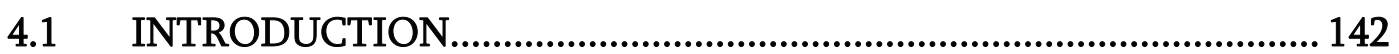

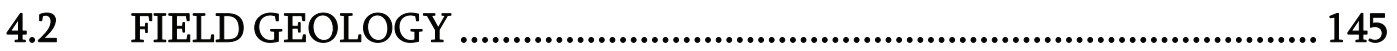

$4.3 \quad$ ANALYTICAL TECHNIQUES.......................................................... 147

4.4 PETROGRAPHY \& MINERAL CHEMISTRY ....................................... 151

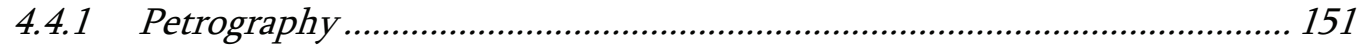

4.4.2 Mineral chemistry ............................................................................ 153

4.5 WHOLE ROCK MAJOR \& TRACE ELEMENT CHEMISTRY ............... 159

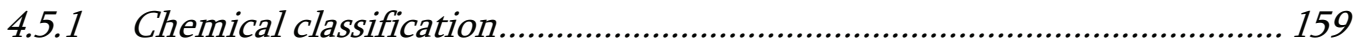

4.5.2 Major element chemistry .................................................................. 159

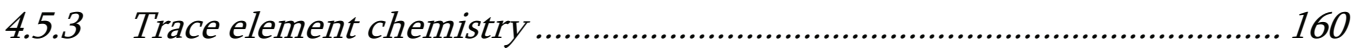

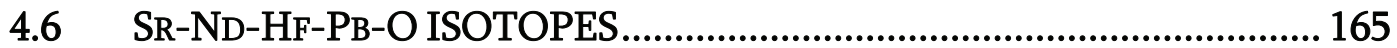

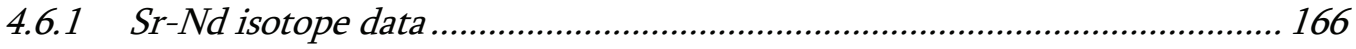

4.6.2 Hf isotope data.................................................................................... 166

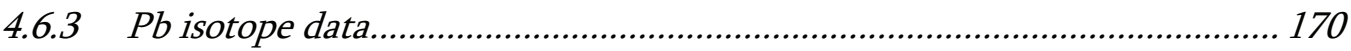

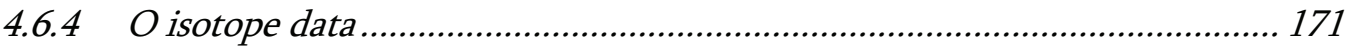

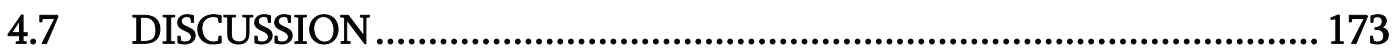

4.7.1 Crustal magmatic processes .................................................................... 173

4.7.2 Mantle melting processes and the nature of the mantle source of the

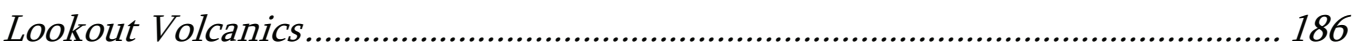

4.7.3 Implications for stable isotope studies of volcanic rocks ........................... 194

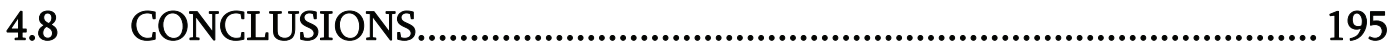

CHAPTER 5: GEOCHRONOLOGY

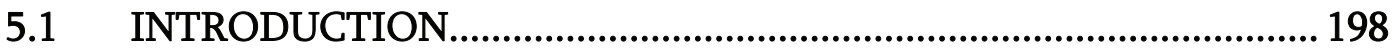

5.2 STRATIGRAPHIC RELATIONSHIPS ................................................... 198 
5.3 ERUPTION OF THE LOOKOUT VOLCANICS 199

5.3.1 Rb-Sr isochron ages 199

5.3.2 Interpretation of $\mathrm{Rb}$-Sr isochron ages......................................................... 199

5.3.3 Crystal-groundmass disequilibrium ............................................................ 201

5.3.4 Limitations of the dating results .................................................................. 203

5.4 BLUE MOUNTAIN IGNEOUS COMPLEX....................................... 203

5.5 GEOLOGICAL IMPLICATIONS ..................................................... 204

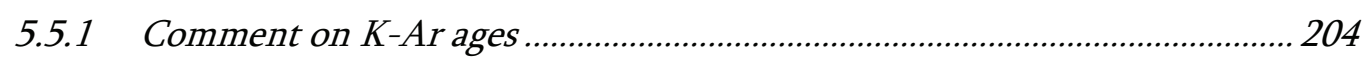

5.5.2 Volcanism in the mid-Cretaceous ............................................................ 205

\section{CHAPTER 6: SYNTHESIS \& CONCLUSIONS}

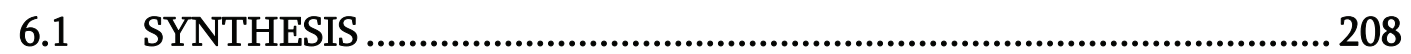

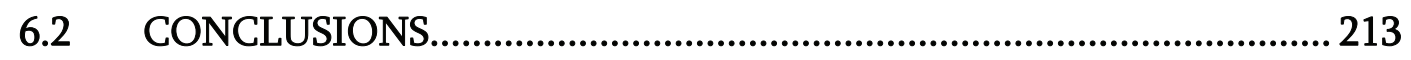

6.3 SUGGESTIONS FOR FUTURE WORK................................................... 215

REFERENCES..................................................217

\section{APPENDIX 1: ANALYTICAL TECHNIQUES}

A1.1 ROCK CRUSHING \& MINERAL SEPARATION ................................ 236

A1.1.1 Rock crushing .............................................................................................. 236

A1.1.2 Mineral separation ........................................................................................ 236

A1.2 WHOLE ROCK MAJOR ELEMENT ANALYSES .............................. 237

A1.2.1 X-ray fluorescence spectrometry ................................................................ 237

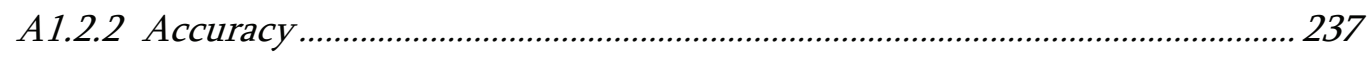

A1.3 WHOLE ROCK TRACE ELEMENT ANALYSES ................................ 238

A1.3.1 Sample preparation............................................................................. 238

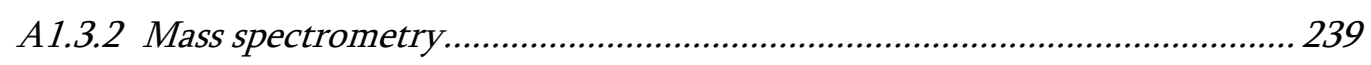

A1.3.3 Data reduction and concentration calculations........................................ 241

A1.3.4 Precision and accuracy of trace element data.......................................... 242

A1.4 MINERAL MAJOR ELEMENT CHEMISTRY .................................... 247

A1.4.1 Introduction ............................................................................................ 247

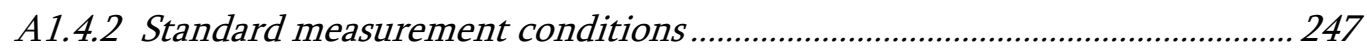

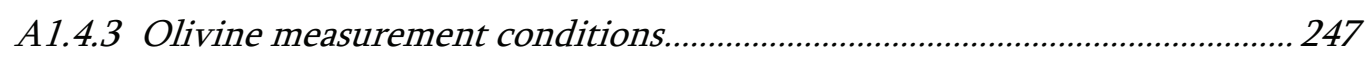

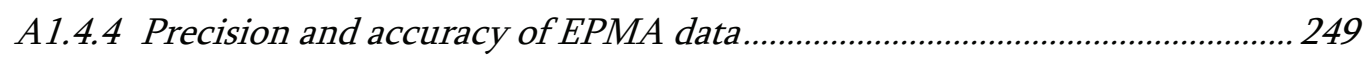


A1.5 LA-ICP-MS TRACE ELEMENT ANALYSES ..................................... 250

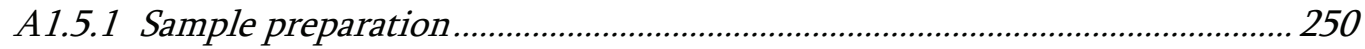

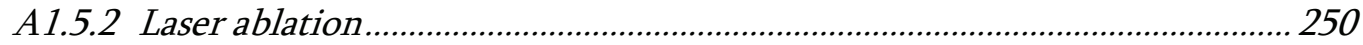

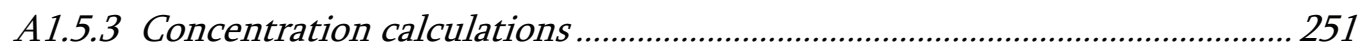

A1.5.4 Precision and accuracy of LA-ICP-MS ...................................................... 252

A1.6 SR-ND-HF-PB ISOTOPES BY MC-ICP-MS ........................................ 253

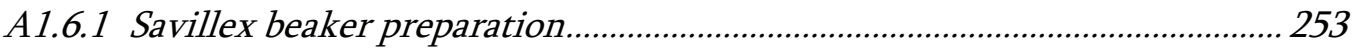

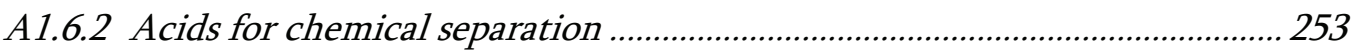

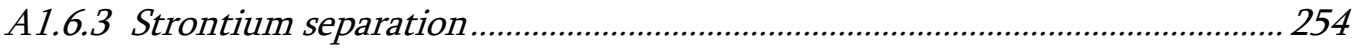

A1.6.4 Hafnium and neodymium separation ......................................................... 256

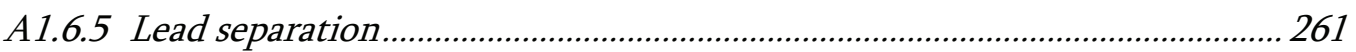

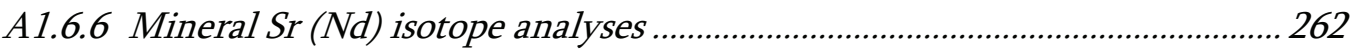

A1.6.7 Mass spectrometry and isotopic analysis................................................... 263

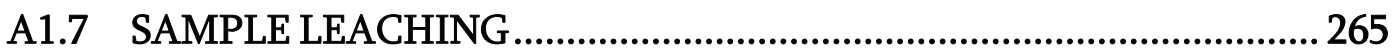

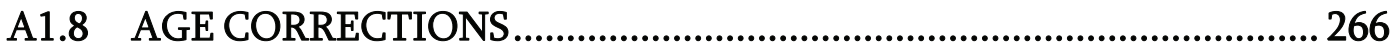

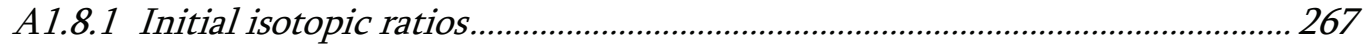

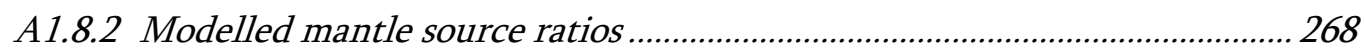

A1.9 OXYGEN ISOTOPE ANALYSES ................................................... 271

APPENDIX 2: SAMPLE INFORMATION..................................272

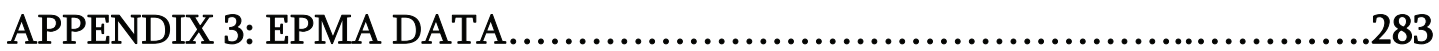

APPENDIX 4: COMPARATIVE OLIVINE DATA...........................310

APPENDIX 5: CHEMICAL \& ISOTOPIC DATA...............................326 


\section{LIST OF FIGURES}

\section{CHAPTER 1: INTRODUCTION}

1.1: Simplified geological map of the Inland Kaikoura Region

1.2: Simplified tectonic map of northeastern South Island, New Zealand, showing the major faults that comprise the Marlborough Fault System

1.3: Paleo-reconstructions of eastern Gondwana in the Early Cretaceous, mid-Cretaceous and Late Cretaceous showing the postulated tectonic processes that led to the separation of the New Zealand microcontinent from Marie Byrd Land, West Antarctica.....

1.4: Subducted slab capture model applied to the margin of eastern Gondwana in the mid-Cretaceous

1.5: Map illustrating the distribution of Cretaceous to Recent intraplate volcanism in

New Zealand

1.6: Isotope diagrams showing the variability of selected ocean island and mid ocean ridge basalt 'mantle components' in isotopic space

\section{CHAPTER 2: FIELD GEOLOGY}

2.1: Geological map of the Mount Lookout area ................................................................ 59

2.2: Panoramic photograph of the Lookout Volcanics......................................................... 62

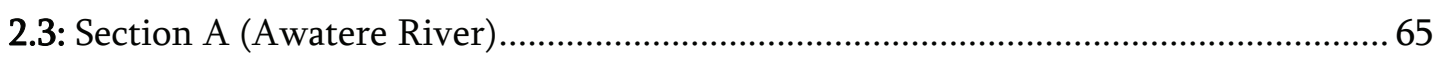

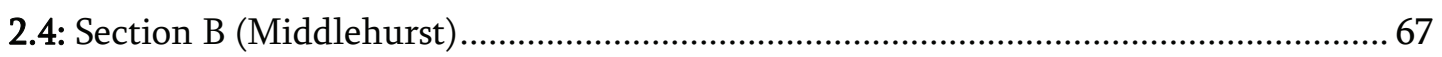

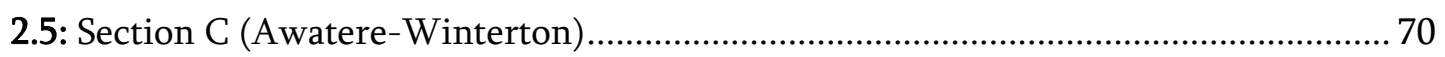

2.6: Sedimentary rocks and lava flows of Section C........................................................... 71

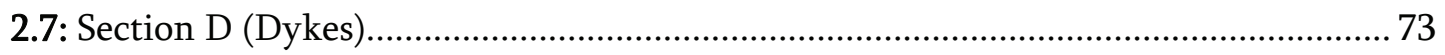

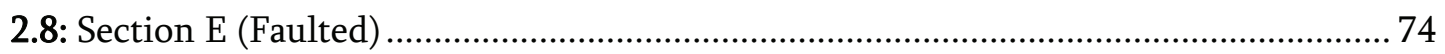

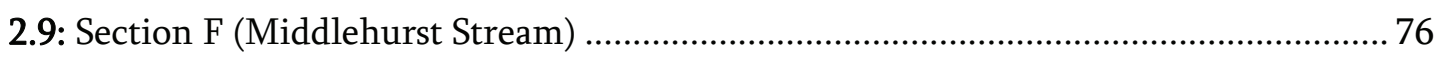

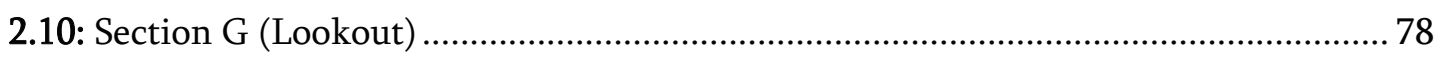

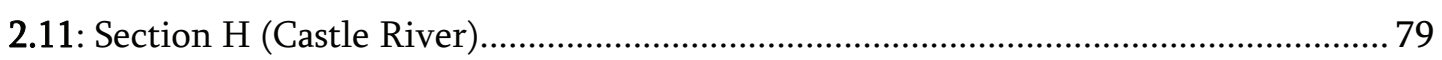

2.12: Composite volcanic stratigraphy of the Lookout Volcanics ...................................... 81

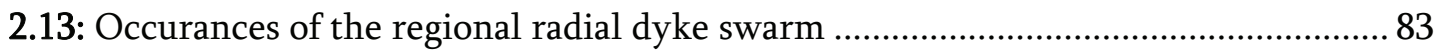

\section{CHAPTER 3: PETROGRAPHY \& MINERAL CHEMISTRY}

3.1: Thin sections of highly porphyritic olivine-clinopyroxene phyric Type I rocks ...... 87

3.2: Backscattered electron images of olivine and clinopyroxene phenocrysts ................. 88 
3.3: Backscattered electron images comparing the groundmasses of different rock types from the Lookout Volcanics

3.4: Thin sections of moderately porphyritic clinopyroxene \pm olivine \pm plagioclase-phyric Type II rocks

3.5: Thin sections of poorly porphyritic clinopyroxene \pm plagioclase-phyric Type III rocks

3.6: Thin sections of aphyric to sparsely porphyritic clinopyroxene + plagioclase $+\mathrm{Fe}-\mathrm{Ti}$ oxide bearing Type IV rocks .95

3.7: Thin sections of type examples of Type V-VII samples 97

3.8: Backscattered electron images of honeycombed plagioclase phenocrysts and orthopyroxne clusters 98

3.9: Variation of olivine phenocrysts in the Lookout Volcanics 100

3.10: Minor element variabilty of olivine phenocrysts from basalts erupted in various tectonic settings

3.11: Comparison of the $\mathrm{NiO}$ contents of olivine phenocrysts from various mafic eruptives from Yemen

3.12: Comparison of olivine phenocrysts from the Lookout Volcanics with those from Quaternary intraplate eruptives from Yemen ............................................................. 108

3.13: Clinopyroxene types in the Lookout Volcanics ....................................................... 109

3.14: Major element variation of clinopyroxenes from the Lookout Volcanics ............. 110

3.15: Photograph of strongly zoned clinopyroxene from AMB-39 ............................ 113

3.16: Chemical variability of zoned clinopyroxene phenocrysts in the Lookout Volcanics

3.17: Anorthite-albite-orthoclase ternary diagram 115

3.18: Fe-Ti oxide ternary diagrams 118

3.19: Schematic illustration of the secondary pyroxenite source model for the generation mantle plume basalts with elevated $\mathrm{Ni}$ contents 126

3.20: Chromian spinels within the Lookout Volcanics 137

\section{CHAPTER 4: PETROGENESIS OF THE LOOKOUT VOLCANICS}

4.1: Regional geological map and tectonic history of the Lookout Volcanics ................. 143

4.2: Simplified geological map of the Lookout Volcanics.................................................... 147

4.3: Petrographic photographs of the rocks of the Lookout Volcanics ........................... 153

4.4: $\mathrm{NiO}$ and $\mathrm{CaO}$ versus forsterite content of olivine phenocrysts from a range of tectonic settings and the Lookout Volcanics 
4.5: Major and trace element variability of clinopyroxene phenocrysts within the Lookout Volcanics

4.6: Total alkalis silica classification diagram showing the rock types of the Lookout

Volcanics

4.7: Plots of selected major elements versus $\mathrm{MgO}$ content............................................... 163

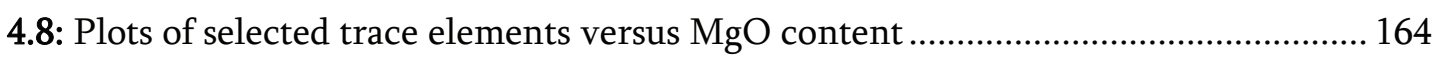

4.9: Rare earth element chondrite-normalised and primitive-mantle-normalised multielement plots...

4.10: $\mathrm{Sr}-\mathrm{Nd}-\mathrm{Hf}-\mathrm{Pb}$ isotopic plots comparing mantle end-member compositions with intraplate volcanic rocks from New Zealand

4.11: Phenocryst $\delta^{18} \mathrm{O}$ values plotted against whole rock and clinopyroxene $\mathrm{Sr}$ isotopic composition

4.12: Graphs showing correlations between trace element and isotope ratios that are suggestive of crustal contributions

4.13: Bulk crustal assimilation models explaining the isotopic variability of the Lookout

Volcanics in $\mathrm{Sr}-\mathrm{Nd}-\mathrm{Pb}$ isotopic space

4.14: Partial melting curves assuming the non-modal fractional melting of a range of mantle source compositions

\section{CHAPTER 5: GEOCHRONOLOGY}

5.1: Partial composite volcanic stratigraphy of the Lookout Volcanics with new $\mathrm{Rb}-\mathrm{Sr}$ ages superimposed

\section{APPENDIX 1: ANALYTICAL TECHNIQUES}

A1.1: Accuracy of ICP-MS whole rock trace element data .............................................. 246

A1.2: Comparison of olivine EPMA data under variable analytical conditions .............. 248

A1.3: Elution curves for a single pass through Sr-specific resin........................................ 255

A1.4: Flow chart showing the method for Hf and rare earth element separation .......... 257

A1.5: Ln-spec column elution procedure ....................................................................... 259

A1.6: Comparison of the REE elution curves for used and new Ln-spec columns .......... 260

\section{APPENDIX 2: SAMPLE INFORMATION}

A2.1: EPMA thin section catalogue 278 


\section{LIST OF TABLES}

\section{CHAPTER 1: INTRODUCTION}

1.1: Ages of mid-Cretaceous igneous rocks from southern New Zealand 44

1.2: Isotopic data for HIMU ocean islands and New Zealand intraplate volcanism 54

\section{CHAPTER 3: PETROGRAPHY \& MINERAL CHEMISTRY}

3.1: Summary of the petrographic variation observed within the Lookout Volcanics ......86

3.2: Representative analyses of olivine phenocrysts from the Lookout Volcanics..... 104

3.3: Representative analyses of olivine phenocrysts in basalts from a range of global tectonic settings. 105

3.4: Representative analyses of olivine phenocrysts from basaltic eruptives in Yemen . 106

3.5: Adjectival modifiers to be used for pyroxene mineral names 109

3.6: Representative analyses of clinopyroxene phenocrysts from the Lookout Volcanics

3.7: Analyses of orthopyroxene phenocrysts from the Lookout Volcanics. 114

3.8: Representative analyses of feldspars from the Lookout Volcanics. 116

3.9: Representative analyses of Fe-Ti oxide minerals in the Lookout Volcanics. 119

3.10: Representative analyses of chromian spinels from the Lookout Volcanics 120

3.11: Comparison of the Ni concentrations of partial melts generated through the melting of peridotitic or pyroxenitic mantle sources.

3.12: The proportion of pyroxenite in the mantle source of various magma types. 129

\section{CHAPTER 4: PETROGENESIS OF THE LOOKOUT VOLCANICS}

4.1: Precision and accuracy of ICP-MS trace element analyses 149

4.2: Representative LA-ICP-MS analyses of clinopyroxne phenocrysts ........................... 156

4.3: Representative major and trace element analyses of lava flows................................. 160

4.4: Whole rock Rb-Sr, Sm-Nd, Lu-Hf and Sr-Nd-Hf isotopic data.................................. 166

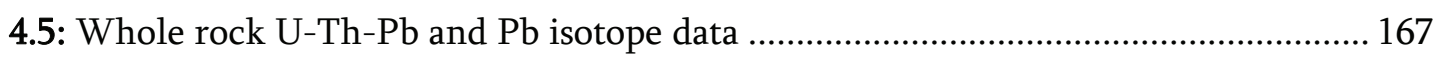

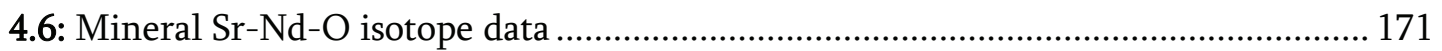




\section{CHAPTER 5: GEOCHRONOLOGY}

5.1: $\mathrm{Rb}-\mathrm{Sr}$ isotopic data used in the construction of isochrons......................................... 200

5.2: Calculated Rb-Sr ages for the Lookout Volcanics .................................................... 200

5.3: Calculated Rb-Sr age for the Blue Mountain Igneous Complex................................ 204

5.4: Age constraints on volcanism in the Central Marlborough Igneous Province.......... 204

\section{APPENDIX 1: ANALYTICAL TECHNIQUES}

A1.1: Accuracy of XRF major element data 237

A1.2: ICP-MS instrumental and analytical conditions .

A1.3: Preferred trace element concentrations of USGS rock standards.

A1.4: ICP-MS trace element data showing the reproducibility of repeat digestions of BHVO-2

A1.5: ICP-MS trace element data showing the reproducibility of repeat digestions of BCR-2

A1.6: External reproducibility of ICP-MS trace element ratios ..................................... 246

A1.7: EPMA precision and accuracy for international mineral and glass standards ....... 249

A1.8: LA-ICP-MS instrumental and analytical conditions.

A1 9: External reproducibility of international standards during MC-ICP-MS analyses .....

A1.10: ${ }^{87} \mathrm{Sr} /{ }^{86} \mathrm{Sr}$ isotopic ratios of variably acid leached samples. 266

A1.11: Parameters of the isotopic systems used in this study. 268

A1.12: Calculated age corrections for selected samples from the Lookout Volcanics..... 268

A1.13: Lookout Volcanics primitive average and calculated mantle source composition 269

A1.14: The isotopic compositions of reservoirs used for mantle source modelling 270

\section{APPENDIX 2: SAMPLE INFORMATION}

A2.1: Igneous samples of the Lookout Volcanics 273

A2.2: Sedimentary samples collected in close proximity to the Lookout Volcanics ...... 276

A2.3: Information on comparative samples analysed in this study. 


\section{APPENDIX 3: EPMA DATA}

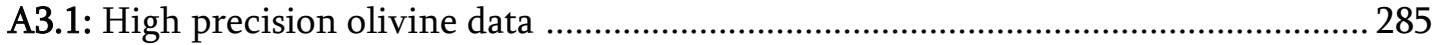

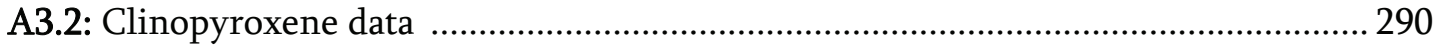

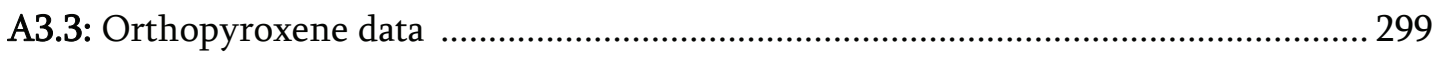

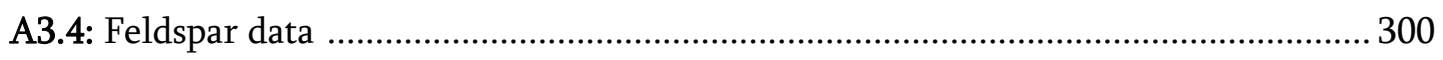

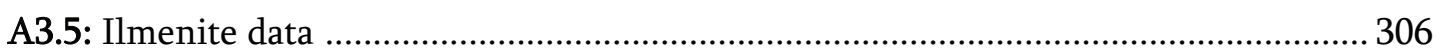

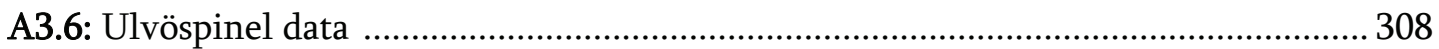

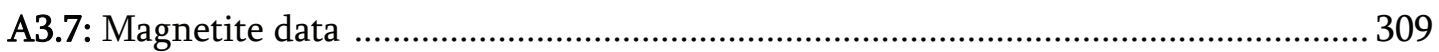

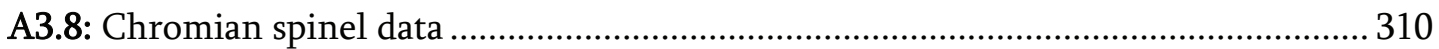

\section{APPENDIX 4: COMPARATIVE OLIVINE DATA}

A4.1: EPMA data for basaltic samples from Yemen.......................................................... 313

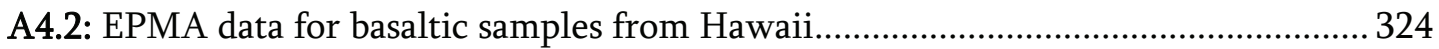

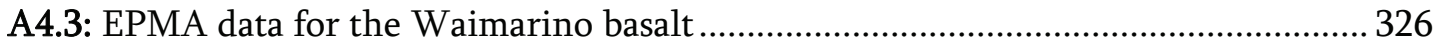

\section{APPENDIX 5: CHEMICAL \& ISOTOPIC DATA}

A5.1: X-ray fluorescence major element data (53 samples)................................................... 328

A5.2: Solution ICP-MS trace element data (35 samples) ...................................................... 330

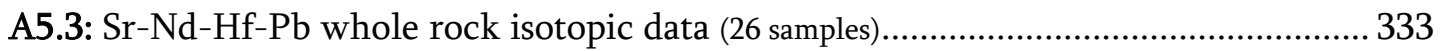

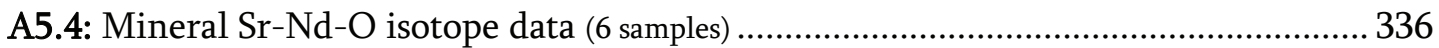

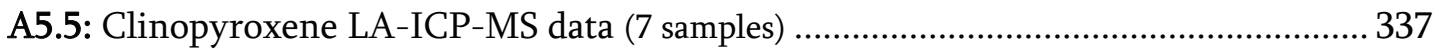




\section{LIST OF PLATES}

P1: The summit of Mount Lookout comprises a westward dipping sequence of over 300 m of terrestrial lava flows

P2: Nearing the summit of Mount Lookout with the lava flows of the Middlehurst section prominent in the background

P3: View looking to the northeast with the Awatere River meandering through outcrops of lava flows of the Lookout Formation. 57

P4: Back-scattered electron image of AMB-5 showing the fluid related zonation of calcite amygdule and the growth zonation of a clinopyroxene phenocryst in a coarse grained groundmass dominated by plagioclase.

P5: Thick basaltic lava flows form cliffs at the top of the Middlehurst Section with the peak of Mount Lookout in the distance

P6: Interbedded sandstone-siltstone of the shallow marine Winterton Formation

conformably overlain by basaltic lava flows on the eastern flank Mount Lookout 197

P7: Nearing the summit of Mount Tapaueouenuku with Mount Alarm and Mitre Peak in the background

P8: View looking to the north from the Old Middlehurst Hut at sunset

P9: Tribute to the sledge hammer: an explosive impact with a large calcite amygdule on the banks of Middlehurst Stream

P10: The descent into Trail Stream on the western side of the Red Hills via a large scree slope (ca. $350 \mathrm{~m})$

P11: The hazardous ridgeline of Mitre Peak rises above the clouds in the heart of the Inland Kaikoura Range

P12: Basement greywacke intensively intruded by dykes of the regional swarm in the headwaters of Totara Stream 


\section{LIST OF ACRONYMS}

BMIC: Blue Mountain Igneous Complex

CFB: $\quad$ continental flood basalt

CMIP: Central Marlborough Igneous Complex

EPMA: $\quad$ electron probe micro-analysis

GMC: $\quad$ Great Marlborough Conglomerate

HFSE: high field strength element e.g. Zr, Hf

HIMU: $\quad$ High $\mu$ i.e. ${ }^{206} \mathrm{~Pb} /{ }^{204} \mathrm{~Pb}>20.5$

HREE: heavy rare earth element e.g. Yb, Lu

ICP-MS: inductively coupled plasma mass spectrometry

IKR: $\quad$ Inland Kaikoura Range

LA-ICP-MS: laser ablation inductively coupled plasma mass spectrometry

LILE: large ion lithophile element e.g. Sr, Ba

LIP: $\quad$ large igneous province

LREE: $\quad$ light rare earth element e.g. La, Ce, $\mathrm{Pr}$

MBL: $\quad$ Marie Byrd Land

MC-ICP-MS: multicollector inductively coupled plasma mass spectrometry

MFS: $\quad$ Marlborough Fault System

MIC: $\quad$ Mandamus Igneous Complex

MICE: moderately incompatible element e.g. Lu, Y

MORB: $\quad$ mid ocean ridge basalt

MREE: middle rare earth element e.g. Eu, Gd

OIB: $\quad$ ocean island basalt

OSMA: olivine-spinel mantle array

REE: $\quad$ rare earth element i.e. La-Lu

SCLM: subcontinental lithospheric mantle

SSZ: $\quad$ Sisters Shear Zone

TIC: Tapuaeouenuku Igneous Complex

TPC: $\quad$ Tapuaeouenuku Plutonic Complex

TVZ: Taupo Volcanic Zone

VICE: very incompatible element e.g. $\mathrm{Ba}, \mathrm{Nb}, \mathrm{La}$

XRF: $\quad$ X-ray fluorescence spectrometry 


\section{ACKNOWLEDGEMENTS}

Joel Baker and Richard Wysoczanski are greatly thanked for their supervision of this project, always being available for discussions and creating a far superior scientist than existed two years ago. Joel is especially thanked for driving the broad scientific scope of this project, thus giving me the opportunity to experience a range of analytical techniques.

William and Susan MacDonald are thanked for use of the Old Middlehurst hut and giving us free reign over their property, without which this project would not have been possible.

The assistance of James Langdon is greatly appreciated for two impromptu weeks spent in the Awatere Valley helping collect over $200 \mathrm{~kg}$ of rocks, and his excellent photography skills.

The following people are thanked for their assistance during this project: Kevin Faure for undertaking oxygen isotope analyses and for useful discussions; John Patterson for assistance with electron probe analyses and slide photography; Stewart Bush for preparing thin sections; Tim Little for providing volcanic clasts from the Great Marlborough Conglomerate that were analysed in this study; Robert Grant and Laurence Ellis providing support during the second field season; Marc-Alban Millet for helping with setting up the $\mathrm{Pb}$ chemistry; Aidan Allan for helping with a range of quandaries and useful discourse.

The members of team lab (Kim, Martin, Monica, Marc-Alban, Julia, Rachael \& Wazza) who helped cut the monotony in the white room are thanked for assistance and entertainment. My office buddies (Aidan, Evie \& Matt) and the members of the geology crew (Hamish, Chris, Boots, Thor, Julene, Anette, John, Sarah, Jess, Kate \& many more...) are thanked for all the good times.

My parents Tony West and Susan McCoy are thanked for their tolerance, love, and financial support during the course of my studies. And lastly, Sophie Barton is thanked for her love and support, your quest for knowledge is inspirational. 


\section{CHAPTER 1: INTRODUCTION}

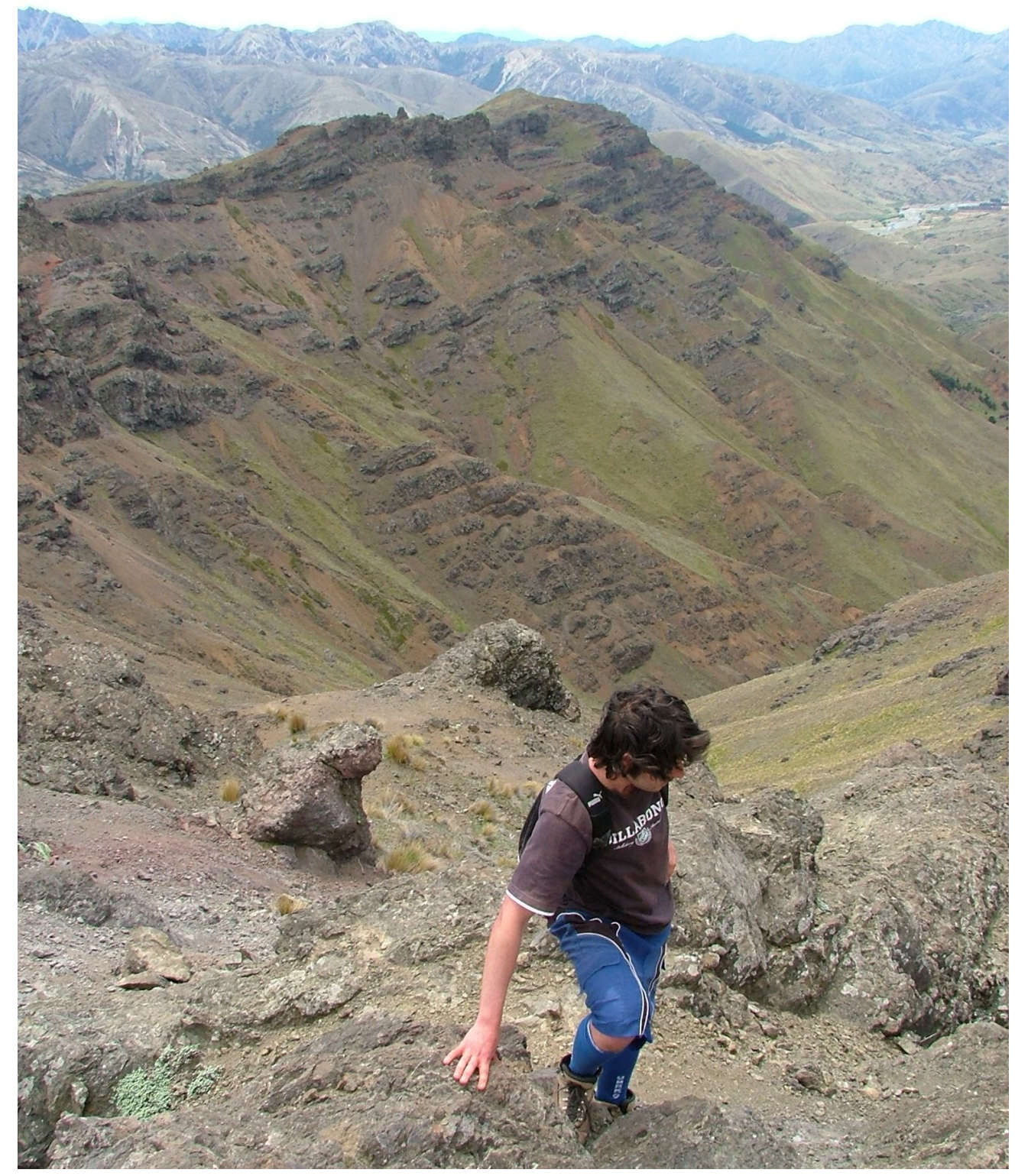

Plate 2: Nearing the summit of Mount Lookout with the lava flows of the Middlehurst section prominent in the background. 


\subsection{LOCATION}

The Lookout Formation is located in northeastern Marlborough at the northern end of South Island, New Zealand (Figure 1.1). The volcanic rocks are preserved in the fault angle depression of the Awatere Fault that is marked by the Awatere River Valley. The coeval Tapuaeouenuku Plutonic Complex (TPC) is uplifted by the Clarence Fault and outcrops among the highest peaks of the Inland Kaikoura Range (IKR: Mount Tapuaeouenuku, 2885 m). A regional dyke swarm outcrops continuously between the volcanic and plutonic rocks and has a regional extent of at least $300 \mathrm{~km}^{2}$, excluding possible occurrences in the Seaward Kaikoura Range and the southern North Island. The area of this study is restricted to Geological Map 13 of the Institute of Geological and Nuclear Sciences 1:250,000 QMap Series.

\subsection{PHYSIOGRAPHY AND CLIMATE}

The Lookout Volcanics form an elongate body preserved parallel to the Awatere Fault and outcrop at the floor of the Awatere Valley. The volcanic rocks outcrop on the land of the Camden, Middlehurst and Upcot sheep stations. However, the majority of the outcrop is confined to the Middlehurst Station. The study area is typical New Zealand high country farmland with steep hills covered in grasses. Outcrop occurs from an altitude of approximately $400 \mathrm{~m}$ to $1800 \mathrm{~m}$. Excellent exposure of the lava flows is found on the banks of the Awatere River, the cliffs above Middlehurst Stream, and above the regional bushline ( $>1500 \mathrm{~m}$ ). The IKR experiences extremes in climate. During winter, heavy snowfalls are common and snow will often settle in the valley. From mid-winter to late spring, snow generally covers the range above $1500 \mathrm{~m}$. Summer temperatures are high and vary from $20-30^{\circ} \mathrm{C}$ with minimal rainfall allowing fieldwork to be easily carried 
out in this season. Access to the Lookout Volcanics was via a $7 \mathrm{~km}$ hike into the Old Middlehurst Hut $(650 \mathrm{~m})$ located at the eastern margin of the main body of volcanic rocks.

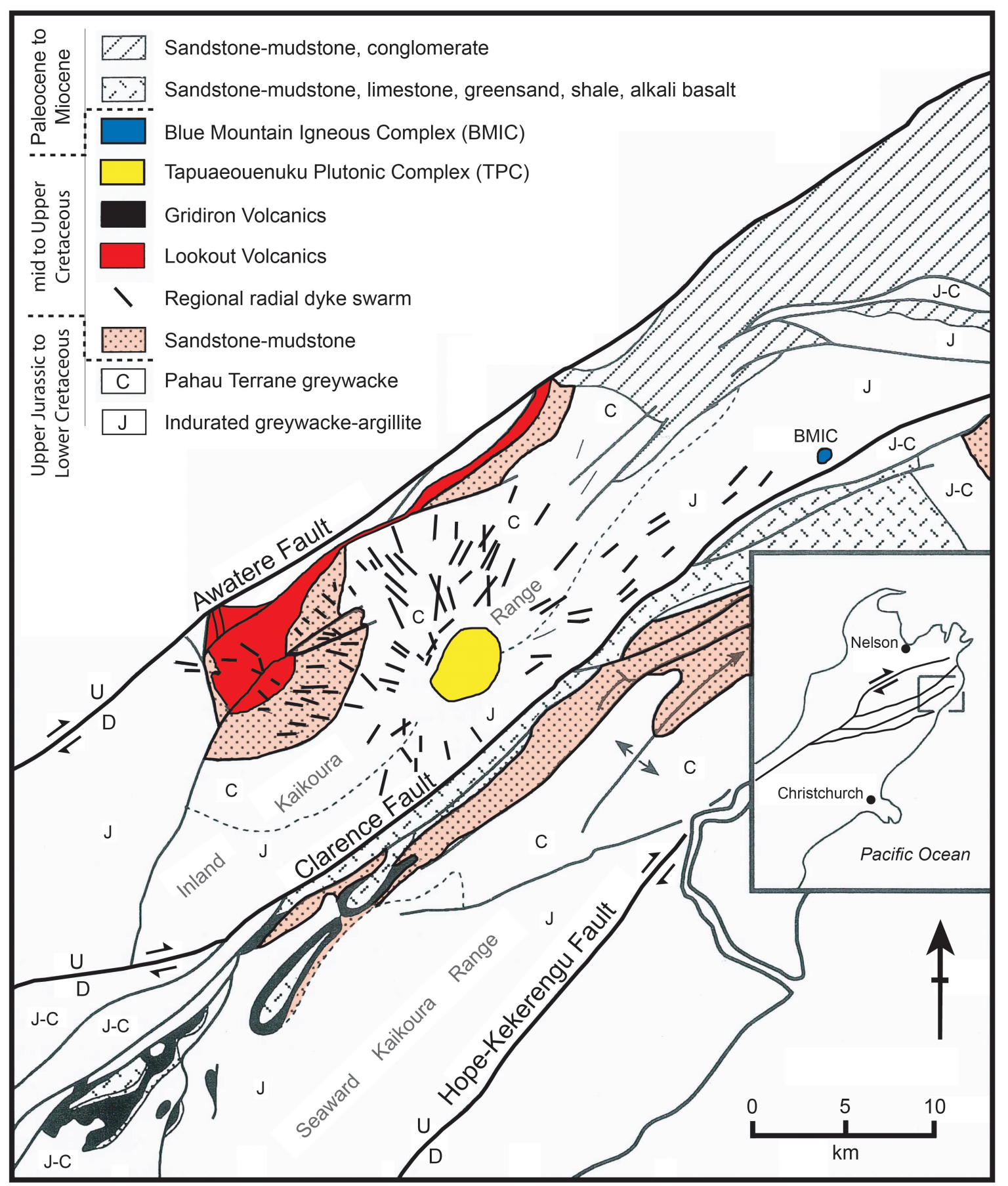

Figure 1.1: Simplified geological map of the Inland Kaikoura Region. Modified after Baker et al. (1994). 


\subsection{REGIONAL STRATIGRAPHY}

The following account of the generalised stratigraphy of Marlborough is based on Rattenbury et al. (2006). For more detailed accounts of the stratigraphy of Marlborough the reader is referred to the following: middle Awatere Valley (Allen, 1962; Challis, 1966; Melhuish, 1988); middle Clarence Valley (Suggate, 1958; Reay, 1993), lower Clarence Valley (Hall, 1962); a regional summary of Marlborough stratigraphy (Waters, 1988). The regional geology of Marlborough is illustrated in Figure 1.1. Also shown are the occurrences of igneous rocks outcropping in this area, which are described in Section 1.6.

The oldest rocks exposed in central Marlborough are Upper Jurassic to Lower Cretaceous Torlesse Supergroup greywackes of the Pahau Terrane. The greywacke comprises complexly deformed massive sandstone and alternating greywacke/argillite. These basement rocks crop out in the core of the Kaikoura Ranges with the older Jurassic greywacke found close to the axis of these large anticlinoria (Lensen, 1962). The greywacke contains occasional intercalations of conglomerate and spillite. The TPC intrudes the Torlesse Supergroup basement. Dykes are also common in this basement, although they intrude younger rocks up to earliest Ngaterian (95.2 Ma) in age. Basement is unconformably overlain by widespread marine shale and glauconitic sandstone of Motuan age, and these grade upwards into shallow marine or terrestrial sediments of Ngaterian age. Minor coal measures are occasionally interbedded with terrestrial sediments. In the Awatere Valley, the Ngaterian sediments are directly overlain by the Lookout Volcanics (Challis, 1966; this study) and in the Clarence Valley by the Gridiron Volcanics (Suggate, 1958; Reay, 1993). In this area the oldest volcanics are terrestrial, however, submergence began during the volcanism and marine tuffs are interbedded with Ngaterian fossiliferous sediments found in the middle Awatere Valley. Subsequent sedimentation of greensand, argillaceous limestone and bentonites occurred from the Late Ngaterian to the Oligocene. This period 
was characterised by continued submergence and slow sedimentation rates. Minor volcanism producing alkali basalt flows and dykes occurred during this period (e.g. Cookson Volcanics).

In the Miocene, renewed tectonism increased the sedimentation rate with a transition from biogenic to clastic sedimentation. The Great Marlborough Conglomerate (GMC), a chaotic widespread unit, locally containing clasts up to tens of metres in size was deposited in an extensive sheet east of the Clarence Fault. Later Miocene deposits represent a shallowing of the clastic depositional environment as uplift caused further restriction of marine basins. Sediment character grades from sand to mud with sporadic fresh water conglomerates. Pliocene strata are represented by nearshore sediments similar to the Miocene clastics. The presence of clasts of Ngaterian volcanics in the GMC implies that the Palaeogene rocks of Central Marlborough had been eroded before or during the deposition of this unit. Erosion has resulted in the restriction of the remaining outcrops of volcanic rocks to the fault angle depressions of the Awatere and Clarence Valleys. The confinement of the volcanic rocks to these fault angle depressions suggests that the Awatere and Clarence Faults were initiated during the deposition of the GMC.

\subsection{REGIONAL TECTONICS}

The tectonic regime of the Marlborough region is dominated by the Marlborough Fault System (MFS; Bibby, 1976), which consists from west to east of five major faults; the Wairau, Awatere, Clarence, Kekerengu and Hope Faults (Figure 1.2). This system forms the northern extension of the Alpine Fault, a plate boundary accommodating dextral oblique continental collision between the Campbell Plateau on the Pacific Plate and the Challenger Plateau on the Australian Plate. The MFS is situated at the southern end of the Hikurangi Trough, a destructive plate margin where Pacific oceanic lithosphere is subducted in a westward 
direction under the North Island. Plate motions derived from the last $3 \mathrm{Ma}$ of seafloor spreading data predict that in the northeastern South Island the Pacific Plate has moved $38 \mathrm{~mm} / \mathrm{yr}$ toward $258^{\circ}$ relative to an assumed fixed Australian Plate (DeMets et al., 1990 \& 1994). Along the Hikurangi Trough, the relative plate motion decreases to the southwest, while the obliquity of plate motion increases (Kelsey et al., 1995), resulting in a greater margin-parallel component of motion in the northeastern South Island (Wallace et al., 2004). The plate motion vector decreases from $45 \mathrm{~mm} / \mathrm{yr}$ at East Cape to $38 \mathrm{~mm} / \mathrm{yr}$ in Marlborough where the subduction interface is strongly coupled under the MFS.

The MFS is a ca. $150 \mathrm{~km}$ wide belt of active transcurrent faults that accommodate dextral compression associated with the westward movement of the Pacific Plate relative to the Australian Plate. The major faults of the system strike east-northeast and are spaced ca. $30 \mathrm{~km}$ apart. Knuepfer (1992) calculated average latest Quaternary right lateral slip rates on the faults of the MFS from west to east to be $3-10,5-10,7-10,5-7$ and $25-40 \mathrm{~mm} / \mathrm{yr}$, respectively. Lamb \& Bibby (1989) suggested that $80 \%$ of plate motion is being accommodated by movement within the MFS. The kinematic development and timing of inception of faults in the MFS during the Cenozoic is poorly documented. It is complicated by Neogene clockwise vertical axis rotations of up to ca. $100^{\circ}$ (Vickery \& Lamb, 1995). The Awatere Fault is the only fault in Marlborough to offset a major Neogene basin, making it an informative target for structural studies. Since ca. 7 Ma, at least $34 \pm 10 \mathrm{~km}$ of dextral slip has occurred on the Awatere Fault (Little \& Jones, 1998). Comparison of Miocene offsets with late Quaternary offsets suggests that the rate of motion has remained constant or may have possibly decelerated through time (Little \& Jones, 1998). The faults of the MFS release accumulated strain in major oblique strike slip earthquakes. The October 1848 earthquake on the Awatere Fault had a moment magnitude of $M_{w}=7.4-7.7$ and extended inland from the coast for ca. $110 \mathrm{~km}$ with 5-8 $\mathrm{m}$ of strike slip displacement and a locally variable throw of 0-3.5 m (Little et al., 1998; Mason \& Little, 2006). 


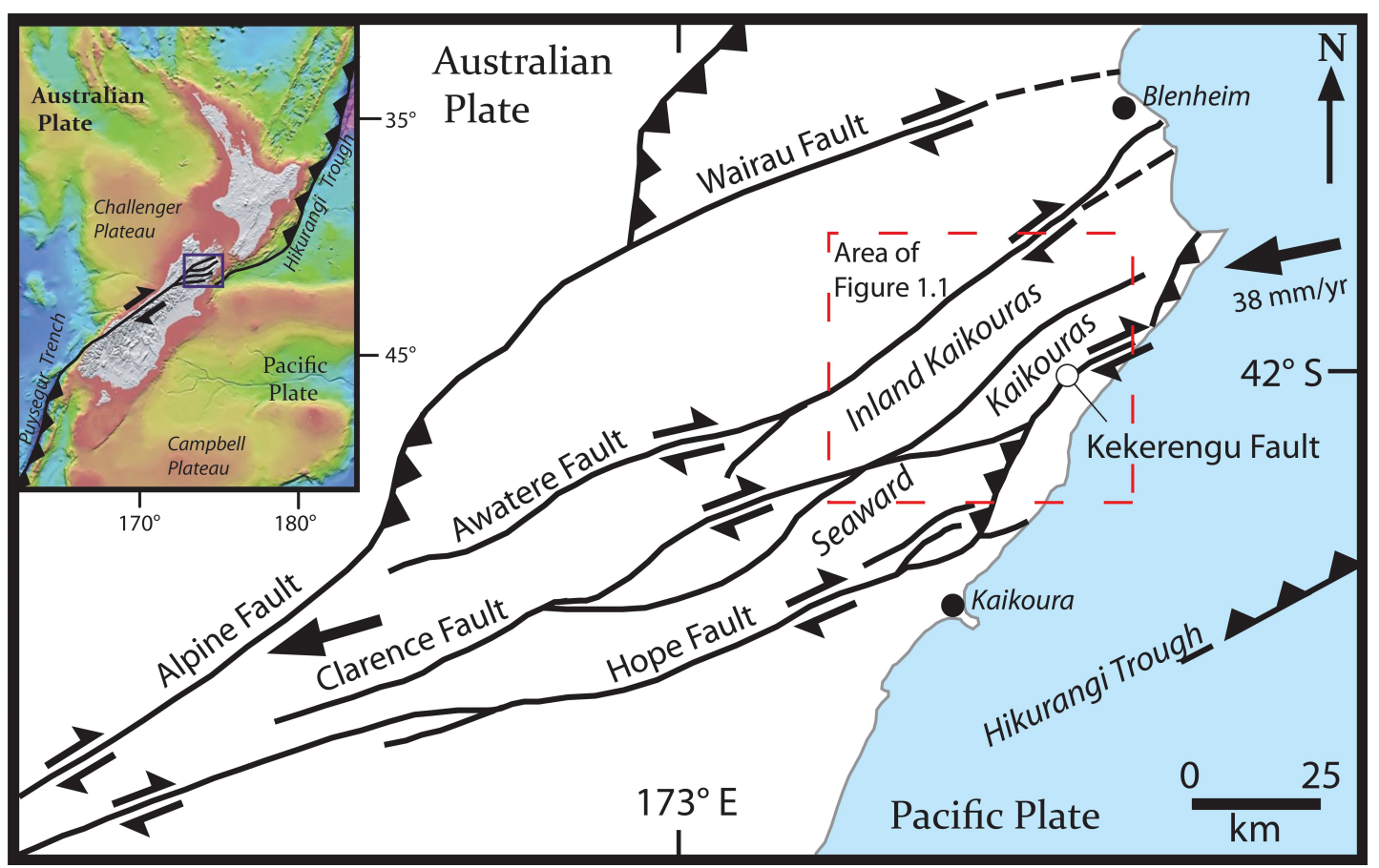

Figure 1.2: Simplified tectonic map of northeastern South Island, New Zealand, showing the major faults that comprise the Marlborough Fault System. Bold arrows are Nuvel-1a plate motion vectors for Australian-Pacific relative plate motion calculated from the pole of rotation of DeMets et al. (1990 \& 1994). Modified after Little \& Jones (1998). Inset courtesy of NIWA.

A ca. $20^{\circ}$ discordance between the mean strike of the faults of the MFS and the local plate motion vector results in a zone of transpressive deformation. Oblique slip on major strands of the MFS is responsible for the rapid and ongoing uplift of the Inland and Seaward Kaikoura Ranges. The component of thrusting on the faults in Marlborough increases toward the subduction front, with a major transition between the Awatere and Clarence Faults. The uplift of the IKR was initiated in the early Miocene (22 Ma) based on fission track cooling ages of apatite from the TPC (Baker \& Seward, 1996). Uplift maps of South Island and Marlborough based on summit heights and uplifted marine terraces suggest uplift rates of $10 \mathrm{~mm} / \mathrm{yr}$ for the IKR (Wellman, 1979; Lamb \& Bibby, 1989). However, uplift has not occurred continuously and involved a period of nearly pure strike slip faulting in the Miocene, reverting to a slightly compressional regime about 12 Ma (Sutherland, 1995). At ca. 6.4 Ma, greater shortening across the margin accompanied a southwest shift in the euler pole position, and convergence has continued to increase to the present day (Walcott, 1998). 
A large positive magnetic anomaly is centred on Mount Tapuaeouenuku (Hunt, 1969) and is undoubtedly related to the large plutonic body located here. The size of the anomaly indicates the intrusion is larger at depth, or that another separate larger (?) intrusion is located beneath the TPC. A premise that is corroborated by the field geology and petrology of the intrusion (Baker, 1990).

\subsection{GEOLOGICAL HISTORY}

\subsubsection{Mid-Cretaceous extension of proto-New Zealand}

The Pahau Terrane basement of the northeastern South Island comprises deformed massive greywacke and alternating argillite, with intercalations of conglomerate and spilite. This basement was accreted to the Pacific margin of the supercontinent Gondwana by a series of collisional events from the Late Jurassic to Early Cretaceous. At ca. $100 \mathrm{Ma}$ an extensional and magmatic event affected the thickened accretionary margin of Gondwana. Extension is evidenced by a number of geological features recognisable in New Zealand today:

1) Ultramafic-gabbro-syenite plutonic complexes (Grapes, 1975; Weaver \& Pankhurst, 1991; Baker et al., 1994) and the associated regional radial dyke swarm in Marlborough.

2) The development of metamorphic core complexes in Westland record continental extension in the mid-Cretaceous (Tulloch \& Kimbrough, 1989). The Early Cretaceous Separation Point Batholith (ca. $118 \mathrm{Ma}$ ) has the chemistry of convergent magmatism (Muir et al., 1997). However, combined $\mathrm{U} / \mathrm{Pb}, \mathrm{K} / \mathrm{Ar},{ }^{40} \mathrm{Ar} /{ }^{39} \mathrm{Ar}$ and fission track dates record the rapid unroofing (cooling rates of $110{ }^{\circ} \mathrm{C} / \mathrm{Ma}$ ) of lower plate rocks from ca. $110-90 \mathrm{Ma}$ (Muir et al., 1994; Spell et al., 2000). Mylonitic rocks were uplifted to the surface, exposed and eroded by 105-100 Ma. The rapid uplift in the midCretaceous was accompanied by synchronous deposition of coarse nonmarine breccia in half grabens. Uplifted basement yields $\mathrm{K}$-Ar dates as 
young as $88 \mathrm{Ma}$, and tilting and graben sediments indicate detachment continued well into the Late Cretaceous (Tulloch \& Kimbrough, 1989), when both cover and basement rocks were intruded by a swarm of alkali lamprophyre dykes.

3) Davy (1984) first related the Cretaceous opening of the Bounty Trough to the separation of New Zealand from Gondwana. Grobys et al. (2007) report that the Bounty Trough exhibits crustal thicknesses that are reduced by 9 $\mathrm{km}$ relative to the adjacent Chatham Rise and Campbell Plateau. A high velocity/density body is interpreted as a magmatic intrusion into extensional thinned continental crust.

4) Extensive mid-Upper Cretaceous alkali intraplate volcanic rocks preserved in the sedimentary sequences of the northern South Island and the Chatham Rise. The only preserved remnants of this volcanism are restricted to central Marlborough (Nicol, 1977; this study), north Canterbury (Barley, 1987; Weaver \& Pankhurst, 1991) and the Chatham Islands (Morris, 1981 \& 1985b).

\subsubsection{Mechanisms for New Zealand-Gondwana rifting}

The separation of the New Zealand microcontinent from Gondwana was the last of a series of continental rifting events involved in the disintegration of the supercontinent. A zone of pre-existing weakness and an appropriate ambient regional stress system is required to split continental lithosphere (Dalziel et al., 2000). Continental rifting can occur due to rapid changes in the motions of tectonic plates, or the impingement of a mantle plume on the lithosphere. The separation of New Zealand from Antarctica was a magmatic rifting event that is now represented by exposed mafic dyke complexes and anorogenic granitoids along the Marie Byrd Land (MBL) margin of Antarctica (Weaver et al., 1994) and some small igneous complexes within New Zealand (Weaver \& Pankhurst, 1991; Baker et al., 1994; Panter et al., 2006). 
A prolonged period of subduction-related calc-alkaline magmatism beginning at $320 \pm 3 \mathrm{Ma}$ is recorded by granodiorites, monzogranites, and granites from the Ruppert-Hobbs coast of MBL (Mukasa \& Dalziel, 2000). During the Early Cretaceous the Phoenix Plate was being subducted beneath the paleo-Pacific margin of Gondwana (Figure 1.3), forming wide accretionary complexes that are now exposed in New Zealand and magmatic arc rocks present in both New Zealand and MBL (Weaver et al., 1994). U-Pb ages reported by Mukasa \& Dalziel (2000) show that in MBL subduction-related calc-alkaline magmatism ceased at $110 \pm 1 \mathrm{Ma}$ along the Ruppert-Hobbs coast, but continued until $96 \pm 1 \mathrm{Ma}$ in the Pine Island Bay area to the east. Rift-related magmatism along the RuppertHobbs coast first appeared in the form of mafic and intermediate dykes dated at $101 \pm 1 \mathrm{Ma}$, followed by a short-lived episode of dyke free anorogenic magmatism between $102 \pm 1 \mathrm{Ma}$ and $98.4 \pm 0.8 \mathrm{Ma}$ (Mukasa \& Dalziel, 2000). Thus, the regime had shifted from subduction-related to rift-related magmatism in a period of ca. 9 Ma. The Chatham Rise started to separate from the margin of Antarctica late within the Cretaceous Normal Polarity Superchron (118-83 Ma). Subsequently, the Campbell Plateau also separated during the reversed part of Chron 33 (8379.1 Ma) (Larter et al., 2002; Eagles et al., 2004). The inception of the PacificAntarctic ridge and seafloor spreading between New Zealand and Antarctica is constrained at ca. $84 \mathrm{Ma}$ by the oldest oceanic crust beside the Campbell Plateau. The length of the Cretaceous Normal Polarity Superchron complicates unravelling the exact chronology of progression from continental extension to sea floor spreading. Two hypotheses have been postulated as the cause of this rifting event.

\section{A mantle plume as the break-up mechanism}

Weaver et al. (1994) suggested that plume activity along the proto-Pacific margin of Gondwana may have begun ca. $100 \mathrm{Ma}$, and may have destabilised the margin causing rifting. 


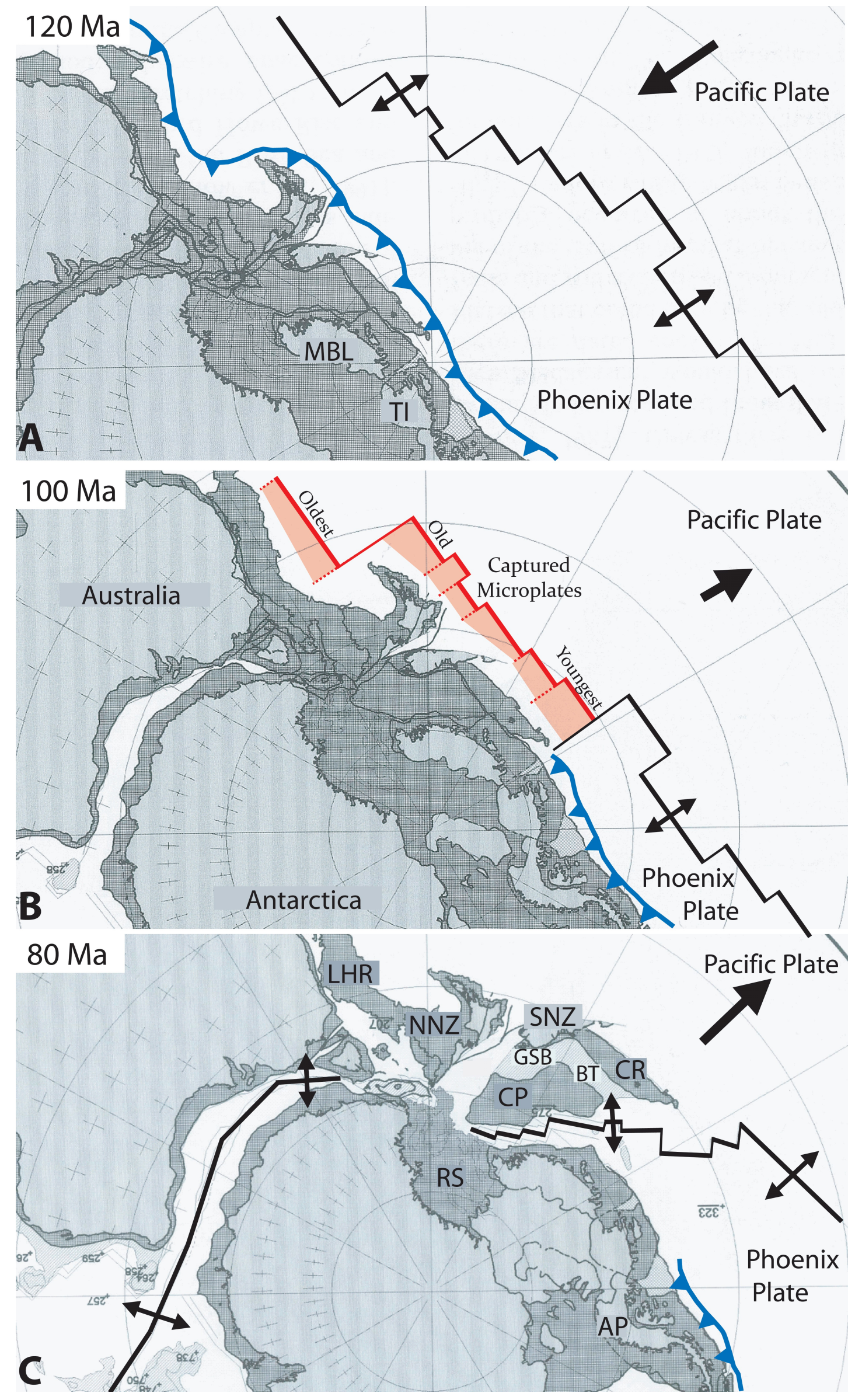


Figure 1.3 (previous page): Paleo-reconstructions of eastern Gondwana in the Early Cretaceous, mid-Cretaceous and Late Cretaceous showing the postulated tectonic processes that led to the separation of the New Zealand microcontinent from Marie Byrd Land (MBL), West Antarctica. Modified from Lawver et al. (1992). Bold arrows represent approximate plate motion vectors of the Pacific Plate relative to a stationary East Antarctica. (A) 120 Ma: The long lived subduction of the Phoenix Plate at the eastern margin of Gondwana continues, the Pacific Plate is slowly moving southwest, thus the mid-ocean ridge is approaching the continental margin. (B) $100 \mathrm{Ma}$ : As the spreading centre nears the trench spreading slows and eventually stops. This occurred progressively from west to east due to the oblique interaction of the spreading centre with the continental margin. When subduction stops microplates become captured by the overlying plate. In the Aptian, the Pacific Plate reversed and started moving slowly northward resulting in the extension of proto-New Zealand and MBL. (C) 80 Ma: The Pacific Plate accelerated its northward motion and the Udintsev Fracture Zone reached the tip of the Chatham Rise at ca. 84 Ma. This resulted in the inception of the Pacific-Antarctic ridge and seafloor spreading between New Zealand and MBL. AP-Antarctic Peninsula; BT-Bounty Trough; CP-Campbell Plateau; CR - Chatham Rise; GSB — Great South Basin; LHR—Lord Howe Rise; MBL—Marie Byrd Land; NZ-New Zealand (N—Northern; S—Southern); RS; Ross Sea; TI—Thurston Island.

Storey et al. (1999) also advocated the existence of a mid-Cretaceous mantle plume beneath the anorogenic and mafic dykes suites of MBL based on the following evidence: (1) the volume of magmatism is consistent with a volcanic margin formed above a mantle plume; (2) the mafic dykes contain a tholeiitic asthenospheric end-member component. Storey et al. (1999) consider that tholeiitic magmatism indicates that the degree of mantle melting was greater than that associated with normal mantle temperatures, assuming that lithospheric thicknesses were not unusually thin; (3) Storey et al. (1999) report isotopic data indicating that the asthenospheric component was HIMU-like, typical of plumederived sources in the South Pacific region; (4) allowing for motion of the Antarctic Plate relative to the hot-spot reference frame (Mueller et al., 1993), a stationary hot-spot situated below the Ruppert-Hobbs coast during midCretaceous times would now be situated beneath Mount Erebus where it is responsible for the voluminous, intraplate alkaline McMurdo Volcanic Group (Weaver et al., 1994).

However, LeMasurier \& Landis (1996) found no evidence for plume related doming in either New Zealand or MBL in the mid-Cretaceous. The tholeiitic geochemical signature could have been the result of thinned crust in an area undergoing regional extension. The generation of the HIMU-like signature of the 
dykes in MBL also does not require the involvement of a mantle plume, but could reflect the involvement of metasomatically altered subducted oceanic crust in the mantle source of this volcanism (e.g. see Section 1.8). Furthermore, the highest ${ }^{206} \mathrm{~Pb} /{ }^{204} \mathrm{~Pb}$ ratio reported by Storey et al. (1999) is 19.02 which is not particularly radiogenic and clearly not diagnostic of a HIMU source. Thus, the existence of a mid-Cretaceous mantle plume along the coast of MBL remains uncertain.

\section{$\underline{\text { Ridge interaction as the break-up mechanism }}$}

The age pattern of subduction related volcanism in MBL suggests that subduction ceased first along the western sector at ca. $110 \mathrm{Ma}$ and persisted until about ca. 95 $\mathrm{Ma}$ in the east. This is consistent with tectonic models of the Pacific margin of Gondwana that include a diachronous propagation of the triple junction of the Pacific-Phoenix Ridge from west to east (Eagles et al., 2004).

Paleomagnetic data indicate that in the Early Cretaceous the Pacific Plate was moving southward (Larson et al., 1992). Therefore, during this period the Pacific-Phoenix spreading centre was moving southward and approaching Gondwana. Based on robust plate reconstructions the oblique arrival of the Pacific-Phoenix Ridge at Gondwana's proto-Pacific margin is constrained to have occurred at ca. $100 \mathrm{Ma}$ (Barker, 1982). There is a strong link between triple junction migration and continental break-up along the proto Pacific margin of Gondwana due to the fact rifting propagated from west to east. Subduction was still continuing in eastern MBL while anorogenic rift-related magmatism had been initiated in western MBL (Mukasa \& Dalziel, 2000). Bradshaw (1989) first hypothesised the cessation of subduction along this margin was the result of the collision of Pacific-Phoenix spreading ridge with the subduction zone. Luyendyk (1995) applied the subducted slab capture scenario where the spreading ridge comes to a standstill just prior to trench collision, and this scenario has also been used to describe the Cenozoic evolution of the Californian margin of North America (Nicholson et al., 1994). 
A synthesis of the subducted slab capture process as described by Luyendyk (1995) follows (Figure 1.4). When a spreading ridge approaches subparallel to a subduction zone following the edge of the downgoing plate, the age of the subducting plate is decreasing with time. Young oceanic crust is thermally buoyant. Thus, as the subducting plate approaches the subduction zone it may fragment into microplates outlined by transform faults that intersect the trench. Eventually it may become too small to subduct, and spreading slows and stops. The spreading ridge stalls many tens of kilometres outboard of the subduction zone. The subducted plate welds to the outboard plate across the dormant spreading centre and is captured by it. The captured plate then acquires the motion of the plate it is welded to, and if the outboard plate is diverging then rifting may occur in the overriding plate. Extension within the overlying plate produces a zone of weakness which acts as a locus for rifting within it.

Assessment of the slab-capture hypothesis requires examination of evidence for supporting observations, including an extinct spreading centre outboard of the paleo-subduction zone and an abrupt change in tectonic regime in the overlying plate. The change in Pacific Plate motion in the Early Cretaceous is well documented (Bradshaw, 1989; Larson et al., 1992). In Aptian time (125-112 Ma), the Pacific Plate reversed direction and started to move slowly northward. The rate of northward motion of the Pacific Plate accelerated dramatically during the Late Cretaceous, ultimately reaching more than $100 \mathrm{~km} / \mathrm{Ma}$ just prior to the commencement of sea-floor spreading between New Zealand and MBL (Larson et al., 1992). Luyendyk (1995) notes that this acceleration could have increased shear on the overlying margin leading to crustal failure and sea-floor spreading. Locating an extinct ridge system is more complicated because when spreading ended it was during the Cretaceous Normal Polarity Superchron, a period of no magnetic reversals, thus a symmetric magnetic anomaly pattern cannot be found. However, Luyendyk (1995) discovered using satellite gravity data a gravity low trending northeast of the Chatham Rise that is interpreted as the rift valley of the stalled spreading centre. 

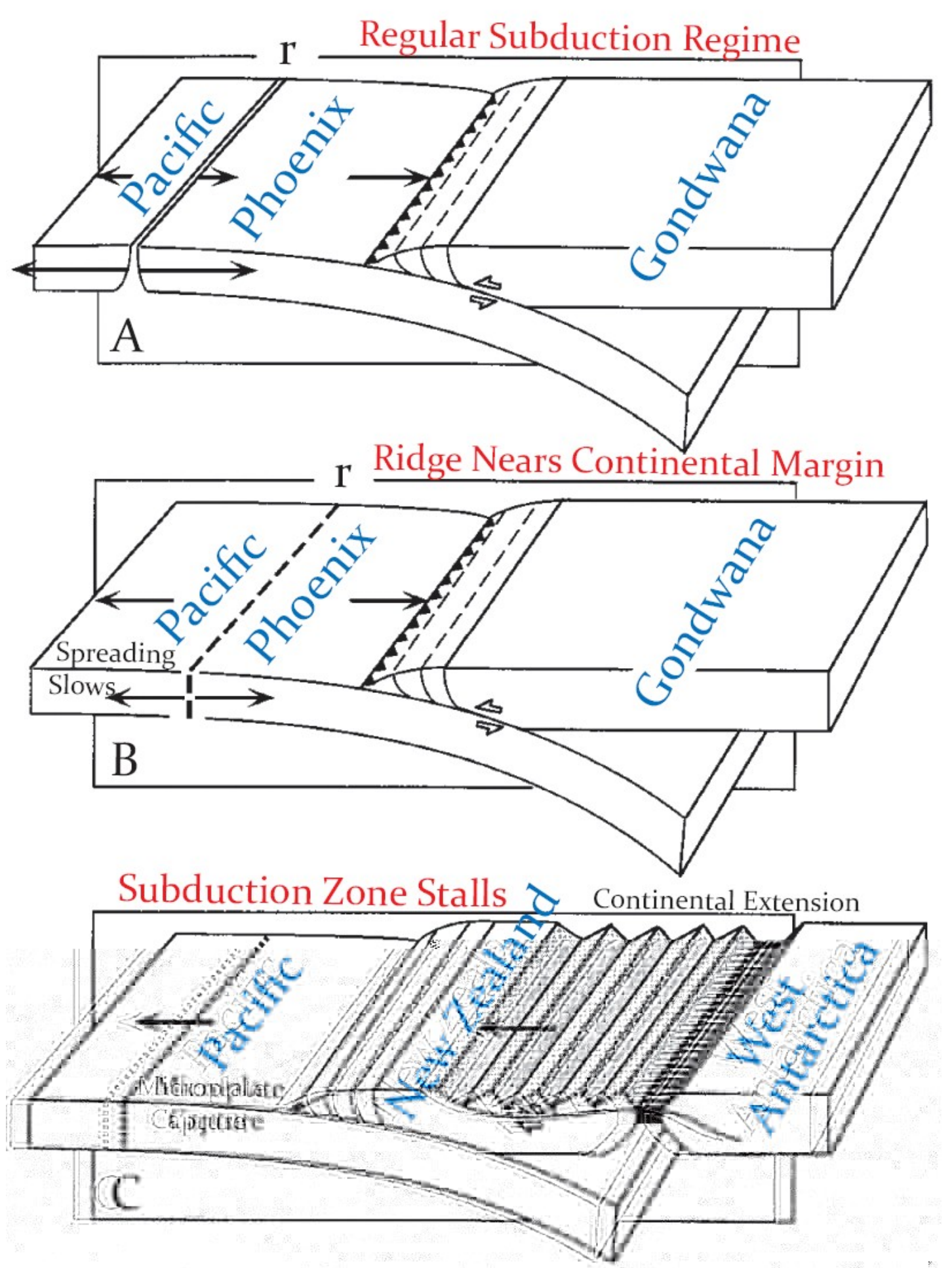

Figure 1.4: Subducted slab capture model applied to the margin of eastern Gondwana in the midCretaceous modified after Nicholson et al. (1994) and Luyendyk (1995). (A) Pacific-Phoenix ridge approaches trench and subduction zone of eastern Gondwana. Vectors atop plates are relative to east Gondwana or West Antarctica; half-spreading-rate vectors are shown on plate sides. Spreading centre approaches subduction zone at rate r. (B) Spreading and subduction rates decrease as slab pull force decreases. Ridge stops approaching trench when half rate equals vector of Pacific Plate, and retreats slowly from trench as spreading stops. (C) Spreading stops and Phoenix Plate is captured by the Pacific Plate. Basal traction of the Phoenix Plate on the overlying New Zealand margin extends and rifts it away from West Antarctica, opening a new ocean basin. 
In the southwest Pacific, the Pacific-Phoenix Ridge approached the east Gondwana margin as the Phoenix Plate subducted beneath proto-New Zealand and MBL in Cretaceous time (Figure 1.). As the young crust of the Phoenix Plate became too buoyant, spreading and subduction ceased between ca. 110-105 Ma, and some sections of the Phoenix Plate became welded to the Pacific Plate.

Northward motion of the Pacific Plate began in Aptian time, pulling the captured subducted microplates with it. This movement exerted a basal traction on the overlying Gondwana margin and resulted in extension of New Zealand and MBL eventually leading to the inception of sea-floor spreading between New Zealand and Antarctica.

Luyendyk (1995) attributed the time lag between the beginning of extension and seafloor spreading to the large northern offset of the Udintsev fracture zone at this time. The fracture subsequently migrated southeast to reach the tip of the Chatham Rise before $84 \mathrm{Ma}$. From the onset of rift-related magmatism at $101 \pm 1$ Ma to formation of new oceanic crust between West Antarctica and greater New Zealand at chron 34 (ca. $84 \mathrm{Ma}$ ) required only $17 \mathrm{Ma}$ (Mukasa \& Dalziel, 2000). This is slightly more than half the $30 \mathrm{Ma}$ it took for the Central Atlantic to open (Leitch et al., 1998). The swiftness of separation in this case is more consistent with models advocating microplate capture as the primary cause of break-up rather than active plume rifting (Mukasa \& Dalziel, 2000).

Kula et al. (2007) conducted K-feldspar thermochronometry on the footwall of the recently discovered Sisters Shear Zone (SSZ) a Late Cretaceous detachment fault system exposed for $40 \mathrm{~km}$ along the southeast coast of Stewart Island, New Zealand. Moderately rapid cooling $\left(20-30{ }^{\circ} \mathrm{C} / \mathrm{Ma}\right)$ is observed due to tectonic denudation from ca. 89-82 Ma, followed by a return to slow cooling at $82 \mathrm{Ma}$ coinciding with the age of the oldest seafloor adjacent to the Campbell Plateau. The cooling variations in the SSZ reflect the mechanical transition from continental extension to lithospheric rupture and formation of the PacificAntarctic Ridge and agree well with the chronology observed from volcanism. 


\subsubsection{Mid-Cretaceous regression and volcanism}

The TPC is a large alkaline intrusion that was emplaced into Upper JurassicLower Cretaceous Torlesse greywacke/argillite near the axis of the IKR.

Concordant $\mathrm{Rb}$-Sr, K-Ar and titanite/zircon fission track cooling ages of ca. 105 to $93 \mathrm{Ma}$ (Baker et al., 1994) place the uplift of this pluton during the extension of proto-New Zealand. Updoming and uplift which accompanied extension are also evidenced by the uplift of the marine Split Rock Formation above sea level where it was eroded (Lensen, 1962). Basement is overlain by widespread conglomerates, sandstones and mudstones of the Split Rock Formation of Motuan age (105-100 Ma). They represent a marine fan delta sequence (Reay, 1993) and are overlain unconformably by terrestrial sediments of the Warder Formation of Ngaterian age (ca. 100-94 Ma). These sediments represent the end of the regressive event. In the Awatere Valley, Ngaterian sediments are conformably overlain by the Lookout Formation (Challis, 1966) which is almost entirely ca. $1000 \mathrm{~m}$ of volcanic flows, and in the Clarence Valley by thick intraplate basalts of the Gridiron Volcanics (Reay, 1993). Stratigraphic and paleontological evidence suggest that the Lookout Formation is of Ngaterian age (Challis, 1966; Nicol, 1977).

\subsubsection{Post Ngaterian transgressive marine sedimentation}

During the Cretaceous and Palaeogene, Marlborough lay on the generally north facing, Pacific-margin of proto-New Zealand. Palinspastic maps record the progressive drowning of the continental margin with shelf deposits turning into bathyal depths (Crampton et al., 2003). The cessation of extension and magmatism resulted in cooling of the lithosphere and slow thermal subsidence which is reflected in the deposition of a marine sedimentary sequence from the Late Cretaceous to the Oligocene (Rattenbury et al., 2006). In the middle Clarence Valley, the Gridiron Volcanics are overlain by and interfinger the shallow marine Bluff Sandstone, probably of Arowhanan age (94 Ma), suggesting that subsidence was underway at this time. This was followed by a period of 
relative quiescence reflected in the deposition of the Piripauan greensands from 85 to $75 \mathrm{Ma}$. The next 10 Myr saw a further increase in sedimentation before a prolonged period of quiescence and deposition of marine Eocene-Oligocene limestones (Amuri from 55-36 Ma and Weka Pass from 32-22 Ma; Rattenbury et al., 2006) during which time New Zealand remained passively part of the Pacific Plate. Some minor volcanism, consisting of alkali basalt flows and dyke intrusions also occurred during this period (e.g. Cookson Volcanics). This postNgaterian to 22 Ma sedimentary sequence in Marlborough is estimated to be 1.7$3.8 \mathrm{~km}$ thick (Waters, 1988).

\subsubsection{Miocene-Recent uplift of the Kaikoura Ranges}

The inception of the Alpine Fault and Hikurangi subduction margin occurred at ca. $24 \mathrm{Ma}$ (Cooper et al., 1987; Rait et al., 1991). The commencement of the present-day plate boundary led to thrusting and shortening in Marlborough, and thus a change from biogenic to clastic sedimentary deposits (Waima Siltstone) occurred. The existence of the proto-MFS in the early Miocene is suggested by the synsedimentary deposition of the widespread olistostromal Great Marlborough Conglomerate (Lamb \& Bibby, 1989). Apatite fission track ages of the TPC reveal the pluton was rapidly uplifted from depth in the early Miocene ca. $22 \mathrm{Ma}$ (Baker \& Seward, 1996). To raise the pluton to its present altitude (2885 $\mathrm{m}$ ), the uplift rate required based on a constant rate over $22 \mathrm{Ma}$ is 0.2 $\mathrm{mm} / \mathrm{yr}$. However, estimates of present day uplift rates are $10 \mathrm{~mm} / \mathrm{yr}$ (Lamb \& Bibby, 1989). This suggests two periods of Late Cenozoic uplift must have occurred with a long period of quiescence between, a conclusion also supported by the major mid-Miocene unconformity below Quaternary sediments in the Marlborough region. Greater shortening across the Alpine Fault began at ca. 6.4 Ma (Walcott, 1998), with oblique slip on major strands of the MFS responsible for the rapid and ongoing uplift of the Inland and Seaward Kaikoura Ranges. 


\subsection{IGNEOUS ROCKS OF MARLBOROUGH}

The igneous rocks of Marlborough can be subdivided into five major occurrences. These were collectively named the Central Marlborough Igneous Province (Reid, 1972; CMIP). These occurrences are briefly outlined and described below. A more comprehensive description of the rocks of the Lookout Formation, the subject of this thesis follows in Chapter 2. The locations of the components of the CMIP are illustrated in Figure 1.1. This igneous province is notable in that there is simultaneous exposure of comagmatic plutonic, hypabyssal and volcanic rocks due to uplift associated with Neogene block faulting and tilting. The plutonic bodies now occupy the highest parts of the westward tilted Inland Kaikoura fault block and the lavas are partially preserved in the fault angle depressions of the Awatere and Clarence Valleys.

\subsubsection{Lookout Formation}

The Lookout Volcanics (Lookout Formation; Challis, 1960a \& 1966) consist of alkaline ultramafic-mafic volcanic rocks. The majority of the formation is composed of terrestrial lava flows but minor marine tuffs and non-volcanic sediments are preserved at the top of the section. Although they must once have formed a more extensive sheet, the volcanic rocks are now restricted to the fault angle depression of the Awatere Valley where the formation covers an area of ca. $50 \mathrm{~km}^{2}$. Although due to faulting no complete sequence is preserved within the formation, at least $1000 \mathrm{~m}$ of lava flows are preserved near Mount Lookout. A narrow band of volcanic rocks extends for ca. $15 \mathrm{~km}$ to the north along the Awatere Fault as fault bound slivers. Volcanism occurred at ca. $100 \mathrm{Ma}$ with the volcanic flows overlying shallow marine and terrestrial sediments of Ngaterian

age. K-Ar ages have been obtained on six trachybasalt flows which produced ages of $99.9 \pm 0.7$ to $90.3 \pm 1.6 \mathrm{Ma}$ (Nicol, 1977). Breccias and agglomerates that may indicate a central vent are generally absent from the formation. A pipe breccia 
cutting Motuan sediments is present northwest of Mount Lookout, which has an outcrop area of ca. $150 \mathrm{~m}^{2}$. The pipe contains weathered volcanic and sedimentary fragments, and is cut by dykes of the regional dyke swarm. Nicol (1977) identified an alkaline ankaramite-trachybasalt-transitional trachybasalttrachyandesite series in these rocks. Trachybasalt and ankaramite rock types form the majority of the volcanic rocks and are volumetrically more dominant than more felsic rocks. Geochemically, the lava flows are indistinguishable from the regional radial dyke swarm (Nicol, 1977; Baker, 1990).

\subsubsection{Gridiron Formation}

The Gridiron Formation (Suggate, 1958) comprises alkaline mafic volcanic rocks interbedded with a minor amount of freshwater and marine sediments. Agglomerates, tuffs and volcanic conglomerates are also found within the formation. The volcanic rocks are of Ngaterian age based on stratigraphic evidence and record a continuous eruption sequence. K-Ar ages of $98.3 \pm 1.3$ to $93.5 \pm 2.0 \mathrm{Ma}(2 \sigma)$ have been obtained from basaltic lava flows (Reay, 1993). The formation is restricted to the middle Clarence Valley and discontinuously outcrops over a distance of ca. $35 \mathrm{~km}$, occurring within a series of small synclines and faulted outliers that contain a series of Upper Cretaceous to Tertiary rocks. The volcanic rocks reach a maximum thickness of ca. $365 \mathrm{~m}$ (14 flows) near Gore Stream and decrease in thickness to the northwest. At Seymour Stream the volcanic rocks are entirely terrestrial, but to the north the sequence becomes more marine. The lava flows have a similar appearance to those exposed in the Awatere Valley although individual flows tend to be thicker and are up to $25 \mathrm{~m}$ thick. Nicol (1977) identified an alkaline basalt-trachybasalt-transitional trachybasalt series in these rocks that has strong petrographic and geochemical similarities with the Lookout Volcanics. Despite the strong similarities between the Lookout and Gridiron Volcanics, the Gridiron Formation does not contain ankaramites and trachyandesites, and the trachybasalts of the Gridiron Formation 
are more plagioclase phyric than those from Lookout Formation. Suggate (1958) hypothesised that the central volcanic vent of the Gridiron Formation would have been situated somewhere south of Seymour Stream, due to the thinning observed in the volcanic rocks away from this region.

\subsubsection{Blue Mountain Igneous Complex}

The Blue Mountain Igneous Complex (BMIC; Grapes, 1972 \& 1975) is a centraltype alkali ultramafic-gabbro ring complex of mid-Cretaceous age intruding Upper Jurassic sediments at the northern end of the Inland Kaikoura Range. The complex outcrops for $1.5 \mathrm{~km}^{2}$ and is composed of an $800 \mathrm{~m}$ layered sequence of olivine pyroxenites, olivine-plagioclase pyroxneites and olivine ferrogabbros which dip steeply inward (ca. $70^{\circ}$ ) near the margin and flatten towards the centre of the intrusion. The rocks of the BMIC can be divided into four rock types which in order of emplacement are:

1) Ultramafic-gabbroic rocks;

2) Titanaugite-ilmenite gabbro and lamprophyre ring dykes;

3) Marginal alkali gabbro ring dyke;

4) Lamprophyre dyke swarms.

Petrographically, many of the rock types present in the BMIC are similar to those of the TPC, but ultramafic variants are more common in the BMIC. Grapes (1975) considered the BMIC to be a sub-volcanic magma chamber that was formed at a depth of ca. $4 \mathrm{~km}$. Cyclical variations in mineral compositions of the cumulate olivine and diopside in the ultramafic-gabbroic rocks indicate at least three injections of magma into the magma chamber. The BMIC is cut by a swarm of lamprophyre dykes (> 70 dykes), most of which strike north-northeast and form part of the much larger regional swarm intruding Jurassic-Cretaceous sediments in Marlborough. The large number of lamprophyre dykes intruding the pluton and the small number in the surrounding sediments suggests the that the plutonic rocks acted as a locus of weakness for dyke intrusion (Grapes, 1975). 


\subsubsection{Tapuaeouenuku Igneous Complex}

The Tapuaeouenuku Igneous Complex (TIC; Nicol, 1977) comprises the plutonic rocks exposed at Mount Tapuaeouenuku (Tapuaeouenuku Plutonic Complex (TPC) ; Baker, 1990) and an associated regional radial dyke swarm. The TIC is a multiphase intrusion centred on the highest peaks of the IKR. A ca. $30 \mathrm{~km}^{2}$ pluton intrudes Torlesse greywacke and is also intruded by a number of smaller intrusive bodies. The multiphase intrusion is divided into eight major units on the basis of field relations (in approximate order of intrusive emplacement; Baker, 1990; Baker et al., 1994):

1) Radial Dyke Swarm: The regional dyke swarm intrudes Late Jurassic-Early Cretaceous greywacke and rocks up to late Ngaterian in age including the Lookout Volcanics. The swarm covers an area of $300 \mathrm{~km}^{2}$ and is comprised of basanite, trachybasalt, and shoshonite/latite dykes.

2) Layered Series: Cumulate pyroxenite, gabbro, monzogabbro, and monzonite that volumetrically dominates the intrusion and was the first intrusive phase of the complex.

3) Staircase Intrusives: Non-cumulate gabbro, monzogabbro, monzonite and syenite that intrudes the lower part of the layered series near the western margin of the intrusion.

4) Lower Hodder Gabbro and minor gabbroic intrusives: Small non-cumulate gabbro, monzogabbro, and monzonite that intrude the Layered Series and hornfelsed greywacke near the western margin of the intrusion. A continuous sheet of gabbro and monzogabbro, intruded along the Layered Series-hornfels contact in the northwestern part of the complex, that may be a ring dyke is referred to as the Lower Hodder Gabbro.

5) Red Hills Pipe Breccia: Intrusive breccia emplaced as a pipe or diatreme along part of the western margin of the intrusion.

6) Hodder Intrusives; Non-cumulate monazite and syenite stocks intruding the Layered Series in the southwestern part of the intrusion. 
7) Monzonite, orthoclase syenite and quartz syenite sills and dykes.

8) Highly alkaline lamprophyre, phonotephrite, tephrophonolite, and phonolite dykes: A suite of dykes cutting the plutonic complex that have significantly higher total alkali contents, at a given silica content, than the regional dyke swarm.

The intrusion of the TPC was accompanied by the development of a biotite-rich hornfels contact metamorphic aureole (Robertson, 1989). The timing of intrusion of the TPC is constrained by a precise $\mathrm{Rb}$-Sr biotite-whole rock age of $96.1 \pm 0.5$ Ma (Baker \& Seward, 1996). The regional dyke swarm is particularly intensive in the Mount Gladstone and Winterton River areas. Grapes et al. (1992) reported KAr ages for 21 basanitic dykes ranging from $100.0 \pm 1.4$ to $59.8 \pm 1.1 \mathrm{Ma}$ and interpreted the ages as reflecting an extended period (40 Myr) of magmatic activity. However, Baker et al. (1994) considered the younger ages to be the result of post crystallisation radiogenic Ar loss as many of the dykes are highly altered and fine grained compared with their eruptive equivalents and are likely to have been susceptible to loss of radiogenically produced Ar from the K-rich groundmass and alteration products. Furthermore, the igneous relationships between the TPC, dyke swarm and volcanic rocks argue against a prolonged period of dyke intrusion. Intrusion of the radial dyke swarm, at least in part, predated the intrusion of the TPC. The scarcity of dykes within the pluton and the limited number of dykes seen to be fed directly by the intrusion in the field imply that the radial dyke swarm was sourced from a larger (?) underlying intrusion that predated the exposed intrusive body. In the Red Hills, cone sheets related to the plutonic complex cut dykes from the regional swarm confirming that some dykes pre-date the plutonic complex (Baker, 1990).

\subsubsection{Mandamus Igneous Complex}

The Mandamus Igneous Complex (MIC; Reid, 1972) is the basal remnant of an alkaline volcano of mid-Cretaceous age. The MIC outcrops over an area of ca. 10 
$\mathrm{km}^{2}$ in north Canterbury $23 \mathrm{~km}$ east of Culverdon. Field relationships suggest the MIC represents a high level differentiated pluton with a partially intact volcanic carapace. Reid (1972) subdivided the MIC into four major units:

1) Korari Volcanics: An alkaline basalt-trachybasalt-trachyandesite-trachyte lineage representing the remains of an eroded volcano. A suite of dykes of similar chemistry is also intruded into the surrounding country rock. Lava flows of mafic compositions (basalt and hawaiite) are rare within the suite.

2) Mandamus Intrusives: A differentiated alkali gabbro-syenodioriteperalkaline syenite series.

3) Hut Gabbro: A cumulate olivine gabbro presumed to represent the lowest exposed part of the sub-volcanic intrusion.

4) Dove Volcaniclastics: Breccia and agglomerate explosively created in a diatreme during the late stage crystallisation of the Mandamus Intrusives. Stratigraphic evidence implies a Ngaterian age for the MIC in agreement with a $\mathrm{Rb}$-Sr whole-rock and mineral isochron age of $97.0 \pm 0.5 \mathrm{Ma}$ (Weaver \& Pankhurst, 1991). Geochemical data (Mason, 1958; Reid, 1972) indicate the rocks of the MIC have distinctly alkaline compositions. Despite the spatial isolation from the other members of the CMIP, the close temporal association and similarity of rock types warrants its inclusion in the province.

\subsubsection{Other Igneous Occurrences}

In addition to the five major groupings of igneous rocks described above, the following Ngaterian (based largely on stratigraphic evidence) igneous rocks are included in the CMIP (Nicol, 1977): (1) submarine volcanics and basic dykes outcropping near Hungry Hill; (2) small gabbroic intrusions in the Blue Mountain Range near Big Hill and Black Mount; (3) Small gabbroic intrusions in the headwaters of the Hapuku River (Seaward Kaikoura Range). Gravity surveys may also indicate the presence of shallow intrusives near Blairich and Hungry Hill (Hunt, 1969). 


\subsection{INTRAPLATE VOLCANISM IN NEW ZEALAND}

\subsubsection{Intraplate Volcanism}

Continental intraplate volcanism is part of the 'within-plate' category of volcanism. This category also includes continental flood volcanism (e.g. Deccan Traps), volcanic passive margins (e.g. Norwegian margin), oceanic plateaux (e.g. Hikurangi Plateau), submarine ridges (e.g. Faeroe-Iceland-Greenland Ridge) and seamount chains (e.g. Hawaiian-Emperor islands/seamounts) (Coffin \& Eldholm, 1992). These latter types of volcanism are collectively referred to as large igneous provinces (LIP) and defined as regions of voluminous, predominantly mafic, extrusive and intrusive volcanic rocks whose origins lie in processes other than 'normal' sea floor spreading (Head \& Coffin, 1997). The difference between intraplate volcanism and LIP like continental flood volcanism is a matter of magnitude - intraplate volcanism is volumetrically small compared to LIP magmatic events. For example, intraplate volcanism in Jordan is estimated to have produced ca. 12,000 $\mathrm{km}^{3}$ of volcanic products, compared to the YemenEthiopia flood basalt province which has produced ca. $350,000 \mathrm{~km}^{3}$ of volcanic lava flows (Shaw, 2003). Models for the generation of LIP in recent years have favoured the involvement of upwelling, hot mantle plumes. The plume provides the thermal anomaly that permits abnormal amounts of decompression melting and generates the vast volume of magma erupted in these provinces (McKenzie \& Bickle, 1988). The reason for the relatively small volume of intraplate volcanism compared to continental flood volcanism is generally attributed to the absence of a mantle plume. For example, in Yemen, intraplate volcanic rocks have trace element ratios (i.e. lower $\mathrm{Zr} / \mathrm{Nb}$ ) that suggest smaller degrees of mantle melting than in the case of earlier flood basalts (Baker et al., 1997). Continental intraplate volcanic rocks tend to be alkaline in nature, compared to the tholeiitic nature of flood basalts. However, the absence of a mantle plume makes the origins of the mantle sources of intraplate volcanism uncertain. Intraplate volcanism is often 
chemically and isotopically distinct from flood volcanism and the sources of this volcanism are potentially lithospheric or asthenospheric.

New Zealand straddles an active plate boundary and relatively recent subduction-related volcanism attributable directly to interaction between the Australian and Pacific Plates is widespread in the central North Island. However, throughout the country preserved on both the Pacific and Australian Plates are occurrences of intraplate continental volcanism ranging in age from midCretaceous to Recent (Figure 1.5). A summary of reliable age data for Cretaceous intraplate volcanism in southern New Zealand is presented in Table 1.1. These age data suggest that there were two periods of magmatic activity, the first from 100-90 Ma related to the extension of proto-New Zealand and the second in the Chatham Islands from 86-82 Ma relating to the inception of seafloor spreading between New Zealand and Antarctica. The intraplate volcanics of New Zealand are alkaline-subalkaline and mostly mafic with rare evolved samples. A brief account of this volcanism follows.

Table 1.1: Ages of mid-Cretaceous igneous rocks from southern New Zealand.

\begin{tabular}{|c|c|c|c|}
\hline Igneous Suite & Rock Description and Locality & Age (Ma) & $\begin{array}{c}\text { Dating } \\
\text { technique }\end{array}$ \\
\hline $\begin{array}{l}\text { Tapuaeouenuku } \\
\text { Plutonic }\end{array}$ & $\begin{array}{l}\text { Kaersutite mineral separate from } \\
\text { pegmatite dyke }\end{array}$ & $101.2 \pm 1.4$ & $\mathrm{~K}-\mathrm{Ar}(\mathrm{A})$ \\
\hline \multirow[t]{3}{*}{ Complex } & $\begin{array}{l}\text { Biotite-whole rock pairs of three } \\
\text { biotite bearing gabbros }\end{array}$ & $96.1 \pm 0.5$ & $\mathrm{Rb}-\mathrm{Sr}(\mathrm{H})$ \\
\hline & Zircon (quartz syenite) & $93 \pm 10$ & fission track (D) \\
\hline & Titanite (phonotephrite) & $103 \pm 11$ & fission track (D) \\
\hline \multirow[t]{2}{*}{ Radial Dyke Swarm } & $\begin{array}{l}\text { Coarse grained trachybasalt dyke, } \\
\text { Awatere Valley }\end{array}$ & $100 \pm 1.4$ & $\mathrm{~K}-\mathrm{Ar}(\mathrm{F})$ \\
\hline & Trachybasalt dyke, Aorangi Ranges & $98.9 \pm 3.2$ & $\mathrm{~K}-\mathrm{Ar}(\mathrm{B})$ \\
\hline Lookout Volcanics & $\begin{array}{l}\text { Six trachybasalt flows, Awatere } \\
\text { Valley }\end{array}$ & $\begin{array}{c}90.3 \pm 1.6 \text { to } \\
99.9 \pm 0.7\end{array}$ & $\mathrm{~K}-\mathrm{Ar}(\mathrm{A})$ \\
\hline Gridiron Volcanics & Trachybasalt flows, Clarence Valley & $\begin{array}{c}93.5 \pm 2.0 \text { to } \\
98.3 \pm 1.3\end{array}$ & $\mathrm{~K}-\mathrm{Ar}(\mathrm{G})$ \\
\hline $\begin{array}{l}\text { Mandamus Igneous } \\
\text { Complex }\end{array}$ & $\begin{array}{l}\text { Suite of plutonic and volcanic rocks } \\
\text { and mineral separates }\end{array}$ & $97.2 \pm 1.2$ & $\mathrm{Rb}-\mathrm{Sr}(\mathrm{E})$ \\
\hline $\begin{array}{l}\text { Mt Somers Volcanic } \\
\text { Group }\end{array}$ & Suite of rhyolites, Mt Somers & $88.8 \pm 2.0$ & $\mathrm{Rb}-\mathrm{Sr}(\mathrm{C})$ \\
\hline Chatham Islands & Southern Volcanics & $\begin{array}{c}82.26 \pm 0.79 \text { to } \\
85.45 \pm 0.59\end{array}$ & ${ }^{40} \mathrm{Ar}-{ }^{39} \mathrm{Ar}(\mathrm{I})$ \\
\hline
\end{tabular}

Age data is sourced from the following A: Nicol (1977); B: George (1988); C: Barley et al. (1988); D: Baker (1990); E: Weaver \& Pankhurst (1991); F: Grapes et al. (1992); G: Reay (1993); H: Baker \& Seward (1996); I: Panter et al. (2006). 


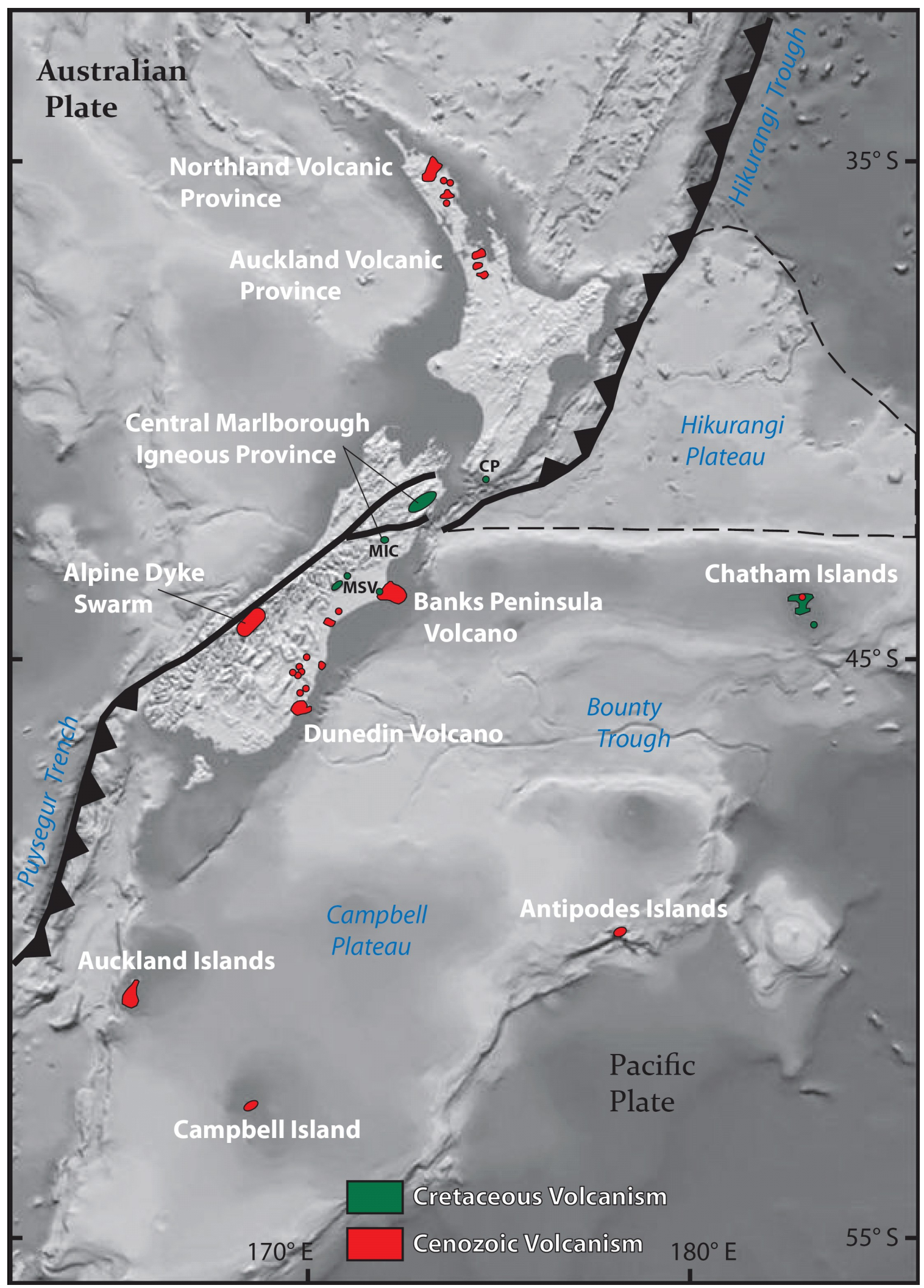

Figure 1.5: Map illustrating the distribution of Cretaceous to Recent intraplate volcanism in New Zealand relative to the present day plate boundary. Based on diagrams in Weaver \& Smith (1989). The Sub-Antarctic Islands comprise the Auckland Islands, Antipodes Islands and Campbell Island. CP-Cape Palliser; MIC-Mandamus Igneous Complex; MSV-Mount Somers Volcanics.

Background courtesy of NIWA. 


\subsubsection{Central Marlborough Igneous Province}

The rocks of the CMIP (as described in Section 1.6) are the oldest examples of intraplate volcanic rocks (e.g. Lookout Volcanics) in onshore New Zealand. They were erupted during an extensional tectonic regime on the margin of Gondwana from 100 to $90 \mathrm{Ma}$.

\subsubsection{Mount Somers Volcanics}

The Mount Somers Volcanics (Wood, 1974; Barley, 1987) of mid-Canterbury appear to be temporally related to the CMIP. A Rb-Sr age of $88.8 \pm 2.0 \mathrm{Ma}$ has been obtained for these rocks (Barley et al., 1988). The Mount Somers Volcanics comprise a series of garnet-bearing high-K andesites to rhyolites. Barley (1987) concluded that these rocks are the result of crustal anatexis due to the increased heat and magma flux due to the change from compressional to extensional tectonics ca. $100 \mathrm{Ma}$. The geochemical traits of these non arc-like rocks are consistent with assimilation of lower crust by tholeiitic magmas.

\subsubsection{Cape Palliser}

Minor igneous rocks consisting of spilitic basalt, dolerite and camptonites, are present as flows, dykes and sills in the southern Aorangi Range-Cape Palliser area of the southeastern, North Island (Challis, 1960b). The pillow lavas are mostly green, although some are reddish, with both types present in some outcrops. Irregular dykes and sills up to $1.5 \mathrm{~m}$ thick intrude Late Cretaceous greywacke, but they can only be traced along strike for a few metres. A K-Ar age of $98.9 \pm 3.2$ Ma has been obtained on a camptonite dyke from Kupe Stream (George, 1988). The Aorangi dykes have a strongly alkaline signature, and thus the camptonites of Aorangi Range are considered to be distinct from those at Brocken Range (Challis, 1960b; Grapes, 1970), but co-magmatic with those of the Inland Kaikouras. The geochronological, mineralogical and geochemical similarities of the dykes of the Aorangi Range and Awatere Valley indicate the Aorangi 
lamprophyres represent a northern extension of the CMIP. However, more recently Baker (1990) concluded the Aorangi dykes are less chemically evolved and their composition is controlled by the evolution of a nearby pluton, making them distinct from the Awatere dykes despite their similar age.

\subsubsection{Chatham Islands}

The Chatham Islands, located at the eastern end of the Chatham Rise, are the remnants of a large basaltic shield volcano that began forming in the Late Cretaceous during an extensional tectonic regime. Grindley et al. (1977) recognized that volcanism on the Chatham Islands occurred in three distinct episodes on the basis of mapping and $26 \mathrm{~K}$-Ar dates; Late Cretaceous (81-70 Ma) Southern Volcanics, Late Eocene (41-36 Ma) Northern Volcanics and MiocenePliocene (5-0 Ma) Rangitihi Volcanics. New ${ }^{40} \mathrm{Ar}^{3}{ }^{39} \mathrm{Ar}$ ages for the Late Cretaceous Southern Volcanics of 85-82 Ma suggest an earlier more rapid period of volcanism (Panter et al., 2006), which would be consistent with formation of the Pacific-Antarctic spreading ridge. Morris (1985a \& 1985b) studied the petrology and geochemistry of the Eocene and Cretaceous volcanic rocks in detail. The Late Cretaceous alkaline volcanic rocks on the Chatham Islands comprise a basalt-trachyte suite on the south of the two main islands (Chatham and Pitt). The Southern Volcanics are volumetrically the most significant and widely distributed group, consisting of 2-5 m thick lava flows that typically have reddened brecciated bases and scoriaceous tops indicative of subaerial emplacement. Exposed lava sequences up to $300 \mathrm{~m}$ thick occur on the southern coast of Chatham Island and thin progressively to the north, consistent with a vent located in the Pitt Strait (Morris, 1985b).

\subsubsection{South Island}

The South Island is marked by widely scattered areas of Cenozoic continental intraplate volcanism of predominantly mafic, alkaline to sub-alkaline compositions. For a more comprehensive review of this volcanism the reader is 
referred to Weaver \& Smith (1989). Major episodes of activity were in the Paleocene to Lower Eocene, Upper Eocene to Lower Oligocene, and in the Miocene, with minor volcanism in the Pliocene. The most recognisable volcanic areas are the large Miocene shields of the Banks Peninsula and Dunedin volcanoes. Other occurrences include the mafic lava fields of Canterbury, Marlborough, and Otago, and small volumes of lava and minor intrusions in South Westland and the Southern Alps.

The three largest preserved intraplate volcanic events in the South Island occurred in the Miocene. Adams \& Cooper (1996) relate this alkaline magmatism to a transtensional tectonic regime related to the inception of the Alpine Fault plate boundary in the South Island. The Alpine Dyke Swarm is a lamprophyre dyke swarm extending ca. $110 \mathrm{~km}$ from the Alpine Fault in southern Westland to northwest Otago (Cooper, 1986). Ten lamprophyre dykes near Wanaka yielded K-Ar ages of 32-25 Ma (Adams \& Cooper, 1996). The swarm includes dykes, sills and diatremes intruded into the Haast Schist. The dykes have predominant eastwest orientations and are typically $<2 \mathrm{~m}$ wide. The Dunedin Volcano was constructed between 13 and $10 \mathrm{Ma}(\mathrm{McD}$ ougall \& Coombs, 1973) with the earliest activity being shallow marine eruptions of silica-saturated trachytes and basalts and the most recent events the subaerial emplacement of phonolitic domes and lava flows. The largest accumulation of Miocene volcanic rocks in the South Island occurred at Banks Peninsula (11-5.8 Ma). The peninsula is the remnants of two large composite volcanoes; the Lyttelton volcano in the northwest and the Akaroa volcano in the southeast. The present diameters of these volcanoes are ca. 25 and ca. $35 \mathrm{~km}$, respectively, although both extend for a considerable distance under the surrounding plains (Weaver et al., 1985). Adams \& Cooper (1996) propose the termination of this major period of volcanism in the Late Miocene was the result of change to a compressional tectonic regime. 


\subsubsection{North Island}

In the North Island, Cenozoic volcanism unrelated to subduction in the Hikurangi Trough is rare. However, a dominantly basaltic volcanic association on the Northland-Auckland peninsula has intraplate petrographic and geochemical characteristics (Weaver \& Smith, 1989). This association is Pliocene to Holocene in age and has no obvious tectonic relationship with the active plate boundary. Volcanism is considered intraplate in character having developed on the Australian Plate well behind the present plate boundary. The Northland and Auckland provinces are $500-700 \mathrm{~km}$ and $350-400 \mathrm{~km}$ behind the convergent plate boundary, respectively. The intraplate basaltic rocks of the North Island are divided on the basis of geographical separation and petrographic differences into two provinces, although their ages overlap. The Northland Province contains basalts transitional between alkaline and tholeiitic. It includes minor intermediate rocks and rare rhyolites. The Auckland Province contains an exclusively basaltic spectrum of rock types ranging from nephelinite and basanite, through to alkaline and tholeiitic basalt. The province is divided into three distinct fields comprising ca. 138 distinct eruptive centres, with Rangitoto Island the youngest and largest individual eruptive centre $\left(23 \mathrm{~km}^{2}\right)$.

\subsubsection{Sub-Antarctic Islands}

Volcanism on the Sub-Antarctic Islands of the Campbell Plateau decreases in age from west to east. The Auckland Islands are $400 \mathrm{~km}$ south of New Zealand at the western edge of the Campbell Plateau. The islands comprise two coalesced volcanic shields of dominantly mafic lava flows; the Carnley Volcano to the south and Ross Volcano in the north (Gamble \& Adams, 1985). Based on K-Ar age determinations the Carnley Volcano is $21.2 \pm 3.2 \mathrm{Ma}$ and Ross Volcano is younger at $15.3 \pm 1.9 \mathrm{Ma}$ (Adams, 1983). Campbell Island is New Zealand's southernmost Sub-Antarctic Island. Miocene volcanic rocks cover most of the island and include lava flows, pyroclastic rocks and volcanoclastic breccias (Morris, 1984). 
Apart from a shallow intrusion of gabbro that predates volcanism by ca. $9 \mathrm{Ma}$, most of the deposits are late Miocene in age (Adams et al., 1979). The Antipodes Islands are a small, isolated, island group that lies at the eastern edge of the Campbell Plateau. The islands are composed of alkaline lavas and pyroclastic rocks, including tuff cone and ring deposits (Gamble et al., 1986). A Quaternary age for the islands is inferred based on the well-preserved volcanic morphology and two K-Ar dates (Cullen, 1969).

\subsection{HIMU VOLCANISM}

\subsubsection{Definition of HIMU volcanism}

The parameter $\mu$ is the ${ }^{238} \mathrm{U} /{ }^{204} \mathrm{~Pb}$ ratio of a sample. Although ${ }^{238} \mathrm{U} /{ }^{204} \mathrm{~Pb}$ ratios change significantly with time, by convention $\mu$ is defined as the present day (i.e. zero age, $\mathrm{t}=0$ ) ${ }^{238} \mathrm{U} /{ }^{204} \mathrm{~Pb}$ ratio (Hofmann, 2003). Mantle sources are characterised on the basis of varying isotopic characteristics (Zindler \& Hart, 1986; Hart et al., 1992). A mantle component labelled HIMU (high $\mu$ ) is one of these originally defined reservoirs with highly radiogenic $\mathrm{Pb}$ isotope ratios observed in basalts from a number of ocean islands e.g., St Helena in the Atlantic Ocean and the Cook-Austral islands in the South Pacific. While some authors use HIMU in the originally defined sense, others refer to HIMU as a ubiquitous component in many mid-ocean ridge and ocean island basalt (MORB and OIB) sources. While there is extensive overlap between $\mathrm{Pb}$ isotope ratios found in MORB and OIB, the most radiogenic $\mathrm{Pb}$ isotopes are found in OIB and classified as HIMU-like OIB forming a distinct field in isotopic space (Figure 1.6). The term HIMU has often been used to loosely describe basalts with ${ }^{206} \mathrm{~Pb} /{ }^{204} \mathrm{~Pb}>19.5$ (Stracke et al., 2005). However, OIB with the most radiogenic $\mathrm{Pb}$ can actually be divided into two groups; the first group is represented by the most radiogenic $\mathrm{Pb}$ isotope signatures among MORB and OIB $\left({ }^{206} \mathrm{~Pb} /{ }^{204} \mathrm{~Pb}>20.5\right)$ and relatively low $\left({ }^{87} \mathrm{Sr} /{ }^{86} \mathrm{Sr}<0.703\right)$, and is hereafter referred to as HIMU. The second group is characterised by 
slightly less radiogenic $\mathrm{Pb}$ isotope ratios but more radiogenic $\mathrm{Sr}$ isotopes $\left({ }^{206} \mathrm{~Pb} /{ }^{204} \mathrm{~Pb}=19.5-20.5\right.$ and ${ }^{87} \mathrm{Sr} /{ }^{86} \mathrm{Sr}=0.7028-0.7034$, respectively $)$; it overlaps and extends the trend of MORB in ${ }^{206} \mathrm{~Pb} /{ }^{204} \mathrm{~Pb}$ versus ${ }^{87} \mathrm{Sr} /{ }^{86} \mathrm{Sr}$ diagram. This moderately HIMU-like component is called FOZO after the ubiquitous component of Stracke et al. (2005).

\subsubsection{Generation of HIMU volcanism}

The origin of the HIMU mantle end-member has been variously ascribed to the preferential partitioning of $\mathrm{Pb}$ into the core during early Earth accretion (Vidal \& Dosso, 1978), recycling of ancient oceanic lithosphere (Hofmann \& White, 1982; Sun \& McDonough, 1989), delamination of the subcontinental lithosphere (McKenzie \& O'Nions, 1983), metasomatism by $\mathrm{CO}_{2}$ rich fluids (Nakamura \& Tatsumoto, 1988), and $\mathrm{Pb}$ being more incompatible than $\mathrm{U}$ during partial melting (Meijer et al., 1990). However, more recently there has been a general consensus that oceanic lithosphere recycling processes are in some way involved in the formation of HIMU mantle sources (Weaver, 1991; Chauvel et al., 1992). HIMU ocean islands are marked by their extreme isotopic homogeneity, when compared to other OIB types. Isotopic variability decreases noticeably towards high ${ }^{206} \mathrm{~Pb} /{ }^{204} \mathrm{~Pb}$ ratios, and thus such rocks could represent a pure end-member composition uncontaminated by additional components (Woodhead, 1996). This is consistent with the involvement of recycled oceanic lithosphere as this constitutes one of the most geochemically homogeneous reservoirs known. HIMU type OIB sources are quite rare, with the production of these sources likely to represent a special combination of age and composition of subduction modified recycled oceanic crust. Stracke et al. (2003a) demonstrate quantitatively that HIMU sources can only be created by recycling igneous oceanic crust if it has undergone substantial modification during subduction. The highly radiogenic $\mathrm{Pb}$ of HIMU samples require mantle sources with high $\mathrm{U} / \mathrm{Pb}$ and $\mathrm{Th} / \mathrm{Pb}$ ratios. At the same time, HIMU samples are among those OIB with the 

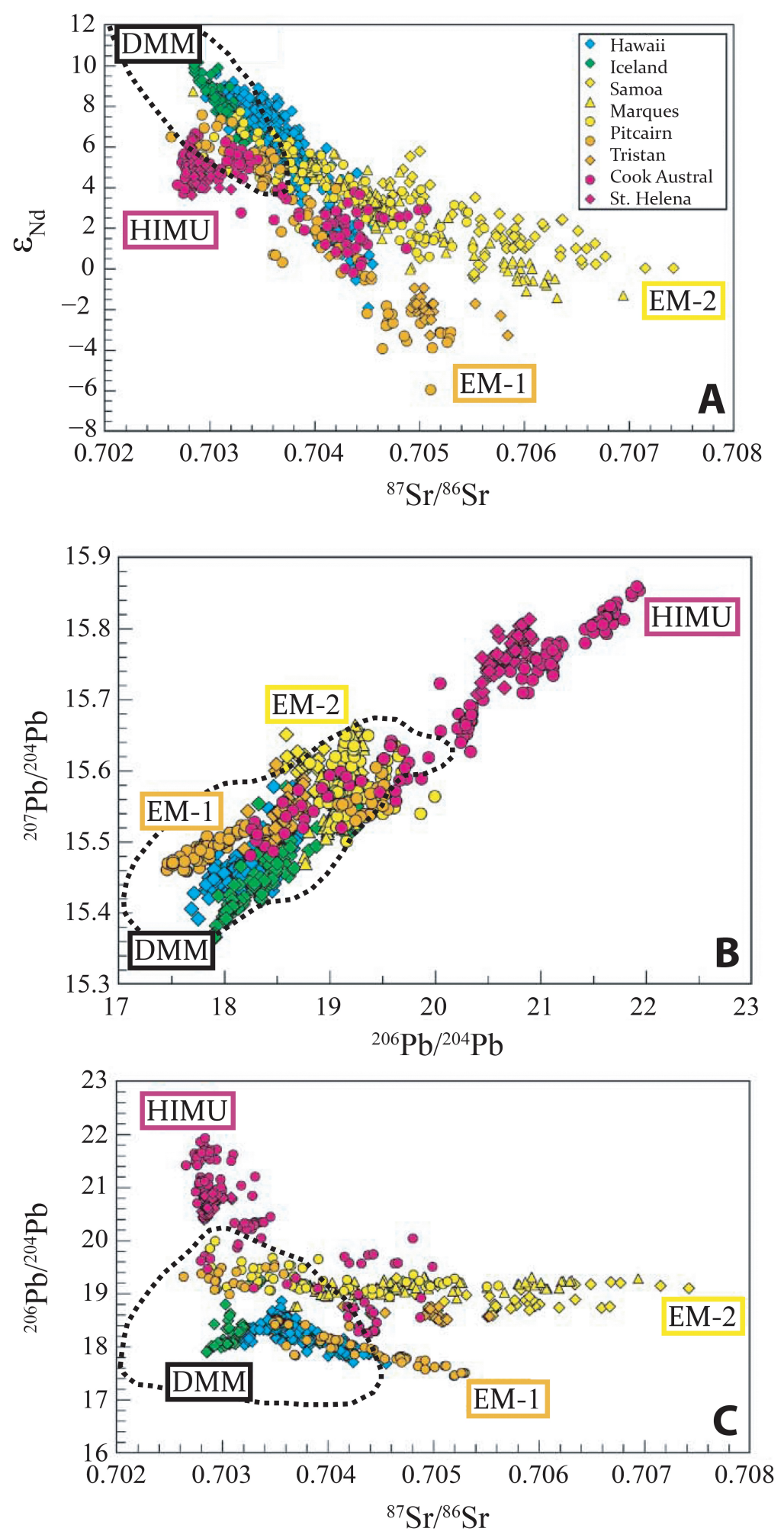

Figure 1.6: Isotope diagrams showing the variability of selected OIB (excluding island arcs) and MORB 'mantle components' in isotopic space. The islands or island groups selected are chosen to represent extreme isotopic compositions in isotope diagrams. They are the "type localities" for HIMU (Cook-Austral Islands and St. Helena), EM-1 (Pitcairn-Gambier and Tristan), EM-2 (Society Islands, Samoa, Marquesas). The DMM is represented by the black dotted line and comprises the variability shown by Atlantic, Indian and Pacific MORBs. (A) ${ }^{87} \mathrm{Sr} /{ }^{86} \mathrm{Sr}$ versus $\varepsilon_{\mathrm{Nd}}$; (B) ${ }^{206} \mathrm{~Pb} /{ }^{204} \mathrm{~Pb}$ versus ${ }^{207} \mathrm{~Pb} /{ }^{204} \mathrm{~Pb}$; (C) ${ }^{87} \mathrm{Sr} /{ }^{86} \mathrm{Sr}$ versus ${ }^{206} \mathrm{~Pb} /{ }^{204} \mathrm{~Pb}$. EM-1: Enriched Mantle 1; EM-2: Enriched Mantle 2; DMM; Depleted MORB Mantle. Modified after Hofmann (2003). 
least radiogenic $\mathrm{Sr}$, requiring source $\mathrm{Rb} / \mathrm{Sr}$ ratios nearly as low as those of the more depleted MORB (Hofmann, 2003). The currently popular hypothesis is that the generation of HIMU sources requires the incorporation of recycled oceanic crust, which has lost alkalis and $\mathrm{Pb}$ during alteration and subduction (Hofmann \& White, 1982; Chauvel et al., 1992). Pb loss would result in elevated U/Pb and Th/ $\mathrm{Pb}$ and produce elevated ${ }^{206} \mathrm{~Pb} /{ }^{204} \mathrm{~Pb}$ ratios with time. However, another possibility is that the characteristics of HIMU sources might also be explained by enriching oceanic lithosphere metasomatically by the infiltration of low-degree partial melts, which have high $\mathrm{U} / \mathrm{Pb}$ and $\mathrm{Th} / \mathrm{Pb}$ ratios because of magmatic enrichment of $\mathrm{U}$ and Th over $\mathrm{Pb}$ (Sun \& McDonough, 1989). The Rb/Sr ratios of these sources should then also be elevated over those of ordinary MORB sources, but this enrichment would be insufficient to significantly raise ${ }^{87} \mathrm{Sr} /{ }^{86} \mathrm{Sr}$ ratios because the initial $\mathrm{Rb} / \mathrm{Sr}$ of these sources was well below the level where any significant ingrowth of radiogenic ${ }^{87} \mathrm{Sr}$ could occur (Hofmann, 2003).

\subsubsection{HIMU-like volcanism in New Zealand}

The intraplate igneous rocks of southern New Zealand are low in volume $\left(<10,000 \mathrm{~km}^{3}\right)$, are widely scattered within a $8000 \mathrm{~km}^{2}$ area and include several large shield volcanoes, mafic lava fields and small intrusive complexes (Weaver \& Smith, 1989). The mafic rocks are predominantly alkaline and have OIB-like major and trace element compositions and isotopic signatures that resemble a HIMU OIB (Gamble et al., 1986; Barreiro \& Cooper, 1987; Weaver \& Smith, 1989; Baker et al., 1994; Hoke et al., 2000; Price et al., 2003; Panter et al., 2006). The isotopic data in Table 1.2 show there is a strong similarity between the mafic intraplate rocks of southern New Zealand and HIMU OIB. This HIMU-like source in southern New Zealand is a long lived feature with volcanism erupted for $100 \mathrm{Ma}$ exhibiting similar characteristics. It has been suggested that the HIMU source resides within the subcontinental lithosphere and was generated by 
a prolonged period of Palaeozoic subduction that occurred along the Pacific margin of Gondwana before 100 Ma (Panter et al., 2006; Sprung et al. 2007).

Table 1.2: Isotopic data for HIMU ocean islands and New Zealand intraplate volcanism.

\begin{tabular}{|c|c|c|c|}
\hline & ${ }^{87} \mathrm{Sr} /{ }^{86} \mathrm{Sr}$ & $\varepsilon^{\mathrm{Nd}}$ & ${ }^{206} \mathrm{~Pb} /{ }^{204} \mathrm{~Pb}$ \\
\hline Depleted MORB & 0.7025 & +8.0 to +12.0 & 17.7 \\
\hline \multicolumn{4}{|l|}{ HIMU OIB } \\
\hline St Helena & $0.7028-30$ & +5.0 & $>20.5$ \\
\hline Tubaii & 0.7029 & +5.0 & 21.2 \\
\hline Mangaia & $0.7027-29$ & +5.0 to +5.7 & 21.5-21.9 \\
\hline \multicolumn{4}{|l|}{ New Zealand } \\
\hline Tapuaeouenuku Igneous & $0.7028-30$ & +3.5 to +5.0 & 20.1 \\
\hline \multicolumn{4}{|l|}{ Complex $(96 \pm 0.5 \mathrm{Ma})$} \\
\hline Chatham Is (85-82 Ma) & $0.7029-31$ & +4.2 to +4.9 & $20.2-20.6$ \\
\hline Dunedin (21-10 Ma) & $0.7028-33$ & +4.5 to +5.6 & $19.5-20.0$ \\
\hline $\begin{array}{l}\text { Westland lamprophyres } \\
(32-25 \mathrm{Ma})\end{array}$ & $0.7029-35$ & +3.5 to +5.3 & $19.2-20.6$ \\
\hline Campbell Is (16-7 Ma) & $0.7037-40$ & +3.6 to +4.7 & $19.2-19.3$ \\
\hline Antipodes Is (<0.5 Ma) & 0.7029 & +5.3 to +5.5 & 20.5-20.6 \\
\hline $\begin{array}{l}\text { South Auckland volcanic } \\
\text { field (1.6-0.5 Ma) }\end{array}$ & $0.7027-31$ & +6.0 to +6.7 & $19.0-19.3$ \\
\hline
\end{tabular}

\subsection{OBJECTIVES AND OUTLINE OF THIS STUDY}

The Lookout Volcanics of central Marlborough are the oldest manifestation of the HIMU-like volcanism found in the Zealandia region, yet they have not been the subject of a modern petrological, geochemical and isotopic study. Previous work is limited to basic field, petrographic and whole rock chemical studies of reconnaissance samples from the Lookout Volcanics, which were carried out 3050 years ago (Challis, 1960a \& 1966; Nicol, 1977).

This thesis presents a detailed field, petrological, chemical and isotopic study of an extensive suite of lava flows collected from a ca. $650 \mathrm{~m}$ section of the 
Lookout Volcanics with the objective of better understanding the formation of the HIMU mantle source beneath the New Zealand region, and the processes of magma generation and modification in central Marlborough during the midCretaceous. Research involved the following aspects: (a) three weeks of fieldwork sampling the Lookout Volcanics in the Mount Lookout region; (b) extensive petrographic and electron microprobe characterisation of the volcanic rocks and the minerals they contain; (c) high precision electron microprobe analysis of minor elements $(\mathrm{Ca}, \mathrm{Ni})$ in olivine phenocrysts in the Lookout Volcanics in order to evaluate the nature of the mantle source (i.e., peridotitic or pyroxenitic) using the approach of Sobolev et al. (2005 \& 2007); (d) laser ablation inductively coupled plasma mass spectrometer trace element analysis of clinopyroxene phenocrysts in the Lookout Volcanics; (e) major and trace element analysis of whole rock samples of the Lookout Volcanics by X-ray fluorescence spectrometry and solution inductively coupled plasma mass spectrometry; (f) radiogenic isotope analysis ( $\mathrm{Sr}-\mathrm{Nd}-\mathrm{Pb}-\mathrm{Hf})$ of selected volcanic rocks and clinopyroxene phenocrysts, by multi-collector inductively coupled plasma mass spectrometry; (g) laser fluorination oxygen isotope analysis of minerals (olivine and zoned clinopyroxene crystals) from selected samples.

This thesis is structured as follows:

1) Chapter 1 Introduction: An overview of the geology of Marlborough (i.e., stratigraphy, tectonics, geologic history and igneous rocks) and brief reviews of intraplate volcanism in New Zealand and the nature of HIMU volcanism.

2) Chapter 2 Field Geology \& Sampling: A chapter showing the locations of sample collection, and details of constructing the composite volcanic stratigraphy and relationships with the regional dyke swarm.

3) Chapter 3 Petrography \& Mineral Chemistry: Detailed petrographic description and classification of the rocks of the Lookout Volcanics combined with characterisation of minerals by electron microprobe. 
4) Chapter 4 Petrogenesis of the Lookout Volcanics: a manuscript prepared for submission to Journal of Petrology incorporating the findings of this thesis.

5) Chapter 5 Geochronology: A brief summary of geochronological data related to the eruption of the Lookout Volcanics including new $\mathrm{Rb}-\mathrm{Sr}$ age constraints.

6) Chapter 6 Synthesis \& Conclusions: A brief overview and summary of this thesis including the conclusions reached on the nature of the HIMU source under southern New Zealand and the processes occurring during the eruption of the Lookout Volcanics.

7) Appendices including a detailed description of the analytical methods used in this thesis, a complete sample list, and tables listing the data acquired in this study. 


\section{CHAPTER 2: FIELD GEOLOGY \& SAMPLING}

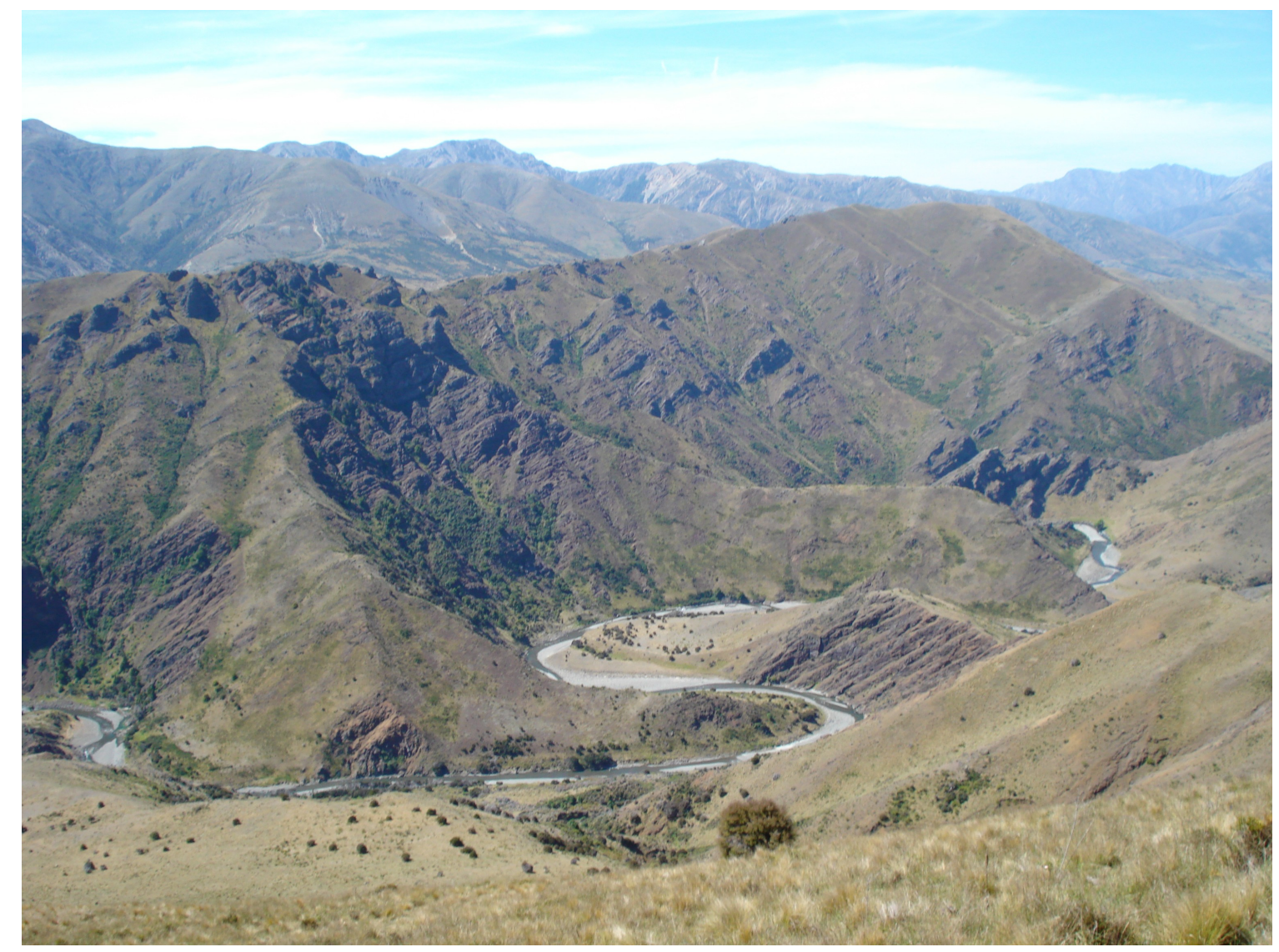

Plate 3: View looking to the northeast with the Awatere River meandering through outcrops of lava flows of the Lookout Formation. 


\subsection{INTRODUCTION}

The Lookout Volcanics outcrop in the middle Awatere Valley between Middlehurst and Gladstone Downs farming stations. Outcrops of volcanic rock are plentiful due to block faulting and the highly erosive climate of the Inland Kaikoura region. Preservation of lava flows varies considerably, but considering the rocks are of mid-Cretaceous age, the majority are extremely well preserved (i.e. $>60 \%$ of ankaramites contain fresh olivine phenocrysts). A detailed sampling of the Lookout Volcanics was undertaken (103 samples) and a ca. $700 \mathrm{~m}$ composite stratigraphic section constructed, largely based on a continuous sequence of lava flows outcropping in Middlehurst Stream (Section B). This chapter illustrates the volcanic rocks sampled in the field, their interrelationships, and how the composite volcanic stratigraphy was constructed.

\subsection{FIELD METHODS}

The rocks of the Lookout Volcanics are exposed from an altitude of ca. $400 \mathrm{~m}$ in the Awatere River to the top of Mount Lookout $(1814 \mathrm{~m})$. Study of the Lookout Volcanics in this thesis is largely based on a ca. $550 \mathrm{~m}$ continuous outcrop of lava flows in Middlehurst Stream (Section B) and two further sections where the basal contact of the volcanic rocks is observed (Sections C \& G) (Figure 2.1). Satellite aerial photographs and topographic maps were used to assess areas with possible outcrops for investigation prior to fieldwork. An initial broad reconnaissance survey ( 3 days) of the Lookout Volcanics was undertaken to find suitable sites for sampling the thickest continuous sections of lava flows. Outcrop locations were made using a portable global positioning system. Sampling of sections was undertaken in stratigraphic order (i.e. from bottom to top), with considerable care taken to collect the freshest possible volcanic material. In all the sections 
studied, care was taken to ensure that representative rock types were sampled as well as any unusual lithologies that were discovered. Dips of lava flows are generally between $20-40^{\circ}$, which is approximately perpendicular to the dip slope of outcrops meaning the true thickness of the lava flows is approximately the apparent thickness observed in outcrops. Section B was measured in detail using a tape measure to ascertain the average thickness of lava flows in the formation.

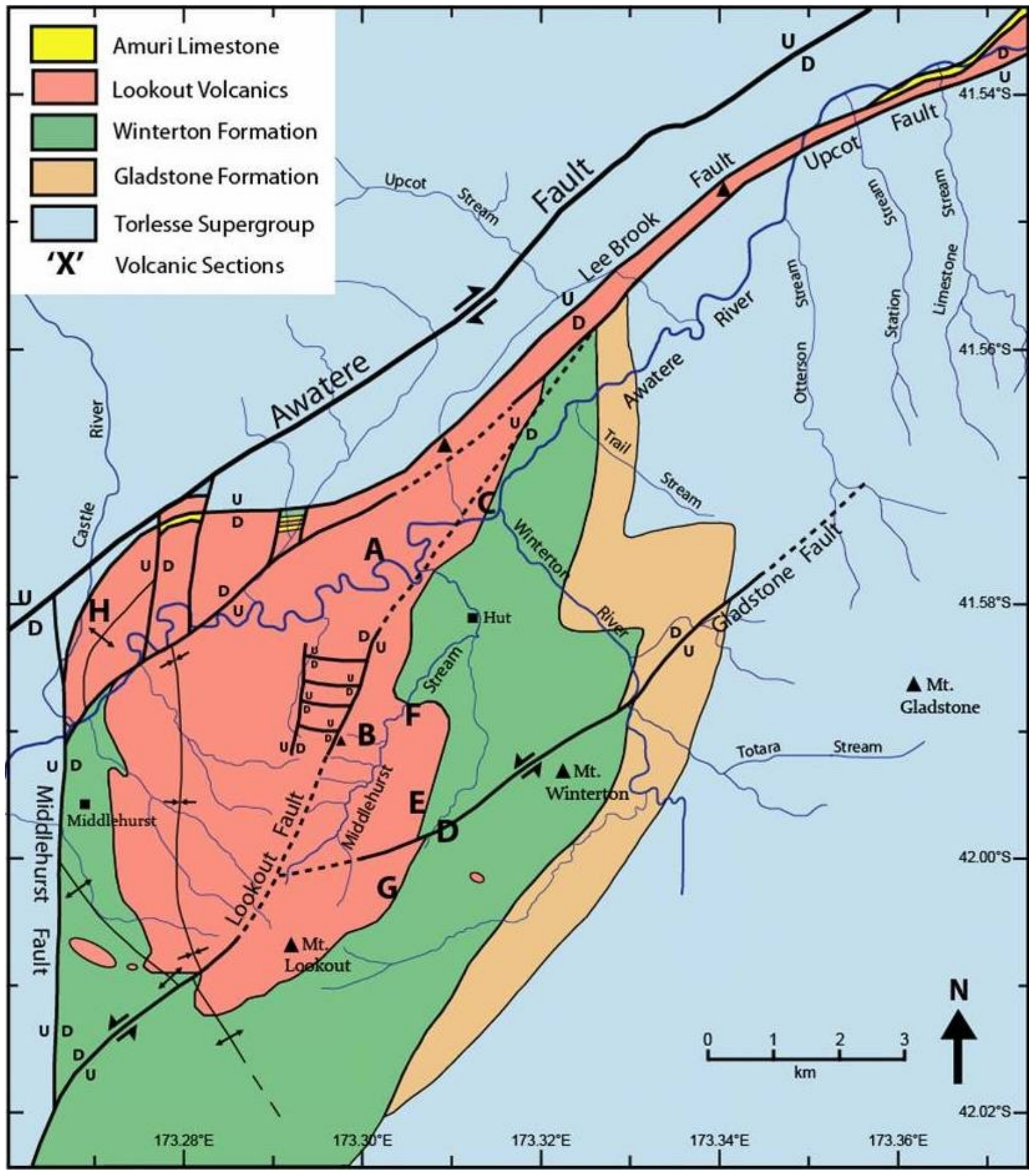

Figure 2.1: Geological map of the Mount Lookout area, showing the preservation of stratigraphic units, and the complex structure of the Lookout Formation. Locations of volcanic sections sampled in this study are shown. Locations of faults are inferred when their exact location is uncertain. Modified after Challis (1960a) and Nicol (1977). 


\subsection{STRATIGRAPHY}

A brief description of the units outcropping in the middle Awatere Valley based on observations in the field and the work of Challis (1966), Nicol (1977) and Rattenbury et al. (2006) follows. The distributions of these formations are shown in Figure 2.1.

\subsubsection{Pahau Terrane (Torlesse Supergroup)}

Basement in the central Awatere Valley is Late Jurassic to Early Cretaceous Torlesse Supergroup greywacke of the Pahau Terrane. The greywacke is composed mainly of indurated, grey, quartzo-feldspathic, sandstone and mudstone. Two main varities occur: (1) a thinly interbedded normally graded, sandstone-mudstone unit; (2) a massive, decimetre bedded sandstone unit (Rattenbury et al., 2006). Thin argillite beds are common in the middle Awatere Valley (e.g. in the Hodder River).

\subsubsection{Gladstone Formation}

The late Early Cretaceous (Urutawan) Gladstone Formation is preserved to the east of Mount Lookout between the Awatere and Winterton rivers. The formation comprises poorly fossiliferous, indurated conglomerate, sandstone, siltstone and mudstone that becomes finer grained up section (Montague, 1981). This formation unconformably overlies basement with minor shearing along the contact (Rattenbury et al., 2006).

\subsubsection{Winterton Formation}

The Winterton Formation is of latest Early Cretaceous (Motuan) age and is preserved to the south, east and northeast of Mount Lookout. It consists of laterally discontinuous lenses of moderately indurated, mildly deformed conglomerate and siltstone. The formation onlaps and unconformably overlies the Gladstone Formation and Pahau Terrane. 


\subsubsection{Lookout Volcanics}

The term Lookout Formation (Challis, 1966) is used throughout this work interchangeably with the term Lookout Volcanics. Although block faulting means that no complete sequence is preserved within the formation, at least 1000 $\mathrm{m}$ of lava flows are preserved near Mount Lookout. The majority of the formation consists of terrestrial lava flows but minor marine tuffs and nonvolcanic sediments are preserved at the top of the section. The basal lava package of the Lookout Volcanics is observed in numerous localities, displaying a sharp contact between the basal flow and underlying terrestrial sediments, which in turn rest on shallow marine sediments. The marine sedimentary rocks underlying the Lookout Volcanics contain Inoceramus ipuanus, a type fossil of the Motuan Stage (Challis, 1960a). The top of the formation at Limestone Stream consists of pillow lava interbedded with marine tuff and limestone. The limestone is almost entirely composed of Inoceramus tawhanus fragments, a fossil of the Ngaterian Stage (Challis, 1966). A complete volcanic section is not preserved because the top of the formation is always in fault contact with the Amuri Limestone. Based on stratigraphic evidence, the Lookout Volcanics are inferred to be entirely of Ngaterian age, which is in agreement with K-Ar ages of 100 to 90 Ma from six trachybasalts sampled from the Lookout Volcanics (Nicol, 1977).

Lava flows are typically 2-10 m thick with the thickest lava flow being $24 \mathrm{~m}$ thick. Some lava flows are laterally continuous and can be traced over distances of several kilometres (Figure 2.2 A). Weathering has occurred between some flows, but the relatively unweathered nature of many rocks, especially the more mafic ones and the absence of sediments between flows indicate a rapid accumulation of volcanic material. The volcanic rocks are volumetrically dominated by olivine ankaramite and trachybasalt, with more felsic rocks types being relatively scarce. Nicol (1977) refers to a highly porphyritic olivineclinopyroxene phyric rock within the formation as an ankaramite. 


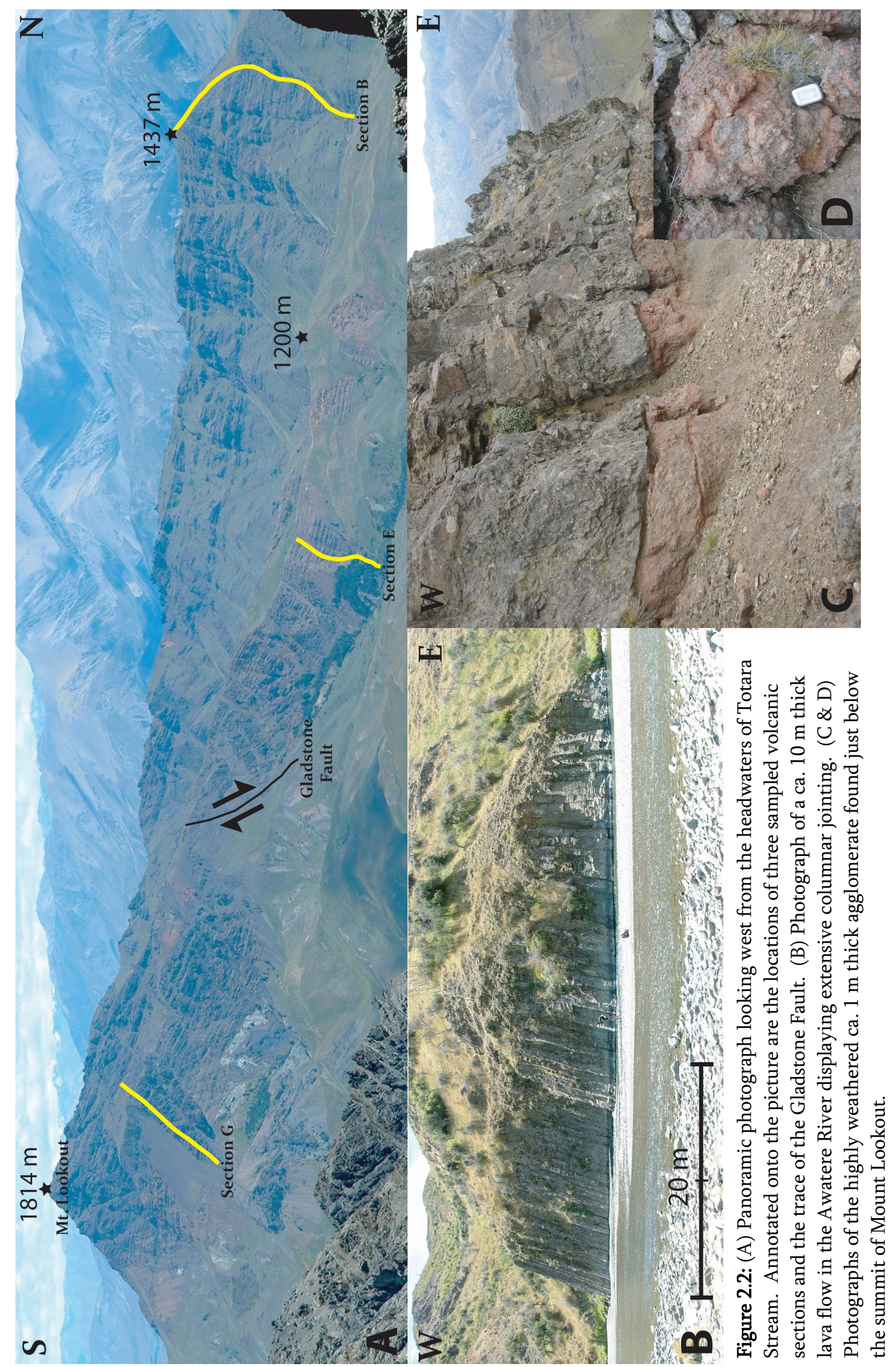


Ankaramites are accumulative rocks which are essentially phenocryst rich (ca. $50 \%$ phenocrysts) basalts. The more basic flows are generally quite fresh, but the more evolved transitional trachybasalts and trachyandesites are frequently hydrothermally altered and highly weathered. The ankaramites stand out as resistant, often massive, flows sometimes with columnar jointing (e.g. Figure 2.2 B). In contrast, the less porphyritic flows are often more fractured and obscured by scree, making it hard to predict the relative proportions of rock types. Breccias and agglomerates that may indicate a central vent are generally absent from the formation. However, a volcanic breccia occurs in Burr Stream in the northern part of the formation which Nicol (1977) inferred to be formed by faulting. A ca. $1 \mathrm{~m}$ thick highly weathered poorly welded agglomerate containing varying lithologies is also preserved just below the summit of Mount Lookout (Figures 2.2 C \& D).

\subsubsection{Amuri Limestone}

The Amuri Limestone is of Miocene age and in the middle Awatere Valley preservation of this formation is limited to small fault bounded slivers near the Awatere Fault. The formation consists of predominantly white, hard, siliceous, micritic limestone or interbedded limestone and marl (Rattenbury et al., 2006).

\subsection{STRUCTURE}

The regional tectonics of Marlborough were described in Chapter 1.4. This section describes the complex structure of the volcanic rocks of the Lookout Formation in the central Awatere Valley. Although the volcanic rocks of the Lookout Formation must once have formed a more extensive sheet, the Lookout Volcanics are now restricted to the fault angle depression of the Awatere Valley where the formation covers an area of ca. $50 \mathrm{~km}^{2}$ (Figure 2.1). A narrow band of volcanic rocks extends for ca. $15 \mathrm{~km}$ to the north along the Awatere Fault as fault 
bound slivers between the Lee Brook and Upcot Faults. Several other faults also cut the volcanic rocks. The upthrown side of the Lookout Fault preserves the base of the volcanic section. The central part of the Lookout Volcanics forms a northwest plunging syncline. Away from the Awatere Fault dips are generally < $45^{\circ}$, but they steepen markedly towards this fault, and in the Burr Stream area are nearly vertical. The structure may be locally quite complex, with a small graben like feature to the west of the Lookout Fault (Figure 2.1). Challis (1961) noted that in the Awatere Valley most dykes are preserved normal to Cretaceous sediments, indicating vertical intrusion. The present dips of the dykes are the result of mainly post-Cretaceous northeast-trending folding. The complex faulted and folded structure of the Lookout Volcanics makes it difficult to assemble a complete volcanostratigraphy.

\subsection{VOLCANIC SECTIONS}

The volcanic sections sampled during this study are marked on Figure 2.1. Extensive sampling was not undertaken at all sites due to the difficulty of correlating between sections. Detailed sampling was carried out at those sections deemed to be of the highest quality.

\subsubsection{Section A (Awatere River)}

Section A outcrops in the Awatere River ca. $5.5 \mathrm{~km}$ northeast of Middlehurst Station. It comprises a continuous package of ca. 55 lava flows, ca. $350 \mathrm{~m}$ in thickness (Figure 2.3). Lava flows are 5-12 m thick, massive, and well preserved with mafic flows dominating the bottom part of the outcrop with fresh olivine in $80 \%$ of the sampled flows. Six samples were collected at this site from the base of the section, but further sampling higher in the section was undertaken at Section B. 


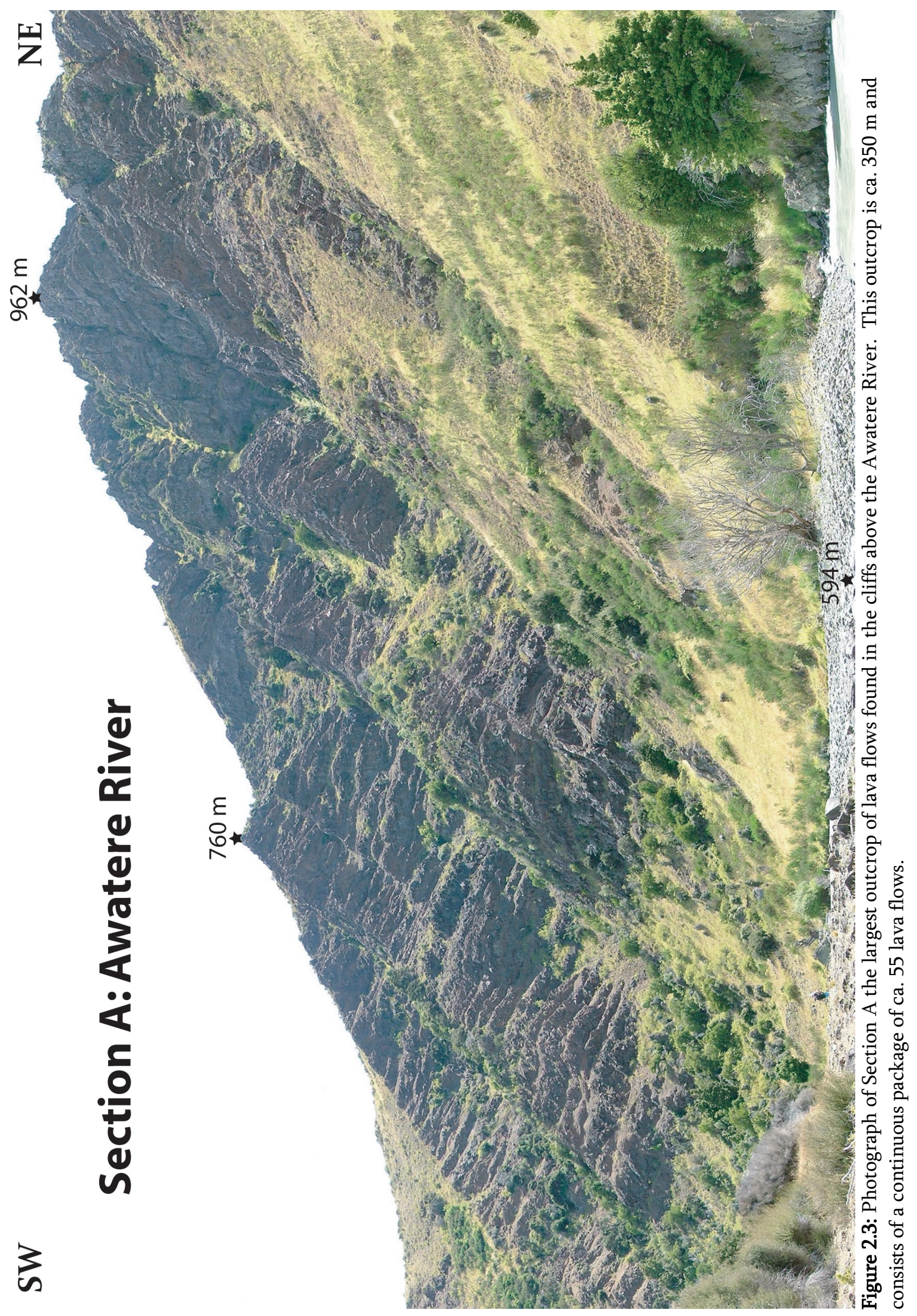




\subsubsection{Section B (Middlehurst)}

Section B contains the bulk of samples studied in detail in this thesis. Careful examination of this section revealed no faulting, indicating it preserves a continuous record of the accumulation of volcanic material. Located on the south-facing cliffs above Middlehurst Stream, sampling of Section B required traversing $550 \mathrm{~m}$ of altitude (Figure 2.4). Fifty-four samples were collected from this package of ca. 100 lava flows. Prominent lava flows were carefully traced horizontally when moving to new sampling localities (i.e. Figures $2.4 \mathrm{~B}$ to C). The locations of collected samples are shown Figure 2.4 A-F. Dykes can be seen throughout Section B, however, they become thinner and more scarce towards the top of the section. Lava flows vary considerably in thickness from 2-24 m with an average thickness of $5.6 \mathrm{~m}(\mathrm{n}=96)$. Fresh mafic flows predominate in the bottom $200 \mathrm{~m}$ of the section. However, up section the percentage of highly weathered and more evolved lava flows increases dramatically. In the top $150 \mathrm{~m}$ of Section B there is only one lava flow that still contains fresh olivine phenocrysts (e.g. AMB-52).

\subsubsection{Section C (Winterton-Awatere)}

Section C comprises a basal lava package of ca. 18 lava flows at the confluence of the Awatere and Winterton Rivers (Figure 2.5). At the bottom right of the figure the underlying sedimentary units are visible. The sedimentary regime immediately prior to the deposition of the Lookout Volcanics at this site was complex. A shallow marine siltstone-sandstone unit that contains Inoceramus spp. fossils (Figure 2.6 A) is unconformably overlain by a $10 \mathrm{~m}$ thick massive light brown fine sandstone unit, which near the top contains $10 \mathrm{~cm}$ thick light grey silt beds (Figure 2.6 B). This is unconformably overlain by a $4 \mathrm{~m}$ lens of $5-10 \mathrm{~cm}$ finely bedded siltstone-sandstone unit that contains no visible fossils (Figure 2.6 C). This unit is terrestrial in origin and was possibly formed in a shallow lake bed. 


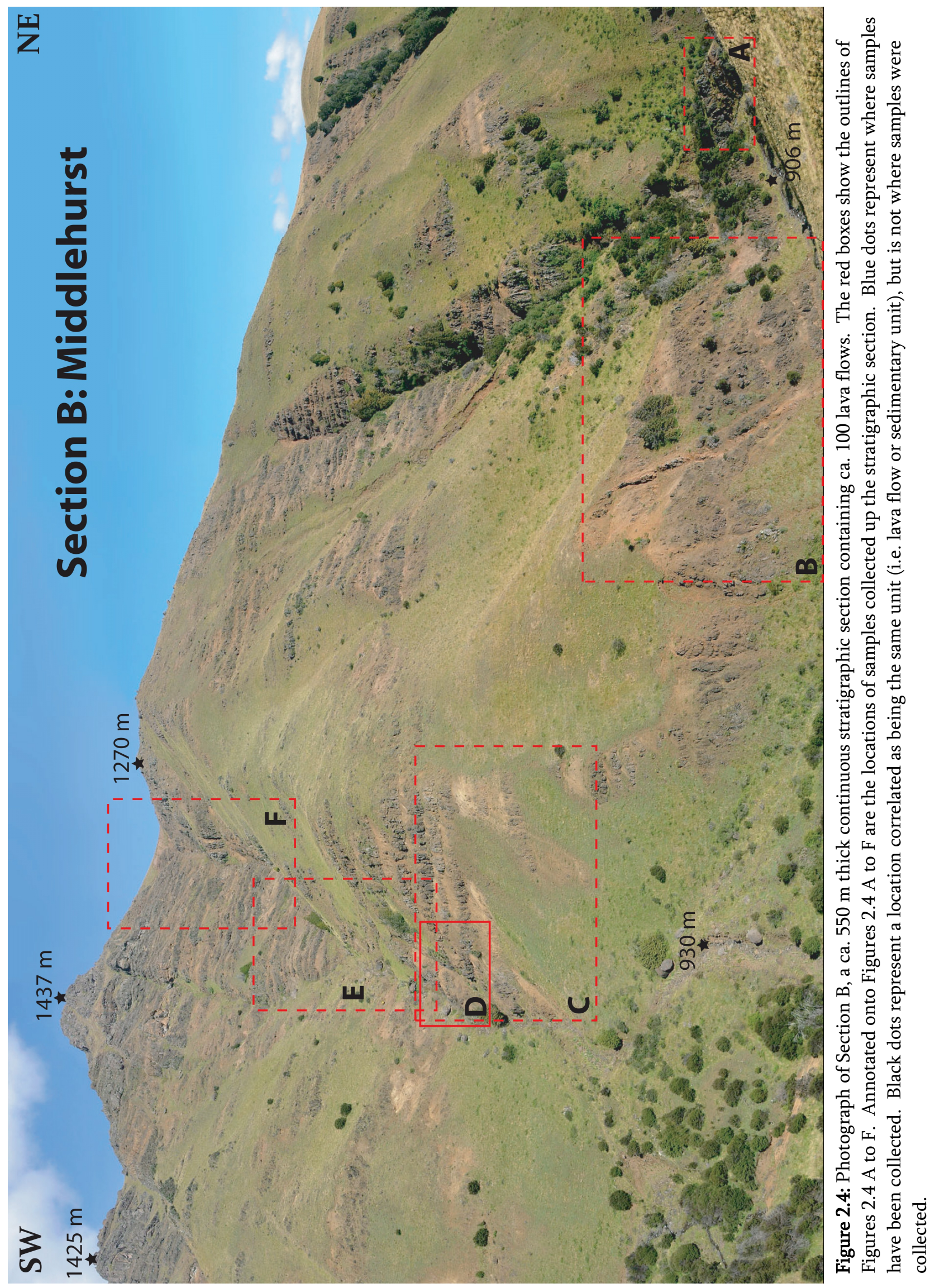




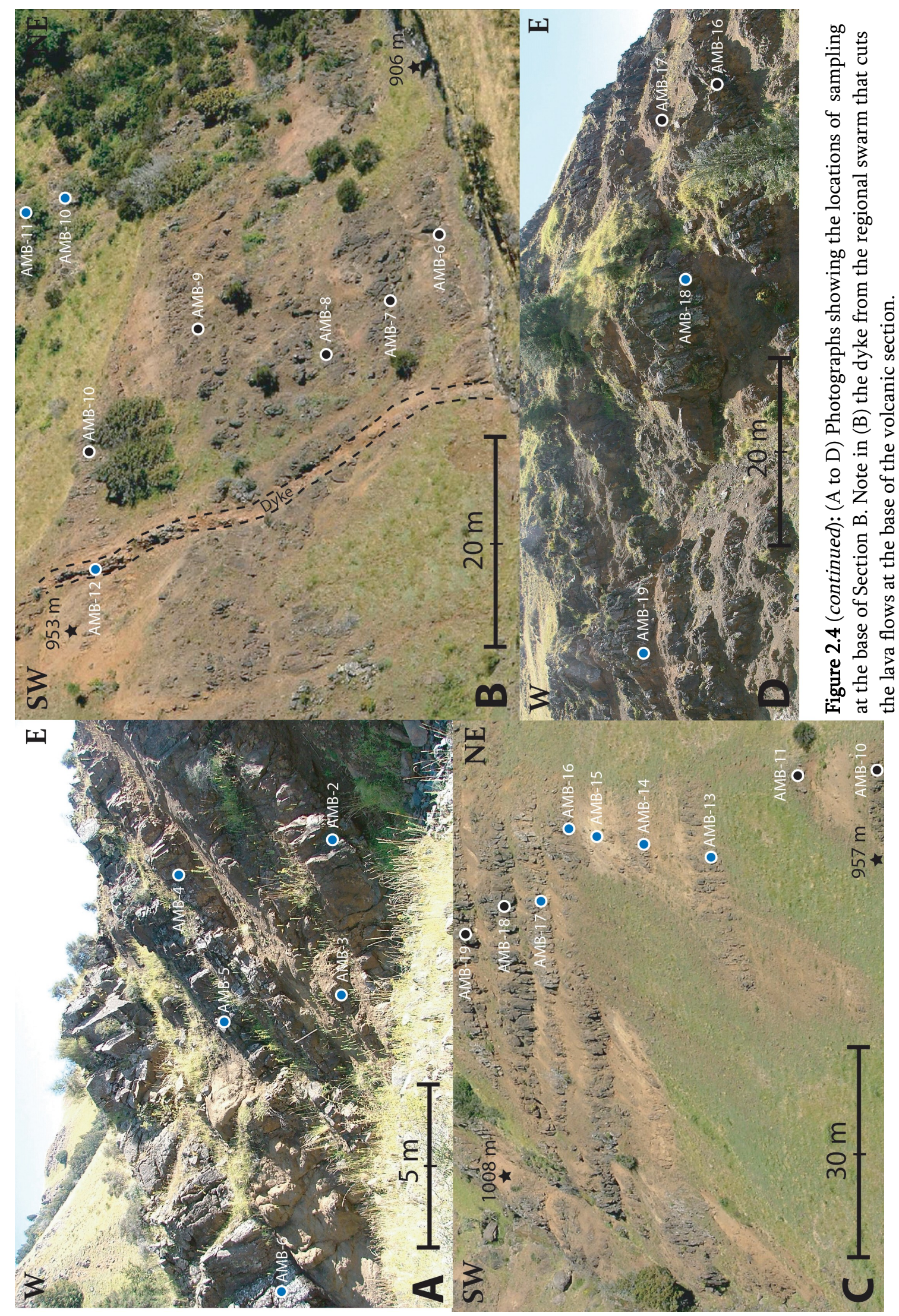




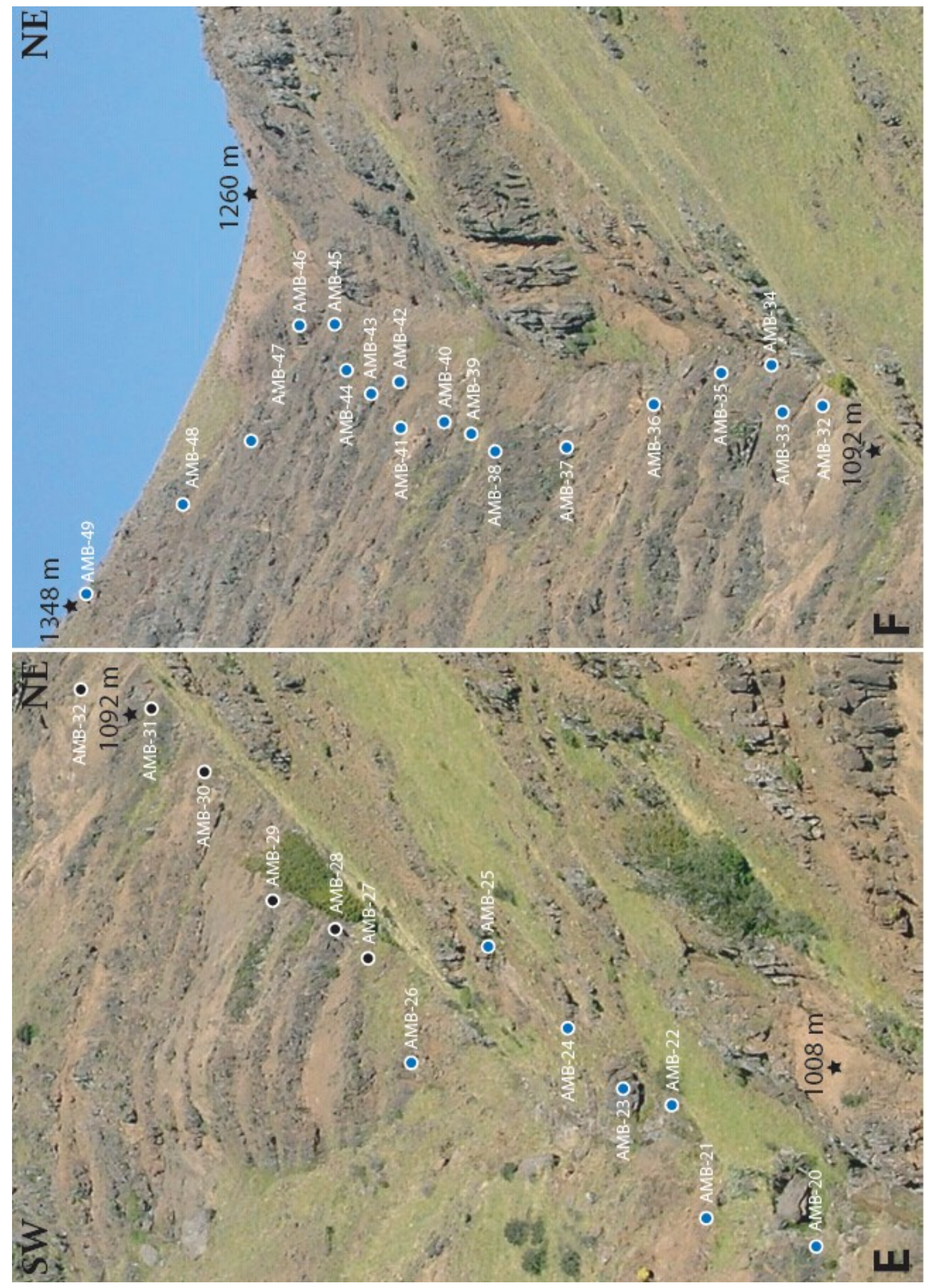

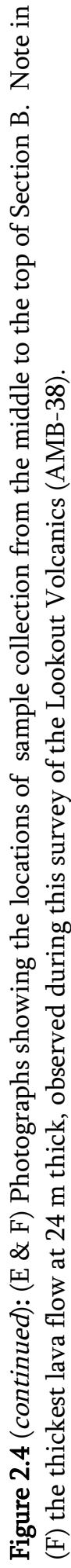




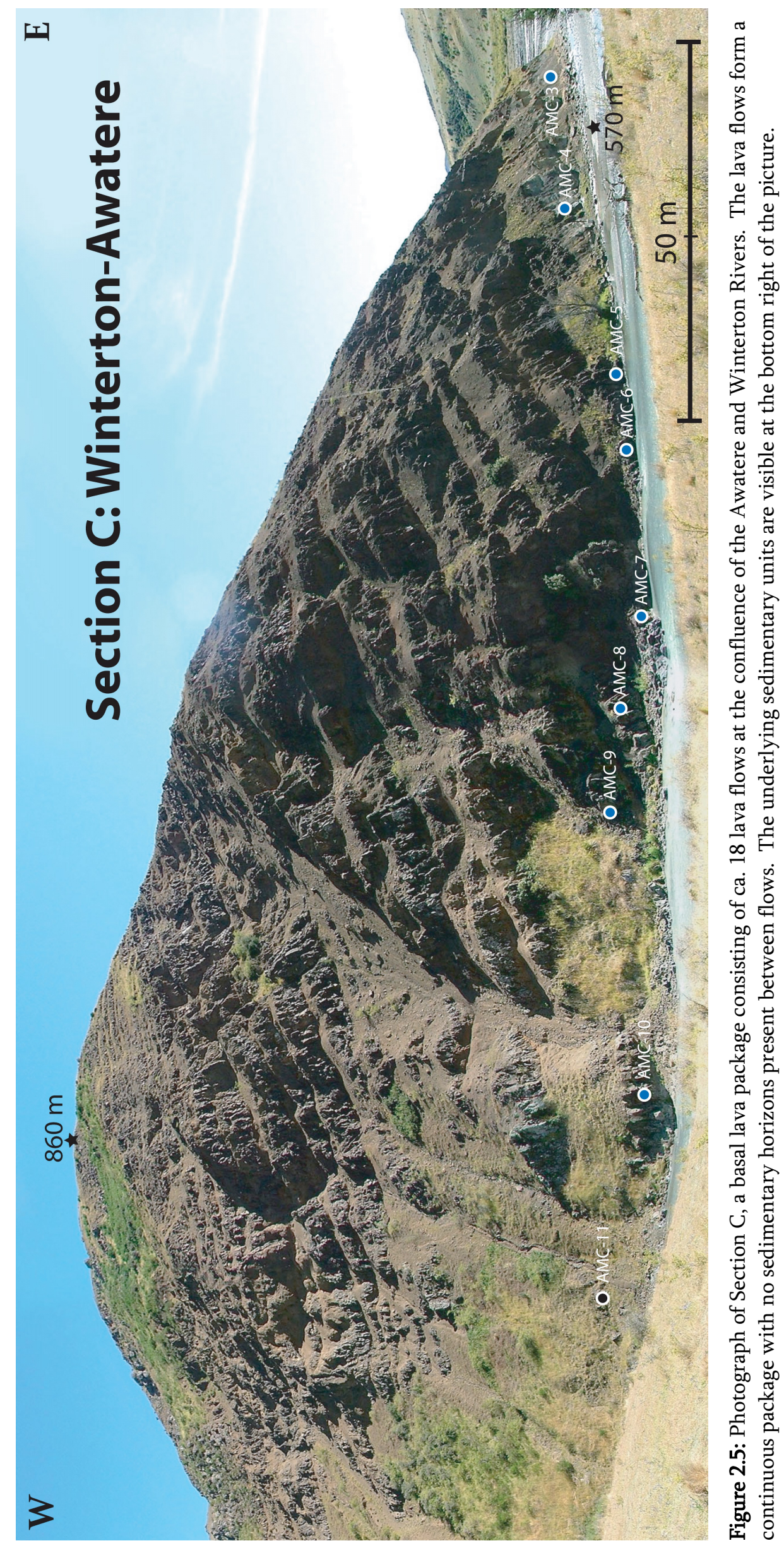



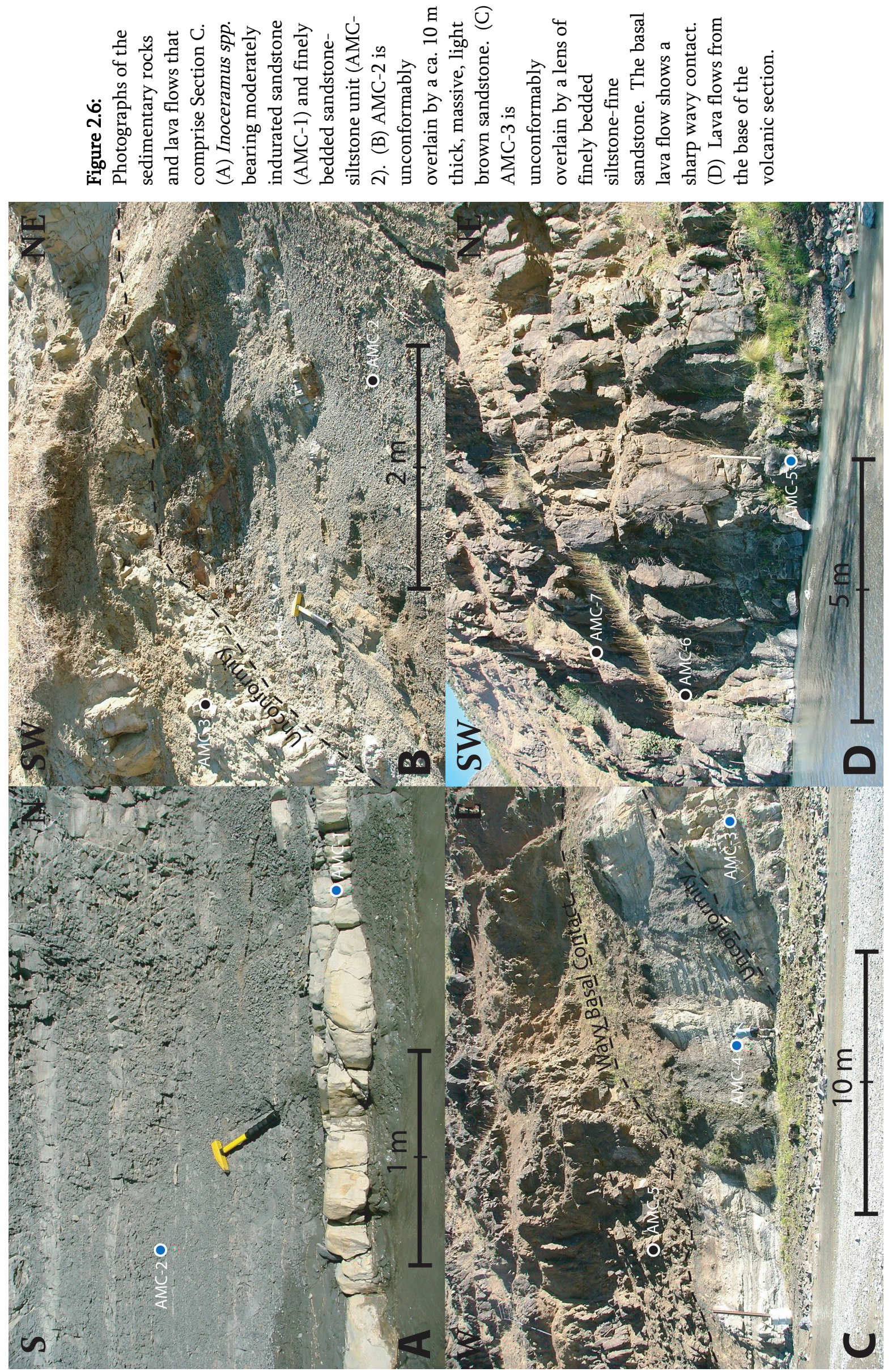
The basal lava flow at this locality is $6 \mathrm{~m}$ thick and highly porphyritic, although fresh olivine is absent in this flow. The basal flow does not possess pillow structures but has a brecciated base and a sharp wavy contact with the underlying sedimentary units. This suggests that uplift and erosion of the lake sediments occurred before the initiation of volcanism and the lava flow was deposited in a terrestrial environment due to its brecciated base. Eleven samples were collected at this locality, with two being the subject of intensive geochemical study (AMC5, AMC-9).

\subsubsection{Section D (Dykes)}

Section D is a zone of intensive dyke intrusion northeast of Mount Lookout (Figure $2.7 \mathrm{~A}$ ). Outcropping $<500 \mathrm{~m}$ from the margin of the Lookout Volcanics, it directly underlies the volcanic rocks. Thirteen dykes intrude the shallow marine rocks of the Winterton Formation (Figures 2.7 C \& E), a highly weathered massive light-brown sandstone containing Inoceramus spp. interbedded with a dark-grey siltstone. The dykes are highly weathered and exhibit a well developed jointing structure (Figures 2.7 C \& D). The thickest dykes result from intrusion of multiple dykes side-by-side. Nine samples were collected at this site.

Lithologically the dykes range from almost aphyric to moderately clinopyroxenephyric $(<15 \%)$ rocks. This outcrop has been created due to uplift of the Gladstone Fault exposing rocks of the Winterton Formation.

\subsubsection{Section E (Faulted)}

Section $\mathrm{E}$ is ca. $1 \mathrm{~km}$ to the north of the Gladstone Fault. At this locality the basal section of the Lookout Volcanics is visible, comprising a package of ca. 14 lava flows (Figure 2.8). The underlying sediment is a terrestrial light brownsandstone containing rounded greywacke clasts up to $2 \mathrm{~cm}$ in size. These sediments are cut by numerous dykes that are intruded perpendicular to the overlying lava flows. 


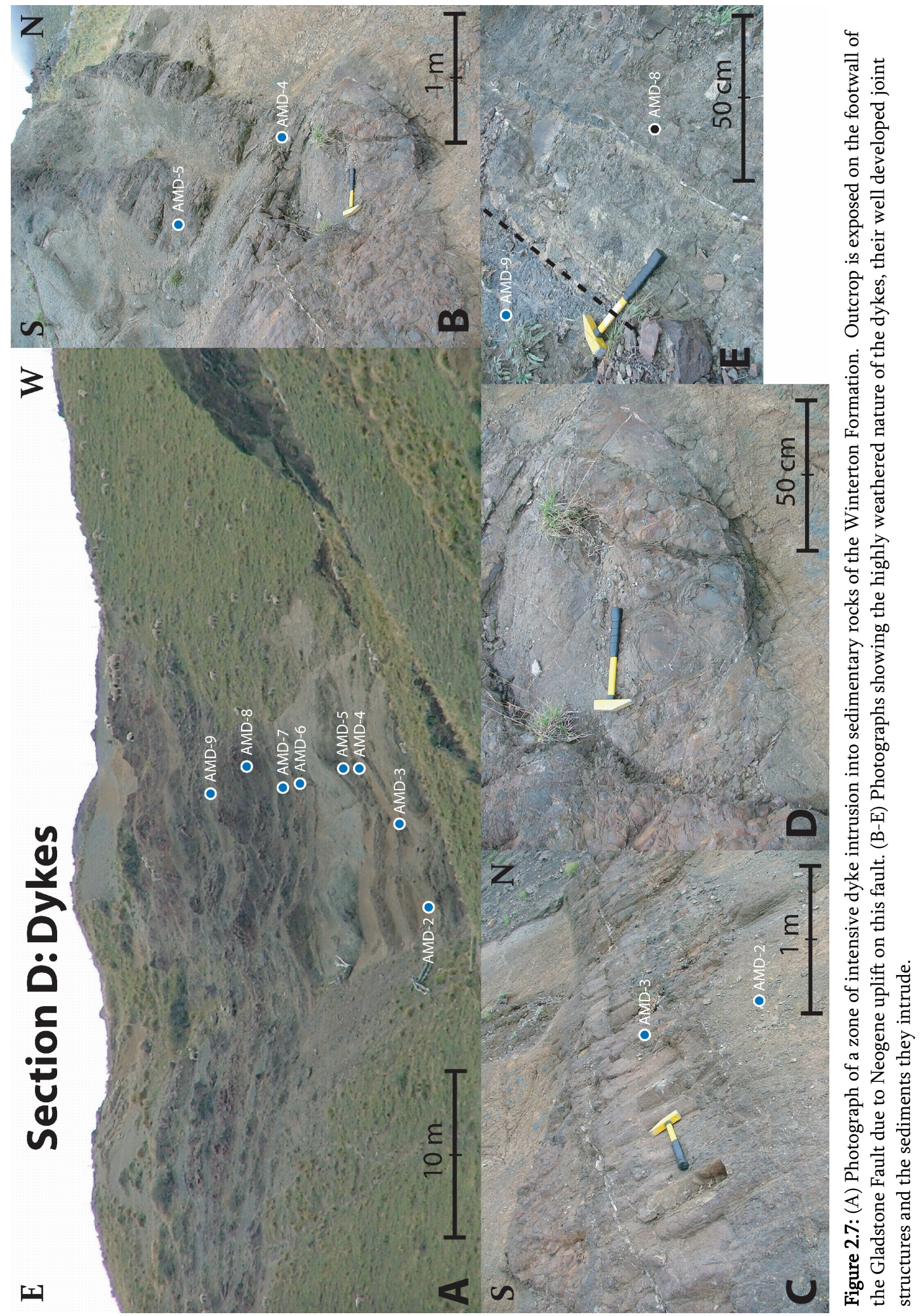




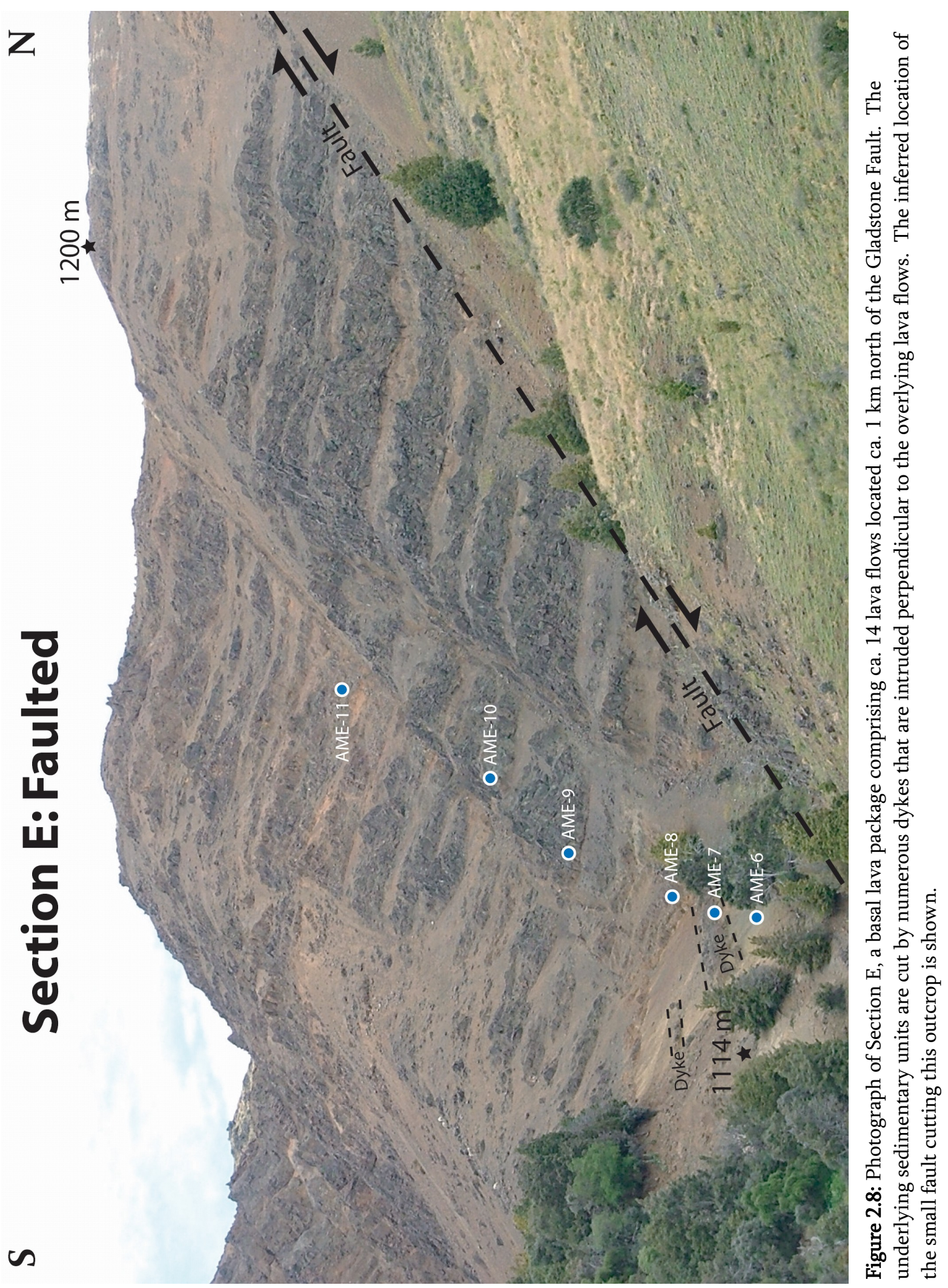


This outcrop is inferred to have been cut by a small fault with at least $50 \mathrm{~m}$ of offset, because the first lava flow observed on the northern side of the gully outcrops at $1080 \mathrm{~m}$. The exact offset of this fault could not be established because of extensive vegetation lower in the gully obscuring the underlying sedimentary units. Eleven samples were collected at this site but further sampling was discounted when Section G was discovered.

\subsubsection{Section F (Middlehurst Stream)}

Section F is a small outcrop in Middlehurst Stream (Figure 2.9 A) that contains interesting information on the depositional environment prior to the eruption of the lava flows it preserves. At the base of the outcrop is an unconsolidated, poorly sorted, fine-matrix supported debris flow containing angular clasts up to $50 \mathrm{~cm}$ in diameter. The debris flow contains two distinct lithotypes of volcanic rock, a highly porphyritic olivine-clinopyroxene rock, and almost aphyric rock with minor clinopyroxene phenocrysts (Figure $2.9 \mathrm{~B}$ ). This is unconformably overlain by a lens of sedimentary material, ca. $1 \mathrm{~m}$ of massive grey siltstone, which in turn is conformably overlain by ca. $2.5 \mathrm{~m}$ of poorly sorted conglomerate, containing well rounded clasts indicative of river gravel (Figure 2.9 C). Clasts in the conglomerate range in size from $5 \mathrm{~mm}$ to $10 \mathrm{~cm}$, and comprise $85 \%$ greywacke and $15 \%$ quartz. Clasts of a volcanic origin are totally absent from this conglomerate. This lens is draped with a ca. $60 \mathrm{~cm}$ layer of massive silty-sandstone with no visible fossils (Figure 2.9 D). A package of three lava flows overlies this sandstone, with the basal flow highly brecciated (Figure 2.9 E). This is just one of two localities at which plagioclase phyric (ca. 35\%) basalts have been observed in the Lookout Volcanics. The absence of clasts originating from the Lookout Volcanics or the underlying sedimentary (Winterton and Gladstone Formations) rocks in the fluvial conglomerate suggests that at the time of deposition of this unit the sedimentary units had undergone complete denudation. 


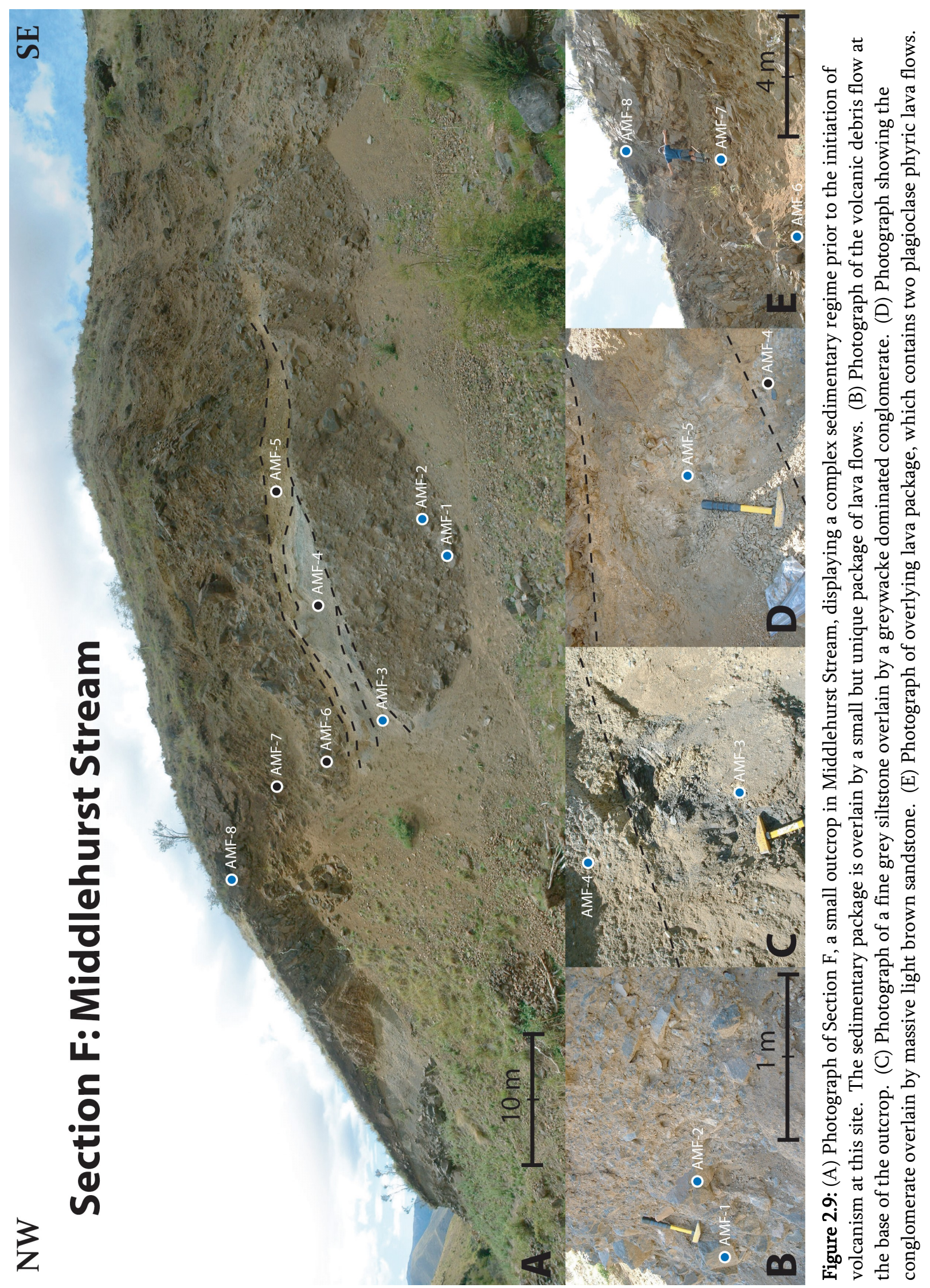


This implies fault driven variable unroofing occurred prior or synchronously to the deposition of the lava flows at this site. Faulting may have been related to graben formation associated with the extension of proto-New Zealand around this time.

\subsubsection{Section G (Lookout)}

Section $\mathrm{G}$ is a basal section exposed on the southeastern flank of Mount Lookout where $\sim 23$ lava flows conformably overlie the shallow marine rocks of the Winterton Formation (Figure 2.10 A). The underlying Winterton Formation comprises massive moderately indurated siltstone, coarsely bedded on a 1-5 m scale, that contains minor conglomeratic bands up to $30 \mathrm{~cm}$ thick (Figures $2.10 \mathrm{C}$ \& D). Immediately underlying the volcanics is a poorly lithified sandstone containing random pebbles of greywacke up to $3 \mathrm{~cm}$ (Figures $2.10 \mathrm{~B} \& \mathrm{E}$ ). Lava flows are extremely well preserved at this site, with a lack of weathering between flows. A distinctive autoclastic breccia occurs beneath a well preserved olivineclinopyroxene phyric flow AMG-8 (Figure $2.10 \mathrm{~F}$ ). This site was the only locality where a Si-oversaturated trachyandesite flow containing orthopyroxene (AMG10) was found in this study.

\subsubsection{Section H (Castle River)}

Section $\mathrm{H}$ is a basal section of the Lookout Volcanics and the type section described by Nicol (1977). Approximately $200 \mathrm{~m}$ of terrestrial lava flows overlie a interbedded conglomerate and sandstone with minor coal measures. The sedimentary units are just visible behind the trees in Figure 2.11. The volcanic rocks at this locality are highly weathered therefore extensive sampling of this site was not carried out. 


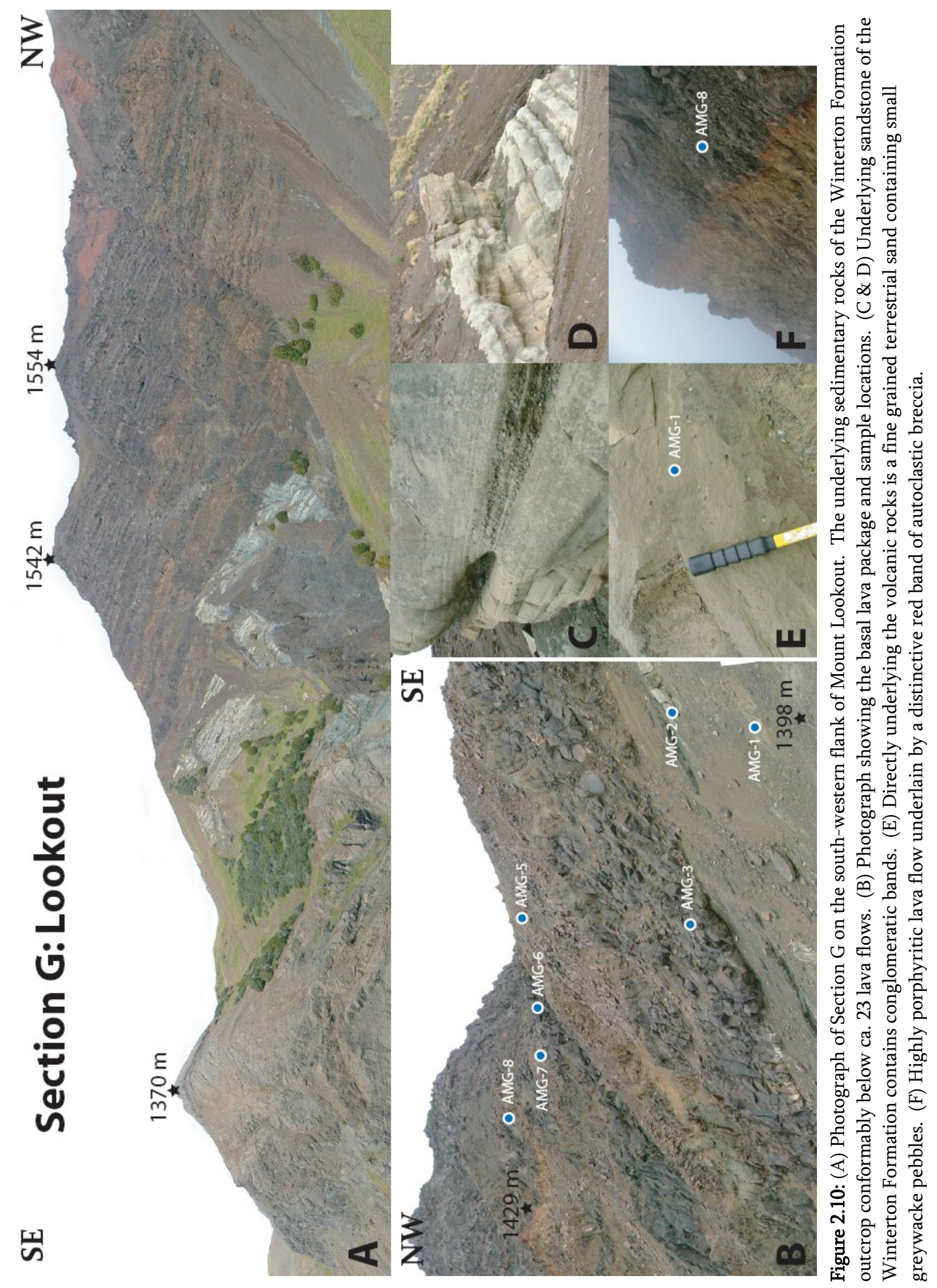




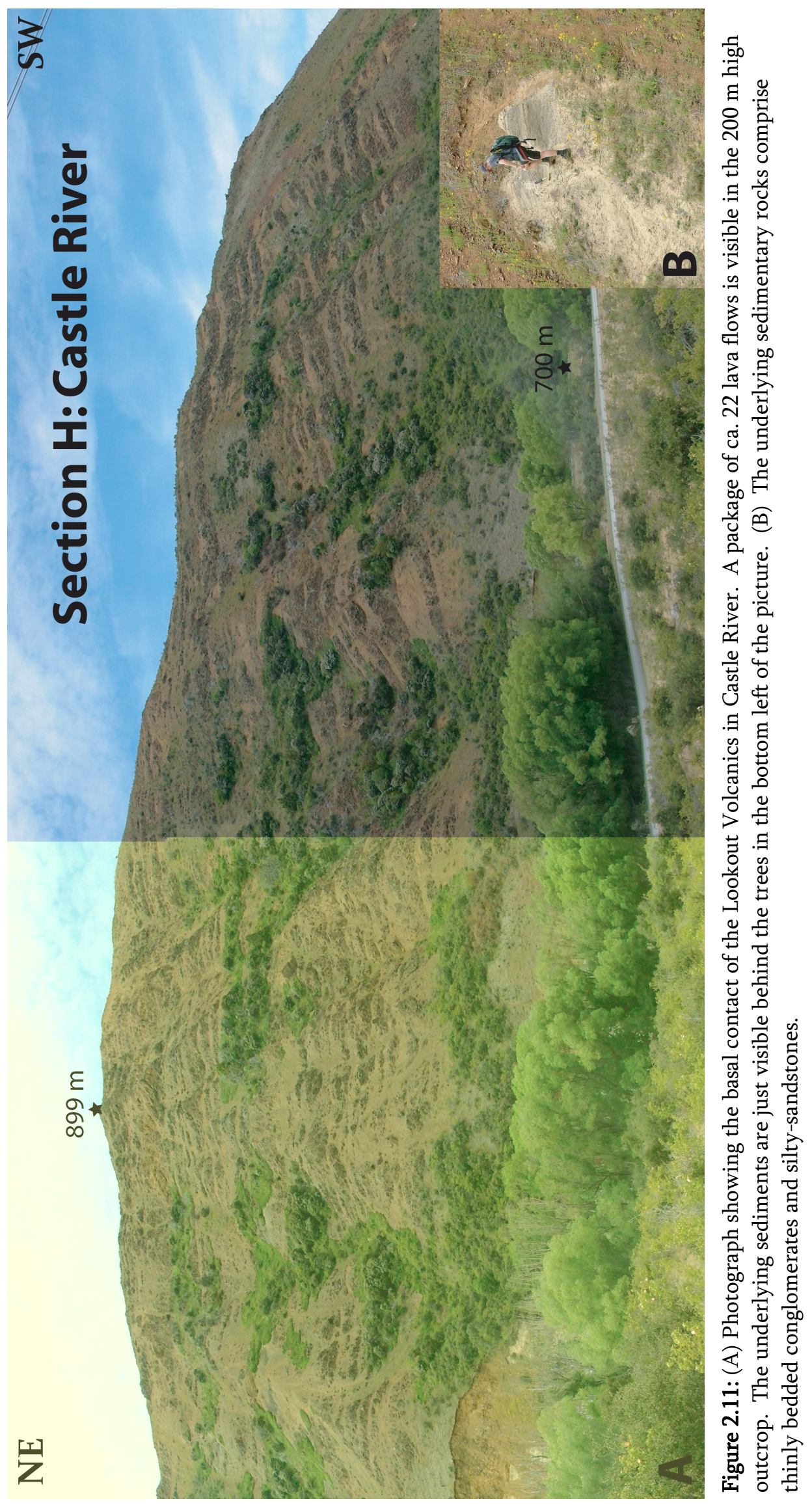




\subsection{COMPOSITE VOLCANIC STRATIGRAPHY}

A ca. $700 \mathrm{~m}$ composite stratigraphic section has been constructed from the volcanic sections described in Section 2.5 (Figure 2.12). Correlation between the different volcanic sections has not been attempted due to a lack of recognisable marker horizons. Rather the different sections have been put in their relative stratigraphic height based on their relationships in the field.

The lava flows of the Lookout Volcanics exhibit a clear petrographic cyclicity with highly porphyritic olivine + clinopyroxene phyric flows overlain by increasingly phenocryst poor flows. This cycle is repeated numerous times in the volcanostratigraphy. This cyclicity was also noted by Nicol (1977) who considered that the cycles comprised 100-150 m of lava, with a thick basal flow of ankaramite overlain by successive flows that become more felsic with the sequence being terminated by a trachyandesite flow. The poor preservation of the felsic units make it difficult to observe this proposed cyclicity, but numerous 20-50 m subcycles can be recognised in Figure 2.12. The subcycles recognised comprise a highly porphyritic olivine-clinopyroxene phyric flow overlain by increasingly phenocryst poor lava flows. The volcanostratigraphy preserved in the basal lava packages (Sections C \& G; Figure 2.12) varies considerably. Variable preservation of lava flows would be expected at sites ca. $6 \mathrm{~km}$ apart but further complicates the compilation of a complete volcanic stratigraphy.

\subsection{RADIAL DYKE SWARM}

The regional extent of the radial dyke swarm is shown in Figure 1.1. The dyke swarm outcrops over an area of ca. $300 \mathrm{~km}^{2}$. Nicol (1977) carried out a survey of ca. 800 dyke orientations at several localities surrounding the Tapuaeouenuku Plutonic Complex, this survey showed that the dykes of the swarm are radially centred on the western margin of the plutonic complex (i.e. near Mount Gladstone). 


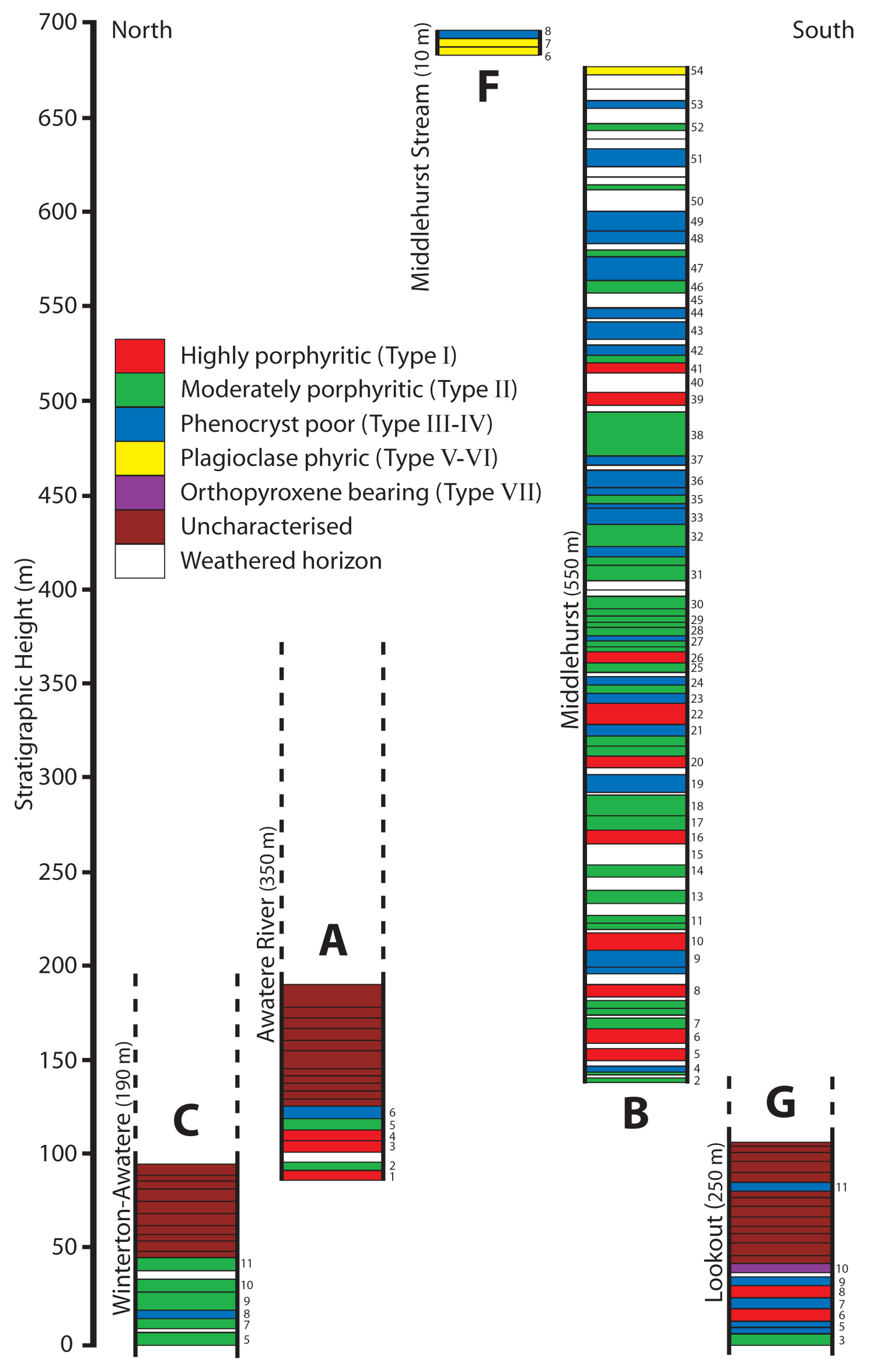


Figure 2.12 (previous page): Composite volcanic stratigraphy of the Lookout Volcanics. Sample numbers of collected rocks are annotated to the volcanic sections. More detailed explanations of the lithotypes in the figure are available in Chapter 3: highly porphyritic flows contain $\geq 40 \%$ phenocrysts; moderately porphyritic flows contain 16-39\% phenocrysts; phenocryst poor flows contain $\leq 15 \%$ phenocrysts; plagioclase phyric flows contains $>20 \%$ plagioclase phenocrysts; orthopyroxene bearing flow is a rare basaltic trachyandesite; uncharacterised flows are distinguishable in photographs but were not petrographically defined; weathered horizons contain poorly preserved volcanic material, but generally contain fresh clinopyroxene phenocrysts.

Dykes intrude greywacke basement (Jurassic to Early Cretaceous) and younger Motuan and Ngaterian sedimentary and volcanic rocks. A Ngaterian age is given to the swarm based on stratigraphic evidence and radiometric dating (Grapes et al., 1992). The dykes comprise similar lithologies to the Lookout Volcanics with the dominant lithology being trachybasalt. Dykes range in thickness from $10 \mathrm{~cm}$ to $10 \mathrm{~m}$ wide with an average thickness of $0.8 \mathrm{~m}$; thicker dykes are often the result of multiple intrusion or dykes being intruded side-by-side (Baker, 1990). The regional dyke swarm outcrops continuously between the comagmatic plutonic and volcanic rocks in the Awatere Valley. Dyke ridges are clearly visible cutting through the Motuan sediments of the Winterton Formation (Figure 2.13

A). Dykes are particularly numerous in the Mount Gladstone and Winterton River areas, where aerial photographs reveal over 900 east-southeast trending dykes (Grapes et al., 1992). Dykes can be seen cutting sedimentary rocks in numerous locations in the middle Awatere Valley (Figures 2.13 B-E). The Lookout Volcanics are cut by numerous dykes but they are sparser and thinner (e.g. $10 \mathrm{~cm}$ to $1.3 \mathrm{~m}$ wide) than those at the centre of the swarm. Two dykes can be seen cutting terrestrial lava flows above Middlehurst Stream (Figure 2.13 F). These dykes appear to be truncated by overlying lava flows, this suggests a contemporaneous emplacement of the volcanic and hypabyssal rocks. The lava flows of the Lookout Volcanics are assumed to have been emplacement by fissure eruptions from dykes of the regional swarm (Challis, 1960a; this study). This is based on the following evidence; (1) a lack of a central volcanic vent within the Lookout Volcanics; (2) the decrease in dyking up the volcanic section; (3) numerous examples of dykes being truncated by lava flows. 


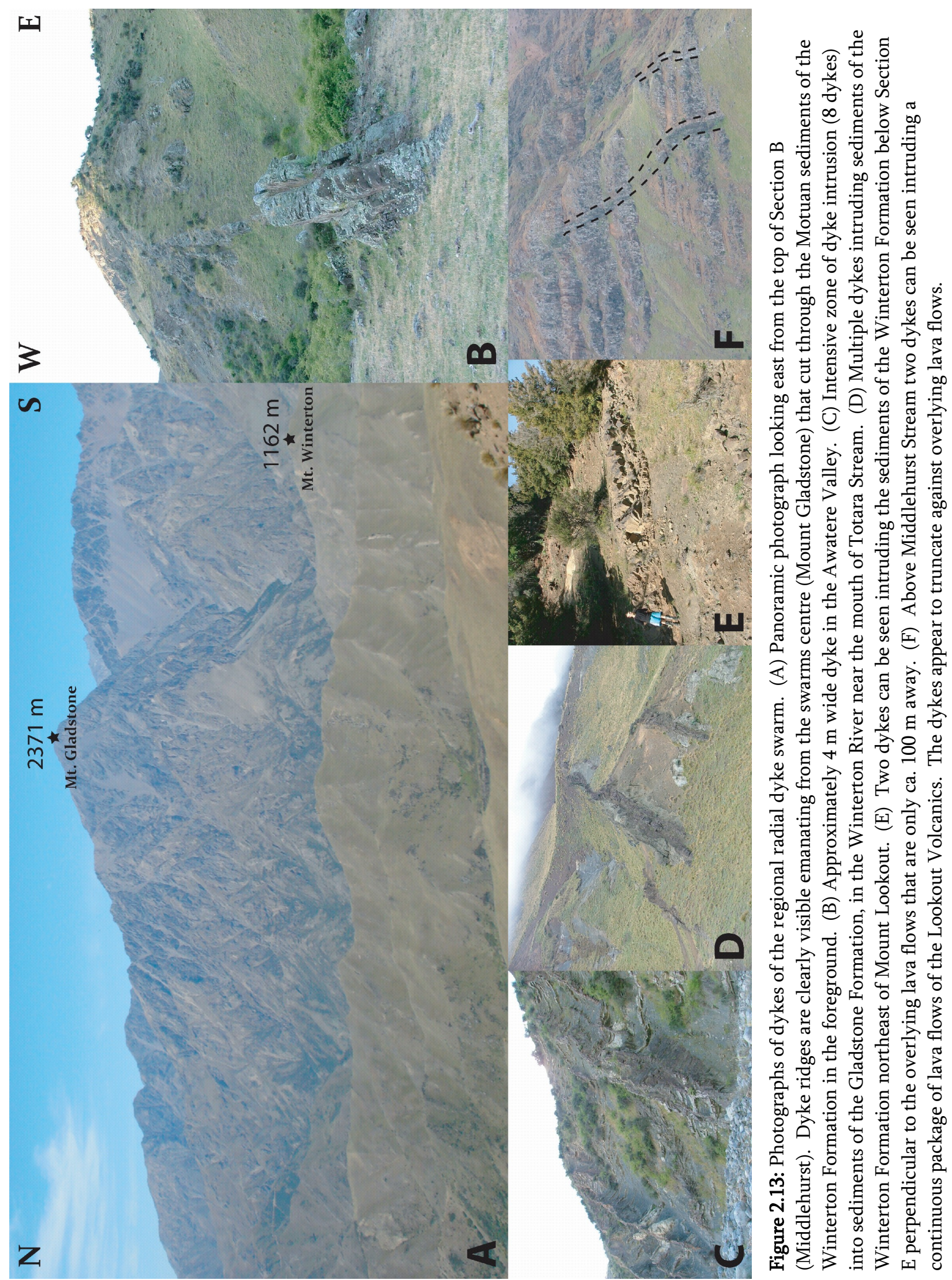




\section{CHAPTER 3: PETROGRAPHY \& MINERAL CHEMISTRY}

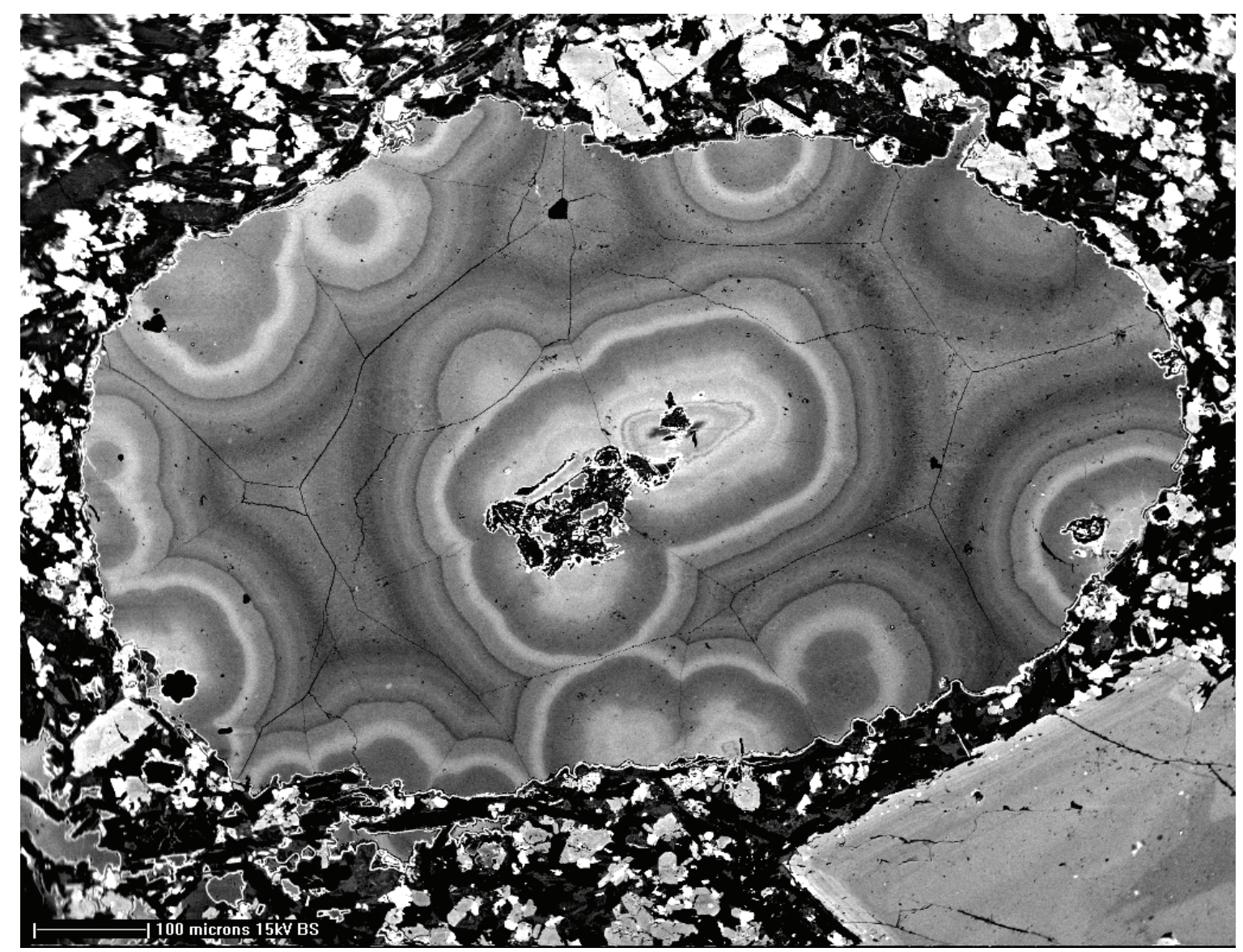

Plate 4: Back-scattered electron image of AMB-5 showing the fluid related zonation of a calcite amygdule and the growth zonation of a clinopyroxene phenocryst in a coarse grained groundmass dominated by plagioclase. 


\subsection{PETROGRAPHY}

The volcanic rocks of the Lookout Formation can be subdivided on the basis of their petrography into seven lithotypes. These rocks are mostly basaltic in composition with the variation related to the dominant mineral assemblage and proportion and size of phenocrysts. The four main rock types (Types I-IV) form a continuum between phenocryst-rich and phenocryst-poor rocks in which the boundaries are gradational. The petrographic variation observed within the Lookout Volcanics is summarised in Table 3.1. A summary of the petrography of all samples collected in this study can be found in Appendix 2.

\subsubsection{Type I (Olivine-clinopyroxene-phyric)}

Type I rocks are highly porphyritic basalts and picrobasalts with $\geq 40 \%$ phenocrysts of olivine + clinopyroxene \pm plagioclase. They comprise $14 \%$ of the lava flows sampled in this study. These rocks are dominated by sub-equal proportions of large olivine and clinopyroxene phenocrysts. Examples of Type I rocks can be seen in Figure 3.1.

Olivine phenocrysts (Fo88-77) are generally subhedral with rare samples displaying euhedral olivine (i.e. AMG-8; Figure 3.2 B). Large olivine phenocrysts $(5-12 \mathrm{~mm})$ comprise $>20 \%$ of these rocks, which are often partially $(<20 \%)$ pseudomorphed by a mixture of chlorite, magnetite and serpentine (Figure $3.2 \mathrm{~A}$ ). Clinopyroxene phenocrysts comprise $>20 \%$ of these rocks and range in size from 2-8 $\mathrm{mm}$. The majority of phenocrysts display extensive growth zoning (Figure 3.2 D). Green to colourless chromian diopside/augite $\left(\mathrm{Mg}_{88} \mathrm{Ti}_{0.9} \mathrm{Cr}_{0.8}\right)$ occurs in the cores of ca. 50\% of crystals. Extensive resorption of the chromian cores of some phenocrysts has occurred, with this being overgrown by $1-3 \mathrm{~mm}$ rims of light brown to pale pink Ti-rich diopside/augite $\left(\mathrm{Mg}_{74} \mathrm{Ti}_{2.4} \mathrm{Cr}_{0.3}\right)$. However, euhedral Cr-rich clinopyroxenes can occur with overgrowths of $<0.1 \mathrm{~mm}$ Ti-rich clinopyroxene. 


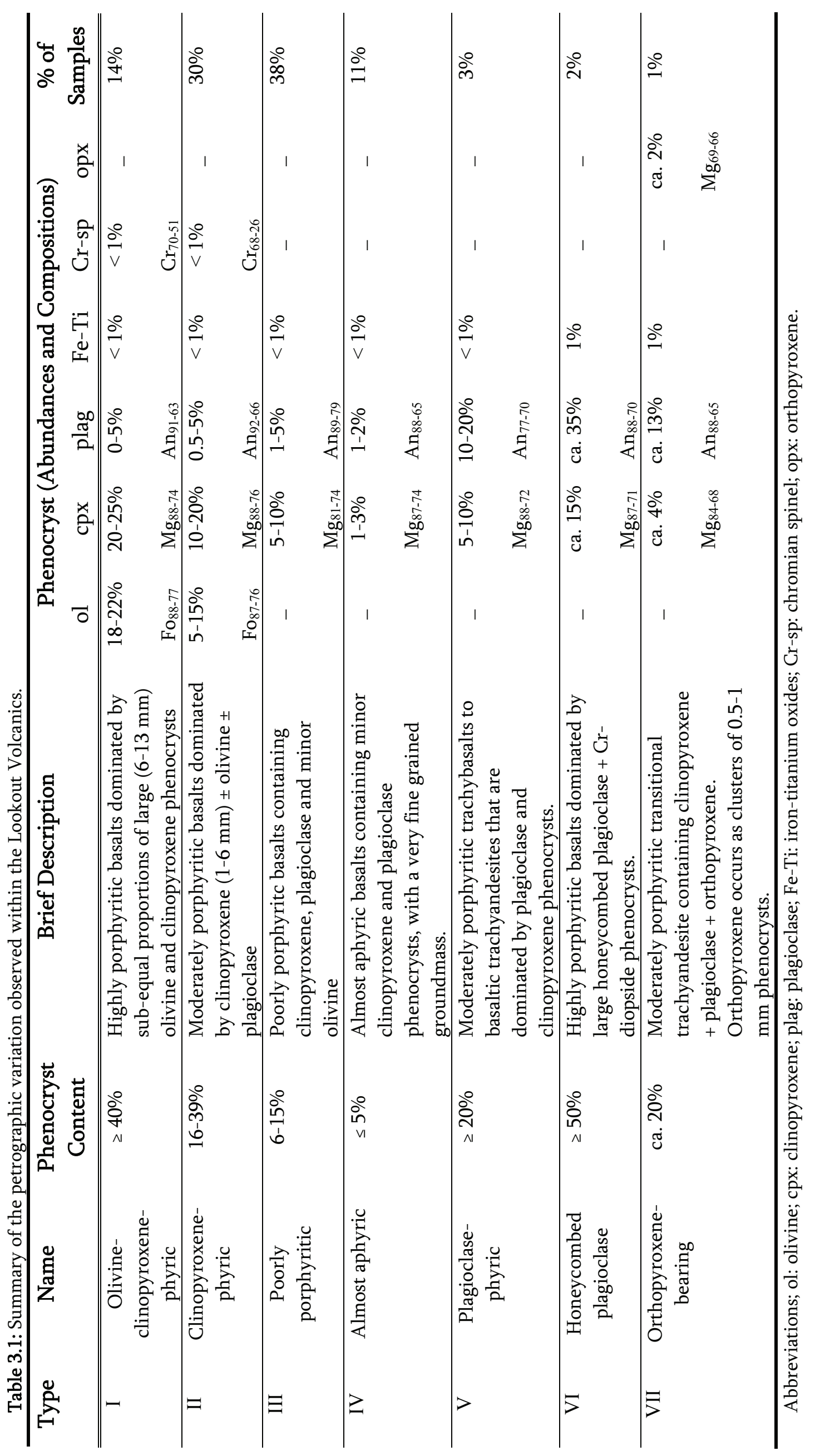



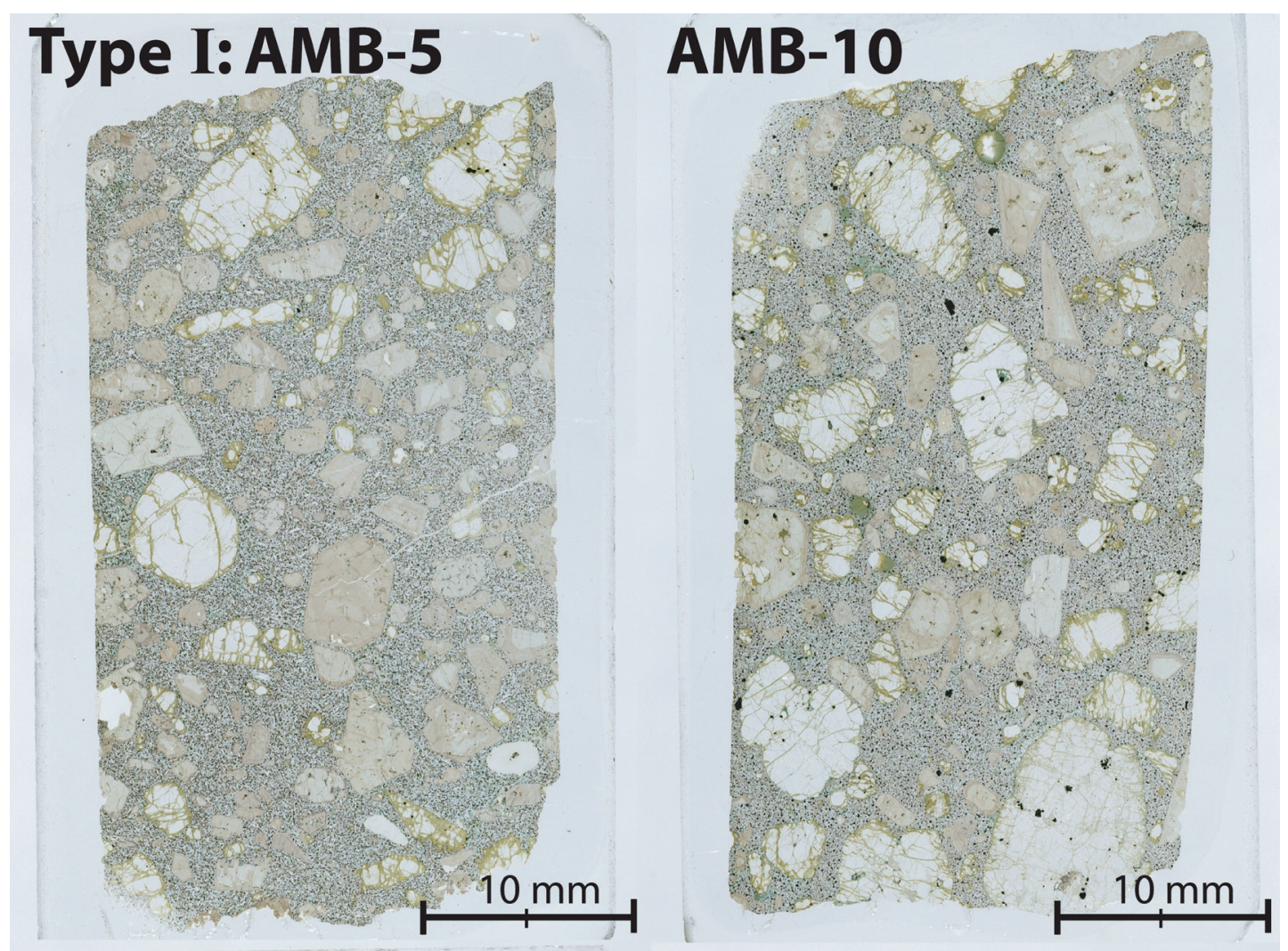

\section{AMB-39}

\section{AMG-8}
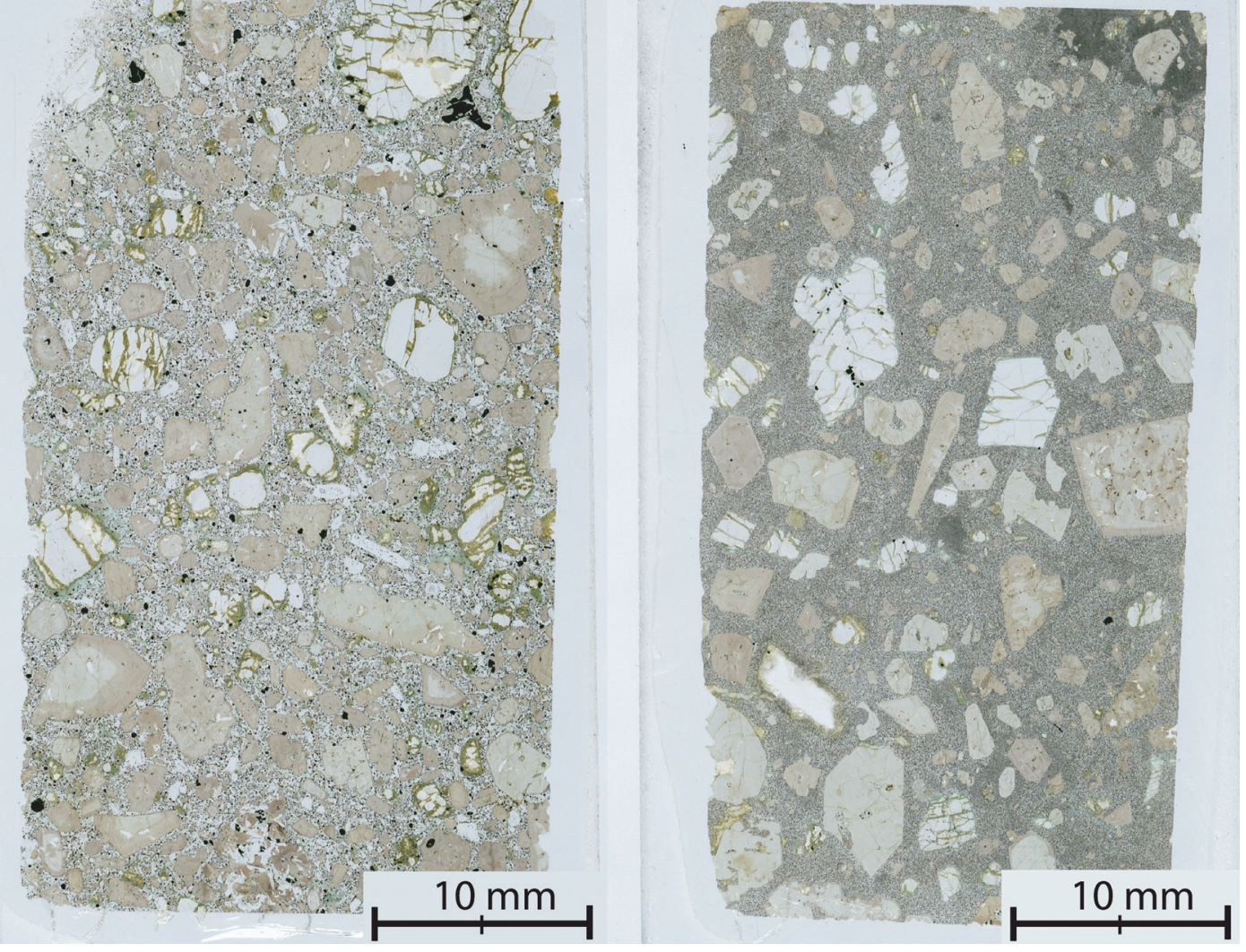

Figure 3.1: Thin sections of highly porphyritic olivine-clinopyroxene phyric Type I rocks. 

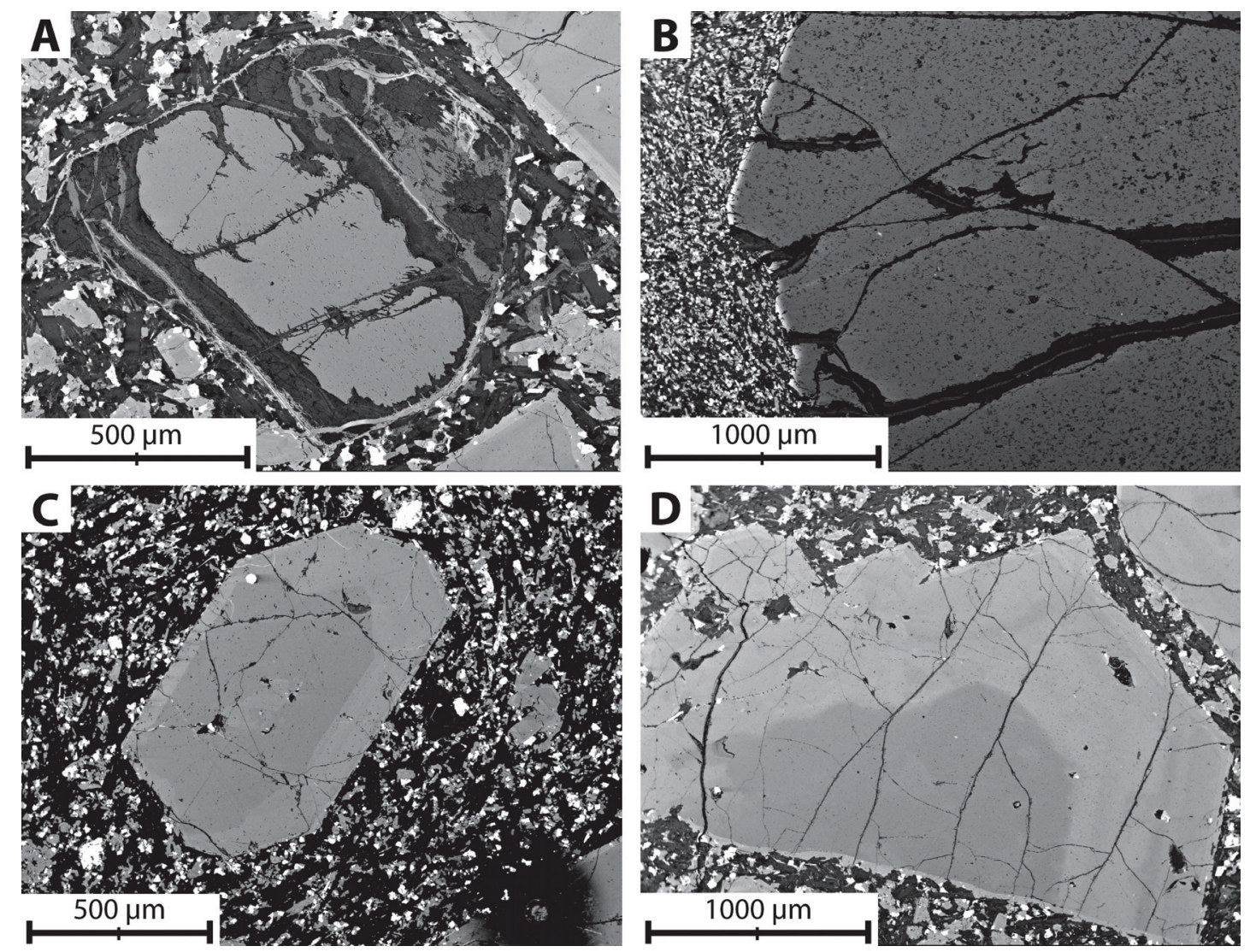

Figure 3.2: Back-scattered electron images of olivine and clinopyroxene phenocrysts. A) Subhedral olivine phenocryst from AMB-5, contains a fresh unzoned core surrounded by a rim that has been altered to chlorite/serpentine. B) Large euhedral and unaltered olivine phenocryst from AMG-8. C) Small euhedral clinopyroxene from AMB-52. This phenocryst displays asymmetric growth zonation, suggesting the bottom edge of the crystal was in contact with something during growth. Note the laser ablation crater in the bottom right of the photograph. D) Fragment of a large strongly zoned clinopyroxene phenocryst from AMB-5, the core appears slightly rounded suggesting minor resorption prior to the crystallisation of the euhedral rim.

Euhedral and entirely light brown Ti-rich clinopyroxene up to $6 \mathrm{~mm}$ in size also occur. Cr-rich phenocrysts are common in Type I rocks, with a maximum $\mathrm{Cr}_{2} \mathrm{O}_{3}$ content of 1.6 weight percent (wt \%) recorded in augite in AMB-39. Plagioclase phenocrysts $\left(A n_{91-63}\right)$ are euhedral to subhedral and range in composition from anorthite to labradorite. Phenocrysts are up to $3 \mathrm{~mm}$ in size, but are rare and only occur in two Type I samples. Chromian spinels $\left(\mathrm{Cr}_{70-51}\right)$ occur as inclusions within or immediately adjacent to olivine phenocrysts. Spinels up to $1.5 \mathrm{~mm}$ in size display normal growth zoning $\left(\mathrm{Cr}_{67-59}\right)$ with $\mathrm{Cr}$-rich cores $\left(\mathrm{Cr}_{2} \mathrm{O}_{3}=42 \mathrm{wt} \%\right)$ and $\mathrm{Cr}$-poor rims $\left(\mathrm{Cr}_{2} \mathrm{O}_{3}=7.6 \mathrm{wt} \%\right)$. Fe-Ti oxide accessory minerals include ilmenite and ulvöspinel. Type I rocks contain the coarsest groundmass of all petrographic types (Figure 3.3). This is because these eruptive units are generally 

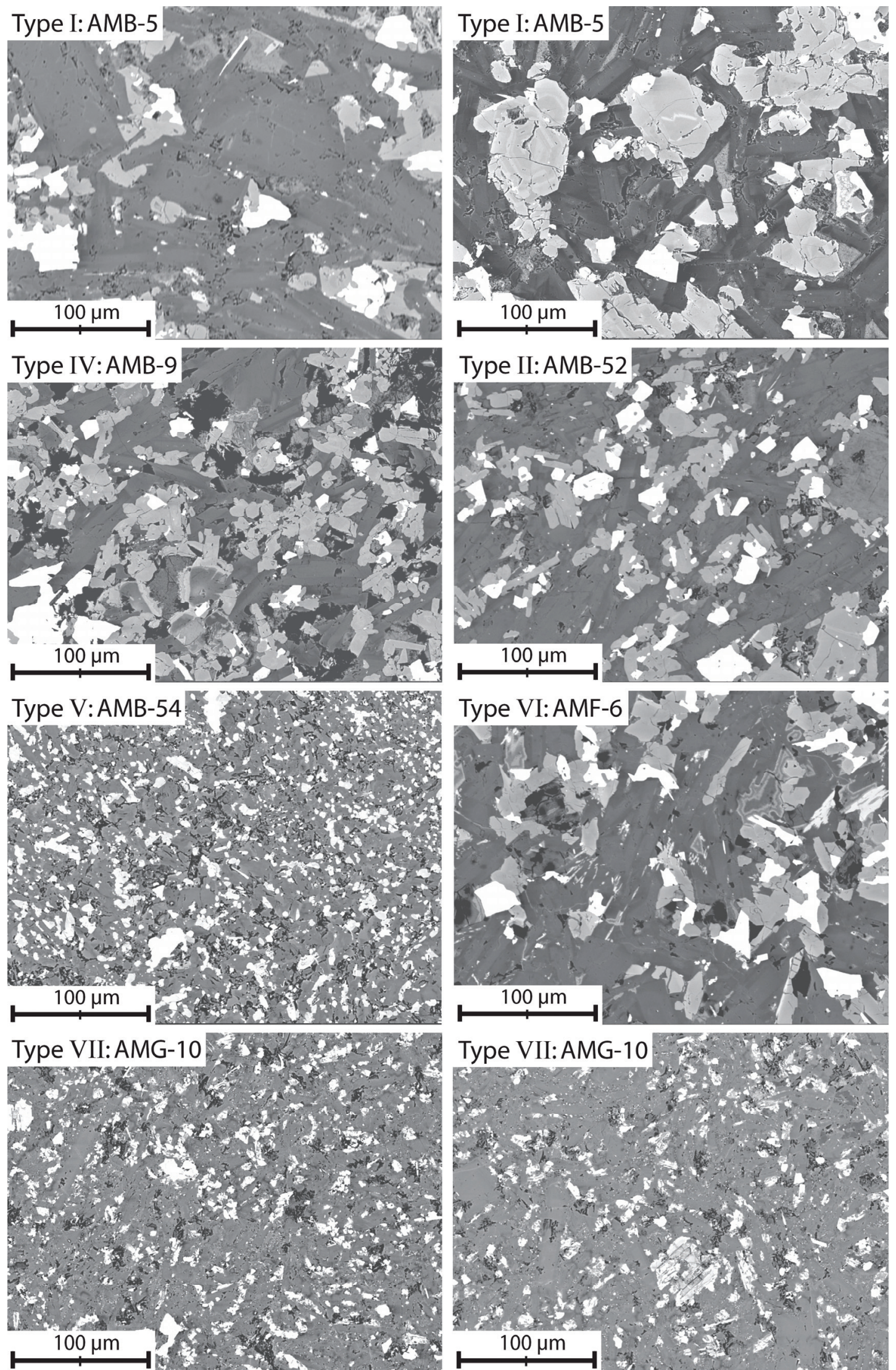

Figure 3.3: Back-scattered electron images comparing the groundmasses of different rock types from the Lookout Volcanics. Note the scale is the same in all the images. Colours: dark grey: feldspars, darker shades within a photograph represent more albitic compositions; light grey: clinopyroxenes; white: Fe-Ti oxides. 
Figure 3.3 (continued): Type I: coarse groundmass of plagioclase + clinopyroxene $+\mathrm{Fe}-\mathrm{Ti}$ oxides. Groundmass clinopyroxenes can exhibit concentric growth zonation i.e. crystal in the photograph on the right. Type II: groundmass dominated by large plagioclases with minor (ca. 25\%) small clinopyroxenes and Fe-Ti oxides. On the right hand side of the photograph is a sepentinised olivine pseudomorph. Type IV: groundmass dominated by fine plagioclase laths and tiny clinopyroxene phenocrysts (ca. 5-10 $\mu \mathrm{m})$. Type V: groundmass composed of a holocrystalline agglomeration of plagioclase laths with interspersed Fe-Ti oxides up to ca. $10 \mu \mathrm{m}$ in size. Type VI: groundmass of plagioclase laths, clinopyroxene and Fe-Ti oxides. Note the presence of pseudomorphed olivines and interstitial calcite. Type VII: very fine grained groundmass of feldspars (mostly plagioclase) and Fe-Ti oxides.

thicker ( $>5 \mathrm{~m}$ ) and thus cooled more slowly. The groundmass is dominated by coarse feldspar laths (ca. 60\%), mostly of bytownite, with minor labradorite, andesine and anorthoclase. The remainder is composed of Fe-Ti oxides, clinopyroxene and olivine.

\subsubsection{Type II (Clinopyroxene-phyric)}

Type II rocks are moderately porphyritic basalts that contain $16-39 \%$ phenocrysts of clinopyroxene \pm olivine \pm plagioclase. They comprise $30 \%$ of the lava flows sampled in this study. Clinopyroxene phenocrysts are volumetrically dominant and present in all samples of this type. Examples of Type II rocks can be seen in Figure 3.4.

Olivine phenocrysts $\left(\mathrm{Fo}_{87-76}\right)$ are subhedral to anhedral and range in size from 1-6 mm, and they comprise between $5-15 \%$ of these rocks. The preservation of olivine in Type II rocks varies considerably with between $10-100 \%$ alteration to secondary minerals such as chlorite and serpentine. However, the majority of samples contain crystals with $50-80 \%$ fresh olivine. The greater the degree of alteration of olivine in a sample the smaller and more evolved the compositional range (e.g. AMB-29; Fo ${ }_{81-76}$ ). Clinopyroxene phenocrysts are euhedral to subhedral, mostly 1-6 mm in size and comprise $10-20 \%$ of these rocks. Colourless chromian diopside/augite $\left(\mathrm{Mg}_{88} \mathrm{Ti}_{0.7} \mathrm{Cr}_{0.6}\right)$ and pale pink Ti-rich diopside/augite $\left(\mathrm{Mg}_{76} \mathrm{Ti}_{2.4} \mathrm{Cr}_{0.2}\right)$ occur in approximately sub-equal proportions in the majority of samples. Clinopyroxenes in Type II rocks display the same growth 


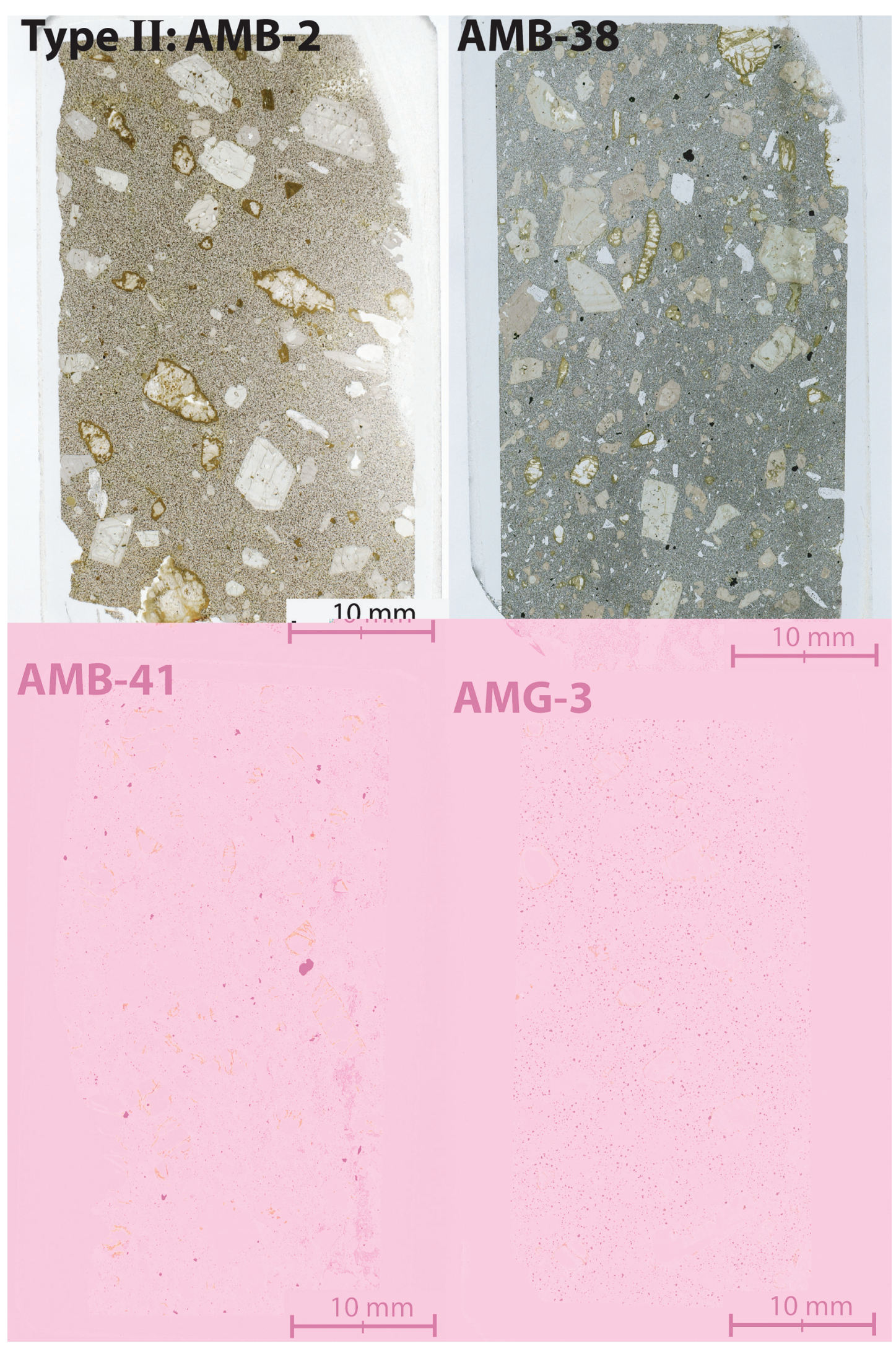

Figure 3.4: Thin sections of moderately porphyritic clinopyroxene \pm olivine \pm plagioclase-phyric Type II rocks. 
zonation and resorption/regrowth patterns of the two clinopyroxenes as Type I rocks (Figure $3.2 \mathrm{C}$ ). Plagioclase phenocrysts are euhedral to subhedral, up to 3 $\mathrm{mm}$ in size and range in composition from anorthite to labradorite ( $\left.\mathrm{An}_{92-66}\right)$. Phenocrysts of plagioclase comprise between $0.5-5 \%$ of these rocks. Plagioclase is at least a trace component $(\geq 0.5 \%)$ in $50 \%$ of Type II lava flows. Chrome spinels $\left(\mathrm{Cr}_{68-26}\right)$ occur only in those samples with the freshest olivine. Ubiquitous accessory minerals include ilmenite and ulvöspinel. Type II rocks contain a finegrained groundmass comprising mostly plagioclase laths (bytownite and labradorite, with minor andesine) and minor amounts of Fe-Ti oxides, clinopyroxene, anorthoclase and olivine or olivine pseudomorphs.

\subsubsection{Type III (Poorly-porphyritic)}

Type III rocks are poorly porphyritic basalts that contain 6-15\% phenocrysts of clinopyroxene + plagioclase \pm olivine. They comprise $38 \%$ of the lava flows sampled in this study. Examples of Type III rocks are illustrated in Figure 3.5.

Olivine and olivine pseudomorphs of chlorite, magnetite and serpentine comprise $2-5 \%$ of these rocks. The majority of samples contain no fresh crystalline olivine. However, poorly preserved ( $<20 \%$ fresh material) anhedral olivine phenocrysts occur in $20 \%$ of Type III samples. Clinopyroxene phenocrysts are euhedral to subhedral and comprise 5-10\% of these rocks. Phenocrysts are generally between 1-4 $\mathrm{mm}$ in size, but rare crystals as large as 9 $\mathrm{mm}$ occur. Extensive growth zonation is not observed within the clinopyroxenes, with the majority of crystals colourless or pale pink diopside/augite. Colourless chromian crystals generally exhibit thin overgrowths of Ti-rich material. Clinopyroxene phenocrysts in Type III rocks span a more restricted and evolved compositional range $\left(\mathrm{Mg}_{81} \mathrm{Ti}_{1.6} \mathrm{Cr}_{0.5}-\mathrm{Mg}_{74} \mathrm{Ti}_{2.2} \mathrm{Cr}_{0.1}\right)$ than Type I and II rocks. Plagioclase phenocrysts $\left(\mathrm{An}_{89-79}\right)$ occur as euhedral to subhedral laths up to $2 \mathrm{~mm}$ in size and comprise 1-5\% of these rocks. Accessory minerals include ilmenite and ulvöspinel. The groundmass is composed dominantly of very fine plagioclase 
laths (mostly bytownite and labradorite) and Fe-Ti oxides, with minor clinopyroxene and pseudomorphs of olivine.
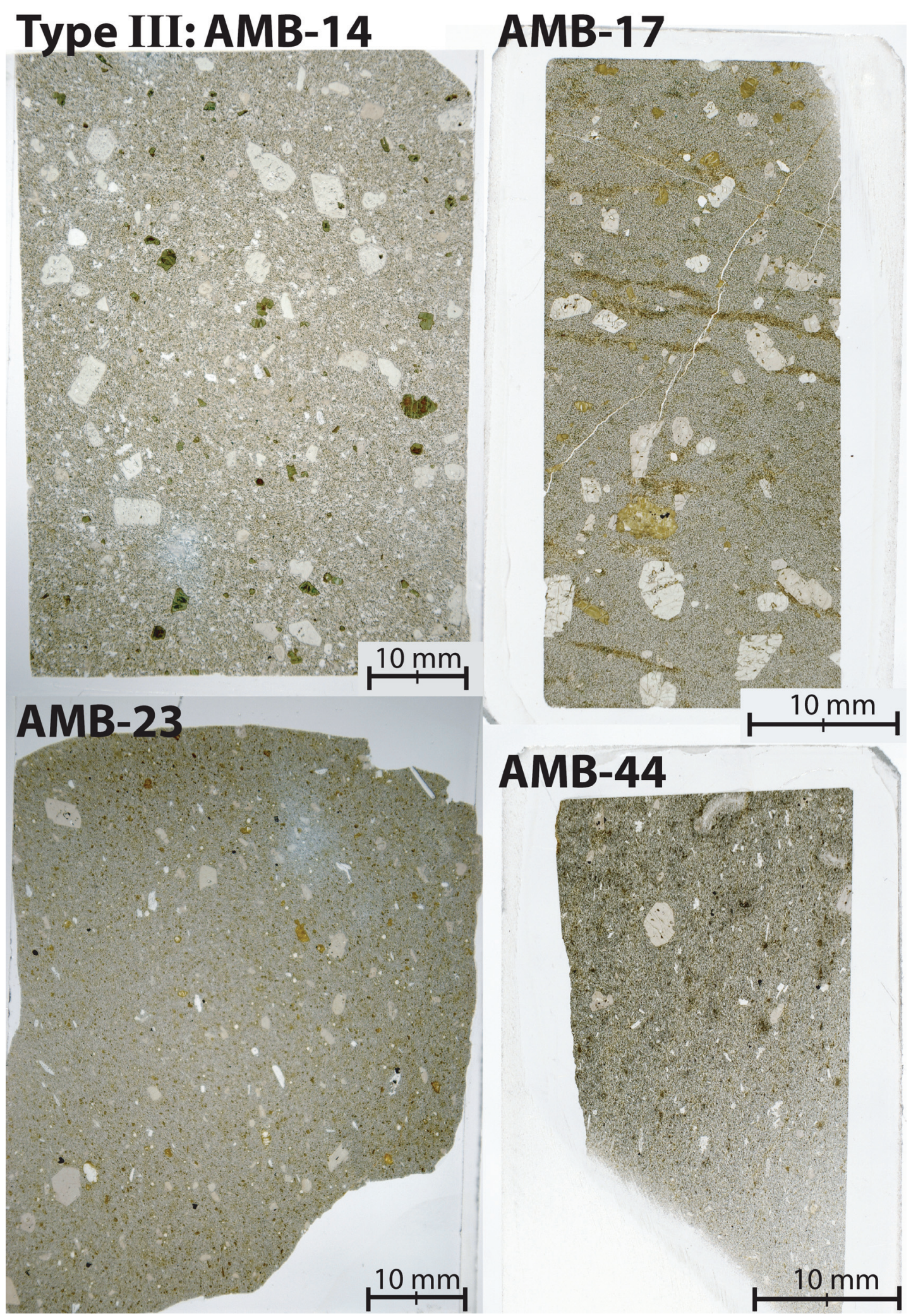

Figure 3.5: Thin sections of poorly porphyritic clinopyroxene \pm plagioclase-phyric Type III rocks. 


\subsubsection{Type IV (Sparsely porphyritic or aphyric)}

Type IV rocks are almost aphyric basalts - trachybasalts containing $\leq 5 \%$ phenocrysts of clinopyroxene and plagioclase. They comprise $11 \%$ of the lava flows sampled in this study. Examples of Type IV rocks can be seen in Figure 3.6.

Clinopyroxene phenocrysts represent $1-2 \%$ of the volume of these rocks, are $\leq$ $2 \mathrm{~mm}$ in diameter, and have a restricted compositional range $\left(\mathrm{Mg}_{80} \mathrm{Ti}_{1.1} \mathrm{Cr}_{0.2}-\right.$ $\left.\mathrm{Mg}_{74} \mathrm{Ti}_{2.1} \mathrm{Cr}_{0.04}\right)$ generally of the Ti-rich variety. However, rare phenocrysts are Cr-rich $\left(\mathrm{Mg}_{87} \mathrm{Ti}_{0.6} \mathrm{Cr}_{1.1}\right)$. Plagioclase phenocrysts comprise $0.5-1 \%$ of these rocks. They are $\leq 1 \mathrm{~mm}$ in length and range from bytownite to labradorite in composition $\left(\mathrm{An}_{88-65}\right)$. Rare pseudomorphs of olivine up to $2 \mathrm{~mm}$ in size occur. Trace amounts of ilmenite and ulvöspinel phenocrysts are present. The groundmass of Type IV rocks is composed of extremely fine-grained crystals (Figure 3.3) mostly dominated (ca. 75\%) by plagioclase laths of bytownite, with minor labradorite and trace amounts of andesine. Groundmass phenocrysts also include clinopyroxene, Fe-Ti oxides and altered olivine.

\subsubsection{Type V (Plagioclase-phyric)}

Type V rocks are moderately porphyritic, plagioclase-phyric trachybasalts basaltic trachyandesites containing $\geq 20 \%$ phenocrysts. They comprise $3 \%$ of the lava flows sampled in this study. Crystalline plagioclase $(\geq 10 \%)$ dominates the mineral assemblage of rocks of this type. A petrographic slide of the type sample, AMB-54, is shown in Figure 3.7 A.

Olivines are mostly subhedral and up to $3 \mathrm{~mm}$ in length and comprise ca. 5\% of these rocks. Olivine phenocrysts have undergone complete alteration and are replaced by chlorite, magnetite and serpentine. The majority of clinopyroxene phenocrysts are pink augites $\left(\mathrm{Mg}_{80} \mathrm{Ti}_{0.9} \mathrm{Cr}_{0.2}-\mathrm{Mg}_{72} \mathrm{Ti}_{1.6} \mathrm{Cr}_{0.1}\right)$, with minor green diopside/augite $\left(\mathrm{Mg}_{88} \mathrm{Ti}_{0.7} \mathrm{Cr}_{0.4}\right)$. Plagioclase phenocrysts $\left(\mathrm{An}_{77-64}\right)$ are mostly euhedral and up to $4 \mathrm{~mm}$ in length and comprise $10-20 \%$ of Type $\mathrm{V}$ rocks. Multiple twinning and normal growth zoning $\left(\mathrm{An}_{77-70}\right)$ is observed in larger phenocrysts. 

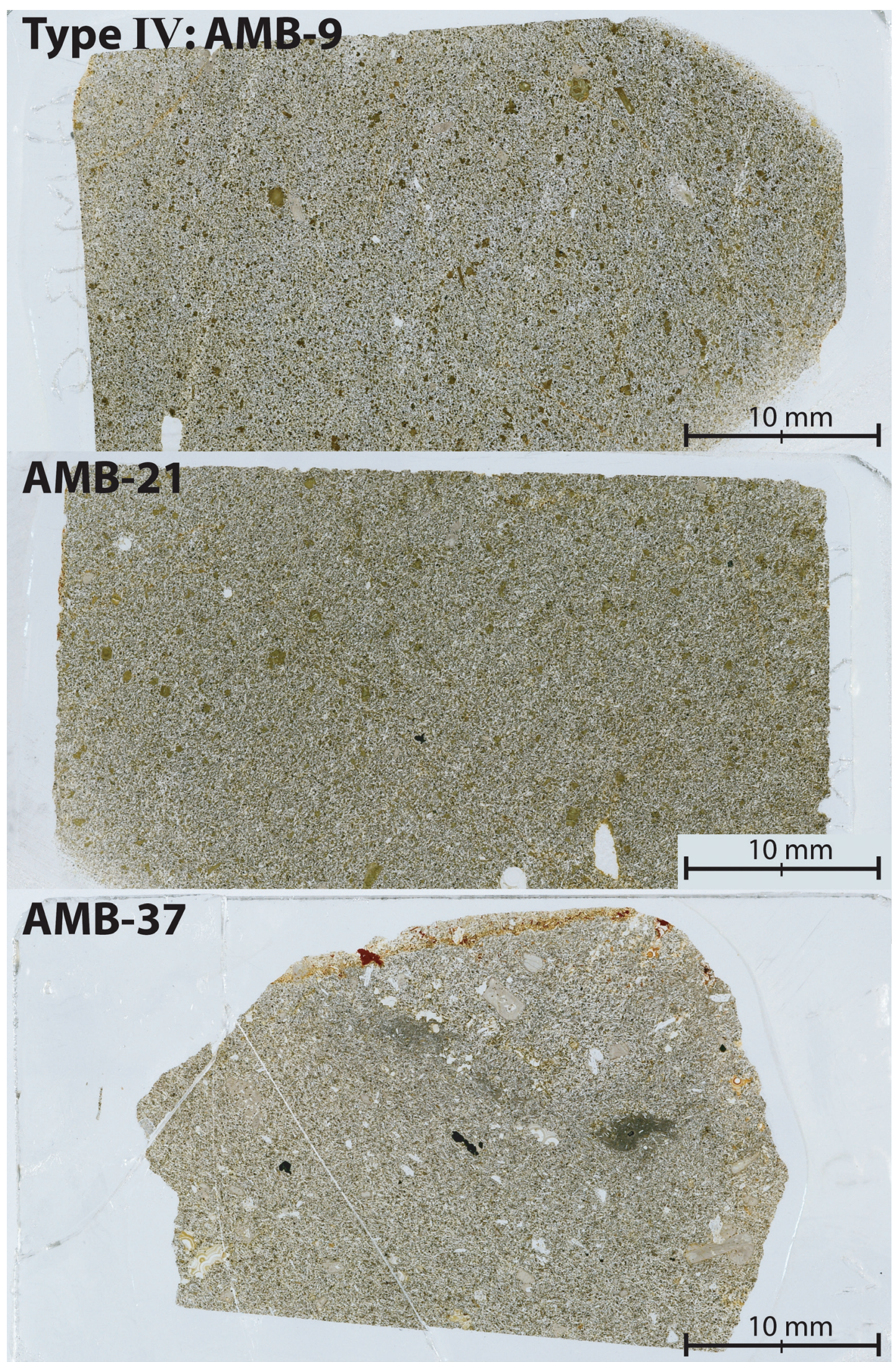

Figure 3.6: Thin sections of aphyric (AMB-9; AMB-21) to sparsely porphyritic (AMB-37) clinopyroxene + plagioclase $+\mathrm{Fe}$-Ti oxide bearing Type IV rocks. 
Plagioclase phenocrysts are $>99 \%$ of the crystalline variety with only rare honeycombed phenocrysts. The groundmass is dominantly fine-grained labradorite and andesine, with minor bytownite, anorthoclase, clinopyroxene, Fe-Ti oxides and olivine pseudomorphs (Figure 3.3).

\subsubsection{Type VI (Honeycombed plagioclase)}

Type VI rocks are highly porphyritic basalts with $\geq 50 \%$ phenocrysts that are dominated by honeycomb-textured plagioclase phenocrysts (> 25\%). They comprise $2 \%$ of the lava flows sampled in this study. The two samples of this type were discovered at the same location and could represent a single brecciated lava flow. A petrographic slide of the type sample, AMF-6, is shown in Figure 3.7 B.

Olivine phenocrysts up to $6 \mathrm{~mm}$ in size have undergone complete alteration to secondary minerals, these pseudomorphs comprise ca. $5 \%$ of these rocks. Clinopyroxene phenocrysts are subhedral to euhedral and comprise ca. $20 \%$ of these rocks exhibiting a significant compositional range $\left(\mathrm{Mg}_{87-71}\right)$. However, no strongly zoned clinopyroxene phenocrysts are observed. Instead, sub-equal amounts of $\mathrm{Cr}$ diopside/augite $\left(\mathrm{Mg}_{86} \mathrm{Ti}_{0.7} \mathrm{Cr}_{0.5}\right)$ and Ti-rich diopside/augite $\left(\mathrm{Mg}_{77} \mathrm{Ti}_{2.1} \mathrm{Cr}_{0.1}\right)$ 1-3 mm and 0.5-1.0 $\mathrm{mm}$ in size, respectively, were observed. Plagioclase phenocrysts comprise $>25 \%$ of rocks of this type. Plagioclase phenocrysts $\left(\mathrm{An}_{88-70}\right)$ are up to $14 \mathrm{~mm}$ in length. However, the larger crystals are agglomerates of smaller honeycomb-textured laths that are joined together through secondary plagioclase crystallisation. The honeycomb texture is visible in $80 \%$ of plagioclase phenocrysts in Type VI rocks (Figure $3.8 \mathrm{~A}$ ). Honeycombed plagioclases are interstitially filled $(<20 \mu \mathrm{m})$ with crystalline clinopyroxene and pseudomorphed olivine (Figure 3.8 B). The largest laths of crystalline plagioclase observed are only $0.5 \mathrm{~mm}$ in length. Trace Fe-Ti oxides (ilmenite and ulvöspinel) up to $0.5 \mathrm{~mm}$ in size are also found in these rocks. The groundmass is dominantly fine laths of labradorite and andesine with minor bytownite, clinopyroxene, FeTi oxides and altered olivine (Figure 3.3). 


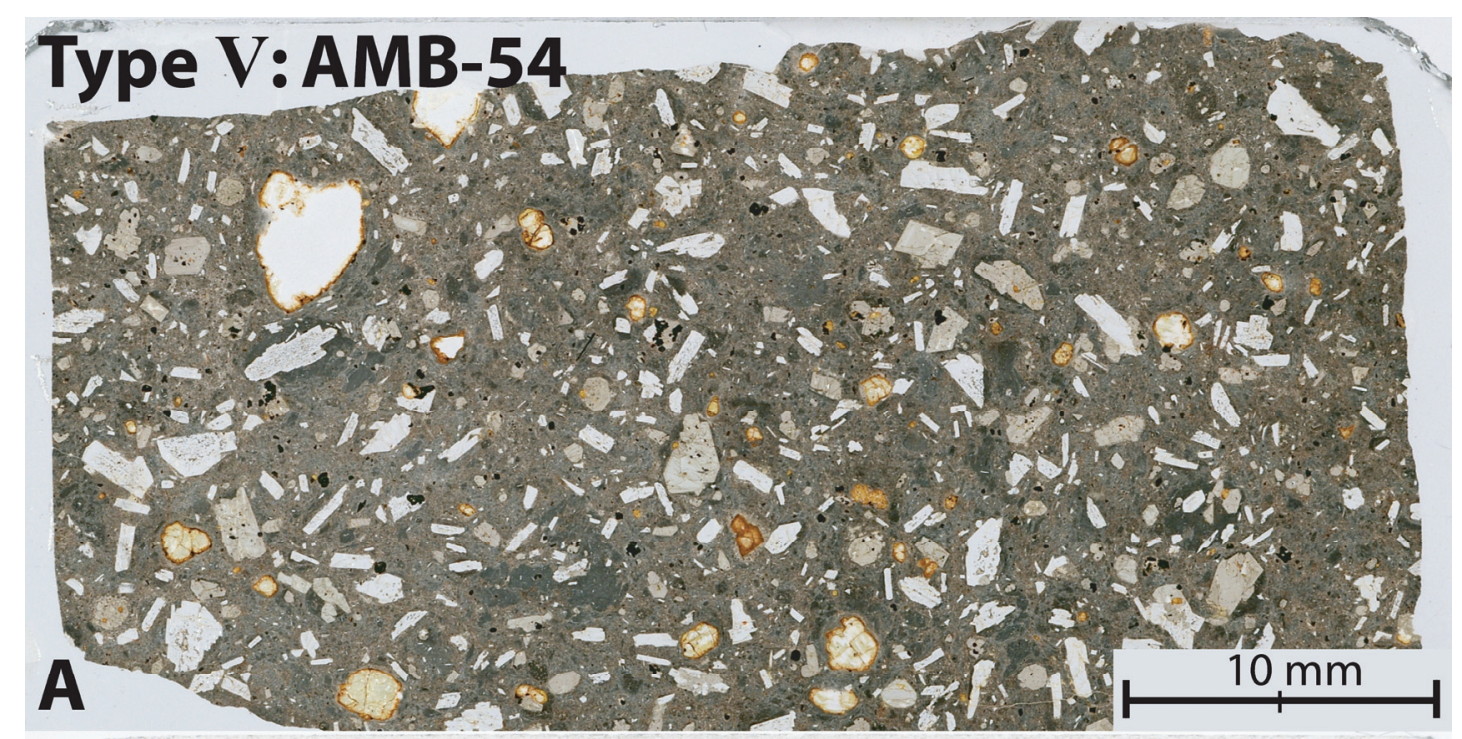

\section{Type VI: AMF-6}
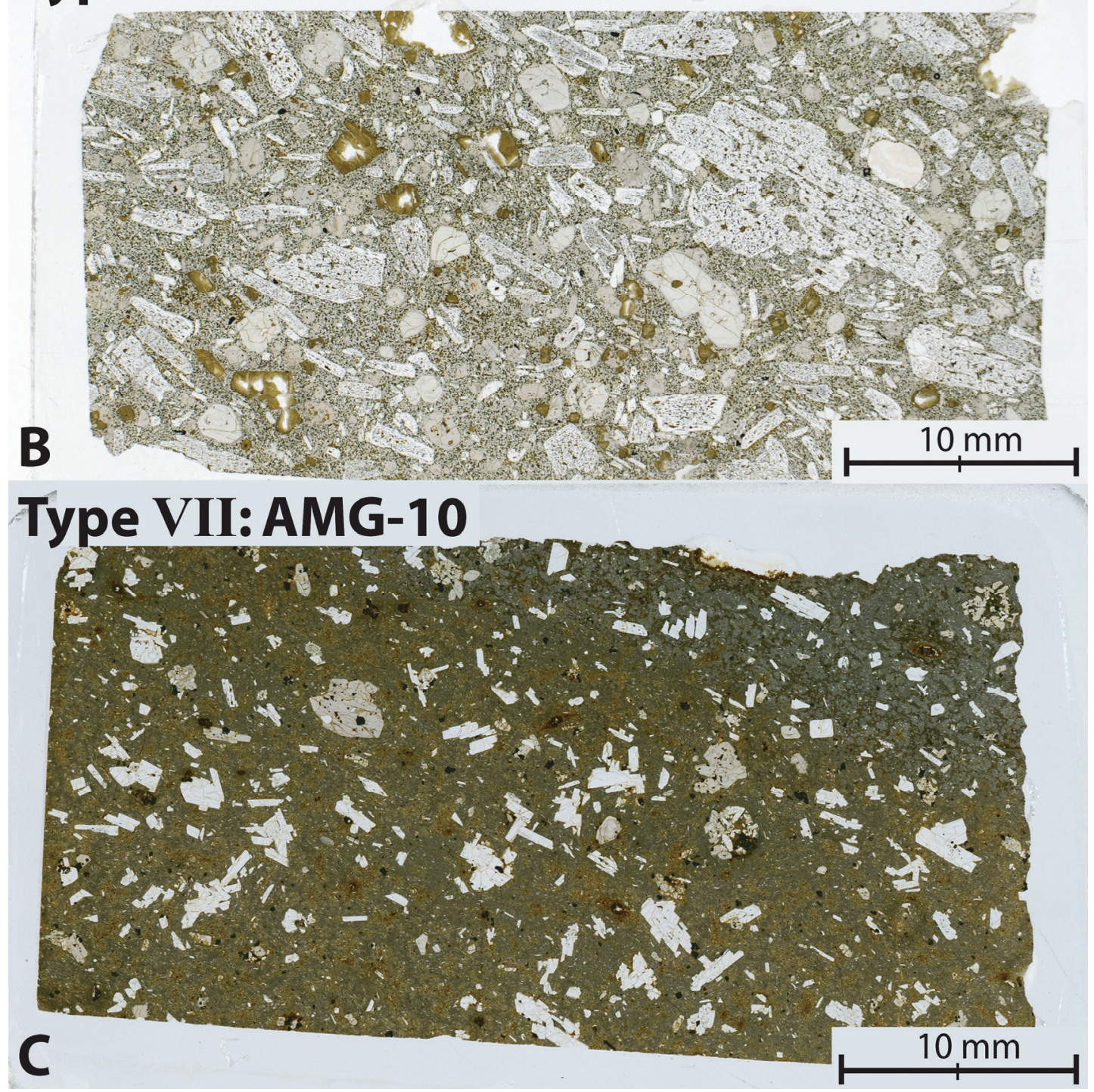

Figure 3.7: Thin sections of type examples of Type V-VII samples. A) Type V: moderately porphyritic plagioclase-phyric basaltic trachyandesite. B) Type VI: highly porphyritic honeycomb-textured plagioclase-phyric basalt. C) Type VII: moderately porphyritic orthopyroxene-bearing transitional trachyandesite. 


\subsubsection{Type VII (Orthopyroxene-bearing)}

Type VII rocks comprise $1 \%$ of the lava flows sampled in this study. This type consists of a single atypical lava flow AMG-10. AMG-10 is a moderately

porphyritic transitional trachyandesite (shoshonite) containing ca. 20\%

phenocrysts of clinopyroxene, plagioclase and orthopyroxene. A petrographic

slide of AMG-10 is shown in Figure 3.7 C.

Clinopyroxene phenocrysts up to $3 \mathrm{~mm}$ in size comprise ca. $4 \%$ of this rock. The clinopyroxenes in AMG-10 are augites $\left(\mathrm{Ca}_{42-32}\right)$ that become progressively enriched in $\mathrm{SiO}_{2}\left(50-55\right.$ wt \%) with magmatic evolution $\left(\mathrm{Mg}_{84-68}\right)$.
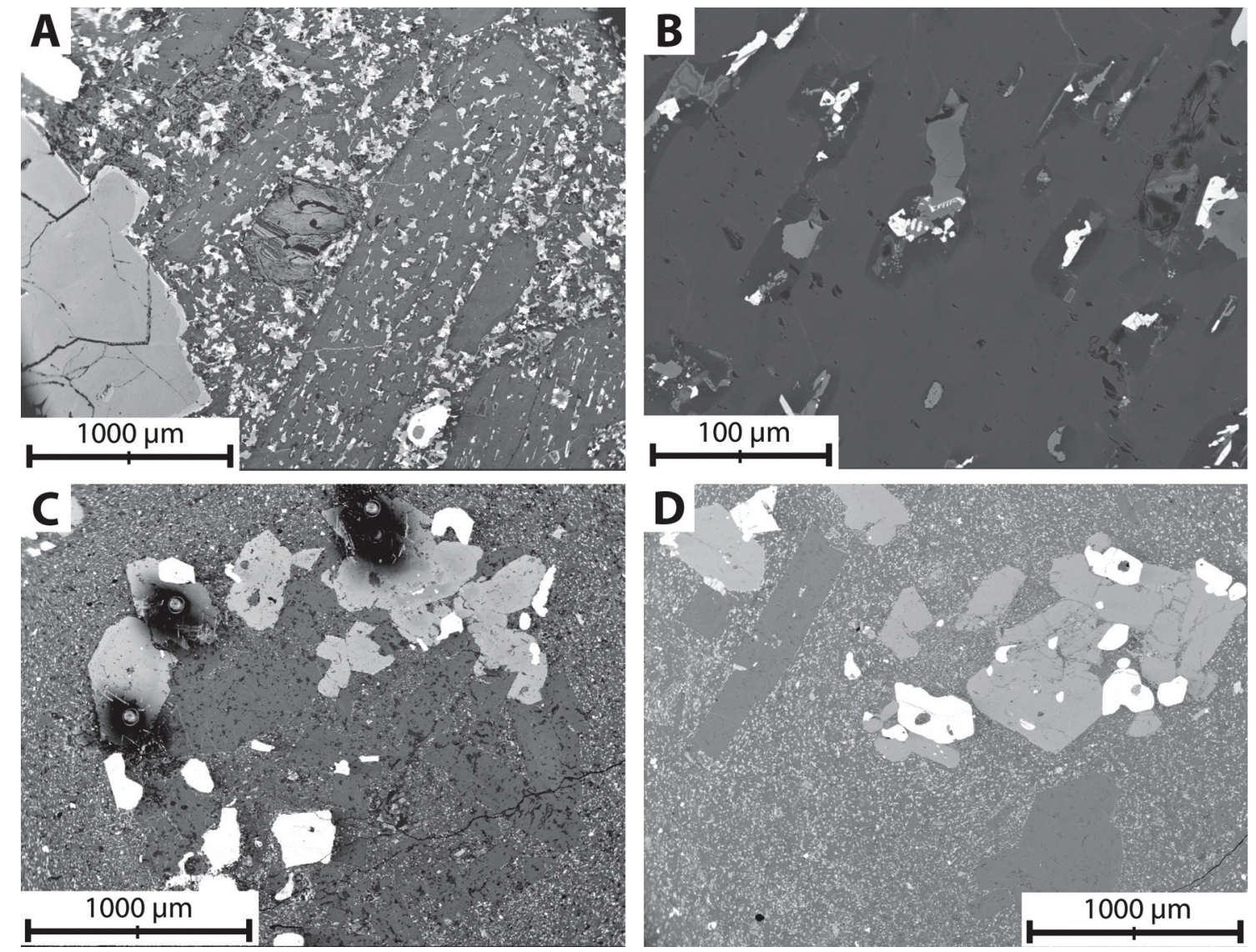

Figure 3.8: Back-scattered electron images of honeycombed plagioclase and orthopyroxne clusters in Type VI and Type VII samples, respectively. A) Honeycombed plagioclase phenocrysts of various sizes in AMF-6. Also visible are a Cr-rich diopside, pseudomorphed olivine and ilmenite grains. B) Honeycombed plagioclase of AMF-6 showing that the interstitial melt is now totally crystalline. The walls of the melt pockets crystallise more albitic plagioclase (darker), crystallisation of clinopyroxene, ilmenite and olivine (now pseudomorphed) also occurred. C) Orthopyroxene cluster in AMG-10; this circular feature comprises orthopyroxene, plagioclase and Fe-Ti oxides. D) Orthopyroxene cluster in AMG-10 comprising ca. 9 crystals. 
The augites are generally unzoned and form a low-Ti-Al-Cr series $\left(\mathrm{Mg}_{84} \mathrm{Ti}_{1.1} \mathrm{Cr}_{0.2}\right.$ - $\left.\mathrm{Mg}_{68} \mathrm{Ti}_{0.3} \mathrm{Cr}_{0.04}\right)$ which is distinct from other clinopyroxene phenocrysts within Lookout Volcanics, exhibiting an inverse crystallisation trend to those commonly displayed (i.e. decreasing $\mathrm{Al}_{2} \mathrm{O}_{3}$ and $\mathrm{TiO}_{2}$ with decreasing $\mathrm{Mg} \#$ ). Orthopyroxene phenocrysts (Enstatite; $\mathrm{Mg}_{69-66} \mathrm{Ca}_{3}$ ) between 0.5-1.0 mm in size comprise ca. $2 \%$ of this rock. The orthopyroxene crystals often form clusters of 5-10 randomly oriented grains (Figure 3.8 C \& D). Plagioclase crystals are subhedral to euhedral up to $4 \mathrm{~mm}$ in length and comprise ca. $13 \%$ of this rock. Phenocrysts $\left(\mathrm{An}_{74-62}\right)$ are ca. $70 \%$ bytownite and ca. 30\% labradorite. Plagioclase does not exhibit a honeycombed texture (Figure 3.8 D). Fe-Ti oxides (ilmenite and minor ulvöspinel) up to $0.5 \mathrm{~mm}$ comprise $1 \%$ of the phenocrysts visible in this rock. The groundmass comprises ca. 75\% microscopic feldspar laths (in relative proportion: andesine, labradorite and anorthoclase, respectively), ca. 15\% Fe-Ti oxides, and ca. $10 \%$ pseudomorphed clinopyroxene phenocrysts.

\subsection{MINERAL CHEMISTRY}

\subsubsection{Olivine}

Olivine major and mineral element data were acquired by electron probe microanalysis (EPMA) with a higher beam current and longer count times than normal analyses to improve data precision allowing an accurate assessment of the small variations in minor element concentrations within olivine phenocrysts (e.g. $\mathrm{Ni}$, $\mathrm{Ca}, \mathrm{Mn} ; \Delta \mathrm{wt} \%=0.2$ ). Details of the analytical settings used during the analysis of olivine are provided in Appendix A1.4.3.

\section{Lookout Volcanics}

Representative analyses of olivine from the Lookout Volcanics are shown in Table 3.2. Olivines from 12 lava flows were analysed and all samples display similar compositional trends $\left(\mathrm{Fo}_{74-88} ; \mathrm{NiO}=0.14-0.32 \mathrm{wt} \% ; \mathrm{CaO}=0.21-0.26\right.$ wt 
$\% ; \mathrm{MnO}=0.21-0.26 \mathrm{wt} \%)$. Elemental concentrations of olivine phenocrysts are plotted against forsterite $(\mathrm{Fo}=100 \times\{\mathrm{Mg} /(\mathrm{Mg}+\mathrm{Fe})\})$ contents in Figure 3.9. Si, $\mathrm{Ni}$ and Ca decrease with decreasing Fo content, while Mn conversely increases. Highlighted in Figure 3.9 are the olivines from AMB-10, a highly porphyritic rock containing ca. 20\% large olivine phenocrysts. Phenocrysts within AMB-10 display a rapid decrease in $\mathrm{Ni}(0.35-0.24 \mathrm{wt} \%)$ and increase in $\mathrm{Ca}(0.26-0.42 \mathrm{wt}$ \%) over a very restricted Fo range $\left(\mathrm{Fo}_{88-86}\right)$. Below $\mathrm{Fo}_{86}$ the rate of Ni depletion reduces significantly and $\mathrm{Ca}$ also begins to decrease.

Olivines from basaltic rocks erupted in a range of tectonic settings and localities around the world were also analysed in this study to enable comparison with the Lookout Volcanics. Representative EPMA data for these samples are shown in Table 3.3. Additional information on these samples is available in Appendix 2.
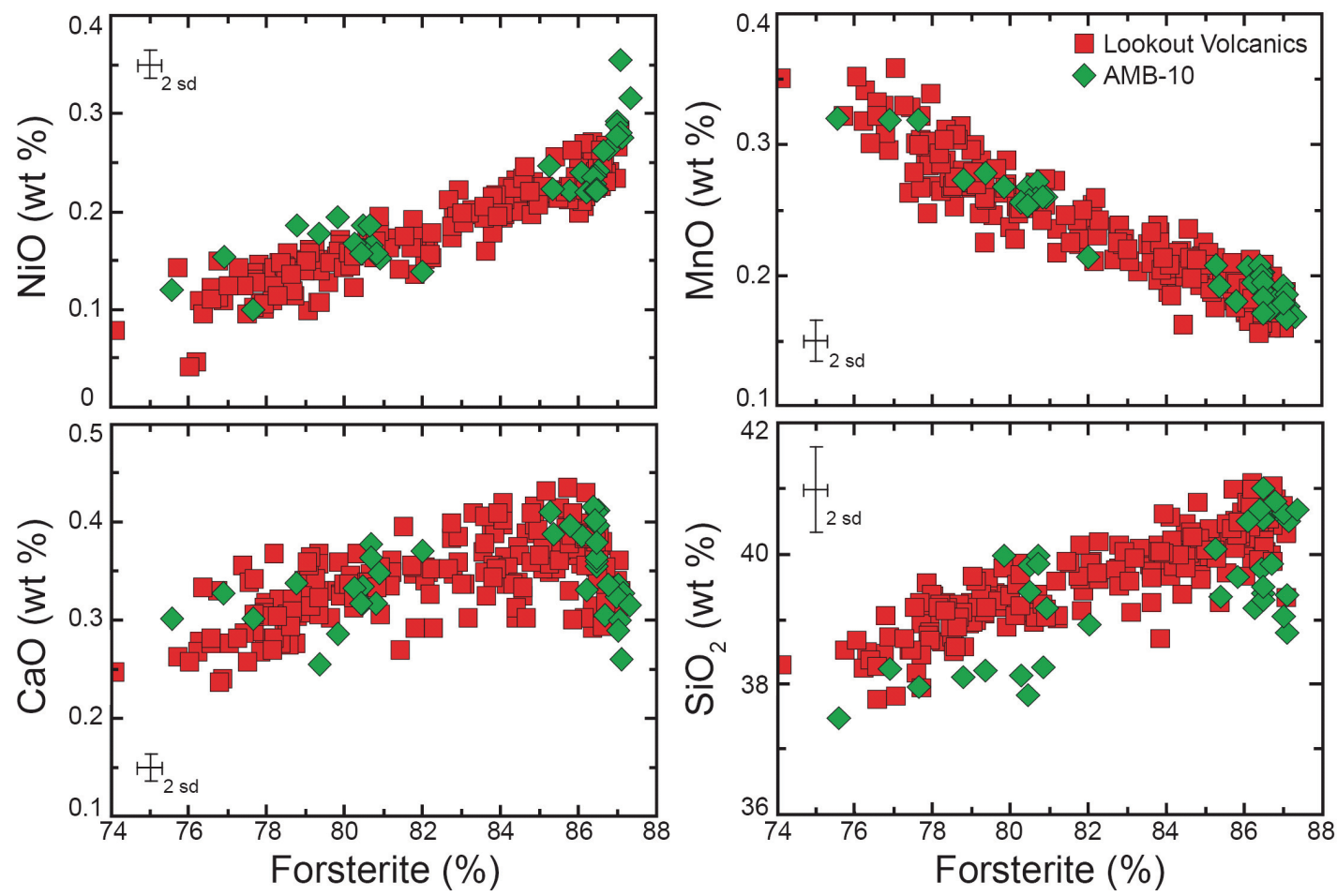

Figure 3.9: Element oxide variation of olivines in the Lookout Volcanics plotted against forsterite content. This variation represents analyses of olivine from 12 samples (AMB-5, 10, 22, 26, 29, 38, 39, 41, 52, AMC-9, AMG-3, 8). 


\section{Ocean island basalts (Hawaii)}

Hawaii is an example of ocean island basalt (OIB) magmatism and a type locality for plume-derived volcanism above a long-lived mantle hotspot. The Hawaiian samples used in this study are Late Quaternary eruptives, C35 is from the last eruption of Mauna Loa in 1950. Olivine phenocrysts from Hawaiian basalts were analysed to allow direct comparison between the results of this study and those of Sobolev et al. (2005 \& 2007). Phenocryst compositions were analysed from the lavas of two Hawaiian volcanoes (Mauna Loa and Mauna Kea). Olivines from Mauna Loa were analysed in two samples C35 ( $\mathrm{Fo}_{70-84} ; \mathrm{NiO}=0.14-0.32 \mathrm{wt} \%$; $\mathrm{CaO}=0.21-0.26$ wt \%) and $\mathrm{C} 38\left(\mathrm{Fo}_{81-87} ; \mathrm{NiO}=0.27-0.34\right.$ wt \%; $\mathrm{CaO}=0.27-0.34$ wt \%). Olivines analysed from Mauna Kea are from sample $\mathrm{C} 31\left(\mathrm{Fo}_{76-86} ; \mathrm{NiO}=\right.$ 0.12-0.27 wt \%; $\mathrm{CaO}=0.28-0.39$ wt \%). Olivines from Mauna Kea have lower $\mathrm{NiO}$ and higher $\mathrm{CaO}$ at a given Fo content than those from Mauna Loa (Figure 3.10). Olivines from Mauna Loa have higher Ni contents than phenocrysts from the Lookout Volcanics, while phenocrysts from Mauna Kea possess comparable $\mathrm{Ni}$ contents to Lookout samples.

\section{Arc basalt (Waimarino)}

The Waimarino basalt is an arc basalt erupted in the Taupo Volcanic Zone (TVZ), above the westward subducting Pacific Plate. Occurring at the southern end of the TVZ, it possess an unusual tholeiitic composition and is inferred to be younger than $20 \mathrm{ka}$ (Houghton et al., 1987). Olivine phenocrysts in the Waimarino basalt possess similar $\mathrm{Ni}$ and $\mathrm{Ca}$ contents as mid-ocean ridge basalts (MORB; Figure 3.10). Analysed olivine compositions show large $\mathrm{NiO}$ but minimal $\mathrm{CaO}$ variability $\left(\mathrm{Fo}_{82-94} ; \mathrm{NiO}=0.09-0.56\right.$ wt \%; $\mathrm{CaO}=0.12-0.20$ wt \%). $\mathrm{Ni}$ contents initial fall rapidly over a restricted Fo range $\left(\mathrm{Fo}_{93.6-89.4} ; \mathrm{NiO}=0.56-\right.$ 0.24 wt \%) and then decrease more slowly ( $\left.\mathrm{Fo}_{89.4-82.6} ; \mathrm{NiO}=0.24-0.09 \mathrm{wt} \%\right)$ on a trend parallel to but lower than that displayed by the Lookout Volcanics (Figure $3.10)$ 

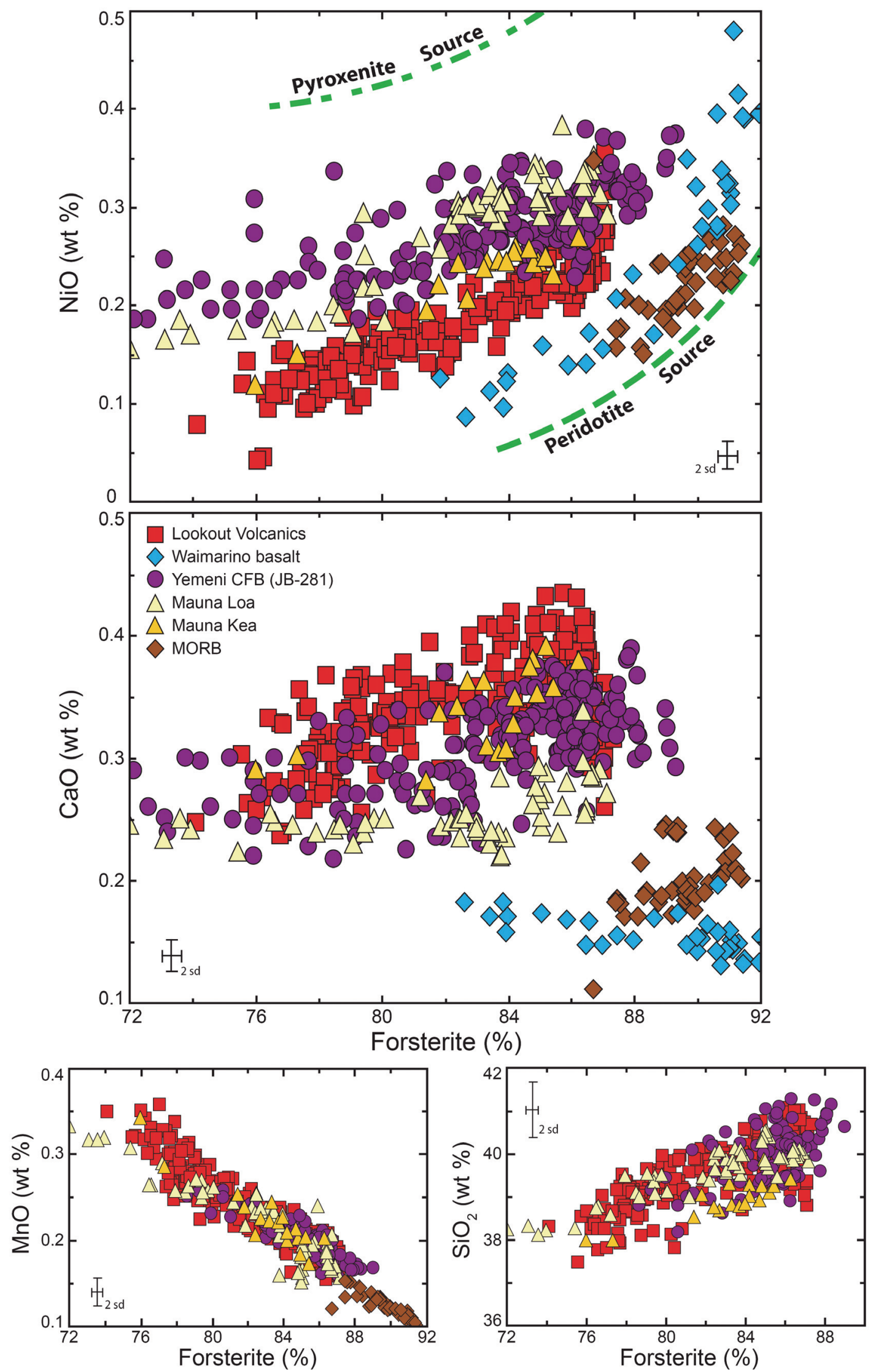

Figure 3.10: Element oxide variability of olivine phenocrysts from basalts erupted in various tectonic settings plotted against forsterite content. MORB data is taken from Sobolev et al. (2007). 


\section{Continental flood volcanism (Yemen)}

Representative analyses of olivine phenocrysts from basaltic eruptives in Yemen are reported in Table 3.4. Eruptives from Sana'a, Yemen were studied because of the range of magmas preserved and the presence of two distinct types of volcanism in close spatial and temporal proximity. Two major phases of Cenozoic volcanism have occurred in Yemen. In the Oligocene continental flood volcanism was widespread, and more recently there has been minor Quaternary intraplate volcanism (Baker et al., 1997). The main Yemen sample analysed in this study was the crustally uncontaminated continental flood basalt (CFB) JB-281 (Baker et al., 1996). 213 analyses were undertaken on olivine phenocrysts in JB$281\left(\mathrm{Fo}_{65-88} ; \mathrm{NiO}=0.15-0.38\right.$ wt $\% ; \mathrm{CaO}=0.22-0.39$ wt \%). JB-281 contains olivine phenocrysts with comparable $\mathrm{NiO}$ contents to Mauna Loa basalts from Hawaii (Figure 3.10), but displays a significantly greater range of $\mathrm{Ni}$ and $\mathrm{Ca}$ contents at a given Fo than any other sample.

The variability of the $\mathrm{NiO}$ contents of olivine phenocrysts from different Yemen samples are illustrated in Figure 3.11. Olivines from a second CFB JB-129 $\left(\mathrm{Fo}_{68-89} ; \mathrm{NiO}=0.04-0.39\right.$ wt \%) have similar Ni contents in Fo-rich crystals to those displayed by JB-281. JB-129 also displays a large range of $\mathrm{NiO}$ at a given $\mathrm{Fo}$, but Ni contents decrease more rapidly with decreasing Fo than JB-281. Two basanites erupted in Yemen during the Oligocene were also analysed in this study; JB-171 ( $\left.\mathrm{Fo}_{68-89} ; \mathrm{NiO}=0.07-0.22 \mathrm{wt} \%\right)$ and JB-231(II) $\left(\mathrm{Fo}_{75-89} ; \mathrm{NiO}=0.10-\right.$ 0.34 wt \%). The basanites form an overlapping and narrow (i.e. small vertical range) array with strongly decreasing Ni with decreasing Fo. The final eruptive unit from the Oligocene analysed was MNY-361 ( $\mathrm{Fo}_{75-89} ; \mathrm{NiO}=0.10-0.34$ wt \%), a sample that has been contaminated by a felsic Archaean crustal component (Kent et al., 2002). MNY-361 has lower Ni contents at all Fo contents than JB-281, Ni contents initially decline quickly with falling Fo and then almost level off after Fo86. 


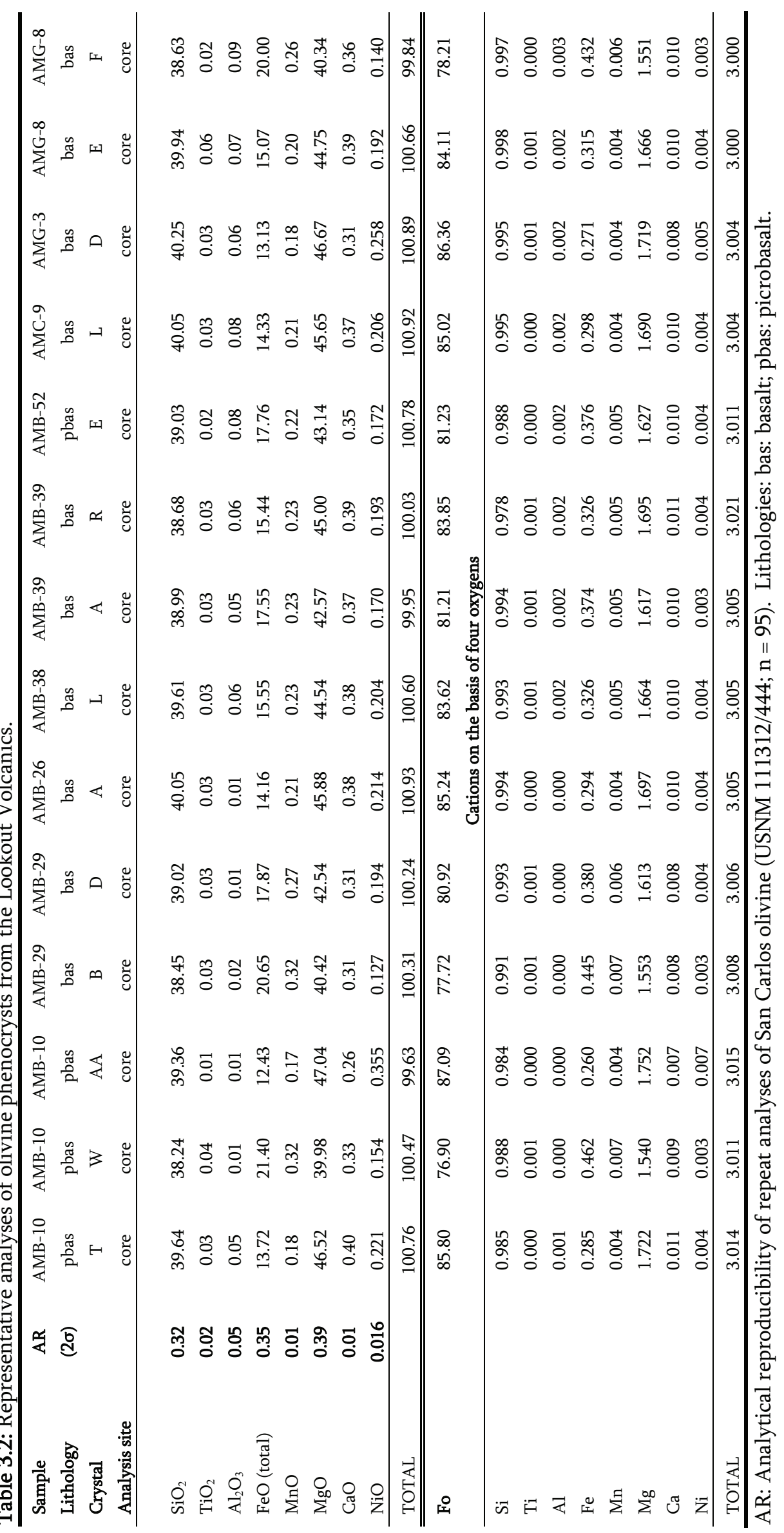




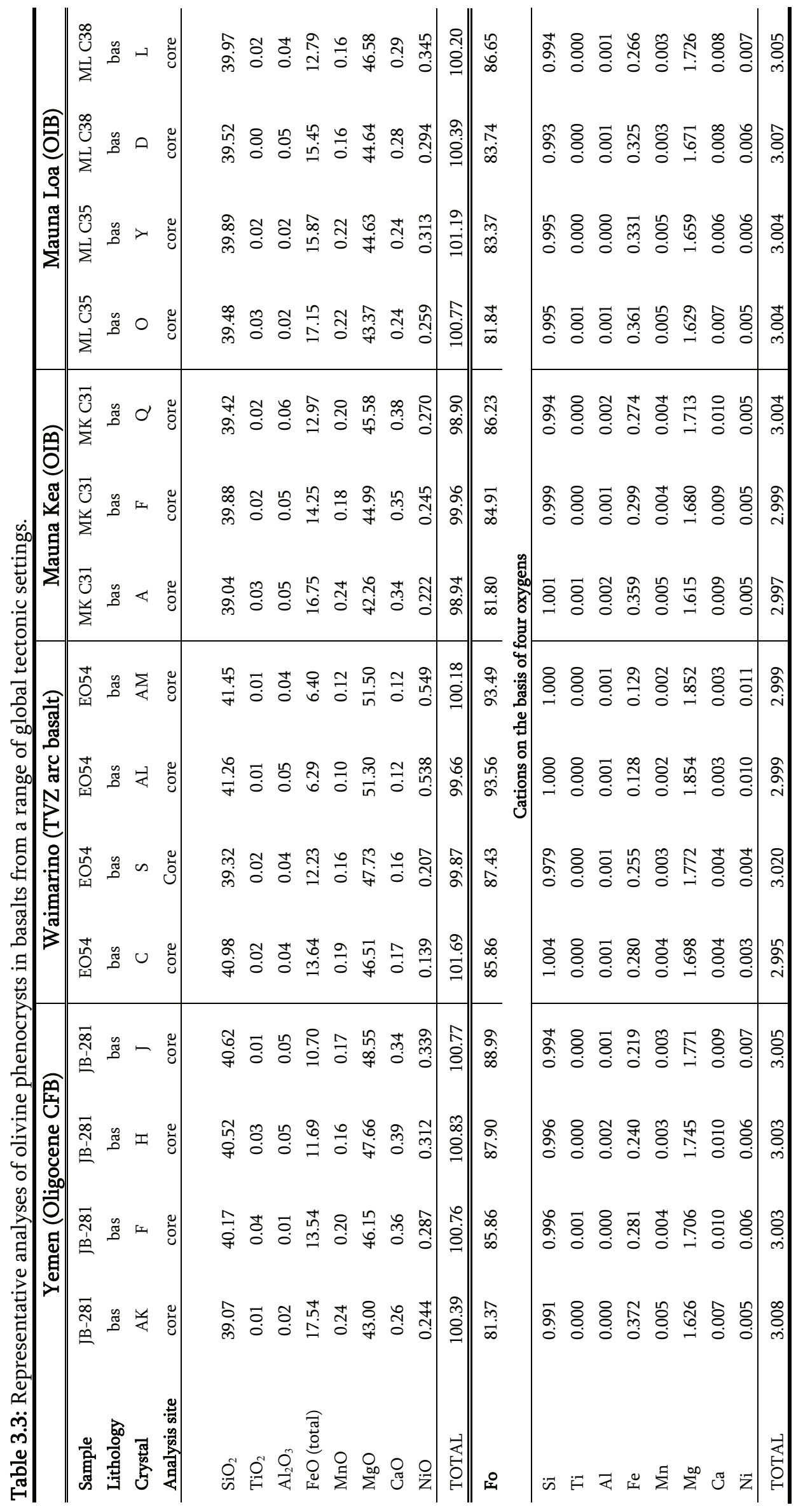




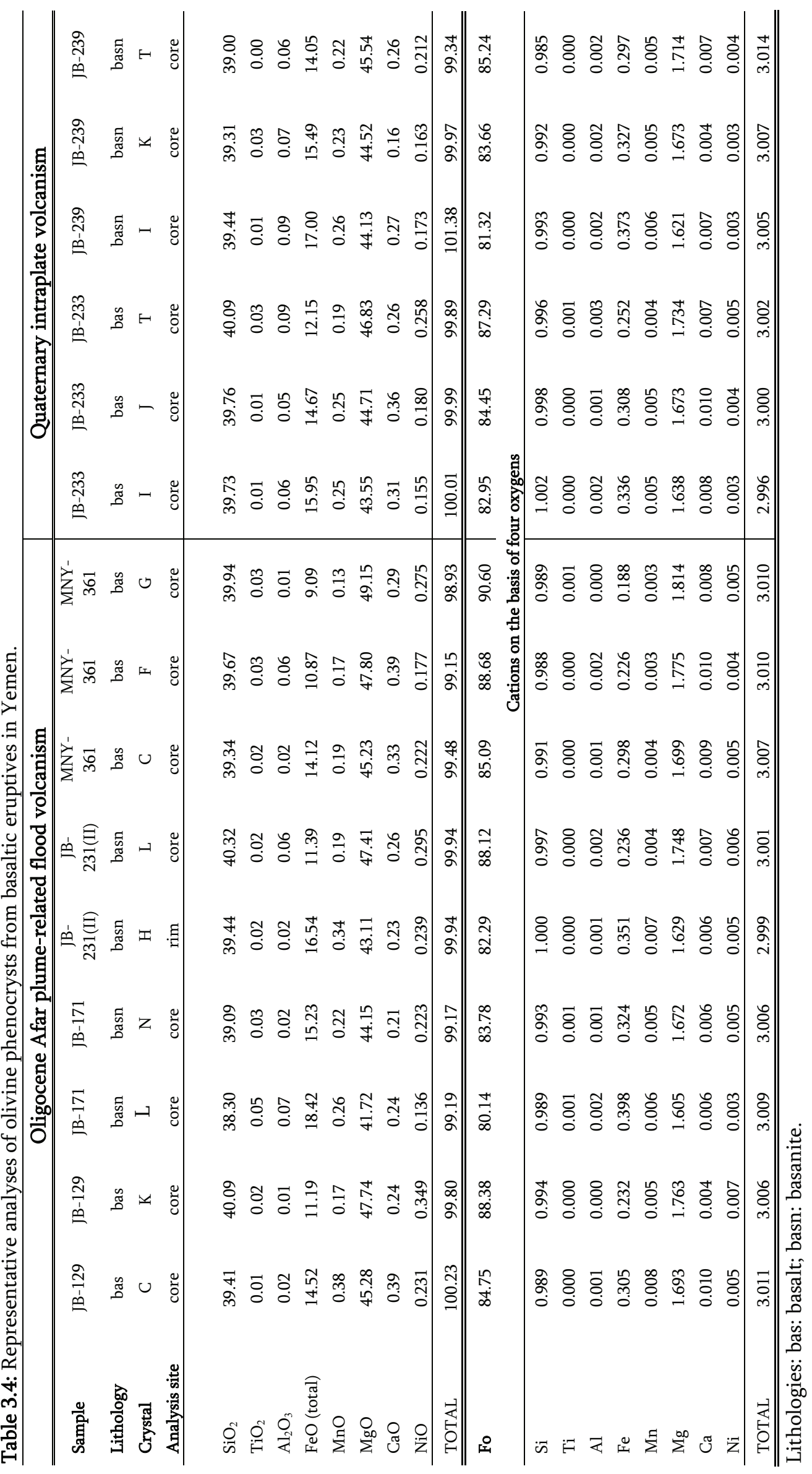




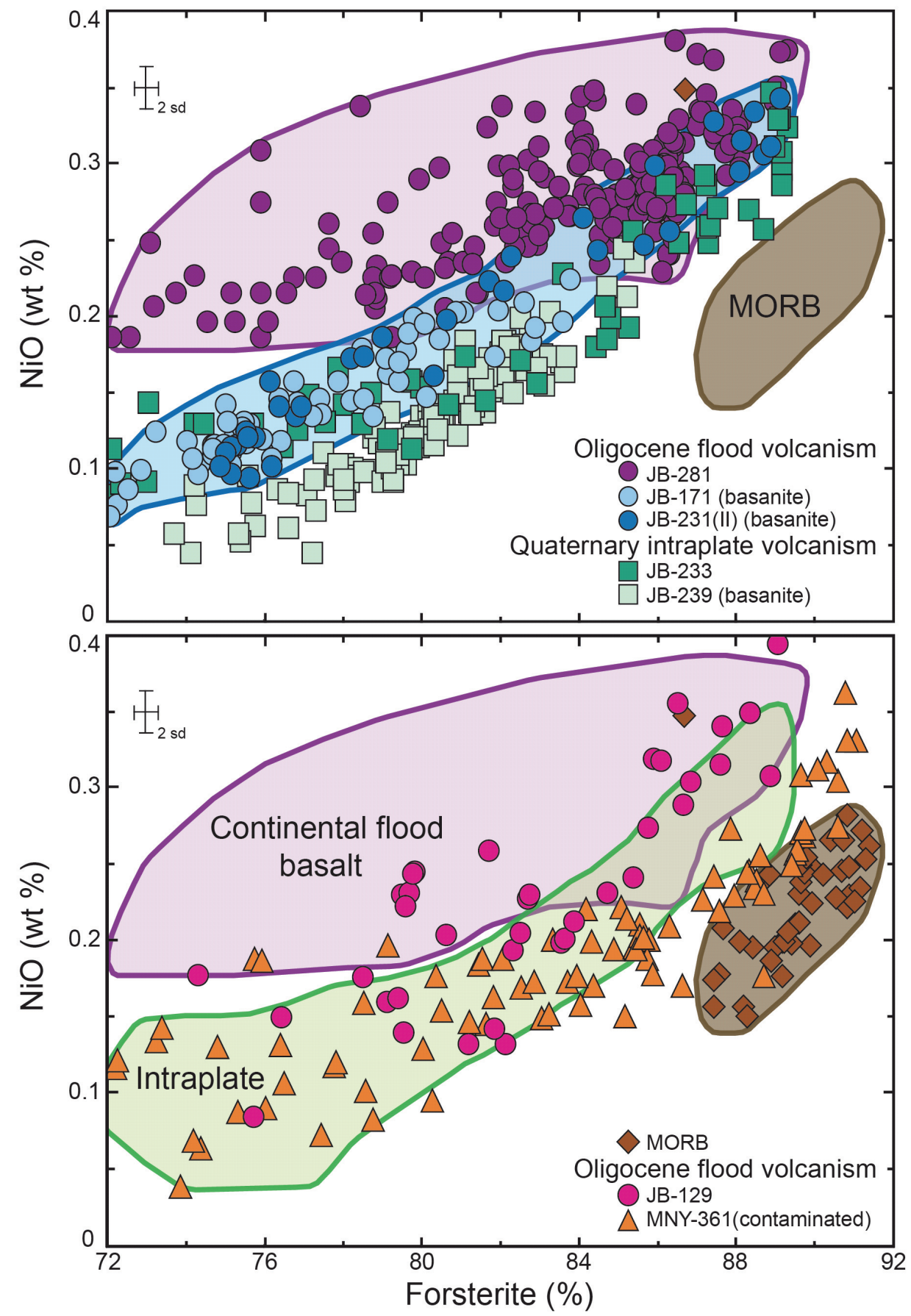

Figure 3.11: Comparison of the $\mathrm{NiO}$ contents of olivine phenocrysts from various mafic eruptives from Yemen plotted versus forsterite content. MORB data is taken from Sobolev et al. (2007).

\section{Intraplate volcanism (Yemen)}

Olivine phenocrysts from two Quaternary intraplate volcanic samples from

Yemen were analysed in this study, including a basalt JB-233 $\left(\mathrm{Fo}_{62-89} ; \mathrm{NiO}=0.07-\right.$

0.35 wt \%; $\mathrm{CaO}=0.22-0.59 \mathrm{wt} \%)$ and basanite JB-239 $\left(\mathrm{Fo}_{67-85} ; \mathrm{NiO}=0.02-0.25\right.$ wt $\% ; \mathrm{CaO}=0.15-0.50 \mathrm{wt} \%)$. The intraplate eruptives possess the lowest $\mathrm{NiO}$ contents of any of the samples from Yemen, except MNY-361. Olivines within 
the intraplate eruptives from Yemen have similar Ni contents to those of the Lookout Volcanics (Figure 3.12). However, $\mathrm{CaO}$ displays distinctly different trends with JB-233 having approximately constant Ca, and JB-239 displaying increasing $\mathrm{CaO}$ with decreasing Fo.
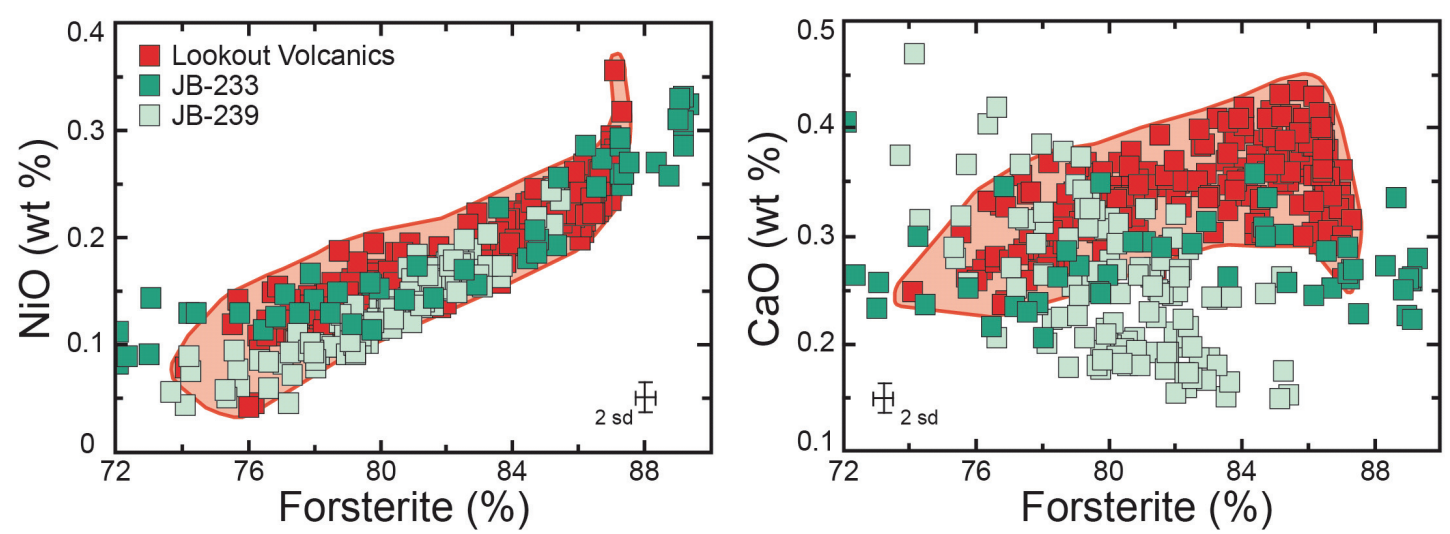

Figure 3.12: Comparison of $\mathrm{NiO}$ and $\mathrm{CaO}$ contents of olivine phenocrysts from the Lookout Volcanics with those from Quaternary intraplate eruptives from Yemen. The red field represents the range of compositions displayed by olivines in the Lookout Volcanics.

\subsubsection{Clinopyroxene}

\section{Nomenclature}

Nomenclature for classifying pyroxenes was finalised by the Commission on New Minerals and Mineral Names of the International Mineralogical Association (Morimoto, 1988). Clinopyroxenes within the Lookout Volcanics are entirely diopsides $\left((\mathrm{Mg}, \mathrm{Fe}) \mathrm{CaSi}_{2} \mathrm{O}_{6}\right)$ or augites $\left((\mathrm{Ca}, \mathrm{Mg}, \mathrm{Fe})_{2} \mathrm{Si}_{2} \mathrm{O}_{6}\right)$ with a sub-equal amount of both minerals occurring (Figure $3.13 \mathrm{~A}$ ). Distinction between these mineral names is made on the basis of the proportion cations in the M2M1 site (i.e. $\mathrm{Ca} \#=100 \times\left\{\mathrm{Ca} /\left(\mathrm{Ca}+\mathrm{Mg}+\mathrm{Fe}^{2+}\right)\right\}$ ), with diopside $\left(\mathrm{Ca}_{45-50}\right)$ and augite $\left(\mathrm{Ca}_{20-45}\right)$. Morimoto (1988) defined adjectival modifiers to be affixed to pyroxene mineral names containing a sufficient amount of a selected cation (Table 3.5). On the basis of this classification, the phenocrysts of the Lookout Volcanics comprise an Al-rich suite of generally aluminian clinopyroxenes (Figure 3.13 B), with many crystals having double the $\mathrm{Al}^{3+}$ required for this classification. Within the suite chromian, titanian and subsilicic phenocrysts are also observed. 

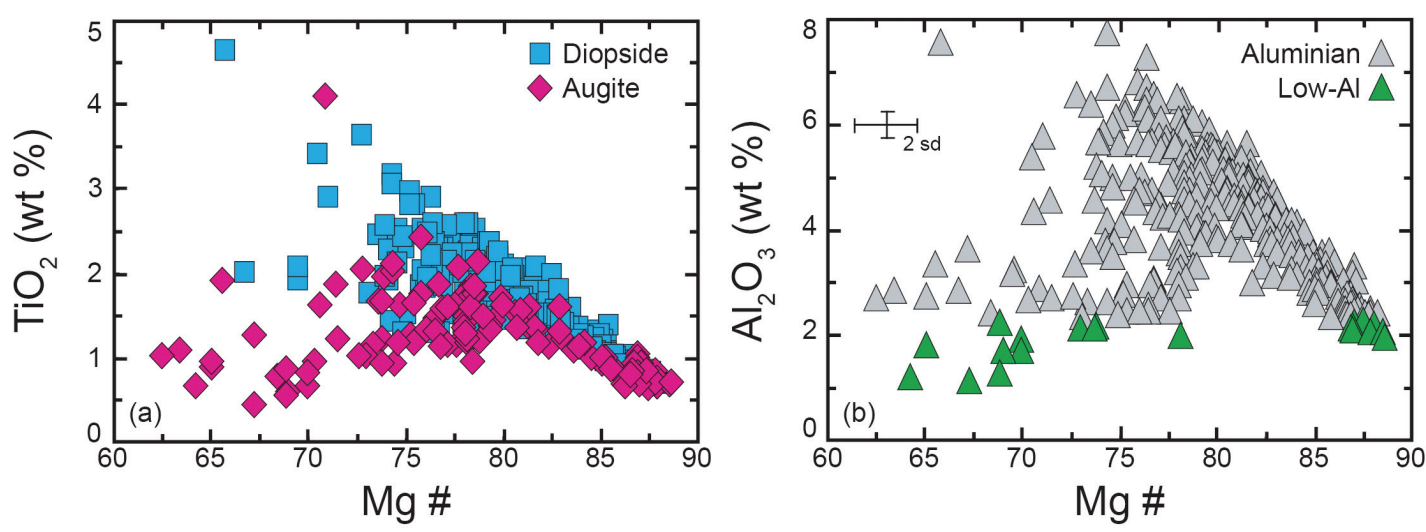

Figure 3.13: A) Graph of $\mathrm{TiO}_{2}$ versus $\mathrm{Mg} \#$ highlighting the compositional differences between diopside and augite. At $\mathrm{Mg} \#<80$ diopsides and augites appear to be compositionally distinct. B) Graph of $\mathrm{Al}_{2} \mathrm{O}_{3}$ versus $\mathrm{Mg} \#$ showing the composition of aluminian clinopyroxenes in the Lookout Volcanics.

Table 3.5: Adjectival modifiers to be used for pyroxene mineral names.

\begin{tabular}{ccc}
\hline Cation & Content & Name \\
\hline $\mathrm{Al}^{3+}$ & $>0.10$ & Aluminian \\
$\mathrm{Ca}^{2+}$ & $>0.10$ & Calcian \\
$\mathrm{Cr}^{3+}$ & $>0.01$ & Chromian \\
$\mathrm{Na}^{+}$ & $>0.10$ & Sodian \\
$\mathrm{Mg}^{2+}$ & $>0.10$ & Magnesian \\
$\mathrm{Mn}^{2+}$ & $>0.10$ & Manganoan \\
$\mathrm{Ni}^{2+}$ & $>0.01$ & Nickeloan \\
$\mathrm{Si}^{4+}$ & $<1.75$ & Subsilicic \\
$\mathrm{Ti}^{4+}$ & $>0.10$ & Titanian \\
\hline
\end{tabular}

Content is the number of cations per formula unit $\mathrm{M}_{2} \mathrm{M}_{1} \mathrm{~T}_{2} \mathrm{O}_{6}$. If the mineral name itself implies the presence of certain cations, adjectival modifiers for these cations should not be used ("subsilicic" is an exception). Table is from Morimoto (1988).

\section{Chemical variation}

Shown in Table 3.6 are representative analyses of clinopyroxene phenocrysts from the Lookout Volcanics. Twenty four samples were analysed with phenocrysts displaying significant compositional variability $\left(\mathrm{Al}_{2} \mathrm{O}_{3}=1.15-7.73 \mathrm{wt}\right.$ $\% ; \mathrm{TiO}_{2}=0.45-4.65$ wt \%; $\mathrm{Cr}_{2} \mathrm{O}_{3}=0-1.67$ wt \%; $\mathrm{Na}_{2} \mathrm{O}=0.20-0.63$ wt \%; $\mathrm{SiO}_{2}=$ 44.6-54.8 wt \%) and Mg-numbers $(\mathrm{Mg} \#=100 \times\{\mathrm{Mg} /(\mathrm{Mg}+\mathrm{Fe})\})$ from 62-89. High $\mathrm{Mg} \#\left(\mathrm{Mg}_{85-89}\right)$ clinopyroxenes are $\mathrm{Cr}_{2} \mathrm{O}_{3}-\mathrm{SiO}_{2}$ rich and $\mathrm{Al}_{2} \mathrm{O}_{3}-\mathrm{TiO}_{2}$ poor diopside/augites (Figure 3.14). With decreasing Mg\# the majority of crystals display decreasing $\mathrm{Cr}$ and $\mathrm{Si}$ and increasing $\mathrm{Al}, \mathrm{Ti}$ and $\mathrm{Na}$. However, this is not the only trend observed in the clinopyroxenes of the Lookout Volcanics with the high-Si rocks (e.g. AMB-54, AMG-10; Chapter 4) producing a different 
crystallisation trend (Figure 3.14). These rocks contain relict phenocrysts that lie on the main crystallisation trend (i.e. Cr-rich augites). These relict crystals are only observed to $\mathrm{Mg \#}=80$, after which point the high-Si melts produce their own unique trend with consistently high $\mathrm{SiO}_{2}$, but low $\mathrm{Cr}_{2} \mathrm{O}_{3}, \mathrm{Al}_{2} \mathrm{O}_{3}$ and $\mathrm{TiO}_{2}$. The Ca content $\left(\mathrm{CaO}=15.6-20.6\right.$ wt \%; $\left.\mathrm{Ca}_{32-43}\right)$ of the most $\mathrm{Mg}$-poor clinopyroxenes in the high-Si rocks begins to falls rapidly from $\mathrm{Mg}_{72-62}$ whereas the main crystallisation trend does not record this effect with Ca\# staying approximately constant from $\mathrm{Mg}_{65-75}$.
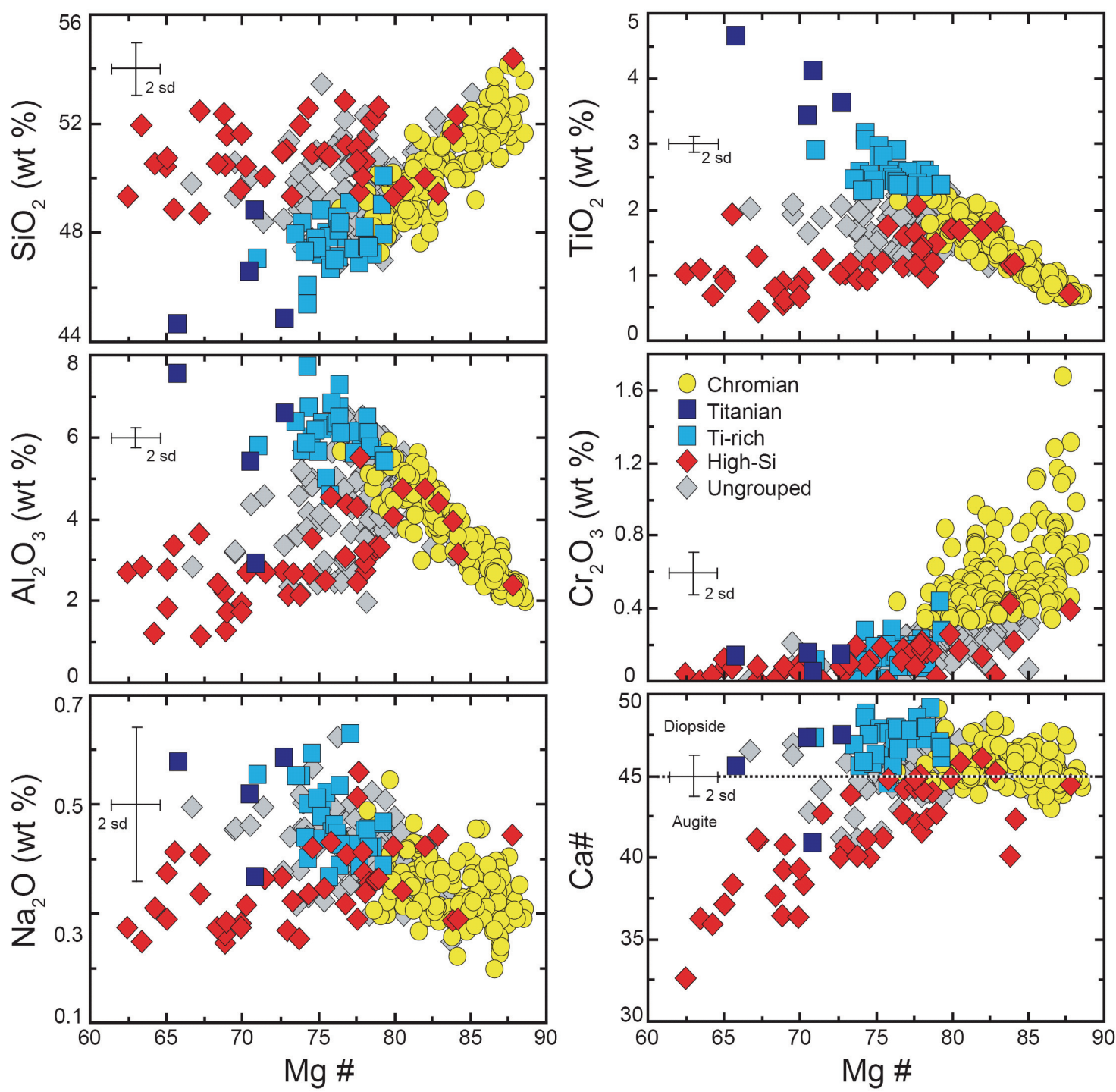

Figure 3.14: Graphs of element oxides and Ca\# versus Mg\# of clinopyroxenes from the Lookout Volcanics showing clinopyroxene crystallisation trends. Clinopyroxenes were grouped as follows: Chromian: $\mathrm{Cr}^{3+}>0.01$; Titanian: $\mathrm{Ti}^{4+}>0.10$; Ti-rich: $\mathrm{Ti}^{4+}>0.065$; High-Si: are the clinopyroxene phenocrysts from the two rocks with the highest $\mathrm{SiO}_{2}$ contents in the Lookout Volcanics (AMB54, AMG-10); ungrouped: clinopyroxenes that do not qualify for any of the above groups. 


\section{Growth zoning}

Large clinopyroxene phenocrysts that exhibit core to rim growth zonation

(Figure 3.15) display large major element variations marked by two main endmember types: (1) Green Cr-rich diopside/augite cores with up to $1.6 \mathrm{wt} \% \mathrm{Cr}_{2} \mathrm{O}_{3}$, $<1$ wt $\% \mathrm{TiO}_{2}$ and $\mathrm{Mg \#}$ up to 89; (2) Brown Ti-rich diopside rims with up to $3 \mathrm{wt}$ $\% \mathrm{TiO}_{2},<0.5 \mathrm{wt} \% \mathrm{Cr}_{2} \mathrm{O}_{3}$ and $\mathrm{Mg \#}$ of $79-84$. Ti-rich overgrowths vary in size considerably from $<0.5 \mathrm{~mm}$ around well preserved euhedral cores to $\leq 2.5 \mathrm{~mm}$ around strongly resorbed cores. Core and rim analyses from zoned clinopyroxene phenocrysts are shown in Figure 3.16. The green clinopyroxene cores have high $\mathrm{SiO}_{2}$ and $\mathrm{Cr}_{2} \mathrm{O}_{3}$ and low $\mathrm{Al}_{2} \mathrm{O}_{3}$ and $\mathrm{TiO}_{2}$, with the reciprocal observed in the brown clinopyroxene rims. Phenocryst cores appear to exhibit slightly lower $\mathrm{Na}_{2} \mathrm{O}$ than their rims, however, the error on $\mathrm{Na}$ measurement at this concentration is significant.

\subsubsection{Orthopyroxene}

Analyses of orthopyroxene are reported in Table 3.7. Orthopyroxene is a minor crystallising phase amongst the rocks of the Lookout Volcanics only occurring in the most evolved magmas in the suite. EPMA confirmed the presence of orthopyroxene in only two samples. In AMG-10 orthopyroxene occurs in small clusters of crystals $(n=5-6)$ and a single analysis detected orthopyroxene in the groundmass of AMB-54.

\subsubsection{Feldspar}

Representative analyses of feldspars from the Lookout Volcanics are shown in Table 3.8. Feldspar phenocrysts are entirely plagioclase and range in composition from anorthite to labradorite $\left(\mathrm{An}_{93-64}\right)$. Plagioclase displays silica-alumina coupled substitution, with $\mathrm{SiO}_{2}$ contents increasing from 46-56 wt \%, while $\mathrm{Al}_{2} \mathrm{O}_{3}$ contents fall from 34-26 wt \% with decreasing anorthite $(\mathrm{An}=100 \times\{\mathrm{Ca} /(\mathrm{Ca}+\mathrm{Na}+\mathrm{K})\})$ content. 


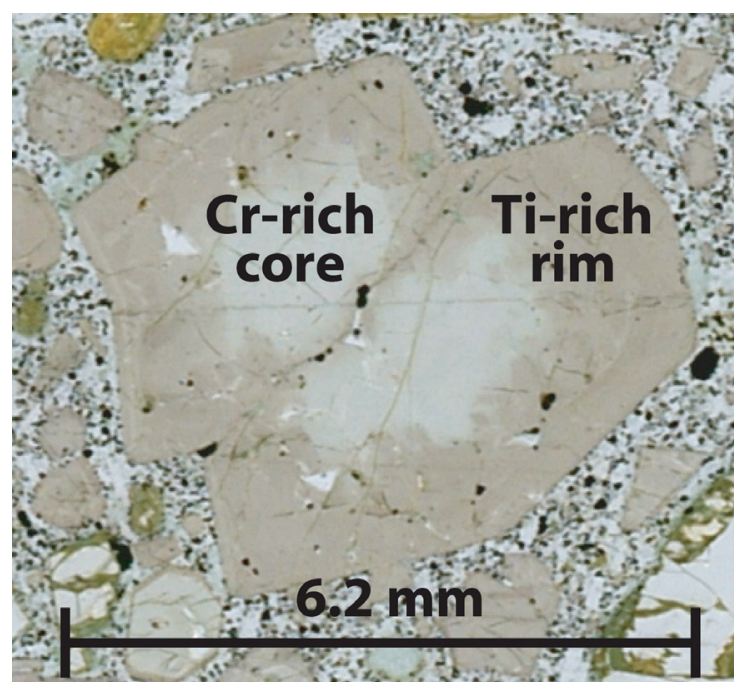

Figure 3.15: Photograph of a clinopyroxene phenocryst from AMB-39 (Type I). The crystal has a chromian augite core (grey) that has been slightly resorbed and overgrown by a Ti-rich diopside rim (brown). Composition is shown in Table 3.6.
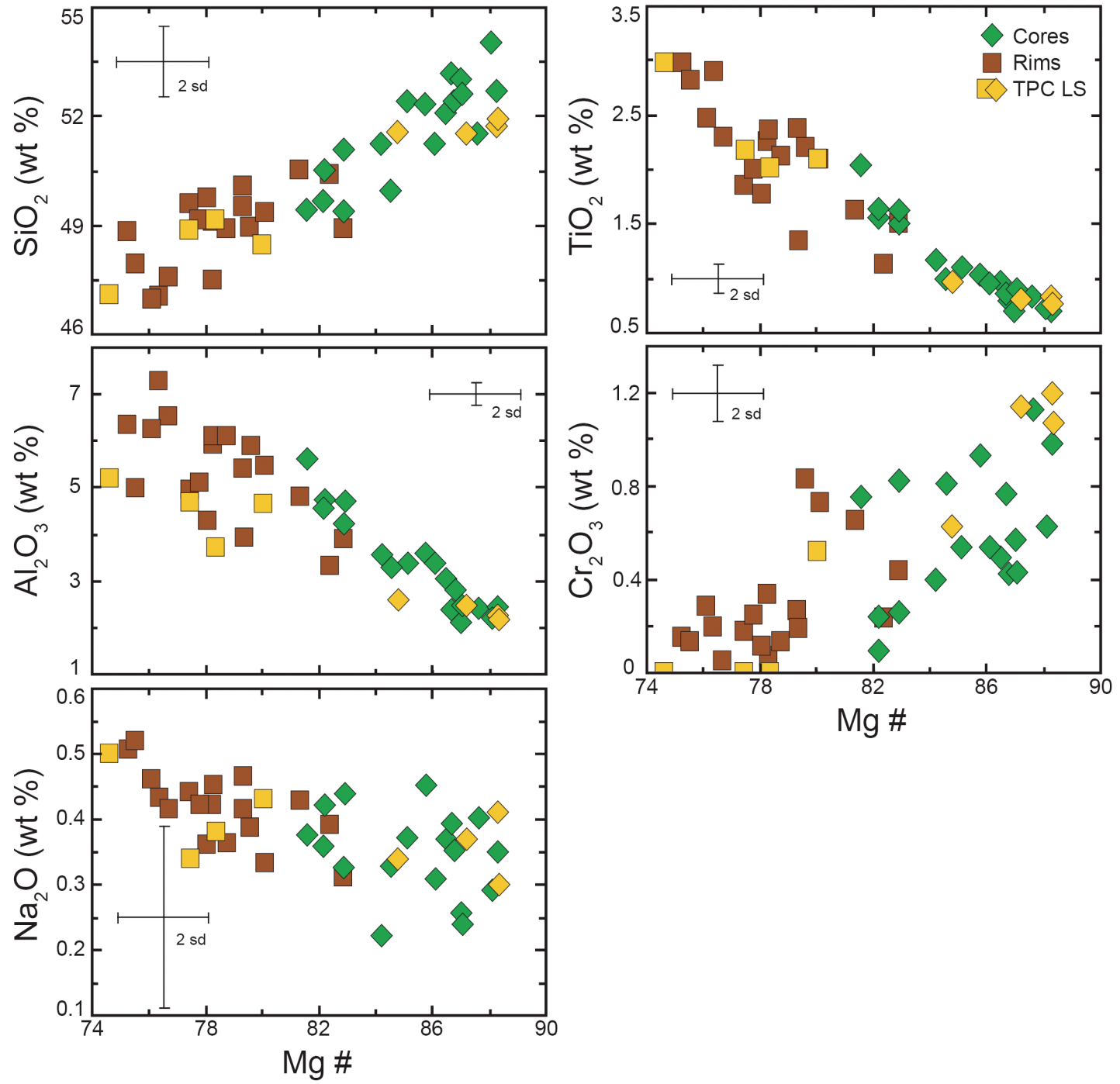

Figure 3.16: Graphs of the element oxide variability versus $\mathrm{Mg \#}$ of zoned clinopyroxene phenocrysts within the Lookout Volcanics. Crystal cores and rims form distinct compositional fields. Also plotted are core and rim (diamonds and squares, respectively) compositions of clinopyroxene from the Layered Series rocks of the Tapuaeouenuku Plutonic Complex (Baker, 1990). 
Table 3.7: Analyses of orthopyroxene phenocrysts from the Lookout Volcanics.

\begin{tabular}{|c|c|c|c|c|c|c|c|}
\hline $\begin{array}{l}\text { Sample } \\
\text { Lithology } \\
\text { Crystal } \\
\text { Analysis site }\end{array}$ & $\begin{array}{c}\text { AMB-54 } \\
\text { shos } \\
\text { GM (A) }\end{array}$ & $\begin{array}{c}\text { AMG-10 } \\
\text { shos } \\
\text { A } \\
\text { core } \\
\end{array}$ & $\begin{array}{l}\text { AMG-10 } \\
\text { shos } \\
\text { B } \\
\text { core } \\
\end{array}$ & $\begin{array}{c}\text { AMG-10 } \\
\text { shos } \\
\text { C } \\
\text { core }\end{array}$ & $\begin{array}{l}\text { AMG-10 } \\
\text { shos } \\
\text { D } \\
\text { core }\end{array}$ & $\begin{array}{c}\text { AMG-10 } \\
\text { shos } \\
\text { E } \\
\text { core } \\
\end{array}$ & $\begin{array}{c}\text { AMG-10 } \\
\text { shos } \\
\text { GM (A) }\end{array}$ \\
\hline $\mathrm{SiO}_{2}$ & 51.28 & 55.23 & 53.08 & 52.29 & 52.91 & 52.08 & 51.93 \\
\hline $\mathrm{TiO}_{2}$ & 0.54 & 0.37 & 0.45 & 0.32 & 0.37 & 0.29 & 0.48 \\
\hline $\mathrm{Cr}_{2} \mathrm{O}_{3}$ & 0.00 & 0.04 & 0.05 & 0.00 & 0.04 & 0.04 & 0.01 \\
\hline $\mathrm{Al}_{2} \mathrm{O}_{3}$ & 0.62 & 0.97 & 1.21 & 1.21 & 0.86 & 0.90 & 1.07 \\
\hline $\mathrm{FeO}$ & 24.94 & 19.08 & 20.16 & 20.85 & 22.03 & 21.40 & 17.82 \\
\hline $\mathrm{MnO}$ & 0.76 & 0.26 & 0.41 & 0.31 & 0.38 & 0.28 & 0.40 \\
\hline $\mathrm{MgO}$ & 17.33 & 24.64 & 24.66 & 24.97 & 24.37 & 24.19 & 23.13 \\
\hline $\mathrm{CaO}$ & 3.89 & 1.72 & 2.01 & 1.74 & 1.65 & 1.69 & 1.72 \\
\hline $\mathrm{Na}_{2} \mathrm{O}$ & 0.10 & 0.06 & 0.08 & 0.06 & 0.06 & 0.07 & 0.00 \\
\hline $\mathrm{NiO}$ & 0.03 & 0.15 & 0.12 & 0.10 & 0.06 & 0.08 & 0.00 \\
\hline TOTAL & 99.47 & 102.53 & 102.23 & 101.85 & 102.72 & 101.02 & 96.57 \\
\hline $\mathrm{Mg}$ & 50.79 & 67.36 & 65.91 & 65.85 & 64.28 & 64.66 & 67.30 \\
\hline $\mathrm{Fe}$ & 41.02 & 29.27 & 30.23 & 30.86 & 32.60 & 32.10 & 29.10 \\
\hline $\mathrm{Ca}$ & 8.19 & 3.37 & 3.86 & 3.29 & 3.13 & 3.24 & 3.61 \\
\hline \multirow[t]{2}{*}{ Mg\# } & 55.32 & 69.71 & 68.55 & 68.09 & 66.35 & 66.83 & 69.81 \\
\hline & \multicolumn{7}{|c|}{ Cations on the basis of six oxygens } \\
\hline $\mathrm{Si}$ & 1.972 & 1.974 & 1.926 & 1.912 & 1.925 & 1.924 & 1.971 \\
\hline $\mathrm{Ti}$ & 0.016 & 0.010 & 0.012 & 0.009 & 0.010 & 0.008 & 0.014 \\
\hline $\mathrm{Cr}$ & 0.000 & 0.004 & 0.002 & 0.000 & 0.001 & 0.001 & 0.000 \\
\hline $\mathrm{Al}$ & 0.028 & 0.041 & 0.052 & 0.052 & 0.037 & 0.039 & 0.048 \\
\hline $\mathrm{Fe}$ & 0.802 & 0.570 & 0.612 & 0.637 & 0.670 & 0.661 & 0.566 \\
\hline $\mathrm{Mn}$ & 0.025 & 0.008 & 0.012 & 0.009 & 0.012 & 0.009 & 0.013 \\
\hline $\mathrm{Mg}$ & 0.993 & 1.313 & 1.334 & 1.361 & 1.322 & 1.332 & 1.309 \\
\hline $\mathrm{Ca}$ & 0.160 & 0.066 & 0.078 & 0.068 & 0.064 & 0.067 & 0.070 \\
\hline $\mathrm{Na}$ & 0.007 & 0.004 & 0.005 & 0.004 & 0.004 & 0.005 & 0.000 \\
\hline $\mathrm{Ni}$ & 0.001 & 0.004 & 0.003 & 0.003 & 0.002 & 0.002 & 0.000 \\
\hline TOTAL & 4.003 & 3.995 & 4.037 & 4.055 & 4.047 & 4.050 & 3.991 \\
\hline Name & $\begin{array}{c}\text { calcian } \\
\text { enstatite }\end{array}$ & enstatite & enstatite & enstatite & enstatite & enstatite & enstatite \\
\hline
\end{tabular}

Within a single lava flow, phenocrysts usually span a small compositional range (ca. $A_{10-15}$; Figure 3.17 B). However, the highly porphyritic rock AMB-39 displays a larger variation with the smallest phenocrysts containing the most albitic compositions. Feldspar laths in the groundmass of rocks from the Lookout Volcanics exhibit more varied compositions (Figure 3.17 A), with andesine, anorthoclase and sanidine all observed. 

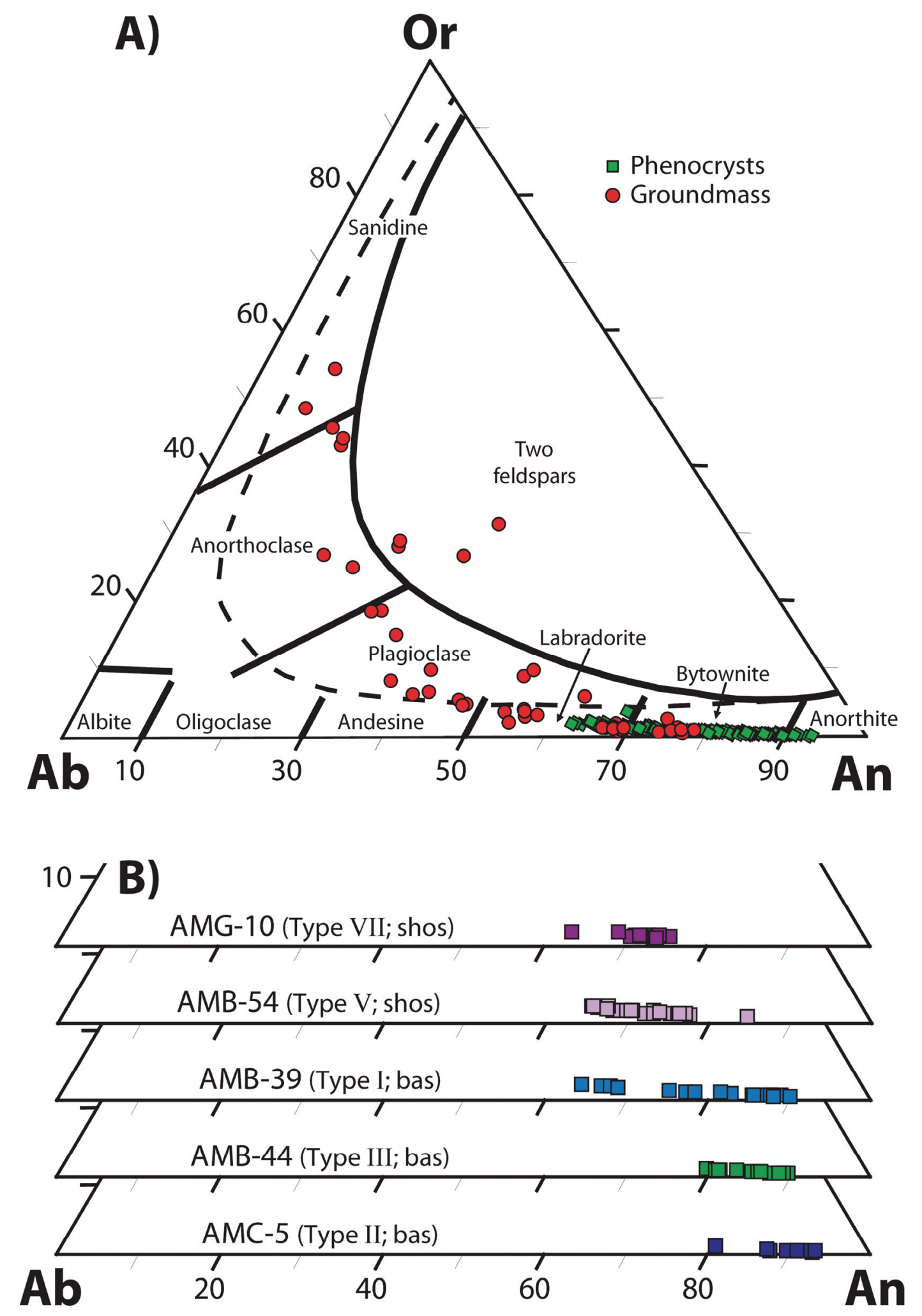

Figure 3.17: A) Anorthite-albite-orthoclase (An-Ab-Or) ternary diagram showing the variability exhibited by phenocrysts and groundmass crystals in the lavas of the Lookout Volcanics. B) Anorthite-albite plots showing the differences in phenocryst composition between different rock types and lithologies. Lithologies: bas: basalt; shos: shoshonite (K-basaltic-trachyandesite). 


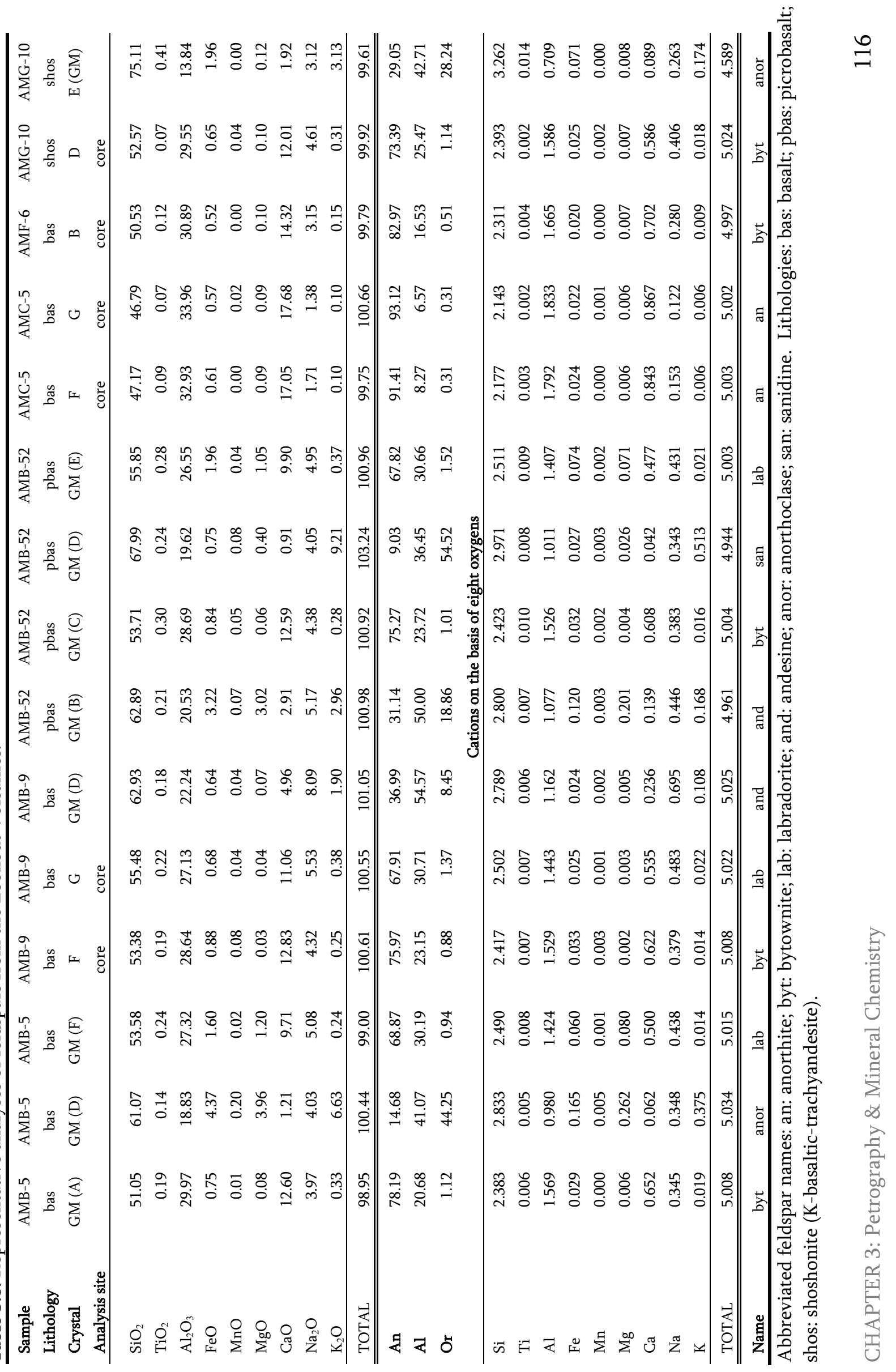




\subsubsection{Fe-Ti Oxides}

Three types of Fe-Ti oxide minerals are observed in the Lookout Volcanics, these are ilmenite, ulvöspinel and magnetite (Figure 3.18 A). Representative EPMA data from Fe-Ti oxide minerals are shown in Table 3.9. Fe-Ti oxide minerals display a large range of compositions, with $\mathrm{Mg}$ and $\mathrm{Cr}$ the major substituting elements.

Ilmenite $\left(\mathrm{FeTiO}_{3}\right)$ is a ubiquitous accessory mineral occurring in the groundmass of all samples in the suite, often comprising $10-20 \%$ of the groundmass. Phenocrysts of significant size (ca. $1 \mathrm{~mm}$ ) are generally only present in the more evolved samples. Ti-numbers $\left(\mathrm{Ti} \#=100 \times\left\{\mathrm{Ti} /\left(\mathrm{Ti}+\mathrm{Fe}^{2+}+\mathrm{Fe}^{3+}\right)\right\}\right)$ range from 44-56 (Figure $3.18 \mathrm{~A}$ ), with $\mathrm{MgO}$ contents varying from 1.5-7.8 wt \%, $\mathrm{Cr}$ is a minor constituent making up $<0.55 \mathrm{wt} \%$.

Ulvöspinel $\left(\mathrm{Fe}_{2} \mathrm{TiO}_{4}\right)$ occurs in the majority of samples displaying extensive compositional variability (Figure 3.18 B). Crystals are generally microphenocrysts comprising part of the groundmass, but rare phenocrysts up to $1 \mathrm{~mm}$ in size are observed. Ti\# of ulvöspinel generally vary from 17-38, and $\mathrm{Cr}_{2} \mathrm{O}_{3}$ and $\mathrm{MgO}$ make up 0-8.9 wt \% and 0.1-7.9 wt \% of these crystals, respectively.

Magnetite $\left(\mathrm{Fe}_{3} \mathrm{O}_{4}\right)$ is relatively rare and is only observed in close proximity to weathered olivine phenocrysts. This suggests that magnetite is a secondary mineral created during the high temperature hydrothermal alteration of lava flows soon after eruption. Ti\# range from 2-11 (Figure $3.18 \mathrm{~A}$ ), $\mathrm{MgO}$ is a minor constituent only comprising $1-2$ wt $\%$ with $\mathrm{Cr}_{2} \mathrm{O}_{3}<4.5$ wt \%.

\subsubsection{Chromian Spinels}

Representative analyses of chromian spinels $\left(\left(\mathrm{Mg}, \mathrm{Fe}^{2+}\right)\left(\mathrm{Cr}, \mathrm{Al}, \mathrm{Fe}^{3+}\right)_{2} \mathrm{O}_{4}\right)$ are shown in Table 3.10. Cr-spinels exhibit significant compositional variability with the major substitutions occurring being $\mathrm{Fe}-\mathrm{Mg}$ and $\mathrm{Cr}-\mathrm{Al}(\mathrm{FeO}=27.5-62.3 \mathrm{wt} \%$; $\mathrm{MgO}=3.0-13.2$ wt \%; $\mathrm{Cr}_{2} \mathrm{O}_{3}=5.2-42.3$ wt \%; $\mathrm{Al}_{2} \mathrm{O}_{3}=3.6-17.5$ wt \%). 

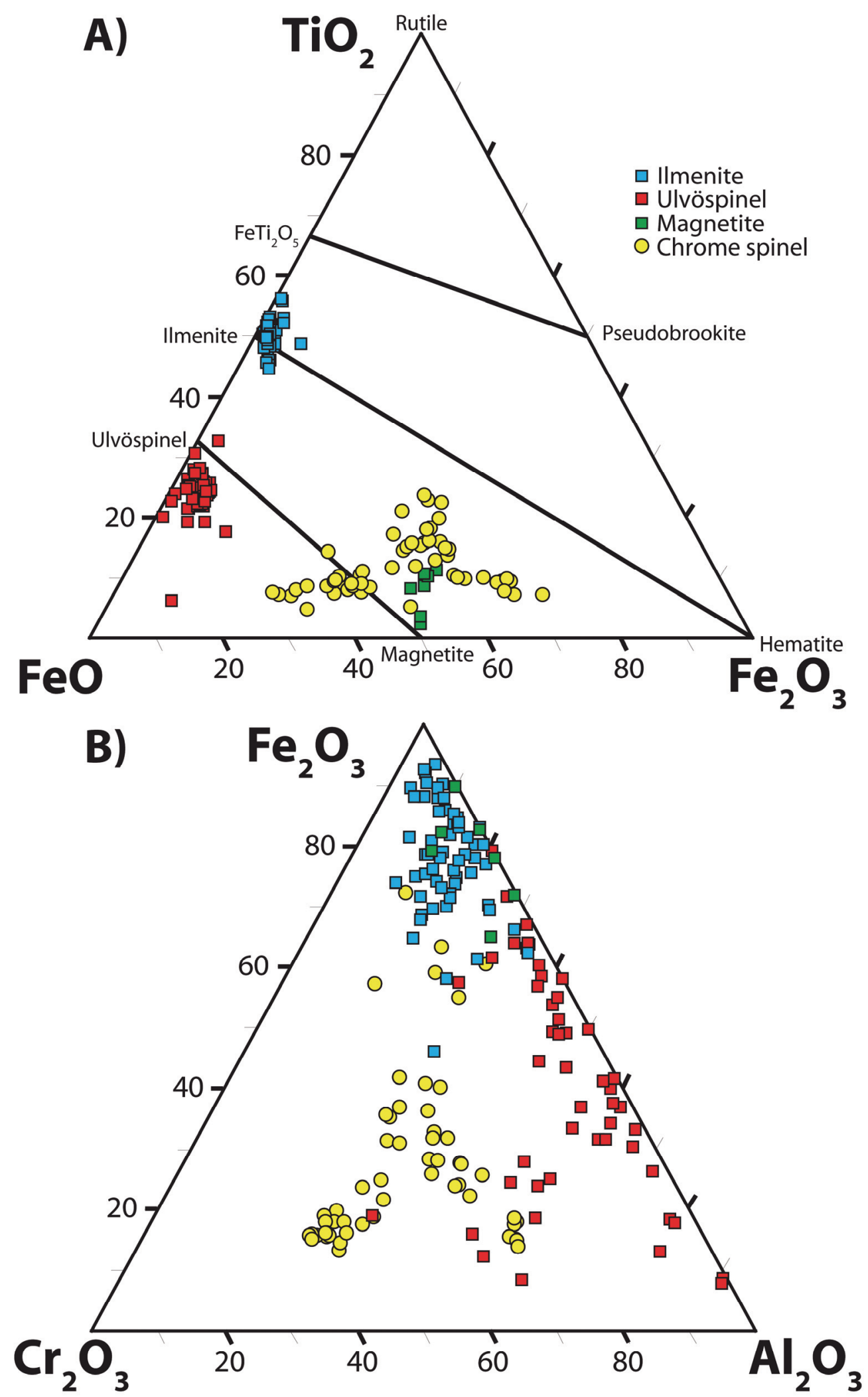

Figure 3.18: A) $\mathrm{FeO}-\mathrm{Fe}_{2} \mathrm{O}_{3}-\mathrm{TiO}_{2}$ ternary diagram showing the three compositionally distinct Fe-Ti oxide minerals of the Lookout Volcanics. Also shown are the major high temperature solid solution series magnetite-ulvöspinel, hematite-ilmenite, pseudobrookite-FeTi $\mathrm{O}_{5}$. B) $\mathrm{Cr}_{2} \mathrm{O}_{3^{-}}$ $\mathrm{Al}_{2} \mathrm{O}_{3}-\mathrm{Fe}_{2} \mathrm{O}_{3}$ triangular plot that represents projection onto the end face of the spinel prism, showing the variability in spinel compositions. 


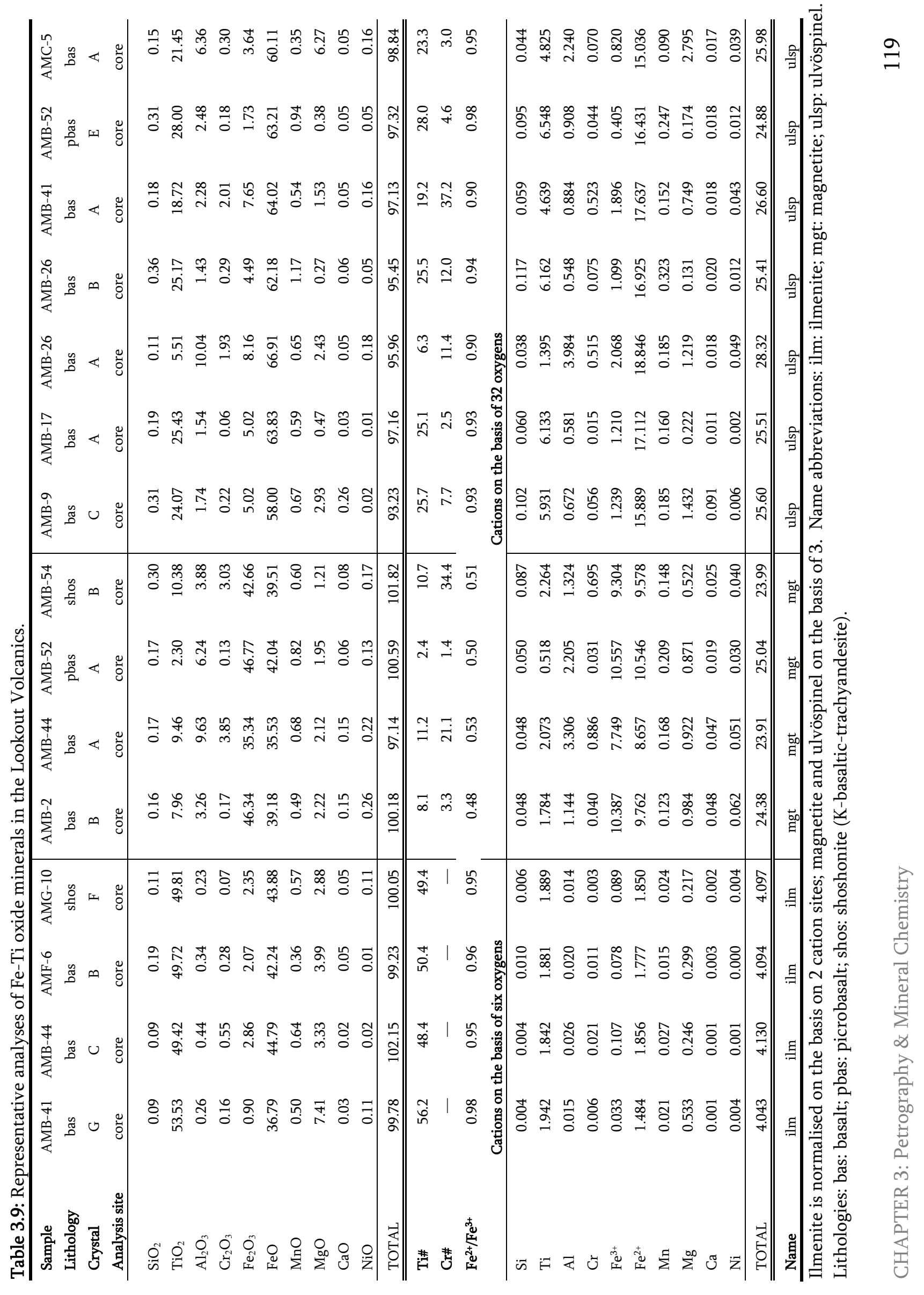




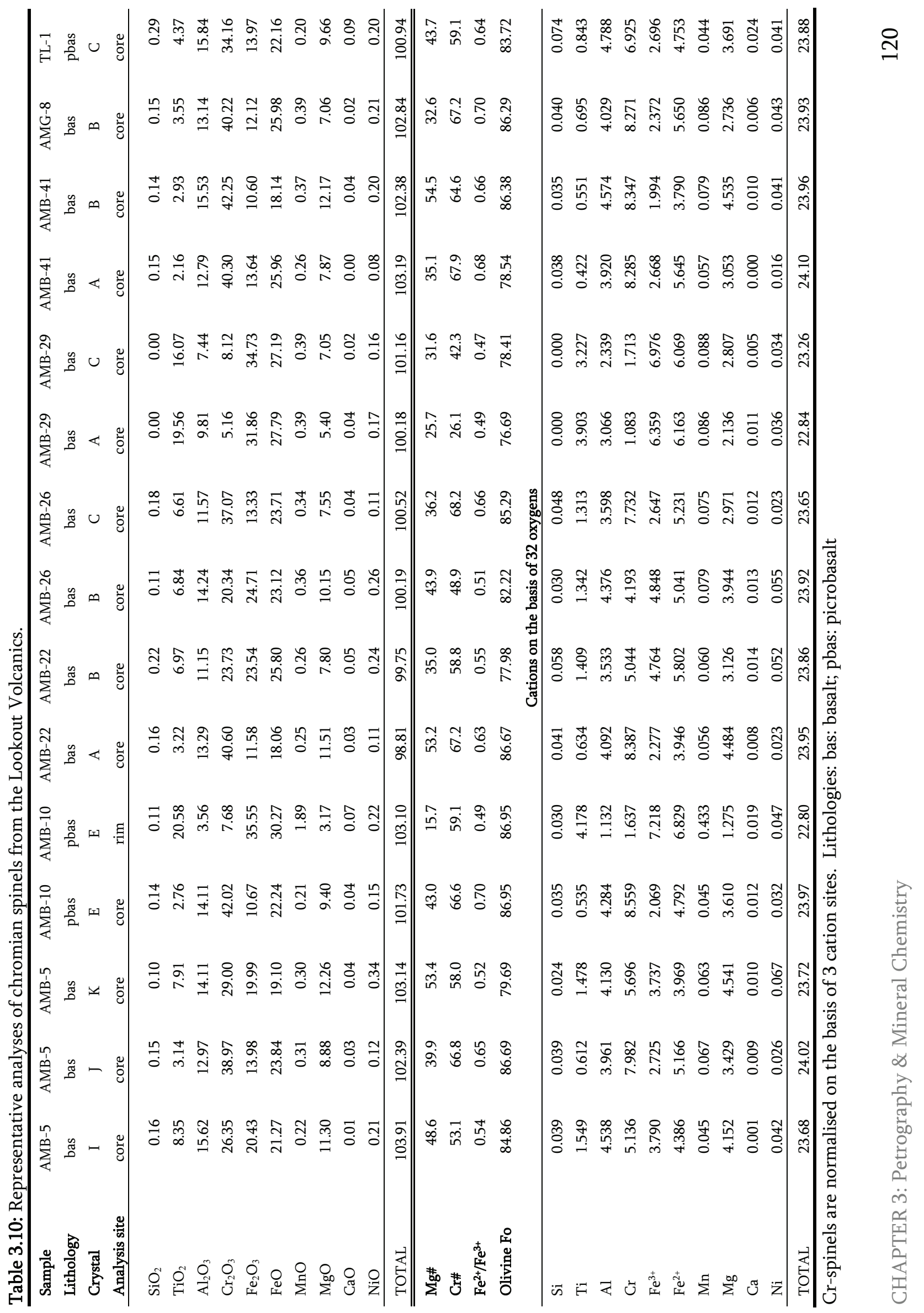


Cr-numbers $(\mathrm{Cr} \#=100 \times\{\mathrm{Cr} /(\mathrm{Cr}+\mathrm{Al})\})$ range from 26-70 and $\mathrm{Mg} \#$ from 15-56.

Spinels can display normal growth zoning $\left(\mathrm{Cr}_{67-59}\right)$ with Cr-rich cores $\left(\mathrm{Cr}_{2} \mathrm{O}_{3}=42\right.$ wt \%) and $\mathrm{Cr}$-poor rims $\left(\mathrm{Cr}_{2} \mathrm{O}_{3}=7.6 \mathrm{wt} \%\right.$; Table 3.10). As the $\mathrm{Cr}$ content of spinels fall Ti substitution increases considerably $\left(\mathrm{TiO}_{2}=2.2-20.6 \mathrm{wt} \%\right)$.

\subsection{IMPLICATIONS OF MINERAL CHEMISTRY DATA}

\subsubsection{Magmatic evolution as recorded by phenocrysts}

\section{Olivine records the initiation of clinopyroxene crystallisation}

Olivine phenocrysts display negative $\mathrm{Ni}$ and $\mathrm{Ca}$ trends with decreasing Fo due to their progressive depletion through the crystallisation of olivine and clinopyroxene phenocrysts (Figure 3.9). However, Mn contents increase due to its incompatible behaviour resulting in the enrichment of $\mathrm{Mn}$ in the residual melt as fractional crystallisation proceeds. The initiation of clinopyroxene crystallisation is recorded by olivine phenocrysts in AMB-10, a highly porphyritic rock containing ca. 20\% large olivine phenocrysts. The initial crystallisation of just olivine in AMB-10 causes the Ni content of the co-existing melt to fall rapidly, as recorded by olivines displaying $\mathrm{Ni}$ contents $(\mathrm{NiO}=0.35-0.24 \mathrm{wt} \%)$ that fall significantly over a very restricted range of Fo (Fo88-86; Figure 3.9). The rate of $\mathrm{Ni}$ depletion in the melt reduces significantly below $\mathrm{Fo}_{86}$ due to the initiation of clinopyroxene crystallisation. As the $\mathrm{D}_{\mathrm{Bulk}}$ for $\mathrm{Ni}\left(\mathrm{D}_{\mathrm{ol}}=7.77 ; \mathrm{D}_{\mathrm{cpx}}=\right.$ 2.5; Sobolev et al., 2005) in the magma falls significantly when clinopyroxene begins crystallising, Ni depletion of the residual melt occurs at slower rate. During pure olivine crystallisation the rapid reduction of $\mathrm{Ni}$ in the melt creates space in the crystal lattice of olivine which is filled by substitution with increasing amounts of $\mathrm{Ca}(\mathrm{CaO}=0.26-0.42 \mathrm{wt} \%)$, as seen between $\mathrm{Fo}_{88-86}$ in AMB-10 (Figure 3.9). The crystallisation of Ca-rich clinopyroxene (Ca49-43) results in depletion of $\mathrm{Ca}$ in the residual melt creating the negative $\mathrm{CaO}$ crystallisation trend observed in olivine below $\sim$ Fo86. The almost trimodal 
nature of the olivine phenocryst population in AMB-10 suggests that olivine growth occurred during distinct periods of the magmatic evolution of this sample (Figure 3.9).

\section{Crystallisation of clinopyroxene in a shallow level magma chamber}

The most primitive (i.e. highest Mg\#, first crystallised) clinopyroxene phenocrysts in the Lookout Volcanics are Cr-Si rich and Al-Ti poor diopside/augites (Figure 3.14), with continued fractional crystallisation leading to increasingly $\mathrm{Ti}-\mathrm{Al}$ rich and $\mathrm{Cr}$-Si poor diopsides being crystallised. The extensive growth zonation displayed by large clinopyroxene phenocrysts within the Lookout Volcanics suggests that growth occurred during a prolonged period in an evolving magma chamber. Crystallisation is presumed to have occurred on the walls and floor of the magma chamber due to the thermal contrast between the country rock and the magma (i.e. solidification fronts form on all margins of the magma chamber; Marsh, 2006). The fact that crystals with Cr-rich cores are all overgrown by a Tirich zone and that within a single lava flow entirely Ti-rich crystals are generally smaller than those possessing a Cr-rich core suggests that these phenocrysts formed in an evolving magma chamber. If these crystals had formed in separate magma chambers, two distinct clinopyroxene populations would be expected, instead of the continuous compositional trends observed (Figure 3.14; Figure 3.16). Evolution of the magma chamber with time results in enrichment of the intercumulus melt in elements that are incompatible in the dominant crystallising phases. In this case olivine and clinopyroxene comprise the fractionating assemblage thus $\mathrm{Al}$ and $\mathrm{Ti}$ would become progressively enriched in the remaining melt. Al-Ti enrichment of the melt suggests plagioclase, and $\mathrm{Fe}-\mathrm{Ti}$ oxide fractionation was not occurring or was very minor, to allow the intercumulus melt of the magma chamber to become significantly enriched in these elements to crystallise Al-Ti-rich diopsides.

The core to rim zonation of clinopyroxene phenocrysts is shown in Figure 3.16 , along with analyses of clinopyroxene phenocrysts from the Tapuaeouenuku 
Plutonic Complex (TPC). Clinopyroxene phenocrysts from the TPC are chemically indistinguishable from phenocrysts in the Lookout Volcanics displaying the same core to rim growth zonation. This magma chamber or a similar shallow crustal magma chamber is a possible source for the strongly zoned clinopyroxene phenocrysts found in the lavas of the Lookout Volcanics. The existence of a significantly larger magma chamber at depth under the TPC has previously been suggested (Hunt, 1969; Baker, 1990). It is hypothesised that throughout the eruption of the Lookout Volcanics, mafic magma periodically infiltrated this magma chamber from below and entrained phenocrysts that had experienced variable growth histories. The Lookout Volcanics are believed to have been emplaced by dykes thus providing a plausible mechanism for the entrainment of variable portions of a partially solidified and stratified magma chamber.

\section{Orthopyroxene crystallisation records a drastic change in magma chemistry} Orthopyroxene is a $\mathrm{Si}$-saturated mineral and is an uncommon phase in $\mathrm{Si}$ undersaturated alkali basalts like the Lookout Volcanics. The magmas that contain orthopyroxene must have become stalled in the upper crust during their ascent and evolved in isolation forming magmas that are compositionally distinct. These rocks (e.g. AMB-54, AMG-10) have the highest $\mathrm{SiO}_{2}$ and $\mathrm{Al}_{2} \mathrm{O}_{3}$ and lowest $\mathrm{CaO}, \mathrm{FeO}$ and $\mathrm{TiO}_{2}$ contents of the samples in this suite. The phenocrysts of these high Si-melts record a unique crystallisation trend within their clinopyroxene phenocrysts (Figure 3.14) with continued magmatic evolution producing crystals with increasing $\mathrm{Si}$ and decreasing $\mathrm{Al}$ and Ti. AMG-10 contains augite $\left(\mathrm{Ca}_{32-42}\right)$ phenocrysts that become progressively enriched in $\mathrm{Si}\left(\mathrm{SiO}_{2}=49.3\right.$ $52.5 \mathrm{wt} \%)$ and depleted in $\mathrm{Ca}(\mathrm{CaO}=15.7-22.3 \mathrm{wt} \%)$ with magmatic evolution $\left(\mathrm{Mg}_{84-68}\right)$. Eventually the continued depletion of the Ca content of the melt and increasing Si saturation leads to the initiation of orthopyroxene crystallisation at $\mathrm{Mg} \#=64$. 
A magma cannot rapidly change from being Si-undersaturated to $\mathrm{Si}$ oversaturated through standard fractional crystallisation (i.e. to generate the $\mathrm{SiO}_{2}$ content of AMG-10 requires the fractionation of $80 \%$ clinopyroxene and $\mathrm{Fe}-\mathrm{Ti}$ oxides at a 60:40 proportion) and therefore requires the addition of Si from an external source. Thus it is suggested the changes in magma chemistry shown by the clinopyroxenes in the high-Si rocks are the result of the crustal contamination of these magmas. When the magma became Si-saturated clinopyroxene crystallisation ceased and orthopyroxene crystallisation begun. Phenocrysts of orthopyroxene are only observed in the isotopically most evolved magma in the Lookout Volcanics (AMG-10; ${ }^{87} \mathrm{Sr} /{ }^{86} \mathrm{Sr}_{\mathrm{i}}=0.7039$; Chapter 4). Isotopic modelling (Chapter 4) has shown that AMG-10 underwent the rapid assimilation of ca. $28 \%$ crustal material this explains the Si-saturation of this melt and the initiation of orthopyroxene crystallisation in these magmas.

\subsubsection{Pyroxenitic contributions to the mantle source}

Until recently general scientific consensus was that mantle derived melts are generated in equilibrium with olivine because it comprises $>50 \%$ of the peridotite in the Earth's upper mantle. The high olivine content of upper mantle lherzolites results in them generating low Ni melts, as Ni is highly compatible in olivine $\left(D_{\mathrm{Ni}}=7.77\right.$; olivine has the highest partition coefficient for $\mathrm{Ni}$ of any mantle silicate; Sobolev et al., 2005) and therefore will preferentially remain in the mantle source during partial melting. This buffering produces low $\mathrm{Ni}$ contents in the olivine phenocrysts generated in equilibrium with standard peridotitic sources (e.g. MORB). Sobolev et al. (2005) recognised that the unusually high $\mathrm{Ni}$ and silica contents of most parental Hawaiian magmas are inconsistent with a deep olivine-bearing source. Olivines from shield-stage Hawaiian basalts show large ranges in $\mathrm{NiO}$ contents at a given Fo content $(\Delta \mathrm{Ni}=$ 0.3 wt \%), with the majority considerably enriched in $\mathrm{NiO}$ relative to magmas that can be modelled to have formed by partial melting of standard peridotitic 
sources. These variations can be resolved if the olivine component of mantle peridotite is consumed by a reaction with melts derived from recycled oceanic crust, to form a secondary pyroxenite. Sobolev et al. (2005) showed that more than half of the Hawaiian magmas erupted in the last 1 Ma were generated from a pyroxenitic source. The proportion of recycled oceanic crust incorporated in the mantle source was estimated to vary from $30 \%$ near the plume centre to insignificant levels at the periphery.

\section{Pyroxenitic source model}

Due to the inability of conventional peridotitic plume models to account for the high $\mathrm{Ni}$ and $\mathrm{SiO}_{2}$ content of Hawaiian tholeiites, Sobolev et al. (2005) proposed a pyroxenitic source model for the generation of these magmas. Mantle plumes originally consist of two different lithologies: recycled oceanic crust and mantle peridotite (Figure 3.19). The recycled crustal component is concentrated in the centre of the plume, is $\mathrm{Si}$-oversaturated and derived from a mixture of primitive oceanic basalts, oceanic gabbros and sediments. The solidus temperature of eclogite is considerably lower than peridotite, and this causes eclogite to start melting at higher pressures (greater depths) than peridotite. The seismic lowvelocity zone at a depth of $130-170 \mathrm{~km}$ in Figure 3.19 corresponds to significant melting of eclogite. The melting of eclogite produces a high-Si melt $\left(\mathrm{SiO}_{2}=57.8\right.$ wt \%) that is mixed into a highly reactive olivine-bearing peridotite. As the eclogite melt infiltrates the peridotite it converts olivine into pyroxene, changing the melt from an olivine-bearing peridotite to a secondary olivine-free pyroxenite.

$$
\begin{array}{cccc}
\text { Olivine } & + \text { Excess silica } & = & \text { Orthopyroxene } \\
(\mathrm{Mg}, \mathrm{Fe})_{2} \mathrm{SiO}_{4}+ & \mathrm{SiO}_{2} & =(\mathrm{Mg}, \mathrm{Fe})_{2} \mathrm{Si}_{2} \mathrm{O}_{6}
\end{array}
$$

Sobolev et al. (2005) calculated that $40-60 \mathrm{wt} \%$ melt is required to convert all the olivine in a typical peridotite to pyroxene. Melting of the eclogite continues until the eclogite becomes too refractory to undergo further melting. 


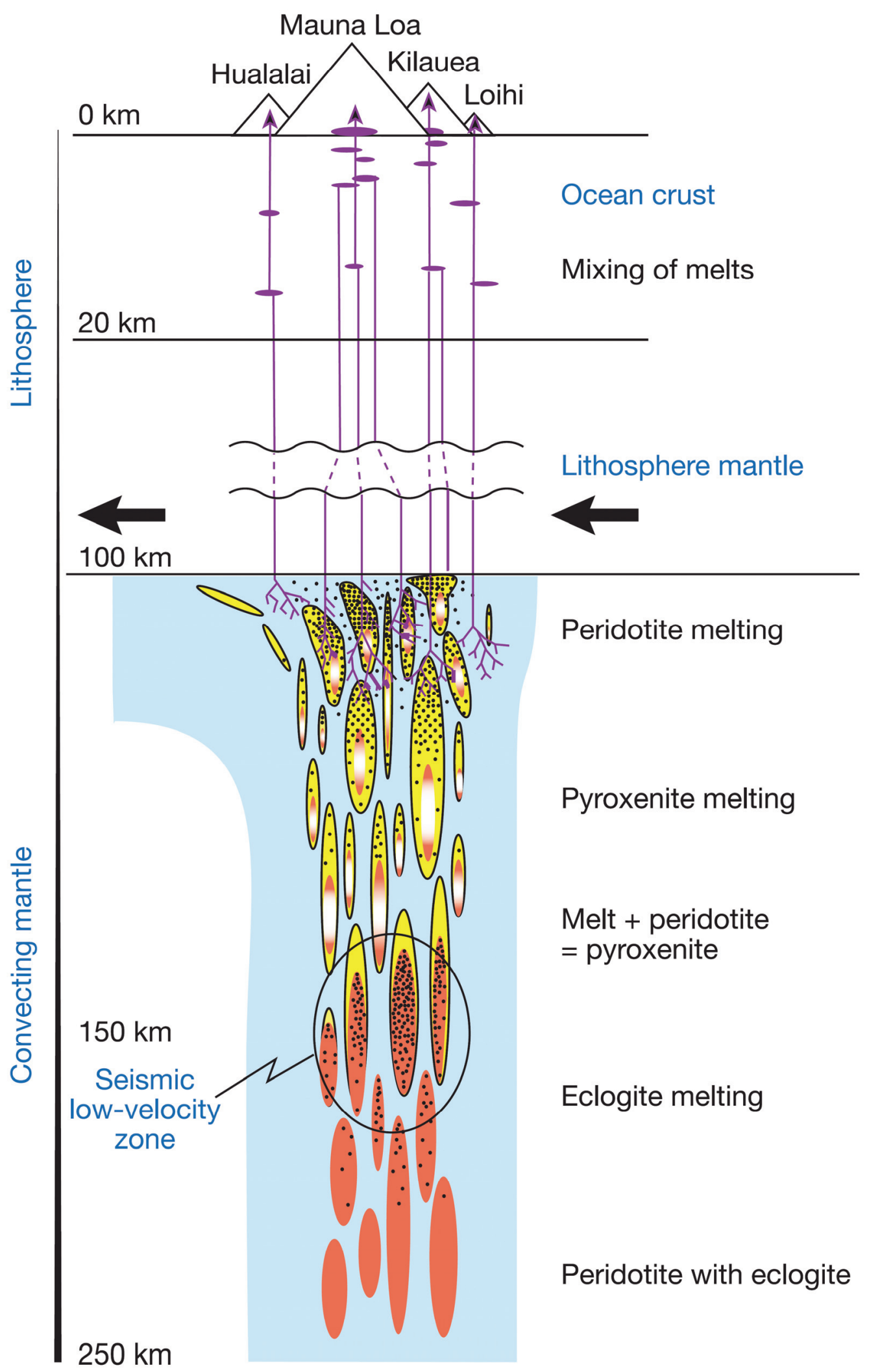

Figure 3.19: Schematic illustration of the secondary pyroxenite source model for the generation mantle plume basalts with elevated Ni contents in Hawaii. Notes: 1) Primary and secondary rock types are colour coded as follows: red, eclogite representing recycled oceanic crust; blue, peridotite; yellow, reaction (secondary) pyroxenite produced by infiltration of eclogite derived melt into peridotite; white and red, eclogitic restite; black dots, melts; violet, magma pathways, conduits and small magma chambers. Source: Sobolev et al. (2005). 
At this point there will be three different lithologies: olivine-free secondary pyroxenite, original peridotite unaffected by the eclogite melt, and an eclogitic refractory restite that can undergo no further melting. As the eclogitic refractory restite can sustain no further melting pyroxenitic magmas originate from the mixing of melts from two lithologies; secondary pyroxenite and the original peridotite. As the plume rises the secondary pyroxenite starts melting at a much greater rate than normal peridotite. Melting occurs in non-modal proportions due to the different thermodynamic properties (pressure-temperature $(\mathrm{P}-\mathrm{T})$ tolerances) of various silicate minerals. Olivine melts at a much slower rate than pyroxene and as a major component of a normal peridotite (ca. 50\%) it suppresses the melt production rate of peridotite. Sobolev et al. (2007) showed that the melting of olivine free pyroxenite is more voluminous than peridotite at any P-T conditions. The suppression of peridotite melting by olivine causes melts to take on a distinctly pyroxenitic character, thus the Ni content of melts derived from olivine-free pyroxenites sharply increase because olivine no longer controls the bulk partition coefficient of $\mathrm{Ni}$ in the melt (Table 3.11).

Table 3.11: Comparison of the Ni concentrations of partial melts generated through the melting of peridotitic and pyroxenitic sources.

\begin{tabular}{lcccccccc}
\hline & Peridotite & \multicolumn{3}{c}{ Pyroxenite } \\
Olivine (\%) & 59.8 & 42.6 & 33.0 & 19.6 & 10.7 & 4.7 & 1.2 & 0 \\
$\mathrm{C}_{\mathrm{Ni}, \mathrm{s}}$ & 1900 & 1448 & 1298 & 1147 & 1072 & 1030 & 1008 & 1000 \\
Melt (\%) & \multicolumn{3}{c}{ Concentration of nickel in the melt $\left(\mathrm{C}_{\mathrm{Ni}, \mathrm{m}}\right)$} \\
0.1 & 358 & 340 & 352 & 398 & 457 & 503 & 567 & 586 \\
0.5 & 358 & 339 & 351 & 396 & 455 & 500 & 563 & 579 \\
1 & 357 & 338 & 349 & 395 & 452 & 497 & 559 & 570 \\
2 & 355 & 335 & 347 & 391 & 447 & 490 & 550 & 552 \\
5 & 349 & 329 & 339 & 379 & 431 & 469 & 524 & 502 \\
10 & 340 & 318 & 326 & 361 & 405 & 435 & 481 & 425 \\
Ni enrichment & 1.00 & 0.95 & 0.98 & 1.11 & 1.27 & 1.39 & 1.57 & 1.60 \\
\hline
\end{tabular}

Calculated partial melting model assuming non-modal fractional melting of a garnet lherzolite (ol: 0.598; opx: 0.211; cpx: 0.076; grt: 0.115 that melts in proportions $0.05 \mathrm{ol}, 0.2 \mathrm{opx}, 0.3 \mathrm{cpx}, 0.45 \mathrm{grt}$ ). Modelling used Ni distribution coefficients of Sobolev et al. (2005) for the Kettle River peridotite (ol 7.72; opx 2.41; cpx 1.38; grt 0.61). Bulk Ni concentrations of the source are: $1900 \mathrm{ppm}$ for peridotite and $1000 \mathrm{ppm}$ for pyroxenite. Ni enrichment is the degree of enrichment of $1 \%$ melt from a specific source composition over a peridotitic source. Olivine was progressively removed from the source to assess its effect on melt Ni concentrations. 
Resolving pyroxenitic contributions from olivine phenocrysts in the Lookout Volcanics

Pyroxenitic melts are characteristically enriched in $\mathrm{Ni}$ and $\mathrm{Si}$ but depleted in $\mathrm{Mg}$, Ca and Mn compared with their peridotitic counterparts (Sobolev et al., 2007). Minor element concentrations of olivine phenocrysts from different tectonic settings were measured to examine whether pyroxenitic contributions to the mantle source of a magma could be inferred. The proportion of pyroxenite in the mantle source of various magmas has been calculated using the method of Sobolev et al. (2007). In this study the most mafic crystals in a sample were used because they preserve the closest approximation of equilibrium with the primitive melt. Due to the similar $100 \mathrm{Mn} / \mathrm{Fe}$ of the majority of samples their proportions of pyroxenite are comparable (Table 3.12).

Variations in the $\mathrm{NiO}$ content of olivines from different locations can be attributed to varying amounts of pyroxenite in the mantle source of the magma. Hawaiian basalts were found to have elevated $\mathrm{NiO}$ contents over samples with dominantly peridotitic sources (i.e. MORB; Figure 3.10). The proportion of pyroxenite $\left(X_{p x}\right)$ in MORB derived magmas is generally $5-20 \%$, with rare exceptions (Sobolev et al., 2007). Sobolev et al. (2005) calculated the proportion of pyroxenite forming the magmas erupted at Mauna Loa $\left(\mathrm{X}_{\mathrm{px}}=0.57\right)$ and Mauna Kea $\left(X_{p x}=0.45\right)$. This study produces comparable result with olivines from Mauna Loa having consistently higher $\mathrm{NiO}$ contents than those from Mauna Kea, and calculated $X_{\mathrm{px}}$ are similar to those of Sobolev et al. (2005) (Table 3.12).

Olivine phenocrysts in the Lookout Volcanics contain NiO contents elevated over those of MORB, and comparable and lower than those of Mauna Kea (Figure 3.10). The proportion of pyroxenite derived melt in the source of the Lookout Volcanics is estimated at $\mathrm{X}_{\mathrm{px}}=\mathrm{ca} .38-52 \%$. The eastern margin of Gondwana was a subduction zone for ca. 200 Ma prior to the eruption of the Lookout Volcanics (ca. $96 \mathrm{Ma}$ ). Thus the generation of high-Si melts of subducted oceanic lithosphere and incorporation of these into the upwelling mantle that formed the Lookout Volcanics could have resulted in a partially pyroxenitic source. 
Table 3.12: The proportion of pyroxenite in the mantle source of various magma types.

\begin{tabular}{lccc}
\hline & $100 \mathrm{Mn} / \mathrm{Fe}$ & $\mathrm{Ni}(\mathrm{Mg} / \mathrm{Fe})^{*} 1000$ & $\mathrm{X}_{\mathrm{px}}$ \\
\hline Lookout Volcanics & 1.43 & 0.57 & 0.518 \\
Hawaii & & & \\
Mauna Loa & 1.41 & 0.68 & 0.551 \\
Mauna Kea & 1.45 & 0.61 & 0.485 \\
Yemen & & & \\
JB-281 (CFB) & 1.45 & 0.57 & 0.488 \\
JB-129 (CFB) & 1.46 & 0.63 & 0.465 \\
JB-233 (intraplate) & 1.43 & 0.50 & 0.534 \\
MNY-361 (contaminated) & 1.58 & 0.40 & 0.207 \\
\hline
\end{tabular}

The proportion of pyroxenite is calculated using the equation of Sobolev et al. (2007) $\mathrm{X}_{\mathrm{px}}=3.48$ $(2.071 \times(100 \mathrm{Mn} / \mathrm{Fe}))$. The numbers reported in this table are the average of the ten most mafic (i.e. Fo-rich) olivine phenocrysts.

The variation observed within the Lookout Volcanics represents olivines from 12 lava flows. Whereas the Yemeni CFB JB-281 exhibits a greater variation in a single eruptive unit $\left(\mathrm{Fo}_{87-86} ; \mathrm{NiO}=0.23-0.38\right)$. This large variation in $\mathrm{Ni}$ content suggests that this lava flow was generated from a crustal magma chamber that had incorporated olivine phenocrysts from multiple melt batches that were created through the melting of variable proportions of peridotite and pyroxenite $\left(\mathrm{X}_{\mathrm{px}}=\mathrm{ca}\right.$. $42-55 \%)$.

Olivines from the Waimarino basalt (TVZ) display low NiO contents comparable to those of MORB at low Fo contents. However, some vey Fo-rich olivines in the Waimarino Basalt have high $\mathrm{NiO}$ contents $\left(\mathrm{Fo}_{93.5} ; \mathrm{NiO}=0.56 \mathrm{wt}\right.$ $\%)$. This may be due to interaction with a sulphur bearing silicic melt undergoing mantle metasomatism as has been suggested for the generation of $\mathrm{Ni}$ rich olivines above the slab in Kamchatka (Ishimaru \& Arai, 2008).

Variations in the Ca contents of olivines from distinct tectonics settings can clearly be observed in Figure 3.10. The reason for these variations is complex and not solely related to the amount of pyroxenite in the source. These variations are discussed further in Section 3.3.3. Although pyroxenitic magmas are depleted in $\mathrm{Mn}$, this effect is not transferred to the olivine phenocrysts crystallised from these magmas, or the accuracy of the EPMA data reported here is insufficient to 
discern these differences clearly. The most pyroxenitic sample (i.e. Mauna Loa) appears to have slightly lower $\mathrm{MnO}$ content at a given Fo content than the rest of the samples.

\section{Variation in the Ni contents of mafic eruptives from Yemen}

The pyroxenite source model has successfully explained the elevated Ni contents of Hawaiian basalts (Sobolev et al., 2005). A study of basaltic eruptives from Yemen was undertaken to establish whether the Afar plume produces magmas with similarly elevated Ni contents. Elevated Ni contents in basalts from Yemen would indicate the Afar plume has a pyroxenitic component, and therefore pyroxenitic sources in mantle plumes could be more widespread than initially thought.

The Yemeni CFB (JB-281) contains olivines with elevated $\mathrm{NiO}$ comparable to those from Hawaii (Figure 3.10). This magma is estimated to have a significant proportion of pyroxenite in its source $\left(\mathrm{X}_{\mathrm{px}}=\right.$ ca. $\left.42-55 \%\right)$. Another flood basalt (JB-129) has even higher $\mathrm{Ni}\left(\mathrm{Fo}_{89} ; \mathrm{NiO}=0.39 \mathrm{wt} \%\right)$ with $\mathrm{X}_{\mathrm{px}}=$ ca. $57 \%$ (Figure 3.11). The intraplate basalt (JB-233) and basanite (JB-239) have lower $\mathrm{NiO}$ contents than the flood basalt, the pyroxenitic component is estimated at $\mathrm{X}_{\mathrm{px}}=\mathrm{ca}$. $42 \%$. Intraplate basalts are not directly sourced from the mantle plume but are erupted through the continental crust in response to decompression melting of the upper mantle, thus a lower plume derived pyroxenitic component is expected in these magmas. MNY-361 is a crustal contaminated flood basalt (Kent et al., 2002) with marginally higher $\mathrm{NiO}$ contents than those of MORB (Figure 3.11). Crustal contamination results in the olivines in this magma appearing to take on more peridotitic characteristics $\left(\mathrm{X}_{\mathrm{px}}=\mathrm{ca} .18-27 \%\right)$, however, this is probably a consequence of the diluted $\mathrm{Ni}$ content of the melt with the addition of ca $10-15 \%$ crustal material. The Ni contents of olivines in the majority of samples from Yemen decrease rapidly with decreasing Fo (i.e. basanites) due to a fractionating assemblage dominated by olivine. 


\section{Partial melting modelling}

Fractional melting of a garnet lherzolite source was modelled to quantify the amount of olivine that must be removed from the mantle source to generate $\mathrm{Ni}$ enriched melts (Table 3.11). Olivines from various tectonic settings display $\mathrm{NiO}$ contents enriched over those in MORB, which are dominantly sourced from peridotite. The average $\mathrm{NiO}$ content of olivines in MORB and JB-281 from Fo87.588.5 is 0.177 and 0.315 , respectively. This is a $78 \%$ enrichment in the Ni content of the Yemeni CFB (JB-281) relative to MORB. To produce significant enrichment ( $\geq 40 \%$ ) in the Ni content of a melt requires the removal of $>90 \%$ of the olivine from the peridotite source. Modelling shows that Ni enrichment of $60 \%$ can be generated by melting a pyroxenitic instead of a peridotitic source (Table 3.11). This model is only an approximation because if the Ni content of the pyroxenite source was increased or the degree of partial melting was smaller larger $\mathrm{Ni}$ enrichments would be generated.

Within the Lookout Volcanics the average $\mathrm{NiO}$ content of the ten most primitive olivine phenocrysts observed is 0.286 (Fo87.3-87.0), which corresponds to a Ni enrichment over MORB of $62 \%$. A significant proportion of the peridotite in the mantle source of the Lookout Volcanics is required to have been converted to secondary pyroxenite.

\subsubsection{Ca in olivine strongly controlled by melt composition}

\section{Factors controlling the incorporation of calcium into olivine}

Calcium is one of the most significant minor elements in natural magmatic olivines, with concentrations ranging from 0.01-2 wt \% (Libourel, 1999). This variation means Ca may potentially provide information about the evolution of the melt phase during crystallisation. Early studies showed that the Ca content of olivines in volcanic rocks strongly correlates with their Fe contents (Simkin \& Smith, 1970; Ferguson, 1978). Jurewicz \& Watson (1988) conducted experiments in Fe-bearing systems on synthetic alkali-poor picrites and high-Mg basalts, at various temperatures, pressures and oxygen fugacities. This work showed that 
$\mathrm{CaO}$ concentrations of olivines increase with decreasing Fo content. However, the partitioning of $\mathrm{Ca}$ into olivine is found to be unaffected directly by variations in oxygen fugacity, temperature and pressure (< $20 \mathrm{kbar}$ ) (Roeder, 1974; Longhi et al., 1978; Watson, 1979; Libourel, 1999).

Therefore the Ca content of olivines is a complex function of melt composition, which is primarily controlled by the amount of $\mathrm{Ca}$ in the melt (e.g. increasing the $\mathrm{Ca}$ content of the melt increases the $\mathrm{CaO}$ content of the coexisting olivines). Libourel (1999) showed that olivine Ca contents are not only dependent on the Ca melt content and olivine forsterite content, but large variations can be produced through varying the composition of the coexisting melt. For a melt with a fixed Ca content the results of Libourel (1999) show that the $\mathrm{CaO}$ concentration of the olivine is strongly sensitive to the amount of silica $\left(\mathrm{SiO}_{2}\right)$, alumina $\left(\mathrm{Al}_{2} \mathrm{O}_{3}\right)$, alkali $\left(\mathrm{Na}_{2} \mathrm{O}\right)$ and ferrous iron $(\mathrm{FeO})$ present in the melt. Increasing $\mathrm{SiO}_{2}$ and $\mathrm{Al}_{2} \mathrm{O}_{3}$ lowers the $\mathrm{CaO}$ content of coexisting olivines. This implies Ca-rich olivines coexist with Si-undersaturated melts rich in $\mathrm{Ca}$, while olivines depleted in $\mathrm{Ca}$ are found in Si-rich melts depleted in Ca. Increasing the Fe in a melt increases the amount of $\mathrm{Ca}$ in olivine via the following mechanism, higher $\mathrm{FeO}$ contents in olivine distorts the M2 site which allows larger cations (i.e. Ca) to be accommodated more easily (Shi \& Libourel, 1991). The CaO concentration of olivine dramatically increases with the addition of alkalis to a melt, and this increase is positively correlated with the alkali content of the melt (Shi, 1993). The olivines richest in Ca will crystallise from melts with low Mg\# and high $\mathrm{Na}$ contents.

\section{Variability in the Ca contents of olivines from different tectonic settings}

The variability in $\mathrm{CaO}$ contents observed in Figure 3.10 is related to variable melt compositions at the different localities. Pyroxenitic melts are depleted in $\mathrm{Ca}$ relative to their peridotitic counterparts (Sobolev et al., 2007). If this was the primary control on $\mathrm{CaO}$ contents of olivine phenocrysts the samples with the greatest peridotitic component (e.g. MORB, Waimarino basalt) should contain 
olivines with the highest $\mathrm{CaO}$ contents. However, these samples actually contain olivine phenocrysts with lowest Ca contents, thus primary melt composition has a greater effect than the proportion of pyroxenite. Lavas from MORB and arc settings experience a greater amount of partial melting resulting in Si-rich $\mathrm{Ca}-\mathrm{Na}$ poor melts, thus $\mathrm{CaO}$ poor olivines (Waimarino basalt ${ }_{\mathrm{WR}}$ (whole rock); $\mathrm{CaO}=9.6$ wt \%; Gamble et al., 1990).

The effect of pyroxenite in the mantle source can be observed in the Hawaiian OIB samples that are from similar degree partial melts and their parental magmas have similar estimated source $\mathrm{Ca}$ concentrations (Mauna $\mathrm{Kea} \mathrm{CaO}=8.5 \mathrm{wt} \%$; Mauna Loa $\mathrm{CaO}=8.0$ wt \%; Sobolev et al. 2005). The more pyroxenitic lavas from Mauna Loa have lower olivine Ca contents than the sample from Mauna Kea. The Yemeni CFB has intermediate $\mathrm{CaO}$ between the Hawaiian samples, similar to its $\mathrm{NiO}$ content thus it could be controlled by the degree of pyroxenite or possible variation in melt composition $\left(\mathrm{JB}-281_{\mathrm{WR}} \mathrm{CaO}=10.9 \mathrm{wt} \%\right.$; Baker et al., 1997).

Olivines from the Lookout Volcanics exhibit the highest $\mathrm{CaO}$ contents of the settings investigated. This is a melt composition effect with the Lookout Volcanics comprising a suite of Si-undersaturated alkaline intraplate basalts. Thus the magmas have low $\mathrm{Si}$ and high $\mathrm{Ca}$ and Na contents which result in olivines with high $\mathrm{CaO}$ contents.

\subsubsection{Chromian spinel as a petrogenetic indicator}

Chromian spinel is a ubiquitous accessory phase occurring in basalts and peridotites from a variety of geologic settings. Spinels form over a wide range of $\mathrm{P}-\mathrm{T}$ conditions and it has long been recognised that the composition of spinels is highly sensitive to the environment in which they form (Irvine, 1965, 1967), with the primary control on spinel composition being parental magma composition (Roeder \& Reynolds, 1991; Arai, 1994a). Spinels are relatively refractory and resistant to alteration, particularly compared with other high temperature igneous minerals (i.e. olivine) making them valuable petrogenetic 
indicators in highly weathered ultramafic rocks. A large amount of EPMA data (Barnes \& Roeder, 2001) is available allowing rigorous comparisons between spinels from various tectonic settings based on their composition.

\section{Controls on chromian spinel composition}

Cr-spinel compositions are a complex function of magma (and source peridotite) composition (Irvine, 1965, 1967; Dick \& Bullen, 1984; Arai, 1994a \& 1994b; Barnes \& Roeder, 2001; Kamenetsky et al., 2001), crystallisation temperature (Sack \& Ghiorso, 1991), oxygen fugacity $\left(f \mathrm{O}_{2}\right)$ (Murck \& Campbell, 1986) and possibly pressure (Ballhaus et al., 1991; Roeder \& Reynolds, 1991). The Cr content of basaltic melts saturated with chromite increases with increasing temperature and decreasing $\mathrm{fO}_{2}$ (Roeder \& Reynolds, 1991). However, Roeder \& Reynolds (1991) found that pressure has a negligible effect on dissolved chromite content. The Cr\# of Cr spinels does not vary significantly within the observed range of natural mantle $f \mathrm{O}_{2}$ or lithostatic pressures (Ballhaus et al., 1991; Roeder \& Reynolds, 1991).

The only variable that has a significant effect on chromite compositions at liquidus temperatures is changing melt composition (Allan et al., 1988; Roeder \& Reynolds, 1991). Chromite is an early crystallising phase in basaltic melts. However, with the exception of $\mathrm{Cr}_{2} \mathrm{O}_{3}$ content, spinel crystallisation does not significantly change the total concentration of any element in the melt, as the major crystallising phases that affect melt composition are olivine, plagioclase and pyroxene. The crystallisation of olivine decreases the Mg\# of the melt, and consequently that of the Cr spinel, but it has no significant effect on the Cr\# of the spinel. The crystallisation or resorption of plagioclase can produce large variations in the $\mathrm{Al}_{2} \mathrm{O}_{3}$ content of the melt (Roeder \& Reynolds, 1991; Umino et al., 1991), and thus can have a profound effect on the Cr\# of chromite. The effect of clinopyroxene crystallisation is opposite to that of plagioclase crystallisation, as clinopyroxene has a higher $\mathrm{Cr} / \mathrm{Al}$ ratio than that of the 
coexisting melt and thus clinopyroxene crystallisation decreases the Cr\# of the associated $\mathrm{Cr}$ spinels.

\section{Spinel Mg-numbers}

Kamenetsky et al. (2001) investigated controls on Mg\# of spinels concluding that changes in Mg\# should be interpreted with caution, as it is a complex function of a number of factors: (1) Mg\# of the parental melt; (2) partitioning of $\mathrm{Al}$ and $\mathrm{Cr}$ in spinel, and hence $\mathrm{Al}_{2} \mathrm{O}_{3}$ in the melt; (3) $\mathrm{Fe}^{2+} / \mathrm{Fe}^{3+}$ in the melt, and hence $f \mathrm{O}_{2}$; (4) post-entrapment re-equilibration with silicate minerals, and hence cooling rate and grain size. They found that lavas quenched in submarine environments tend to have a higher $\mathrm{Mg \#}$ at a given $\mathrm{Cr} \#$ relative to terrestrial lavas, even when post entrapment conditions are considered.

\section{Mantle melting residues}

The olivine-spinel mantle array (OSMA) is a mantle melting residue trend formed in the spinel lherzolite field defined by forsterite content of olivine and Cr\# of spinel (Figure 3.20 A). Primary Mg-rich magmas form in chemical equilibrium with their mantle restites, and so the earliest crystallising phases, olivine and chromian spinel have the same composition as those in their mantle restites (spinel peridotites) if physical conditions do not significantly differ (Arai, 1994b). Upper mantle peridotites from various tectonic settings occupy reasonably distinct regions of the OSMA due to their distinct mantle melting conditions (Umino et al., 1991; Arai, 1994a). Arai (1994b) reports that the Cr\# of intraplate alkali basalts are $0.2-0.5$, with intraplate tholeiites at ca. 0.7 . The mantle restite of a magma group can be assessed by extrapolating its Fo-Cr\# fractionation line back to the OSMA. This method is only applicable if the melt was generated at low pressure. However, high pressure melts can equilibrate with shallower peridotites to be in equilibrium with $\mathrm{Cr}$ spinel on route to the surface (Kelemen et al., 1990). 


\section{Tectonic setting of crystallisation}

Chromites in basalts from different tectonic settings have distinct $\mathrm{Cr} /(\mathrm{Cr}+\mathrm{Al})$ ratios which reflect differences in magma composition. These differences may be due to the fertility of the mantle source or differing degrees of partial melting. The less fertile the mantle source (i.e. has experienced previous depletion via partial melting) or the larger the degree of melting, the higher the $\mathrm{Cr} \#$ of the resulting chromite (Fujii \& Scarfe, 1985). Chrome spinel $\mathrm{Al}_{2} \mathrm{O}_{3}$ and $\mathrm{TiO}_{2}$ contents show good correlations with parental melt composition (Kamenetsky et al., 2001). It is suggested that increased activity of $\mathrm{Al}_{2} \mathrm{O}_{3}$ decreases the partitioning of $\mathrm{TiO}_{2}$ into spinels. Although $\mathrm{Al}_{2} \mathrm{O}_{3}$ content may be a useful indicator of the degree of partial melting in mantle peridotities, in volcanic spinels this relationship is obscured with $\mathrm{Al}_{2} \mathrm{O}_{3}$ content controlled by melt composition rather than mantle source composition. Kamenetsky et al. (2001) argue that the application of $\mathrm{Al}_{2} \mathrm{O}_{3}$ content (and Cr\#) alone to constrain mantle source composition is not confirmed. Spinels can be subdivided on the basis of tectonic setting and mode of occurrence using an $\mathrm{Al}_{2} \mathrm{O}_{3}$ vs $\mathrm{TiO}_{2}$ diagram (i.e. Figure $3.20 \mathrm{~B}$ ).

\section{Chromian spinels in the Lookout Volcanics}

Cr spinels in the Lookout Volcanics have a relatively constant Cr\# of ca. 0.6 from Fo $_{87-81}$ indicative of the fractional crystallisation of olivine (Figure 3.20 A). The initiation of clinopyroxene crystallisation with its higher $\mathrm{Cr} / \mathrm{Al}$ ratio than the melt results in the crystallisation of spinels with decreasing Cr\# from ca. Fo81. Extrapolation of the Fo-Cr\# fractionation line back to the OSMA provides a mantle restite with $\mathrm{Cr} \#=0.62$, which is broadly consistent with the spread of intraplate volcanic data of Arai (1994b). However, the applicability of this method to the Lookout Volcanics is questionable. These melts were generated at depth $\left(A M G-8_{W R}: \mathrm{La} / \mathrm{Yb}_{\mathrm{N}}=13.8\right.$; Chapter 4$)$ but may have re-equilibrated in a shallow level magma chamber so the Cr\# of spinel is possibly the result of reequilibration (i.e. diffusion of $\mathrm{Cr}$ and $\mathrm{Al}$ ) and not comparable to its mantle restite. Primitive spinels from the Lookout Volcanics plot on the high $\mathrm{TiO}_{2}$ side of the 

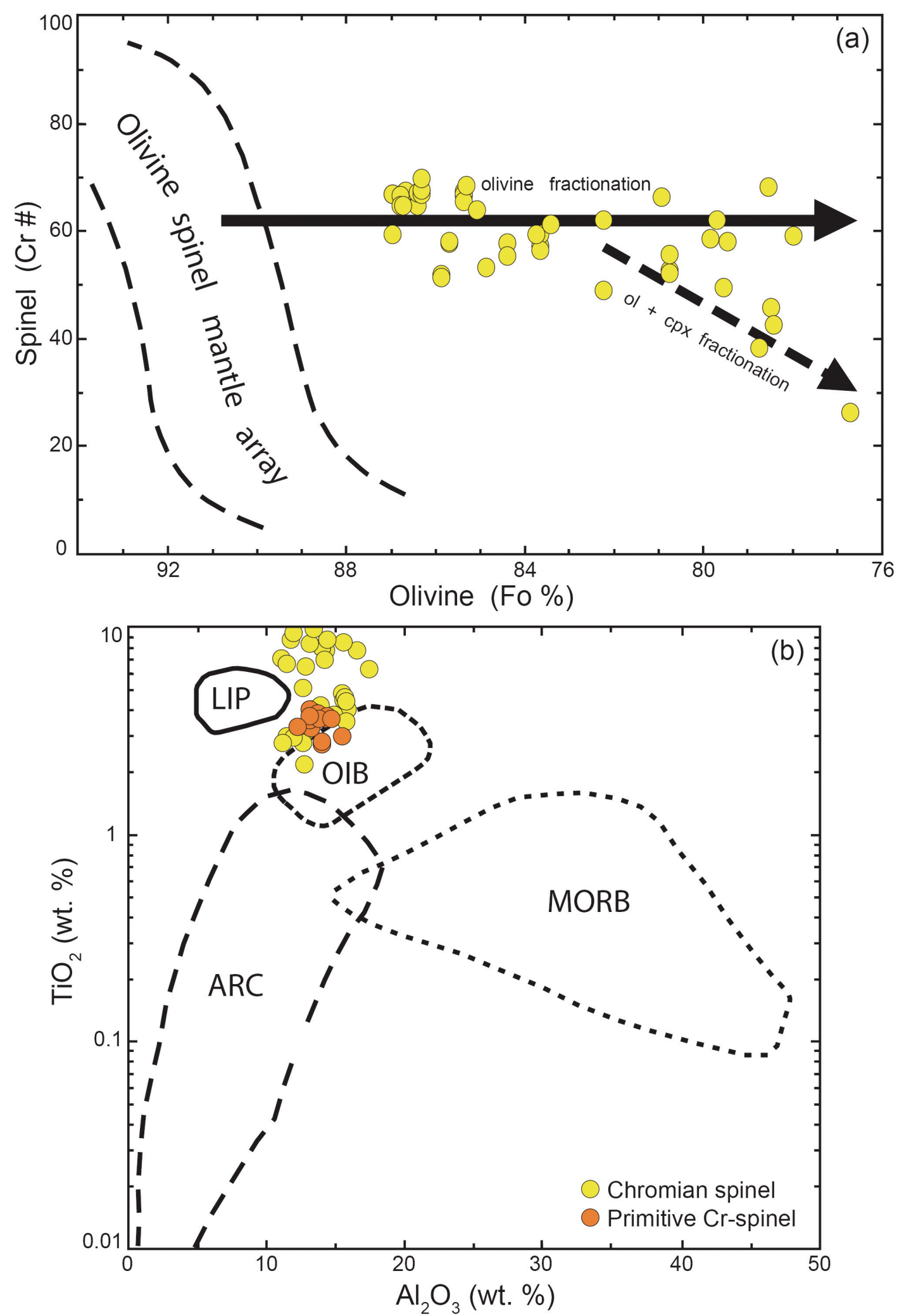

Figure 3.20: A) Relationship between the forsterite content of olivine and the $\mathrm{Cr} \#$ of the coexisting chromian spinel. Fo-Cr\# fractionation lines are shown for pure olivine crystallisation and olivine and clinopyroxene crystallisation within the Lookout Volcanics. Also shown is the olivine spinel mantle array (OSMA) of Arai (1994a). B) $\mathrm{Al}_{2} \mathrm{O}_{3} \mathrm{vs} \mathrm{TiO}_{2}$ of $\mathrm{Cr}$-spinels in the Lookout Volcanics. Compositional fields are taken from Kamenetsky et al. (2001). Primitive Crspinels are those with $>40 \mathrm{wt} \% \mathrm{Cr}_{2} \mathrm{O}_{3}$. 
OIB compositional field on an $\mathrm{Al}_{2} \mathrm{O}_{3}-\mathrm{TiO}_{2}$ diagram (Figure $3.20 \mathrm{~B}$ ). The depletion of $\mathrm{Cr}_{2} \mathrm{O}_{3}$ in the residual melt and initiation of clinopyroxene crystallisation results in the formation of increasingly $\mathrm{Cr}_{2} \mathrm{O}_{3}$ poor spinels. These spinels exhibit increasing $\mathrm{TiO}_{2}$ while $\mathrm{Al}_{2} \mathrm{O}_{3}$ remains relatively constant.

\subsection{SUMMARY}

This chapter classifies the rocks of the Lookout Volcanics on the basis of their petrography and mineral chemistry. A brief summary of the main findings of this chapter are presented here:

1) The rocks of the Lookout Volcanics have been divided into 7 lithotypes on the basis of their crystal assemblages and phenocryst contents. The four main rock types (Type I-IV; 95\% of samples) form a continuum between highly porphyritic basalts with $>40 \%$ large olivine and clinopyroxene phenocrysts to almost aphyric basalts with small clinopyroxene and plagioclase phenocrysts. Unusual rock types include highly porphyritic basalts with $>35 \%$ large highly honeycombed plagioclase phenocrysts (Type VI) and a moderately porphyritic basaltic-trachyandesite containing phenocrysts of plagioclase, clinopyroxene and orthopyroxene (Type VII).

2) The elevated $\mathrm{NiO}$ contents of olivine phenocrysts in Hawaiian magmas are a consequence of their generation by melting of an olivine-free secondary pyroxenite (Sobolev et al., 2005). Olivine phenocrysts in the Lookout Volcanics possess $\mathrm{NiO}$ contents comparable to intraplate magmas from Yemen, and marginally lower than those of Hawaiian OIB and Yemeni CFB. However, these values are considerably greater than those observed in standard mantle peridotite source regions (i.e. MORB). The magmas of the Lookout Volcanics are consistent with a mantle source region that contains ca. $50 \%$ pyroxenitic material. This source region was generated by the 
incorporation of Si-rich melts generated from oceanic crust subducted on the eastern margin of Gondwana at ca. $300 \mathrm{Ma}$.

3) Although pyroxenitic magmas are characteristically depleted in Ca relative to magmas generated from peridotite. The proportion of pyroxenite in a magma produces no systematic variability in $\mathrm{CaO}$ content of olivine phenocrysts analysed in this study. Instead the $\mathrm{CaO}$ content of olivines is strongly controlled by primary melt composition.

4) Large strongly zoned clinopyroxene phenocrysts in the Lookout Volcanics possess $\mathrm{Cr}$-Si-rich cores and $\mathrm{Al}-\mathrm{Ti}$-rich rims. These variations reflect phenocryst growth in a solidifying magma chamber in which the intercumulus melt was becoming progressively enriched in elements incompatible in the main crystallising phases (i.e. Al-Ti in olivine \& clinopyroxene). The emplacement of the Lookout Volcanics by dykes provides a viable mechanism through which to entrain strongly zoned phenocrysts from a partially crystallised magma chamber.

5) The unique low $\mathrm{Cr}-\mathrm{Al}-\mathrm{Ti}$ and high-Si clinopyroxene phenocrysts observed in the most evolved samples coupled with the crystallisation of orthopyroxene in AMG-10 correspond to the progressive Si-saturation of these magmas. The dominant crystallisation assemblage in the Lookout Volcanics (olivine + clinopyroxene \pm plagioclase) cannot generate the degree of Si-enrichment required to initiate orthopyroxene crystallisation thus these magmas require significant crustal contributions.

6) The compositions of chromian spinels in the Lookout Volcanics are consistent with a mantle restite that is comparable to other intraplate magmas worldwide. Spinel inclusions with olivine phenocrysts record a change in magma chemistry at $\mathrm{Fo}_{81}$ resulting from the initiation of clinopyroxene crystallisation. 


\section{CHAPTER 4: PETROGENESIS OF THE LOOKOUT VOLCANICS}

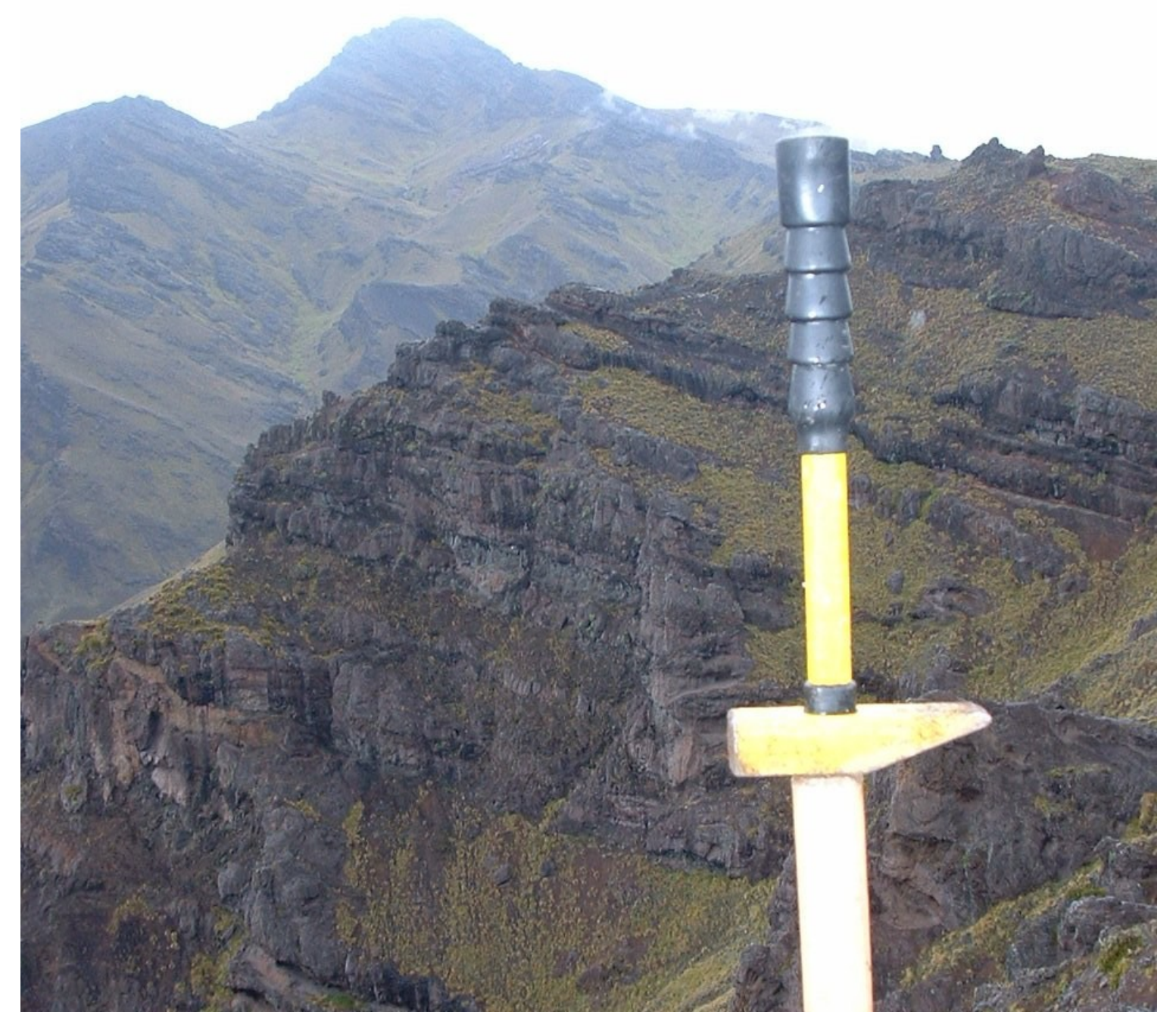

Plate 5: Thick basaltic lavas flows form cliffs at the top of Middlehurst (Section B) with the peak of Mount Lookout in the distance.

Note: This chapter has been prepared in the style of an article ready for submission to the Journal of Petrology.

Petrogenesis of mid-Cretaceous continental intraplate volcanism in Marlborough, New Zealand: during the break-up of Gondwana.

A. J. McCoy-West, J. A. Baker, K. Faure 


\section{ABSTRACT}

The Lookout Volcanics outcropping in Marlborough, northern South Island, New Zealand represent the remnants of extensive mid-Cretaceous (ca. $96 \mathrm{Ma}$ ) intraplate volcanic rocks erupted just prior to the rifting of New Zealand from Gondwana. The volcanic rocks which cover an area of ca. $50 \mathrm{~km}^{2}$ with exposed thicknesses up to $1000 \mathrm{~m}$, are preserved in a fault angle depression bounded by the Awatere Fault. We have carried out detailed sampling of the Lookout Volcanics and constructed a ca. $700 \mathrm{~m}$ composite stratigraphic section, largely based on a continuous sequence of lava flows outcropping in Middlehurst Stream.

The samples are predominantly mafic and alkaline and include basalt, picrobasalt, basanite, trachybasalt and basaltic trachyandesite rock types. No samples represent primary magmas with all samples having undergone accumulation or fractionation of olivine + clinopyroxene \pm plagioclase $\pm \mathrm{Fe}-\mathrm{Ti}$ oxides. Initial Sr-Nd-Hf-Pb isotopic variations $\left({ }^{87} \mathrm{Sr} /{ }^{86} \mathrm{Sr}=0.7030-0.7039\right.$; ${ }^{143} \mathrm{Nd} /{ }^{144} \mathrm{Nd}=0.51272-0.51264 ;{ }^{176} \mathrm{Hf} /{ }^{177} \mathrm{Hf}=0.28283-0.28278 ;{ }^{206} \mathrm{~Pb} /{ }^{204} \mathrm{~Pb}=20.32-$ 18.82) are the result of mixing between melts of a HIMU-like mantle component, and up to $25-30 \%$ of an Early Cretaceous upper crustal component.

Oxygen isotope ratios determined by laser fluorination methods, for 6 lava flows yielded $\delta^{18} \mathrm{O}=4.7-5.0 \%$ for olivine, 4.8-5.4\%o in clinopyroxene cores, and $3.9-5.5 \%$ in clinopyroxene rims. Average olivine (4.8\%o) and clinopyroxene core $(5.0 \%)$ values are in isotopic equilibrium and comparable to those of HIMU OIB. Oxygen isotopic disequilibrium between clinopyroxene cores and rims suggest that phenocrysts grew in a magma chamber with an active meteoric water system. Because phenocrysts can be scavenged from multiple sources and rapidly erupted, caution must be exercised when interpreting phenocrysts with low $\delta^{18} \mathrm{O}$ as being derived from the mantle. The effects of crustal assimilation can be observed in the isotopic compositions of clinopyroxene phenocrysts from the most evolved sample where elevated $\delta^{18} \mathrm{O}$ is coupled with higher ${ }^{87} \mathrm{Sr} /{ }^{86} \mathrm{Sr}$.

The Lookout Volcanics are the oldest occurrence of HIMU-like magmatism in Zealandia. Variations in incompatible trace element ratios suggest small degrees of partial melting ca. 2-5\% of an amphibole-bearing garnet pyroxenite mantle source $\left(\mathrm{La} / \mathrm{Yb}_{\mathrm{N}}=12.5-20.2 ; \mathrm{Dy} / \mathrm{Yb}_{\mathrm{N}}=1.90-2.20\right)$. Moreover, the elevated $\mathrm{NiO}$ contents of olivine phenocrysts are consistent with melts being generated from a pyroxenitic mantle source. Evidence suggests this source was generated along the East Gondwana subduction margin and resides in the subcontinental lithospheric mantle. 


\subsection{INTRODUCTION}

Although continental intraplate magmatism is commonly associated with regions of continental rifting or mantle upwelling, the ultimate sources and processes responsible for the generation of such magmas remain uncertain. A key question is whether source regions are dominated by the hydrous subcontinental lithospheric mantle (SCLM) (e.g. Gallagher \& Hawkesworth, 1992; Hawkesworth \& Gallagher, 1993) or by the asthenospheric mantle with only minor contributions from the SCLM (McKenzie \& Bickle, 1988; White \& McKenzie, 1989).

Mid-Cretaceous to Recent intraplate volcanism occurs sporadically throughout the New Zealand micro-continent (Zealandia; Luyendyk, 1995). The intraplate volcanic rocks of southern Zealandia are low volume $\left(<10,000 \mathrm{~km}^{3}\right)$ and widely scattered within a $8000 \mathrm{~km}^{2}$ area include several large shield volcanoes, mafic lava fields and small intrusive complexes (Weaver \& Smith, 1989). Predominantly mafic and alkaline volcanic rocks display ocean island basalt (OIB) like major and trace element signatures that are similar to a HIMU (high time integrated ${ }^{238} \mathrm{U} /{ }^{204} \mathrm{~Pb}$ or high $\mu$ ) mantle source (Gamble et al., 1986; Barreiro \& Cooper, 1987; Baker et al., 1994; Hoke et al., 2000; Panter et al., 2006; Sprung et al., 2007).

The Lookout Volcanics, Marlborough, South Island, New Zealand (i.e. Lookout Formation; Challis, 1966) consist of dominantly mafic-ultramafic alkaline volcanic rocks erupted during a period of extensive intraplate volcanism in the mid-Cretaceous $(100-82 \mathrm{Ma})$, related to the extension of proto-New Zealand and its eventual separation from Gondwana (Figure 4.1). The Lookout Volcanics conformably overlie thin terrestrial sediments which rest on shallow marine sediments of Ngaterian age (100.2-95.2 Ma), which in turn rest on the basement rocks of the northeastern South Island Pahau Terrane (Torlesse Supergroup). Torlesse Supergroup rocks comprise an alternating sequences of 

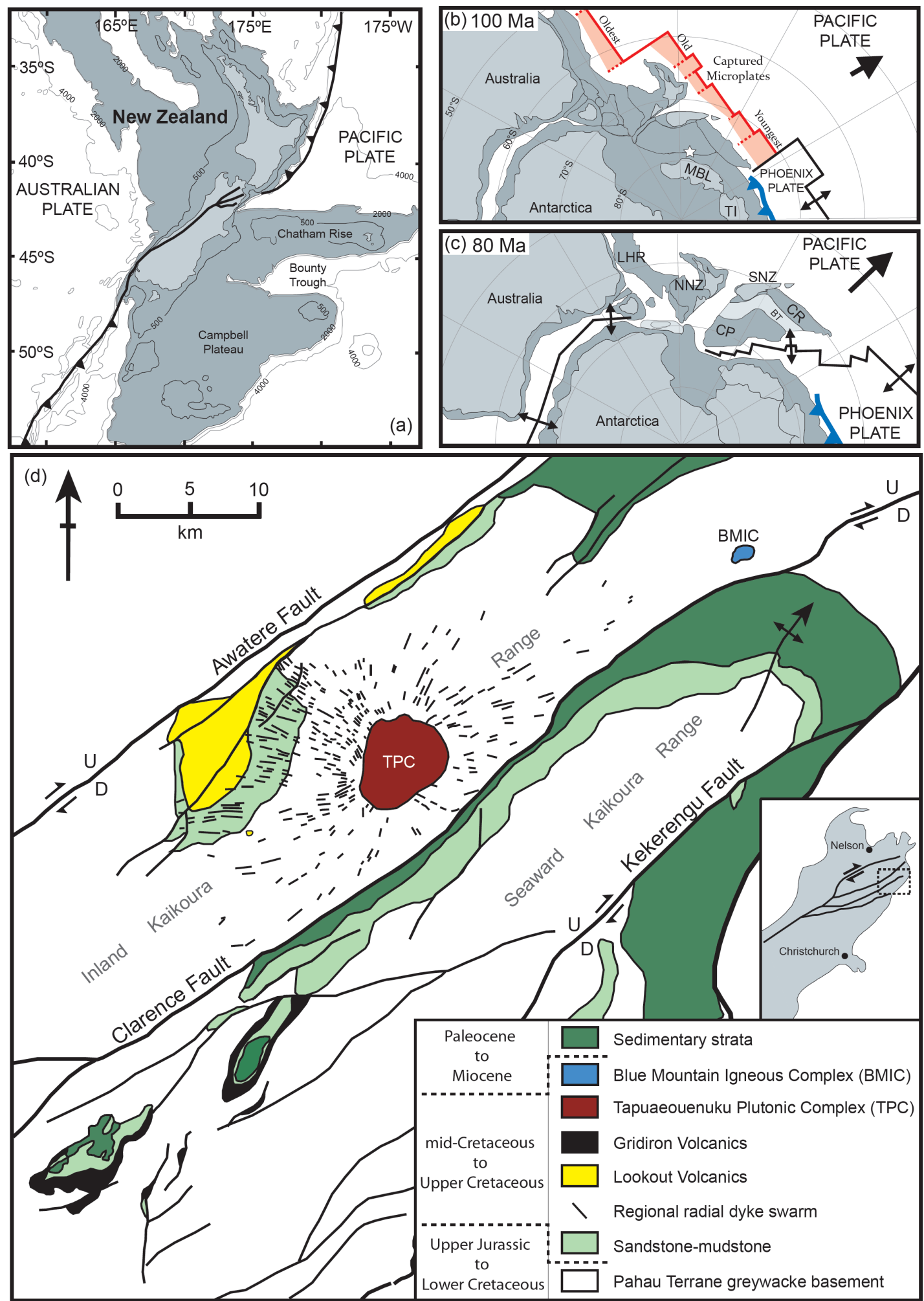

Figure 4.1: (a) Present day configuration of the New Zealand microcontinent. (b-c) Paleoreconstructions showing the East Gondwana margin at $100 \mathrm{Ma}$ and $80 \mathrm{Ma}$, respectively. Modified after Lawver et al. (1992). Arrows on the Pacific Plate represent the relative motion of this plate with respect to Antarctica. $100 \mathrm{Ma}$ : As the spreading centre nears the trench spreading slows, and eventually stops causing microplates to become captured by the over riding plate (Luyendyk, 1995). Microplates become progressively younger from west to east due to the oblique interaction of the spreading centre with the continental margin. In the Aptian, the Pacific Plate reversed and started moving slowly northward resulting in the extension of proto-New Zealand and Marie Byrd Land. 
Figure 4.1 (continued): Star represents the hypothesised mantle plume centre of Weaver et al. (1994). 80 Ma: The Pacific Plate accelerated its northward motion and the Udintsev Fracture Zone reached the tip of the Chatham Rise at $84 \mathrm{Ma}$. This resulted in the inception of the PacificAntarctic ridge and seafloor spreading between New Zealand and MBL. BT-Bounty Trough; CP -Campbell Plateau; CR —Chatham Rise; LHR — Lord Howe Rise; MBL—Marie Byrd Land; NZNew Zealand (N-Northern; S-Southern); TI-Thurston Island. (d) Simplified geological map of the Inland Kaikoura Region. Modified after Baker et al. (1994).

deformed massive greywacke and argillites, that were accreted to the Pacific margin of Gondwana by a series of collisional events from the Late Jurassic to Early Cretaceous (Weaver et al., 1994; Mortimer, 2004). Subduction related calcalkaline magmatism ceased in western Marie Byrd Land, Antarctica in the Early Cretaceous (110 Ma) and rift-related magmatism had begun by $101 \mathrm{Ma}$ (Mukasa \& Dalziel, 2000) marking a rapid change from subduction-related to rift-related magmatism in a period of ca. 9 Ma. The Pacific Plate reversed direction and started moving slowly northward during the Early Cretaceous (125-112 Ma), accelerating dramatically during the Late Cretaceous reaching plate velocities > $100 \mathrm{~km} / \mathrm{Myr}$ just prior to the commencement of sea-floor spreading between New Zealand and Marie Byrd Land (Bradshaw, 1989; Larson et al., 1992). Sea-floor spreading between Zealandia and Antarctica is constrained at ca. 84 Ma by the oldest oceanic crust adjacent to the Campbell Plateau (Larter et al., 2002; Eagles et al., 2004).

In New Zealand the inception of extension is evidenced by a number of geological features recognisable today: (1) ultramafic-gabbro-syenite plutonic complexes and the associated regional radial dyke swarm in Marlborough (Grapes, 1975; Weaver \& Pankhurst, 1991; Baker et al., 1994); (2) metamorphic core complexes in Westland that record the initiation of continental extension in the mid-Cretaceous (Tulloch \& Kimbrough, 1989; Muir et al., 1994; Spell et al., 2000); (3) the opening of the Bounty Trough (Davy, 1984; Grobys et al., 2007); (4) extensive exposures of mid-Upper Cretaceous volcanic rocks including the Lookout Volcanics preserved in the northern South Island and the Chatham Islands (Suggate, 1958; Nicol, 1977; Morris, 1985; Barley, 1987; Panter et al., 2006). The exact cause of rifting is still unclear having previously been attributed 
to subducted slab capture (Luyendyk, 1995), or the impingement of a mantle plume on the continental lithosphere (Weaver et al., 1994; Storey et al., 1999).

The Lookout Volcanics and associated intrusive igneous rocks represent the oldest example of HIMU-like volcanism that is preserved in Zealandia. A lithospheric or sub-lithospheric source of the HIMU component in continental basalts in the southwest Pacific (New Zealand, West Antarctica, southeast Australia) has been a matter of debate for several decades. A variety of models have been used to explain the origin of intraplate volcanism in southern New Zealand including the migration of an active mantle plume (Adams, 1981), metasomatised source regions (Gamble et al., 1986), lithospheric sources with fossilised mantle plume signatures (Weaver et al., 1994), the presence of metasomatised Gondwanaian SCLM in the source region (Finn et al., 2005), the storage of metasomatically enriched uppermost mantle at the base of the crust (Panter et al., 2006), or the reactivation of fossilised HIMU-like asthenospheric melts in the SCLM (Sprung et al., 2007). In addition to the HIMU component, an enriched mantle component has also been proposed to be involved in the genesis of New Zealand intraplate magmas (Hoernle et al., 2006).

This paper presents detailed chemical and isotopic data from the remnants of a once extensive sheet of mid-Cretaceous intraplate volcanic rocks from South Island, New Zealand. These data are used to assess the roles of fractional crystallisation, crustal contamination, mantle source heterogeneity and variable degrees of partial melting on the formation of these rocks and subsequently speculate on the nature of the mantle source and the origins of this continental intraplate volcanism.

\subsection{FIELD GEOLOGY}

The volcanic rocks of the Lookout Formation are preserved in the Awatere Valley, Marlborough, South Island, New Zealand (Figure 4.1). Coeval magmatism 
is exposed by Tertiary block faulting with the Tapuaeouenuku Plutonic Complex (TPC) outcropping amongst the highest peaks of the Inland Kaikoura Range and a regional dyke swarm with an extent of ca. $300 \mathrm{~km}^{2}$ outcropping continuously between the volcanic and plutonic rocks. Exposures are restricted to the fault angle depression of the Awatere Valley where the formation covers an area of ca. $50 \mathrm{~km}^{2}$. The majority of outcrop occurs in the Mount Lookout region with > $1000 \mathrm{~m}$ of lava flows preserved. The volcanic rocks are dominantly terrestrial lava flows (95\%), however, minor marine tuffs and non-volcanic sediments are preserved at the top of the volcanic section, near Limestone Stream (Figure 4.2a). The basal lava flow displays a sharp contact with the underlying terrestrial sediments, which in turn rest on shallow marine sediments of Ngaterian age (100.2-95.2 Ma). Lava flows are typically 4-10 m thick with the thickest lava flow being $24 \mathrm{~m}$ thick. Weathering has occurred between some flows, but the relatively unweathered nature of many rocks, especially the more mafic ones and absence of sediments between flows indicate a rapid accumulation of volcanic material. Lava flows are assumed to have been emplacement by fissure eruptions from dykes of the regional swarm on the basis of the following evidence: (1) a lack of a central volcanic vent within the Lookout Volcanics; (2) the decrease in the amount of dyking up the volcanic section; (3) numerous examples of dykes being truncated by lava flows.

We have carried out detailed sampling (103 samples) of the Lookout Volcanics and constructed a ca. $700 \mathrm{~m}$ composite stratigraphic section, largely based on a continuous sequence of lava flows outcropping in Middlehurst Stream (550 m) (Figure 4.2b). Correlation between the different volcanic sections was not attempted due to a lack of recognisable marker horizons and instead sections were placed in relative stratigraphic height based on their relationships in the field. 


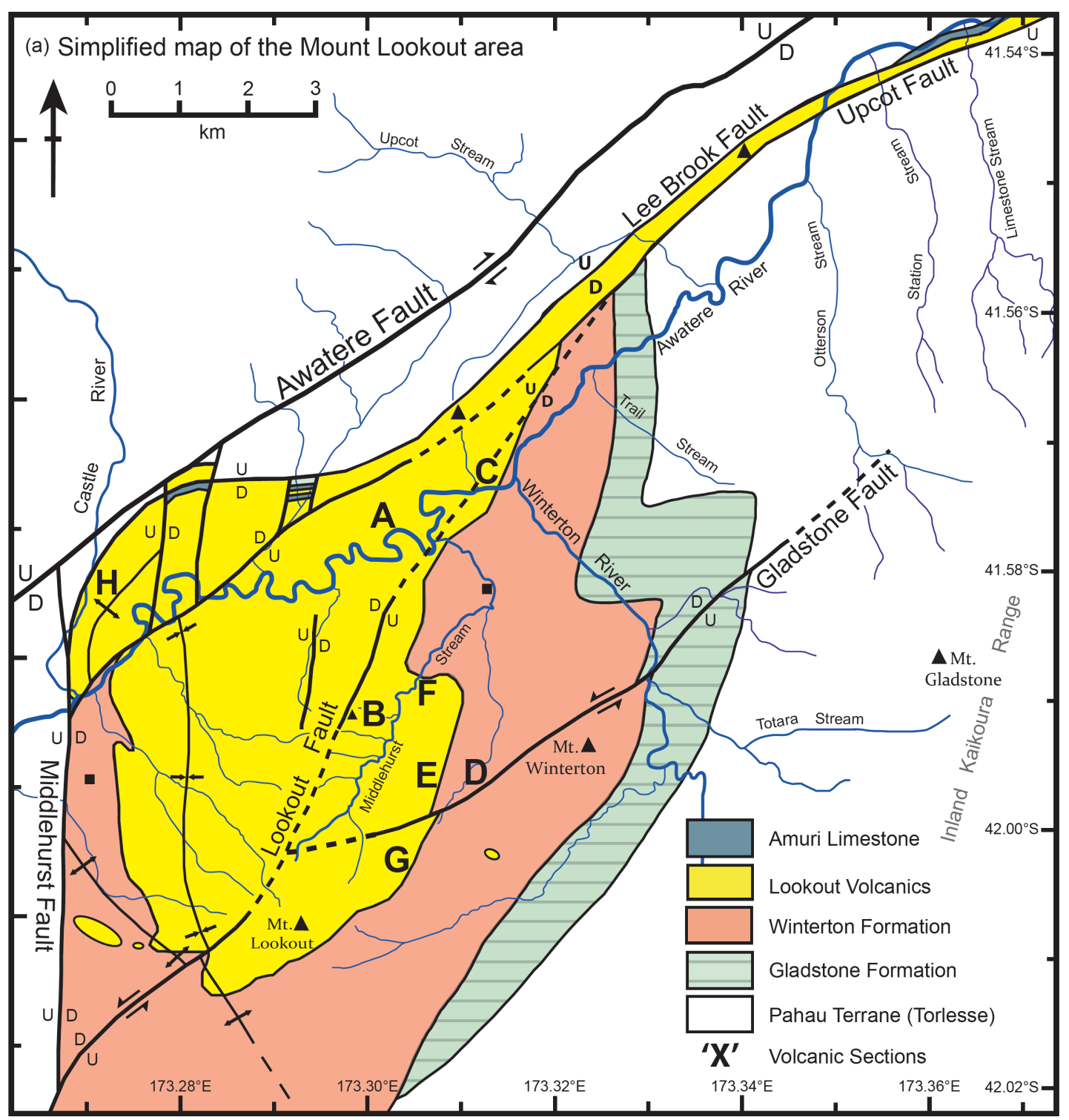

Figure 4.2: Simplified geological map of the Mount Lookout region. Locations of volcanic sections sampled in this study are shown. Modified after Challis (1960a) \& Nicol (1977).

\subsection{ANALYTICAL TECHNIQUES}

Electron probe micro-analysis (EPMA) was undertaken at Victoria University of Wellington (VUW), New Zealand using a JEOL 733 Superprobe equipped with three wavelength dispersive spectrometers. The instrument was calibrated daily using a series of synthetic and natural standards: $\mathrm{Al}, \mathrm{Cr}, \mathrm{Fe}, \mathrm{Mg}, \mathrm{Mn}, \mathrm{Ni}$ and $\mathrm{Ti}-$ synthetic element oxides; $\mathrm{Si}$ and $\mathrm{Ca}$ - wollastanite; $\mathrm{Na}$ - jadeite; $\mathrm{K}$ - orthoclase. Appropriate mineral standards were analysed between samples to monitor spectrometer drift and precision. Standard operating conditions involved the use 
of a static electron beam with a current of $120 \mathrm{nA}$ and accelerating voltage of 15 $\mathrm{kV}$. Analysis of olivine was performed using the analytical conditions of Sobolev et al. (2007) (300 nA; $20 \mathrm{kV})$. Analytical reproducibility of EPMA on the San Carlos Olivine (USNM 11312/444) is better than: $\mathrm{SiO}_{2} \pm 0.7$ wt \%; $\mathrm{Fe}_{2} \mathrm{O}_{3} \pm 0.2$ wt $\% ; \mathrm{MgO} \pm 0.6$ wt $\% ; \mathrm{CaO} \pm 0.013$ wt $\% ; \mathrm{MnO}_{ \pm 0.016}$ wt $\% ; \mathrm{NiO} \pm 0.014$ wt $\%( \pm$ $2 \mathrm{SD} ; \mathrm{n}=95)$.

Laser ablation induction coupled plasma mass spectrometer (LA-ICP-MS) trace element analysis of clinopyroxene phenocrysts were performed at VUW using a New Wave deep ultraviolet (193 nm solid state) laser ablation system coupled to an Agilent 7500CS ICP-MS. Abundances of trace elements were calculated relative to a bracketing standard (BCR-2G), which was analysed under identical conditions throughout the analytical session. The method employed in this study follows that of Pearce et al. (1996) where a minor isotope of a major element (here ${ }^{43} \mathrm{Ca}$ ) previously determined by EPMA was included in the LAICP-MS analysis and used as an internal standard for secondary data normalisation. Complete analytical details of the LA-ICP-MS technique are described in Allan et al. (2008).

Major element abundances were determined on fused glass discs by X-ray fluorescence (XRF) spectrometry at the University of Auckland, New Zealand. Analysis of international rock standards BCR-2 and BHVO-2 show that XRF data are accurate to within $1 \%$ for $\mathrm{Si}, \mathrm{Ti}, \mathrm{Al}, \mathrm{Mn}, \mathrm{Mg}, \mathrm{Ca}, \mathrm{Na}$, and $\mathrm{K}$ and to $3 \%$ for $\mathrm{Fe}$ and P. Trace element concentrations were determined by external normalisation to bracketing analyses of BHVO-1 using an Agilent 7500CS ICP-MS at VUW. ${ }^{43} \mathrm{Ca}$ was monitored during trace element analysis and used for secondary data normalisation against $\mathrm{CaO}$ values already determined by XRF analysis. Plasma torch conditions were optimised so that the element oxide production (estimated from measured $\mathrm{CeO}^{+} / \mathrm{Ce}^{+}$ratios) was $\leq 1 \%$ throughout the analysis session. Duplicate digestions of BHVO-2 $(\mathrm{n}=7)$ and BCR-2 $(\mathrm{n}=9)$ produced data with a precision and accuracy of $\leq \pm 4 \%$ (2 SD) for Sc, V, Cr, Co, Ni, Cu, Ga, Rb, Sr, Y, 
$\mathrm{Zr}, \mathrm{Nb}, \mathrm{Ba}$, and rare earth elements (REE) and $\pm 5 \%$ for $\mathrm{Zn}, \mathrm{Hf}, \mathrm{Ta}, \mathrm{Th}$, and $\mathrm{U}$ and $\pm 10 \%$ for $\mathrm{Tl}$ and $\mathrm{Cs}$ and $\pm 15 \%$ for Mo and $\mathrm{Pb}$ (Table 4.1 ).

$\mathrm{Sr}, \mathrm{Nd}, \mathrm{Hf}$ and $\mathrm{Pb}$ were chemically separated in class 10 laminar flow hoods. Sample powders for Sr were leached in hot $6 \mathrm{M} \mathrm{HCl}$ for $2 \mathrm{~h}$ and rinsed repeatedly using ultraclean water (> 18.2 $\mathrm{M} \Omega$ ) before $\mathrm{HF}-\mathrm{HNO}_{3}$ digestion. Sr was separated using a double pass through columns containing Eichrom Sr-specific resin. Nd and Hf were separated by a method modified after the work of Pin \& Zalduegui (1997), Ulfbeck et al. (2002), Le Fèrve \& Pin, (2005) and Connelly et al. (2006). Flux fusion digestions were undertaken at $1100^{\circ} \mathrm{C}$ in graphite crucibles with a $1: 3$ sample powder to $\mathrm{LiBO}_{2}$ flux ratio (Ulfbeck et al., 2002). Hf was separated by passing samples sequentially through columns filled with cation exchange and DGA resins (Connelly et al., 2006). After the elution of matrix elements Hf was collected off the DGA column in dilute $\mathrm{HNO}_{3}+\mathrm{HF}$. In dilute $\mathrm{HCl}$ a $\mathrm{REE}$ cut is collected off the DGA column and Nd is separated from the other REE using Lnspecific resin (Pin \& Zalduegui, 1997). Rock chips for Pb isotope analysis were acid washed in hot $2 \mathrm{M} \mathrm{HCl}$ for 2 periods of $30 \mathrm{~min}$ before $\mathrm{HF}-\mathrm{HNO}_{3}$ digestion. $\mathrm{Pb}$ was separated by conventional technique with a double pass through anion exchange resin eluting matrix elements in $1 \mathrm{M} \mathrm{HBr}$ and collecting $\mathrm{Pb}$ in 6-7 M HCl. Total procedural blanks for $\mathrm{Sr}, \mathrm{Nd}, \mathrm{Hf}$ and $\mathrm{Pb}$ were ca. 1.1, 0.3, 0.1 and 0.01 ng, respectively, and are negligible.

$\mathrm{Sr}, \mathrm{Nd}, \mathrm{Hf}$ and $\mathrm{Pb}$ isotope ratios were determined by multi-collector (MC-) ICP-MS at VUW. Analytical procedures for Sr and Nd isotope analyses are described by Waight et al. (2002) and Luais et al. (1997), respectively. In-run internal precisions of ${ }^{87} \mathrm{Sr} /{ }^{86} \mathrm{Sr}$ and ${ }^{143} \mathrm{Nd} /{ }^{144} \mathrm{Nd}$ measurements were typically $< \pm$ 0.000015 and \pm 0.000008 , respectively (2 SE). External reproducibilities of Sr and $\mathrm{Nd}$ isotope ratios were $<0.000018$ and 0.000028 (2 SD for BHVO-2; $\mathrm{n}=4$ and 5), respectively. ${ }^{87} \mathrm{Sr} /{ }^{86} \mathrm{Sr}$ is reported relative to a value of 0.710248 for SRM987 and ${ }^{143} \mathrm{Nd} /{ }^{144} \mathrm{Nd}$ is reported relative to 0.512260 for the $\mathrm{Nd}$ standard Alfa Aesar. This ${ }^{143} \mathrm{Nd} /{ }^{144} \mathrm{Nd}$ ratio corresponds to a value of 0.51186 for the La Jolla standard. 
Table 4.1: Normalising values and precision and accuracy of ICP-MS trace element analyses.

\begin{tabular}{|c|c|c|c|c|c|c|c|c|c|}
\hline \multirow{2}{*}{\multicolumn{2}{|c|}{$\begin{array}{c}\text { BHVO-1 } \\
\text { Preferre } \\
\mathrm{d} \\
\text { values } \\
\end{array}$}} & \multicolumn{4}{|c|}{ BCR-2 (n = 9) } & \multicolumn{4}{|c|}{ BHVO-2 (n = 7) } \\
\hline & & $\begin{array}{c}\text { Mean } \\
( \pm 2 \mathrm{SD}) \\
\end{array}$ & $\begin{array}{c}\begin{array}{c}\text { Preferred } \\
\text { values }\end{array} \\
\end{array}$ & $\begin{array}{c}\% \\
\text { Offset }\end{array}$ & $\begin{array}{c}\% \\
2 \mathrm{SD} \\
\end{array}$ & $\begin{array}{c}\text { Mean } \\
( \pm 2 \mathrm{SD}) \\
\end{array}$ & $\begin{array}{c}\text { Geore } \\
\mathrm{m}\end{array}$ & $\begin{array}{c}\% \\
\text { Offset } \\
\end{array}$ & $\begin{array}{c}\% \\
2 \mathrm{SD} \\
\end{array}$ \\
\hline${ }^{45} \mathrm{Sc}$ & 31 & $32.8 \pm 0.6$ & 33 & $-0.7 \%$ & $1.9 \%$ & $31.4 \pm 0.7$ & 32 & $-1.9 \%$ & $2.2 \%$ \\
\hline${ }^{51} \mathrm{~V}$ & 318 & $419 \pm 4$ & 416 & $+0.7 \%$ & $1.0 \%$ & $320 \pm 6$ & 317 & $+0.9 \%$ & $1.8 \%$ \\
\hline${ }^{53} \mathrm{Cr}$ & 287 & $14.8 \pm 0.7$ & 16 & $-7.4 \%$ & $4.9 \%$ & $292 \pm 9$ & 280 & $+4.4 \%$ & $3.1 \%$ \\
\hline${ }^{59} \mathrm{Co}$ & 45 & $37.4 \pm 0.6$ & 37 & $+1.1 \%$ & $1.7 \%$ & $45.1 \pm 1$ & 45 & $+0.2 \%$ & $2.2 \%$ \\
\hline${ }^{60} \mathrm{Ni}$ & 118 & $12.1 \pm 0.4$ & 13 & $-6.8 \%$ & $3.4 \%$ & $120 \pm 3$ & 119 & $+0.7 \%$ & $2.8 \%$ \\
\hline${ }^{63} \mathrm{Cu}$ & 137 & $19.9 \pm 1.3$ & 21 & $-5.4 \%$ & $6.6 \%$ & $128 \pm 4$ & 127 & $+0.7 \%$ & $3.5 \%$ \\
\hline${ }^{66} \mathrm{Zn}$ & 106 & $128 \pm 6$ & 130 & $-1.6 \%$ & $4.9 \%$ & $103 \pm 6$ & 103 & $+0.5 \%$ & $5.5 \%$ \\
\hline${ }^{71} \mathrm{Ga}$ & 21 & $21.6 \pm 0.4$ & 22 & $-2.0 \%$ & $2.0 \%$ & $21.0 \pm 0.7$ & 22 & $-4.7 \%$ & $3.5 \%$ \\
\hline${ }^{85} \mathrm{Rb}$ & 9.19 & $46.3 \pm 1.2$ & 46.9 & $-1.3 \%$ & $2.7 \%$ & $9.07 \pm 0.25$ & 9.11 & $-0.4 \%$ & $2.7 \%$ \\
\hline${ }^{86} \mathrm{Sr}$ & 396 & $333 \pm 11$ & 340 & $-2.1 \%$ & $3.4 \%$ & $393 \pm 16$ & 396 & $-0.8 \%$ & $4.0 \%$ \\
\hline${ }^{89} \mathrm{Y}$ & 26 & $35.4 \pm 0.7$ & 36 & $-1.8 \%$ & $2.0 \%$ & $25.8 \pm 0.8$ & 26 & $-0.6 \%$ & $3.3 \%$ \\
\hline${ }^{90} \mathrm{Zr}$ & 174 & $188 \pm 4$ & 189 & $-0.7 \%$ & $2.3 \%$ & $173 \pm 5$ & 172 & $+0.7 \%$ & $2.7 \%$ \\
\hline${ }^{93} \mathrm{Nb}$ & 18.6 & $12.3 \pm 0.2$ & 13 & $-2.3 \%$ & $1.8 \%$ & $18.5 \pm 0.8$ & 18.1 & $+2.1 \%$ & $4.1 \%$ \\
\hline${ }^{95} \mathrm{Mo}$ & 1.0 & $252 \pm 28$ & 250 & $+0.7 \%$ & $11.0 \%$ & $3.43 \pm 0.52$ & 4.0 & $-14.1 \%$ & $15.1 \%$ \\
\hline${ }^{133} \mathrm{Cs}$ & 0.09 & $1.06 \pm 0.04$ & 1.10 & $-3.4 \%$ & $3.4 \%$ & $0.094 \pm 0.01$ & 0.1 & $-5.8 \%$ & $8.4 \%$ \\
\hline${ }^{137} \mathrm{Ba}$ & 133 & $681 \pm 24$ & 677 & $+0.6 \%$ & $3.5 \%$ & $132 \pm 4$ & 131 & $+0.5 \%$ & $3.3 \%$ \\
\hline${ }^{139} \mathrm{La}$ & 15.52 & $24.9 \pm 0.7$ & 25.12 & $-0.8 \%$ & $2.8 \%$ & $15.4 \pm 0.5$ & 15.2 & $+1.0 \%$ & $3.5 \%$ \\
\hline${ }^{140} \mathrm{Ce}$ & 38.23 & $52.6 \pm 1.8$ & 53.31 & $-1.2 \%$ & $3.4 \%$ & $37.8 \pm 1.4$ & 37.5 & $+0.9 \%$ & $3.6 \%$ \\
\hline${ }^{141} \operatorname{Pr}$ & 5.411 & $6.76 \pm 0.24$ & 6.756 & $+0.02 \%$ & $3.6 \%$ & $5.35 \pm 0.17$ & 5.35 & $+0.1 \%$ & $3.2 \%$ \\
\hline${ }^{146} \mathrm{Nd}$ & 24.79 & $28.4 \pm 0.9$ & 28.71 & $-1.0 \%$ & $3.2 \%$ & $24.6 \pm 0.9$ & 24.5 & $+0.3 \%$ & $3.8 \%$ \\
\hline${ }^{147} \mathrm{Sm}$ & 6.14 & $6.52 \pm 0.23$ & 6.58 & $-1.0 \%$ & $3.5 \%$ & $6.12 \pm 0.21$ & 6.07 & $+0.8 \%$ & $3.4 \%$ \\
\hline${ }^{151} \mathrm{Eu}$ & 2.066 & $1.98 \pm 0.07$ & 1.944 & $+1.9 \%$ & $3.7 \%$ & $2.06 \pm 0.07$ & 2.07 & $-0.4 \%$ & $3.3 \%$ \\
\hline${ }^{157} \mathrm{Gd}$ & 6.29 & $6.84 \pm 0.22$ & 6.73 & $+1.7 \%$ & $3.3 \%$ & $6.22 \pm 0.26$ & 6.24 & $-0.3 \%$ & $4.1 \%$ \\
\hline${ }^{159} \mathrm{~Tb}$ & 0.96 & $1.07 \pm 0.03$ & 1.07 & $-0.4 \%$ & $3.0 \%$ & $0.961 \pm 0.04$ & 0.92 & $+4.4 \%$ & $3.8 \%$ \\
\hline${ }^{163} \mathrm{Dy}$ & 5.36 & $6.38 \pm 0.17$ & 6.44 & $-0.9 \%$ & $2.7 \%$ & $5.36 \pm 0.23$ & 5.31 & $+0.9 \%$ & $4.2 \%$ \\
\hline${ }^{165} \mathrm{Ho}$ & 0.98 & $1.28 \pm 0.04$ & 1.28 & $-0.3 \%$ & $2.8 \%$ & $0.978 \pm 0.03$ & 0.98 & $-0.2 \%$ & $3.4 \%$ \\
\hline${ }^{166} \mathrm{Er}$ & 2.57 & $3.65 \pm 0.11$ & 3.71 & $-1.6 \%$ & $2.9 \%$ & $2.57 \pm 0.10$ & 2.54 & $+1.2 \%$ & $4.0 \%$ \\
\hline${ }^{169} \mathrm{Tm}$ & 0.33 & $0.51 \pm 0.02$ & 0.54 & $-5.3 \%$ & $3.6 \%$ & $0.329 \pm 0.01$ & 0.33 & $-0.2 \%$ & $4.0 \%$ \\
\hline${ }^{172} \mathrm{Yb}$ & 1.98 & $3.29 \pm 0.09$ & 3.34 & $-1.5 \%$ & $2.9 \%$ & $1.98 \pm 0.08$ & 2.0 & $-1.2 \%$ & $4.2 \%$ \\
\hline${ }^{175} \mathrm{Lu}$ & 0.279 & $0.50 \pm 0.02$ & 0.499 & $-0.7 \%$ & $3.1 \%$ & $0.280 \pm 0.01$ & 0.274 & $+2.1 \%$ & $4.1 \%$ \\
\hline${ }^{178} \mathrm{Hf}$ & 4.51 & $4.94 \pm 0.21$ & 4.97 & $-0.6 \%$ & $4.2 \%$ & $4.52 \pm 0.21$ & 4.36 & $+3.6 \%$ & $4.7 \%$ \\
\hline${ }^{181} \mathrm{Ta}$ & 1.21 & $0.79 \pm 0.04$ & 0.81 & $-2.1 \%$ & $4.2 \%$ & $1.21 \pm 0.05$ & 1.14 & $+5.7 \%$ & $4.3 \%$ \\
\hline${ }^{205} \mathrm{Tl}$ & 0.044 & $0.28 \pm 0.02$ & 0.3 & $-8.0 \%$ & $6.9 \%$ & $0.021 \pm 0.002$ & - & - & $9.3 \%$ \\
\hline${ }^{208} \mathrm{~Pb}$ & 2.40 & $11.1 \pm 1.1$ & 11 & $+1.0 \%$ & $10.2 \%$ & $1.72 \pm 0.26$ & 1.6 & $+7.7 \%$ & $15.4 \%$ \\
\hline${ }^{232} \mathrm{Th}$ & 1.23 & $5.89 \pm 0.26$ & 5.90 & $-0.1 \%$ & $4.4 \%$ & $1.22 \pm 0.06$ & 1.22 & $+0.4 \%$ & $4.7 \%$ \\
\hline${ }^{238} \mathrm{U}$ & 0.409 & $1.61 \pm 0.07$ & 1.69 & $-4.6 \%$ & $4.4 \%$ & $0.408 \pm 0.02$ & 0.403 & $+1.1 \%$ & $4.3 \%$ \\
\hline
\end{tabular}

BHVO-1 values are those used for standard-sample bracketing and calculation of concentration data for BCR-2, BHVO-2 and unknowns. Preferred values vary from Georem recommended values when in italics. Rare earth element and $\mathrm{Hf}$ values were determined by isotope dilution MC-ICP-MS (Baker et al., 2002). Compilations for some elements in the BCR-2 data set suffer from a lack of data, biasing the Georem recommended numbers so in such cases the better constrained BCR-1 values were use for these elements.

Internal precision (2 SE) of ${ }^{176} \mathrm{Hf} /{ }^{177} \mathrm{Hf}$ measurements was $< \pm 0.000007$, with comparable external reproducibility of $< \pm 0.000010$ (2 SD for BHVO-2; $\mathrm{n}=3$ ). ${ }^{176} \mathrm{Hf} /{ }^{177} \mathrm{Hf}$ ratios are reported relative to a value of 0.282160 for JMC475. $\mathrm{Pb}$ 
isotope ratios were corrected for instrumental mass bias by sample-standard bracketing relative to analyses of SRM $981\left({ }^{206} \mathrm{~Pb} /{ }^{204} \mathrm{~Pb}=16.9416 ;{ }^{207} \mathrm{~Pb} /{ }^{204} \mathrm{~Pb}=\right.$ $15.5000 ;{ }^{208} \mathrm{~Pb} /{ }^{204} \mathrm{~Pb}=36.7262$; Baker et al., 2004). Internal precisions (2 SE) of ${ }^{206} \mathrm{~Pb} /{ }^{204} \mathrm{~Pb},{ }^{207} \mathrm{~Pb} /{ }^{204} \mathrm{~Pb}$ and ${ }^{208} \mathrm{~Pb} /{ }^{204} \mathrm{~Pb}$ were $< \pm 0.0005, \pm 0.0004$ and \pm 0.0013 , respectively. External reproducibility estimated from replicate digestions and analyses of JB-2 is ${ }^{206} \mathrm{~Pb} /{ }^{204} \mathrm{~Pb}= \pm 0.0030,{ }^{207} \mathrm{~Pb} /{ }^{204} \mathrm{~Pb}= \pm 0.0035$ and ${ }^{208} \mathrm{~Pb} /{ }^{204} \mathrm{~Pb}= \pm$ $0.0102(2 \mathrm{SD} ; \mathrm{n}=9$ ), corresponding to errors of 162, 223 and $266 \mathrm{ppm}$, respectively.

Oxygen was extracted from minerals for isotope analysis by laser fluorination (Sharp, 1990) with a $10.3 \mu \mathrm{m} \mathrm{CO}_{2}$-laser and $\mathrm{BrF}_{5}$ oxidation at Geological and Nuclear Sciences, Lower Hutt, New Zealand. Samples were evacuated for ca. 24 hours and left overnight in a vapour of $\mathrm{BrF}_{5}$. Blank $\mathrm{BrF}_{5}$ runs were done until the oxygen yield was $<0.1 \mu \mathrm{mol}$. Oxygen extracted from the samples was passed through a fluorine-getter before it was converted to $\mathrm{CO}_{2}$ by a graphite furnace, yields were recorded, and the gas was analysed on a Geo20-20 mass spectrometer. Samples were normalised to the garnet standard UWG-2 using a value of 5.8\%o (Valley et al., 1995). Values for four UWG-2 standards analysed with the samples yielded $\delta^{18} \mathrm{O}$ values that varied by $<0.1 \%$.

\subsection{PETROGRAPHY \& MINERAL CHEMISTRY}

\subsubsection{Petrography}

The volcanic rocks of the Lookout Formation have been subdivided into seven lithotypes on the basis of their petrographic variation (Figure 4.3a-h). While the samples are mostly basaltic in composition the defined lithotypes are related to the dominant mineral assemblage and proportion and size of phenocrysts. The four main rock types (Type I-IV) comprise $95 \%$ of the collected samples (14, 30, 38 and 11\%, respectively) and form a continuum between phenocryst-rich and phenocryst-poor rocks. Each rock type has the following features: (1) Type I: 
highly porphyritic basalts containing $>40 \%$ large $(6-13 \mathrm{~mm})$ olivine + clinopyroxene phenocrysts; (2) Type II: moderately porphyritic basalts (16-39\% phenocrysts) dominated by clinopyroxene \pm olivine \pm plagioclase; (3) Type III: poorly porphyritic basalts containing 5-15\% clinopyroxene + plagioclase phenocrysts; (4) Type IV: sparsely porphyritic to almost aphyric basalts and trachybasalts with $<5 \%$ clinopyroxene + plagioclase phenocrysts; (5) Type V: moderately porphyritic trachybasalts and basaltic trachyandesites that are dominated by plagioclase (> 15\%) + clinopyroxene phenocrysts; (6) Type VI: highly porphyritic basalts comprising $>45 \%$ phenocrysts dominated by large honeycombed plagioclase + Cr-diopside phenocrysts; (7) Type VII: moderately porphyritic transitional basaltic trachyandesite containing ca. $20 \%$ plagioclase + clinopyroxene + orthopyroxene phenocrysts.

Olivine phenocrysts are generally unzoned, subhedral and partially altered to chlorite/serpentine and magnetite (Figure 4.3k) although rare samples contain unaltered, euhedral olivine (i.e. AMG-8). Large clinopyroxene phenocrysts can display extensive growth zonation with green diopside/augite cores being overgrown by brown diopside rims (Figure 4.31) or phenocrysts can be almost exclusively one of these types. Overgrowths vary in size considerably from $<0.5$ $\mathrm{mm}$ around well preserved euhedral cores to $\leq 2.5 \mathrm{~mm}$ around strongly resorbed cores. Plagioclase is minor phase comprising just 1-5\% in the majority of samples, and occurs in increasing abundance in more evolved samples. Orthopyroxene is only present in small clusters of $0.5-1.0 \mathrm{~mm}$ crystals in AMG-10 (Figure 4.3h). Fe-Ti oxides, and especially, ilmenite are a common accessory mineral in the more evolved samples $(\mathrm{MgO}<6 \mathrm{wt} \%)$. Chromian spinels are present in olivinebearing samples as inclusions or phenocrysts up to $1 \mathrm{~mm}$ in size. Groundmass textures are cryptocrystalline with the thicker highly porphyritic flows being characterised by coarser-grained groundmasses relative to the almost aphyric samples (Figure 4.3i-j). Where identifiable the groundmass mineralogy invariably includes plagioclase + clinopyroxene + Fe-Ti oxides + altered olivine. 


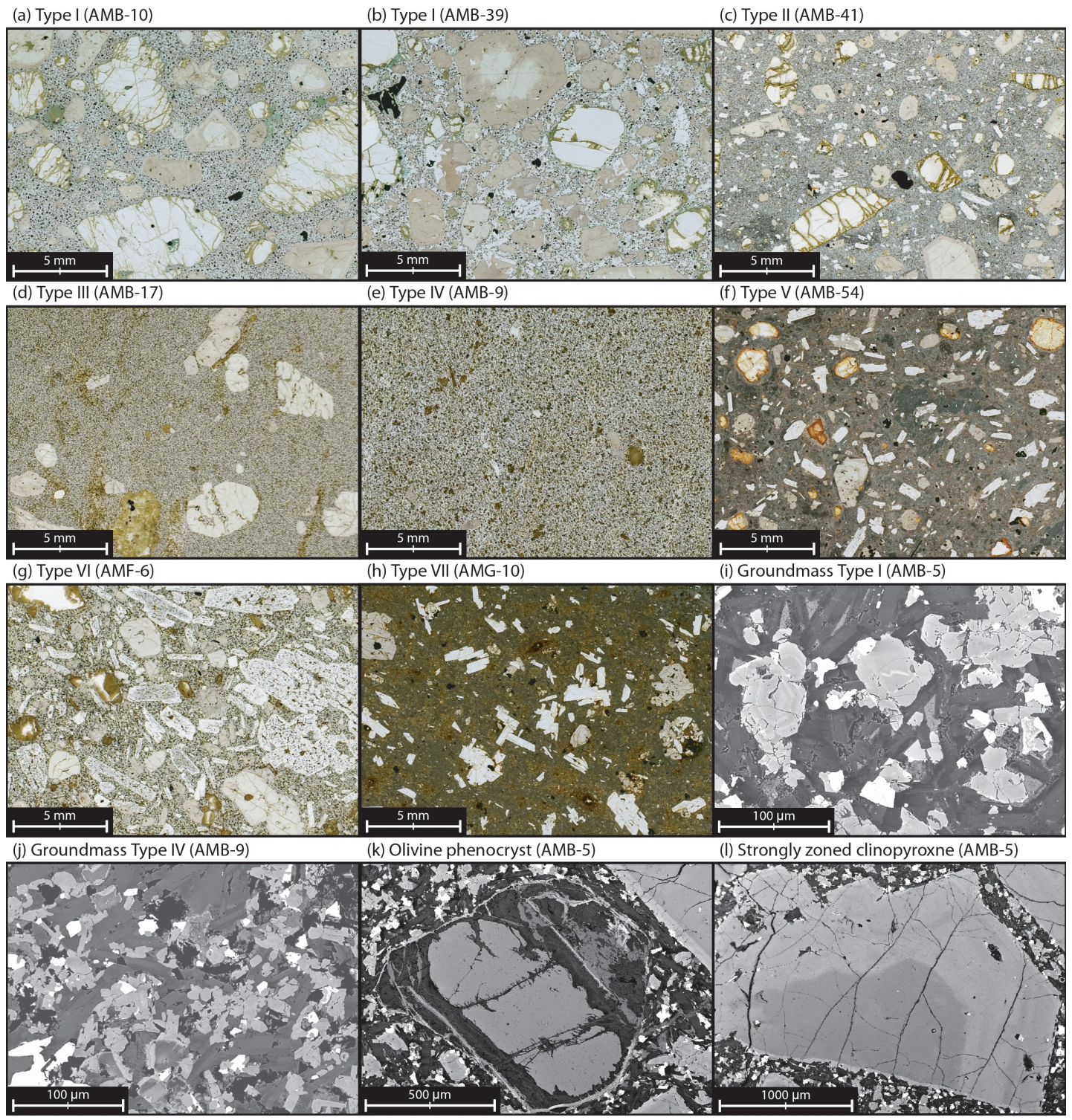

Figure 4.3: (a-h) Plane light photographs of $100 \mu \mathrm{m}$ thick polished thin sections: (a-b) highly porphyritic ol + cpx phyric basalts. Note the large strongly zoned cpx phenocryst in b; (c) moderately porphyritic ol + cpx phyric basalt; (d) poorly porphyritic cpx phyric basalt; (e) sparsely porphyritic basalt; (f) moderately porphyritic $\mathrm{cpx}+$ plag phyric basaltic trachyandesite with relict olivine phenocrysts; (g) highly porphyritic honeycombed plag + cpx basalt; (h) moderately porphyritic cpx + plag + opx phyric rock, (note opx occurs in clusters of small crystals right side of the photograph). (i-l) back scattered electron images: (i-j) comparison of the groundmass in highly porphyritic and almost aphyric rocks; (k) subhedral olivine phenocryst from AMB-5 (Type I) contains a fresh unzoned core surrounded by a rim that has been altered to chlorite/serpentine; (1) fragment of a large strongly zoned clinopyroxene phenocryst from AMB-5 with a core that appears slightly rounded suggesting minor resorption prior to the crystallisation of the euhedral rim.

\subsubsection{Mineral chemistry}

\section{Olivine major and minor element chemistry}

Olivine phenocrysts from 12 Type I and II lava flows were analysed. All samples

display similar compositional trends $\left(\mathrm{Fo}_{74-88} ; \mathrm{SiO}_{2}=37.5-41.0\right.$ wt $\% ; \mathrm{CaO}=0.21-$ 
$0.26 \mathrm{wt} \% ; \mathrm{NiO}=0.14-0.32 \mathrm{wt} \% ; \mathrm{MnO}=0.21-0.26 \mathrm{wt} \%$ ). Figure 4.4 shows the relationships between $\mathrm{NiO}$ and $\mathrm{CaO}$ and the forsterite content of olivine phenocrysts from the Lookout Volcanics, compared with data for olivines from basalts from a range of eruptive settings. Olivines in the Lookout Volcanics display slightly lower $\mathrm{NiO}$ contents than phenocrysts from Hawaiian OIB and a Yemeni continental flood basalt (CFB), but significantly higher concentrations than olivine from mid ocean ridge basalts (MORB) and the Waimarino basalt

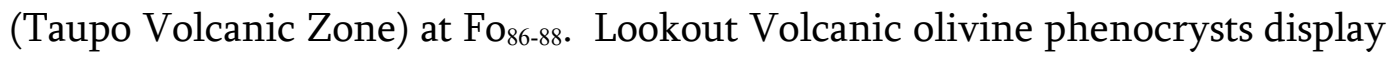
higher $\mathrm{CaO}$ contents than olivine from basaltic samples from any other tectonic setting analysed.

\section{Clinopyroxene major and trace element chemistry}

Clinopyroxene phenocrysts from 24 samples were analysed and display significant compositional variability $\left(\mathrm{Mg} \#=62-89 ; \mathrm{SiO}_{2}=44.6-54.8\right.$ wt \%; $\mathrm{Al}_{2} \mathrm{O}_{3}=$ 1.15-7.73 wt \%; $\mathrm{TiO}_{2}=0.45-4.65$ wt $\% ; \mathrm{Cr}_{2} \mathrm{O}_{3}=0-1.67$ wt $\% ; \mathrm{Na}_{2} \mathrm{O}=0.20-0.63$ wt \%). High Mg-number $(\mathrm{Mg \#}=85-89)$ clinopyroxenes are $\mathrm{Cr}$-Si-rich and $\mathrm{Al}-\mathrm{Ti}$ poor diopside/augites, and with decreasing Mg-number most crystals display negative $\mathrm{Cr}-\mathrm{Si}$ and positive $\mathrm{Al}-\mathrm{Ti}$ and $\mathrm{Na}$ trends (Figure 4.5).
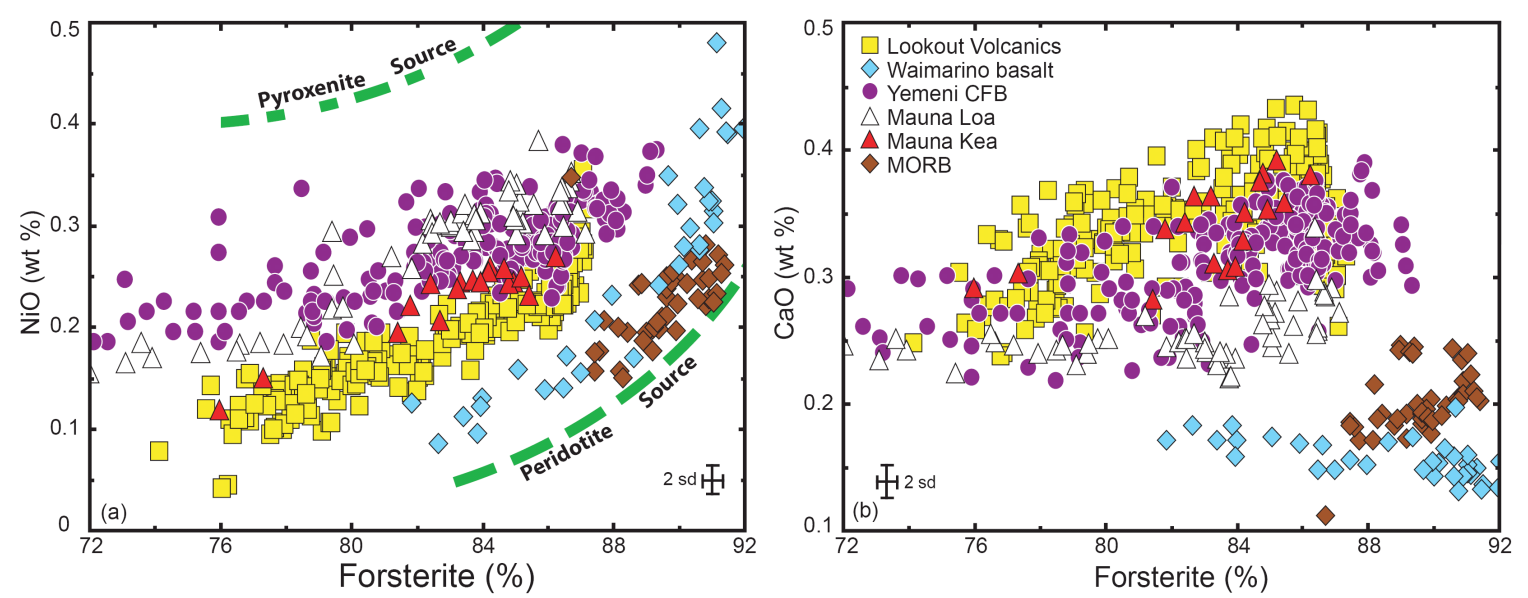

Figure 4.4: High precision $\mathrm{NiO}$ and $\mathrm{CaO}$ analyses of olivine phenocrysts from various tectonic settings and the Lookout Volcanics plotted against their forsterite content. MORB data is taken from Sobolev et al. (2007). Dotted lines on the Fo-Ni plot represent the hypothetical NiO concentrations of olivine phenocrysts that would crystallise from melts of dominantly peridotite and pyroxenite mantle sources. 
However, this is not the only trend observed with the high-Si rocks (e.g. AMB54, AMG-10) containing clinopyroxene with consistently high-Si, but low Cr-AlTi. Strongly zoned clinopyroxene phenocrysts in Type I samples contain two distinct end-members: (1) green Cr diopside/augite cores with up to $1.6 \mathrm{wt} \%$ $\mathrm{Cr}_{2} \mathrm{O}_{3},<1$ wt $\% \mathrm{TiO}_{2}$ and $\mathrm{Mg} \#=85-89$; (2) brown Ti-rich diopside rims with up to 3 wt $\% \mathrm{TiO}_{2},<0.5$ wt $\% \mathrm{Cr}_{2} \mathrm{O}_{3}$ and $\mathrm{Mg} \#=79-84$.

Trace element data were measured in clinopyroxene phenocrysts from 7 samples (101 analyses), and are presented in Table 4.2. Analysis sites were positioned to best assess changes in trace element composition across compositional zones, with mapping revealing strong correlations between the minor and trace element concentrations of zones. Fluctuations in trace element abundances record changes during growth zoning, for example $\mathrm{Zr}$ concentrations progressively increase from the core to rim of cpx-M in AMB-52 (22, 46, 62, 83, $81 \mathrm{ppm}$; Table 4.2; Figure 4.5g). Variations in very incompatible trace element (VICE) and moderately incompatible trace element (MICE) abundances mimic variations in the $\mathrm{TiO}_{2}$ and $\mathrm{Al}_{2} \mathrm{O}_{3}$. Phenocrysts from primitive samples were separated into 3 groups on the basis of Ti content: (1) low- $\mathrm{Ti}(\mathrm{Ti}=<5500 \mathrm{ppm} ; \mathrm{n}$ = 13); (2) high- $\mathrm{Ti}(\mathrm{Ti}=12000-16000$ ppm; $\mathrm{n}=15) ;(3) \max -\mathrm{Ti}(\mathrm{Ti}=19200$ ppm; $\mathrm{n}$ =1). Increases in Ti content strongly correlate with increasing VICE and MICE clinopyroxene abundances (Figure 4.5e-f). When comparing two elements of similar concentration and incompatibility the effect of increasing the Ti content is more pronounced on high field strength elements (HFSE; e.g. Hf) than REE (e.g. Dy; Figure 4.5c-d). On primitive-mantle-normalised-multielement plots with increasing $\mathrm{Ti}$ content the $\mathrm{Pb}$ concentration of clinopyroxene from primitive samples remains constant, however, a strongly negative Sr anomaly develops (Figure 4.5f). As is the case for major elements the phenocrysts in AMG-10 differ significantly in their trace element compositions from the majority of samples. The concentration of incompatible trace elements including $\mathrm{Pb}$ in the low- $\mathrm{Ti}$ phenocrysts in AMG-10 $(\mathrm{Ti}=<5500 \mathrm{ppm} ; \mathrm{n}=10)$ is almost an order of magnitude higher than the low-Ti crystals in primitive samples (Figure $4.5 \mathrm{~h}$ ). 

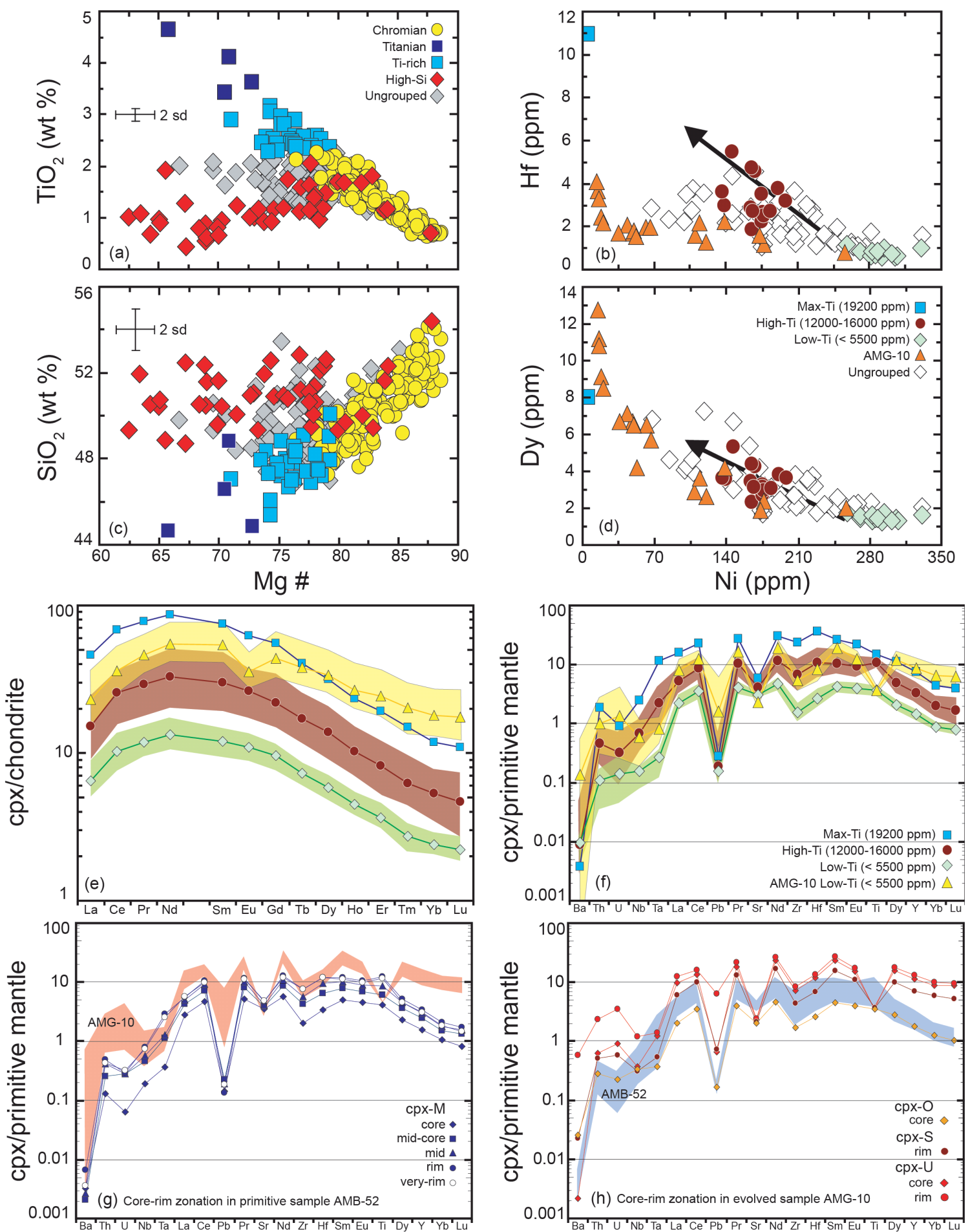

Figure 4.5: (a-h) Major and trace element variations of clinopyroxene phenocrysts within the Lookout Volcanics. (a, c) $\mathrm{TiO}_{2}$ and $\mathrm{SiO}_{2}$ plotted against Mg\# (Mg-number $=100^{*}(\mathrm{Mg} /(\mathrm{Mg}+\mathrm{Fe}))$. Clinopyroxenes were grouped as follows; Chromian: $\mathrm{Cr}^{3+}>0.01$; Titanian: $\mathrm{Ti}^{4+}>0.10$; Ti-rich: $\mathrm{Ti}^{4+}$ $>0.065$; Hi-Si: phenocrysts from the two rocks with the highest $\mathrm{SiO}_{2}$ contents in the Lookout Volcanics (AMB-54, AMG-10); ungrouped: do not qualify for any of the above groups. (b, d) Hf and Dy plotted against Ni. Analyses from primitive samples $\left({ }^{87} \mathrm{Sr} /{ }^{86} \mathrm{Sr}_{\mathrm{i}}<0.7031\right)$ were divided into groups based on phenocryst Ti content: low-Ti (< 5500 ppm; $\mathrm{n}=13)$; high-Ti (12000 -16000 ppm; $\mathrm{n}=15)$; $\max -\mathrm{Ti}(19200 \mathrm{ppm} ; \mathrm{n}=1)$. Phenocrysts from AMG-10 are plotted separately $(\mathrm{n}=19)$; samples classified as ungrouped do not qualify for any of the above groups $(n=52)$. Arrows represent the effect of increasing Ti content on incompatible trace element concentration. (e-f) rare earth element chondrite-normalised (Sun \& McDonough , 1989) and multielement primitivemantle-normalised plots (McDonough \& Sun, 1995), respectively. 
Figure 4.5 (continued): Groups are the same as (d) except only low-Ti samples from AMG-10 (< $5500 \mathrm{ppm} ; \mathrm{n}=10)$ are plotted. ( $\mathrm{g}-\mathrm{h})$ multielement plots showing the variation of trace elements within single clinopyroxene phenocrysts within AMB-52 (cpx-M) and AMG-10 (cpx-O, S \& U). Ti-contents were not measured in cpx-U from AMG-10 but are assumed low-Ti (ca. 4800 ppm) on the basis of EPMA data.

Table 4.2: Representative LA-ICP-MS analyses of clinopyroxene phenocrysts.

\begin{tabular}{|c|c|c|c|c|c|c|c|c|c|}
\hline Sample & AMB-10 & AMB-10 & AMB-52 & AMB-52 & AMB-52 & AMB-52 & AMB-52 & AMB-54 & AMB-54 \\
\hline Crystal & G & G & M & M & M & M & M & $\mathrm{H}$ & $\mathrm{H}$ \\
\hline Zone & core & rim & core & $\mathrm{m}$-core & mid & m-rim & rim & core & rim \\
\hline $\mathrm{CaO}$ & 22.59 & 22.59 & 22.10 & 22.10 & 22.26 & 22.41 & 22.41 & 21.68 & 21.68 \\
\hline Sc & 63.2 & 77.5 & 64.3 & 67.4 & 76.0 & 70.3 & 76.0 & 66.4 & 74.2 \\
\hline $\mathrm{Ti}$ & 3899 & 4363 & 5252 & 7835 & 10980 & 15634 & 14520 & 7430 & 7007 \\
\hline V & 130 & 150 & 201 & 256 & 300 & 360 & 342 & 341 & 393 \\
\hline $\mathrm{Cr}$ & 6051 & 2971 & 6810 & 4766 & 2380 & 91.1 & 1990 & 1228 & 485 \\
\hline $\mathrm{Mn}$ & 664 & 712 & 830 & 968 & 985 & 1035 & 925 & 1562 & 1975 \\
\hline Co & 35.2 & 37.4 & 42.2 & 42.6 & 43.0 & 45.8 & 44.1 & 46.1 & 52.5 \\
\hline $\mathrm{Ni}$ & 307 & 271 & 331 & 249 & 178 & 136 & 175 & 162 & 119 \\
\hline $\mathrm{Cu}$ & 2.71 & 1.26 & 0.744 & 0.908 & 0.978 & 1.65 & 2.64 & 0.756 & 0.869 \\
\hline $\mathrm{Zn}$ & 17.9 & 18.4 & 24.1 & 30.7 & 32.0 & 33.5 & 30.7 & 49.9 & 65.5 \\
\hline $\mathrm{Ga}$ & 4.16 & 4.35 & 7.39 & 10.5 & 12.3 & 16.6 & 15.3 & 10.9 & 11.8 \\
\hline $\mathrm{Rb}$ & $\mathrm{b} / \mathrm{d}$ & $\mathrm{b} / \mathrm{d}$ & $\mathrm{b} / \mathrm{d}$ & 0.001 & 0.005 & 0.008 & $\mathrm{~b} / \mathrm{d}$ & $\mathrm{b} / \mathrm{d}$ & 0.004 \\
\hline $\mathrm{Sr}$ & 63.6 & 61.9 & 70.8 & 78.5 & 82.2 & 94.6 & 97.0 & 73.7 & 72.0 \\
\hline Y & 5.57 & 6.75 & 6.78 & 10.8 & 12.8 & 14.7 & 13.4 & 22.4 & 30.9 \\
\hline $\mathrm{Zr}$ & 13.1 & 16.0 & 21.8 & 45.5 & 61.8 & 83.1 & 80.7 & 62.7 & 79.7 \\
\hline $\mathrm{Nb}$ & 0.047 & 0.063 & 0.112 & 0.269 & 0.340 & 0.461 & 0.432 & 0.275 & 0.272 \\
\hline Mo & 0.048 & 0.042 & 0.014 & 0.023 & 0.025 & 0.020 & 0.020 & 0.059 & 0.099 \\
\hline Cs & $\mathrm{b} / \mathrm{d}$ & $\mathrm{b} / \mathrm{d}$ & $\mathrm{b} / \mathrm{d}$ & $\mathrm{b} / \mathrm{d}$ & $\mathrm{b} / \mathrm{d}$ & 0.002 & $\mathrm{~b} / \mathrm{d}$ & $\mathrm{b} / \mathrm{d}$ & $\mathrm{b} / \mathrm{d}$ \\
\hline $\mathrm{Ba}$ & 0.027 & 0.059 & 0.023 & 0.014 & 0.018 & 0.046 & 0.024 & $\mathrm{~b} / \mathrm{d}$ & 0.023 \\
\hline $\mathrm{La}$ & 1.32 & 1.39 & 1.91 & 2.89 & 3.44 & 3.83 & 3.84 & 4.79 & 6.32 \\
\hline $\mathrm{Ce}$ & 5.01 & 5.30 & 8.34 & 12.8 & 16.2 & 18.4 & 17.7 & 22.1 & 29.5 \\
\hline $\operatorname{Pr}$ & 0.94 & 1.06 & 1.41 & 2.16 & 2.69 & 3.13 & 2.97 & 3.85 & 5.22 \\
\hline $\mathrm{Nd}$ & 5.59 & 6.09 & 7.56 & 11.5 & 14.3 & 17.0 & 15.6 & 21.2 & 28.4 \\
\hline $\mathrm{Sm}$ & 1.64 & 1.79 & 2.13 & 3.42 & 4.30 & 5.05 & 4.75 & 6.39 & 8.52 \\
\hline $\mathrm{Eu}$ & 0.565 & 0.652 & 0.736 & 1.11 & 1.46 & 1.70 & 1.59 & 1.92 & 2.46 \\
\hline Gd & 1.81 & 2.04 & 2.21 & 3.44 & 4.16 & 4.75 & 4.48 & 6.59 & 8.94 \\
\hline $\mathrm{Tb}$ & 0.239 & 0.289 & 0.307 & 0.475 & 0.597 & 0.669 & 0.607 & 0.910 & 1.26 \\
\hline Dy & 1.30 & 1.59 & 1.62 & 2.56 & 3.17 & 3.61 & 3.23 & 5.35 & 7.28 \\
\hline Но & 0.229 & 0.264 & 0.278 & 0.428 & 0.527 & 0.590 & 0.561 & 0.888 & 1.28 \\
\hline $\mathrm{Er}$ & 0.550 & 0.662 & 0.643 & 0.991 & 1.27 & 1.35 & 1.25 & 2.25 & 3.21 \\
\hline $\mathrm{Tm}$ & 0.063 & 0.072 & 0.071 & 0.120 & 0.150 & 0.168 & 0.159 & 0.270 & 0.363 \\
\hline $\mathrm{Yb}$ & 0.358 & 0.451 & 0.485 & 0.688 & 0.815 & 0.969 & 0.841 & 1.57 & 2.24 \\
\hline $\mathrm{Lu}$ & 0.057 & 0.070 & 0.058 & 0.095 & 0.112 & 0.122 & 0.103 & 0.218 & 0.31 \\
\hline $\mathrm{Hf}$ & 0.649 & 0.769 & 1.01 & 1.96 & 2.86 & 3.60 & 3.53 & 2.72 & 3.54 \\
\hline $\mathrm{Ta}$ & 0.005 & 0.008 & 0.015 & 0.045 & 0.052 & 0.114 & 0.103 & 0.051 & 0.062 \\
\hline W & 0.002 & 0.002 & 0.001 & $\mathrm{~b} / \mathrm{d}$ & $\mathrm{b} / \mathrm{d}$ & $\mathrm{b} / \mathrm{d}$ & 0.002 & 0.001 & $\mathrm{~b} / \mathrm{d}$ \\
\hline $\mathrm{Pb}$ & 0.019 & 0.023 & 0.026 & 0.042 & 0.035 & 0.025 & 0.035 & 0.094 & 0.102 \\
\hline Th & 0.007 & 0.005 & 0.011 & 0.022 & 0.035 & 0.041 & 0.035 & 0.04 & 0.057 \\
\hline $\mathrm{U}$ & 0.002 & 0.002 & 0.001 & 0.006 & 0.006 & 0.006 & 0.007 & 0.011 & 0.016 \\
\hline
\end{tabular}

Note: $\mathrm{b} / \mathrm{d}=$ below detection limit; $\mathrm{n} / \mathrm{m}=$ not measured. 
Table 4.2 (continued): Representative LA-ICP-MS analyses of clinopyroxene phenocrysts.

\begin{tabular}{|c|c|c|c|c|c|c|c|c|c|}
\hline Sample & AMG-8 & AMG-8 & AMG-10 & AMG-10 & AMG-10 & AMG-10 & AMG-10 & AMG-10 & AMG-10 \\
\hline Crystal & I & K & I & I & $\mathrm{O}$ & S & $\mathrm{T}$ & $\mathrm{U}$ & $\mathrm{U}$ \\
\hline Zone & core & core & core & rim & core & rim & core & core & rim \\
\hline $\mathrm{CaO}$ & 21.92 & 22.14 & 22.01 & 22.01 & 20.49 & 20.49 & 20.49 & 20.49 & 20.49 \\
\hline $\mathrm{Sc}$ & 75.4 & 76.2 & 65.8 & 66.2 & 62.1 & 79.3 & 96.8 & 109 & 111 \\
\hline $\mathrm{Ti}$ & 13208 & 6827 & 7175 & 10906 & 4501 & 4748 & 4799 & $\mathrm{n} / \mathrm{m}$ & $\mathrm{n} / \mathrm{m}$ \\
\hline V & 396 & 252 & 289 & 320 & 171 & 338 & 310 & 289 & 295 \\
\hline $\mathrm{Cr}$ & 2079 & 3599 & 1394 & 1704 & 3722 & 78.6 & 14.2 & 5.56 & 3.16 \\
\hline $\mathrm{Mn}$ & 899 & 732 & 1017 & 1150 & 1007 & 2345 & 2479 & 2506 & 2606 \\
\hline Co & 39.7 & 38.5 & 44.9 & 42.4 & 41.4 & 48.4 & 43.6 & 38.4 & 39.8 \\
\hline $\mathrm{Ni}$ & 183 & 228 & 120 & 114 & 257 & 43.7 & 18.1 & 15.4 & 14.3 \\
\hline $\mathrm{Cu}$ & 1.18 & 2.18 & 1.05 & 1.13 & 0.886 & 1.20 & 1.06 & 0.599 & 2.48 \\
\hline Zn & 25.4 & 19.4 & 28.7 & 35.3 & 26.5 & 69.8 & 82.2 & 81.7 & 86.6 \\
\hline $\mathrm{Ga}$ & 11.6 & 7.09 & 7.93 & 11.6 & 4.86 & 8.44 & 8.48 & 8.26 & 8.71 \\
\hline $\mathrm{Rb}$ & 0.001 & 0.005 & 0.004 & 0.022 & 0.027 & 0.021 & 0.004 & 0.039 & 0.596 \\
\hline $\mathrm{Sr}$ & 71.5 & 60.2 & 62.6 & 71.2 & 41.7 & 43.8 & 42.0 & 47.1 & 49.8 \\
\hline Y & 12.3 & 6.79 & 10.0 & 13.8 & 7.89 & 31.4 & 37.6 & 50.2 & 57.6 \\
\hline $\mathrm{Zr}$ & 62.4 & 25.2 & 29.1 & 55.8 & 18.4 & 48.1 & 58.7 & 78.4 & 92.7 \\
\hline $\mathrm{Nb}$ & 0.276 & 0.092 & 0.151 & 0.423 & 0.198 & 0.188 & 0.212 & 0.221 & 0.714 \\
\hline Mo & 0.030 & 0.036 & 0.025 & 0.045 & 0.052 & 0.103 & 0.114 & 0.088 & 0.119 \\
\hline Cs & 0.001 & $\mathrm{~b} / \mathrm{d}$ & 0.001 & 0.008 & 0.001 & 0.004 & $\mathrm{~b} / \mathrm{d}$ & 0.005 & 0.164 \\
\hline $\mathrm{Ba}$ & 0.029 & 0.022 & 0.035 & 0.290 & 0.175 & 0.156 & 0.025 & 0.015 & 3.97 \\
\hline $\mathrm{La}$ & 2.99 & 1.71 & 2.19 & 3.71 & 1.42 & 4.16 & 5.47 & 6.72 & 8.63 \\
\hline $\mathrm{Ce}$ & 13.1 & 7.33 & 10.1 & 16.1 & 6.29 & 18.2 & 24.3 & 24.4 & 28.6 \\
\hline $\operatorname{Pr}$ & 2.23 & 1.31 & 1.73 & 2.68 & 1.09 & 3.62 & 4.44 & 5.02 & 5.93 \\
\hline $\mathrm{Nd}$ & 12.7 & 7.04 & 9.30 & 14.1 & 6.12 & 22.4 & 26.2 & 31.0 & 35.6 \\
\hline Sm & 3.78 & 2.06 & 2.78 & 4.10 & 1.98 & 6.75 & 8.38 & 10.2 & 11.8 \\
\hline $\mathrm{Eu}$ & 1.25 & 0.707 & 0.938 & 1.36 & 0.656 & 1.81 & 2.04 & 2.49 & 2.83 \\
\hline Gd & 3.59 & 2.17 & 2.79 & 4.04 & 2.04 & 7.22 & 8.96 & 11.7 & 13.4 \\
\hline $\mathrm{Tb}$ & 0.534 & 0.317 & 0.446 & 0.604 & 0.325 & 1.15 & 1.46 & 1.90 & 2.14 \\
\hline Dy & 3.06 & 1.72 & 2.65 & 3.63 & 2.00 & 7.14 & 9.11 & 11.2 & 12.8 \\
\hline Ho & 0.514 & 0.289 & 0.436 & 0.592 & 0.320 & 1.18 & 1.59 & 2.00 & 2.33 \\
\hline Er & 1.17 & 0.64 & 1.10 & 1.50 & 0.82 & 3.41 & 4.31 & 5.39 & 6.00 \\
\hline $\mathrm{Tm}$ & 0.135 & 0.078 & 0.129 & 0.181 & 0.097 & 0.420 & 0.516 & 0.689 & 0.771 \\
\hline $\mathrm{Yb}$ & 0.786 & 0.437 & 0.748 & 1.129 & 0.594 & 2.77 & 3.061 & 4.12 & 4.64 \\
\hline $\mathrm{Lu}$ & 0.107 & 0.054 & 0.099 & 0.142 & 0.075 & 0.376 & 0.449 & 0.628 & 0.680 \\
\hline $\mathrm{Hf}$ & 2.72 & 1.13 & 1.27 & 2.20 & 0.786 & 2.08 & 2.44 & 3.64 & 4.09 \\
\hline Ta & 0.059 & 0.018 & 0.025 & 0.070 & 0.015 & 0.022 & 0.029 & 0.050 & 0.056 \\
\hline W & 0.004 & & 0.003 & 0.010 & 0.004 & 0.012 & 0.001 & 0.014 & 0.204 \\
\hline $\mathrm{Pb}$ & 0.033 & 0.021 & 0.044 & 0.139 & 0.031 & 0.137 & 0.122 & 0.124 & 1.20 \\
\hline Th & 0.025 & 0.008 & 0.021 & 0.060 & 0.024 & 0.043 & 0.047 & 0.053 & 0.198 \\
\hline U & 0.005 & 0.003 & 0.004 & 0.018 & 0.005 & 0.013 & 0.009 & 0.020 & 0.077 \\
\hline
\end{tabular}

On a chondrite-normalised-REE plot the low-Ti samples from AMG-10 display a negative Eu anomaly $\left(\mathrm{Eu}^{*} / \mathrm{Eu}=0.74\right.$; Figure $\left.4.5 \mathrm{e}\right)$. Some phenocrysts within AMG-10 also show dramatic increases in the Pb and VICE (i.e. Ba, U, Th) abundances over their cores at constant Ti (e.g. cpx-U; Figure 4.5h). 


\subsection{WHOLE ROCK MAJOR \& TRACE ELEMENT CHEMISTRY}

\subsubsection{Chemical classification}

Representative major and trace element analyses of Lookout Volcanic samples are presented in Table 4.3. Apart from two samples (AMB-54 \& AMG-10; basaltic trachyandesite) all of the samples have $\mathrm{SiO}_{2}<52 \mathrm{wt} \%$ and can be classified as basalt (44), picrobasalt (3), basanite (1) and trachybasalt (3) (Le Bas et al., 1986) (Figure 4.6). All samples are nepheline normative (i.e. alkaline), except the basaltic trachyandesites which are hypersthene normative (i.e. sub-alkaline) (Le Bas \& Streckeisen, 1991). The more evolved compositions of the suite are K-rich and assigned the sub-root names potassic-trachybasalt and shoshonite, respectively. The samples have been divided into two subsets on the basis of petrography and chemistry. Samples have been classed cumulative if $\mathrm{MgO}>8 \mathrm{wt}$ $\%$ and these samples contain $>15 \%$ large olivine + clinopyroxene phenocrysts.

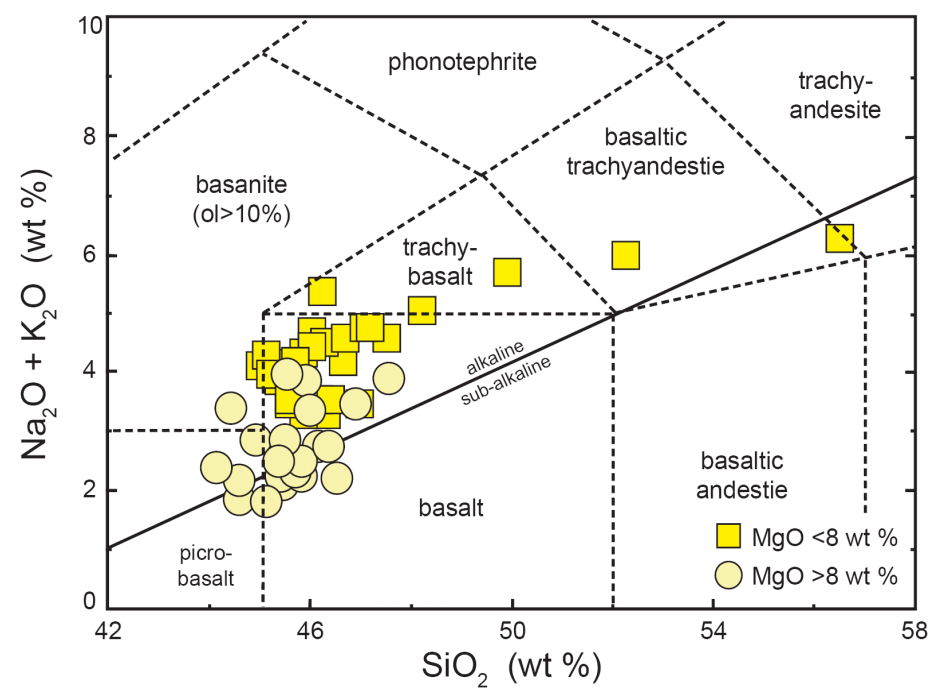

Figure 4.6: Total alkalis silica classification diagram showing the rock types of the Lookout Volcanics. Samples have been divided into cumulates with $>8 \mathrm{wt} \%$ $\mathrm{MgO}$ and rocks with $<8 \mathrm{wt} \%$ $\mathrm{MgO}$. Rock type fields are after Le Bas et al. (1986); the alkaline-subalkaline line is from MacDonald (1968).

\subsubsection{Major element chemistry}

$\mathrm{MgO}$ contents vary from 2.1 to $18.4 \mathrm{wt} \%$, although all but two samples have $>4$ wt $\% \mathrm{MgO}$. Plots of $\mathrm{MgO}$ versus other major elements show the following trends 
with decreasing $\mathrm{MgO}$ (Figure 4.7): (1) increasing $\mathrm{Al}_{2} \mathrm{O}_{3}$ and $\mathrm{Na}_{2} \mathrm{O}$ in all samples; (2) slowly increasing $\mathrm{SiO}_{2}$ until $\mathrm{MgO}$ ca. 5.5 wt \% (3) increasing $\mathrm{P}_{2} \mathrm{O}_{5}$ in all samples except those with $\mathrm{MgO}<3$ wt \%; (4) increasing $\mathrm{TiO}_{2}$ and $\mathrm{Fe}_{2} \mathrm{O}_{3}$ in all samples until $\mathrm{MgO}$ ca. 6.5 wt \% when some samples exhibit marked decreases, especially at low $\mathrm{MgO}$ contents; (5) increasing $\mathrm{K}_{2} \mathrm{O}$ in all samples except rare plagioclase (i.e. anorthite) cumulative samples (e.g. AMF-6); (6) increasing or constant $\mathrm{CaO}$ until $\mathrm{MgO}$ ca. 13 wt \% then decreasing $\mathrm{CaO}$ with marked decreases at low $\mathrm{MgO}$ contents. Another feature highlighted by Figure 4.7 is the inflection of the data array at $\mathrm{MgO}$ ca. $13 \mathrm{wt} \%$. Geochemically, the lava flows are indistinguishable from those of the regional radial dyke swarm (Figure 4.7; Nicol, 1977).

\subsubsection{Trace element chemistry}

\section{Bivariate $\mathrm{MgO}$-trace element diagrams}

Plots of trace element data versus $\mathrm{MgO}$ display the following trends with decreasing $\mathrm{MgO}$ (Figure 4.8): (1) decreasing Ni and Cr abundances. (2) increasing Sc and $\mathrm{V}$ until $\mathrm{MgO}$ ca. 13 wt \% and ca. 8 wt \%, respectively then decreasing concentrations; (3) increasing Sr until $\mathrm{MgO}$ ca. $4 \mathrm{wt} \%$ and then decreasing $\mathrm{Sr}$ at lower $\mathrm{MgO}$ contents; (4) increasing $\mathrm{Ba}, \mathrm{Rb}$ and $\mathrm{Pb}$.

\section{$\underline{\text { Multielement diagrams }}$}

Rare earth element patterns are strongly light REE (LREE) enriched relative to chondrites ( $\mathrm{La}=90-330 \mathrm{x}$ chondrite). The majority of samples are marked by a continuous slope throughout the REE pattern. However, the most evolved samples (e.g. AMG-10) exhibit significant flattening of the REE pattern from the MREE through to the HREE. High-MgO samples exhibit no Eu anomalies $\left(\mathrm{Eu} / \mathrm{Eu}^{*}=0.99-1.02\right.$; Figure 4.9a), but some low-MgO samples exhibit marked negative or positive anomalies $\left(\mathrm{Eu} / \mathrm{Eu}^{*}\right.$ : $\mathrm{AMG}-10=0.89$; $\left.\mathrm{AMF}-6=1.09\right)$. An important feature of the REE data is that the patterns for some samples cross reflecting small variations in LREE/HREE ratios which are difficult to explain by fractional crystallisation of the phenocryst assemblage observed in these rocks. 
Table 4.3: Representative major (wt \%) and trace element (ppm) analyses of lava flows from the Lookout Volcanics.

\begin{tabular}{|c|c|c|c|c|c|c|c|c|c|c|c|c|c|c|c|c|}
\hline $\begin{array}{l}\text { Sample: } \\
\text { Rock type: }\end{array}$ & $\begin{array}{l}\text { AMB-9 } \\
\text { bas }\end{array}$ & $\begin{array}{l}\text { AMB-10 } \\
\text { pbas }\end{array}$ & $\begin{array}{l}\text { AMB-26 } \\
\text { bas }\end{array}$ & $\begin{array}{l}\text { AMB-37 } \\
\text { tbas }\end{array}$ & $\begin{array}{l}\text { AMB- } 41 \\
\text { bas }\end{array}$ & $\begin{array}{c}\text { AMB- } 48 \\
\text { bas }\end{array}$ & $\begin{array}{c}\text { AMB-52 } \\
\text { pbas }\end{array}$ & $\begin{array}{c}\text { AMB-53 } \\
\text { tbas }\end{array}$ & $\begin{array}{l}\text { AMB-54 } \\
\text { shos }\end{array}$ & $\begin{array}{l}\text { AMC-5 } \\
\text { bas }\end{array}$ & $\begin{array}{c}\text { AMC-9 } \\
\text { bas }\end{array}$ & $\begin{array}{c}\text { AMF-6 } \\
\text { bas }\end{array}$ & $\begin{array}{c}\text { AMG-3 } \\
\text { bas }\end{array}$ & $\begin{array}{c}\text { AMG-8 } \\
\text { bas }\end{array}$ & $\begin{array}{c}\text { AMG-10 } \\
\text { shos }\end{array}$ & $\begin{array}{l}\text { TL-1 } \\
\text { pbas }\end{array}$ \\
\hline \multicolumn{17}{|c|}{ Major element analyses (XRF) } \\
\hline $\mathrm{SiO}_{2}$ & 45.80 & 44.65 & 45.86 & 48.27 & 46.93 & 47.22 & 44.95 & 46.28 & 52.29 & 45.62 & 46.41 & 47.01 & 45.53 & 45.40 & 56.50 & 44.18 \\
\hline $\mathrm{TiO}_{2}$ & 4.23 & 2.37 & 3.04 & 4.49 & 3.29 & 3.77 & 3.59 & 3.62 & 2.67 & 3.78 & 3.17 & 3.48 & 3.56 & 3.12 & 2.14 & 3.23 \\
\hline $\mathrm{Al}_{2} \mathrm{O}_{3}$ & 13.32 & 7.49 & 9.64 & 15.06 & 11.89 & 13.90 & 10.74 & 15.83 & 14.47 & 12.72 & 10.50 & 15.25 & 11.31 & 9.52 & 16.07 & 9.18 \\
\hline $\mathrm{Fe}_{2} \mathrm{O}_{3}$ & 13.82 & 13.36 & 13.05 & 12.29 & 12.85 & 13.41 & 13.42 & 12.16 & 10.89 & 13.36 & 12.87 & 11.69 & 13.75 & 13.06 & 10.11 & 13.68 \\
\hline $\mathrm{MnO}$ & 0.16 & 0.18 & 0.17 & 0.14 & 0.16 & 0.19 & 0.18 & 0.25 & 0.15 & 0.17 & 0.16 & 0.14 & 0.18 & 0.17 & 0.13 & 0.17 \\
\hline $\mathrm{MgO}$ & 7.02 & 17.79 & 12.96 & 4.26 & 10.94 & 6.39 & 11.45 & 5.12 & 5.24 & 7.60 & 12.05 & 6.14 & 10.82 & 13.02 & 2.07 & 13.13 \\
\hline $\mathrm{CaO}$ & 11.28 & 12.02 & 12.40 & 9.60 & 10.02 & 9.58 & 12.26 & 10.26 & 7.67 & 12.43 & 11.59 & 12.36 & 11.34 & 12.83 & 6.13 & 13.56 \\
\hline $\mathrm{Na}_{2} \mathrm{O}$ & 2.63 & 1.21 & 1.64 & 3.28 & 2.33 & 2.93 & 1.84 & 2.81 & 3.66 & 2.19 & 1.84 & 2.58 & 1.93 & 1.62 & 3.75 & 1.52 \\
\hline $\mathrm{K}_{2} \mathrm{O}$ & 1.01 & 0.62 & 0.83 & 1.74 & 1.12 & 1.81 & 0.98 & 2.51 & 2.28 & 1.32 & 0.87 & 0.87 & 0.91 & 0.84 & 2.47 & 0.85 \\
\hline $\mathrm{P}_{2} \mathrm{O}_{5}$ & 0.72 & 0.32 & 0.41 & 0.87 & 0.47 & 0.81 & 0.59 & 1.16 & 0.68 & 0.80 & 0.53 & 0.48 & 0.68 & 0.43 & 0.62 & 0.49 \\
\hline LOI & 4.08 & 3.53 & 2.43 & 3.83 & 1.30 & 2.20 & 1.86 & 3.61 & 0.71 & 3.80 & 2.85 & 3.47 & 2.43 & 1.10 & 2.19 & 2.48 \\
\hline Orig. sum & 95.75 & 95.77 & 97.49 & 96.09 & 98.90 & 99.77 & 97.98 & 95.55 & 98.49 & 95.74 & 97.06 & 96.24 & 97.61 & 98.63 & 97.40 & 97.65 \\
\hline Mg\# & 47.5 & 70.4 & 63.9 & 38.2 & 60.3 & 45.9 & 60.3 & 42.9 & 46.2 & 50.3 & 62.5 & 48.4 & 58.4 & 64.0 & 26.7 & 63.1 \\
\hline \multicolumn{17}{|c|}{ CIPW normalisation } \\
\hline ne & 11.3 & 7.4 & 7.8 & 12.1 & 8.6 & 12.2 & 9.9 & 15.9 & - & 11.3 & 7.2 & 10.8 & 7.8 & 9.0 & - & 9.3 \\
\hline hy & - & - & - & - & - & - & - & - & 0.2 & - & - & - & - & - & 18.8 & - \\
\hline ol & 14.5 & 33.7 & 23.9 & 10.9 & 23.9 & 15.7 & 21.2 & 13.4 & 16.0 & 14.1 & 23.5 & 13.6 & 21.9 & 23.2 & - & 24.1 \\
\hline Q & - & - & - & - & - & - & - & - & - & - & - & - & - & - & 2.4 & - \\
\hline \multicolumn{17}{|c|}{ Trace element analyses (ICP-MS) } \\
\hline $\mathrm{Sc}$ & 26.9 & 33.2 & 35.7 & 18.9 & 27.6 & 20.0 & 31.1 & 13.0 & 16.8 & 25.0 & 29.7 & 24.8 & 30.8 & 38.6 & 15.2 & 37.8 \\
\hline $\mathrm{V}$ & 294 & 205 & 249 & 285 & 252 & 254 & 255 & 179 & 192 & 250 & 255 & 250 & 286 & 271 & 176 & 256 \\
\hline $\mathrm{Cr}$ & 367 & 1482 & 924 & 48.1 & 604 & 205 & 689 & 101 & 275 & 394 & 1013 & 337 & 650 & 992 & 18.8 & 961 \\
\hline Co & 52.5 & 80.5 & 62.6 & 30.6 & 58.8 & 45.1 & 58.9 & 33.4 & 36.0 & 52.9 & 57.2 & 54.6 & 60.4 & 69.6 & 25.1 & 72.5 \\
\hline $\mathrm{Ni}$ & 142 & 504 & 244 & 36.0 & 229 & 84.3 & 236 & 33.9 & 96.6 & 178 & 264 & 140 & 225 & 281 & 13.3 & 342 \\
\hline $\mathrm{Cu}$ & 54.2 & 98.0 & 81.6 & 39.6 & 56.6 & 44.6 & 90.6 & 25.5 & 17.4 & 93.7 & 87.3 & 59.0 & 74.4 & 87.1 & 25.1 & 94.8 \\
\hline $\mathrm{Zn}$ & 124 & 92 & 96 & 166 & 100 & 133 & 101 & 123 & 104 & 113 & 87 & 93 & 109 & 100 & 110 & 105 \\
\hline $\mathrm{Ga}$ & 22.7 & 12.6 & 16.3 & 25.2 & 18.6 & 25.2 & 17.9 & 23.8 & 23.5 & 21.1 & 16.3 & 21.0 & 19.4 & 17.3 & 24.7 & 16.8 \\
\hline $\mathrm{Rb}$ & 11.6 & 12.8 & 17.5 & 34.8 & 24.9 & 38.1 & 17.7 & 55.8 & 61.4 & 21.8 & 18.2 & 15.8 & 16.9 & 17.4 & 69.8 & 16.0 \\
\hline
\end{tabular}


Table 4.3 (continued): Representative major (wt \%) and trace element (ppm) analyses of lava flows from the Lookout Volcanics.

\begin{tabular}{|c|c|c|c|c|c|c|c|c|c|c|c|c|c|c|c|c|}
\hline $\begin{array}{l}\text { Sample: } \\
\text { Rock type: }\end{array}$ & $\begin{array}{l}\text { AMB-9 } \\
\text { bas }\end{array}$ & $\begin{array}{l}\text { AMB-10 } \\
\text { pbas }\end{array}$ & $\begin{array}{c}\text { AMB-26 } \\
\text { bas }\end{array}$ & $\begin{array}{c}\text { AMB-37 } \\
\text { tbas }\end{array}$ & $\begin{array}{c}\text { AMB-41 } \\
\text { bas }\end{array}$ & $\begin{array}{c}\text { AMB-48 } \\
\text { bas }\end{array}$ & $\begin{array}{c}\text { AMB-52 } \\
\text { pbas }\end{array}$ & $\begin{array}{c}\text { AMB-53 } \\
\text { tbas }\end{array}$ & $\begin{array}{c}\text { AMB-54 } \\
\text { shos }\end{array}$ & $\begin{array}{c}\text { AMC-5 } \\
\text { bas }\end{array}$ & $\begin{array}{c}\text { AMC-9 } \\
\text { bas }\end{array}$ & $\begin{array}{c}\text { AMF-6 } \\
\text { bas }\end{array}$ & $\begin{array}{c}\text { AMG-3 } \\
\text { bas }\end{array}$ & $\begin{array}{c}\text { AMG-8 } \\
\text { bas }\end{array}$ & $\begin{array}{c}\text { AMG-10 } \\
\text { shos }\end{array}$ & $\begin{array}{l}\text { TL-1 } \\
\text { pbas }\end{array}$ \\
\hline $\mathrm{Sr}$ & 798 & 419 & 413 & 830 & 487 & 786 & 722 & 2183 & 660 & 1125 & 445 & 941 & 623 & 485 & 604 & 602 \\
\hline Y & 31.7 & 16.9 & 22.5 & 33.5 & 25.1 & 36.9 & 25.0 & 38.2 & 32.2 & 29.8 & 20.8 & 21.6 & 26.2 & 23.2 & 34.9 & 22.6 \\
\hline $\mathrm{Zr}$ & 355 & 162 & 218 & 404 & 253 & 423 & 276 & 486 & 379 & 345 & 195 & 201 & 240 & 230 & 375 & 237 \\
\hline $\mathrm{Nb}$ & 69.4 & 29.2 & 38.9 & 79.7 & 45.1 & 85.7 & 54.5 & 113.9 & 63.9 & 74.4 & 36.7 & 40.8 & 49.3 & 43.9 & 56.6 & 49.0 \\
\hline Mo & 1.78 & 0.854 & 1.28 & 2.40 & 2.08 & 3.96 & 1.77 & 3.34 & 2.63 & 3.39 & 1.26 & 0.71 & 1.68 & 1.28 & 2.40 & 1.44 \\
\hline Cs & 1.03 & 0.544 & 0.595 & 0.368 & 0.522 & 0.227 & 0.845 & 1.48 & 1.34 & 2.24 & 1.08 & 0.304 & 0.509 & 0.450 & 1.60 & 0.166 \\
\hline $\mathrm{Ba}$ & 368 & 159 & 200 & 426 & 262 & 435 & 386 & 978 & 496 & 833 & 204 & 246 & 287 & 232 & 567 & 257 \\
\hline $\mathrm{La}$ & 48.2 & 20.8 & 28.0 & 55.9 & 33.6 & 60.7 & 38.7 & 79.0 & 53.4 & 52.4 & 27.4 & 29.2 & 36.1 & 30.9 & 54.8 & 34.5 \\
\hline $\mathrm{Ce}$ & 104.1 & 45.8 & 62.5 & 119.2 & 73.0 & 130.9 & 84.6 & 164.1 & 113.0 & 110.6 & 61.2 & 63.6 & 80.0 & 68.7 & 113.1 & 75.0 \\
\hline $\operatorname{Pr}$ & 13.0 & 5.89 & 8.02 & 14.7 & 9.18 & 15.9 & 10.3 & 19.7 & 13.7 & 13.6 & 7.77 & 8.04 & 10.1 & 8.69 & 13.9 & 9.34 \\
\hline $\mathrm{Nd}$ & 53.4 & 25.1 & 33.0 & 59.7 & 37.9 & 63.7 & 42.1 & 76.4 & 54.0 & 54.3 & 32.4 & 34.0 & 42.2 & 36.2 & 54.6 & 38.4 \\
\hline $\mathrm{Sm}$ & 10.77 & 5.43 & 7.23 & 11.88 & 7.75 & 12.54 & 8.61 & 14.26 & 10.57 & 10.68 & 6.77 & 7.06 & 8.89 & 7.69 & 10.58 & 7.86 \\
\hline $\mathrm{Eu}$ & 3.36 & 1.72 & 2.25 & 3.70 & 2.43 & 3.84 & 2.68 & 4.34 & 3.08 & 3.34 & 2.13 & 2.46 & 2.87 & 2.44 & 2.99 & 2.47 \\
\hline $\mathrm{Gd}$ & 9.91 & 5.12 & 6.97 & 10.77 & 7.34 & 11.37 & 7.95 & 12.40 & 9.77 & 9.79 & 6.26 & 6.69 & 8.34 & 7.31 & 10.01 & 7.36 \\
\hline $\mathrm{Tb}$ & 1.34 & 0.711 & 0.967 & 1.44 & 1.02 & 1.53 & 1.07 & 1.65 & 1.32 & 1.29 & 0.869 & 0.912 & 1.12 & 1.00 & 1.35 & 0.980 \\
\hline Dy & 6.87 & 3.64 & 4.97 & 7.37 & 5.36 & 7.87 & 5.42 & 8.27 & 6.75 & 6.53 & 4.47 & 4.68 & 5.80 & 5.12 & 7.06 & 4.96 \\
\hline Ho & 1.19 & 0.632 & 0.851 & 1.27 & 0.957 & 1.38 & 0.936 & 1.44 & 1.21 & 1.13 & 0.779 & 0.815 & 0.988 & 0.878 & 1.27 & 0.843 \\
\hline Er & 3.02 & 1.62 & 2.18 & 3.20 & 2.49 & 3.60 & 2.40 & 3.75 & 3.18 & 2.87 & 1.95 & 2.05 & 2.49 & 2.26 & 3.44 & 2.13 \\
\hline $\mathrm{Tm}$ & 0.382 & 0.199 & 0.266 & 0.401 & 0.310 & 0.443 & 0.293 & 0.462 & 0.413 & 0.349 & 0.239 & 0.253 & 0.303 & 0.275 & 0.450 & 0.259 \\
\hline $\mathrm{Yb}$ & 2.22 & 1.15 & 1.59 & 2.36 & 1.89 & 2.63 & 1.70 & 2.81 & 2.50 & 2.07 & 1.43 & 1.49 & 1.78 & 1.60 & 2.79 & 1.51 \\
\hline $\mathrm{Lu}$ & 0.304 & 0.164 & 0.221 & 0.329 & 0.270 & 0.370 & 0.239 & 0.389 & 0.355 & 0.284 & 0.201 & 0.206 & 0.244 & 0.222 & 0.403 & 0.206 \\
\hline $\mathrm{Hf}$ & 8.12 & 3.98 & 5.39 & 8.96 & 5.99 & 9.46 & 6.47 & 9.87 & 8.82 & 7.62 & 4.62 & 4.74 & 5.66 & 5.58 & 8.83 & 5.69 \\
\hline $\mathrm{Ta}$ & 4.37 & 1.85 & 2.53 & 5.09 & 2.96 & 5.39 & 3.48 & 7.23 & 4.11 & 4.67 & 2.38 & 2.70 & 3.15 & 2.85 & 3.63 & 3.14 \\
\hline $\mathrm{Tl}$ & 0.004 & 0.012 & 0.009 & 0.026 & 0.125 & 0.122 & 0.009 & 0.196 & 0.085 & 0.148 & 0.007 & 0.011 & 0.140 & 0.012 & 0.211 & 0.004 \\
\hline $\mathrm{Pb}$ & 3.19 & 1.68 & 2.01 & 3.92 & 2.48 & 4.51 & 2.42 & 4.83 & 5.05 & 2.95 & 1.84 & 2.16 & 2.37 & 2.20 & 12.10 & 2.11 \\
\hline Th & 5.39 & 2.30 & 3.30 & 6.73 & 4.59 & 7.63 & 4.49 & 9.95 & 9.39 & 5.83 & 3.08 & 2.91 & 3.62 & 3.46 & 10.11 & 3.84 \\
\hline $\mathrm{U}$ & 1.47 & 0.561 & 0.901 & 1.83 & 1.20 & 2.16 & 1.24 & 2.92 & 2.37 & 1.70 & 0.738 & 0.773 & 1.01 & 0.942 & 2.52 & 1.05 \\
\hline
\end{tabular}

Abbreviations: bas: basalt; pbas: picrobasalt; tbas: trachybasalt; shos: shoshonite; ne: nepheline; hy: hypersthene; ol: olivine; Q: quartz. 

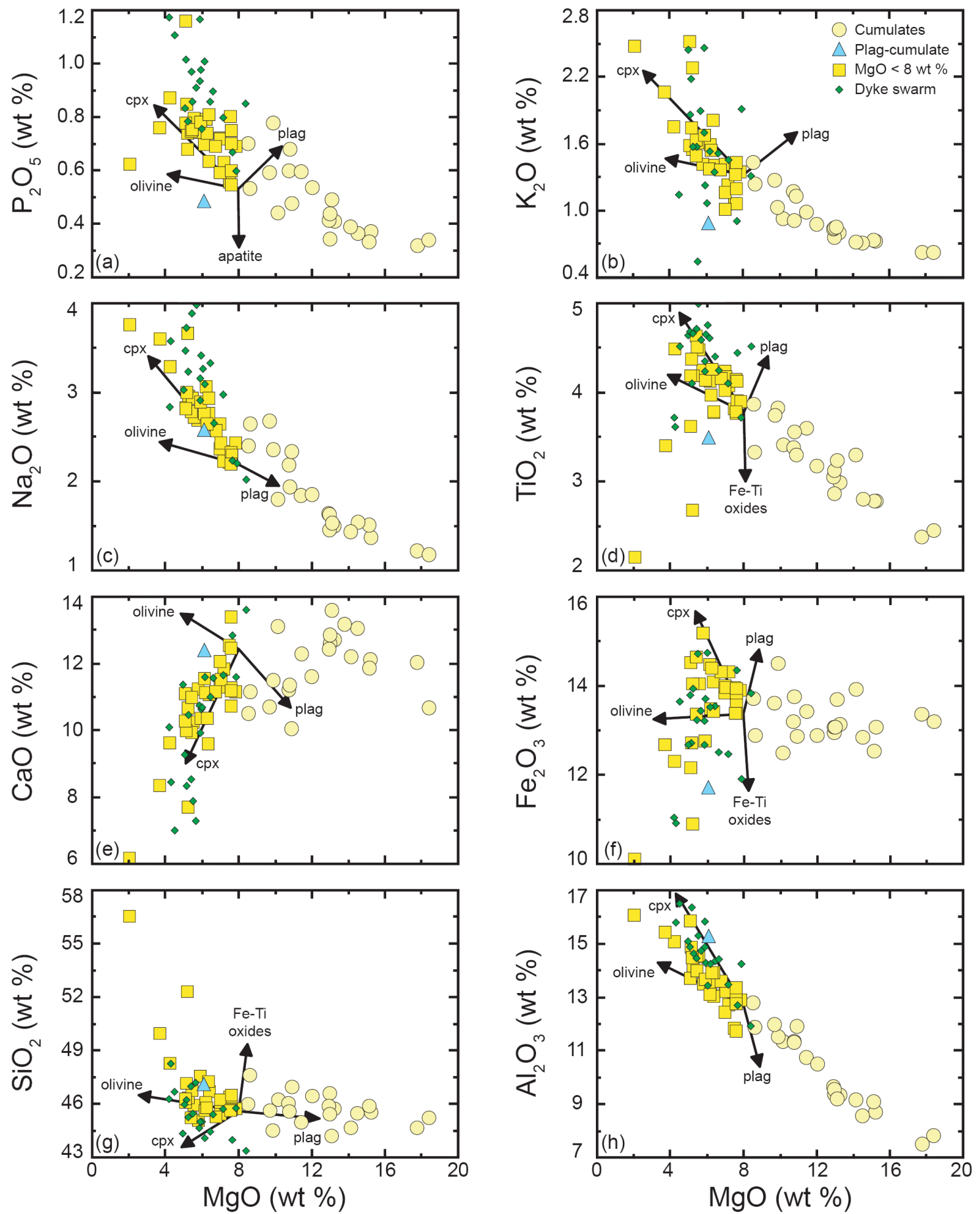

Figure 4.7: Plots of selected major elements versus $\mathrm{MgO}$ content. Symbols are the same as Figure 4.6 except that the plagioclase cumulate sample (AMF-6) that contains $>40 \%$ large honeycombed plagioclase crystals is plotted separately. Also shown are fractionation vectors for the main phenocryst phases observed in the Lookout Volcanics. Samples from the coeval radial regional dyke swarm are also plotted (Grapes et al. 1992).

Primitive-mantle-normalised-multielement diagrams display a wide range of VICE relative to MICE abundances $(\mathrm{Nb} / \mathrm{Y}=10.3-19.0)$ that are not solely related to changing $\mathrm{MgO}$ contents (Figure 4.9d). High-MgO samples display lower concentrations of all incompatible trace elements (Figure 4.9c) compared to the 

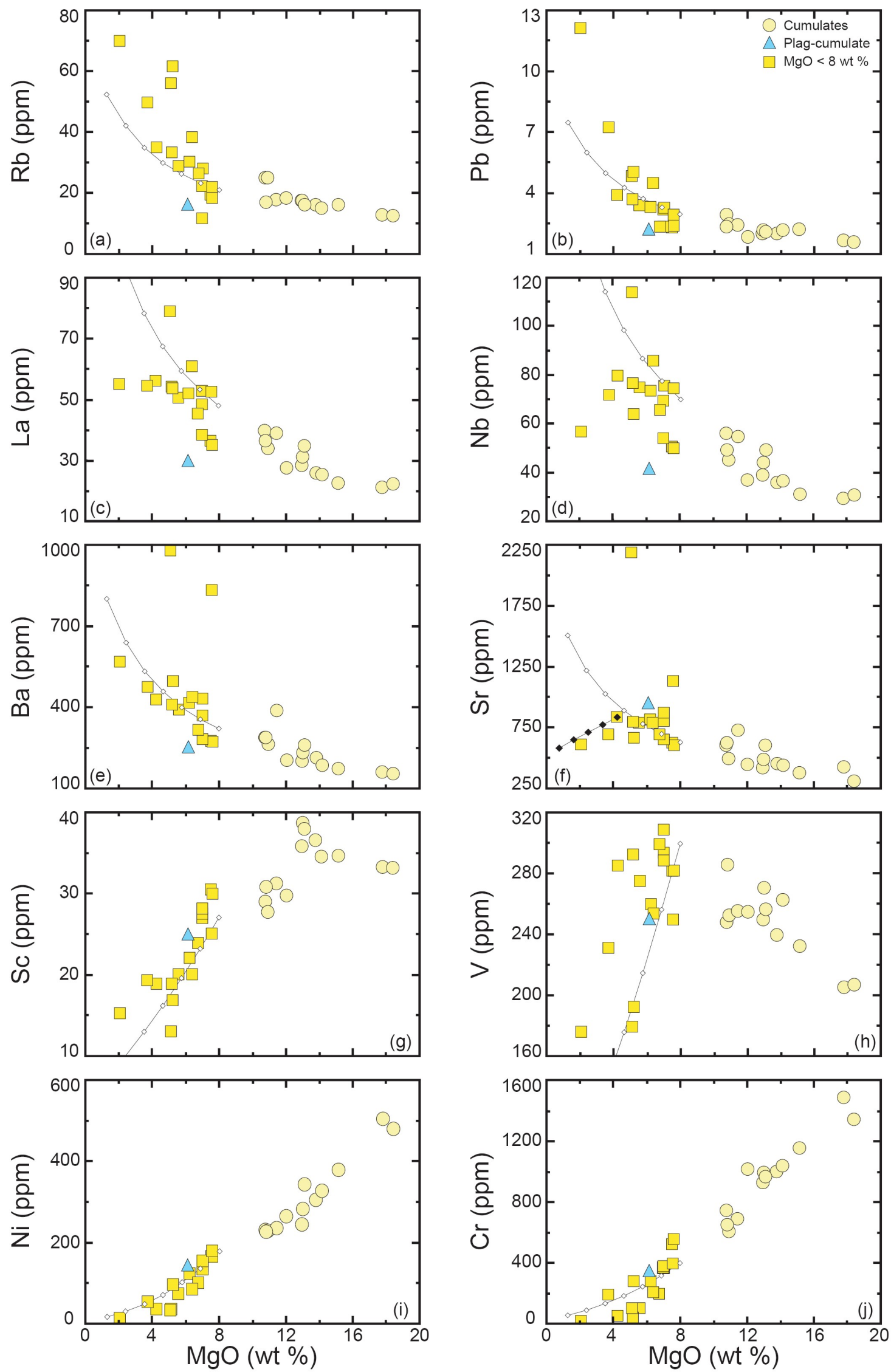

Figure 4.8: Plots of selected trace elements versus $\mathrm{MgO}$ content. Symbols are the same as Figure 7. (a-j) grey lines represent a fractional crystallisation model for $\mathrm{cpx}+$ ol fractionation in 80:20 proportions from a basaltic parent, white diamonds are $10 \%$ crystallisation increments. (f) black line represents a fractional crystallisation model for plag $+\mathrm{cpx}$ fractionation in 60:40 proportions from AMB-37 (an evolved sample that has not experienced plag or Fe-Ti oxide fractionation), with black diamonds being $10 \%$ crystallisation increments. 
evolved samples, with patterns peaking at Ta and displaying negative $\mathrm{Pb}$ and $\mathrm{Sr}$ and positive $\mathrm{P}$ and $\mathrm{Ti}$ anomalies. The low-MgO samples display similar patterns at higher concentrations, however, several samples are heavily enriched in VICE relative to MICE (i.e. $\mathrm{AMB}-53 ; \mathrm{Nb} / \mathrm{Y}=19.0$ ) and display positive $\mathrm{Ba}$ and $\mathrm{Sr}$ anomalies. The most evolved sample (AMG-10) peaks at $\mathrm{U}$ and displays a significantly lower Ti content than all other samples, and is characterised by negative $\mathrm{Ba}$ and $\mathrm{Sr}$ and positive $\mathrm{Pb}$ anomalies. Mafic samples have multielement and REE patterns similar to some OIB (e.g. Mangaia Cook-Australs; Figure 4.9).
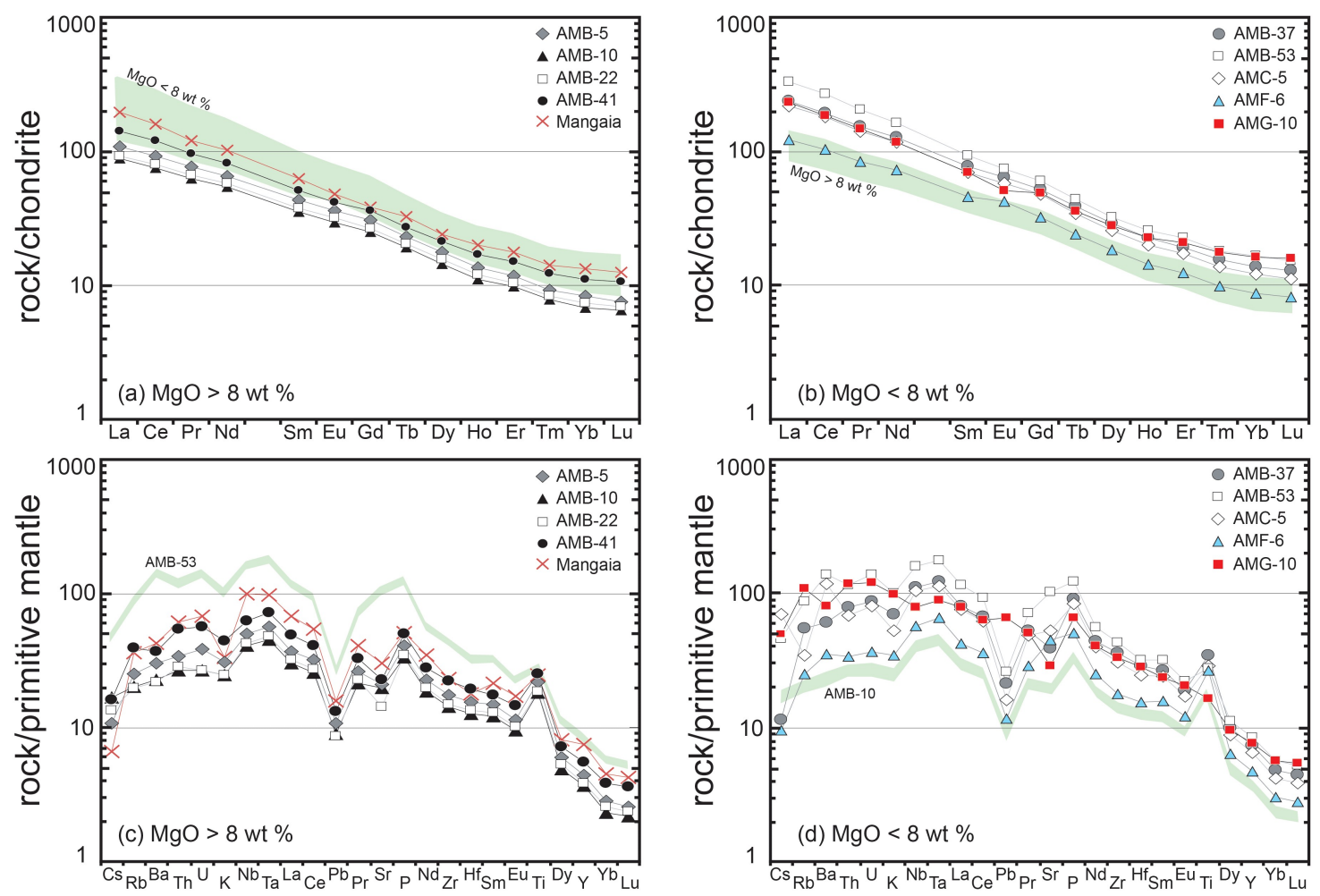

Figure 4.9: (a-b) Rare earth element chondrite-normalised (Sun \& McDonough , 1989) plots of representative samples from the Lookout Volcanics. (c-d) primitive-mantle-normalised (McDonough \& Sun, 1995) multielement plots of representative samples from the main Lookout Volcanics. Samples are divided and plotted into two separate groups according to their $\mathrm{MgO}$ contents. Also shown is a representative HIMU OIB (Mangaia M16; Woodhead, 1996).

\subsection{Sr-Nd-Hf-Pb-O ISOTOPES}

Sr-Nd-Hf isotopic data are presented in Table 4.4. Pb isotopic data for 18 samples are presented in Table 4.5. Sr-Nd-O isotopic data for various mineral phases separated from the Lookout Volcanics are presented in Table 4.6. 


\subsubsection{Sr-Nd isotope data}

Samples with $\mathrm{SiO}_{2}<52$ wt \% have a restricted range of initial ${ }^{87} \mathrm{Sr} /{ }^{86} \mathrm{Sr}$ ratios that vary from 0.70230 to 0.7032 . The basaltic trachyandesite samples extend this range to $0.7035-0.7038$. Similarly, initial ${ }^{143} \mathrm{Nd} /{ }^{144} \mathrm{Nd}$ ratios for most samples range from 0.51272 to 0.51269 , with the basaltic trachyandesites having slightly lower ratios of 0.51267-0.51264. Model present-day mantle source Sr-Nd isotopic values for the Lookout Volcanics are compared with isotopic data from intraplate volcanic rocks erupted elsewhere in Zealandia and mantle end-member components in Figure 4.10. The Lookout Volcanics display Sr-Nd isotopic signatures that are similar to the HIMU mantle end-member. Amongst the New Zealand intraplate volcanic data the Lookout Volcanics are most similar to volcanic rocks from the Chatham Islands. Other intraplate volcanic rocks from the South and North Island have higher $\varepsilon_{\mathrm{Nd}}$ and less radiogenic $\mathrm{Pb}$ relative to the Lookout Volcanics and trend towards more MORB-like compositions. Sr and Nd isotope ratios are strongly correlated forming an array that trends towards crustal terranes from the Eastern Province of New Zealand (Figure 4.10g), specifically those of the Torlesse Supergroup (i.e. Pahau and Rakaia terranes) that possess low $\varepsilon_{\mathrm{Nd}}$ values (Wandres et al., 2004; Adams et al., 2005).

\subsubsection{Hf isotope data}

Samples with $\mathrm{SiO}_{2}<52$ wt \% have initial ${ }^{176} \mathrm{Hf} /{ }^{177} \mathrm{Hf}$ isotopic ratios varying from 0.28283 to 0.28281 , with the basaltic trachyandesites extending this range to 0.28278 (Table 4.4). Model present-day mantle source $\varepsilon_{\mathrm{Hf}}$ values are strongly correlated with $\varepsilon_{\mathrm{Nd}}$ values (Figure $4.10 \mathrm{e}$ ) and plot consistently below the MORBOIB mantle array (Nowell et al., 1998). Samples from the Lookout Volcanics exhibit unradiogenic $\varepsilon_{\mathrm{Hf}}$ at a given $\varepsilon_{\mathrm{Nd}}$ compared to the mantle array and are similar to other HIMU sources especially St. Helena (Figure 4.10e; Chaffey et al., 1989; Salters \& White, 1998). 
Table 4.4: Whole rock Rb-Sr, Sm-Nd, Lu-Hf and Sr-Nd-Hf isotopic data for the Lookout Volcanics.

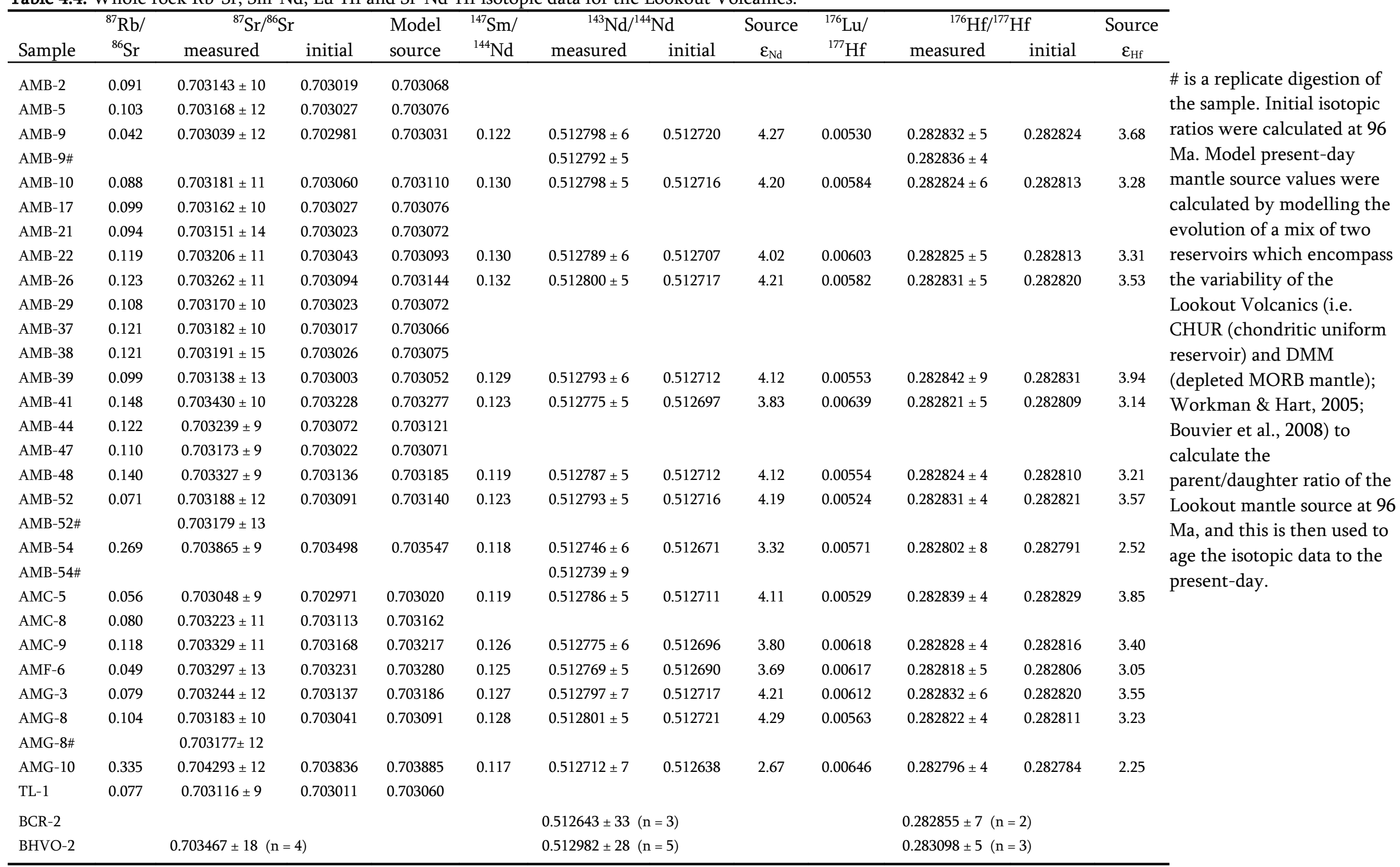


Table 4.5: Whole rock $\mathrm{U}-\mathrm{Th}-\mathrm{Pb}$ and $\mathrm{Pb}$ isotope data for the Lookout Volcanics.

\begin{tabular}{|c|c|c|c|c|c|c|c|c|c|c|c|c|}
\hline \multirow[b]{2}{*}{ Sample } & \multirow{2}{*}{$\begin{array}{l}{ }^{238} \mathrm{U} / \\
{ }^{204} \mathrm{~Pb}\end{array}$} & \multirow{2}{*}{$\begin{array}{l}{ }^{235} \mathrm{~Pb} / \\
{ }^{204} \mathrm{~Pb} \\
\end{array}$} & \multirow{2}{*}{$\begin{array}{l}{ }^{232} \mathrm{Th} / \\
{ }^{204} \mathrm{~Pb}\end{array}$} & \multicolumn{2}{|c|}{${ }^{206} \mathrm{~Pb} /{ }^{204} \mathrm{~Pb}$} & \multirow{2}{*}{$\begin{array}{l}\text { Model } \\
\text { source }\end{array}$} & \multicolumn{2}{|c|}{${ }^{207} \mathrm{~Pb} /{ }^{204} \mathrm{~Pb}$} & \multirow{2}{*}{$\begin{array}{l}\text { Model } \\
\text { source }\end{array}$} & \multicolumn{2}{|c|}{${ }^{208} \mathrm{~Pb} /{ }^{204} \mathrm{~Pb}$} & \multirow{2}{*}{$\begin{array}{l}\text { Model } \\
\text { source }\end{array}$} \\
\hline & & & & measured & initial & & measured & initial & & measured & initial & \\
\hline AMB-9 & 30.7 & 0.223 & 116.8 & $20.4196 \pm 10$ & 19.959 & 20.214 & $15.7246 \pm 8$ & 15.703 & 15.715 & $40.1529 \pm 22$ & 39.597 & 39.932 \\
\hline AMB-10 & 22.3 & 0.161 & 94.4 & $20.2032 \pm 10$ & 19.869 & 20.125 & $15.7222 \pm 9$ & 15.706 & 15.718 & $40.0276 \pm 23$ & 39.578 & 39.913 \\
\hline AMB-21 & 31.7 & 0.230 & 124.6 & $20.4574 \pm 9$ & 19.981 & 20.237 & $15.7326 \pm 8$ & 15.710 & 15.722 & $40.2289 \pm 22$ & 39.636 & 39.972 \\
\hline AMB-22 & 23.4 & 0.170 & 104.7 & $20.2720 \pm 11$ & 19.921 & 20.177 & $15.7279 \pm 9$ & 15.711 & 15.723 & $40.1361 \pm 26$ & 39.638 & 39.974 \\
\hline AMB-26 & 29.8 & 0.216 & 112.8 & $20.2741 \pm 9$ & 19.828 & 20.083 & $15.7182 \pm 8$ & 15.697 & 15.709 & $40.0270 \pm 21$ & 39.490 & 39.825 \\
\hline AMB-39 & 24.2 & 0.175 & 89.1 & $20.4811 \pm 11$ & 20.118 & 20.375 & $15.7353 \pm 10$ & 15.718 & 15.730 & $40.1611 \pm 26$ & 39.737 & 40.074 \\
\hline AMB-47 & 39.5 & 0.286 & 150.9 & $20.6591 \pm 9$ & 20.067 & 20.324 & $15.7404 \pm 8$ & 15.712 & 15.724 & $40.3083 \pm 21$ & 39.590 & 39.926 \\
\hline AMB-48 & 31.9 & 0.232 & 116.5 & $20.4244 \pm 11$ & 19.945 & 20.201 & $15.7221 \pm 9$ & 15.699 & 15.711 & $40.0496 \pm 23$ & 39.495 & 39.830 \\
\hline AMB-52 & 34.5 & 0.250 & 129.0 & $20.7139 \pm 10$ & 20.196 & 20.453 & $15.7411 \pm 9$ & 15.716 & 15.729 & $40.3848 \pm 23$ & 39.771 & 40.108 \\
\hline AMB-54 & 30.5 & 0.221 & 124.8 & $19.2756 \pm 9$ & 18.818 & & $15.6666 \pm 8$ & 15.645 & & $39.1489 \pm 23$ & 38.555 & \\
\hline AMC-5 & 38.9 & 0.282 & 137.9 & $20.9016 \pm 11$ & 20.318 & 20.576 & $15.7456 \pm 9$ & 15.718 & 15.730 & $40.5496 \pm 24$ & 39.893 & 40.232 \\
\hline AMC-9 & 26.6 & 0.193 & 114.8 & $20.0667 \pm 11$ & 19.667 & 19.921 & $15.7175 \pm 10$ & 15.698 & 15.710 & $39.9179 \pm 25$ & 39.371 & 39.704 \\
\hline AMF-6 & 23.7 & 0.172 & 92.3 & $20.1105 \pm 11$ & 19.755 & 20.009 & $15.7164 \pm 11$ & 15.699 & 15.712 & $39.8807 \pm 30$ & 39.441 & 39.775 \\
\hline AMG-8\# & 28.7 & 0.208 & 108.9 & $20.4432 \pm 11$ & 20.013 & 20.269 & $15.7353 \pm 9$ & 15.715 & 15.727 & $40.2294 \pm 25$ & 39.711 & 40.048 \\
\hline AMG-10 & 13.5 & 0.098 & 56.0 & $19.2697 \pm 10$ & 19.067 & & $15.6727 \pm 10$ & 15.663 & & $39.1590 \pm 24$ & 38.892 & \\
\hline TL-1 & 33.6 & 0.244 & 126.8 & $20.8019 \pm 8$ & 20.298 & 20.556 & $15.7474 \pm 7$ & 15.723 & 15.736 & $40.4601 \pm 19$ & 39.856 & 40.195 \\
\hline$J B-2(n=9)$ & & & & $18.3423 \pm 30$ & & & $15.5611 \pm 35$ & & & $38.2753 \pm 102$ & & \\
\hline$J B-2$ & & & & $18.3435 \pm 17$ & & & $15.5619 \pm 16$ & & & $38.2784 \pm 50$ & & \\
\hline SRM-981 & & & & 16.9416 & & & 15.5000 & & & 36.7262 & & \\
\hline
\end{tabular}

Values of SRM-981 used for standard-sample bracketing and comparative JB-2 values $(\mathrm{n}=14)$ in italics both from Baker et al. (2004) are shown. Initial isotopic ratios were calculated at $96 \mathrm{Ma}$. Model present-day mantle source values were calculated assuming a $\mathrm{HIMU}$ signature $(\mathrm{Pb}=0.170 \mathrm{ppm} ; \mathrm{Th}=0.176 ; \mathrm{U}=0.044 \mathrm{ppm})$ with $\mathrm{U} / \mathrm{Pb}=0.2588$ and $\mathrm{Th} / \mathrm{Pb}=1.035$ similar to that of Chauvel et al. (1992). ${ }^{238} \mathrm{U} /{ }^{204} \mathrm{~Pb}(16.5-17.2),{ }^{235} \mathrm{U} /{ }^{204} \mathrm{~Pb}(0.120-0.125)$ and ${ }^{232} \mathrm{Th} /{ }^{204} \mathrm{~Pb}(68.4-71.1)$ ratios were

calculated for each sample using the initial atomic weight of $\mathrm{Pb}$ in the sample, the mantle source is then aged to the present-day as per Table 4.4. The ${ }^{238} \mathrm{U} /{ }^{204} \mathrm{~Pb}(\mu)$ values calculated in this study are broadly consistent with those reported by Panter et al. (2006) (15.6-16.5). 

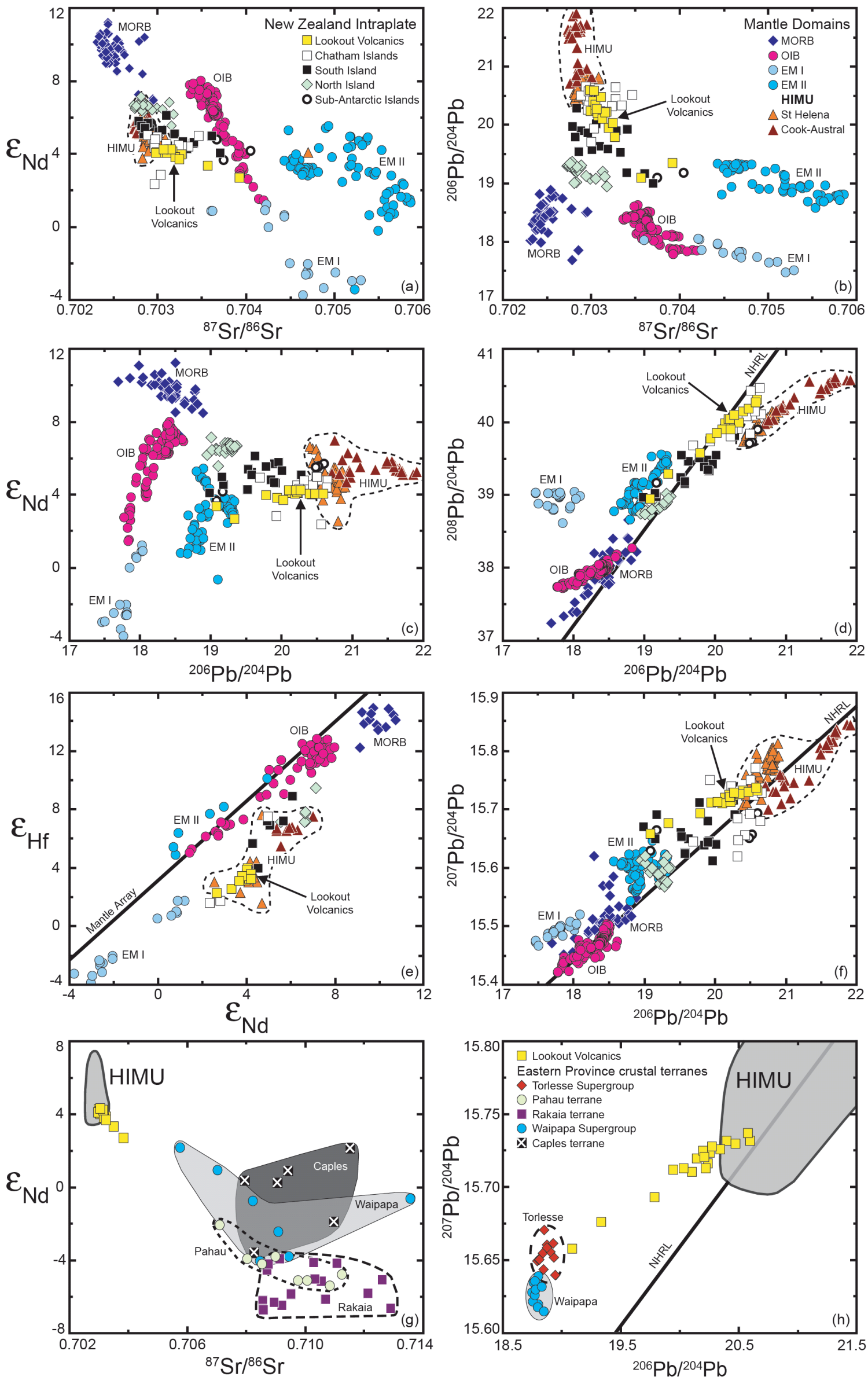

Figure 4.10: (a-f): Sr-Nd-Hf-Pb isotopic plots comparing mantle end-member compositions with intraplate volcanic rocks from New Zealand. 
Figure 4.10 (continued): Data sources from the literature were as follows: Pacific-Antarctic MORB (Castillo et al., 1998; Vlastélic et al., 1999); MORB (for Hf) (Chauvel \& Blichert-Toft, 2001); OIB (Hawaiian) (Tanaka et al., 2002; Gaffney et al., 2004; Marske et al., 2007); HIMU (Chaffey et al., 1989; Woodhead, 1996; Chauvel et al., 1997; Salters \& White, 1998); EM-I (Eisele et al., 2002); EM-II (Workman et al., 2004; Pfander et al., 2007); New Zealand intraplate (Price et al., 2003; Cook et al., 2005; Panter et al., 2006; Sprung et al., 2007). The Lookout Volcanics data shown here are present-day model source corrected values (Tables $4.4 \& 4.5)$. (g-h) comparison of the Lookout Volcanics with New Zealand crustal terranes of the Eastern Province. HIMU field (as above) and crustal terranes from: (Graham et al., 1992; Wandres et al., 2004; Adams et al., 2005). The Northern Hemisphere Reference Line is from Hart (1984) and the OIB-MORB mantle array is from Nowell et al. (1998).

The Hf isotopic composition of volcanic rocks in Zealandia is poorly characterised. However, the Lookout Volcanics appear broadly similar in composition to limited analyses of basalts from the Chatham Islands with samples from other regions having higher $\varepsilon_{\mathrm{Hf}}$ values and exhibiting more MORB-like compositions (Figure 4.10).

\subsection{3 $\mathrm{Pb}$ isotope data}

Unlike the other radiogenic isotope systems, the initial $\mathrm{Pb}$ isotopic composition of basaltic samples varies markedly (e.g. ${ }^{206} \mathrm{~Pb} /{ }^{204} \mathrm{~Pb}=19.52-20.32$; Table 4.5), with the basaltic trachyandesites extending this range significantly $\left({ }^{206} \mathrm{~Pb} /{ }^{204} \mathrm{~Pb}=18.82\right.$ 19.07). In plots of ${ }^{207} \mathrm{~Pb} /{ }^{204} \mathrm{~Pb}$ and ${ }^{208} \mathrm{~Pb} /{ }^{204} \mathrm{~Pb}$ versus ${ }^{206} \mathrm{~Pb} /{ }^{204} \mathrm{~Pb}$ samples form a linear array that extends from compositions similar to the HIMU mantle endmember to less radiogenic compositions (Figure 4.10). Plots of ${ }^{87} \mathrm{Sr} /{ }^{86} \mathrm{Sr}$ and $\varepsilon_{\mathrm{Nd}}$ versus ${ }^{206} \mathrm{~Pb} /{ }^{204} \mathrm{~Pb}$ allow discrimination of compositional characteristics of intraplate volcanism from around New Zealand (Figure 4.10b-c). Samples from the Chatham Islands display HIMU-like signatures with high ${ }^{206} \mathrm{~Pb} /{ }^{204} \mathrm{~Pb}$ and ${ }^{87} \mathrm{Sr} /{ }^{86} \mathrm{Sr}$ and low $\varepsilon_{\mathrm{Nd}}$, whereas South Island samples have intermediate ${ }^{206} \mathrm{~Pb} /{ }^{204} \mathrm{~Pb}$, ${ }^{87} \mathrm{Sr} /{ }^{86} \mathrm{Sr}$ and $\varepsilon_{\mathrm{Nd}}$, while North Island samples are more MORB-like with low ${ }^{206} \mathrm{~Pb} /{ }^{204} \mathrm{~Pb},{ }^{87} \mathrm{Sr} /{ }^{86} \mathrm{Sr}$ and high $\varepsilon_{\mathrm{Nd}} . \mathrm{Pb}$ isotopic variations exhibited by the Lookout Volcanics trend towards crustal compositions of the Eastern Province, in particular the Torlesse Supergroup metasediment field of Graham et al. (1992). 


\subsubsection{O isotope data}

Olivine $\delta^{18} \mathrm{O}$ values from 3 high-MgO samples display a restricted range from 4.7 to $5.0 \%$ o (Table 4.6; Figure 4.11), that are lower than the range of values observed in olivines separated from a wide variety of mantle peridotite xenoliths from the SCLM (Mattey et al., 1994; Eiler et al., 1995) and MORB (Eiler et al., 1997). However, these values are consistent with the lowest $\delta^{18} \mathrm{O}$ values displayed by OIB (Eiler et al., 1997) that represent the HIMU end-member $(5.03 \pm 0.22 \%$; $n=$ 14). Clinopyroxene phenocrysts show much greater $\delta^{18} \mathrm{O}$ variations with values varying from 3.9 to $5.5 \%$ o (Figure 4.11 ). Samples from the higher end of this range overlap the lower values of clinopyroxene from mantle peridotites (Mattey et al., 1994) but analyses of other samples extend to significant lower $\delta^{18} \mathrm{O}$ values. The coloured regions of strongly zoned clinopyroxene phenocrysts, green (cores) and brown (rims) display significant oxygen isotope variability.

Table 4.6: Mineral Sr-Nd-O isotope data.

\begin{tabular}{|c|c|c|c|c|c|c|}
\hline Sample & Mineral & $\delta^{18} \mathrm{O}(\%)$ & ${ }^{87} \mathrm{Rb} /{ }^{86} \mathrm{Sr}$ & ${ }^{87} \mathrm{Sr} /{ }^{86} \mathrm{Sr}$ & ${ }^{147} \mathrm{Sm} /{ }^{144} \mathrm{Nd}$ & ${ }^{143} \mathrm{Nd} /{ }^{144} \mathrm{Nd}$ \\
\hline \multirow{5}{*}{$\begin{array}{c}\text { AMB-39 } \\
(\mathrm{MgO}= \\
14.2 \mathrm{wt} \%)\end{array}$} & green $\mathrm{cpx}$ & 4.78 & 0.0003 & $0.703021 \pm 12$ & 0.1735 & $0.512838 \pm 12$ \\
\hline & brown cpx & 4.80 & 0.0009 & $0.703047 \pm 10$ & 0.1818 & $0.512831 \pm 11$ \\
\hline & brown cpx\# & & & $0.703092 \pm 8$ & & \\
\hline & olivine & 4.78 & & & & \\
\hline & olivine\# & 4.78 & & & & \\
\hline AMB-54 & green cpx & 5.38 & 0.0004 & $0.703240 \pm 14$ & & \\
\hline$(\mathrm{MgO}=$ & brown cpx & 4.91 & 0.0012 & $0.703532 \pm 10$ & & \\
\hline $5.24 \mathrm{wt} \%)$ & plagioclase & 7.74 & & $0.703522 \pm 19$ & & \\
\hline AMC-5 & green cpx & 5.05 & 0.0003 & $0.703022 \pm 14$ & & \\
\hline$(\mathrm{MgO}=$ & brown cpx & 4.45 & 0.0006 & $0.703026 \pm 9$ & & \\
\hline 7.60 wt \%) & brown cpx\# & 4.30 & & & & \\
\hline AMC-9 & green cpx & 5.00 & 0.0003 & $0.703013 \pm 9$ & & \\
\hline$(\mathrm{MgO}=$ & brown cpx & 5.30 & 0.0029 & $0.703129 \pm 9$ & & \\
\hline $12.1 \mathrm{wt} \%)$ & olivine & 4.86 & & & & \\
\hline AMG-8 & green cpx & 5.29 & 0.0005 & $0.703007 \pm 13$ & & \\
\hline$(\mathrm{MgO}=$ & brown cpx & 3.93 & 0.0023 & $0.703022 \pm 9$ & & \\
\hline \multirow[t]{3}{*}{$13.0 \mathrm{wt} \%)$} & olivine & 4.78 & & & & \\
\hline & olivine\# & 4.72 & & & & \\
\hline & olivine\# & 4.97 & & & & \\
\hline $\begin{array}{c}\text { AMG-10 } \\
(\mathrm{MgO}= \\
2.07 \text { wt \%) }\end{array}$ & brown cpx & 5.47 & 0.0069 & $0.703839 \pm 8$ & 0.1929 & $0.512775 \pm 10$ \\
\hline
\end{tabular}

\# is an analysis of an additional phenocryst separate. ${ }^{87} \mathrm{Rb} /{ }^{86} \mathrm{Sr}$ and ${ }^{147} \mathrm{Sm} /{ }^{144} \mathrm{Nd}$ values are averages calculated from LA-ICP-MS data. 

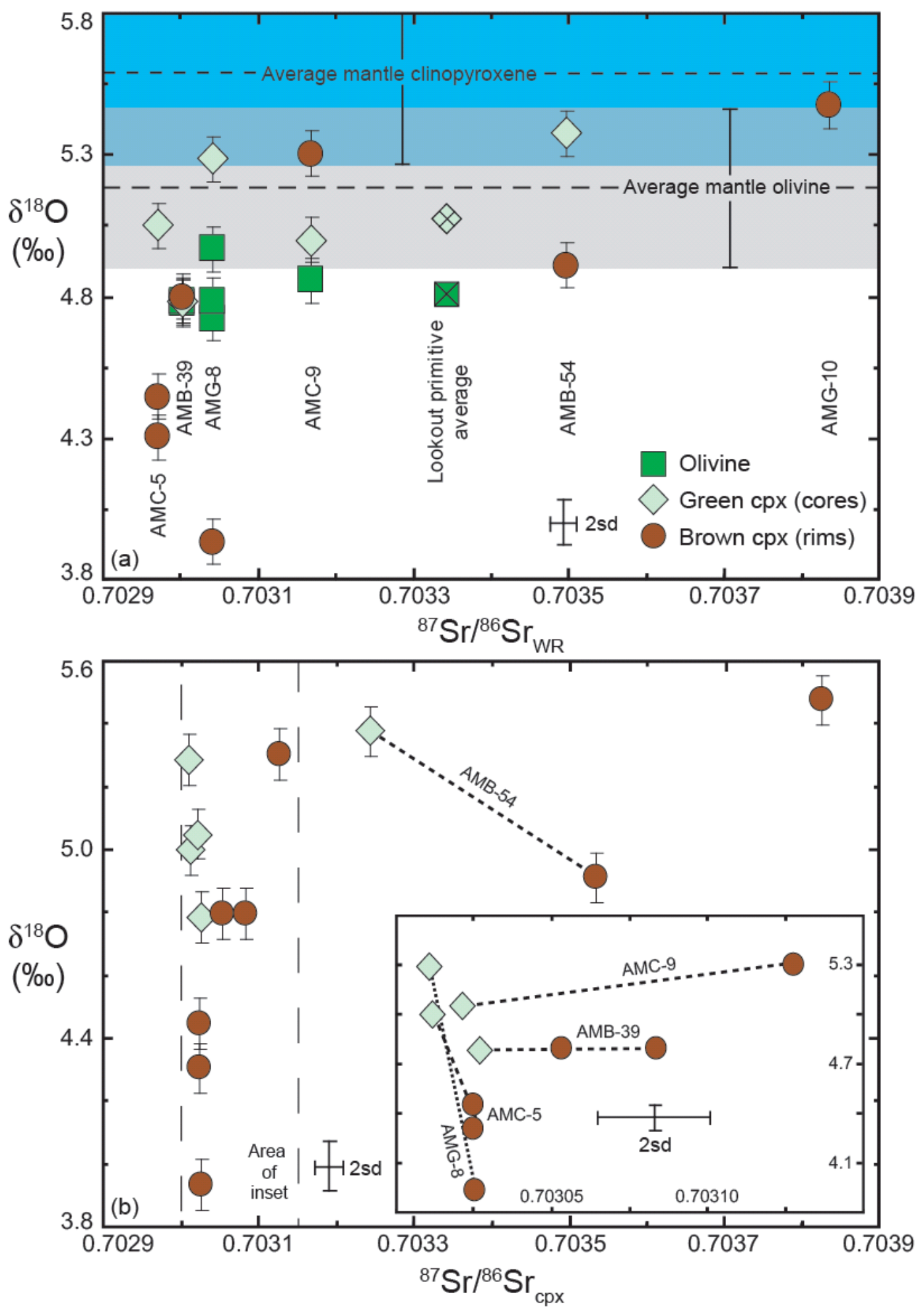

Figure 4.11: (a) Phenocryst $\delta^{18} \mathrm{O}$ versus whole rock initial ${ }^{87} \mathrm{Sr} /{ }^{86} \mathrm{Sr}$. The average mantle olivine $(5.18 \pm 0.28 \%$ o $)$ and clinopyroxene $(5.57 \pm 0.36 \%$ ) values are from Mattey et al. (1994). The average for minerals from primitive Lookout Volcanic samples was calculated from samples with ${ }^{87} \mathrm{Sr} /{ }^{86} \mathrm{Sr}<0.7032\left(\mathrm{ol}=4.81 \%\right.$; green $\mathrm{cpx}=5.03 \%$ ). (b) clinopyroxene $\delta^{18} \mathrm{O}$ versus clinopyroxene ${ }^{87} \mathrm{Sr} /{ }^{86} \mathrm{Sr}$ showing the variable relationships between brown and green clinopyroxene in different samples. 
Green cores are relatively uniform with $\delta^{18} \mathrm{O}=4.8$ to $5.4 \%$, compared with brown rims that have $\delta^{18} \mathrm{O}=3.9$ to $5.5 \%$. The degree and nature of disequilibrium between clinopyroxene cores and rims is variable. Several samples display strong negative disequilibrium $\left(\Delta^{18} \mathrm{O}_{\text {brown-green }}=-0.5\right.$ to $-1.4 \%$ o), although one sample displays isotopic equilibrium (AMB-39; $\delta^{18} \mathrm{O}=4.8 \%$ o). Plagioclase $\delta^{18} \mathrm{O}$ was measured in sample AMB-54 at 7.7\%o. Given the relatively small oxygen isotopic fractionation between melt and plagioclase at magmatic temperatures $\left(\Delta_{\text {melt-plag }}=-0.1\right.$ to $-0.3 \%$; Kalamarides, 1986$)$ this plagioclase can be considered to be in equilibrium with $\delta^{18} \mathrm{O}_{\text {melt }}=7.5 \%$.

In general, $\mathrm{Sr}-\mathrm{Nd}$ isotopic data for green and brown clinopyroxene are the same and very similar to the initial ${ }^{87} \mathrm{Sr} /{ }^{86} \mathrm{Sr}$ of the whole rock despite the corerim differences in clinopyroxene $\delta^{18} \mathrm{O}$ (Figure 4.11). However, in two samples (AMB-54 \& AMC-9) green clinopyroxene cores have less radiogenic Sr than the brown rims and the initial ${ }^{87} \mathrm{Sr} /{ }^{86} \mathrm{Sr}$ of the whole rocks.

\subsection{DISCUSSION}

\subsubsection{Crustal magmatic processes}

\section{Crystal accumulation and fractional crystallisation}

Petrographic observations (Figure 4.3) suggest that olivine + clinopyroxene may have been important cumulative and fractionating phases in the volcanic rocks of the Lookout Formation. Fe-Ti oxides and plagioclase may have also begun to crystallise at lower $\mathrm{MgO}$ contents (<6 wt \%).

Crystal accumulation. Samples with $>8$ wt \% MgO display chemical trends consistent with the accumulation of olivine + clinopyroxene phenocrysts (in variable proportions) controlling much of the major and trace element variation observed in these rocks (Figures 4.7 \& 4.8). With increasing $\mathrm{MgO}$ cumulate samples display decreasing concentrations of all major elements, except $\mathrm{CaO}$ which has variable concentrations and $\mathrm{Fe}_{2} \mathrm{O}_{3}$ which remains almost constant. 
Samples with $\mathrm{MgO}>13$ wt \% have $\mathrm{Ni}$ and $\mathrm{Cr}$ concentrations comparable to those of primary basalts (Roeder \& Emslie, 1970; Hart \& Davis, 1978). However, these high $\mathrm{MgO}$, $\mathrm{Ni}$ and $\mathrm{Cr}$ contents are considered the result of the accumulation olivine + clinopyroxene phenocrysts in the most magnesian samples. The somewhat scattered $\mathrm{CaO}$ contents in the high- $\mathrm{MgO}$ samples reflect variations in the relative abundance of olivine + clinopyroxene in the accumulated mineral assemblage consistent with the petrography of these rocks.

Sample AMF-6 displays the lowest $\mathrm{K}_{2} \mathrm{O}$ and highest $\mathrm{CaO}$ and $\mathrm{Al}_{2} \mathrm{O}_{3}$ contents of all samples at its $\mathrm{MgO}$ content (Figure 4.7), which coupled with low concentrations of VICE and a small positive Eu anomaly (Figures 4.8 \& 4.9) are indicative of plagioclase accumulation and consistent with its petrography (Figure $4.3 \mathrm{~g})$.

Quantitative modelling of crystal accumulation. Modelling (not shown) requires the accumulation of up to $35 \%$ olivine + clinopyroxene in 30:70 proportions in samples with $8-13 \mathrm{wt} \% \mathrm{MgO}$ at which point the accumulative assemblage changes to being dominated by olivine (70:30) and requires a further ca. $20 \%$ crystal accumulation to generate the most $\mathrm{MgO}$-rich samples. This model produces a good fit for the majority of major elements with a poorer fit generated by the alkali elements. Modelling (not shown) to produce the plagioclase cumulate (i.e. AMF-6) requires the accumulation of ca. $40 \%$ plagioclase + clinopyroxene phenocrysts in the proportions 75:25, in accordance with the observed petrography of the rock.

Fractional crystallisation. Major and trace element differentiation trends at $\mathrm{MgO}<8 \mathrm{wt} \%$ are consistent with the fractionation of olivine + clinopyroxene \pm plagioclase $\pm \mathrm{Fe}$-Ti oxides having played a role, at some stage, in generating the elemental variations observed in these rocks (Figures $4.7 \& 4.8$ ). Marked decreases in the $\mathrm{MgO}$ and $\mathrm{Ni}$ contents require olivine fractionation throughout the fractionation sequence, while large decreases in $\mathrm{CaO}, \mathrm{Cr}$ and $\mathrm{Sc}$ concentrations also require the continuous crystallisation of clinopyroxene. 
Strong correspondence between major element variation and the fractionation vectors for these minerals plotted on Figure 4.7 suggests these minerals dominate the fractionating assemblage. Decreasing $\mathrm{Sr}$ in the most evolved samples $(\mathrm{MgO}<$ $4 \mathrm{wt} \%$ ) requires the initiation of plagioclase fractionation (Figure 4.6f), which is supported by the development of small negative Eu anomalies and decreasing $\mathrm{Sr} /$ $\mathrm{Nd}$ ratios (Figure 4.9). However, plagioclase fractionation was minimal (i.e. it was not the dominant fractionating phase) because $\mathrm{Al}_{2} \mathrm{O}_{3}$ contents continued to increase with decreasing $\mathrm{MgO}$. Decreases in $\mathrm{Fe}_{2} \mathrm{O}_{3}, \mathrm{TiO}_{2}$ and $\mathrm{V}$ in the most evolved samples $(\mathrm{MgO}<4-6 \mathrm{wt} \%)$ require the fractionation of an $\mathrm{Fe}$-Ti oxide phase.

Quantitative modelling of fractional crystallisation. Modelling of the major element variations observed in the Lookout Volcanics was undertaken after the selection of representative parent-daughter compositions. The variability of the vast majority of samples in the suite can be explained by the fractionation of up to $22 \%$ clinopyroxene + olivine $(80: 20)$. This model is valid for all samples that show no geochemical effects of plagioclase $+\mathrm{Fe}-\mathrm{Ti}$ oxide fractionation (7.6-4.3 wt $\% \mathrm{MgO}$; AMC-5-AMB-37), providing good fits for the majority of major elements, with poorer fits on alkali elements. Plotted on Figure 8 this model reproduces the majority of trace element variability observed in the Lookout Volcanics across this $\mathrm{MgO}$ range. Crystallisation of Fe-Ti oxides was modelled in the most evolved sample (i.e. AMG-10) and requires ca. 20\% crystallisation of FeTi oxides + clinopyroxene (20:80). Late stage plagioclase crystallisation was modelled and on the basis of $\mathrm{Al}_{2} \mathrm{O}_{3}$ contents requires ca. $20 \%$ further fractionation (clinopyroxene + plagioclase; 70:30). However, on the basis of Sr concentrations requires ca. 30\% fractionation (clinopyroxene + plagioclase; 60:40). Inconsistency between the amount of fractionation required between major and trace element modelling is due to: (1) the simplicity of the models used in terms of chemical evolution and changes in the relative proportion of phases with time i.e. plagioclase fractionation probably occurred in a high proportion 
(ca. 80-90\%) for a short period prior to eruption; or (2) the increased sensitivity of trace elements in magmatic systems mean changes are recorded more accurately.

Several samples have VICE abundances that are 20-200\% outside the enrichment that can be produced by the fractional crystallisation model (i.e. Sr, $\mathrm{Ba}, \mathrm{Pb}$, etc.; Figure 4.8). These discrepancies are not simply a function of the partition coefficients used in the models and still remain even if the element is assumed to be totally incompatible (i.e. $\mathrm{D}_{\mathrm{Ba}}=0$ ) and therefore require the operation of other magmatic processes.

\section{Crustal contamination}

The range in incompatible trace element ratios and isotopic compositions exhibited by the Lookout Volcanics is no larger than that observed in many individual ocean islands, and considerably less than the range inferred for all asthenosphere or plume derived OIB (Zindler \& Hart, 1986; Weaver, 1991). However, the Lookout Volcanics were erupted through the continental crust and are clearly not primary magmas. This raises the possibility that crustal contamination produced the isotopic and trace element variability of these samples rather than heterogeneity in the mantle source.

Components involved in intraplate volcanism. Sr- $\mathrm{Nd}-\mathrm{Hf}-\mathrm{Pb}$ isotopic data indicate that mixing of two components contributed to the petrogenesis of the Lookout Volcanics. Samples with low ${ }^{87} \mathrm{Sr} /{ }^{86} \mathrm{Sr}, \Delta 7 / 4$ and $\Delta 8 / 4$ and high ${ }^{143} \mathrm{Nd} /{ }^{144} \mathrm{Nd},{ }^{176} \mathrm{Hf} /{ }^{177} \mathrm{Hf}$ and ${ }^{206} \mathrm{~Pb} /{ }^{204} \mathrm{~Pb}$ values reflect a component that lies inside the compositional field defined by HIMU OIB (Figure 4.10). Low $\mathrm{MgO}$ and high $\mathrm{SiO}_{2}$ samples with enriched $\mathrm{Sr}-\mathrm{Nd}$ isotopic compositions have unradiogenic $\mathrm{Pb}$ and high $\Delta 7 / 4$ and $\Delta 8 / 4$ values that extend towards the composition of crustal terranes of New Zealand's Eastern Province. The second component involved in the petrogenesis of these magmas is therefore likely to be Torlesse Supergroup greywacke with its unradiogenic $\mathrm{Pb}$ and enriched $\mathrm{Sr}-\mathrm{Nd}$ isotopic signature.

Some incompatible trace element ratios strongly correlate with isotopic composition. Samples with low ${ }^{206} \mathrm{~Pb} /{ }^{204} \mathrm{~Pb}$ and high ${ }^{87} \mathrm{Sr} /{ }^{86} \mathrm{Sr}$ have higher large 
ion lithophile element (LILE)/HFSE and LILE/LREE ratios than other samples (e.g. $\mathrm{Ba} / \mathrm{Nb})$. Although ratios such as $\mathrm{Nb} / \mathrm{La}(0.67-0.97)$ and $\mathrm{Ba} / \mathrm{Nb}(4.7-10.0)$ are within the range of oceanic basalts (Weaver, 1991), they trend from HIMU-like compositions towards those of the Torlesse Supergroup (Figure 4.12b). Compared with mafic samples whose multielement patterns peak at Ta and display strongly negative $\mathrm{Pb}$ anomalies, evolved samples peak at $\mathrm{U}$ and display small positive $\mathrm{Pb}$ anomalies (Figure 4.9). Increasing $\mathrm{Pb}$ concentrations and $\mathrm{Nd} / \mathrm{Pb}$ ratios are strongly correlated with isotopic composition (Figure 4.12). Lookout Volcanic samples exhibit strong correlations between $\mathrm{SiO}_{2}$ and radiogenic isotopic compositions (Figure 4.12a), with the most evolved sample (AMG-10) clearly having the highest ${ }^{87} \mathrm{Sr} /{ }^{86} \mathrm{Sr}$. However, in a plot of ${ }^{206} \mathrm{~Pb} /{ }^{204} \mathrm{~Pb}$ versus $\mathrm{SiO}_{2}$ the most evolved samples exhibit variable trends with respect to the primitive samples (Figure 4.12c). This difference can be accounted for by: (1) the Torlesse Supergroup contaminant comprising a range of sedimentary lithologies which have heterogeneous elemental and isotopic compositions; or (2) AMG-10 exhibits low VICE abundances (i.e. Nb; Figure 4.8d) and displays a shallower MREE to HREE pattern than the majority of samples (Figure $4.9 \mathrm{~b}$ ). Thus it may represent a larger degree partial melt resulting in higher primary $\mathrm{SiO}_{2}$ and lower VICE abundances in the basaltic parent. The addition of crustal material produces variable effects on different chemical and isotopic parameters used to monitor crustal contamination. For example, large changes in the $\mathrm{Nd} / \mathrm{Pb}$ ratio are observed while ${ }^{87} \mathrm{Sr} /{ }^{86} \mathrm{Sr}$ ratios change more slowly due to low $\mathrm{Pb}$ and high $\mathrm{Sr}$ concentrations of alkali basalts, respectively (Figure 4.12).

The mechanisms through which crustal material can be added to magmas vary considerably from combined assimilation and fractional crystallisation (AFC; De Paolo, 1981) through to assimilation of crust by hot magmas with little or no concomitant fractionation (Huppert \& Sparks, 1985; Devey \& Cox, 1987; Kerr et al., 1995). 

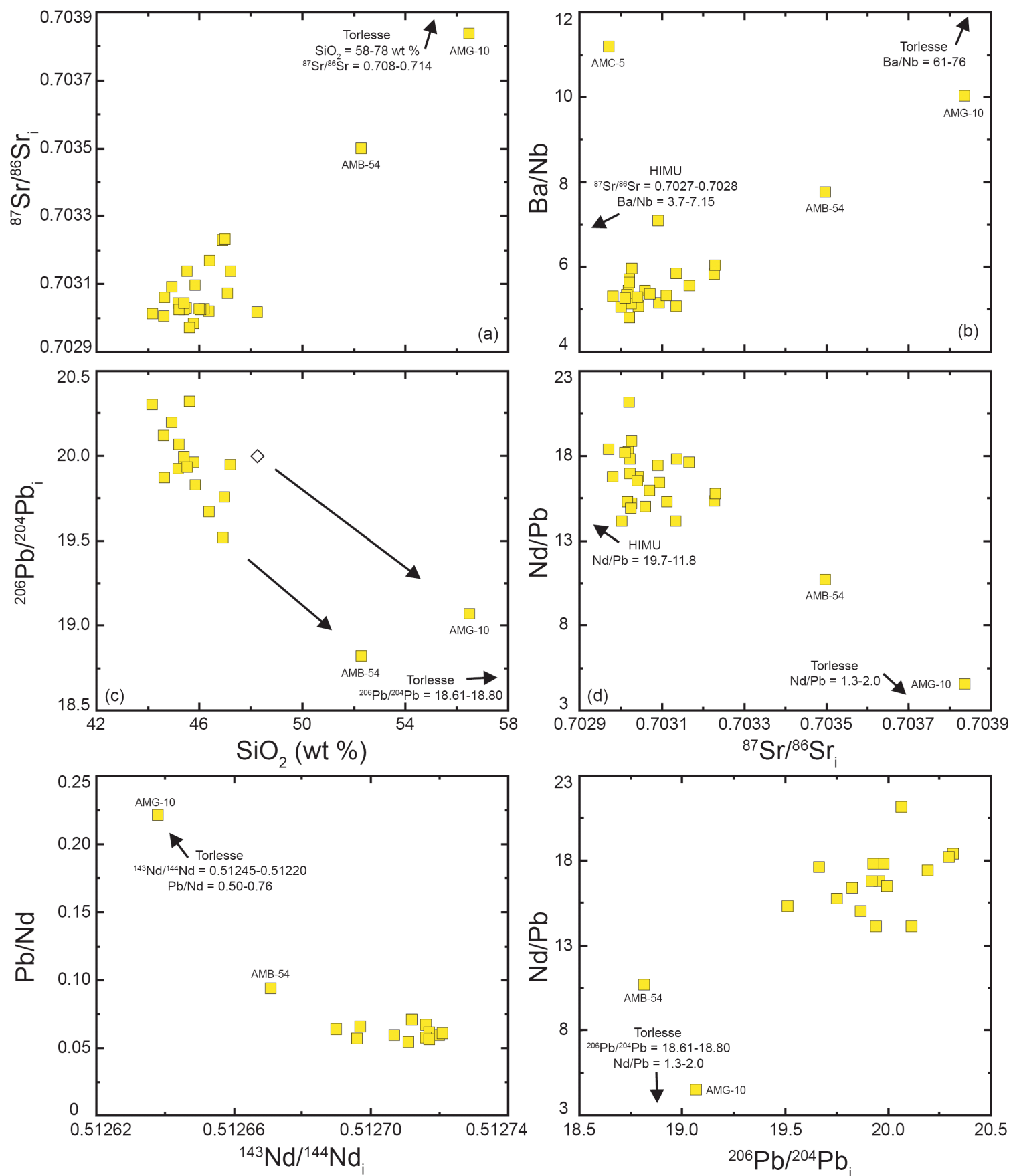

Figure 4.12: (a, c) Sr- $\mathrm{Pb}$ isotopes plotted versus $\mathrm{SiO}_{2}$. (b, d) $\mathrm{Ba} / \mathrm{Nb}$ and $\mathrm{Nd} / \mathrm{Pb}$ plotted versus ${ }^{87} \mathrm{Sr} /{ }^{86} \mathrm{Sr}$. (e) $\mathrm{Pb} / \mathrm{Nd}$ versus ${ }^{143} \mathrm{Nd} /{ }^{144} \mathrm{Nd}$. (f) $\mathrm{Nd} / \mathrm{Pb}$ versus ${ }^{206} \mathrm{~Pb} /{ }^{204} \mathrm{~Pb}$. In (c) the large arrows represent varied contamination paths of AMB-54 and AMG-10, and the white diamond represents a basaltic parent with a postulated higher primary $\mathrm{SiO}_{2}$ content. End-member data is from: HIMU (Woodhead, 1996); Torlesse (George, 1988; Graham et al., 1992; Wandres et al., 2005).

AFC depends on the existence of a sub-spherical magma chamber in which the release of latent heat of crystallisation into the surrounding wall rocks eventually leads to contamination. AFC results in the most evolved rocks becoming the most contaminated which is consistent with the elemental and isotopic variability 
displayed by the Lookout Volcanics. Moreover, the presence of magma chambers in close proximity to the Lookout Volcanics such as the TPC which contains quartz syenites is supportive of AFC (Baker et al. 1994).

Quantitative modelling of crustal contamination processes. Modelling of crustal assimilation was undertaken using a bulk assimilation model for the following reasons: (1) AFC (De Paolo, 1981) models produce minimal variations from bulk assimilation when mineral crystallisation is minimal; (2) modelling of partial fusion of the crustal component is non-trivial due to the poorly constrained and highly heterogeneous nature of the upper crustal rocks of the Torlesse Supergroup; (3) basaltic magmas at magmatic temperatures are sufficiently hot to completely melt all the components of sedimentary rocks in a heated and thermally weakened upper crust.

Hypothetical bulk mixing in $\mathrm{Sr}-\mathrm{Nd}-\mathrm{Pb}$ isotopic space of the contamination of primitive magmas of the Lookout Volcanics with Torlesse Supergroup sediments is illustrated in Figure 4.13. These calculations indicate that: (1) $0-30 \%$ assimilation of a crustal component with ${ }^{87} \mathrm{Sr} /{ }^{86} \mathrm{Sr}=0.7087,{ }^{143} \mathrm{Nd} /{ }^{144} \mathrm{Nd}=0.51230$ and ${ }^{206} \mathrm{~Pb} /{ }^{204} \mathrm{~Pb}=18.73$ and typical $\mathrm{Sr}, \mathrm{Nd}$ and $\mathrm{Pb}$ concentrations for the Torlesse Supergroup can account for most of the isotopic variation observed in the Lookout Volcanics; (2) the majority of the Lookout Volcanic samples require minimal crustal contributions of between $0-8 \%$ of this average Pahau Terrane crust which only significantly affects $\mathrm{Pb}$ isotope ratios; (3) ca. 25\% crustal assimilation of a crustal component with ${ }^{87} \mathrm{Sr} /{ }^{86} \mathrm{Sr}=0.7063,{ }^{143} \mathrm{Nd} /{ }^{144} \mathrm{Nd}=0.51245$ and ${ }^{206} \mathrm{~Pb} /{ }^{204} \mathrm{~Pb}=18.61$ and the $\mathrm{Sr}, \mathrm{Nd}$ and $\mathrm{Pb}$ concentrations of the Pahau Terrane in the Awatere Valley is required to generate the isotopic signature of sample AMB-54. In $\mathrm{Pb}$ isotopic space, $\mathrm{AMB}-54$ significantly diverges from the main $\mathrm{Pb}$ isotopic array with low ${ }^{206} \mathrm{~Pb} /{ }^{204} \mathrm{~Pb}$ relative to ${ }^{87} \mathrm{Sr} /{ }^{86} \mathrm{Sr}$. To generate a mixing array through this composition (AMB-54) requires its parental basalt to have a lower $\mathrm{Pb}$ concentration than the other samples, which is consistent with the highly porphyritic samples in the suite and the observation of relict olivine 
phenocrysts in AMB-54, and a crustal component with lower ${ }^{206} \mathrm{~Pb} /{ }^{204} \mathrm{~Pb}$ and ${ }^{208} \mathrm{~Pb} /{ }^{204} \mathrm{~Pb}$ than that which contaminated the other samples.

The incorporation of isotopically variable end-members is plausible given the heterogeneous nature of the rocks of the Torlesse Supergroup, which vary from sandstone to argillite lithologies. The crustal contamination model inferred from isotopic data is also consistent with the high $\mathrm{SiO}_{2}$ contents of the most contaminated samples and their silica-saturated compositions.
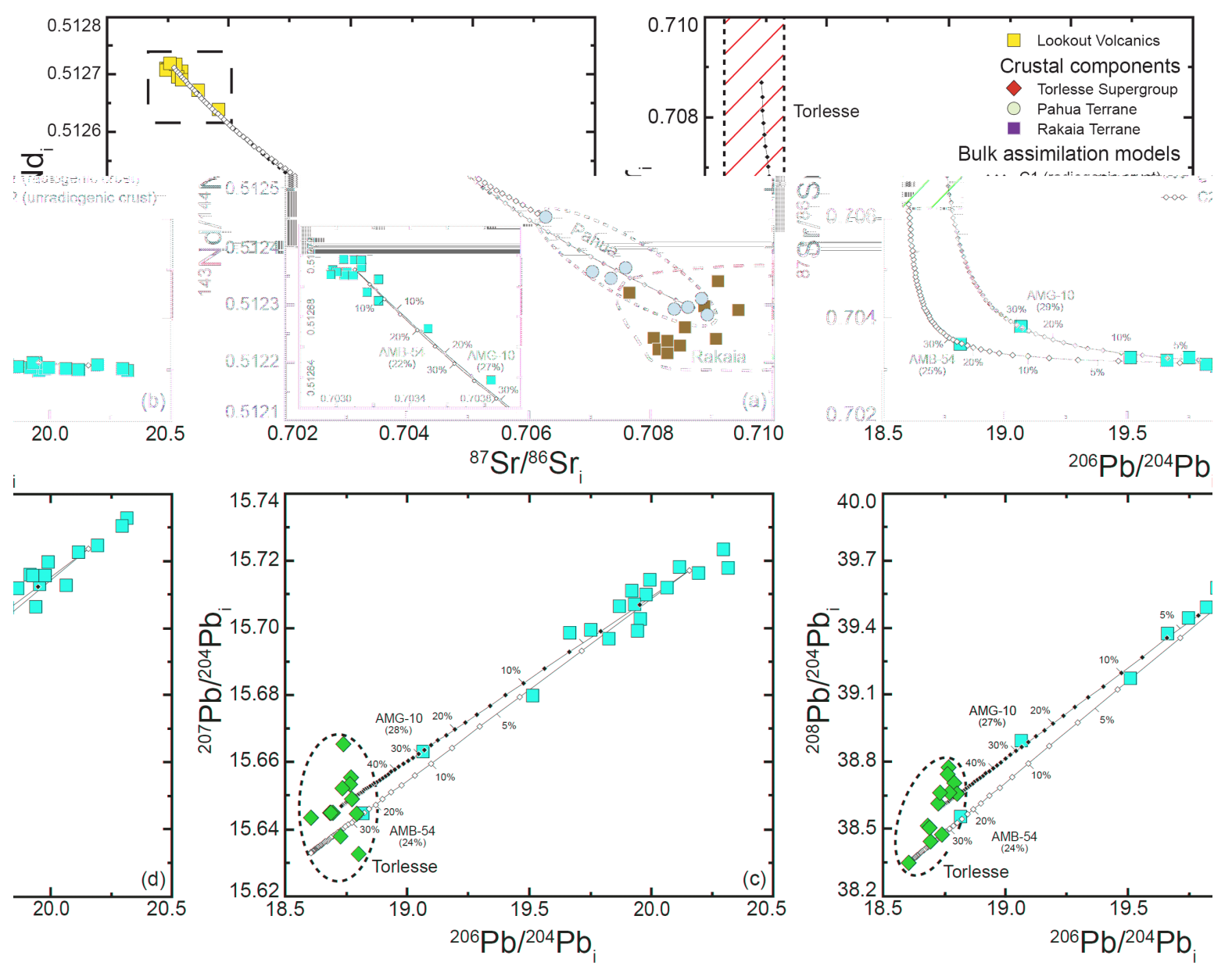

Figure 4.13: Bulk crustal assimilation curves modelling the isotopic variability observed in the Lookout Volcanics in $\mathrm{Sr}-\mathrm{Nd}-\mathrm{Pb}$ isotopic space. Dots on the contamination arrays represent $2 \%$ incremental additions of continental crust. Initial isotopic compositions of the volcanic rocks and Torlesse Supergroup samples (Graham et al., 1992; Wandres et al., 2004; Adams et al., 2005) were calculated to $96 \mathrm{Ma}$. Parameters used in modelling were: primitive magma $\left({ }^{87} \mathrm{Sr} /{ }^{86} \mathrm{Sr}=0.7031\right.$; ${ }^{143} \mathrm{Nd} /{ }^{144} \mathrm{Nd}=0.512711 ;{ }^{206} \mathrm{~Pb} /{ }^{204} \mathrm{~Pb}=20.157 ;{ }^{207} \mathrm{~Pb} /{ }^{204} \mathrm{~Pb}=15.717 ;{ }^{208} \mathrm{~Pb} /{ }^{204} \mathrm{~Pb}=39.754 ; \mathrm{Sr}=644$ $\mathrm{ppm} ; \mathrm{Nd}=40.5 \mathrm{ppm} ; \mathrm{Pb}=2.31 \mathrm{ppm})$; contaminant $1\left(\mathrm{C} 1\right.$ radiogenic crust: ${ }^{87} \mathrm{Sr} /{ }^{86} \mathrm{Sr}=0.708692$; ${ }^{143} \mathrm{Nd} /{ }^{144} \mathrm{Nd}=0.512295 ;{ }^{206} \mathrm{~Pb} /{ }^{204} \mathrm{~Pb}=18.731 ;{ }^{207} \mathrm{~Pb} /{ }^{204} \mathrm{~Pb}=15.647 ;{ }^{208} \mathrm{~Pb} /{ }^{204} \mathrm{~Pb}=38.592 ; \mathrm{Sr}=245.5$ ppm; $\mathrm{Nd}=24.59 \mathrm{ppm} ; \mathrm{Pb}=18.4 \mathrm{ppm})$; contaminant $2\left(\mathrm{C} 2\right.$ unradiogenic crust: ${ }^{87} \mathrm{Sr} /{ }^{86} \mathrm{Sr}=0.706273$; ${ }^{143} \mathrm{Nd} /{ }^{144} \mathrm{Nd}=0.512452 ;{ }^{206} \mathrm{~Pb} /{ }^{204} \mathrm{~Pb}=18.605 ;{ }^{207} \mathrm{~Pb} /{ }^{204} \mathrm{~Pb}=15.633 ;{ }^{208} \mathrm{~Pb} /{ }^{204} \mathrm{~Pb}=38.348 ; \mathrm{Sr}=305.2$ ppm; $\mathrm{Nd}=28$ ppm; $\mathrm{Pb}=28$ ppm; and basalt with lower $\mathrm{Pb}=1.5 \mathrm{ppm}$ ). 
Significantly lowering the trace element concentration of the primary basalt (i.e. consistent with a larger degree partial melt) has a minimal effect (ca. 3\%) on the crustal contribution required to generate the isotopic variability of the most evolved sample.

\section{Oxygen isotope constraints on crustal magmatic processes}

Clinopyroxene phenocrysts in the Lookout Volcanics exhibit a significant range in $\delta^{18} \mathrm{O}$ from $3.9-5.5 \%$ o that significantly exceeds the analytical reproducibility of the technique $\left( \pm 0.15 \%\right.$ o). Increasing $\delta^{18} \mathrm{O}$ values appear broadly correlated with increases in ${ }^{87} \mathrm{Sr} /{ }^{86} \mathrm{Sr}$ (Figure 4.11) with the most crustally contaminated sample AMG-10 containing clinopyroxene with the highest $\delta^{18} \mathrm{O}$. However, core to rim changes in $\delta^{18} \mathrm{O}$ of clinopyroxene crystals do not consistently follow this pattern, with large $\delta^{18} \mathrm{O}$ decreases observed at constant ${ }^{87} \mathrm{Sr} /{ }^{86} \mathrm{Sr}$ (e.g. AMG-8: green cpx core $\delta^{18} \mathrm{O}=5.3 \%$; brown cpx $\operatorname{rim} \delta^{18} \mathrm{O}=3.9 \%$ ). Thus, these oxygen isotope variations are attributed to two distinct mechanisms, changes in magma composition due to the incorporation of crustal rocks and the interaction of (some) phenocrysts with low $\delta^{18} \mathrm{O}$ meteoric groundwater.

Fossilised hydrothermal systems are often observed around igneous plutons intruded into permeable upper crustal rocks (Taylor, 1971; Sheppard \& Taylor, 1974; Taylor \& Forester, 1979; Nevle et al., 1994; Dallai et al., 2001; Harris \& Chaumba, 2001). Convective circulation of groundwaters down around these plutons to depths of up to $10 \mathrm{~km}$ leads to oxygen and hydrogen isotopic exchange via interaction with the hydrothermal fluids (e.g. Sheppard \& Taylor, 1974). The final $\delta^{18} \mathrm{O}$ values of mineral phases exposed to meteoric fluids are dependent on the temperature of fluid infiltration, the fluid/rock ratio and the longevity of the hydrothermal system (Norton \& Taylor, 1979; Taylor \& Criss, 1986).

Clinopyroxene phenocrysts have been shown to be less susceptible to $\delta^{18} \mathrm{O}$ isotopic exchange than plagioclase in gabbroic plutons (Taylor \& Forester, 1979; Gregory et al., 1989). However, within the Lookout Volcanics brown clinopyroxenes still display distinct $\delta^{18} \mathrm{O}$ depletion relative to their cores (Figure 
4.11). This suggests these phenocrysts grew in an upper crustal magma chamber surrounded by an active meteoric groundwater circulation system. Extensive graben formation during the extension of proto-New Zealand and the porous nature of sandstones of the Torlesse Supergroup would have been conducive to the infiltration of meteoric water down to depths of $4-7 \mathrm{~km}$ in the presence of heat provided by a gabbroic pluton (e.g. TPC; Baker \& Seward, 1996).

The isotopic composition of meteoric water at ca. $96 \mathrm{Ma}$ in New Zealand was more negative than it is today (middle New Zealand; $\delta \mathrm{D}=-40 \%$; $\delta^{18} \mathrm{O}=-6.6 \%$; Stewart et al., 1983), with the isotopic composition of precipitation being related to a number of environmental parameters at a given site, such as latitude, altitude, distance to the coast, amount of precipitation and surface air temperature (Dansgaard, 1964; Rozanski et al., 1993). Robust plate tectonic reconstructions of the southwest Pacific place Marlborough, New Zealand ca. $30^{\circ} \mathrm{S}$ of its present location at ca. $70^{\circ} \mathrm{S}$ during the eruption of the Lookout Volcanics at 96 Ma (Lawver et al., 1992; Eagles et al., 2004). During the midCretaceous the Earth's climate was also drastically different, being in what is referred to as a "Greenhouse World", with $\mathrm{CO}_{2}$ levels four times those at present, no major continental ice sheets and global mean temperatures $6-12^{\circ} \mathrm{C}$ warmer than today (Barron et al., 1995; Huber et al., 1995; Clarke \& Jenkyns, 1999). A warmer atmosphere resulted in increased precipitation during the Cretaceous, which has been estimated at ca. 28\% greater than present (Barron et al., 1989). The effect of increased precipitation on $\delta^{18} \mathrm{O}$ values was quantified by Ludvigson et al. (1998), where sphaerosiderites formed during the Cretaceous were shown to have significantly more depleted $\delta^{18} \mathrm{O}$ for their respective paleolatitudes than the values calculated for those formed at the same latitudes today. Using the depletion of $\delta^{18} \mathrm{O}$ in the mid-Cretaceous calculated by Ludvigson et al. (1998) and modern $\delta^{18} \mathrm{O}$ at $70^{\circ} \mathrm{S}$, meteoric water in the mid-Cretaceous is estimated at ca. $-12 \%$ and is clearly capable of lowering the $\delta^{18} \mathrm{O}$ of phenocrysts growing in the presence of this water at magmatic temperatures. 
At magmatic temperatures the diffusion of oxygen in natural Fe-bearing diopside is approximately twice as fast as in synthetic samples (Ingrin et al., 2001). Linear extrapolation of this Fe effect to the Mg-numbers of clinopyroxenes in the Lookout Volcanic samples results in a diffusion coefficient of $5.68 \times 10^{-19} \mathrm{~m}^{2} / \mathrm{s}$. A simple diffusion-time relationship (i.e. $t=x^{2} / D$; Albarède, 1995) has been used to calculate the period required for oxygen equilibration across mineral zones. At $1200^{\circ} \mathrm{C}$ complete equilibration across a $1 \mathrm{~mm}$ and $2 \mathrm{~mm}$ zone will take $3.67 \mathrm{ka}$ and $223 \mathrm{ka}$, respectively. Recent studies constrain magma ascent rates at between 0.7-12 m/s (Kelley \& Wartho, 2000; Demouchy et al., 2006; Burgisser \& Scaillet, 2007), with alkali basaltic magmas shown to have ascended rapidly $(6 \pm 3 \mathrm{~m} / \mathrm{s})$ from depths of 60-70 km (Demouchy et al., 2006). Thus, given the phenocrysts in the Lookout Volcanics are up to $6 \mathrm{~mm}$ in size it is unsurprising that oxygen isotopic disequilibrium in crystals scavenged from a shallow crustal magma chamber are preserved.

Oxygen isotopes are a powerful and unequivocal way to test the relative contributions of crustal and mantle components to the generation of continental intraplate magmas (e.g. Baker et al., 2000). The mantle generally exhibits low and relatively invariant $\delta^{18} \mathrm{O}$ (Mattey et al., 1994) compared with the continental crust making oxygen isotopes an excellent discriminator of crustal contributions. Mantle-derived melts should have $\delta^{18} \mathrm{O}=6.0-6.2 \%$, and should crystallise clinopyroxene phenocrysts with $\delta^{18} \mathrm{O}=5.6 \%$ at near liquidus temperatures of basaltic magmas $\left(1000^{\circ} \mathrm{C}\right.$; Mattey et al., 1994). The oxygen isotopic composition of Torlesse Supergroup sediments is $12.2 \pm 2.3 \%$ (Blattner \& Reid, 1982; McCulloch et al., 1994). The green clinopyroxene cores from Lookout Volcanic samples exhibit a restricted range of $\delta^{18} \mathrm{O}$ values (4.8-5.4\%o) that generally correlate with the ${ }^{87} \mathrm{Sr} /{ }^{86} \mathrm{Sr}$ ratio of the crystal (Figure 4.11). Correlated increases in ${ }^{87} \mathrm{Sr} /{ }^{86} \mathrm{Sr}$ and $\delta^{18} \mathrm{O}$ suggest that crustal contamination of these high ${ }^{87} \mathrm{Sr} /{ }^{86} \mathrm{Sr}$ and $\delta^{18} \mathrm{O}$ and magmas has occurred. The isotopic composition of green clinopyroxene in $\mathrm{AMB}-54\left(\delta^{18} \mathrm{O}=5.4 \%\right.$ o; $\left.{ }^{87} \mathrm{Sr} /{ }^{86} \mathrm{Sr}=0.7032\right)$ is consistent with the addition of $6 \%$ 
and $11 \%$ Torlesse crust on the basis of $\mathrm{O}$ and $\mathrm{Sr}$ isotopes, respectively, as compared to other primitive green clinopyroxene phenocrysts at $1200^{\circ} \mathrm{C}\left(\delta^{18} \mathrm{O}=\right.$ $\left.5.0 \% ;{ }^{87} \mathrm{Sr} /{ }^{86} \mathrm{Sr}=0.7030\right)\left(\Delta_{\text {melt-cpx }}=0.25 \%\right.$; Kalamarides, 1986). The fractionation of olivine + clinopyroxene \pm plagioclase $\pm \mathrm{Fe}-\mathrm{Ti}$ oxides can produce small increases in melt $\delta^{18} \mathrm{O}$ values $\left(<0.3 \%\right.$ ), however, this is offset by increasing $\Delta_{\text {melt- }}$ cpx at lower temperatures as the $\Delta_{\text {melt-cpx }}$ fractionation factor increases $0.08 \%$ o for a $100^{\circ} \mathrm{C}$ decrease in temperature (Kalamarides, 1986). The measured $\delta^{18} \mathrm{O}$ value of plagioclase in AMB-54 is consistent with the addition $24 \%$ crustal material to the magma required by ${ }^{87} \mathrm{Sr} /{ }^{86} \mathrm{Sr}$ isotopic systematics if the phenocrysts crystallised in a magma that had cooled to ca. $900^{\circ} \mathrm{C}\left(\Delta_{\text {melt-plag }}=-0.7 \%\right.$; Kalamarides, 1986$)$. Brown clinopyroxene from the most evolved sample exhibits the highest $\delta^{18} \mathrm{O}$ value and ${ }^{87} \mathrm{Sr} /{ }^{86} \mathrm{Sr}$ of the analysed phenocrysts (Figure 4.11 ). The effect of crustal contamination is masked due to the larger $\Delta_{\text {melt-cpx }}$ fractionation factor at lower temperatures. This value could also be significantly too low due to the susceptibility of brown clinopyroxene rims to resetting by meteoric water and scavenging from subvolcanic magma chambers.

\section{Insights into crustal magmatic processes as recorded by clinopyroxene}

Clinopyroxene phenocrysts from cumulate volcanic rocks in the Lookout Volcanics are strongly zoned with systematic core to rim increases in $\mathrm{Al}_{2} \mathrm{O}_{3}$ (1.157.73 wt \%) and $\mathrm{TiO}_{2}(0.45-4.65 \mathrm{wt} \%)$. Within these phenocrysts magmatic evolution (i.e. increasing Ti) is strongly correlated with increasing HFSE and REE concentrations (Figure 4.5). For example, within a single phenocryst Hf concentrations can increase from 0.63 to $2.97 \mathrm{ppm}$.

The partitioning of incompatible trace elements between clinopyroxene and synthetic melt has been the subject of numerous experimental studies (Gallahan \& Nielsen, 1992; Forsythe et al., 1994; Gaetani \& Grove, 1995; Blundy et al., 1996; Lundstrom et al., 1998; Wood \& Trigila, 2001). Variable partition coefficients for HFSE and REE in clinopyroxene have been shown to be strongly correlated with increases in the tetrahedral $\mathrm{Al}_{2} \mathrm{O}_{3}\left({ }^{\mathrm{IV}} \mathrm{Al}\right.$ ) content (Lundstrom et al., 1998; Wood \& 
Trigila, 2001; Wood \& Blundy, 2003). Variation within clinopyroxene crystals from primitive Lookout Volcanic samples is attributed to changing clinopyroxene-melt distribution coefficients in accordance with tetrahedral $\mathrm{Al}_{2} \mathrm{O}_{3}$ content. Recent laser ablation studies report up to threefold variations in the absolute concentrations of HFSE and REE in single clinopyroxene phenocrysts (Claeson et al., 2007; Francis \& Minarik, 2008). The strong correlation between increasing $\mathrm{Al}_{2} \mathrm{O}_{3}$ contents and HFSE concentrations in the Lookout Volcanics (i.e. fivefold increases) suggests the effect of $\mathrm{Al}$ on trace element partition coefficients in natural magmatic systems may still be underestimated.

The evolved samples contain Ti-Al-poor clinopyroxene phenocrysts (AMG$10_{\text {average: }} \mathrm{n}=22 ; \mathrm{TiO}_{2}=1.06$ wt \%; $\mathrm{Al}_{2} \mathrm{O}_{3}=2.77$ wt \%). However, at essentially constant Ti contents (i.e. $<5500 \mathrm{ppm}$ ) phenocrysts in this sample show an almost twofold enrichment in incompatible trace element concentrations over those observed in primitive samples (Figure 4.5). Due to the restricted major element compositions of these clinopyroxene phenocrysts, increasing incompatible element concentrations (Figure 4.5d) cannot be directly attributed to changing partition coefficients and are thus interpreted to record progressively changing magma composition driven by fractional crystallisation and crustal contamination. The fractional crystallisation of plagioclase and $\mathrm{Fe}-\mathrm{Ti}$ oxides are inferred from the development of negative $\mathrm{Eu}, \mathrm{Sr}$ and $\mathrm{Ti}$ anomalies, respectively (Figure 4.5h). Systematic increases in trace element abundances including an order of magnitude increase in Pb concentrations are observed in AMG-10. Dy contents are higher than crystals with greater partition coefficients (i.e. max-Ti sample; Figure $4.5 \mathrm{~d}$ ) and as such these crystals are interpreted to record on a crystal and sub-crystal scale progressive crustal contributions to this magma. 


\subsubsection{Mantle melting processes and the nature of the mantle source of the Lookout Volcanics}

\section{$\underline{\text { A peridotitic versus pyroxenitic mantle source }}$}

Until recently general scientific consensus has been that mantle-derived melts are generated in equilibrium with olivine because it comprises ca. $50 \%$ of the peridotites in the upper mantle. Recent work by Sobolev et al. (2005 \& 2007) has challenged this view and suggested that secondary pyroxenitic mantle material forms in regions of mantle upwelling that contain recycled oceanic crust and can generate mantle derived melts. Si-saturated eclogites melt preferentially over peridotite due to a lower solidus, resulting in the formation of secondary olivinefree pyroxenite during mantle upwelling. The removal of olivine as a buffering mineral results in pyroxenite source regions forming melts that are relatively enriched in $\mathrm{Ni}$ and $\mathrm{Si}$ but depleted in $\mathrm{Ca}, \mathrm{Mn}$ and $\mathrm{Mg}$ compared to their peridotitic counterparts. Minor element concentrations of olivine phenocrysts from a range of tectonic settings were measured in this study for comparison with the Lookout Volcanics in order to assess the involvement of pyroxenite in the genesis of these continental intraplate magmas (Figure 4.4).

The proportion of pyroxenite in samples was calculated using the same approach as Sobolev et al. (2007). Olivine phenocrysts from Mauna Loa and Mauna Kea exhibit similar $\mathrm{NiO}$ contents and pyroxenitic proportions at 0.55 and 0.48 as those reported by Sobolev et al. (2005). Primitive olivines from Lookout Volcanics exhibit comparable $\mathrm{NiO}$ to the Mauna Kea sample with the amount of pyroxenite in the melt calculated at ca. 50\%. East Gondwana was the location of continuous subduction for ca. 200 Ma prior to the eruption of the Lookout Volcanics (ca. $96 \mathrm{Ma}$ ). Thus there is a direct mechanism for the incorporation of recycled oceanic crust or Si-rich melts into the mantle source of the Lookout Volcanics. The variation in Ni concentrations observed within olivines of the Lookout Volcanics represents phenocrysts from 12 lava flows suggesting a reasonably homogeneous amount of pyroxenite in the source of these magmas. 
However, the continental flood basalt from Yemen (JB-281) exhibits greater variation in a single eruptive unit $\left(\mathrm{Fo}_{87-86} ; \mathrm{NiO}=0.23-0.38 \mathrm{wt} \%\right)$ suggesting this lava flow was generated from a crustal magma chamber that had incorporated olivine phenocrysts that crystallised from multiple melt batches that were created through the melting of variable proportions of peridotite and pyroxenite in the mantle $\left(\mathrm{X}_{\mathrm{px}}=\right.$ ca. $\left.40-55 \%\right)$.

Enrichment of VICE in some Lookout Volcanic samples is significantly greater than that which can be generated through normal fractional crystallisation processes (Figure 4.8). Given the common primitive Sr- $\mathrm{Nd}-\mathrm{Pb}$ isotopic signatures of these samples it suggests these variations were generated through differences in partial melting, rather than source heterogeneity. The strong LREE enrichment $\left(\mathrm{La}_{\mathrm{N}}=90-330\right)$ and the steep HREE patterns (e.g. $\mathrm{Dy}_{\mathrm{N}} / \mathrm{Yb}_{\mathrm{N}}>>1$ ) of the Lookout Volcanic samples requires small degree partial melting of a source that contains residual garnet. Ratios of VICE/MICE such as $\mathrm{Ce} / \mathrm{Y}(2.70-4.26)$ and $\mathrm{La} / \mathrm{Yb}$ (17.4-28.1) also vary significantly suggesting variable degrees of melting of this source.

The presence of amphibole or phlogopite in the upper mantle during partial melting results in the retention of alkali elements (e.g. K, Rb, Ba) and water relative to normal anhydrous mineral melting (Adam et al., 1993; La Tourrette et al., 1995). Thus the negative $\mathrm{K}$ anomalies in the Lookout Volcanics and other intraplate rocks throughout Zealandia appear to require the presence of a Kbearing mineral such as potassic amphibole or phlogopite in the mantle source. The relative abundances of the alkali and alkaline earth elements can be used to distinguish between the presence of amphibole or phlogopite in the mantle source. Due to incompatibility differences, melts in equilibrium with phlogopite are expected to have significantly higher $\mathrm{Rb} / \mathrm{Sr}(>0.1)$ and lower $\mathrm{Ba} / \mathrm{Rb}(<20)$ ratios than those formed from amphibole-bearing mantle sources $(\mathrm{Rb} / \mathrm{Sr}<0.06$; $\mathrm{Ba} / \mathrm{Rb}$ > 20; Furman \& Graham, 1999). Lookout Volcanic samples have low Rb/Sr 
(0.015-0.051) and high $\mathrm{Ba} / \mathrm{Rb}$ (10.6-38.3) ratios suggesting that amphibole rather than phlogopite was the main potassic phase in the mantle source.

The melt models presented in Figure 4.14 use point-average, non-modal, fractional melt modelling (Shaw, 1970) to test the hypothesis that the Lookout Volcanics were produced through variable degrees of partial melting. Modelling used the REE distribution coefficients of McKenzie \& O'Nions (1991), with partition coefficients for $\mathrm{Y}, \mathrm{Nb}$ and $\mathrm{Zr}$ taken from Kelemen et al. (1993) and Halliday et al. (1995). Models assume the melting of a moderately enriched mantle i.e. a 50:50 mix of the primitive mantle and enriched mantle compositions of McDonough \& Sun, (1995) \& Baker et al. (1997), respectively. The significant range of $\mathrm{Ce} / \mathrm{Y}$ ratios of the Lookout Volcanic samples at nearly constant $\mathrm{Zr} / \mathrm{Nb}$ is inconsistent with these magmas being generated by melting of a spinel or garnet lherzolite from this moderately enriched mantle source (Figure 4.14). Modelling of the melting of a garnet pyroxenite produces a closer fit to the $\mathrm{Zr} / \mathrm{Nb}-\mathrm{Ce} / \mathrm{Y}$ systematics of the Lookout Volcanics. However, the $\mathrm{Dy} / \mathrm{Yb}$ ratio of the melt of a garnet pyroxenite is too high, thus requiring a phase in the mantle source that shows a greater affinity to MREE than HREE (i.e. amphibole: $\mathrm{D}_{\mathrm{Dy}}=0.78 ; \mathrm{D}_{\mathrm{Yb}}=$ 0.59; Chazot et al., 1996). Moreover the large variation in VICE/MICE at restricted $\mathrm{Zr} / \mathrm{Nb}$ ratio is also inconsistent with variable degrees of melting of normal lherzolite due to the large difference of incompatibility of $\mathrm{Nb}$ and $\mathrm{Zr}$ during standard mantle melting (Tiepolo et al., 2001), and therefore requires a $\mathrm{Nb}$-bearing mineral (i.e. rutile, phlogopite, amphibole) in the source of these magmas. The presence of amphibole in the mantle source of HIMU-like basalts in Zealandia has previously been suggested (Panter et al., 2006) and is consistent with the negative $\mathrm{K}$ anomalies of the Lookout Volcanic samples. Modelling incorporating amphibole into a garnet pyroxenite was undertaken using the partition coefficients for amphibole of Chazot et al. (1996) which are consistent with other values reported in the literature (Adam et al., 1993; Brenan et al., 1995). 

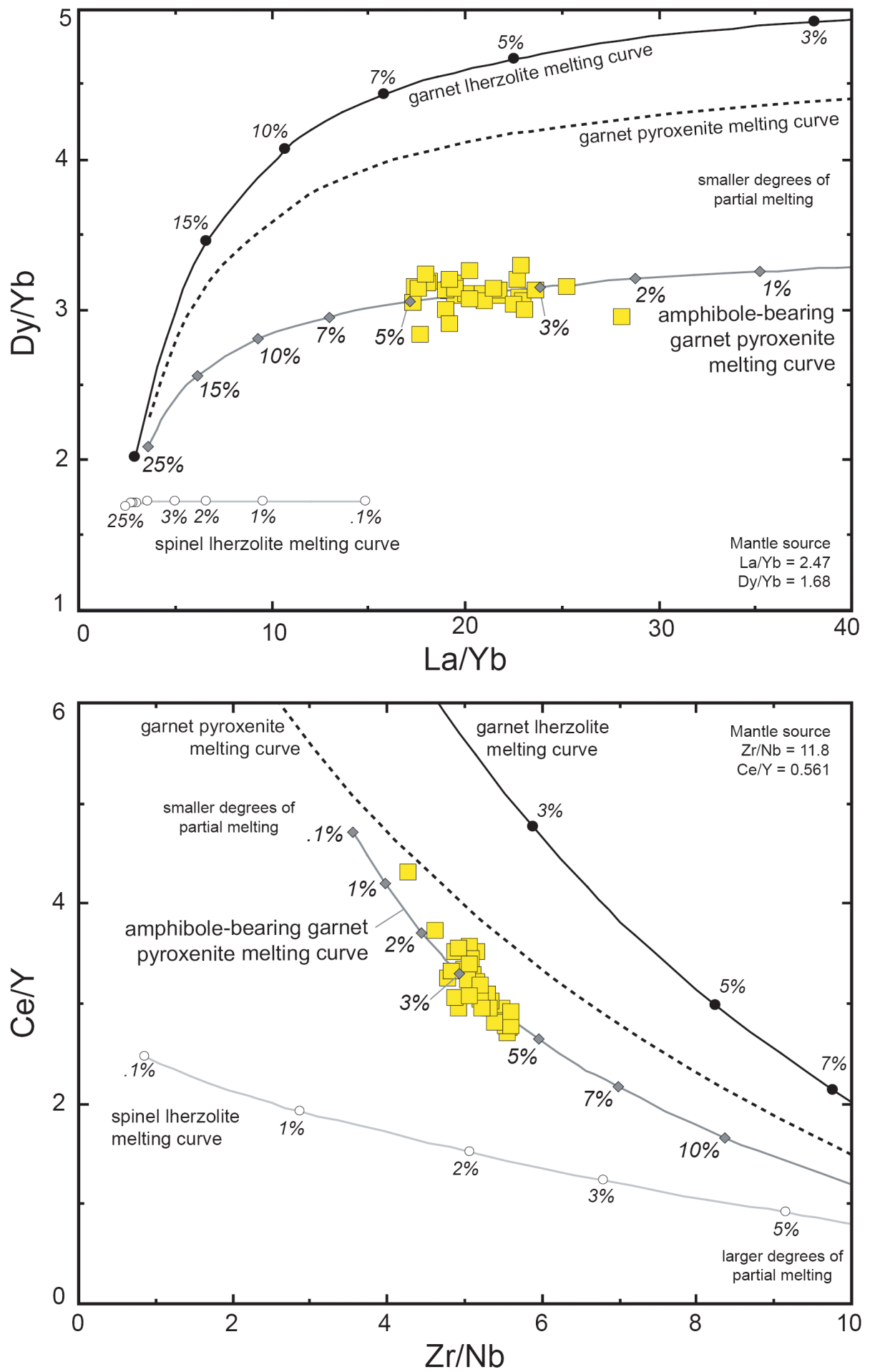

Figure 4.14: Calculated partial melting curves assuming non-modal fractional melting of spinel and garnet lherzolite (spinel lherzolite: $0.578 \mathrm{ol} ; 0.27 \mathrm{opx} ; 0.119 \mathrm{cpx} ; 0.033 \mathrm{sp}$ that melts in the proportions $0.1 \mathrm{ol} ; 0.27 \mathrm{opx} ; 0.5 \mathrm{cpx} ; 0.13 \mathrm{sp}$; garnet lherzolite: $0.598 \mathrm{ol} ; 0.211 \mathrm{opx} ; 0.115 \mathrm{cpx}$; 0.115 grt that melts in the proportions $0.05 \mathrm{ol} ; 0.2 \mathrm{opx} ; 0.3 \mathrm{cpx} ; 0.45$ grt; Thirlwall et al., 1994), garnet pyroxenite $(0.75 \mathrm{opx} ; 0.156 \mathrm{cpx} ; 0.115$ grt that melts in the proportions $0.25 \mathrm{opx} ; 0.3 \mathrm{cpx}$; $0.45 \mathrm{grt})$ and an amphibole-bearing garnet pyroxenite $(0.11 \mathrm{ol} ; 0.50 \mathrm{cpx} ; 0.20 \mathrm{cpx} ; 0.07 \mathrm{grt} ; 0.12$ amp that melts in the proportions $0.02 \mathrm{ol} ; 0.15 \mathrm{opx} ; 0.23 \mathrm{cpx} ; 0.25 \mathrm{grt} ; 0.35 \mathrm{amp})$. Modelling used distribution coefficients from McKenzie \& O'Nions (1991), Kelemen et al. (1993), Halliday et al. (1995), and Chazot et al. (1996). Modelling assumes the melting of a moderately enriched mantle source $(\mathrm{La}=0.974 \mathrm{ppm} ; \mathrm{Ce}=2.39 \mathrm{ppm} ; \mathrm{Dy}=0.662 \mathrm{ppm} ; \mathrm{Yb}=0.394 ; \mathrm{Y}=4.26 \mathrm{ppm} ; \mathrm{Zr}=13.1 \mathrm{ppm}$; $\mathrm{Nb}=1.12 \mathrm{ppm}$ ). Evolved and crustally contaminated samples with $\mathrm{SiO}_{2}>49 \mathrm{wt} \%$ have been excluded from this figure. 
Partial melt modelling of an amphibole-bearing garnet pyroxenite shows that: (1) the majority of Lookout Volcanic samples are consistent with ca. 2-5\% melting of an amphibole-bearing source; (2) the modal abundance of amphibole in this source is ca. 12\%; (3) the $\mathrm{Dy} / \mathrm{Yb}$ ratio of the melt which is normally strongly controlled by garnet due to the high compatibility of HREE in this phase, can be significantly lowered by the addition of amphibole because of the higher MREE compatibility in this phase; (4) the lower $\mathrm{Dy} / \mathrm{Yb}$ and higher $\mathrm{Zr} / \mathrm{Nb}$ ratio of the evolved and crustally contaminated samples within the suite can be accounted for by $15-25 \%$ bulk mixing with the Torlesse crust (not shown). It should be noted that the existence of small amounts of phlogopite in the mantle source is not precluded by this modelling.

\section{The existence of mantle heterogeneity?}

The least crustally contaminated samples in the Lookout Volcanics have initial isotope ratios of: ${ }^{87} \mathrm{Sr} /{ }^{86} \mathrm{Sr}_{\mathrm{i}}=0.70297-0.70314 ;{ }^{143} \mathrm{Nd} /{ }^{144} \mathrm{Nd}_{\mathrm{i}}=0.51272-0.51269 ;{ }^{176} \mathrm{Hf} /$ ${ }^{177} \mathrm{Hf}_{\mathrm{i}}=0.28283-0.28281 ;{ }^{206} \mathrm{~Pb} /{ }^{204} \mathrm{~Pb}_{\mathrm{i}}=20.32-19.67$. Thus, it appears that the Lookout Volcanics formed from a highly homogeneous HIMU-like mantle source $\left({ }^{206} \mathrm{~Pb} /{ }^{204} \mathrm{~Pb}_{\mathrm{i}}=20.0-20.3\right)$ with the majority of isotopic variability observed in these rocks $(60-80 \%)$ resulting from crustal contamination. Previously high-Si intraplate volcanic rocks from southern New Zealand have been suggested to result from mixing with an enriched lithospheric mantle component (Hoernle et al., 2006). However, the data presented here suggest the 'enriched mantle' signatures previously reported for high-Si intraplate volcanic rocks from the South Island actually represent a crustal contribution during magma ascent to the surface.

\section{The nature of the HIMU mantle source}

This study is the first to present oxygen isotope data for the HIMU-like volcanic rocks of New Zealand intraplate volcanism. Olivine phenocrysts in the Lookout Volcanics display lower $\delta^{18} \mathrm{O}$ values than crystals from a range of mantle peridotites (Mattey et al., 1994), but are consistent with values measured in 
phenocrysts from HIMU OIB (Eiler et al., 1997). Brown clinopyroxene phenocrysts within the Lookout Volcanics, however, exhibit anomalously low $\delta^{18} \mathrm{O}$ values due to interaction with meteoric water, so potential meteoric water perturbations of the olivine $\delta^{18} \mathrm{O}$ values must be considered. Two lines of evidence suggest that the olivines are unaffected by interaction with meteoric water. Firstly, the diffusion of oxygen in olivine is ca. 20 times slower than in clinopyroxene (Ryerson et al., 1989) meaning they are less susceptible to isotopic variations through interactions with groundwater. Secondly, the isotopic equilibrium between the olivine phenocrysts and green clinopyroxene cores in the most pristine sample $\left(\Delta_{\text {ol-cpx }}=-0.32\right.$ to $-0.56 \%$; AMG-8) suggest that the phenocrysts record magmatic equilibrium at ca. $1100^{\circ} \mathrm{C}$ (Kalamarides, 1986). Therefore the mantle source of HIMU continental intraplate volcanic rocks from Zealandia apparently has low $\delta^{18} \mathrm{O}$ values.

The infiltration of hydrous or carbonatitic fluids or low degree partial melts into normal peridotitic mantle causes enrichment of the mantle in incompatible trace elements. Such modification may result in the formation of new mineral phases such as amphibole or phlogopite and, more rarely, apatite, sulfides, carbonate and oxides, and these act as volatile-bearing phases in the metasomatised mantle (Ionov et al., 1997; Grégoire et al., 2000). High Zr/Hf ratios are a feature diagnostic of mantle metasomatism (Dupuy et al., 1992; Rudnick et al., 1993), with values ranging from ca. 45-100. All Lookout samples have higher $\mathrm{Zr} / \mathrm{Hf}$ (39.9-49.2) than the primitive mantle (37.1; McDonough \& Sun, 1995), suggesting the mantle source has experienced metasomatism.

Distinction between carbonate and silicate driven metasomatism can be made on the basis of the relative enrichment of REE to HFSE (e.g. Ti/Eu; Powell et al., 2004). Carbonate metasomatism is characterised by high $\mathrm{La}_{\mathrm{N}} / \mathrm{Yb}_{\mathrm{N}}(30-100)$ and low $\mathrm{Ti} / \mathrm{Eu}(<1000)$. This is inconsistent with the chemistry of the Lookout Volcanic basalts which exhibit relatively low $\mathrm{La}_{\mathrm{N}} / \mathrm{Yb}_{\mathrm{N}}(12.4-20.2)$ and high $\mathrm{Ti} / \mathrm{Eu}$ (> 8000). The mantle source of the Lookout Volcanics therefore requires the 
infiltration of silicate fluids or melts into their mantle source, consistent with the findings of Schiano \& Clocchiatti (1994) that volatile and silica-rich metasomatic melts are present throughout the lithospheric source regions of continental and oceanic intraplate magmas worldwide.

Metasomatism of the shallow mantle has been variously attributed to the interaction of asthenospheric melts from mantle plumes, or to the infiltration of fluids or melts derived from subducted oceanic lithosphere (Schiano et al., 1995; Baker et al., 1998; Larsen et al., 2003; Jiang et al., 2006; Gregoire et al., 2008). Although a mantle plume has been advocated to have played a role in the separation of Zealandia from Gondwana (Weaver et al., 1994; Storey et al., 1999), plume-related doming associated with a mantle plume in the mid-Cretaceous is absent from New Zealand and Marie Byrd Land (LeMasurier \& Landis, 1996) and the effect of the impingement of this mantle plume on the East Gondwana subduction zone is unresolved. However, subduction of the Phoenix Plate at the East Gondwana margin occurred almost continuously from ca. 320-110 Ma (Mukasa \& Dalziel, 2000) and resulted in the accretion of the basement terranes of eastern New Zealand. The infiltration of low degree partial melts from Si-rich subducted oceanic crust has been shown to result in the alteration of peridotites in the sub-arc mantle (Schiano et al., 1995). Mantle xenoliths may record multiple episodes of the infiltration of compositional diverse metasomatic fluids derived from subducted slabs (Gregoire et al., 2008). The longevity of the subduction zone in East Gondwana suggests that the repeated infiltration of slab derived melts could have produced a distinctive mantle source signature.

New Zealand intraplate magmas are thought to be derived from the lithospheric mantle on the basis of the following evidence: (1) the presence of residual hydrous phases in the source; (2) the long lived persistence of HIMU-like New Zealand intraplate magmas. Volatile-rich mineral phases such as amphibole and phlogopite are stable in the lithospheric mantle (Wallace \& Green, 1991; Foley, 1992) and have been found in mantle xenoliths (Ionov et al., 1997). 
However, at the temperatures of the convecting upper mantle or upwelling thermal plumes hydrous minerals are unstable and breakdown rapidly (Class \& Goldstein, 1997). Partial melting modelling and the geochemical characteristics of the Lookout Volcanics require the presence of amphibole as a residual phase in the mantle source of these samples and thus melting is consistent with a SCLM source. Mantle convection does not occur in the SCLM, which can therefore act as a rigid and chemical isolated entity over geological time (Hawkesworth \& Gallagher, 1993; Wilson et al., 1995). The persistence of the HIMU-like isotopic and trace element signature of the intraplate basalts in New Zealand that have been erupted intermittently over the last ca. $100 \mathrm{Ma}$ (Gamble et al., 1986; Baker et al., 1994; Price et al., 2003; Panter et al., 2006; Sprung et al., 2007) suggests the existence of a long-lived mantle heterogeneity. We propose that amphibolebearing garnet pyroxenite residing at the base of the SCLM experienced decompression melting during the extension of proto-New Zealand resulting in the eruption of the Lookout Volcanics.

Additional evidence that this reservoir resides in the SCLM is as follows: (1) volcanism on the Chatham Islands comprises three distinct periods- the Southern Volcanics (85-82 Ma), Northern Volcanics (41-36 Ma) and Rangitihi Volcanics (5 Ma) (Grindley et al., 1977; Panter et al., 2006) that all possess a HIMU signature $\left({ }^{206} \mathrm{~Pb} /{ }^{204} \mathrm{~Pb}>20.5\right)$. During the duration of this volcanic activity the Chatham Islands have drifted nearly $3000 \mathrm{~km}$ north (Eagles et al., 2004) without major changes in the source composition or depth of melting (Panter et al., 2006) suggesting strongly that this signature resides in the lithospheric mantle; and (2) basalts from nearby ocean islands (e.g. Macquarie; Kamenetsky et al., 2000) have consistently lower ${ }^{206} \mathrm{~Pb} /{ }^{204} \mathrm{~Pb}(19.0-19.5)$ showing that the radiogenic $\mathrm{Pb}$ signature in this region is restricted to continental basalts and therefore the source of this HIMU magmatism is inferred to reside in the SCLM. The Lookout Volcanics represent the oldest preserved example of HIMU volcanism in Zealandia and the continued production of volcanism intermittently over the last 
100 Ma during the $>3000 \mathrm{~km}$ northward migration of Zealandia constrains the source of the intraplate volcanism to the subcontinental lithospheric mantle.

\subsubsection{Implications for stable isotope studies of volcanic rocks}

The interpretation of anomalously low whole rock and phenocryst $\delta^{18} \mathrm{O}$ values has been variously ascribed to assimilation of hydrothermally altered crust (Gee et al., 1998; Eiler et al., 2000; Bindeman et al., 2006; Bindeman et al., 2008) or as a mantle signature with low $\delta^{18} \mathrm{O}$ reflecting crust-mantle recycling (Skovgaard et al., 2001; Maclennan et al., 2003; Stracke et al., 2003b; Macpherson et al., 2005). Although low $\delta^{18} \mathrm{O}$ values of Icelandic basalts have previously being attributed to crustal assimilation of hydrothermally altered crust, Thirlwall et al. (2006) showed that low $\delta^{18} \mathrm{O}$ values of some Icelandic lavas are a mantle signature, with low $\delta^{18} \mathrm{O}$ samples from the Reykjanes Ridge erupted significant below the influence of meteoric waters. However, Garcia et al. (2008) and Wang \& Eiler (2008) demonstrated that the low $\delta^{18} \mathrm{O}$ signature of some Hawaiian magmas results from the incorporation of basement rocks rather than heterogeneous and low $\delta^{18} \mathrm{O}$ recycled mantle components as previously suggested (Hauri, 1996; Lassiter \& Hauri, 1998).

The results presented in this study show that phenocrysts in Lookout Volcanic samples, preserve the effects of three distinct processes: (1) low mantle $\delta^{18} \mathrm{O}$; (2) the infiltration of meteoric waters; and (3) crustal contamination. Distinguishing between these effects is complicated by the successive overprinting of isotopic signatures.

Interpretation of low phenocryst $\delta^{18} \mathrm{O}$ values as mantle signatures is still controversial, but this study suggests that when selecting volcanic rocks to accurately constrain the oxygen isotopic composition of the mantle source the following should be considered. Firstly, low $\delta^{18} \mathrm{O}$ values can be imparted into phenocrysts through the interaction with meteoric waters at magmatic temperatures. Therefore multiple phenocryst phases should be analysed to 
confirm magmatic oxygen isotope equilibrium between phases. Secondly, phenocrysts can be scavenged from subcrustal magma chambers where their oxygen isotopic composition was perturbed due to meteoric waters or crustal contributions. To preclude the possibility that the isotopic signature of the melt has been modified by one of these processes, it is suggested that only microphenocrysts that can unequivocally be shown to have crystallised from the melt in which they were erupted should be analysed.

\subsection{CONCLUSIONS}

A detailed chemical and isotopic study of mid-Cretaceous (96 Ma) continental intraplate volcanism preserved as the Lookout Volcanics in Marlborough, South Island, New Zealand, erupted during the extension of proto-New Zealand has shown that:

1) None of the Lookout samples represent primary magmas with all having undergone the accumulation or fractional crystallisation of olivine + clinopyroxene \pm plagioclase $\pm \mathrm{Fe}-\mathrm{Ti}$ oxides

2) $\mathrm{Sr}-\mathrm{Nd}-\mathrm{Pb}$ isotopic variations in the samples although substantially less than exhibited by oceanic basalts can be explained by the assimilation of ca. 0 $30 \%$ of heterogeneous upper crustal rocks of the Torlesse Supergroup. The least contaminated samples of the Lookout Volcanics were produced by melting of a HIMU mantle source. Previously published suggestions of enriched mantle source contributions to New Zealand intraplate volcanic rocks are most likely erroneous and actually reflect crustal contamination.

3) Variations in MICE/VICE ratios that are unrelated to crustal contamination are predominantly the result of small degree partial melting ca. 2-5\% of an amphibole-bearing garnet pyroxenite source residing in the SCLM. This source was created through metasomatism of the base of the SCLM of East 
Gondwana by small degree partial melts derived from recycled oceanic lithosphere over $200 \mathrm{Ma}$ ago.

4) The HIMU mantle source of intraplate magmas from New Zealand is also characterised by low $\delta^{18} \mathrm{O}$ mantle that is found at other HIMU OIB localities. However, the resetting of phenocryst $\delta^{18} \mathrm{O}$ signatures due to interaction with meteoric water is a widespread process. The existence of well preserved phenocrysts should not alone be used to interpret the oxygen isotopic signature of phenocrysts as unequivocal evidence that a melt crystallised in equilibrium with the mantle. 


\section{CHAPTER 5: GEOCHRONOLOGY}

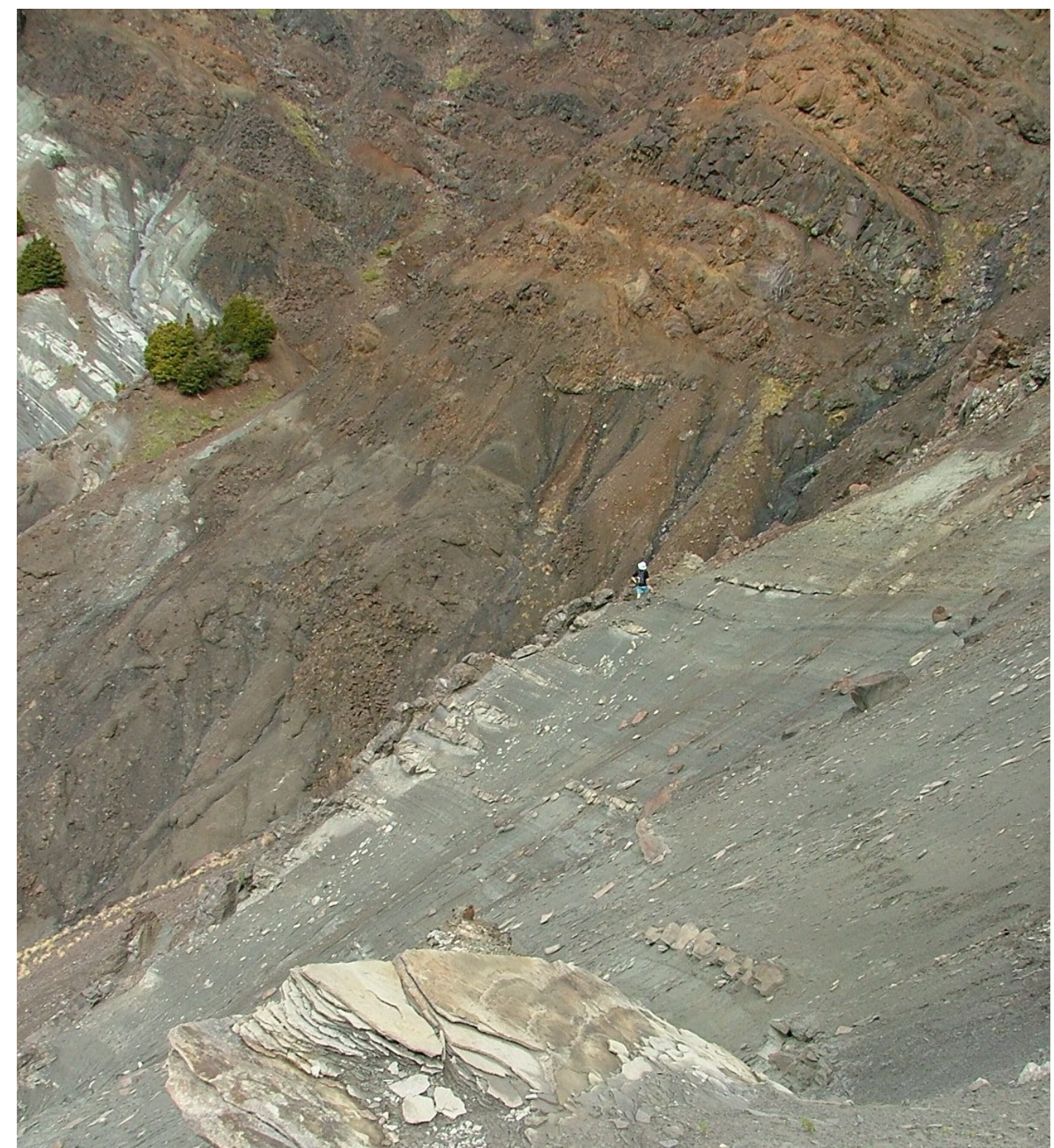

Plate 6: Interbedded sandstone-siltstone of the shallow marine Winterton Formation conformably overlain by basaltic lavas flows on the eastern flank of Mount Lookout. 


\subsection{INTRODUCTION}

This chapter presents new geochronological data for the Lookout Volcanics and the Blue Mountain Igneous Complex (BMIC). These age data allow the geochronology of the Lookout Volcanics and associated radial dyke swarm to be reviewed and the temporal relationship with other volcanism in the Central Marlborough Igneous Complex to be assessed. Ages presented here were calculated using Isoplot (Ludwig, 2000) and a decay constant of $1.42 \times 10^{-11} \mathrm{yr}^{-1}$ for ${ }^{87} \mathrm{Rb}$ (Steiger \& Jäger, 1977).

\subsection{STRATIGRAPHIC RELATIONSHIPS}

The basal lava package of the Lookout Volcanics is observed in numerous localities, displaying a sharp contact between the basal lava flow and underlying terrestrial sediments, which in turn rest on shallow marine sediments. The terrestrial sediments comprise sandstones, conglomerates and minor coal measures inferred to be of Ngaterian age (100-94 Ma). These are underlain by the Winterton Formation, an alternating sandstone-siltstone sequence of marine sedimentary rocks (Plate 6). Near the top of the formation indurated sandstone units contain Inoceramus ipuanus, a type fossil of the Motuan Stage (103.3-100.2 Ma; (Challis, 1960a). The top of the Lookout Formation near Limestone Stream consists of pillow lava interbedded with marine tuffs and limestone. The limestone is almost exclusively composed of Inoceramus tawhanus fragments, which is a fossil of the Ngaterian Stage (Challis, 1966). Thus on the basis of stratigraphic evidence the Lookout Volcanics are inferred to be entirely of Ngaterian age.

On the basis of stratigraphic evidence (Section 2.7) the Lookout Volcanics are believed to have been erupted from dykes of the radial dyke swarm. 
Therefore it is likely the dykes and volcanic rocks are contemporaneous. No stratigraphic evidence can be used to directly determine the age of the Tapuaeonuku Plutonic Complex (TPC). However, the plutonic complex can be inferred to post-date the dyke swarm and thus the Lookout Volcanics on the basis of stratigraphic relationships (Section 1.6.4).

\subsection{ERUPTION OF THE LOOKOUT VOLCANICS}

Previous work has used the K-Ar dating technique to provide age constraints on the eruption of the Lookout Volcanics. Nicol (1977) dated six trachybasalt lava flows which yielded ages from $99.9 \pm 0.7$ to $90.3 \pm 1.6 \mathrm{Ma}$. Five trachybasalts from the radial dyke swarm were also dated and produced a more restricted range from $96.4 \pm 1.9$ to $93.0 \pm 1.6 \mathrm{Ma}$ (George, 1988). Grapes et al. (1992) also report $\mathrm{K}$-Ar ages for 21 basanitic dykes in the regional swarm which range from $100.0 \pm$ 1.4 to $59.8 \pm 1.1 \mathrm{Ma}$.

\subsection{1 $\mathrm{Rb}-\mathrm{Sr}$ isochron ages}

A Rb-Sr isotopic investigation of the rocks and minerals (clinopyroxene and plagioclase) of the Lookout Volcanics was primarily undertaken to assess the mantle source of these magmas and examine the processes responsible for the diversity displayed by the erupted lava flows. However, Sr isotopic data for whole rocks and mineral separates has allowed the construction of "isochrons" to potentially date the rocks of the Lookout Volcanics. The isotopic data used to obtain ages are shown in Table 5.1 with calculated ages presented in Table 5.2.

\subsubsection{Interpretation of $\mathrm{Rb}-\mathrm{Sr}$ isochron ages}

Two sensible $\mathrm{Rb}$-Sr ages consistent with previous age data have been obtained from isochrons constructed using the most evolved samples in this study where the whole rock and minerals have significantly different $\mathrm{Rb} / \mathrm{Sr}$ ratios and measured ${ }^{87} \mathrm{Sr} /{ }^{86} \mathrm{Sr}$. 
Table 5.1: Rb-Sr isotopic data used in the construction of isochrons.

\begin{tabular}{lccc}
\hline Sample & Phase & ${ }^{87} \mathrm{Rb} /{ }^{86} \mathrm{Sr}$ & ${ }^{87} \mathrm{Sr} /{ }^{86} \mathrm{Sr}$ \\
\hline AMB-39 & whole rock & 0.0992 & $0.703138 \pm 13$ \\
& green cpx & 0.0003 & $0.703021 \pm 12$ \\
brown cpx & 0.0012 & $0.703047 \pm 10$ \\
AMB-54 & whole rock & 0.2666 & $0.703865 \pm 9$ \\
& green cpx & 0.0003 & $0.703240 \pm 14$ \\
& brown cpx & 0.0009 & $0.703532 \pm 10$ \\
plagioclase & 0.0000 & $0.703522 \pm 19$ \\
AMC-9 & whole rock & 0.1183 & $0.703329 \pm 11$ \\
& green cpx & 0.0006 & $0.703013 \pm 9$ \\
AMG-8 & brown cpx & 0.0023 & $0.703129 \pm 9$ \\
& whole rock & 0.1044 & $0.703183 \pm 10$ \\
& green cpx & 0.0006 & $0.703007 \pm 13$ \\
AMG-10 & brown cpx & 0.0023 & $0.703022 \pm 9$ \\
& whole rock & 0.1044 & $0.704293 \pm 12$ \\
& brown cpx b & 0.0069 & $0.703839 \pm 8$ \\
& plagioclase & 0.0000 & $0.703676 \pm 21$ \\
\hline
\end{tabular}

$\mathrm{The} \mathrm{Rb} / \mathrm{Sr}$ of ratio of whole rock powders was measured using ICP-MS, the $\mathrm{Rb} / \mathrm{Sr}$ ratio of clinopyroxene phenocrysts was taken from LA-ICP-MS, and the $\mathrm{Rb} / \mathrm{Sr}$ ratio of plagioclase was assumed at $1 \times 10^{-5}$ on the basis of the very incompatible nature of $\mathrm{Rb}$ in plagioclase. A $1 \%$ error was assumed and used on ${ }^{87} \mathrm{Rb} /{ }^{86} \mathrm{Sr}$ during calculations on the basis of repeated measurements of the $\mathrm{Rb} / \mathrm{Sr}$ ratio of duplicate digestions of BCR-2 (Table A1.6).

Table 5.2: Calculated Rb-Sr ages for the Lookout Volcanics.

\begin{tabular}{|c|c|c|c|}
\hline Sample & Rock Type & Phases & Age \\
\hline AMB-39 & basalt & $\begin{array}{l}\text { whole rock, green cpx } \\
\text { whole rock, brown cpx }\end{array}$ & $\begin{array}{l}84 \pm 12 \mathrm{Ma} \\
66 \pm 12 \mathrm{Ma}\end{array}$ \\
\hline AMB-54 & $\begin{array}{c}\text { basaltic } \\
\text { trachyandesite }\end{array}$ & $\begin{array}{c}\text { whole rock, green cpx } \\
\text { whole rock, brown cpx } \\
\text { whole rock, brown cpx, plagioclase }\end{array}$ & $\begin{aligned} & 165.2 \pm 4.6 \mathrm{Ma} \\
& 88.4 \pm 3.6 \mathrm{Ma} \\
& 88.8 \pm 3.4 \mathrm{Ma} \\
&{ }^{87} \mathrm{Sr} /{ }^{86} \mathrm{Sr}_{\text {initial }}=0.703529 \pm 9\end{aligned}$ \\
\hline AMC-9 & basalt & $\begin{array}{l}\text { whole rock, green cpx } \\
\text { whole rock, brown cpx }\end{array}$ & $\begin{array}{l}188.8 \pm 8.5 \mathrm{Ma} \\
122.2 \pm 8.6 \mathrm{Ma}\end{array}$ \\
\hline AMG-8 & basalt & $\begin{array}{l}\text { whole rock, green cpx } \\
\text { whole rock, brown cpx }\end{array}$ & $\begin{array}{c}119 \pm 11 \mathrm{Ma} \\
111.4 \pm 9.2 \mathrm{Ma}\end{array}$ \\
\hline AMG-10 & $\begin{array}{c}\text { basaltic } \\
\text { trachyandesite }\end{array}$ & $\begin{array}{c}\text { whole rock, brown cpx } \\
\text { whole rock, brown cpx, plagioclase }\end{array}$ & $\begin{array}{c}97.6 \pm 3.2 \mathrm{Ma} \\
{ }^{87} \mathrm{Sr} /{ }^{86} \mathrm{Sr}_{\text {initial }}=0.703830 \pm 8 \\
102 \pm 280 \mathrm{Ma}\end{array}$ \\
\hline
\end{tabular}

Ages in bold represent the most accurate age constraints placed on the eruption of the Lookout Volcanics from work in this study. Ages in italics are considered erroneous for reasons explained in Section 5.3.2.

The initiation of volcanism is dated at the base of Section G (i.e. AMG-10) at 97.6 \pm 3.2 Ma. The youngest eruptive unit sampled in this study, AMB-54 at the top of 
Section B, has been dated at $88.8 \pm 3.4 \mathrm{Ma}$. This suggests a time span of volcanism of $8.8 \pm 4.4 \mathrm{Ma}$ consistent with the variation reported by Nicol (1977). Age data have been plotted on the composite volcanic stratigraphy (Figure 5.1), and the consistency of these ages with the relative position of the lavas in the eruptive sequence provides some confidence in these ages.

The erroneous age when plagioclase was included in the AMG-10 isochron is attributed to the Sr isotopic composition being modified by secondary calcite. Evidence to support this conclusion comes from the oxygen isotopic composition of plagioclase in AMG-10 $\left(\delta^{18} \mathrm{O}=22.4 \%\right.$ o which can only be generated by a significant percentage of calcite in the phenocrysts.

The ability to obtain accurate $\mathrm{Rb}$-Sr whole rock-mineral age relies on (1) significant variations in the $\mathrm{Rb} / \mathrm{Sr}$ ratios of the whole rock and minerals to produce variations in the amount of radiogenic ${ }^{87} \mathrm{Sr}$ ingrowth with time; (2) the premise that the mineral phases have all, at the same time been in equilibrium with each other and the melt now represent by the groundmass of the rock. The low $\mathrm{Rb} / \mathrm{Sr}$ ratios of the whole rocks in the basaltic samples make it difficult to construct accurate isochrons. The existence of isotopic equilibrium between large phenocrysts in highly porphyritic rocks and their groundmass is also questionable within the Lookout Volcanics. It is likely that this compromises most of the ages presented in Table 5.2.

\subsubsection{Crystal-groundmass disequilibrium}

The highly porphyritic rocks of the Lookout Volcanics contain large strongly zoned clinopyroxene phenocrysts. The cores (green) and rims (brown) of these phenocrysts were picked from crushed material and analysed separately. Green cores of phenocrysts generally have lower ${ }^{87} \mathrm{Sr} /{ }^{86} \mathrm{Sr}$ isotopic compositions than their respective rims, although these are within error in some cases. This isotopic disequilibrium causes the $\mathrm{Rb}-\mathrm{Sr}$ ages calculated using the green clinopyroxene analyses to be more erroneous than those calculated with brown clinopyroxene because the rims are closer to magmatic equilibrium with the groundmass. 


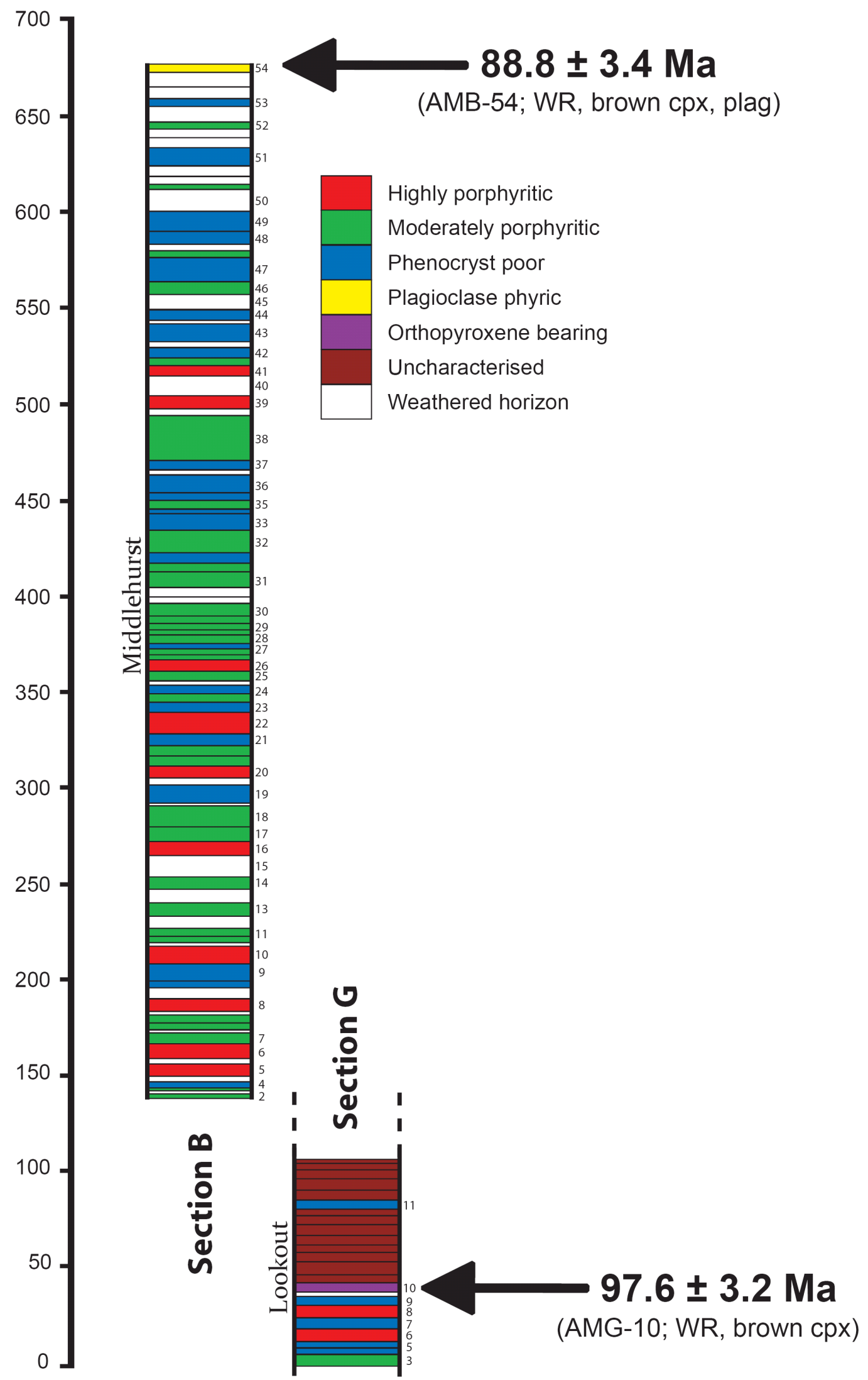

Figure 5.1: Partial composite volcanic stratigraphy of the Lookout Volcanics with new Rb-Sr ages superimposed. Description of rock types can be found in Chapter 3. Weathered horizons contain altered volcanic material which is confirmed as being volcanic by the presence of unaltered clinopyroxene phenocrysts. Abbreviations: WR: whole rock; plag: plagioclase; cpx: clinopyroxene. 
Calculated ages, however, can still be inaccurate due to the small $\mathrm{Rb} / \mathrm{Sr}$ variations in the constituents of the porphyritic basaltic rocks. In the most porphyritic rock for which ages were calculated (AMB-39), the green clinopyroxene age is more realistic suggesting that due to the large proportion of mafic phenocrysts in this sample the primitive cores are closer to being in isotopic equilibrium with the whole rock composition.

\subsubsection{Limitations of the dating results}

The small variability in the $\mathrm{Rb} / \mathrm{Sr}$ ratios of the minerals found in the lavas of the Lookout Volcanics mean that these ages are not sufficiently accurate to precisely constrain the eruption of the Lookout Volcanics. The lack of high $\mathrm{Rb} / \mathrm{Sr}$ (i.e. mica) mineral phases throughout the suite limits the age resolution producible using the $\mathrm{Rb}-\mathrm{Sr}$ dating method.

Additionally crystal-whole rock disequilibrium can bias calculated Rb-Sr ages. Although sample AMB-54 yields a sensible $\mathrm{Rb}-\mathrm{Sr}$ age there are visible signs of disequilibrium in this sample (i.e. relict olivine and two types of clinopyroxene), thus this age could potentially be erroneous. However, there is no evidence for magmatic disequilibrium in AMG-10 and thus this age is considered robust.

\subsection{BLUE MOUNTAIN IGNEOUS COMPLEX}

A study of a sample from the Blue Mountain Igneous Complex was also carried out. The sample used in this study was the olivine gabbro SC-9 from the Victoria University teaching collection. Isotopic results and the calculated age are shown in Table 5.3. These data are presented here due to the relevance of this age to further constraining the timing of mid-Cretaceous volcanism in the Marlborough region. 
Table 5.3: Calculated Rb-Sr age for the Blue Mountain Igneous Complex.

\begin{tabular}{ccc}
\hline Analysis & ${ }^{87} \mathrm{Rb} /{ }^{86} \mathrm{Sr}$ & ${ }^{87} \mathrm{Sr} /{ }^{86} \mathrm{Sr}$ \\
\hline plagioclase & $0.0273 \pm 3$ & $0.703189 \pm 20$ \\
whole rock & $0.0720 \pm 7$ & $0.703255 \pm 20$ \\
clinopyroxene & $0.0804 \pm 8$ & $0.703270 \pm 20$ \\
biotite 1 & $7.610 \pm 76$ & $0.713682 \pm 20$ \\
biotite 2 & $8.662 \pm 87$ & $0.715085 \pm 20$ \\
\hline
\end{tabular}

Age: $\quad 97.1 \pm 0.7 \mathrm{Ma}$

${ }^{87} \mathrm{Sr} /{ }^{86} \mathrm{Sr}_{\text {initial }}=0.70316 \pm 1 ; \mathrm{MSWD}=0.22 ;$ probability $=0.88$

\subsection{GEOLOGICAL IMPLICATIONS}

Table 5.4 presents radiometric age constraints on the igneous components of the Central Marlborough Igneous Complex.

\subsubsection{Comment on $\mathrm{K}-\mathrm{Ar}$ ages}

$\mathrm{K}$-Ar ages are susceptible to the addition or loss of $\mathrm{K}$ in altered volcanic rocks.

The K-Ar ages of 100 to 60 Ma reported by Grapes et al. (1992) for the regional dyke swarm were interpreted as reflecting an extended period (40 Myr) of magmatic activity. However, Baker et al. (1994) considered the younger ages to be the result of post crystallisation Ar loss as many of the dykes are highly altered

Table 5.4: Age constraints on volcanism in the Central Marlborough Igneous Province.

\begin{tabular}{|c|c|c|c|}
\hline Igneous Complex & Age (Ma) & Method & Reference \\
\hline \multirow[t]{2}{*}{ Lookout Volcanics } & $\begin{array}{c}97.6 \pm 3.2 \text { to } \\
88.8 \pm 3.4\end{array}$ & $\mathrm{Rb}-\mathrm{Sr}$ & This study \\
\hline & $\begin{array}{c}99.9 \pm 0.7 \text { to } \\
90.3 \pm 1.6\end{array}$ & $\mathrm{~K}-\mathrm{Ar}$ & Nicol (1977) \\
\hline Gridiron Volcanics & $\begin{array}{c}98.3 \pm 1.3 \text { to } \\
93.5 \pm 2.0\end{array}$ & $\mathrm{~K}-\mathrm{Ar}$ & Reay (1993) \\
\hline Radial dyke swarm & $\begin{array}{c}96.4 \pm 1.9 \text { to } \\
93.0 \pm 1.6\end{array}$ & $\mathrm{~K}-\mathrm{Ar}$ & George (1988) \\
\hline $\begin{array}{l}\text { Tapuaeouenuku Plutonic } \\
\text { Complex (TPC) }\end{array}$ & $96.1 \pm 0.5$ & $\mathrm{Rb}-\mathrm{Sr}$ & $\begin{array}{l}\text { Baker \& Seward } \\
\quad(1996)\end{array}$ \\
\hline $\begin{array}{l}\text { Blue Mountain Igneous } \\
\text { Complex (BMIC) }\end{array}$ & $97.1 \pm 0.7$ & $\mathrm{Rb}-\mathrm{Sr}$ & This study \\
\hline $\begin{array}{l}\text { Mandamus Igneous } \\
\text { Complex (MIC) }\end{array}$ & $97.2 \pm 1.2$ & $\mathrm{Rb}-\mathrm{Sr}$ & $\begin{array}{c}\text { Weaver \& Pankhurst } \\
\text { (1991) }\end{array}$ \\
\hline
\end{tabular}


and fine grained compared with their eruptive equivalents and are likely to have been susceptible to loss of radiogenically produced Ar from the groundmass and alteration products. The ages presented by Nicol (1977) suggest eruption of the Lookout Volcanics over a period of ca. 9 Ma. However if radiogenic Ar loss has occurred in these samples, which is a possibility as the trachybasalts are generally fine-grained and partially weathered samples, the time span of eruption could be significantly shorter.

\subsubsection{Rapid volcanism in the mid-Cretaceous?}

During the three week period spent in the Awatere Valley no significant paleosols or evidence of a hiatus accompanied by erosion was visible within the lava flows of the Lookout Volcanics. If the Lookout Volcanics were erupted over a ca. 9 Myr period significant soil development would be expected, thus it is considered that $9 \mathrm{Ma}$ is significantly too long for this eruptive episode. The TPC, BMIC and MIC have now been Rb-Sr dated to within 1 Myr of each other (Table 5.4), which means they are statistically the same age (i.e. within error). Thus the plutonic complexes constrain the initiation of volcanism in the CMIP to ca. 97 Ma.

The volcanic rocks of the Lookout Formation are more difficult to accurately date, however, the large $\left(25-35 \mathrm{~km}^{2}\right)$ intraplate basaltic shield volcanoes of Dunedin and Banks Peninsula provide an analogue of the Lookout Volcanics. The Dunedin Volcano was erupted intermittently in the late Middle Miocene (13-10 Ma; McDougall \& Coombs, 1973; Coombs et al., 1986). At Banks Peninsula volcanism occurred for a more extended period in the Late Miocene (11.0-5.8 Ma; Weaver et al., 1985). However, the two major shield volcanoes the Lyttelton volcano (11.0-9.7 Ma) and Akoroa volcano (9.1-8.0 Ma) were erupted over periods of ca. 1-2 Ma (Sewell et al., 1992). On the basis of the radiometric age evidence presented here and constraints from other large shield volcanoes it is speculated that the Lookout Volcanics were erupted rapidly from ca. 98-96 Ma 
accompanying the simultaneous intrusion of three plutonic complexes between northern Marlborough and North Canterbury.

To test this hypothesis it is suggested that high precision $\mathrm{U}-\mathrm{Pb}$ isotopic analyses are undertaken to date the Lookout and Gridiron Volcanics and the plutonic complexes. Although susceptible to the same disequilibrium effects as $\mathrm{Rb}$ - $\mathrm{Sr}$ dating, there are greater differences in $\mathrm{U}-\mathrm{Pb}$ partitioning between minerals with, for example Nicol (1977) reporting that there are trachyandesites containing apatite (a high $\mathrm{U} / \mathrm{Pb}$ phase) within the formation. 


\section{CHAPTER 6: SYNTHESIS \& CONCLUSIONS}

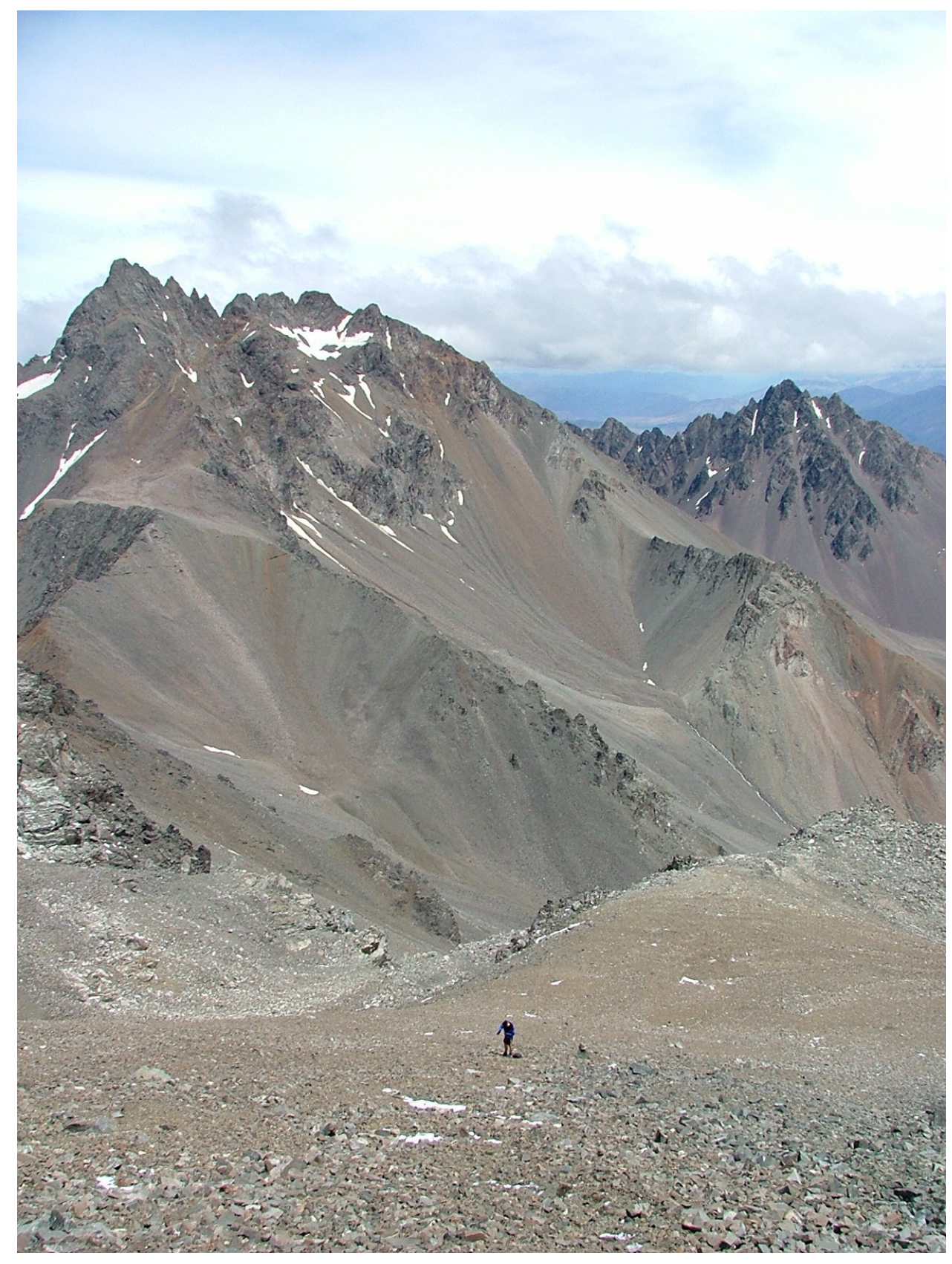

Plate 7: Nearing the summit of Mount Tapuaeouenuku (2885 m) with Mount Alarm (2877 m) and Mitre Peak (2621 m) in the background. 


\subsection{SYNTHESIS}

The Lookout Volcanics are the remnants of an extensive sheet of mid-Cretaceous intraplate volcanic rocks, preserved in a fault angle depression bounded by the Awatere Fault, Marlborough, South Island, New Zealand. Based on the remaining outcrops in Awatere and Clarence valleys the pre-erosion eruptive volume may have been ca. $1500 \mathrm{~km}^{3}$. The Lookout Volcanics are part of the Central Marlborough Igneous Complex (CMIP) a collection of mid-Cretaceous alkaline igneous complexes that outcrop from northern Marlborough to North Canterbury. Volcanism occurred during the initial extension of Zealandia prior to final separation from Gondwana at ca. $84 \mathrm{Ma}$. The igneous rocks of the Inland Kaikoura Region are unique in that the coeval plutonic (e.g. Tapuaeouenuku Plutonic Complex), hypabyssal (e.g. regional dyke swarm covering an area of ca. $300 \mathrm{~km}^{2}$ ) and volcanic rocks (e.g. Lookout Volcanics) are exposed due to tilting and block faulting initiated in the Miocene.

Field Geology: The Lookout Volcanics crop out in the middle Awatere Valley covering an area of ca. $50 \mathrm{~km}^{2}$. The majority of the formation is restricted to the Mount Lookout area where exposed thicknesses of lava flows are $>1000 \mathrm{~m}$. Lava flows are dominantly terrestrial (ca. 95\%) but at the top of the volcanic section pillow basalts are interspersed with limestone suggesting submergence during emplacement of the eruptive sequence. The volcanic rocks are inferred to have been emplaced by fissure eruptions from the dykes of the coeval regional swarm on the basis of stratigraphic evidence. A composite volcanic stratigraphy of ca. $700 \mathrm{~m}$ comprising 103 samples has been constructed largely based on a continuous $500 \mathrm{~m}$ section in Middlehurst Stream. Correlation between volcanic sections is difficult due to the lack of distinctive marker horizons, however, sections have been placed in relative stratigraphic height based on field relationships. 
Geochronology: On the basis of stratigraphic evidence the Lookout Volcanics are inferred to be entirely of Ngaterian age. New $\mathrm{Rb}$-Sr age constraints on the Lookout Volcanics (AMG-10; 97.6 \pm 3.2 Ma) and the Blue Mountain Igneous Complex $(97.1 \pm 0.7 \mathrm{Ma})$ are in agreement with previous $\mathrm{Rb}-\mathrm{Sr}$ isochron ages of plutonic complexes in the CMIP (Weaver \& Pankhurst, 1991; Baker \& Seward, 1996). K-Ar ages that suggest an extended period of volcanism c. $10 \mathrm{Ma}$ for the emplacement of the Lookout Volcanics are considered erroneous due to: (1) highK fine grained rocks (i.e. Lookout trachybasalts) being susceptible to K mobility during alteration; (2) the absence of significant soil development or evidence of erosion between lava flows is indicative of the rapid accumulation of volcanic material. Thus it is hypothesised on the basis of the new ages presented here that the Lookout Volcanics were rapidly erupted from ca. 98-96 Ma concurrently with the intrusion of the plutonic complexes of the CMIP during the initial extension of proto-New Zealand.

Classification and Petrography: The Lookout Volcanics comprise a suite of predominantly alkaline mafic basalts. The rocks have been divided into seven petrographic types on the basis of their phenocryst content and assemblage. The main rock types (Type I-IV; 94\% of samples) form a continuum between highly porphyritic basalts (ca. $40 \%$ phenocrysts) with subequal proportions of large olivine + clinopyroxene to almost aphyric basalts (<1\% phenocrysts) with minor clinopyroxene + plagioclase. Unusual rock types include: plagioclase phyric trachybasalt-basaltic trachyandesite (Type V); highly porphyritic basalt containing ca. $40 \%$ large honeycombed plagioclase phenocrysts (Type VI); and moderately porphyritc basaltic trachyandesite containing phenocrysts of orthopyroxene (Type VII; AMG-10).

The majority of rocks are nepheline normative (i.e. alkaline), contain $<52 \mathrm{wt}$ $\% \mathrm{SiO}_{2}$ and are classified as follows: basalt (44); picrobasalt (3); basanite (1); and trachybasalt (3). The most evolved samples are hypersthene normative and can be classified as basaltic trachyandesites (2; shoshonites). 
Mineral Chemistry: Large clinopyroxene phenocrysts display distinct compositional growth zoning. Green clinopyroxene cores have $\mathrm{Mg \#}>85$ and are $\mathrm{Cr}-\mathrm{Si}$ rich and $\mathrm{Ti}-\mathrm{Al}$ poor, whereas brown clinopyroxene rims have $\mathrm{Mg \#}<82$ and are $\mathrm{Ti}-\mathrm{Al}$ rich and $\mathrm{Cr}-\mathrm{Si}$ poor. These variations are interpreted to result from continuous crystal growth on the walls or floor of a solidifying magma chamber, in which the intercumulus melt became progressively enriched in those elements incompatible in the fractionating assemblage (i.e. $\mathrm{Al}+\mathrm{Ti}$ in olivine + clinopyroxene). Clinopyroxenes in the more evolved samples, however, are compositionally distinct displaying consistently high Si and low Ti-Al-Cr. The initiation of orthopyroxene crystallisation in the evolved sample AMG-10 requires the Si-saturation of this magma. The addition of crustal material is required to rapidly convert magmas from $\mathrm{Si}$-undersaturated (i.e. alkaline) to $\mathrm{Si}$ saturated.

Olivine phenocrysts in the Lookout Volcanics have NiO contents greater than olivine phenocrysts from normal MORB and comparable or slightly lower than those of olivine phenocrysts from Hawaiian OIB. The elevated Ni contents of Hawaiian basalts have been shown to be the result of melting a secondary pyroxenite bearing mantle source (Sobolev et al., 2005). Thus the elevated Ni contents of olivines in the Lookout Volcanics are consistent with generation from a partially pyroxenitic mantle source. Using the calculations of Sobolev et al. (2007) the proportion of pyroxenite in the mantle source of the Lookout Volcanics is ca. $50 \%$.

A LA-ICP-MS study has shown that on a crystal and sub-crystal scale clinopyroxene phenocrysts record changes in magma chemistry. Strongly negative $\mathrm{Sr}$ and $\mathrm{Ti}$ anomalies are related to the fractionation of plagioclase and Fe-Ti oxides, respectively. Increasing incompatible element concentrations including $\mathrm{Pb}$ during crystal growth in the most evolved magmas are attributed to crustal contributions. Furthermore, results presented here are analogous to recent studies showing the partitioning of HFSE and REE in clinopyroxene are 
strongly controlled by clinopyroxene tetrahedral $\mathrm{Al}_{2} \mathrm{O}_{3}\left({ }^{\mathrm{IV}} \mathrm{Al}\right)$ content (e.g. Lundstrom et al., 1998; Wood \& Trigila, 2001; Wood \& Blundy, 2003).

Fractional Crystallisation: None of the Lookout Volcanic samples are considered to be primary basalts with all having undergone the fractional crystallisation or accumulation of olivine + clinopyroxene \pm plagioclase $\pm \mathrm{Fe}-\mathrm{Ti}$ oxides. Rocks with $\mathrm{MgO}>8 \mathrm{wt} \%$ can be modelled by the accumulation of up to $40 \%$ ol + cpx in subequal proportions. Rocks with 4-7 wt \% MgO are consistent with the fractional crystallisation of an assemblage comprising $80 \%$ clinopyroxene and 20\% olivine. With decreasing $\mathrm{MgO}$ the Lookout samples exhibit increasing $\mathrm{Al}_{2} \mathrm{O}_{3}$ suggesting plagioclase fractionation is minor. In samples with $\mathrm{MgO}<5$ wt $\%, \mathrm{Fe}_{2} \mathrm{O}_{3}$ and $\mathrm{TiO}_{2}$ begin to decrease rapidly consistent with the crystallisation of Fe-Ti oxides. Trace elements concentrations are consistent with $\mathrm{Ni}, \mathrm{Cr}$ and Sc decreasing during the crystallisation of clinopyroxene + olivine. In the most evolved sample (AMG-10) Sr decreases due to the fractionation of plagioclase.

Crustal Contamination: Correlated variations between radiogenic isotope and incompatible trace element ratios (i.e. $\mathrm{Nd} / \mathrm{Pb}$ ) within the Lookout Volcanics are related to variable crustal contributions to these magmas. Initial $\mathrm{Sr}-\mathrm{Nd}-\mathrm{Hf}-\mathrm{Pb}$ isotopic variations $\left({ }^{87} \mathrm{Sr} /{ }^{86} \mathrm{Sr}=0.7030-0.7039 ;{ }^{143} \mathrm{Nd} /{ }^{144} \mathrm{Nd}=0.51272-0.51264\right.$; $\left.{ }^{176} \mathrm{Hf} /{ }^{177} \mathrm{Hf}=0.28283-0.28278 ;{ }^{206} \mathrm{~Pb} /{ }^{204} \mathrm{~Pb}=20.32-18.82\right)$ are the result of mixing between melts of a HIMU-like mantle component, and up to 25-30\% of an Early Cretaceous upper crustal component. However, the majority of the samples require only minor crustal contributions of ca. 1-5\%. The crustal assimilant (Pahau Terrane greywacke) is required to be isotopically heterogeneous with respect to $\mathrm{Pb}$ isotopes to account for the isotopic variation observed in the Lookout Volcanic samples. Previously high-Si intraplate volcanic rocks from southern New Zealand have been suggested to result from mixing with an enriched lithospheric mantle component (Hoernle et al., 2006). However, the data presented here suggest the 'enriched mantle' signatures previously reported 
for high-Si intraplate volcanic rocks from the South Island actually represent a crustal contribution during magma ascent to the surface.

Partial Melting: Significant variations in VICE/MICE ratios suggest the Lookout Volcanics are the result of variable small degree partial melts, and MREE/HREE ratios > 2 (e.g. Dy/Yb) are consistent with melting in the garnet stability field. However, partial melt modelling of a standard garnet lherzolite or garnet pyroxenite is inconsistent with the range in $\mathrm{Ce} / \mathrm{Y}$ at a restricted range of $\mathrm{Zr} / \mathrm{Nb}$ and the low $\mathrm{Dy} / \mathrm{Yb}$ exhibited by the Lookout Volcanic samples. Negative $\mathrm{K}$ anomalies and low $\mathrm{Rb} / \mathrm{Sr}$ and high $\mathrm{Ba} / \mathrm{Nb}$ ratios are consistent with melts that contain amphibole in their mantle source. Modelling of an amphibole bearing garnet pyroxenite produces the following results: (1) magmas of the Lookout Volcanics can be produced by ca. 2-5\% melting of an amphibole bearing garnet pyroxenite; (2) this source requires a significant proportion of amphibole (ca. $14 \%$ ) and only a small amount of garnet (ca. $6 \%$ ) to produce the low $\mathrm{Dy} / \mathrm{Yb}$ of the Lookout Volcanic samples.

Oxygen Isotopes: Laser fluorination oxygen isotope analyses of phenocrysts from 6 lava flows of the Lookout Volcanics yielded $\delta^{18} \mathrm{O}=4.7-5.0 \%$ o for olivine, 4.8-5.4\%o in green clinopyroxene cores and 3.9-5.5\%o in brown clinopyroxene rims. Olivine $\delta^{18} \mathrm{O}$ values are lower than those of normal mantle peridotites but are, however, consistent with HIMU OIB (i.e. St Helena). At magmatic temperatures isotopic equilibrium between olivine and green clinopyroxene cores (e.g. AMG-8) suggests the Lookout Volcanics mantle source has low $\delta^{18} \mathrm{O}$. However, phenocrysts also record the effects of crustal assimilation, with the $\delta^{18} \mathrm{O}$ values of green clinopyroxene (5.4\%o) and plagioclase (7.7\%o) in AMB-54 being consistent with crustal contributions of $6 \%$ and $24 \%$, respectively. Thus phenocryst growth is consistent with the progressive crustal contamination of this magma. Additionally, oxygen isotopic disequilibrium exists between the cores and rims of clinopyroxene phenocrysts in Lookout Volcanic samples. This negative disequilibrium is the result of crystal growth in a shallow crustal magma 
chamber with an active meteoric water system. Phenocrysts were scavenged by dykes penetrating the pluton and erupted in the lavas of the Lookout Volcanics. The interpretation of brown clinopyroxene phenocryst $\delta^{18} \mathrm{O}$ in the Lookout Volcanics is considered equivocal. These results highlight the fact that interpretation of mineral $\delta^{18} \mathrm{O}$ values as a mantle signature is severely complicated by processes operating in the crust.

Mantle source characterisation: Primitive Lookout Volcanic samples $\left({ }^{87} \mathrm{Sr} /{ }^{86} \mathrm{Sr}_{\mathrm{i}}\right.$ $<0.7032$ ) have present day model mantle source ${ }^{206} \mathrm{~Pb} /{ }^{204} \mathrm{~Pb}$ values of $19.92-20.57$ consistent with a HIMU source region. This source is homogenous with the observed isotopic variations primarily related to small crustal contributions $(<$ $5 \%$ ). The presence of residual amphibole in the mantle source of these magmas requires melting to have occurred in the hydrous SCLM. The formation of the HIMU signature of these magmas is attributed to metasomatism at the base of the SCLM by Si-rich partial melts derived from subducted oceanic lithosphere. The eastern margin of Gondwana experienced continuous subduction for ca. $200 \mathrm{Ma}$ prior to the eruption of the Lookout Volcanics introducing ample material for the subduction driven metasomatism of the SCLM. No substantive evidence requiring the presence of a mantle plume exists and therefore plume related metasomtism has been discounted. The melts of the Lookout Volcanics are inferred to have been generated by the melting of amphibole-bearing pyroxenitic veins at the base of the SCLM.

\subsection{CONCLUSIONS}

A detailed chemical and isotopic study of mid-Cretaceous continental intraplate volcanism preserved as the Lookout Volcanics in Marlborough, South Island, New Zealand, erupted during the extension of proto-New Zealand has shown that: 
1) The lack of unconformities or evidence of significant soil development between lava flows in the Lookout Formation suggests a rapid accumulation of volcanic material. New Rb-Sr ages for the Lookout Volcanics and Blue Mountain Igneous Complex are speculated to be consistent with a rapid period of volcanic activity from ca. 98-96 Ma during the initial extension of proto-New Zealand.

2) Lookout Volcanic samples do not represent primary magmas with all having undergone the accumulation or fractional crystallisation of olivine + clinopyroxene \pm plagioclase $\pm \mathrm{Fe}$-Ti oxides.

3) Sr- $\mathrm{Nd}-\mathrm{Pb}$ isotopic variations are consistent with the assimilation of up to 25$30 \%$ of heterogeneous upper crustal rocks of the Pahau Terrane (Torlesse Supergroup). The least contaminated samples of the Lookout Volcanics were produced by melting of a HIMU mantle source $\left({ }^{206} \mathrm{~Pb} /{ }^{204} \mathrm{~Pb}=20.2\right.$ 20.6). Previous suggestion of an enriched mantle source contribution to New Zealand intraplate volcanic rocks are most likely erroneous and reflect crustal contamination.

4) Variations in MICE/VICE ratios that are unrelated to crustal contamination are dominantly the result of variable small degree partial melts ca. $2-5 \%$ of an amphibole-bearing garnet pyroxenite source residing in the hydrous SCLM. Moreover, the elevated $\mathrm{NiO}$ contents of Lookout Volcanic olivines are consistent with melting of a pyroxenitic source. This source was created through metasomatism of the base of the SCLM of East Gondwana by small degree partial melts derived from recycled oceanic lithosphere over $200 \mathrm{Ma}$ ago.

5) The HIMU mantle source of intraplate magmas from New Zealand is also characterised by low $\delta^{18} \mathrm{O}$ mantle that is found at other HIMU OIB localities. However, the resetting of clinopyroxene rim $\delta^{18} \mathrm{O}$ signatures due to interaction with meteoric water is a widespread process. 


\subsection{SUGGESTIONS FOR FUTURE WORK}

The data acquired and ideas proposed in this thesis lend themselves to further study to be properly tested. Some recommendations for further study are summarised below:

1) Although field relationships are consistent with the rapid eruption of the Lookout Volcanics this has not been unequivocally proven with radiometric methods. Lookout Volcanic samples are difficult to date with conventional $\mathrm{Rb}$-Sr methods due to a small $\mathrm{Rb}$-Sr variations and crystal-groundmass disequilibrium effects, although disequilibrium effects are minimal in the most evolved samples. Nicol (1977) reported that apatite-bearing trachyandesites are present within the formation. Due to the greater differences in $\mathrm{U}-\mathrm{Pb}$ partitioning between minerals (especially apatite) it is suggested high precision $\mathrm{Pb}$ isotopic analyses are undertaken on these samples to constrain the eruption of the Lookout Volcanics.

2) The Gridiron Volcanics are temporally related to the Lookout Volcanics and may represent the remnants of the same volcanic episode. High precision $\mathrm{Sr}-\mathrm{Nd}-\mathrm{Hf}-\mathrm{Pb}$ isotopic analysis of the Gridiron Volcanics is suggested to: (a) constrain the mantle source of the Gridiron Volcanics; and (b) confirm whether these rocks are the product of a single eruptive episode (i.e. $\mathrm{Pb}$ isotopic dating).

3) Crustal contributions of between $0-30 \%$ account for the isotopic variability exhibited by the Lookout Volcanics, however, the exact isotopic composition of the contaminant (i.e. rocks of the Pahau Terrane) is poorly constrained. Currently there is a paucity of $\mathrm{Pb}$ and $\mathrm{Hf}$ isotopic data for crustal samples from the South Island. To better constrain crustal assimilation processes it is recommended that collection of a range of samples from the Pahau Terrane rocks in Awatere Valley is undertaken and these samples are analysed for Sr-Nd-Hf-Pb isotopes. 
4) The LA-ICP-MS data of clinopyroxene phenocrysts presented here has shown that clinopyroxene provides an excellent record of changes in magma chemistry. It is suggested that a more detailed LA-ICP-MS study of zoned clinopyroxene phenocrysts from Lookout Volcanic samples should be undertaken, with the aim of constructing diffusion profiles across these crystals. These profiles will provide insights into subcrustal magmatic processes, such as magma recharge rates and crystal residence times.

5) The oxygen isotope results presented here show the effects of two crustal processes (i.e. crustal contamination and meteoric water infiltration). Detailed study of the effects of these processes on oxygen isotopes, in combination with crystal residence times from diffusion profiles would provide constraints on the rates of these processes. The following avenues of study are recommended: (a) larger populations of phenocrysts from representative samples should be analysed to assess heterogeneity within the crystal population; (b) in situ analysis of zoned clinopyroxene phenocrysts could be undertaken using the secondary ion microprobe technique to assess the timescales of the meteoric water processes; (c) more phenocrysts should be analysed in the evolved samples to constrain the rate at which crustal contamination occurs.

6) Partial melting modelling in this study requires the presence of amphibole in the mantle source of the Lookout Volcanics. If mantle xenoliths could be found in Lookout Volcanics or other intraplate volcanic rocks in Zealandia it would be possible to test this hypothesis too see if they have the appropriate mineralogy, chemistry and isotopic signatures. 


\section{REFERENCES}

Adam, J., Green, T. H., \& Sie, S. H. (1993). Proton microprobe determined partitioning of Rb, Sr, $\mathrm{Ba}, \mathrm{Y}, \mathrm{Zr}, \mathrm{Nb}$ and $\mathrm{Ta}$ between experimentally produced amphiboles and silicate melts with variable F content. Chemical Geology, 109(1-4), 29-49.

Adams, C. J. (1981). Migration of late Cenozoic volcanism in the South Island of New Zealand and the Campbell Plateau Nature, 294(5837), 153-155.

Adams, C. J. (1983). Age of the volcanoes and granite basement of the Auckland Islands, southwest Pacific. New Zealand Journal of Geology and Geophysics, 26, 227-237.

Adams, C. J., \& Cooper, A. F. (1996). K-Ar age of a lamprophyre dike swarm near Lake Wanaka, west Otago, South Island, New Zealand. New Zealand Journal of Geology and Geophysics, 39, 17-23.

Adams, C. J., Morris, P. A., \& Beggs, J. M. (1979). Age and correlation of volcanic rocks of Campbell Island and metamorphic basement of the Campbell Plateau, southwest Pacific. New Zealand Journal of Geology and Geophysics, 22, 679-691.

Adams, C. J., Pankhurst, R. J., Maas, R., \& Millar, I. L. (2005). Nd and Sr isotopic signatures of metasedimentary rocks around the South Pacific margin and implications for their provenance. Geological Society, London, Special Publications, 246(1), 113-141.

Albarède, F. (1995). Introduction to geochemical modelling: Cambridge University Press. 524 pp.

Allan, A. S. R., Baker, J. A., Carter, L., \& Wysoczanski, R. J. (2008). Reconstructing the Quaternary evolution of the wolrd's most active silicic volcanic system: insights from a 1.65 Ma deep ocean tephra record sourced from Taupo Volcanic Zone, New Zealand. Quaternary Science Reviews, 27, 2341-2360.

Allan, J. F., Sack, R. O., \& Batiza, R. (1988). Cr-rich spinels as petrogenetic indicators: MORB-type lavas from the Lamont seamount chain, eastern Pacific. American Mineralogist, 73, 741753.

Allen, A. D. (1962). The stratigraphy and structure of the Middle Awatere Valley (S35). Unpublished M.Sc. thesis lodged at Victoria University of Wellington, Wellington, New Zealand. pp. 64.

Arai, S. (1994a). Characterization of spinel peridotites by olivine-spinel compositional relationships: review and interpretation. Chemical Geology, 113(3-4), 191-204.

Arai, S. (1994b). Compositional variation of olivine-chromian spinel in Mg-rich magmas as a guide to their residual spinel peridotites. Journal of Volcanology and Geothermal Research, 59(4), 279-293.

Baker, J. A. (1990). The geology of the western margin of the Tapuaenuku Plutonic Complex, Marlborough, New Zealand. Unpublished M.Sc. thesis lodged at Victoria University of Wellington, Wellington, New Zealand. pp. 214.

Baker, J. A. (1996). Stratigraphy, geochronology and geochemistry of Cenozoic volcanism in western Yemen. Unpublished Ph.D. thesis lodged at Royal Holloway University of London, London, England. pp. 386.

Baker, J. A., Chazot, G., Menzies, M. A., \& Thirlwall, M. F. (1998). Metasomatism of the shallow mantle beneath Yemen by the Afar Plume: implications for mantle plumes, flood volcanism, and intraplate volcanism. Geology, 26(5), 431-434. 
Baker, J. A., Gamble, J. A., \& Graham, I. J. (1994). The age, geology, and geochemistry of the Tapuaenuku Igneous Complex, Marlborough, New Zealand. New Zealand Journal of Geology and Geophysics, 37(3), 249-268.

Baker, J. A., Macpherson, C. G., Menzies, M. A., Thirlwall, M. F., Al-Kadasi, M., \& Mattey, D. P. (2000). Resolving crustal and mantle contributions to continental flood volcanism, Yemen: Constraints from mineral oxygen isotope data. Journal of Petrology, 41(12), 18051820.

Baker, J. A., Menzies, M. A., Thirlwall, M. F., \& Macpherson, C. G. (1997). Petrogenesis of Quaternary intraplate volcanism, Sana'a, Yemen: implications for plume-lithospheric interaction and polybaric melt hybridisation. Journal of Petrology, 38, 1359-1390.

Baker, J. A., Peate, D., Waight, T. E., \& Meyzen, C. (2004). Pb isotopic analysis of standards and samples using a ${ }^{207} \mathrm{~Pb}_{-}{ }^{204} \mathrm{~Pb}$ double spike and thallium to correct for mass bias with a double focusing MC-ICP-MS. Chemical Geology, 211, 275-303.

Baker, J. A., \& Seward, D. (1996). Timing of Cretaceous extension and Miocene compression in northeast South Island, New Zealand: constraints from Rb-Sr and fission-track dating of an igneous pluton. Tectonics, 15(5), 976-983.

Baker, J. A., Thirlwall, M. F., \& Menzies, M. A. (1996). Sr-Nd-Pb isotopic and trace element evidence for crustal contamination of plume-derived flood basalts: Oligocene flood volcanism in western Yemen. Geochimica et Cosmochimica Acta, 60(14), 2559-2581.

Baker, J. A., Waight, T. E., \& Ulfbeck, D. G. (2002). Rapid and highly reproducible analysis of rare earth elements by multiple collector inductively coupled plasma mass spectrometry. Geochimica et Cosmochimica Acta, 66(20), 3635-3646.

Ballhaus, C., Berry, R. F., \& Green, D. H. (1991). High pressure experimental calibration of the olivine-orthopyroxene-spinel oxygen geobarometer: implications for the oxidation state of the upper mantle. Contributions to Mineralogy and Petrology, 107, 27-40.

Barker, P. F. (1982). The Cenozoic subduction history of the Pacific margin of the Antarctic Peninsula: ridge crest-trench interactions. Geological Society of London Journal, 139, 787-801.

Barley, M. E. (1987). Origin and evolution of mid-Cretaceous garnet-bearing, intermediate and silicic volcanics from Canterbury, New Zealand. Journal of Volcanology and Geothermal Research, 32, 247-264.

Barley, M. E., Weaver, S. D., \& de Laeter, J. R. (1988). Strontium isotope composition and geochronology of intermediate silicic volcanics, Mt Somers and Banks Peninsula, New Zealand. New Zealand Journal of Geology and Geophysics, 31, 197-206.

Barnes, S. J., \& Roeder, P. L. (2001). The range of spinel compositions in terrestrial mafic and ultramafic rocks. Journal of Petrology, 42(12), 2279-2302.

Barreiro, B. A., \& Cooper, A. F. (1987). A Sr, Nd, Pb isotope study of alkaline lampropyres and related rocks from Westland and Otago, South Island, New Zealand. Geological Society of America special paper, 215.

Barron, E. J., Fawcett, P. J., Peterson, W. H., Pollard, D., \& Thompson, S. L. (1995). A "simulation" of mid-Cretaceous climate. Paleoceanography, 10(5), 953-962.

Barron, E. J., Hay, W. W., \& Thompson, S. (1989). The hydrologic cycle, a major variable during Earth history. Palaeogeography, Palaeoclimatology, Palaeoecology, 75(3), 157-174.

Bibby, H. M. (1976). Crustal strain across the Marlborough faults, New Zealand. New Zealand Journal of Geology and Geophysics, 19, 407-425. 
Bindeman, I. N., Gurenko, A., Sigmarsson, O., \& Chaussidon, M. (2008). Oxygen isotope heterogeneity and disequilibria of olivine crystals in large volume Holocene basalts from Iceland: evidence for magmatic digestion and erosion of Pleistocene hyaloclastites. Geochimica et Cosmochimica Acta, 72(17), 4397-4420.

Bindeman, I. N., Sigmarsson, O., \& Eiler, J. (2006). Time constraints on the origin of large volume basalts derived from $\mathrm{O}$-isotope and trace element mineral zoning and $\mathrm{U}$-series disequilibria in the Laki and Grímsvötn volcanic system. Earth and Planetary Science Letters, 245(1-2), 245-259.

Bizzarro, M., Baker, J. A., \& Ulfbeck, D. (2003). A new digestion and chemical separation technique for rapid and highly reproducible determination of $\mathrm{Lu} / \mathrm{Hf}$ and $\mathrm{Hf}$ isotope ratios in geological materials by MC-ICP-MS. Geostandards Newsletter: The Journal of Geostandards and Geoanalysis, 27(2), 133-145.

Blattner, P., \& Reid, F. (1982). The origin of lavas and ignimbrites of the Taupo Volcanic Zone, New Zealand, in the light of oxygen isotope data. Geochimica et Cosmochimica Acta, $46(8), 1417-1429$.

Blundy, J. D., Wood, B. J., \& Davies, A. (1996). Thermodynamics of rare earth element partitioning between clinopyroxene and melt in the system $\mathrm{CaO}-\mathrm{MgO}-\mathrm{Al}_{2} \mathrm{O}_{3}-\mathrm{SiO}_{2}$. Geochimica et Cosmochimica Acta, 60(2), 359-364.

Bouvier, A., Vervoort, J. D., \& Patchett, P. J. (2008). The Lu-Hf and Sm-Nd isotopic composition of CHUR: Constraints from unequilibrated chondrites and implications for the bulk composition of terrestrial planets. Earth and Planetary Science Letters, 273(1-2), 48-57.

Bradshaw, J. D. (1989). Cretaceous geotectonic patterns in the New Zealand region. Tectonics, $8(4), 803-820$.

Brenan, J. M., Shaw, H. F., Ryerson, F. J., \& Phinney, D. L. (1995). Experimental determination of trace-element partitioning between pargasite and a synthetic hydrous andesitic melt. Earth and Planetary Science Letters, 135(1-4), 1-11.

Burgisser, A., \& Scaillet, B. (2007). Redox evolution of a degassing magma rising to the surface. Nature, 445(7124), 194-197.

Castillo, P. R., Natland, J. H., Niu, Y., \& Lonsdale, P. F. (1998). Sr, Nd and Pb isotopic variation along the Pacific-Antarctic rise crest, $53-57^{\circ} \mathrm{S}$ : implications for the composition and dynamics of the South Pacific upper mantle. Earth and Planetary Science Letters, 154(14), 109-125.

Chaffey, D. J., Cliff, R. A., \& Wilson, B. M. (1989). Characterisation of the St Helena magma source. Geological Society of London Special Publication, 42, 257-276.

Challis, G. A. (1960a). The structure and petrology of the Mount Lookout area, Awatere Valley, New Zealand. Unpublished M.Sc. thesis lodged at Victoria University of Wellington, Wellington, New Zealand. pp. 217.

Challis, G. A. (1960b). Igneous rocks in the Cape Palliser area. New Zealand Journal of Geology and Geophysics, 3(3), 524-542.

Challis, G. A. (1961). Post-intrusion deformation of a dyke swarm, Awatere Valley, New Zealand. Geological Magazine, 98, 441-448.

Challis, G. A. (1966). Cretaceous stratigraphy and structure of the Mount Lookout area, Awatere Valley. Transactions of the Royal Society of New Zealand, 4, 119-137.

Chauvel, C., \& Blichert-Toft, J. (2001). A hafnium isotope and trace element perspective on melting of the depleted mantle. Earth and Planetary Science Letters, 190(3-4), 137-151. 
Chauvel, C., Hofmann, A. W., \& Vidal, P. (1992). HIMU-EM: the French Polynesian connection. Earth and Planetary Science Letters, 110(1-4), 99-119.

Chauvel, C., McDonough, W. F., Guille, G., Maury, R. C., \& Duncan, R. A. (1997). Contrasting old and young volcanism in the Rurutu Islands, Austral Chain. Chemical Geology, 139, 125143.

Chazot, G., Menzies, M. A., \& Harte, B. (1996). Determination of partition coefficients between apatite, clinopyroxene, amphibole, and melt in natural spinel lherzolites from Yemen: implications for wet melting of the lithospheric mantle. Geochimica et Cosmochimica Acta, 60(3), 423-437.

Claeson, D. T., Meurer, W. P., Hogmalm, K. J., \& Larson, S. A. (2007). Using LA-ICPMS mapping and sector zonation to understand growth and trace-element partitioning in sector-zoned clinopyroxene oikocrysts from the Norra Ulvo Gabbro, Sweden. Journal of Petrology, $48(4), 711-728$.

Clarke, L. J., \& Jenkyns, H. C. (1999). New oxygen isotope evidence for long-term Cretaceous climatic changes in the Southern Hemisphere. Geology, 27(8), 699-702.

Class, C., \& Goldstein, S. L. (1997). Plume-lithosphere interactions in the ocean basins: constraints from the source mineralogy. Earth and Planetary Science Letters, 150(3-4), 245-260.

Coffin, M. F., \& Eldholm, O. (1992). Volcanism and continental break-up: a global compilation of large igneous provinces. In B. C. Storey, T. Alabaster \& R. J. Pankhurst (Eds.), Magmatism and the causes of continental breakup (Vol. 68, pp. 17-30): Geological Society of London Special Publication.

Connelly, J. N., Ulfbeck, D. G., Thrane, K., Bizzarro, M., \& Housh, T. (2006). A method for purifying $\mathrm{Lu}$ and $\mathrm{Hf}$ for analyses by MC-ICP-MS using TODGA resin. Chemical Geology, 233(1-2), 126-136.

Cook, C., Briggs, R. M., Smith, I. E. M., \& Maas, R. (2005). Petrology and geochemistry of intraplate basalts in the South Auckland Volcanic Field, New Zealand: evidence for two coeval magma suites from distinct sources. Journal of Petrology, 46(3), 473-503.

Coombs, D. S., Cas, R. A., Kawachi, Y., Landis, C. A., McDonough, W. F., \& Reay, A. (1986). Cenozoic volcanism in north, east and central Otago. Royal Society of New Zealand Bulletin, 23, 278-312.

Cooper, A. F. (1986). A carbonatitic lamprophyre dike swarm from the Southern Alps, Otago and Westland. In I. E. M. Smith (Ed.), Late Cenozoic volcanism in New Zealand (Vol. 23, pp. 313-336): Royal Society of New Zealand - Bulletin.

Cooper, A. F., Barreiro, B. A., Kimbrough, D. L., \& Mattinson, J. M. (1987). Lamprophyre dike intrusion and the age of the Alpine Fault, New Zealand. Geology, 15(10), 941-944.

Crampton, J. S., Laird, M. G., Nicol, A., Townsend, D. B., \& Van Dissen, R. (2003). Palinspastic reconstructions of southeastern Marlborough, New Zealand, for mid-Cretaceous-Eocene times. New Zealand Journal of Geology and Geophysics, 46, 153-175.

Cullen, D. J. (1969). Quaternary volcanism at the Antipodes Islands: its bearing on structural interpretation of the southwest Pacific. Journal of Geophysical Research, 74, 4213-4220.

Dallai, L., Ghezzo, C., \& Longinelli, A. (2001). Fossil hydrothermal systems tracking Eocene climate change in Antarctica. Geology, 29(10), 931-934.

Dalziel, I. W. D., Lawver, L. A., \& Murphy, J. B. (2000). Plumes, orogenesis, and supercontinental fragmentation. Earth and Planetary Science Letters, 178, 1-11.

Dansgaard, W. (1964). Stable isotopes in precipitation. Tellus, 16(4), 436. 
Davy, B. W. (1984). Bounty Trough. Geological Society of New Zealand Annual Conference Abstract. Geological Society of New Zealand Miscellaneous Publication 31A.

De Paolo, D. J. (1981). Trace element and isotopic effects of combined wallrock assimilation and fractional crystallization. Earth and Planetary Science Letters, 53(2), 189-202.

DeMets, C., Gordon, R. G., Argus, D. F., \& Stein, S. (1990). Current plate motions. Geophysical Journal International, 101, 425-478.

DeMets, C., Gordon, R. G., Argus, D. F., \& Stein, S. (1994). Effect of recent revisions to the geomagnetic reversal timescale on estimates of current plate motions. Geophysical Research Letters, 21, 2191-2194.

Demouchy, S., Jacobsen, S. D., Gaillard, F., \& Stern, C. R. (2006). Rapid magma ascent recorded by water diffusion profiles in mantle olivine. Geology, 34(6), 429-432.

Devey, C. W., \& Cox, K. G. (1987). Relationships between crustal contamination and crystallisation in continental flood basalt magmas with special reference to the Deccan Traps of the Western Ghats, India. Earth and Planetary Science Letters, 84(1), 59-68.

Dick, H. J., \& Bullen, T. (1984). Chromian spinel as a petrogenetic indicator in abyssal and alpinetype peridotites and spatially associated lavas. Contributions to Mineralogy and Petrology, 86, 54-76.

Dupuy, C., Liotard, J. M., \& Dostal, J. (1992). Zr/Hf fractionation in intraplate basaltic rocks: carbonate metasomatism in the mantle source. Geochimica et Cosmochimica Acta, 56(6), 2417-2423.

Eagles, G., Gohl, K., \& Larter, R. D. (2004). High-resolution animated tectonic reconstruction of the South Pacific and West Antarctic margin. Geochemistry Geophysics Geosystems, 5, Q07002, doi:10.1029/2003GC000657

Eggins, S. M., Kinsley, L. P. J., \& Shelley, J. M. G. (1998). Deposition and element fractionation processes during atmospheric pressure laser sampling for analysis by ICP-MS. Applied Surface Science, 129, 278-286

Eggins, S. M., Woodhead, J. D., Kinsley, L. P. J., Mortimer, G. E., Sylvester, P., McCulloch, M. T., Hergt, J. M., \& Handler, M. R. (1997). A simple method for the precise determination of $\geq$ 40 trace elements in geological samples by ICPMS using enriched isotope internal standardisation. Chemical Geology, 134(4), 311-326.

Eiler, J. M., Farley, K. A., Valley, J. W., Hauri, E., Craig, H., Hart, S. R., \& Stopler, E. M. (1997). Oxygen isotope variations in ocean island basalt phenocrysts. Geochimica et Cosmochimica Acta, 61(11), 2281-2293

Eiler, J. M., Farley, K. A., Valley, J. W., Stolper, E. M., Hauri, E. H., \& Craig, H. (1995). Oxygen isotope evidence against bulk recycled sediment in the mantle sources of Pitcairn Island lavas. Nature, 377(6545), 138-141.

Eiler, J. M., Gronvold, K., \& Kitchen, N. (2000). Oxygen isotope evidence for the origin of chemical variations in lavas from Theistareykir volcano in Iceland's Northern Volcanic Zone. Earth and Planetary Science Letters, 184, 269-286.

Eisele, J., Sharma, M., Galer, S. J. G., Blichert-Toft, J., Devey, C. W., \& Hofmann, A. W. (2002). The role of sediment recycling in EM-1 inferred from $\mathrm{Os}, \mathrm{Pb}, \mathrm{Hf}, \mathrm{Nd}$, $\mathrm{Sr}$ isotope and trace element systematics of the Pitcairn hotspot. Earth and Planetary Science Letters, 196(34), 197-212.

Ferguson, A. K. (1978). Ca-enrichment in olivines from volcanic rocks. Lithos, 45, 189-194. 
Finn, C. A., Muller, R. D., \& Panter, K. S. (2005). A Cenozoic diffuse alkaline magmatic province (DAMP) in the southwest Pacific without rift or plume origin. Geochemistry Geophysics Geosystems, 6, Q02005, doi:10.1029/2004GC000723.

Foley, S. (1992). Vein-plus-wall-rock melting mechanisms in the lithosphere and the origin of potassic alkaline magmas. Lithos, 28(3-6), 435-453.

Forsythe, L. M., Nielsen, R. L., \& Fisk, M. R. (1994). High-field-strength element partitioning between pyroxene and basaltic to dacitic magmas. Chemical Geology, 117(1-4), 107-125.

Francis, D., \& Minarik, W. (2008). Aluminium-dependent trace element partitioning in clinopyroxene. Contributions to Mineralogy and Petrology, 156, 439-451.

Fujii, T., \& Scarfe, C. M. (1985). Composition of liquids coexisting with spinel lherzolite at 10-kb and the genesis of MORBs. Contributions to Mineralogy and Petrology, 90, 18-28.

Furman, T., \& Graham, D. (1999). Erosion of lithospheric mantle beneath the East African Rift system: geochemical evidence from the Kivu volcanic province. Lithos, 48(1-4), 237-262.

Gaetani, G. A., \& Grove, T. L. (1995). Partitioning of rare earth elements between clinopyroxene and silicate melt: crystal-chemical controls. Geochimica et Cosmochimica Acta, 59(10), 1951-1962.

Gaffney, A. M., Nelson, B. K., \& Blichert-Toft, J. (2004). Geochemical constraints on the role of oceanic lithosphere in intra-volcano heterogeneity at West Maui, Hawaii. Journal of Petrology, 45, 1663-1687.

Gallagher, K., \& Hawkesworth, C. (1992). Dehydration melting and the generation of continental flood basalts. Nature, 358(6381), 57-59.

Gallahan, W. E., \& Nielsen, R. L. (1992). The partitioning of Sc, Y, and the rare earth elements between high-Ca pyroxene and natural mafic to intermediate lavas at 1 atmosphere. Geochimica et Cosmochimica Acta, 56(6), 2387-2404.

Gamble, J. A., \& Adams, C. J. (1985). Volcanic geology of the Carnley volcano, Auckland Islands. New Zealand Journal of Geology and Geophysics, 28, 43-54.

Gamble, J. A., Morris, P. A., \& Adams, C. J. (1986). The geology, petrology and geochemistry of Cenozoic volcanic rocks from the Campbell Plateau and Chatham Rise. In I. E. M. Smith (Ed.), Late Cenozoic volcanism in New Zealand (Vol. 23, pp. 344-365). Royal Society of New Zealand Bulletin.

Gamble, J. A., Smith, I. E. M., Graham, I. J., Kokelaar, B. P., Cole, J. W., Houghton, B. F., \& Wilson, C. J. N. (1990). The petrology, phase relations and tectonic setting of basalts from the Taupo Volcanic Zone, New Zealand and Kermadec Island Arc - Harve Trough, SW Pacific. Journal of Volcanology and Geothermal Research, 43, 235-270.

Garcia, M. O., Ito, E., \& Eiler, J. M. (2008). Oxygen isotope evidence for chemical interaction of Kiauea historical magmas with basement rocks. Journal of Petrology, 49(4), 757-769.

Gee, M. A. M., Thirlwall, M. F., Taylor, R. N., Lowry, D., \& Murton, B. J. (1998). Crustal processes: major controls on Reykjanes Peninsula lava chemistry, SW Iceland. Journal of Petrology, 39, 819-839.

Geochemical Earth Reference Model (GERM) website. (2008). Depleted MORB mantle reservoir database. Retrieved 15/08/2008, from www.earthref.org/GERM

Georem (Max Planck Institute) website. (2008). Geological and environmental reference materials database. Retrieved 10/6/2008, from www.georem.mpch-mainz.gwdg.de/ 
George, A. D. (1988). Accretionary prism rocks of Torlesse Terrane Western Aorangi Range Cape Palliser, New Zealand. Victoria University of Wellington, Wellington, New Zealand. pp. 184.

Graham, I. J., Gulson, B. L., Hedenquist, J. W., \& Mizon, K. (1992). Petrogenesis of Late Cenozoic volcanic rocks from the Taupo Volcanic Zone, New Zealand, in the light of new lead isotope data. Geochimica et Cosmochimica Acta, 56(7), 2797-2819.

Grapes, R. H. (1970). A petrological study of the Kaiwhata Sill, Ngahape, East Wairarapa, New Zealand. Transactions of the Royal Society of New Zealand, 10, 177-196.

Grapes, R. H. (1972). Petrology of the Blue Mountain Igneous Complex, Marlborough, New Zealand. Victoria University of Wellington, Wellington, New Zealand. pp. 236.

Grapes, R. H. (1975). Petrology of the Blue Mountain Igneous Complex, Marlborough, New Zealand. Journal of Petrology, 16, 371-428.

Grapes, R. H., Lamb, S. H., \& Adams, C. J. (1992). K-Ar ages of basanitic dikes, Awatere Valley, Marlborough, New Zealand. New Zealand Journal of Geology and Geophysics, 35, 415419.

Grégoire, M., Jego, S., Maury, R. C., Polve, M., Payot, B., Tamayo Jr, R. A., \& Yumul Jr, G. P. (2008). Metasomatic interactions between slab-derived melts and depleted mantle: insights from xenoliths within Monglo adakite (Luzon arc, Philippines). Lithos, 103(3-4), 415-430.

Grégoire, M., Lorand, J. P., O'Reilly, S. Y., \& Cottin, J. Y. (2000). Armalcolite-bearing, Ti-rich metasomatic assemblages in harzburgitic xenoliths from the Kerguelen Islands: implications for the oceanic mantle budget of high-field strength elements. Geochimica et Cosmochimica Acta, 64(4), 673-694.

Gregory, R. T., Criss, R. E., \& Taylor Jr, H. P. (1989). Oxygen isotope exchange kinetics of mineral pairs in closed and open systems: applications to problems of hydrothermal alteration of igneous rocks and Precambrian iron formations. Chemical Geology, 75(1-2), 1-42.

Grindley, G. W., Adams, C. J., Lumb, J. T., \& Watters, W. A. (1977). Paleomagnetism, K-Ar dating and tectonic interpretation of Upper Cretaceous and Cenozoic volcanic rocks of the Chatham Islands, New Zealand. New Zealand Journal of Geology and Geophysics, 20, 425-467.

Grobys, J. W. G., Gohl, K., Davy, B., Uenzelmann-Neben, G., Deen, T., \& Barker, D. (2007). Is the Bounty Trough off eastern New Zealand an aborted rift? Journal of Geophysical Research-Solid Earth, 112, B03103, doi:10.1029/2005JB004229.

Hall, W. D. M. (1962). The geology of the Coverham and upper Waima Valley, Marlborough. Unpublished M.Sc. thesis lodged at Victoria University of Wellington, Wellington, New Zealand. pp. 82.

Halliday, A. N., Lee, D. C., Tommasini, S., Davies, G. R., Paslick, C. R., Fitton, G. J., \& Dodie, J. E. (1995). Incompatible trace elements in OIB and MORB and source enrichment in the sub-oceanic mantle. Earth and Planetary Science Letters, 133(3-4), 379-395.

Harris, C., \& Chaumba, J. B. (2001). Crustal contamination and fluid-rock interaction during the formation of the Platreef, northern limb of the Bushveld Complex, South Africa. Journal of Petrology, 42(7), 1321-1347.

Hart, S. R. (1984). A large-scale isotope anomaly in the Southern Hemisphere mantle. Nature, 309, 753-757. 
Hart, S. R., \& Davis, K. E. (1978). Nickel partitioning between olivine and silicate melt. Earth and Planetary Science Letters, 4O(2), 203-219.

Hart, S. R., Hauri, E. H., Oschmann, L. A., \& Whitehead, J. A. (1992). Mantle plumes and entrainment: isotopic evidence. Science, 256(5056), 517-520.

Hauri, E. H. (1996). Major-element variability in the Hawaiian mantle plume. Nature, 382(6590), 415-419.

Hawkesworth, C., \& Gallagher, K. (1993). Mantle hotspots, plumes and regional tectonics as causes of intraplate magmatism. Terra Nova 5(6), 552-559.

Head, J. W., \& Coffin, M. F. (1997). Large igneous provinces: a planetary perspective. In M. F. Coffin \& J. J. Mahoney (Eds.), Large igneous provinces: continental, oceanic and planetary flood volcanism (Vol. 100, pp. 411-438): Geophysical Monograph.

Hoernle, K., White, J. D. L., van den Bogaard, P., Hauff, F., Coombs, D. S., Werner, R., Timm, C., Garbe-Schonberg, D., Reay, A., \& Cooper, A. F. (2006). Cenozoic intraplate volcanism on New Zealand: upwelling induced by lithospheric removal. Earth and Planetary Science Letters, 248(1-2), 350-367.

Hofmann, A. W. (2003). Sampling mantle heterogeneity through oceanic basalts: isotopes and trace elements. In Treatise of Geochemistry (Vol. 2.03, pp. 61-101): Elsevier Ltd.

Hofmann, A. W., \& White, W. M. (1982). Mantle plumes from ancient oceanic crust. Earth and Planetary Science Letters, 57(2), 421-436.

Hoke, L., Poreda, R., Reay, A., \& Weaver, S. D. (2000). The subcontinental mantle beneath southern New Zealand, characterised by helium isotopes in intraplate basalts and gas-rich springs. Geochimica et Cosmochimica Acta, 64(14), 2489-2507.

Horn, I., \& Günther, D. (2003). The influence of ablation carrier gases Ar, He and Ne on the particle size distribution and transport efficiencies of laser ablation-induced aerosols: implications for LA-ICP-MS. Applied Surface Science, 207, 144-157.

Houghton, B. F., Wilson, C. J. N., Lloyd, E. F., Gamble, J. A., \& Kokelaar, B. P. (1987). A catalogue of basaltic deposits within the Central Taupo Volcanic Zone. New Zealand Geological Survey Record, 18, 95-101.

Huber, B. T., Hodell, D. A., \& Hamilton, C. P. (1995). Middle-Late Cretaceous climate of the southern high latitudes: stable isotopic evidence for minimal equator-to-pole thermal gradients. Geological Society of America Bulletin, 107(10), 1164-1191.

Hunt, T. M. (1969). Gravity survey of the Lower Awatere District Marlborough, New Zealand. New Zealand Journal of Geology and Geophysics, 12(4), 633-642.

Huppert, H. E., \& Sparks, R. S. J. (1985). Cooling and contamination of mafic and ultramafic magmas during ascent through continental crust. Earth and Planetary Science Letters, 74(4), 371-386.

Ingrin, J., Pacaud, L., \& Jaoul, O. (2001). Anisotropy of oxygen diffusion in diopside. Earth and Planetary Science Letters, 192(3), 347-361.

Ionov, D. A., Griffin, W. L., \& O'Reilly, S. Y. (1997). Volatile-bearing minerals and lithophile trace elements in the upper mantle. Chemical Geology, 141(3-4), 153-184.

Irvine, T. N. (1965). Chromian spinel as a petrogenetic indicator. Part I. Theory. Canadian Journal of Earth Sciences, 2, 648-672.

Irvine, T. N. (1967). Chromian spinels as a petrogenetic indicator. Part 2. Petrologic applications. Canadian Journal of Earth Sciences, 4, 71-103. 
Ishimaru, S., \& Arai, S. (2008). Nickel enrichment in mantle olivine beneath a volcanic front. Contributions to Mineralogy and Petrology, 156, 119-131.

Jiang, Y. H., Jiang, S. Y., Ling, H. F., \& Dai, B. Z. (2006). Low-degree melting of a metasomatized lithospheric mantle for the origin of Cenozoic Yulong monzogranite-porphyry, east Tibet: geochemical and Sr-Nd-Pb-Hf isotopic constraints. Earth and Planetary Science Letters, 241(3-4), 617-633.

Jochum, K. P., Stoll, B., Herwig, K., Willbold, W., Hofmann, A. W., Amini, M., Aarburg, S., Abouchami, W., Hellebrand, E., Mocek, B., Raczek, I., Starcke, A., Alard, O., Bouman, C., Becker, S., Düuck, M., Brätz, H., Klemd, R., de Bruin, D., Canil, D., Cornell, D., de Hoog, C.J., Dalpé, C., Danyushevsky, L., Eisenhauer, A., Gao, Y., Snow, J. E., Groschopf, N., Günther, D., Latkocsy, C., Guillong, M., Hauri, E. H., Höfer, H. E., Lahaye, Y., Horz, K., Jacob, D. E., Kasemann, S. A., Kent, A. J. R., Ludwig, T., Zack, T., Mason, P.R.D., Meixner, A., Rosner, M., Misawa, K., Nash, B. P., Pfänder, J., Premo, W. R., Sun, W. D., Tiepolo, M., Vannucci, R., Vennemann, T., Wayne, D., \& Woodhead, J. D. (2006). MPIDING reference glasses for in situ microanalysis: new reference values for element concentrations and isotope ratios. Geochemistry Geophysics Geosystems, 7, Q020008, doi:10.1029/2005GC001060.

Jurewicz, A. J. G., \& Watson, E. B. (1988). Cations in olivines. 1. Calcium partioning and calciummagnesium distribution between olivines and coexisting melts, with petrological applications. Contributions to Mineralogy and Petrology, 99, 176-185.

Kalamarides, R. I. (1986). High-temperature oxygen isotope fractionation among the phases of the Kiglapait Intrusion, Labrador, Canada. Chemical Geology: Isotope Geoscience section, 58(4), 303-310.

Kamenetsky, V. S., Crawford, A. J., \& Meffre, S. (2001). Factors controlling chemistry of magmatic spinel: an empirical study of associated olivine, $\mathrm{Cr}$-spinel and melt inclusions from primitive rocks. Journal of Petrology, 42(4), 655-671.

Kamenetsky, V. S., Everard, J. L., Crawford, A. J., Varne, R., Eggins, S. M., \& Lanyon, R. (2000). Enriched end-member of primitive MORB melts: Petrology and geochemistry of glasses from Macquarie Island (SW Pacific). Journal of Petrology, 41(3), 411-430.

Kelemen, P. B., Johnson, K. T. M., Kinzler, R. J., \& Irving, A. J. (1990). High-field-strength element depletions in arc basalts due to mantle-magma interaction. Nature, 345, 521-524.

Kelemen, P. B., Shimizu, N., \& Dunn, T. (1993). Relative depletion of niobium in some arc magmas and the continental crust: partitioning of $\mathrm{K}, \mathrm{Nb}$, La and Ce during melt/rock reaction in the upper mantle. Earth and Planetary Science Letters, 120(3-4), 111-134.

Kelley, S. P., \& Wartho, J. A. (2000). Rapid kimberlite ascent and significance of Ar-Ar ages in xenolith phlogopites. Science, 289, 609-611.

Kelsey, H. M., Cashman, S. M., Beanland, S., \& Berryman, K. R. (1995). Structural evolution along the inner fore-arc of the obliquely convergent Hikurangi Margin, New Zealand. Tectonics, 14(1), 1-18.

Kent, A. J. R., Baker, J. A., \& Wiedenbeck, M. (2002). Contamination and melt aggregation processes in continental flood basalts: constraints from melt inclusions in Oligocene basalts from Yemen. Earth and Planetary Science Letters, 202(3-4), 577-594.

Kerr, A. C., Kempton, P. D., \& Thompson, R. N. (1995). Crustal assimilation during turbulent magma ascent (ATA): new isotopic evidence from the Mull Tertiary lava succession, NW Scotland. Contributions to Mineralogy and Petrology, 119, 142-154. 
Knuepfer, P. L. K. (1992). Temporal variations in latest Quaternary slip across the AustralianPacifc plate boundary, northeastern South Island, New Zealand. Tectonics, 11(3), 449464.

Kula, J., Tulloch, A., Spell, T. L., \& Wells, M. L. (2007). Two-stage rifting of Zealandia-AustraliaAntarctica: Evidence from ${ }^{40} \mathrm{Ar} /{ }^{39} \mathrm{Ar}$ thermochronometry of the Sisters shear zone, Stewart Island, New Zealand. Geology, 35(5), 411-414.

La Tourrette, T., Hervig, R. L., \& Holloway, J. R. (1995). Trace element partitioning between amphibole, phlogopite, and basanite melt. Earth and Planetary Science Letters, 135(1-4), 13-30.

Lamb, S. H., \& Bibby, H. M. (1989). The last 25 Ma of rotational deformation in part of the New Zealand plate-boundary zone. Journal of Structural Geology, 11(4), 473-492.

Langmuir, C. H. (1989). Geochemical consequences of in situ crystallisation. Nature, 340, 199-205.

Larsen, L. M., Pedersen, A. K., Sundvoll, B., \& Frei, R. (2003). Alkali picrites formed by melting of old metasomatized lithospheric mantle: Manitdlat Member, Vaigat Formation, Palaeocene of West Greenland. Journal of Petrology, 44(1), 3-38.

Larson, R. L., Steiner, M. B., Ebra, E., \& Lancelot, Y. (1992). Paleolatitudes and tectonic reconstructions of the oldest portion of the Pacific plate: a comparative study, Proceedings of the ocean drilling program: scientific results (Vol. 129, pp. 615-631). Texas: College Station.

Larter, R. D., Cunningham, A. P., Barker, P. F., Gohl, K., \& Nitsche, F. O. (2002). Tectonic evolution of the Pacific margin of Antarctica. 1. Late Cretaceous tectonic reconstructions. Journal of Geophysical Research-Solid Earth, 107, B122345, doi:10.1029/2000JB000052

Lassiter, J. C., \& Hauri, E. H. (1998). Osmium-isotope variations in Hawaiian lavas: evidence for recycled oceanic lithosphere in the Hawaiian plume. Earth and Planetary Science Letters, 164(3-4), 483-496.

Lawver, L. A., Gahagan, L. M., \& Coffin, M. F. (1992). The development of paleoseaways around Antarctica: the Antarctic paleoenvironment: a perspective on global change. Antarctic Research Series, 56, 7-30.

Le Bas, M. J., Le Maitre, R. W., Streckeisen, A., \& Zanettin, B. (1986). A chemical classification of volcanic rocks based on the total alkali silica diagram. Journal of Petrology, 27, 745-750.

Le Bas, M. J., \& Streckeisen, A. L. (1991). The IUGS systematics of igneous rocks. Journal of the Geological Society, 148(5), 825-833.

Le Fèrve, B., \& Pin, C. (2005). A straightforward separation scheme for concomitant $\mathrm{Lu}-\mathrm{Hf}$ and Sm-Nd isotope ratio and isotope dilution analysis. Analytica Chimica Acta, 543, 209-221.

Leitch, A. M., Davies, G. F., \& Wells, M. (1998). A plume head melting under a rifting margin. Earth and Planetary Science Letters, 161(1-4), 161-177.

LeMasurier, W. E., \& Landis, C. A. (1996). Mantle-plume activity recorded by low-relief erosion surfaces in West Antarctica and New Zealand. Geological Society of America Bulletin, $108,1450-1466$.

Lensen, G. J. (1962). Sheet 16 Kaikoura. Geological Map of New Zealand 1:250,000: New Zealand Department of Scientific and Industrial Research.

Libourel, G. (1999). Systematics of calcium partitioning between olivine and silicate melt: implications for melt structure and calcium content of magmatic olivines. Contributions to Mineralogy and Petrology, 136(1-2), 63-80. 
Little, T. A., Grapes, R., \& Berger, G. W. (1998). Late Quaternary strike slip on the eastern part of the Awatere fault, South Island, New Zealand. Geological Society of America Bulletin, $110(2), 127-148$.

Little, T. A., \& Jones, A. (1998). Seven million years of strike-slip and related off-fault deformation, northeastern Marlborough Fault System, South Island, New Zealand. Tectonics, 17(2), 285-302.

Longhi, J., Walker, D., \& Hays, J. F. (1978). The distribution of Fe and Mg between olivine and lunar basaltic liquids. Geochimica et Cosmochimica Acta, 42, 1545-1558.

Luais, B., Telouk, P., \& Albarède, F. (1997). Precise and accurate neodymium isotopic measurements by plasma-source mass spectrometry. Geochemica et Cosmochimica Acta, 61, 4847-4854.

Ludvigson, G. A., Gonzalez, L. A., Metzger, R. A., Witzke, B. J., Brenner, R. L., Murillo, A. P., \& White, T. S. (1998). Meteoric sphaerosiderite lines and their use for paleohydrology and paleoclimatology. Geology, 26(11), 1039-1042.

Ludwig, K. R. (2000). Isoplot (Version 2.45): Berkeley Geochronology Centre.

Lundstrom, C. C., Shaw, H. F., Ryerson, F. J., Williams, Q., \& Gill, J. (1998). Crystal chemical control of clinopyroxene-melt partitioning in the Di-Ab-An system: implications for elemental fractionations in the depleted mantle. Geochimica et Cosmochimica Acta, 62(16), 2849-2862.

Luyendyk, B. P. (1995). Hypothesis for Cretaceous rifting of east Gondwana caused by subducted slab capture. Geology, 23(4), 373-376.

MacDonald, G. A. (1968). Composition and origin of Hawaiian lavas. Memoir Geological Society of America, 116, 477-522.

Maclennan, J., McKenzie, D., Gronvold, K., Shimizu, N., Eiler, J. M., \& Kitchen, N. (2003). Melt mixing and crystallization under Theistareykir, northeast Iceland. Geochemistry Geophysics Geosystems, 4, 8624, doi10.1029/2003GC000558.

Macpherson, C. G., Hilton, D. R., Day, J. M. D., Lowry, D., \& Gronvold, K. (2005). High ${ }^{3} \mathrm{He} /{ }^{4} \mathrm{He}$, depleted mantle and low- $\delta^{18} \mathrm{O}$, recycled oceanic lithosphere in the source of central Iceland magmatism. Earth and Planetary Science Letters, 233, 411-427.

Marsh, B. D. (2006). Dynamics of magmatic systems. Elements, 2, 287-292.

Marske, J. P., Pietruszka, A. J., Weis, D., Garcia, M. O., \& Rhodes, J. M. (2007). Rapid passage of a small-scale mantle heterogeneity through the melting regions of Kilauea and Mauna Loa Volcanoes. Earth and Planetary Science Letters, 259(1-2), 34-50.

Mason, B. (1958). Intrusive rocks of the Kaikoura Mountains, Marlborough, New Zealand. Transactions of the Royal Society of New Zealand, 85, 247-262.

Mason, D. P. M., \& Little, T. A. (2006). Refined slip distribution and moment magnitude of the 1848 Marlborough earthquake, Awatere Fault, New Zealand. New Zealand Journal of Geology and Geophysics, 49(3), 375-382.

Mattey, D., Lowry, D., \& Macpherson, C. (1994). Oxygen isotope composition of mantle peridotite. Earth and Planetary Science Letters, 128(3-4), 231-241.

McCulloch, M. T., Kyser, T. K., Woodhead, J. D., \& Kinsley, L. (1994). Pb-Sr-Nd-O isotopic constraints on the origin of rhyolites from the Taupo Volcanic Zone of New Zealand: evidence for assimilation followed by fractionation from a basalt. Contributions to Mineralogy and Petrology, 115, 303-312. 
McDonough, W. F., \& Sun, S. S. (1995). The composition of the Earth. Chemical Geology, 120(34), 223-253.

McDougall, I., \& Coombs, D. S. (1973). Potassium-argon ages for the Dunedin volcano and outlying volcanics. New Zealand Journal of Geology and Geophysics, 16, 179-188.

McKenzie, D., \& Bickle, M. J. (1988). The volume and composition of melt generated by extension of the lithosphere. Journal of Petrology, 29, 625-679.

McKenzie, D., \& O'Nions, R. K. (1983). Mantle reservoirs and ocean island basalts. Nature, 301(5897), 229-231.

McKenzie, D., \& O'Nions, R. K. (1991). Partial melt distributions from inversion of rare earth element concentrations. Journal of Petrology, 32, 1021-1091.

Meijer, A., Kwon, T. T., \& Tilton, G. R. (1990). U-Th-Pb partitioning behaviour during partial melting in the upper mantle: implications for the origin of high Mu components and the 'Pb Paradox'. Journal of Geophysical Research-Solid Earth and Planets, 95(B1), 433-448.

Melhuish, A. (1988). Synsedimentary faulting in the lower Medway River area, Awatere Valley, Marlborough, New Zealand. Unpublished B.Sc. (Hons) thesis lodged at Victoria University of Wellington, Wellington, New Zealand. pp. 65.

Montague, T. (1981). Cretaceous stratigraphy of the Mt Lookout area and its relation to the proposed regional unconformity at the end of the Rangitata Orogeny. Unpublished M.Sc. thesis lodged at the University of Canterbury, Christchurch, New Zealand.

Morimoto, N. (1988). Nomenclature of pyroxenes. American Mineralogist, 73, 1123-1133.

Morris, P. A. (1981). Mapping and petrochemistry of the Chatham Island Volcanics. Unpublished Ph.D. thesis lodged at Victoria University of Wellington, Wellington, New Zealand. pp. 512.

Morris, P. A. (1984). Petrology of the Campbell Island volcanics, southwest Pacific Ocean. Journal of Volcanology and Geothermal Research, 21, 119-148.

Morris, P. A. (1985a). The geochemistry of Eocene-Oligocene volcanics on the Chatham Islands, New Zealand. New Zealand Journal of Geology and Geophysics, 28, 459-469.

Morris, P. A. (1985b). Petrology of Late Cretaceous alkaline volcanic rocks from the Chatham Islands, New Zealand. New Zealand Journal of Geology and Geophysics, 28, 253-266.

Mortimer, N. (2004). New Zealand's geological foundations. Gondwana Research, 7(1), 261-272.

Mueller, R. D., Royer, J.-Y., \& Lawver, L. A. (1993). Revised plate motions relative to the hotspots from combined Atlantic and Indian Ocean hotspot tracks. Geology, 21(3), 275-278.

Muir, R. J., Ireland, T. R., Weaver, S. D., \& Bradshaw, J. D. (1994). Ion microprobe U-Pb zircon geochronology of granitic magmatism in the Western Province of the South Island, New Zealand. Chemical Geology, 113(1-2), 171-189.

Muir, R. J., Ireland, T. R., Weaver, S. D., Bradshaw, J. D., Waight, T. E., Jongens, R., \& Eby, G. N. (1997). SHRIMP U-Pb geochronology of Cretaceous magmatism in northwest NelsonWestland, South Island, New Zealand. New Zealand Journal of Geology and Geophysics, 40(4), 453-463.

Mukasa, S. B., \& Dalziel, I. W. D. (2000). Marie Byrd Land, West Antarctica: evolution of Gondwana's Pacific margin constrained by zircon U-Pb geochronology and feldspar common-Pb isotopic compositions. Geological Society of America Bulletin, 112(4), 611627. 
Murck, B. W., \& Campbell, I. H. (1986). The effects of temperature, oxygen fugacity and melt composition on the behaviour of chromium in basic and ultrabasic melts. Geochimica et Cosmochimica Acta, 50(9), 1871-1887.

Nevle, R. J., Brandriss, M. E., Bird, D. K., McWilliams, M. O., \& O'Neil, J. R. (1994). Tertiary plutons monitor climate change in East Greenland. Geology, 22(9), 775-778.

Nicholson, C., Sorlien, C. C., Atwater, T., Crowell, J. C., \& Luyendyk, B. P. (1994). Microplate capture, rotation of the Western Transverse Ranges, and initiation of the San Andreas transform as a low-angle fault system. Geology, 22(6), 491-495.

Nicol, E. R. (1977). Igneous petrology of the Clarence and Awatere Valleys, Marlborough. Unpublished Ph.D. thesis lodged at Victoria University of Wellington, Wellington, New Zealand. pp. 328.

Norton, D., \& Taylor, H. P. J. (1979). Quantitative simulation of the hydrothermal systems of crystallizing magmas on the basis of transport theory and oxygen isotope data: an analysis of the Skaergaard Intrusion. Journal of Petrology, 20(3), 421-486.

Nowell, G. M., Kempton, P. D., Noble, S. R., Fitton, J. G., Saunders, A. D., Mahoney, J. J., \& Taylor, R. N. (1998). High precision Hf isotope measurements of MORB and OIB by thermal ionisation mass spectrometry: insights into the depleted mantle. Chemical Geology, 149(3-4), 211-233.

Panter, K. S., Blusztajn, J., Hart, S. R., Kyle, P. R., Esser, R., \& McIntosh, W. C. (2006). The origin of HIMU in the SW Pacific: evidence from intraplate volcanism in southern New Zealand and Subantarctic Islands. Journal of Petrology, 47(9), 1673-1704.

Pearce, N. J. G., Westgate, J. A., \& Perkins, W. T. (1996). Developments in the analysis of volcanic glass shards by laser ablation ICP-MS: quantitative and single internal standard-multielement methods. Quaternary International, 34-36, 213-227.

Pfander, J. A., Munker, C., Stracke, A., \& Mezger, K. (2007). Nb/Ta and Zr/Hf in ocean island basalts: implications for crust-mantle differentiation and the fate of niobium. Earth and Planetary Science Letters, 254, 158-172.

Pin, C., \& Zalduegui, J. S. (1997). Sequential separation of light rare-earth elements, thorium and uranium by miniaturized extraction chromatography: application to isotopic analyses of silicate rocks. Analytica Chimica Acta, 339(1-2), 79-89.

Powell, W., Zhang, M., O'Reilly, S. Y., \& Tiepolo, M. (2004). Mantle amphibole trace-element and isotopic signatures trace multiple metasomatic episodes in lithospheric mantle, western Victoria, Australia. Lithos, 75(1-2), 141-171.

Price, R. C., Cooper, A. F., Woodhead, J. D., \& Cartwright, I. (2003). Phonolitic diatremes within the Dunedin Volcano, South Island, New Zealand. Journal of Petrology, 44(11), 20532080.

Rait, G., Chanier, F., \& Waters, D. W. (1991). Landward and seaward-directed thrusting accompanying the onset of subduction beneath New Zealand. Geology, 19(3), 230-233.

Rattenbury, M. S., Townsend, D. B., \& Johnson, M. R. (2006). Geology of the Kaikoura area: 1:250,000. Institute of Geological and Nuclear Sciences: geological map 13, 1 sheet + 70p.

Reay, M. B. (1993). Geology of the middle Clarence Valley: 1:50,000. Institute of Geological and Nuclear Sciences: geological map 10, 1 sheet + 144p.

Reid, D. L. (1972). A petrological study of the Mandamus Igneous Complex, North Canterbury. Unpublished M.Sc. thesis lodged at Victoria University of Wellington, Wellington, New Zealand. pp. 182. 
Robertson, M. (1989). Metamorphism in the contact aureole of the Tapuaenuku Plutonic Complex, Marlborough, New Zealand. Unpublished B.Sc.(Hons) thesis lodged at Victoria University of Wellington, Wellington, New Zealand. pp. 74.

Roeder, P. L. (1974). Activity of iron and olivine solubility in basaltic liquids. Earth and Planetary Science Letters, 23, 397-410.

Roeder, P. L., \& Emslie, R. F. (1970). Olivine-liquid equilibria. Contributions to Mineralogy and Petrology, 29, 275-289.

Roeder, P. L., \& Reynolds, I. (1991). Crystallization of chromite and chromium solubility in basaltic melts. Journal of Petrology, 32(5), 909-934.

Rozanski, K., Araguas, A. L., \& Gonfiantini, R. (1993). Isotopic patterns in modern global percipitiation. In P. K. Swart (Ed.), Climate change in continental isotopic records (Vol. 78, pp. 1-36). Miami, Florida: Rosentiel School of Marine and Atmospheric Sciences Geophysical Monograph.

Rudnick, R. L., McDonough, W. F., \& Chappell, B. W. (1993). Carbonatite metasomatism in the northern Tanzanian mantle: petrographic and geochemical characteristics. Earth and Planetary Science Letters, 114(4), 463-475.

Ryerson, F. J., Durham, W. B., Cherniak, D. J., \& Lanford, W. A. (1989). Oxygen diffusion in olivine: effect of oxygen fugacity and implications for creep. Journal of Geophysical Research, 94, 4105-4118.

Sack, R. O., \& Ghiorso, M. S. (1991). Chromian spinels as petrogenetic indicators: thermodynamics and petrological applications. American Mineralogist, 76, 827-847.

Salters, V. J. M., \& White, W. M. (1998). Hf isotope constraints on mantle evolution. Chemical Geology, 145(3-4), 447-460.

Schiano, P., \& Clocchiatti, R. (1994). Worldwide occurrence of silica-rich melts in subcontinental and sub-oceanic mantle minerals. Nature, 368(6472), 621-624.

Schiano, P., Clocchiatti, R., Shimizu, N., Maury, R. C., Jochum, K. P., \& Hofmann, A. W. (1995). Hydrous, silica-rich melts in the sub-arc mantle and their relationship with erupted arc lavas. Nature, 377(6550), 595-600.

Sewell, R. J., Weaver, S. D., \& Reay, M. B. (1992). Geology of Banks Peninsula: Scale 1:100,000. Institute of Geological and Nuclear Sciences, geological map 3, 1 sheet.

Sharp, Z. D. (1990). Laser-based microanalytical method for the in situ determination of oxygen isotope ratios of silicates and oxides. Geochemica et Cosmochimica Acta, 54, 1353-1357.

Shaw, D. M. (1970). Trace element fractionation during anatexis. Geochimica et Cosmochimica Acta, 34, 237-243.

Shaw, J. E. (2003). Geochemistry of Cenozoic volcanism and Arabian lithospheric mantle in Jordan. Unpublished Ph.D. thesis lodged at Royal Holloway University of London, London, England. pp. 268.

Sheppard, S. M., \& Taylor, H. P. (1974). Hydrogen and oxygen isotope evidence for the origins of water in the Boulder Batholith and Butte ore-deposits, Montana. Economic Geology, 69(6), 926-946.

Shi, P. (1993). Low pressure phase relationships in the system $\mathrm{Na}_{2} \mathrm{O}-\mathrm{FeO}-\mathrm{MgO}-\mathrm{Al}_{2} \mathrm{O}_{3}-\mathrm{SiO}_{2}$ at $1100^{\circ} \mathrm{C}$ with implications for the differentiation of basaltic magmas. Journal of Petrology, 34, 743-762. 
Shi, P., \& Libourel, G. (1991). The effect of FeO on the system CMAS at low pressure and implications for basalt crystallization processes. Contributions to Mineralogy and Petrology, 108, 129-145.

Simkin, T., \& Smith, J. V. (1970). Minor-element distribution in olivine. Journal of Geology, 78, 304-325.

Skovgaard, A. C., Storey, M., Baker, J. A., Blusztajn, J., \& Hart, S. R. (2001). Osmium-oxygen isotopic evidence for a recycled and strongly depleted component in the Iceland mantle plume. Earth and Planetary Science Letters, 194, 259-275.

Sobolev, A. V., Hofmann, A. W., Kuzmin, D. V., Yaxley, G. M., Arndt, N. T., Chung, S. L., Danyushevsky, L. V., Elliott, T., Frey, F. A., Garcia, M. O., Gurenko, A. A., Kamenetsky, V. S., Kerr, A. C., Krivolutskaya, N. A., Matvienkov, V. V., Nikogosian, I. K., Rocholl, A., Sigurdsson, I. A., Sushchevskaya, N. M., \& Teklay, M. (2007). The amount of recycled crust in sources of mantle-derived melts. Science, 316(5823), 412-417.

Sobolev, A. V., Hofmann, A. W., Sobolev, S. V., \& Nikogosian, I. K. (2005). An olivine-free mantle source of Hawaiian shield basalts. Nature, 434(7033), 590-597.

Spell, T. L., McDougall, I., \& Tulloch, A. J. (2000). Thermochronologic constraints on the breakup of the Pacific Gondwana margin: The Paparoa metamorphic core complex, South Island, New Zealand. Tectonics, 19(3), 433-451.

Sprung, P., Schuth, S., Munker, C., \& Hoke, L. (2007). Intraplate volcanism in New Zealand: the role of fossil plume material and variable lithospheric properties. Contributions to Mineralogy and Petrology, 153(6), 669-687.

Steiger, R. H., \& Jäger, E. (1977). Subcommission on geochronology: Convention on the use of decay constants in geo- and cosmochronology. Earth and Planetary Science Letters, 36(3), 359-362.

Stewart, M. K., Cox, M. A., James, M. R., \& Lyon, G. L. (1983). Deuterium in New Zealand rivers and streams Institute of Nuclear Sciences, Lower Hutt, New Zealand. INS-R-320, $42 \mathrm{pp}$.

Storey, B. C., Leat, P. T., Weaver, S. D., Pankhurst, R. J., Bradshaw, J. D., \& Kelley, S. (1999). Mantle plumes and Antarctica-New Zealand rifting: evidence from the mid-Cretaceous mafic dykes. Journal of the Geological Society of London, 156, 659-671.

Stracke A., Bizimis, M., \& Salters, V. J. M. (2003a) Recycling oceanic crust: quantitative constraints. Geochemistry Geophysics Geosystems, 4 (3), 8003, doi:10.1029/2001GC000223, 2003.

Stracke, A., Hofmann, A. W., \& Hart, S. R. (2005). FOZO, HIMU, and the rest of the mantle zoo. Geochemistry Geophysics Geosystems, 6, Q05007, doi:10.1029/2004GC000824.

Stracke, A., Zindler, A., Salters, V. J. M., McKenzie, D., Blichert-Toft, J., Albarede, F., \& Gronvold, K. (2003b). Theistareykir revisited. Geochemistry Geophysics Geosystems, 4, 8507, doi:10.1029/2001GC000201.

Suggate, R. P. (1958). The geology of the Clarence Valley from Gore Stream to Bluff Hill. Transactions of the Royal Society of New Zealand, 85, 397-408.

Sun, S. S., \& McDonough, W. F. (1989). Chemical and isotopic systematics of oceanic basalts: implications for mantle composition and processes. In A. D. Saunders \& M. J. Norry (Eds.), Magmatism in ocean basins (Vol. 42, pp. 313-345): Geological Society of London special publication.

Sutherland, R. (1995). The Australia-Pacific boundary and Cenozoic plate motions in the SW Pacific: Some constraints from Geosat data. Tectonics, 14(4), 819-831. 
Tanaka, R., Nakamura, E., \& Takahashi, E. (2002). Geochemical evolution of Koolau Volcano, Hawaii. In Hawaiian volcanoes deep underwater perspectives (Vol. 128, pp. 311-332): American Geophysical Union Geophysical Monograph.

Taylor, H. P. (1971). Oxygen isotope evidence for large-scale interaction between meteoric ground waters and Tertiary granodiorite intrusions, western Cascade Range, Oregon. Journal of Geophysical Research, 76(32), 7855-7874.

Taylor, H. P., \& Criss, R. E. (1986). Meteoric hydrothermal systems In J. W. Valley \& et al. (Eds.), Stable isotopes in high temperature geological processes (Vol. 16, pp. 373-424): Mineralogical Society of America Reviews of Mineralogy.

Taylor, H. P. J., \& Forester, R. W. (1979). An oxygen and hydrogen isotope study of the Skaergaard Intrusion and its country rocks: a description of a 55 M.Y. old fossil hydrothermal system. Journal of Petrology, 20(3), 355-419.

Thirlwall, M. F., Gee, M. A. M., Lowry, D., Mattey, D. P., Murton, B. J., \& Taylor, R. N. (2006). Low $\delta^{18} \mathrm{O}$ in the Icelandic mantle and its origins: evidence from Reykjanes Ridge and Icelandic lavas. Geochimica et Cosmochimica Acta, 70(4), 993-1019.

Thirlwall, M. F., Upton, B. G. J., \& Jenkins, C. (1994). Interaction between continental lithosphere and the Iceland plume - Sr- $\mathrm{Nd}-\mathrm{Pb}$ isotope geochemistry of Tertiary basalts, NE Greenland Journal of Petrology, 35, 839-879.

Tiepolo, M., Bottazzi, P., Foley, S. F., Oberti, R., Vannucci, R., \& Zanetti, A. (2001). Fractionation of $\mathrm{Nb}$ and $\mathrm{Ta}$ from $\mathrm{Zr}$ and $\mathrm{Hf}$ at mantle depths: the role of titanian pargasite and kaersutite. Journal of Petrology, 42(1), 221-232.

Tulloch, A. J., \& Kimbrough, D. L. (1989). The Paparoa Metamorphic Core Complex, New Zealand - Cretaceous extension associated with the fragmentation of the Pacific margin of Gondwana. Tectonics, 8(6), 1217-1234.

Ulfbeck, D. G., Baker, J. A., Waight, T. E., \& Krogstad, E. (2002). Rapid sample digestion and by fusion and chemical separation of Hf for isotopic study by MC-ICPMS. Talanta, 59(2), 365-373.

Umino, S., Kato, M., \& Koyama, M. (1991). Diversity of parent magmas of Higashi-Izu monogenetic volcanic group. Journal of Physical Earth, 39, 371-389.

Valley, J. W., Kitchen, N., Kohn, M. J., Niendorf, C. R., \& Spicuzza, M. J. (1995). UWG-2, a garnet standard for oxygen isotope ratios: strategies for high precision and accuracy with laser heating. Geochemica et Cosmochimica Acta, 59, 5223-5231.

Vlastélic, I., Aslanian, D., Dosso, L., Bougault, H., Olivet, J. L., \& Géli, L. (1999). Large-scale chemical and thermal division of the Pacific mantle. Nature, 399(6734), 345-350.

Vickery, S., \& Lamb, S. (1995). Large tectonic rotations since the Early Miocence in a convergent plate-boundary zone, South Island, New Zealand. Earth and Planetary Science Letters, 136(1-2), 43-59.

Vidal, P., \& Dosso, L. (1978). Core formation: catastrophic or continuous? Sr and Pb isotope geochemistry constraints. Geophysical Research Letters, 5(3), 169-172.

Waight, T. E., Baker, J. A., \& Peate, D. (2002). Sr isotope ratio measurements by double-focusing MC-ICPMS: techniques, observations and pitfalls. International Journal of Mass Spectrometry, 221, 229-244.

Walcott, R. I. (1998). Modes of oblique compression: Late Cenozoic tectonics South Island of New Zealand. Reviews of Geophysics, 36, 1-26. 
Wallace, L. M., Beavan, J., McCaffrey, R., \& Darby, D. (2004). Subduction zone coupling and tectonic block rotations in the North Island, New Zealand. Journal of Geophysical Research-Solid Earth, 109, B12406, doi:10.1029/2004JB003241.

Wallace, M., \& Green, D. H. (1991). The effect of bulk rock composition on the stability of amphibole in the upper mantle: implications for solidus positions and mantle metasomatism. Mineralogy and Petrology, 44(1), 1-19.

Wandres, A. M., Bradshaw, J. D., \& Ireland, T. (2005). The Paleozoic-Mesozoic recycling of the Rakaia Terrane, South Island, New Zealand: sandstone clast and sandstone petrology, geochemistry, and geochronology. New Zealand Journal of Geology and Geophysics, 48(2), 229-245.

Wandres, A. M., Bradshaw, J. D., Weaver, S., Maas, R., Ireland, T., \& Eby, N. (2004). Provenance analysis using conglomerate clast lithologies: a case study from the Pahau terrane of New Zealand. Sedimentary Geology, 167(1-2), 57-89.

Wang, Z., \& Eiler, J. M. (2008). Insights into the origin of low- $\delta^{18} \mathrm{O}$ basaltic magmas in Hawaii revealed from in situ measurements of oxygen isotope compositions of olivines. Earth and Planetary Science Letters, 269, 377-387.

Waters, D. W. (1988). The Flags Creek Thrust. Unpublished B.Sc.(Hons) thesis lodged at Victoria University of Wellington, Wellington, New Zealand. pp. 150.

Watson, E. B. (1979). Calcium content of forsterite coexisting with silicate liquid in the system $\mathrm{Na}_{2} \mathrm{O}-\mathrm{CaO}-\mathrm{MgO}-\mathrm{Al}_{2} \mathrm{O}_{3}-\mathrm{SiO}_{2}$. American Mineralogist, 64, 824-829.

Weaver, B. L. (1991). The origin of ocean island basalt end-member compositions: trace element and isotopic constraints. Earth and Planetary Science Letters, 104(2-4), 381-397.

Weaver, S. D., \& Pankhurst, R. J. (1991). A precise Rb-Sr age for the Mandamus Igneous Complex, North Canterbury, and regional tectonic implications. New Zealand Journal of Geology and Geophysics, 34, 341-347.

Weaver, S. D., Sewell, R. J., \& Dorsey, C. J. (1985). Extinct volcanoes: a guide to the geology of Banks Peninsula. Geological Society of New Zealand - Guidebook, 7.

Weaver, S. D., \& Smith, I. E. M. (1989). New Zealand Intraplate Volcanism. In R. W. Johnson (Ed.), Intraplate volcanism in eastern Australia and New Zealand (pp. 157-187): Cambridge University Press.

Weaver, S. D., Storey, B. C., Pankhurst, R. J., Mukasa, S. B., DiVenere, V. J., \& Bradshaw, J. D. (1994). Antarctica-New Zealand rifting and Marie Byrd Land lithospheric magmatism linked to ridge subduction and mantle plume activity. Geology, 22, 811-814.

Wellman, H. W. (1979). An uplift map for the South Island of New Zealand and a model for the uplift of the Southern Alps. In R. I. Walcott \& M. M. Cresswell (Eds.), Origin of the Southern Alps (Vol. 18, pp. 13-20): Royal Society of New Zealand Bulletin.

White, R., \& McKenzie, D. (1989). Magmatism at rift zones - the generation of volcanic continental margins and flood basalts. Journal of Geophysical Research, 94(B6), 76857729 .

Wilson, M., Rosenbaum, J. M., \& Dunworth, E. A. (1995). Melitites: partial melts of the thermal boundary layer? Contributions to Mineralogy and Petrology, 119(2), 181-196.

Wood, B. J., \& Blundy, J. D. (2003). Trace element partitioning under crustal and uppermost mantle conditions: the influences of ionic radius, cation charge, pressure, and temperature. In Treatise of Geochemistry (Vol. 2.09, pp. 395-424): Elsevier Ltd. 
Wood, B. J., \& Trigila, R. (2001). Experimental determination of aluminous clinopyroxene-melt partition coefficients for potassic liquids, with application to the evolution of the Roman province potassic magmas. Chemical Geology, 172(3-4), 213-223.

Wood, C. P. (1974). Petrogenesis of garnet-bearing rhyolites from Canterbury, New Zealand. New Zealand Journal of Geology and Geophysics, 17(4), 759-787.

Woodhead, J. D. (1996). Extreme HIMU in an oceanic setting: the geochemistry of Mangaia Island (Polynesia), and temporal evolution of the Cook-Austral hotspot. Journal of Volcanology and Geothermal Research, 72(1-2), 1-19.

Workman, R. K., \& Hart, S. R. (2005). Major and trace element composition of the depleted MORB mantle (DMM). Earth and Planetary Science Letters, 231(1-2), 53-72.

Workman, R. K., Hart, S. R., Jackson, M. G., Regelous, M., Farley, K. A., Blusztajn, J., Kurz, M. D., \& Staudigel, H. (2004). Recycled metasomatized lithosphere as the origin of the enriched mantle II (EM2) end-member: evidence from the Samoan volcanic chain. Geochemistry Geophysics Geosystems, 5, Q04008, doi:10.1029/2003GC000623.

Zindler, A., \& Hart, S. R. (1986). Chemical geodynamics. Annual Reviews of Earth and Planetary Science, 14, 493-571. 


\section{APPENDIX 1: ANALYTICAL TECHNIQUES}

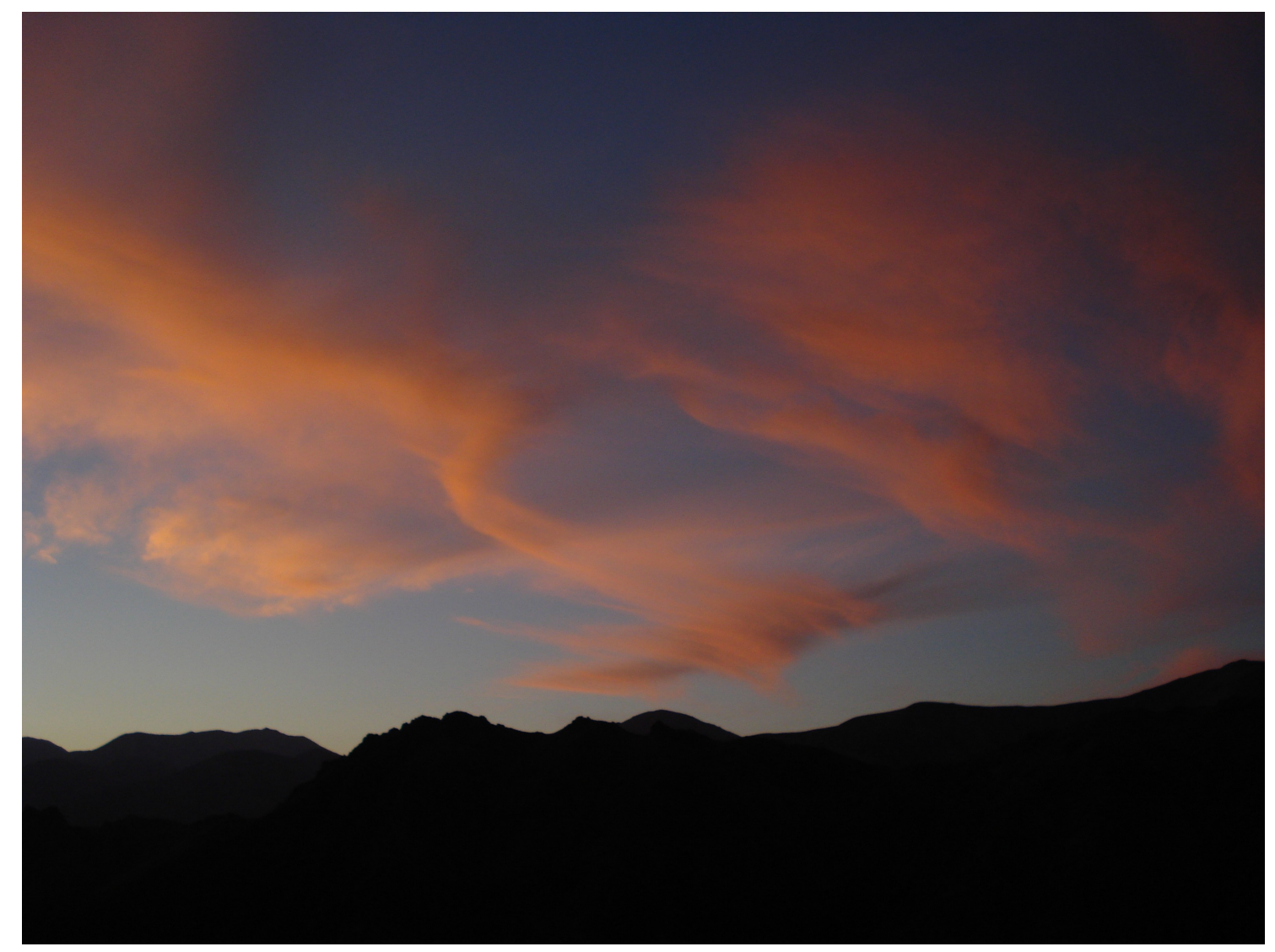

Plate 8: View looking to the north from the Old Middlehurst Hut, middle Awatere Valley: Wispy clouds catch the last rays of sun at dusk. 


\section{A1.1 ROCK CRUSHING \& MINERAL SEPARATION}

\section{A1.1.1 Rock crushing}

Weathered rock surfaces were removed in the field with a geological hammer. A thin section billet $(70 \times 50 \times 10 \mathrm{~mm})$ was separated from the sample using a rock saw, and then the remainder of the sample was prepared for geochemical analysis. Any remaining weathered surfaces and sawn surfaces were removed using a tungsten carbide jaw splitter. Fresh material was then reduced in size to $<10 \mathrm{~cm}$ with the tungsten carbide jaw splitter. Material was further reduced in size to < $2.5 \mathrm{~cm}$ using a tungsten carbide jaw crusher. The jaw crusher was cleaned with a plastic brush and at least 3 washes of acetone between samples. Approximately $100 \mathrm{~g}$ of chip material was powdered to $<10 \mu \mathrm{m}$ in a tungsten carbide tema mill. Excess rock chips were retained for handpicking material for $\mathrm{Pb}$ isotopic analysis. The tema mill was washed with warm water and acetone and dried between samples. After crushing of highly altered samples, the tema mill was cleaned by processing a load of quartz sand.

\section{A1.1.2 Mineral separation}

Coarsely crushed material was sieved to remove all material $>2 \mathrm{~mm}$ in size. The $<2 \mathrm{~mm}$ fraction was repeatedly ( $>5$ times) ultrasonically rinsed in water to remove any fine-grained material adhering to the grains and then dried in an oven at $60^{\circ} \mathrm{C}$. This material was then sieved into four size fractions $(>1 \mathrm{~mm}, 0.5-$ $1 \mathrm{~mm}, 250-500 \mu \mathrm{m}$, and $<250 \mu \mathrm{m})$. Between samples the sieves were cleaned with a $50 \mathrm{~mm}$ paint brush and plastic nail brush, acetone, and then dried with compressed air. Individual minerals were carefully handpicked under a binocular microscope from the $>1 \mathrm{~mm}$ and $0.5-1.0 \mathrm{~mm}$ size fractions depending on the size and preservation of the required minerals in the sample. Olivine and green and brown clinopyroxene were picked for mineral oxygen isotope analyses. Green and brown clinopyroxene and plagioclase were also picked for mineral $\mathrm{Sr}$ isotope analyses. 


\section{A1.2 WHOLE ROCK MAJOR ELEMENT ANALYSES}

\section{A1.2.1 X-ray fluorescence spectrometry}

Major element analyses of volcanic rocks were carried out on a X-ray

fluorescence (XRF) spectrometer at the University of Auckland, Auckland, New

Zealand. Major elements were determined by the analysis of fused lithium metaborate glass discs.

\section{A1.2.2 Accuracy}

International rock standards (BCR-2 and BHVO-2) obtained from the United States Geological Survey (USGS) were included in the samples analysed by XRF. Major element data for these standards are accurate to within ca. $1 \%$ as compared to the recommended values for these standards, except $\mathrm{Fe}, \mathrm{K}$ and $\mathrm{P}$ which are accurate to within 3\% (Table A1.1).

Table A1.1: Accuracy of XRF major element data.

\begin{tabular}{|c|c|c|c|c|c|c|c|}
\hline & \multicolumn{3}{|c|}{ BCR-2 } & \multicolumn{3}{|c|}{ BHVO-2 } & \multirow{2}{*}{$\begin{array}{l}\text { Average } \\
\text { Accuracy }\end{array}$} \\
\hline & Measured & Georem & $\%$ Offset & Measured & Georem & $\%$ Offset & \\
\hline $\mathrm{SiO}_{2}$ & 53.6 & 54.1 & $-0.9 \%$ & 49.4 & 49.9 & $-1.0 \%$ & $-1.0 \%$ \\
\hline $\mathrm{TiO}_{2}$ & 2.26 & 2.26 & $-0.2 \%$ & 2.75 & 2.73 & $+0.7 \%$ & $+0.3 \%$ \\
\hline $\mathrm{Al}_{2} \mathrm{O}_{3}$ & 13.4 & 13.5 & $-1.1 \%$ & 13.5 & 13.5 & $-0.1 \%$ & $-0.6 \%$ \\
\hline $\mathrm{Fe}_{2} \mathrm{O}_{3}$ & 14.2 & 13.8 & $+2.7 \%$ & 12.7 & 12.3 & $+3.5 \%$ & $+3.1 \%$ \\
\hline $\mathrm{MnO}$ & 0.199 & 0.200 & $-0.6 \%$ & 0.172 & 0.170 & $+1.2 \%$ & $+0.3 \%$ \\
\hline $\mathrm{MgO}$ & 3.57 & 3.59 & $-0.6 \%$ & 7.24 & 7.23 & $+0.1 \%$ & $-0.3 \%$ \\
\hline $\mathrm{CaO}$ & 7.07 & 7.12 & $-0.8 \%$ & 11.5 & 11.4 & $+0.4 \%$ & $-0.2 \%$ \\
\hline $\mathrm{Na}_{2} \mathrm{O}$ & 3.14 & 3.16 & $-0.6 \%$ & 2.22 & 2.22 & $\pm 0.0 \%$ & $-0.3 \%$ \\
\hline $\mathrm{K}_{2} \mathrm{O}$ & 1.79 & 1.79 & $-0.1 \%$ & 0.510 & 0.520 & $-1.9 \%$ & $-1.0 \%$ \\
\hline $\mathrm{P}_{2} \mathrm{O}_{5}$ & 0.357 & 0.350 & $+1.9 \%$ & 0.270 & 0.270 & $\pm 0.0 \%$ & $+1.0 \%$ \\
\hline $\mathrm{H}_{2} \mathrm{O}-$ & 0.27 & & & 0.06 & & & \\
\hline LOI & -0.02 & & & -0.45 & & & \\
\hline Total & 99.77 & & & 99.86 & & & \\
\hline $\mathrm{Mg \#}$ & 20.1 & 20.6 & $-2.6 \%$ & 36.3 & 37.0 & $-2.1 \%$ & \\
\hline
\end{tabular}

Table A1.1 shows the measured XRF major element concentrations for two international rock standards (BCR-2 and BHVO-2) compared to the Georem recommended values. The percentage offset represents how much the measured values vary from the recommended values. The average accuracy is the mean accuracy of the two standards for each element. 


\section{A1.3 WHOLE ROCK TRACE ELEMENT ANALYSES}

Trace elements are typically measured by solution inductively coupled plasma mass spectrometry (ICP-MS) using an internal doping technique (Eggins et al., 1997). In this procedure, samples are spiked with a known concentration of enriched isotopes (e.g. ${ }^{115} \mathrm{In}$ : indium; ${ }^{187}$ Re: rhenium) across the mass spectrum, so that complex mass-dependent variations in sensitivity encountered during ICPMS analysis can be monitored and deconvolved. New generation ICP-MS instruments provide better sensitivity and stability across the mass spectrum and as such, in this study ${ }^{43} \mathrm{Ca}$ is used as an internal standard with the $\mathrm{CaO}$ content of samples previously determined to $\pm 1 \%$ by XRF.

\section{A1.3.1 Sample preparation}

\section{$\underline{\text { Sample digestion }}$}

The nature of the ICP-MS analysis method means it is imperative to eliminate sample loss during preparation. Acid cleaned $23 \mathrm{~mL}$ savillex beakers (Section A1.6.1) were rinsed thoroughly with > 18.2 M $\Omega$ ultra-clean water (MilliQ: MQ $\mathrm{H}_{2} \mathrm{O}$ ) and dried. Only round bottom beakers were used as their conical bases form better (i.e. more compact) cakes resulting in less chance of sample loss during evaporation. Approximately $100 \pm 10 \mathrm{mg}$ of whole-rock powder was carefully weighed into the beakers ensuring no powder became stuck to the outside of the beaker. Rock powders were then digested with concentrated hydrofluoric acid (29 M HF; $2 \mathrm{~mL}$ ) and nitric acid (16 $\mathrm{M} \mathrm{HNO}_{3} ; 0.5 \mathrm{~mL}$ ) in sealed savillex beakers on a hot plate at $110^{\circ} \mathrm{C}$ for 3-4 days to ensure complete digestion. This acid was then evaporated on a hot plate at $120^{\circ} \mathrm{C}$, followed by the sequential evaporation of ca. $0.5 \mathrm{~mL}$ of concentrated $\mathrm{HNO}_{3}$, hydrochloric acid (12 M HCl) and $\mathrm{HNO}_{3}$. During the $\mathrm{HF}$ evaporation samples were only dried to incipient dryness (i.e. the cake has just formed but is not overly dry). If samples remained on the hotplate for too long, over dryness caused cracks to form in the cake and a 
build up of static electricity in combination with the ambient air flow in the laminar flow hood occasionally resulted in particulates escaping from the beakers. After drying down with $\mathrm{HNO}_{3}$ the cake is much more solid and the chance of particle loss is greatly reduced but overdryness is still to be avoided. Beakers were monitored closely during these evaporations to avoid these problems. Samples were then brought into solution in ca. $9 \mathrm{~mL}$ of $1 \mathrm{M} \mathrm{HNO}_{3}$ and left on the hot plate for at least 3 days to ensure the samples were completely in solution.

\section{Dilutions}

Ten $\mathrm{mL}$ test tubes and $60 \mathrm{~mL}$ low-density polyethylene bottles were rinsed with MQ $\mathrm{H}_{2} \mathrm{O}$, soaked in dilute $\mathrm{HNO}_{3}$ for 24 hours and then rinsed thoroughly with MQ $\mathrm{H}_{2} \mathrm{O}$. The high precision balance $( \pm 0.0001 \mathrm{~g})$ was tared for the weight of the test tube, and then the $9 \mathrm{~mL}$ of solution was poured into the test tube and weighed ensuring that all drops were removed from the beaker. Samples were then centrifuged at 2000 revolutions per minute (rpm) for 5 min. After centrifuging, test tubes were checked for a gel at the base to ensure the sample was fully in solution. From the test tube, $400 \mu \mathrm{L}$ of solution was pipetted into the $60 \mathrm{~mL}$ bottle and weighed on the tared balance. The bottle was then filled with 40-45 $\mathrm{mL}$ of $1.0 \%$ Seastar $\mathrm{HNO}_{3}$ and the total weight measured so that the dilution of the sample could be accurately determined.

\section{A1.3.2 Mass spectrometry}

The sample dilutions prepared as described above were analysed on an Agilent 7500CS ICP-MS at Victoria University of Wellington (VUW), Wellington, New Zealand. Analysis conditions are shown in Table A1.2. Samples were introduced into the ICP-MS through a wet spray chamber. Background count rates were measured for $90 \mathrm{~s}$ prior to analysis of each sample on an analytical blank and the mean background was subtracted directly from the sample count rates measured during analysis. Total count times on each mass during analysis vary from ca. 1.3-6.0 s. Plasma torch conditions were optimised so that the element oxide 
production monitored using measured $\mathrm{CeO}^{+} / \mathrm{Ce}^{+}$ratios was $\leq 1 \%$. Multiple isotopes of some elements were added to the run table to assess data quality. For example, ${ }^{90} \mathrm{Zr}$ and ${ }^{91} \mathrm{Zr}$ were both included in analyses and resulted in $\mathrm{Zr}$ concentrations that reproduced to $< \pm 0.5 \%$. Each individual analysis represents $135 \mathrm{~s}$ of data acquisition. Abundances of individual trace elements were calculated relative to a matrix-matched bracketing standard (i.e. the USGS basaltic whole rock standard BHVO-1), which was analysed under identical conditions throughout the analysis session.

Table A1.2: ICP-MS instrumental and analytical conditions.

ICP-MS

ICP-MS system

Acquisition mode

Detection mode

\section{Standards and Calibration}

Calibration standard

Secondary standard

Internal Standard

\section{Method}

Background acquisition

Sample/standard acquisition

Washout time

Measured isotopes and integration times

Tuning

Tuning standard

Monitored isotopes during tuning

Calibration standard

Monitored isotopes during tuning

Background

Oxides

Carrier gas (Ar)

Makeup gas (Ar)

RF power

RF matching

Sample depth (z)
Agilent 7500CS octopole

Peak hopping

Pulse and analogue counting (mostly pulse)

BHVO-1

BHVO-2, BCR-2

${ }^{43} \mathrm{Ca}$

$90 \mathrm{~s}$

$180 \mathrm{~s}$

$210 \mathrm{~s}$

$10 \mathrm{~ms}:{ }^{43} \mathrm{Ca},{ }^{45} \mathrm{Sc},{ }^{53} \mathrm{Cr},{ }^{60} \mathrm{Ni},{ }^{63} \mathrm{Cu},{ }^{66} \mathrm{Zn},{ }^{71} \mathrm{Ga},{ }^{86} \mathrm{Sr},{ }^{89} \mathrm{Y},{ }^{90} \mathrm{Zr}$,

${ }^{91} \mathrm{Zr},{ }^{93} \mathrm{Nb},{ }^{137} \mathrm{Ba},{ }^{139} \mathrm{La},{ }^{140} \mathrm{Ce},{ }^{146} \mathrm{Nd}$

$20 \mathrm{~ms}:{ }^{85} \mathrm{Rb},{ }^{141} \mathrm{Pr},{ }^{147} \mathrm{Sm},{ }^{157} \mathrm{Gd},{ }^{163} \mathrm{Dy}$

$50 \mathrm{~ms}:{ }^{95} \mathrm{Mo},{ }^{133} \mathrm{Cs},{ }^{151} \mathrm{Eu},{ }^{153} \mathrm{Eu},{ }^{159} \mathrm{~Tb},{ }^{165} \mathrm{Ho},{ }^{166} \mathrm{Er},{ }^{169} \mathrm{Tm}$,

${ }^{172} \mathrm{Yb},{ }^{175} \mathrm{Lu},{ }^{178} \mathrm{Hf},{ }^{181} \mathrm{Ta},{ }^{205} \mathrm{Tl},{ }^{208} \mathrm{~Pb},{ }^{232} \mathrm{Th},{ }^{238} \mathrm{U}$

Agilent 10 ppb solution (Li, Co, Y, Ce, Tl)

${ }^{89} \mathrm{Y},{ }^{140} \mathrm{Ce},{ }^{205} \mathrm{Tl}$ (\% RSD for each isotope $<3 \%$ )

BHVO-1

${ }^{43} \mathrm{Ca},{ }^{60} \mathrm{Ni},{ }^{86} \mathrm{Sr},{ }^{89} \mathrm{Y},{ }^{137} \mathrm{Ba},{ }^{140} \mathrm{Ce},{ }^{208} \mathrm{~Pb},{ }^{232} \mathrm{Th}$

(\% RSD for each isotope typically $<3 \%$ except $\mathrm{Ca}$ and $\mathrm{Pb}$ $<4 \%$ )

${ }^{43}$ Ca typically $<2000 \mathrm{cps}$ (\% of BHVO-1 cps $=<0.1 \%$ )

All other elements $<1 \%$ with most below $<0.5 \%$

exceptions are $\mathrm{Sc}$ and $\mathrm{Mo}<5 \%$ and $\mathrm{Tl}<10 \%$

$\mathrm{CeO}^{+} / \mathrm{Ce}^{+}: 10 \mathrm{ppb}$ solution $\leq 1 \%$

$0.75-0.70 \mathrm{~L} / \mathrm{min}$

$0.30-0.35 \mathrm{~L} / \mathrm{min}$

$1400-1450 \mathrm{~W}$

$1.75-1.79 \mathrm{~V}$

$7 \mathrm{~mm}$ 
The ICP-MS data acquisition technique employed here is similar to that commonly used during LA-ICP-MS, where a minor isotope of a major element (here ${ }^{43} \mathrm{Ca}$ ), previously determined by XRF was included in ICP-MS analysis and used as an internal standard, for secondary data normalisation. Prior to analysis pulse/analog (P/A) factors were measured on all relevant elements (e.g. Ca, $\mathrm{V}, \mathrm{Cr}$, Co, $\mathrm{Ni}, \mathrm{Sr}, \mathrm{Zr}, \mathrm{Nb}, \mathrm{Ba}, \mathrm{Ce})$. Measurement of P/A factors ensures the ICP-MS correctly performs the correction when switching between pulse and analog counting mode required if an element has a concentration that results in a count rate $>1$ million counts per second.

\section{A1.3.3 Data reduction and concentration calculations}

Analyses of samples are bracketed by analyses of the calibration standard (BHVO1) so that (after corrections for backgrounds) the trace element concentration of element $\mathrm{x}$ in the sample is determined by the relationships:

$$
\begin{aligned}
& C_{\text {sample }}^{\mathrm{CaO}, \mathrm{IPP}-\mathrm{MS}}=C_{\text {std }}^{\mathrm{CaO}} \mathrm{x}\left(C P S_{\text {sample }}^{\mathrm{Ca}} / C P S_{\text {std }}^{\mathrm{Ca}}\right) \\
& C_{\text {sample }}^{x, I C P S}=C_{\text {std }}^{x} \times\left(C_{\text {sample }}^{\mathrm{CaO}, \mathrm{XRF}} / C_{\text {sample }}^{\mathrm{CaO}, \mathrm{ICP}-\mathrm{MS}}\right) \times\left(C P S_{\text {sample }}^{x} / C P S_{\text {std }}^{x}\right)
\end{aligned}
$$

$C_{\text {sample }}^{\mathrm{CaO}, \mathrm{ICP}-\mathrm{MS}}, C_{\text {sample }}^{\mathrm{CaO}, \mathrm{XRF}}=$ concentration of Ca determined by ICP-MS or XRF.

$C_{\text {std }}^{\mathrm{CaO}}=$ Georem $\mathrm{CaO}$ concentration of the BHVO-1 standard.

$C P S_{\text {sample }}^{\mathrm{Ca}}, C P S_{\text {std }}^{\mathrm{Ca}}=$ counts per second obtained on ${ }^{43} \mathrm{Ca}$ during analysis of the whole rock dilution (sample) or BHVO-1 (std).

$C_{\text {sample }}^{x, I C P S}=$ concentration of element $\mathrm{x}$ determined by ICP-MS.

$C_{\text {std }}^{x}=$ reference concentration of element $\mathrm{x}$ in the standard BHVO-1.

$C P S_{\text {sample }}^{x}, C P S_{\text {std }}^{x}=$ counts per second obtained on an isotope of element $\mathrm{x}$ in the whole rock dilution (sample) or BHVO-1 (std).

The trace element concentrations of BHVO-1 are well characterised. BHVO-1 was chosen as the calibration standard as it is a first generation USGS standard 
that has been the subject of repeated analyses for several decades, and thus the concentrations of the majority of elements in BHVO-1 are known with a degree of certainty. However, recent analytical improvements mean some elements can now be measured more precisely (e.g. isotope dilution multi-collector ICP-MS; ID-MC-ICP-MS). The recommended trace element concentrations of standard materials are compiled from the scientific literature on Georem. However, Georem recommended values can be biased by imprecise some methods of data collection so, in this study, preferred values for BHVO-1 and BCR-2 have been selected from the literature (Table A1.3). BCR-2 is a new generation standard that was prepared from material collected in the 1990s from the same location as the first generation sample (BCR-1). In the case of elements where there are difficulties in measurement or where a lack of published values have been used to create the Georem recommended BCR-2 values, the more precisely and accurately measured BCR-1 values have been used. The Georem recommended values have been used for BHVO-2 as they are essentially identical to those for BHVO-1.

\section{A1.3.4 Precision and accuracy of trace element data}

Replicate digestions of basaltic reference materials produced by USGS (BHVO-2 and BCR-2) were undertaken to quantify the precision and accuracy with which trace elements were measured using the ICP-MS technique. This data is presented in Table A1.4 \& A1.5. The accuracy with which multiple digestions of these standards have been made is shown in Figure A1.1. The majority of elements are accurate to significantly $< \pm 5 \%$, with all elements being accurate to $< \pm 10 \%$ except Mo and Tl in BHVO-2. However, this is probably due to the reference values for these elements being poorly constrained. BHVO-2 was prepared from material collected in the 1990s from the same location as BHVO-1, thus these samples are matrix matched and a high degree of accuracy and precision was expected in this data. 
Table A1.3: Preferred trace element concentrations of USGS rock standards.

\begin{tabular}{|c|c|c|c|}
\hline & BHVO-1 & BCR-2 & Notes \\
\hline $\mathrm{Sc}$ & 31.0 & 33.0 & Georem preferred \\
\hline $\mathrm{V}$ & 318 & 416 & Georem preferred \\
\hline $\mathrm{Cr}$ & 287 & 16.0 & $\mathrm{BHVO}=$ Georem preferred; $\mathrm{BCR}-2=\mathrm{BCR}-1$ compilations \\
\hline Co & 45.0 & 37.0 & Georem preferred \\
\hline $\mathrm{Ni}$ & 118 & 13.0 & $\mathrm{BHVO}=$ Georem preferred; $\mathrm{BCR}-2=\mathrm{BCR}-1$ compilations \\
\hline $\mathrm{Cu}$ & 137 & 21.0 & Georem preferred \\
\hline $\mathrm{Zn}$ & 106 & 130 & Georem preferred \\
\hline $\mathrm{Ga}$ & 21.0 & 22.0 & BHVO = Georem preferred; BCR-2 = BCR-1 compilations \\
\hline $\mathrm{Rb}$ & 9.19 & 46.9 & Georem preferred \\
\hline $\mathrm{Sr}$ & 396 & 340 & Georem preferred \\
\hline Y & 26.0 & 36.0 & $\mathrm{BHVO}=$ Georem preferred; $\mathrm{BCR}-2=\mathrm{BCR}-1$ compilations \\
\hline $\mathrm{Zr}$ & 174 & 189 & BHVO = Georem preferred; BCR-2 = BCR-1 compilations \\
\hline $\mathrm{Nb}$ & 18.6 & 12.6 & Georem preferred \\
\hline Mo & 1.00 & 250 & Georem preferred (Poorly constrained) \\
\hline Cs & 0.09 & 1.10 & $\mathrm{BHVO}=10 \%$ lower than Georem preferred; $\mathrm{BCR}-2=$ Georem preferred \\
\hline $\mathrm{Ba}$ & 133 & 677 & Georem preferred \\
\hline $\mathrm{La}$ & 15.52 & 25.12 & JAB DLC ID \\
\hline $\mathrm{Ce}$ & 38.23 & 53.31 & JAB DLC ID \\
\hline $\operatorname{Pr}$ & 5.411 & 6.756 & JAB DLC ID \\
\hline $\mathrm{Nd}$ & 24.79 & 28.71 & JAB DLC ID \\
\hline $\mathrm{Sm}$ & 6.14 & 6.58 & JAB DLC ID \\
\hline $\mathrm{Eu}$ & 2.066 & 1.944 & JAB DLC ID \\
\hline Gd & 6.29 & 6.73 & JAB DLC ID \\
\hline $\mathrm{Tb}$ & 0.96 & 1.07 & Georem preferred \\
\hline Dy & 5.36 & 6.44 & JAB DLC ID \\
\hline Ho & 0.98 & 1.28 & Georem preferred \\
\hline Er & 2.57 & 3.71 & JAB DLC ID \\
\hline $\mathrm{Tm}$ & 0.33 & 0.54 & Georem preferred \\
\hline $\mathrm{Yb}$ & 1.98 & 3.34 & JAB DLC ID \\
\hline $\mathrm{Lu}$ & 0.279 & 0.499 & JAB DLC ID \\
\hline $\mathrm{Hf}$ & 4.51 & 4.97 & JAB DLC ID \\
\hline $\mathrm{Ta}$ & 1.21 & 0.81 & BHVO = GeoReM preferred; BCR-2 = BCR-1 compilations \\
\hline $\mathrm{Tl}$ & 0.044 & 0.300 & BHVO = GeoReM preferred; BCR-2 = BCR-1 (no BCR-2 data) \\
\hline $\mathrm{Pb}$ & 2.40 & 11.0 & GeoReM preferred \\
\hline Th & 1.23 & 5.90 & $\mathrm{BHVO}=\mathrm{GeoReM}$ preferred; BCR $-2=\mathrm{BCR}-1$ compilations \\
\hline $\mathrm{U}$ & 0.409 & 1.69 & GeoReM preferred \\
\hline
\end{tabular}

Notes: JAB DLC ID: Joel Allen Baker Danish Lithospheric Centre isotope dilution MC-ICP-MS data (Baker et al., 2002). Compilations for some elements in the BCR-2 data set suffer from the lack of data, biasing the Georem recommended numbers so it was decided to use the better constrained BCR-1 values for these elements.

For BHVO-2 all elements were measured to a precision ( $\% 2 \mathrm{SD} ; \mathrm{n}=7$ ) of better than $\pm 5 \%$, except $\mathrm{Zn} \pm 6 \%, \mathrm{Cs} \pm 9 \%$ and $\mathrm{Mo} \pm 16 \%$. BCR-2 is not so closely matrix matched to the primary standard BHVO-1 so it serves as a better reflection of the data quality from this method. In BCR-2, all elements were measured to a precision (\% $2 \mathrm{SD} ; \mathrm{n}=9$ ) of better than $\pm 5 \%$ except $\mathrm{Cu}$ and $\mathrm{Tl} \pm 7 \%$, and Mo and $\mathrm{Pb} \pm 12 \%$. 
Table A1.4: ICP-MS trace element data showing the reproducibility of repeat digestions of BHVO-2.

\begin{tabular}{|c|c|c|c|c|c|c|c|c|c|c|c|c|c|}
\hline BHVO-2 & $\mathrm{A}$ & $\mathrm{B}$ & $\mathrm{B}^{*}$ & $\mathrm{C}$ & $\mathrm{C}^{*}$ & $\mathrm{D}$ & $\mathrm{E}$ & Mean & Georem & $\%$ Offset & $2 \mathrm{SD}$ & $\% 2 \mathrm{SD}$ & =Notes: A1.4 \& 5; \\
\hline${ }^{45} \mathrm{Sc}$ & 31.9 & 31.3 & 30.9 & 31.2 & 31.6 & 31.7 & 31.2 & 31.4 & 32 & $-1.9 \%$ & 0.69 & $2.2 \%$ & Letters represent \\
\hline${ }^{51} \mathrm{~V}$ & 317 & 321 & 316 & 322 & 321 & 324 & 319 & 320 & 317 & $+0.9 \%$ & 5.90 & $1.8 \%$ & individual digestions of \\
\hline${ }^{53} \mathrm{Cr}$ & 295 & 293 & 287 & 291 & 286 & 298 & 296 & 292 & 280 & $+4.4 \%$ & 9.03 & $3.1 \%$ & rock standards. * \\
\hline${ }^{59} \mathrm{Co}$ & 45.2 & 45.5 & 44.3 & 44.9 & 45.2 & 45.8 & 44.8 & 45.1 & 45 & $+0.2 \%$ & 0.99 & $2.2 \%$ & represents a duplicate \\
\hline${ }^{60} \mathrm{Ni}$ & 117 & 120 & 118 & 122 & 119 & 121 & 121 & 120 & 119 & $+0.7 \%$ & 3.34 & $2.8 \%$ & ansis of the same \\
\hline${ }^{63} \mathrm{Cu}$ & 126 & 128 & 125 & 128 & 128 & 132 & 128 & 128 & 127 & $+0.7 \%$ & 4.44 & $3.5 \%$ & analysis or the same \\
\hline${ }^{66} \mathrm{Zn}$ & 100 & 106 & 101 & 107 & 102 & 107 & 102 & 103 & 103 & $+0.5 \%$ & 5.65 & $5.5 \%$ & digestion. \% oftset \\
\hline${ }^{71} \mathrm{Ga}$ & 20.7 & 21.1 & 20.4 & 21.4 & 20.9 & 21.4 & 21.0 & 21.0 & 22 & $-4.7 \%$ & 0.73 & $3.5 \%$ & represents the \\
\hline${ }^{85} \mathrm{Rb}$ & 8.96 & 9.12 & 8.89 & 9.21 & 9.11 & 9.22 & 9.00 & 9.07 & 9.11 & $-0.4 \%$ & 0.25 & $2.7 \%$ & \\
\hline${ }^{86} \mathrm{Sr}$ & 392 & 396 & 377 & 399 & 397 & 401 & 389 & 393 & 396 & $-0.8 \%$ & 15.8 & $4.0 \%$ & een the measured \\
\hline${ }^{89} \mathrm{Y}$ & 25.6 & 26.0 & 25.2 & 26.5 & 25.7 & 26.3 & 25.6 & 25.8 & 26 & $-0.6 \%$ & 0.84 & $3.3 \%$ & average and the \\
\hline${ }^{90} \mathrm{Zr}$ & 172 & 174 & 169 & 175 & 174 & 176 & 172 & 173 & 172 & $+0.7 \%$ & 4.70 & $2.7 \%$ & Georem recommended/ \\
\hline${ }^{93} \mathrm{Nb}$ & 18.2 & 18.6 & 17.9 & 18.9 & 18.6 & 18.8 & 18.2 & 18.5 & 18.1 & $+2.1 \%$ & 0.75 & $4.1 \%$ & preferred values. \\
\hline${ }^{95} \mathrm{Mo}$ & 3.61 & 3.32 & 3.31 & 3.19 & 3.16 & 3.87 & 3.57 & 3.43 & 4.0 & $-14.1 \%$ & 0.52 & $15.1 \%$ & Derivation of preferred \\
\hline${ }^{133} \mathrm{Cs}$ & 0.093 & 0.091 & 0.090 & 0.100 & 0.099 & 0.095 & 0.092 & 0.094 & 0.10 & $-5.8 \%$ & 0.01 & $8.4 \%$ & values in Table A1.5 is \\
\hline${ }^{137} \mathrm{Ba}$ & 130 & 132 & 128 & 133 & 132 & 135 & 131 & 132 & 131 & $+0.5 \%$ & 4.30 & $3.3 \%$ & explained in Section \\
\hline${ }^{139} \mathrm{La}$ & 15.3 & 15.4 & 15.0 & 15.8 & 15.3 & 15.6 & 15.2 & 15.4 & 15.2 & $+1.0 \%$ & 0.54 & $3.5 \%$ & A1.3.3. Values in \\
\hline${ }^{140} \mathrm{Ce}$ & 37.4 & 38.1 & 36.7 & 38.4 & 37.9 & 38.8 & 37.6 & 37.8 & 37.5 & $+0.9 \%$ & 1.38 & $3.6 \%$ & italics vary from the \\
\hline${ }^{141} \mathrm{Pr}$ & 5.30 & 5.35 & 5.24 & 5.46 & 5.38 & 5.47 & 5.29 & 5.35 & 5.35 & $+0.1 \%$ & 0.17 & $3.2 \%$ & Georem recommended \\
\hline${ }^{146} \mathrm{Nd}$ & 24.6 & 24.4 & 23.8 & 24.9 & 25.0 & 25.1 & 24.2 & 24.6 & 24.5 & $+0.3 \%$ & 0.94 & $3.8 \%$ & values. BHVO-2 and \\
\hline${ }^{147} \mathrm{Sm}$ & 6.12 & 6.08 & 5.96 & 6.22 & 6.14 & 6.27 & 6.05 & 6.12 & 6.07 & $+0.8 \%$ & 0.21 & $3.4 \%$ & BCR-2 were \\
\hline${ }^{151} \mathrm{Eu}$ & 2.05 & 2.06 & 2.02 & 2.10 & 2.08 & 2.10 & 2.03 & 2.06 & 2.07 & $-0.4 \%$ & 0.07 & $3.3 \%$ & normalised to $\mathrm{CaO}$ \\
\hline${ }^{157} \mathrm{Gd}$ & 6.18 & 6.22 & 6.00 & 6.33 & 6.30 & 6.38 & 6.16 & 6.22 & 6.24 & $-0.3 \%$ & 0.26 & $4.1 \%$ & values of 11.4 and 7.12 \\
\hline${ }^{159} \mathrm{~Tb}$ & 0.949 & 0.960 & 0.936 & 0.985 & 0.972 & 0.979 & 0.944 & 0.961 & 0.92 & $+4.4 \%$ & 0.04 & $3.8 \%$ & wt.\% respectively. \\
\hline${ }^{163} \mathrm{Dy}$ & 5.30 & 5.33 & 5.17 & 5.44 & 5.44 & 5.50 & 5.32 & 5.36 & 5.31 & $+0.9 \%$ & 0.23 & $4.2 \%$ & Measured Ca variations \\
\hline${ }^{165} \mathrm{Ho}$ & 0.977 & 0.978 & 0.946 & 0.994 & 0.983 & 0.996 & 0.970 & 0.978 & 0.98 & $-0.2 \%$ & 0.03 & $3.4 \%$ & were generally $< \pm 5 \%$. \\
\hline${ }^{166} \mathrm{Er}$ & 2.54 & 2.58 & 2.49 & 2.60 & 2.60 & 2.65 & 2.55 & 2.57 & 2.54 & $+1.2 \%$ & 0.10 & $4.0 \%$ & \\
\hline${ }^{169} \mathrm{Tm}$ & 0.326 & 0.334 & 0.317 & 0.332 & 0.335 & 0.335 & 0.327 & 0.329 & 0.33 & $-0.2 \%$ & 0.01 & $4.0 \%$ & \\
\hline${ }^{172} \mathrm{Yb}$ & 1.99 & 1.96 & 1.92 & 2.00 & 2.01 & 2.02 & 1.93 & 1.98 & 2 & $-1.2 \%$ & 0.08 & $4.2 \%$ & \\
\hline${ }^{175} \mathrm{Lu}$ & 0.278 & 0.282 & 0.269 & 0.286 & 0.283 & 0.284 & 0.276 & 0.280 & 0.274 & $+2.1 \%$ & 0.01 & $4.1 \%$ & \\
\hline${ }^{178} \mathrm{Hf}$ & 4.49 & 4.56 & 4.32 & 4.59 & 4.59 & 4.62 & 4.45 & 4.52 & 4.36 & $+3.6 \%$ & 0.21 & $4.7 \%$ & \\
\hline${ }^{181} \mathrm{Ta}$ & 1.20 & 1.20 & 1.16 & 1.23 & 1.23 & 1.22 & 1.20 & 1.21 & 1.14 & $+5.7 \%$ & 0.05 & $4.3 \%$ & \\
\hline${ }^{205} \mathrm{Tl}$ & 0.021 & 0.020 & 0.020 & 0.022 & 0.021 & 0.021 & 0.019 & 0.021 & - & - & 0.002 & $9.3 \%$ & \\
\hline${ }^{208} \mathrm{~Pb}$ & 1.98 & 1.58 & 1.64 & 1.67 & 1.70 & 1.81 & 1.70 & 1.72 & 1.6 & $+7.7 \%$ & 0.26 & $15.4 \%$ & \\
\hline${ }^{232} \mathrm{Th}$ & 1.23 & 1.21 & 1.18 & 1.24 & 1.25 & 1.26 & 1.21 & 1.22 & 1.22 & $+0.4 \%$ & 0.06 & $4.7 \%$ & \\
\hline${ }^{238} \mathrm{U}$ & 0.407 & 0.410 & 0.389 & 0.412 & 0.417 & 0.411 & 0.408 & 0.408 & 0.403 & $+1.1 \%$ & 0.02 & $4.3 \%$ & \\
\hline
\end{tabular}


Table A1.5: ICP-MS trace element data showing the reproducibility of repeat digestions of BCR-2.

\begin{tabular}{|c|c|c|c|c|c|c|c|c|c|c|c|c|c|c|}
\hline BCR-2 & A & $\mathrm{B}$ & $\mathrm{C}$ & $\mathrm{D}$ & $\mathrm{E}$ & $\mathrm{F}$ & $\mathrm{G}$ & $\mathrm{H}$ & $\mathrm{I}$ & Mean & Preferred & $\%$ Offset & $2 \mathrm{SD}$ & $\% 2 \mathrm{SD}$ \\
\hline${ }^{45} \mathrm{Sc}$ & 32.7 & 32.8 & 32.6 & 32.8 & 32.8 & 32.4 & 33.5 & 32.6 & 32.8 & 32.8 & 33 & $-0.7 \%$ & 0.62 & $1.9 \%$ \\
\hline${ }^{51} \mathrm{~V}$ & 418 & 418 & 418 & 422 & 416 & 422 & 417 & 419 & 419 & 419 & 416 & $+0.7 \%$ & 4.37 & $1.0 \%$ \\
\hline${ }^{53} \mathrm{Cr}$ & 14.4 & 15.4 & 14.6 & 15.1 & 14.9 & 15.0 & 15.0 & 14.3 & 14.6 & 14.8 & 16 & $-7.4 \%$ & 0.72 & $4.9 \%$ \\
\hline${ }^{59} \mathrm{Co}$ & 37.0 & 37.5 & 37.3 & 38.0 & 37.2 & 37.7 & 37.1 & 37.6 & 37.3 & 37.4 & 37 & $+1.1 \%$ & 0.63 & $1.7 \%$ \\
\hline${ }^{60} \mathrm{Ni}$ & 11.9 & 12.2 & 11.9 & 12.3 & 12.0 & 12.5 & 12.2 & 12.1 & 11.9 & 12.1 & 13 & $-6.8 \%$ & 0.41 & $3.4 \%$ \\
\hline${ }^{63} \mathrm{Cu}$ & 19.6 & 19.5 & 19.9 & 19.4 & 20.4 & 20.9 & 20.3 & 20.1 & 18.6 & 19.9 & 21 & $-5.4 \%$ & 1.32 & $6.6 \%$ \\
\hline${ }^{66} \mathrm{Zn}$ & 126 & 125 & 124 & 128 & 126 & 133 & 131 & 132 & 127 & 128 & 130 & $-1.6 \%$ & 6.30 & $4.9 \%$ \\
\hline${ }^{71} \mathrm{Ga}$ & 21.5 & 21.5 & 21.4 & 21.8 & 21.8 & 21.7 & 21.4 & 21.7 & 21.2 & 21.6 & 22 & $-2.0 \%$ & 0.43 & $2.0 \%$ \\
\hline${ }^{85} \mathrm{Rb}$ & 45.9 & 45.8 & 45.6 & 47.3 & 47.0 & 46.7 & 46.3 & 46.4 & 45.5 & 46.3 & 46.9 & $-1.3 \%$ & 1.25 & $2.7 \%$ \\
\hline${ }^{86} \mathrm{Sr}$ & 330 & 326 & 328 & 340 & 337 & 339 & 340 & 329 & 329 & 333 & 340 & $-2.1 \%$ & 11.2 & $3.4 \%$ \\
\hline${ }^{89} \mathrm{Y}$ & 35.3 & 35.1 & 35.0 & 35.6 & 36.0 & 35.7 & 35.3 & 35.3 & 34.9 & 35.4 & 36 & $-1.8 \%$ & 0.72 & $2.0 \%$ \\
\hline${ }^{90} \mathrm{Zr}$ & 187 & 187 & 186 & 191 & 191 & 188 & 187 & 187 & 185 & 188 & 189 & $-0.7 \%$ & 4.37 & $2.3 \%$ \\
\hline${ }^{93} \mathrm{Nb}$ & 12.2 & 12.3 & 12.2 & 12.4 & 12.6 & 12.4 & 12.4 & 12.3 & 12.2 & 12.3 & 13 & $-2.3 \%$ & 0.23 & $1.8 \%$ \\
\hline${ }^{95} \mathrm{Mo}$ & 260 & 251 & 249 & 276 & 232 & 256 & 232 & 260 & 249 & 252 & 250 & $+0.7 \%$ & 27.7 & $11.0 \%$ \\
\hline${ }^{133} \mathrm{Cs}$ & 1.04 & 1.06 & 1.06 & 1.06 & 1.07 & 1.10 & 1.06 & 1.06 & 1.04 & 1.06 & 1.1 & $-3.4 \%$ & 0.04 & $3.4 \%$ \\
\hline${ }^{137} \mathrm{Ba}$ & 688 & 688 & 687 & 693 & 685 & 666 & 660 & 692 & 672 & 681 & 677 & $+0.6 \%$ & 23.9 & $3.5 \%$ \\
\hline${ }^{139} \mathrm{La}$ & 24.9 & 24.8 & 24.5 & 25.2 & 25.5 & 25.2 & 24.9 & 24.8 & 24.4 & 24.9 & 25.12 & $-0.8 \%$ & 0.71 & $2.8 \%$ \\
\hline${ }^{140} \mathrm{Ce}$ & 52.0 & 52.6 & 52.2 & 52.9 & 54.6 & 53.4 & 52.5 & 52.1 & 51.5 & 52.6 & 53.31 & $-1.2 \%$ & 1.81 & $3.4 \%$ \\
\hline${ }^{141} \mathrm{Pr}$ & 6.69 & 6.72 & 6.69 & 6.84 & 7.02 & 6.82 & 6.75 & 6.67 & 6.62 & 6.76 & 6.756 & $+0.02 \%$ & 0.24 & $3.6 \%$ \\
\hline${ }^{146} \mathrm{Nd}$ & 27.9 & 28.2 & 28.2 & 28.5 & 29.2 & 28.9 & 28.5 & 28.5 & 27.9 & 28.4 & 28.71 & $-1.0 \%$ & 0.90 & $3.2 \%$ \\
\hline${ }^{147} \mathrm{Sm}$ & 6.41 & 6.53 & 6.47 & 6.48 & 6.74 & 6.54 & 6.56 & 6.58 & 6.34 & 6.52 & 6.58 & $-1.0 \%$ & 0.23 & $3.5 \%$ \\
\hline${ }^{151} \mathrm{Eu}$ & 1.98 & 1.97 & 1.95 & 2.00 & 2.04 & 2.01 & 1.98 & 1.97 & 1.92 & 1.98 & 1.944 & $+1.9 \%$ & 0.07 & $3.7 \%$ \\
\hline${ }^{157} \mathrm{Gd}$ & 6.81 & 6.84 & 6.70 & 6.89 & 6.98 & 6.89 & 6.91 & 6.92 & 6.63 & 6.84 & 6.73 & $+1.7 \%$ & 0.22 & $3.3 \%$ \\
\hline${ }^{159} \mathrm{~Tb}$ & 1.06 & 1.06 & 1.06 & 1.07 & 1.10 & 1.08 & 1.07 & 1.06 & 1.04 & 1.07 & 1.07 & $-0.4 \%$ & 0.03 & $3.0 \%$ \\
\hline${ }^{163} \mathrm{Dy}$ & 6.38 & 6.38 & 6.29 & 6.44 & 6.55 & 6.43 & 6.38 & 6.36 & 6.25 & 6.38 & 6.44 & $-0.9 \%$ & 0.17 & $2.7 \%$ \\
\hline${ }^{165} \mathrm{Ho}$ & 1.27 & 1.27 & 1.27 & 1.28 & 1.31 & 1.29 & 1.28 & 1.27 & 1.24 & 1.28 & 1.28 & $-0.3 \%$ & 0.04 & $2.8 \%$ \\
\hline${ }^{166} \mathrm{Er}$ & 3.67 & 3.62 & 3.60 & 3.67 & 3.74 & 3.68 & 3.68 & 3.64 & 3.55 & 3.65 & 3.71 & $-1.6 \%$ & 0.11 & $2.9 \%$ \\
\hline${ }^{169} \mathrm{Tm}$ & 0.516 & 0.508 & 0.507 & 0.513 & 0.527 & 0.517 & 0.509 & 0.512 & 0.493 & 0.511 & 0.54 & $-5.3 \%$ & 0.02 & $3.6 \%$ \\
\hline${ }^{172} \mathrm{Yb}$ & 3.28 & 3.27 & 3.25 & 3.34 & 3.38 & 3.28 & 3.31 & 3.27 & 3.23 & 3.29 & 3.34 & $-1.5 \%$ & 0.09 & $2.9 \%$ \\
\hline${ }^{175} \mathrm{Lu}$ & 0.496 & 0.496 & 0.488 & 0.496 & 0.509 & 0.498 & 0.500 & 0.493 & 0.482 & 0.495 & 0.499 & $-0.7 \%$ & 0.02 & $3.1 \%$ \\
\hline${ }^{178} \mathrm{Hf}$ & 4.90 & 4.89 & 4.85 & 4.98 & 5.14 & 5.00 & 5.03 & 4.86 & 4.82 & 4.94 & 4.97 & $-0.6 \%$ & 0.21 & $4.2 \%$ \\
\hline${ }^{181} \mathrm{Ta}$ & 0.794 & 0.784 & 0.781 & 0.796 & 0.827 & 0.800 & 0.803 & 0.784 & 0.768 & 0.793 & 0.81 & $-2.1 \%$ & 0.03 & $4.2 \%$ \\
\hline${ }^{205} \mathrm{Tl}$ & 0.278 & 0.267 & 0.263 & 0.287 & 0.280 & 0.281 & 0.286 & 0.281 & 0.262 & 0.276 & 0.3 & $-8.0 \%$ & 0.02 & $6.9 \%$ \\
\hline${ }^{208} \mathrm{~Pb}$ & 11.96 & 11.54 & 11.56 & 11.30 & 11.03 & 10.23 & 10.47 & 11.26 & 10.65 & 11.11 & 11 & $+1.0 \%$ & 1.13 & $10.2 \%$ \\
\hline${ }^{232} \mathrm{Th}$ & 5.88 & 5.83 & 5.82 & 5.89 & 6.14 & 5.99 & 5.96 & 5.85 & 5.68 & 5.89 & 5.90 & $-0.1 \%$ & 0.26 & $4.4 \%$ \\
\hline${ }^{238} \mathrm{U}$ & 1.63 & 1.57 & 1.60 & 1.63 & 1.68 & 1.63 & 1.61 & 1.59 & 1.57 & 1.61 & 1.69 & $-4.6 \%$ & 0.07 & $4.4 \%$ \\
\hline
\end{tabular}


A lower degree of precision (i.e. higher \% $2 \mathrm{SD}$ ) is expected for those elements elements of extremely low concentration (e.g. Cs, Tl, Mo, Pb). The correlation of errors during analyses means that trace element ratios are more precise and accurate than concentration measurements (Table A1.6). Trace element ratios used in this study reproduce to $<\mathrm{ca}$. $2 \%$, except those including $\mathrm{Pb}$ due to the poorer precision of $\mathrm{Pb}$ concentration measurements.

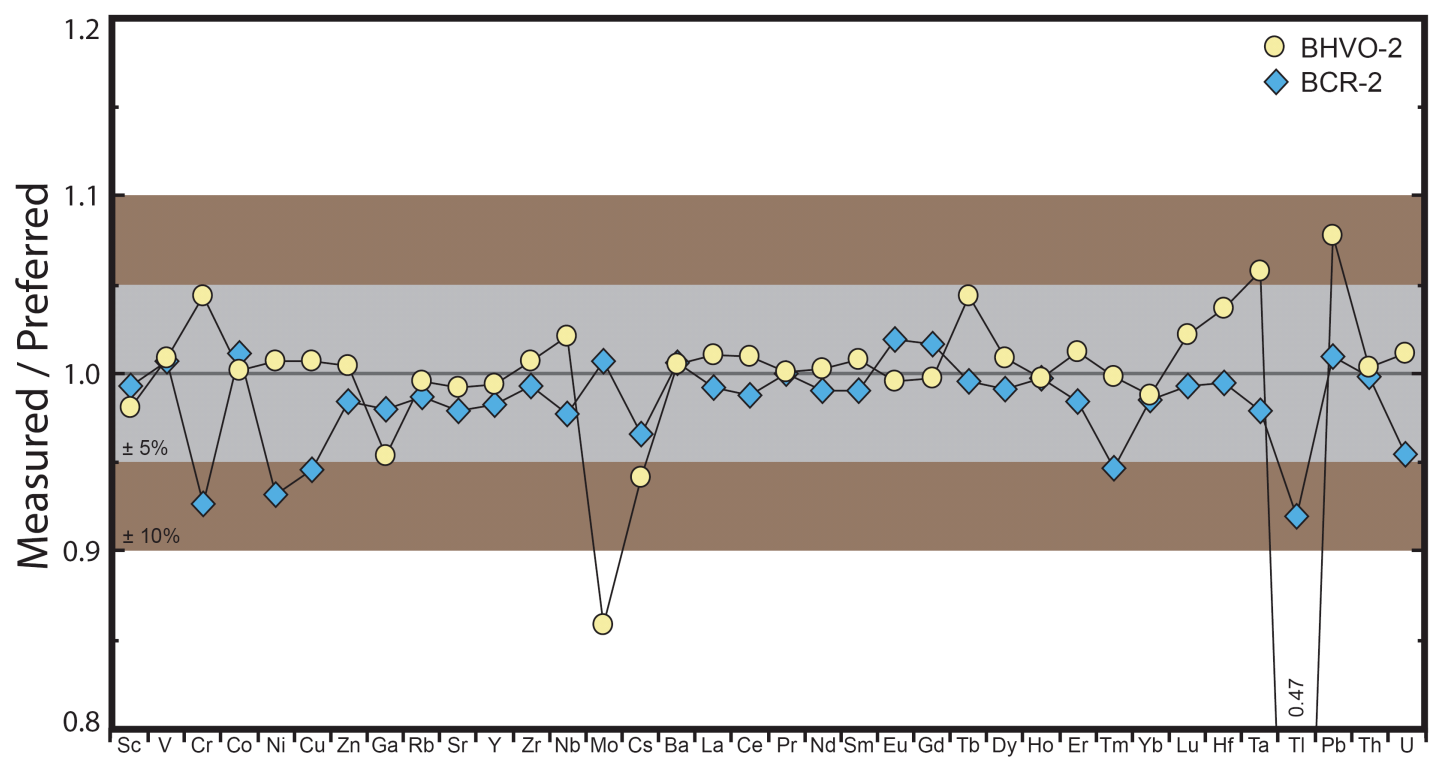

Figure A1.1: Accuracy of ICP-MS whole rock trace element data. Plotted are the mean values of multiple analyses of BHVO-2 ( $n=7)$ and BCR-2 $(n=9)$ normalised to the preferred values shown in Table A1.3.

Table A1.6: External reproducibility of trace element ratios.

\begin{tabular}{lcccccc}
\hline \multicolumn{1}{c}{ Ratio } & Range & Mean & Georem & \% Offset & 2 SD & \% 2 SD \\
\hline $\mathrm{Rb} / \mathrm{Sr}$ & $0.136-0.141$ & $\mathbf{0 . 1 3 9}$ & 0.138 & $+0.8 \%$ & 0.003 & $2.0 \%$ \\
$\mathrm{Sm} / \mathrm{Nd}$ & $0.226-0.232$ & $\mathbf{0 . 2 2 9}$ & 0.229 & $-0.01 \%$ & 0.004 & $1.6 \%$ \\
$\mathrm{Lu} / \mathrm{Hf}$ & $0.099-0.101$ & $\mathbf{0 . 1 0 0}$ & 0.100 & $-0.1 \%$ & 0.002 & $1.8 \%$ \\
$\mathrm{U} / \mathrm{Pb}$ & $0.136-0.159$ & $\mathbf{0 . 1 4 6}$ & 0.154 & $-5.3 \%$ & 0.017 & $11.6 \%$ \\
$\mathrm{Th} / \mathrm{Pb}$ & $0.491-0.585$ & $\mathbf{0 . 5 3 2}$ & 0.536 & $-0.9 \%$ & 0.065 & $12.2 \%$ \\
$\mathrm{U} / \mathrm{Th}$ & $0.270-0.277$ & $\mathbf{0 . 2 7 4}$ & 0.286 & $-4.6 \%$ & 0.006 & $2.1 \%$ \\
$\mathrm{La} / \mathrm{Yb}$ & $7.53-7.70$ & $\mathbf{7 . 5 7}$ & 7.52 & $+0.7 \%$ & 0.102 & $1.3 \%$ \\
$\mathrm{Dy} / \mathrm{Yb}$ & $1.92-1.96$ & $\mathbf{1 . 9 4}$ & 1.93 & $+0.6 \%$ & 0.023 & $1.2 \%$ \\
$\mathrm{Ce} / \mathrm{Y}$ & $1.47-1.52$ & $\mathbf{1 . 4 9}$ & 1.48 & $+0.5 \%$ & 0.026 & $1.7 \%$ \\
$\mathrm{Zr} / \mathrm{Nb}$ & $15.1-15.5$ & $\mathbf{1 5 . 2}$ & 15.0 & $+1.6 \%$ & 0.213 & $1.4 \%$ \\
$\mathrm{Nd} / \mathrm{Pb}$ & $2.33-2.83$ & $\mathbf{2 . 5 7}$ & 2.61 & $-1.7 \%$ & 0.310 & $12.1 \%$ \\
$\mathrm{Zr} / \mathrm{Hf}$ & $37.2-38.4$ & $\mathbf{3 8 . 0}$ & 38.0 & $-0.1 \%$ & 1.06 & $2.8 \%$ \\
$\mathrm{La} / \mathrm{Nb}$ & $2.00-2.04$ & $\mathbf{2 . 0 2}$ & 1.99 & $+1.5 \%$ & 0.027 & $1.3 \%$ \\
\hline $\mathrm{Ra}$ & & &
\end{tabular}

Ratios calculated using BCR-2 data presented in Table A1.5. Range presents the minimum and maximum calculated ratio from the 9 replicates of BCR- 2 . 


\section{A1.4 MINERAL MAJOR ELEMENT CHEMISTRY}

\section{A1.4.1 Introduction}

Electron probe micro-analysis (EPMA) was undertaken at VUW using a JEOL 733 Superprobe equipped with three wavelength dispersive spectrometers. $100 \mu \mathrm{m}$ thick polished thin sections were prepared and coated with a $25 \mathrm{~nm}$ thick carbon film prior to EPMA. Major element concentrations were determined using the ZAF correction method. The instrument was calibrated daily using a series of synthetic and natural standards: $\mathrm{Al}, \mathrm{Cr}, \mathrm{Fe}, \mathrm{Mg}, \mathrm{Mn}, \mathrm{Ni}$ and $\mathrm{Ti}-$ synthetic element oxides; $\mathrm{Si}$ and $\mathrm{Ca}$ - wollastanite; $\mathrm{Na}$ - jadeite; $\mathrm{K}$ - orthoclase. Mineral standards were analysed between samples to monitor any spectrometer drift and monitor precision. The standards used in this study for secondary data normalisation are international mineral and glass standards: San Carlos olivine (USNM 11312/444); Kakanui augite (USNM 122142); and basaltic glass VG-A99 (USNM 113498/1).

\section{A1.4.2 Standard measurement conditions}

Crystals of clinopyroxene, orthopyroxene, plagioclase and Fe-Ti oxides were analysed under a static electron beam (focused beam: $1 \mu \mathrm{m}$ ) with a current of 120 $\mathrm{nA}$ and an accelerating voltage of $15 \mathrm{kV}$. Analysis time was approximately 2-3 min. Detector set up for the electron microprobe was: (1) Al, $\mathrm{Mg}, \mathrm{Na}$ and $\mathrm{Si}$ (TAP); (2) Mn, Fe, Cr and Ni (LIF); (3) K, Ti, Ca (PETJ). During analysis of the basaltic glass VG-A99 the electron beam was defocused to $10 \mu \mathrm{m}$ and $\mathrm{Na}_{2} \mathrm{O}$ and $\mathrm{K}_{2} \mathrm{O}$ were determined first in each run to minimise the effects of alkali loss due to the electron beam heating and devolatising the glass.

\section{A1.4.3 Olivine measurement conditions}

Olivine phenocrysts were analysed with longer count times to increase the precision of minor element ( $\mathrm{Ca}, \mathrm{Ni}$ and $\mathrm{Mn}$ ) concentration measurements. Analysis times were approximately 5-6 min. Initially olivine crystals were 
analysed under a static electron beam (focused beam: $1 \mu \mathrm{m}$ ) with a current of 500 $\mathrm{nA}$ and an accelerating voltage of $20 \mathrm{kV}$. Detector set up for the electron microprobe was: (1) Al, Mg, and Si (TAP); (2) Mn, Fe, and Ni (LIF); (3) Ti and Ca (PETJ). Peak count times were increased over the standard $30 \mathrm{~s}$, with a $10 \mathrm{~s}$ background. Ni was measured for $180 \mathrm{~s}$ with a $60 \mathrm{~s}$ background; $\mathrm{Mg}$, Mn and Ca were measured for $60 \mathrm{~s}$ with a $20 \mathrm{~s}$ background.

Later analyses were undertaken using the analytical conditions of Sobolev et al. (2007) as these are demonstrated to be the optimum conditions for high precision analyses. Olivines were analysed under a static electron beam with a current of $300 \mathrm{nA}$ and an accelerating voltage of $20 \mathrm{kV}$. Detector set up for the electron microprobe was: (1) Al, Mg and Si (TAP); (2) Fe, Mn and Ni (LIF); (3) Ti, $\mathrm{Cr}$ and $\mathrm{Ca}$ (PETJ). Peak count times were as follows: Al, Ti and Fe 60 s; Mg, Mn and Cr 120 s; Si, Ni and Ca 150 s. Backgrounds were set at 20 s, 40 s and $60 \mathrm{~s}$ respectively. Several samples (i.e. JB-281, AMB-5 and AMB-10) were analysed under both sets of analytical conditions and produce similar results for the elements of interest in this study (i.e. $\mathrm{Ni}, \mathrm{Ca}, \mathrm{Mn}, \mathrm{Si}$ ). The Ni data is directly comparable (Figure A1.2), with Mn and Ca producing marginally more precise but consistent data under the Sobolev conditions. Thus the data sets have been combined in the data presented in the main body of this work.
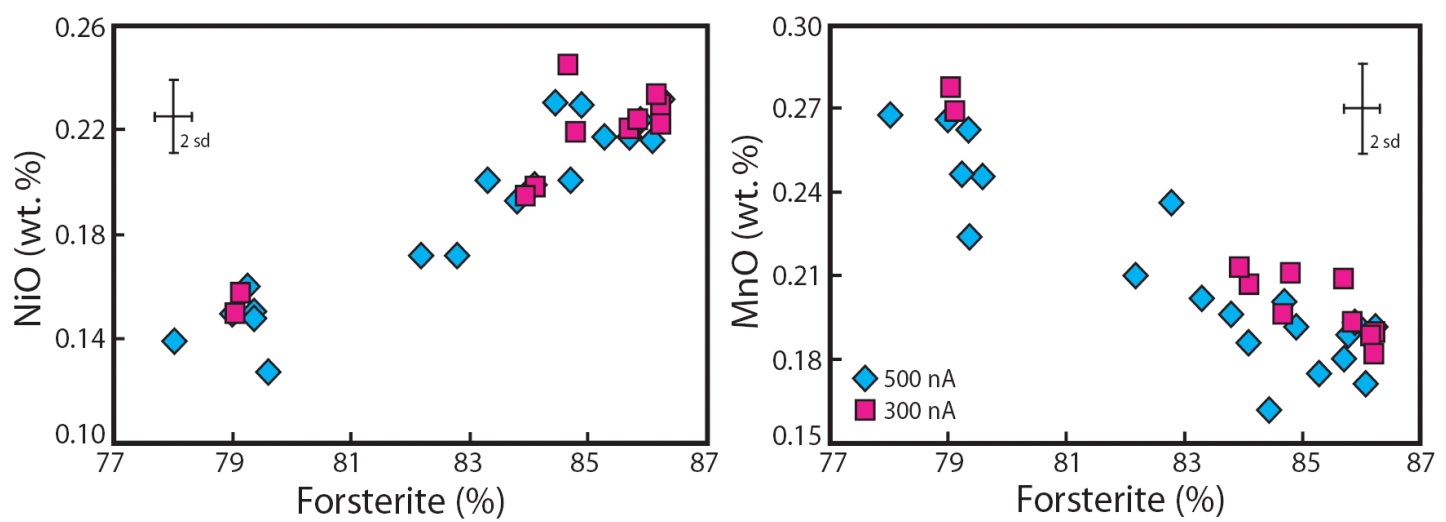

Figure A1.2: Comparison of EPMA results for olivine under $500 \mathrm{nA}$ and $300 \mathrm{nA}$ analytical conditions. Shown are the $\mathrm{NiO}$ and $\mathrm{MnO}$ contents of phenocrysts in AMB-5. The same (but not all) phenocrysts were re-analysed using the Sobolev conditions ( $300 \mathrm{nA}) .2$ sd shown represents errors for the combined data set. 


\section{A1.4.4 Precision and accuracy of EPMA data}

EPMA data for standards are shown in Table A1.7. The high precision analyses of the San Carlos olivine produced data accurate to $< \pm 5 \%$ for all elements. This data is precise (\% $2 \mathrm{SD}$ ) to $< \pm 5 \%$ for all elements, except $\mathrm{MnO}$ and $\mathrm{CaO}$ which

Table A1.7: EPMA precision and accuracy for international mineral and glass standards.

\begin{tabular}{|c|c|c|c|c|c|}
\hline \multicolumn{6}{|c|}{ San Carlos olivine (USNM 11312/444) } \\
\hline & Georem & Mean & $\%$ Offset & $2 \mathrm{SD}$ & $\% 2 \mathrm{SD}$ \\
\hline $\mathrm{SiO}_{2}$ & 40.81 & 41.11 & $+0.7 \%$ & 0.65 & $1.6 \%$ \\
\hline $\mathrm{FeO}$ & 9.55 & 9.68 & $+1.4 \%$ & 0.21 & $2.1 \%$ \\
\hline $\mathrm{MnO}$ & 0.14 & 0.144 & $+2.8 \%$ & 0.016 & $11.5 \%$ \\
\hline $\mathrm{MgO}$ & 49.42 & 49.76 & $+0.7 \%$ & 0.56 & $1.1 \%$ \\
\hline $\mathrm{CaO}$ & & 0.096 & & 0.013 & $13.3 \%$ \\
\hline $\mathrm{NiO}$ & 0.37 & 0.386 & $+4.4 \%$ & 0.014 & $3.8 \%$ \\
\hline TOTAL & 100.29 & 101.18 & & & \\
\hline Forsterite & 90.22 & 90.16 & $-0.1 \%$ & 0.31 & $0.34 \%$ \\
\hline \multicolumn{6}{|c|}{ Kakanui augite (USNM 122142) } \\
\hline & Georem & Mean & $\%$ Offset & $2 \mathrm{SD}$ & $\% 2 \mathrm{SD}$ \\
\hline $\mathrm{SiO}_{2}$ & 50.73 & 50.18 & $-1.1 \%$ & 0.95 & $1.8 \%$ \\
\hline $\mathrm{TiO}_{2}$ & 0.74 & 0.887 & $+19.9 \%$ & 0.118 & $13.3 \%$ \\
\hline $\mathrm{Al}_{2} \mathrm{O}_{3}$ & 8.73 & 8.76 & $+0.3 \%$ & 0.25 & $2.9 \%$ \\
\hline $\mathrm{Cr}_{2} \mathrm{O}_{3}$ & & 0.194 & & 0.117 & $60.2 \%$ \\
\hline $\mathrm{FeO}$ & 6.34 & 6.44 & $+1.6 \%$ & 0.43 & $6.8 \%$ \\
\hline $\mathrm{MnO}$ & 0.13 & 0.168 & $+29.1 \%$ & 0.104 & $62.0 \%$ \\
\hline $\mathrm{MgO}$ & 16.65 & 16.69 & $+0.3 \%$ & 0.31 & $1.9 \%$ \\
\hline $\mathrm{CaO}$ & 15.82 & 15.98 & $+1.0 \%$ & 0.59 & $3.6 \%$ \\
\hline $\mathrm{Na}_{2} \mathrm{O}$ & 1.27 & 1.36 & $+6.7 \%$ & 0.12 & $8.9 \%$ \\
\hline TOTAL & 100.41 & 100.60 & & & \\
\hline $\mathrm{Mg \#}$ & 82.39 & 82.25 & $-1.2 \%$ & 1.61 & $2.0 \%$ \\
\hline \multicolumn{6}{|c|}{ Basaltic glass VG-A99 (USNM 113498/1) } \\
\hline & Georem & Mean & $\%$ Offset & $2 \mathrm{SD}$ & $\% 2 \mathrm{SD}$ \\
\hline $\mathrm{SiO}_{2}$ & 50.94 & 50.44 & $-1.0 \%$ & 1.18 & $2.4 \%$ \\
\hline $\mathrm{TiO}_{2}$ & 4.06 & 4.07 & $+0.2 \%$ & 0.22 & $5.4 \%$ \\
\hline $\mathrm{Al}_{2} \mathrm{O}_{3}$ & 12.49 & 12.76 & $+2.2 \%$ & 0.42 & $3.3 \%$ \\
\hline $\mathrm{FeO}$ & 13.30 & 13.32 & $+0.1 \%$ & 0.50 & $3.7 \%$ \\
\hline $\mathrm{MnO}$ & 0.15 & 0.23 & $+53.9 \%$ & 0.118 & $51.1 \%$ \\
\hline $\mathrm{MgO}$ & 5.08 & 5.20 & $+2.3 \%$ & 0.18 & $3.5 \%$ \\
\hline $\mathrm{CaO}$ & 9.30 & 9.11 & $-2.1 \%$ & 0.36 & $3.9 \%$ \\
\hline $\mathrm{Na}_{2} \mathrm{O}$ & 2.66 & 2.61 & $-1.8 \%$ & 0.31 & $11.8 \%$ \\
\hline $\mathrm{K}_{2} \mathrm{O}$ & 0.82 & 0.837 & $+2.1 \%$ & 0.098 & $11.7 \%$ \\
\hline TOTAL & 98.80 & 98.56 & & & \\
\hline
\end{tabular}

Notes: Values are calculated from daily averages: San Carlos olivine average of 17 daily averages ( $\mathrm{n}$ = 95); Kakanui augite average of 13 daily averages $(n=81)$; basaltic glass VG-A99 average of 11 daily averages $(n=55)$. 
are better than $15 \%$ for the low concentrations present in the standard. Under normal analysis conditions, the precision of EPMA falls significantly. The Kakanui augite was analysed to a precision of $< \pm 5 \%$ for all elements except $\mathrm{FeO}$ and $\mathrm{Na}_{2} \mathrm{O} \pm 10 \%, \mathrm{TiO}_{2} \pm 15 \%$ and $\mathrm{MnO}$ and $\mathrm{Cr}_{2} \mathrm{O}_{3} \pm 65 \%$. The basaltic glass VGA99 was analysed to a precision of $< \pm 5 \%$ for all elements except $\mathrm{TiO}_{2} \pm 6 \%$, $\mathrm{Na}_{2} \mathrm{O}$ and $\mathrm{K}_{2} \mathrm{O} \pm 12 \%$, and $\mathrm{MnO} \pm 52 \%$. All elements are accurate to better than \pm $5 \%$ in these standards except $\mathrm{TiO}_{2}$ in the augite $\pm 20 \%$, and $\mathrm{MnO} \pm 30$ and $55 \%$, respectively.

\section{A1.5 LA-ICP-MS TRACE ELEMENT ANALYSES}

\section{A1.5.1 Sample preparation}

A representative area containing multiple clinopyroxene phenocrysts that had been characterised by EPMA from each sample was selected. Polished thin sections were then cut on a small diamond saw to $28 \mathrm{x} 12 \mathrm{~mm}$ in size so they would fit in the ablation chamber. The carbon coating from EPMA was removed prior to laser ablation inductively coupled plasma mass spectrometry (LA-ICPMS) by cleaning with methanol and $\mathrm{MQ}_{2} \mathrm{O}$.

\section{A1.5.2 Laser ablation}

Laser ablation of clinopyroxene phenocrysts was performed at VUW using a New Wave deep ultraviolet (193 nm solid state) laser ablation system coupled to a Agilent 7500CS ICP-MS. Analysis conditions are shown in Table A1.8. Ablation was carried out using He as the aerosol carrier gas, and this was mixed with the Ar nebuliser gas flow immediately after the ablation chamber. Background count rates were measured for $60 \mathrm{~s}$ prior to ablation and these are subtracted directly from the count rates measured during ablation. Total count time per mass during ablation was ca. $2 \mathrm{~s}$. Plasma torch conditions were optimised so that the element oxide production (estimated from measured $\mathrm{ThO}^{+} / \mathrm{Th}^{+}$ratios) were $<1-2 \%$. Each individual analysis represents $60 \mathrm{~s}$ of data acquisition during ablation. 
Table A1.8: LA-ICP-MS instrumental and analytical conditions.

\begin{tabular}{|c|c|}
\hline \multicolumn{2}{|l|}{ Laser ablation } \\
\hline Laser ablation system & New Wave $193 \mathrm{~nm}$ (deep UV) solid state laser \\
\hline Ablation mode & Static spot analyses \\
\hline Passes & $\begin{array}{l}12 \times 5 \text { s passes with a depth of } 3 \mu \mathrm{m} \text { refocusing after each } \\
\text { pass }\end{array}$ \\
\hline Spot size & $35,50$ or $75 \mu \mathrm{m}$ (predominantly $75 \mu \mathrm{m})$ \\
\hline Repetition rate & $5 \mathrm{~Hz}$ \\
\hline Laser power & $70 \%$ \\
\hline \multicolumn{2}{|l|}{ ICP-MS } \\
\hline ICP-MS system & Agilent 7500CS \\
\hline Acquisition mode & Peak hopping \\
\hline Detection mode & Pulse counting \\
\hline \multicolumn{2}{|l|}{ Standards and Calibration } \\
\hline Calibration standard & BCR-2G \\
\hline Internal standard & ${ }^{43} \mathrm{Ca}$ \\
\hline \multicolumn{2}{|l|}{ Method } \\
\hline Background acquisition & $60 \mathrm{~s}$ \\
\hline Sample/standard acquisition & $60 \mathrm{~s}$ \\
\hline Washout time & $120 \mathrm{~s}$ \\
\hline $\begin{array}{l}\text { Measured isotopes and integration } \\
\text { times. }\end{array}$ & $\begin{array}{l}10 \mathrm{~ms}:{ }^{43} \mathrm{Ca},{ }^{45} \mathrm{Sc},{ }^{47} \mathrm{Ti},{ }^{53} \mathrm{Cr},{ }^{55} \mathrm{Mn},{ }^{59} \mathrm{Co},{ }^{60} \mathrm{Ni},{ }^{63} \mathrm{Cu},{ }^{66} \mathrm{Zn}, \\
{ }^{71} \mathrm{Ga},{ }^{85} \mathrm{Rb},{ }^{88} \mathrm{Sr},{ }^{89} \mathrm{Y},{ }^{90} \mathrm{Zr},{ }^{93} \mathrm{Nb},{ }^{137} \mathrm{Ba},{ }^{139} \mathrm{La},{ }^{140} \mathrm{Ce},{ }^{141} \mathrm{Pr},{ }^{146} \mathrm{Nd} \\
20 \mathrm{~ms}:{ }^{95} \mathrm{Mo},{ }^{133} \mathrm{Cs},{ }^{147} \mathrm{Sm},{ }^{151} \mathrm{Eu},{ }^{157} \mathrm{Gd},{ }^{159} \mathrm{~Tb},{ }^{163} \mathrm{Dy},{ }^{165} \mathrm{Ho}, \\
{ }^{166} \mathrm{Er},{ }^{169} \mathrm{Tm},{ }^{172} \mathrm{Yb},{ }^{175} \mathrm{Lu},{ }^{178} \mathrm{Hf},{ }^{181} \mathrm{Ta},{ }^{182} \mathrm{~W},{ }^{208} \mathrm{~Pb},{ }^{232} \mathrm{Th},{ }^{238} \mathrm{U}\end{array}$ \\
\hline \multicolumn{2}{|l|}{ Tuning } \\
\hline Tuning standard & BCR-2G \\
\hline Ablation mode & Rastering $(2 \mu \mathrm{m} / \mathrm{s})$ beneath a $75 \mu \mathrm{m}$ spot \\
\hline Monitored isotopes & $\begin{array}{l}{ }^{43} \mathrm{Ca},{ }^{89} \mathrm{Y},{ }^{140} \mathrm{Ce},{ }^{208} \mathrm{~Pb}(\% \text { RSD for each isotope typically }< \\
6 \% \text {, } \mathrm{Y} \text { and } \mathrm{Ce}<5 \%)\end{array}$ \\
\hline Background & ${ }^{43}$ Ca typically $<2000 \mathrm{cps}$ \\
\hline Oxides & $\mathrm{ThO}^{+} / \mathrm{Th}^{+}$typically $<1.5 \%$ \\
\hline Carrier gas (Ar) & $0.84-0.90 \mathrm{~L} / \mathrm{min}$ \\
\hline Ablation gas (He) & $87-92 \%$ \\
\hline RF power & $1500 \mathrm{~W}$ \\
\hline RF matching & $1.72 \mathrm{~V}$ \\
\hline Sample depth (z) & $4 \mathrm{~mm}$ \\
\hline
\end{tabular}

\section{A1.5.3 Concentration calculations}

Abundances of individual trace elements were calculated relative to a bracketing standard, the USGS glass standard BCR-2G, which was analysed under identical conditions throughout the analysis session. BCR-2G was chosen as the reference standard in this study as it is a close matrix match to the ablated material $\left(\mathrm{SiO}_{2}=\right.$ $54.4 \%)$. A poor choice of calibration standard may produce differential elemental 
fractionation in the standard and sample (matrix effects) during the analysis resulting in inaccurate data (Eggins et al., 1998; Horn \& Günther, 2003). The LAICP-MS data acquisition technique employed here follows that of Pearce et al. (1996) where a minor isotope of a major element (here ${ }^{43} \mathrm{Ca}$ ), previously determined by EPMA was included in ICP-MS analysis and used as an internal standard, for secondary data normalisation. Analyses of samples are bracketed by analyses of the homogeneous reference material (BCR-2G) so that (after corrections for backgrounds) the trace elements concentration of element $\mathrm{x}$ in a clinopyroxene phenocryst is determined by the relationships:

$$
\begin{gathered}
C_{c p x}^{C a a, L A-I C P-M S}=C_{s t d}^{C a O} \times\left(C P S_{c p x}^{C a} / C P S_{s t d}^{C a}\right) \\
C_{s a m p l e}^{x, L A-I C P-M S}=C_{s t d}^{x} \times\left(C_{c p x}^{C a a, E P M A} / C_{c p x}^{C a O, L A-I C P-M S}\right) \times\left(C P S_{c p x}^{x} / C P S_{s t d}^{x}\right)
\end{gathered}
$$

$C_{c p x}^{C a a, L A-I C P-M S}, C_{c p x}^{C a O, E P M A}=$ concentration of Ca determined by LA-ICP-MS or EPMA. $C_{c p x}^{c a o}=$ Georem $\mathrm{CaO}$ concentration of the BCR-2G standard. $C P S_{c p x}^{c a}, C P S_{s t d}^{c a}=$ counts per second obtained on ${ }^{43} \mathrm{Ca}$ during the ablation of the clinopyroxene phenocrysts (cpx) or BCR-2G (std).

$C_{c p x}^{x_{L A-I C P-M S}}=$ concentration of element $\mathrm{x}$ determined by LA-ICP-MS.

$C_{\text {std }}^{x}=$ reference concentration of element $\mathrm{x}$ in the standard BCR-2G.

$C P S_{c p x}^{x}, C P S_{s t d}^{x}=$ counts per second obtained on an isotope of element $\mathrm{x}$ whilst ablating the clinopyroxene phenocryst (cpx) or BCR-2G (std).

\section{A1.5.4 Precision and accuracy of LA-ICP-MS data}

A secondary standard was not analysed during LA-ICP-MS sessions in this study. Therefore the precision and accuracy of this analytical technique is quantified by a recent study undertaken at VUW (e.g. Allan et al., 2008). A rhyolitic glass standard ATHO-G was repeatedly analysed $(\mathrm{n}=91)$ with the mean measured abundance of 29 trace elements within $\pm 5 \%$ of the recommended values of Jochum et al. (2006), a further 8 elements were measured to $\pm 20 \%$. Allan et al. 
(2008) report day to day precision of LA-ICP-MS analyses is c. $\pm 6 \%$ for the majority of elements. Some elements which Allan et al. (2008) had difficulty measuring with a high degree of precision and accuracy due to low abundances (i.e. $\mathrm{Cr}, \mathrm{Ni}, \mathrm{V}$ ) occur in much higher concentrations in the clinopyroxene phenocrysts ablated in this study.

\section{A1.6 SR-ND-HF-PB ISOTOPE MEASUREMENTS BY MC-ICP-MS}

Samples for isotopic analysis were prepared in an ultra-clean laboratory. The room is positively pressured with the air continuously filtered to Class 100 , to minimise terrestrial contaminants. Column chemistry was undertaken in PicoTrace Class 10 laminar flow workstations.

\section{A1.6.1 Savillex beaker preparation}

New savillex beakers were rinsed in warm $\mathrm{H}_{2} \mathrm{O}$ before being placed in a beaker filled with Citrinox (a desurfactant) mixed with $\mathrm{MQ} \mathrm{H}_{2} \mathrm{O}$ for 1 week. Beakers are then rinsed with $\mathrm{MQ}_{2} \mathrm{O}$ before being placed in 6-8 $\mathrm{M} \mathrm{HNO}_{3}$ for 48 hours at $80^{\circ} \mathrm{C}$. Beakers are removed from the $\mathrm{HNO}_{3}$ and thoroughly rinsed 3 times with $\mathrm{MQ}_{2} \mathrm{O}$ before being filled with 1-2 $\mathrm{mL}$ of $6 \mathrm{M} \mathrm{HCl}$ and placed on a hotplate to flux at $110^{\circ} \mathrm{C}$ for 1 week.

\section{A1.6.2 Acids for chemical separation}

Concentrated acids used in this study were sub-boil distilled in quartz (16 M $\left.\mathrm{HNO}_{3}\right)$ and teflon $(12 \mathrm{M} \mathrm{HCl})$ stills, and dilute acids were prepared by dilution with $\mathrm{MQ} \mathrm{H}_{2} \mathrm{O}(18.2 \mathrm{M} \Omega)$. All hydrofluoric acid (HF) used in this study was Seastar, and Seastar concentrated acids were used during $\mathrm{Pb}$ separation and dilute acids prepared from these with $\mathrm{MQ}_{2} \mathrm{O}$. Acid molarities were checked using an electronic density meter assuming the density $\mathrm{MQ} \mathrm{H}_{2} \mathrm{O}\left(\mathrm{D}=0.9998\right.$ at $\left.18^{\circ} \mathrm{C}\right)$. 


\section{A1.6.3 Strontium separation}

Cleaned $23 \mathrm{~mL}$ savillex beakers are rinsed thoroughly with $\mathrm{MQ} \mathrm{H}_{2} \mathrm{O}$ and dried. Sample powders were acid leached (A1.7) to remove any non-magmatic Sr from the sample as follows. Approximately $1 \mathrm{~g}$ of whole-rock powder was added and covered with $6 \mathrm{M} \mathrm{HCl}$ and placed on the hotplate at $110^{\circ} \mathrm{C}$ for 2 hours or until the solution turned bright yellow. This solution was decanted and the residue was rinsed repeatedly with $\mathrm{MQ} \mathrm{H}_{2} \mathrm{O}$ until all traces of acid were removed, leaving ca. $0.1 \mathrm{~g}$ of powder in the beaker. These leached powders were then digested on a hot plate in sealed savillex beakers with concentrated $\mathrm{HF}(1.5 \mathrm{~mL})$ and $\mathrm{HNO}_{3}$ $(0.5 \mathrm{~mL})$ for up to 48 hours. The acid was then evaporated at $120^{\circ} \mathrm{C}$ in a laminar flow hood and followed sequentially by evaporation of ca. $0.5 \mathrm{~mL}$ of concentrated $\mathrm{HNO}_{3}, \mathrm{HCl}$ and $\mathrm{HNO}_{3}$. Sr was separated by a double pass through Eichrom Srspecific resin. Columns were made from Eppendorf $1 \mathrm{~mL}$ pipette tips and filled with ca. $0.5 \mathrm{~mL}$ Sr-specific resin creating an ca. $5 \mathrm{~mm}$ resin bed. Columns were cleaned with $1.5 \mathrm{~mL}$ of $3 \mathrm{M} \mathrm{HNO}_{3}$ followed by $4.5 \mathrm{~mL}$ of $\mathrm{MQH} \mathrm{H}_{2} \mathrm{O}$. Digested samples were brought into solution in $1 \mathrm{~mL}$ of $3 \mathrm{M} \mathrm{HNO}_{3}$. Columns were pretreated with $1 \mathrm{~mL}$ of $3 \mathrm{M} \mathrm{HNO}_{3}$ and then the sample was added. Matrix elements were eluted in $4.5 \mathrm{~mL}$ of $3 \mathrm{M} \mathrm{HNO}_{3}$ and then the $\mathrm{Sr}$ cut was collected in $3 \mathrm{~mL}$ of MQ $\mathrm{H}_{2} \mathrm{O}$. While the sample was evaporating the column was cleaned with $3 \mathrm{M}$ $\mathrm{HNO}_{3}$ and $\mathrm{MQ} \mathrm{H}_{2} \mathrm{O}$ before a second column pass was undertaken. The sample was then evaporated in preparation for Sr isotopic analysis on the MC-ICP-MS.

\section{$\underline{\text { Sr-spec elution curves }}$}

The majority of matrix elements (e.g. $\mathrm{Mg}, \mathrm{Ca}$ and $\mathrm{Rb}$ ) are effectively removed from Sr-spec columns during the elution of the first $3 \mathrm{~mL}$ of $3 \mathrm{M} \mathrm{HNO}_{3}$ (Figure A1.3). Ba begins to elute from the column more slowly than the other elements and possesses an elution curve with a longer tail. Ca is rapidly removed from the column in $3 \mathrm{M} \mathrm{HNO}_{3}$ but in the first reservoir of $\mathrm{MQ} \mathrm{H}_{2} \mathrm{O}$ the final $6 \% \mathrm{Ca}$ is

eluted from the column. A small proportion of the second Ca spike could be ${ }^{86} \mathrm{Sr}^{++}$ 
but this effect is considered negligible $(<2 \%)$. Sr is effectively removed in the first reservoir of $\mathrm{MQ}_{2} \mathrm{O}(63 \%)$. However, in this example in the fourth reservoir of $3 \mathrm{M} \mathrm{HNO}_{3} \mathrm{Sr}$ is beginning to be eluted from the column (19\%), so to keep Sr yields high only 3 column loads of $3 \mathrm{M} \mathrm{HNO}_{3}$ were eluted during sampling. The rapid removal of $\mathrm{Rb}$ from the column in $3 \mathrm{M} \mathrm{HNO}_{3}$ results in excellent $\mathrm{Rb}$-Sr separation thus minimising ${ }^{87} \mathrm{Rb}$ interference on ${ }^{87} \mathrm{Sr}$ and allowing accurate MC-ICP-MS analyses to be undertaken. Due to the concentration differences between $\mathrm{Sr}$ and $\mathrm{Ca}$ in basaltic samples (i.e. low $\mathrm{Sr} / \mathrm{Ca}$ ) there is still more $\mathrm{Ca}$ in the sample than $\mathrm{Sr}$ after a single elution. A double pass is undertaken to remove any $\mathrm{Ca}$ and $\mathrm{Ba}$ not removed in the first pass.

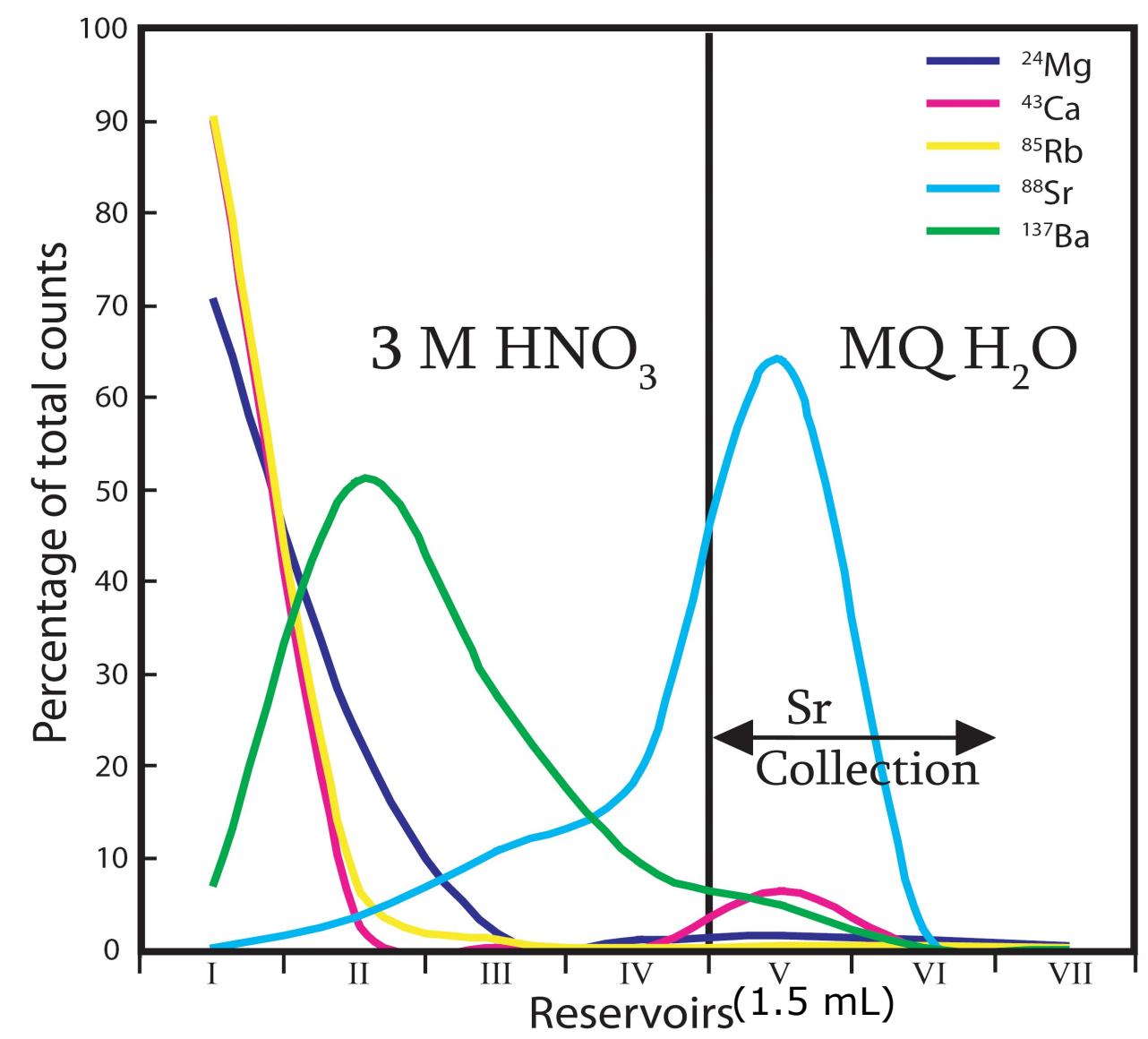

Figure A1.3: Elution curves for a single pass through Sr-specific resin. Reservoirs consist of ca. 1.5 $\mathrm{mL}$ of liquid; 1-4: $3 \mathrm{M} \mathrm{HNO}_{3}$; 5-7: $\mathrm{MQ} \mathrm{H}_{2} \mathrm{O}$. Graph plots counts per second measured on individual reservoirs, on 1:1000 dilutions using an ICP-MS as a percentage of the total counts over all reservoirs. 


\section{A1.6.4 Hafnium and neodymium separation}

The following procedure has been modified after the work of Pin \& Zalduegui (1997), Ulfbeck et al. (2002), Le Fèrve \& Pin, (2005) and Connelly et al. (2006).

\section{Hafnium beaker cleaning}

Following the initial cleaning of beakers, an additional cleaning is undertaken with beakers used for $\mathrm{Hf}$ work. Beakers were cleaned further in $7 \mathrm{M} \mathrm{HNO}+\mathrm{HF}$ for 24 hours at $120^{\circ} \mathrm{C}$ and then rinsed thoroughly with $\mathrm{MQ}_{2} \mathrm{O}$. Hf is highly soluble in HF thus this step substantially reduces the Hf beaker blank.

\section{Flux fusion digestion}

Small $(32 \mathrm{~mm})$ graphite crucibles were pre-ignited at $1100^{\circ} \mathrm{C}$ for 2 minutes to burn off any impurities and prevent melt 'wetting' of the crucibles. Once cooled, approximately $100 \mathrm{mg}$ of whole-rock powder and three times as much lithium metaborate $\left(\mathrm{LiBO}_{2}\right)$ flux were placed in the crucibles in a sandwhich type layering (i.e. flux-sample-flux). Crucibles were then fused at $1100^{\circ} \mathrm{C}$ for $6-8 \mathrm{~min}$, samples were agitated with tongs to ensure homogenisation of material $2 \mathrm{~min}$ before pouring. The molten material (i.e. melted sample and flux) was then poured into $23 \mathrm{~mL}$ savillex beakers containing $14 \mathrm{~mL}$ of $1.5 \mathrm{M} \mathrm{HCl}$. Beakers were then vigorously shaken (using magnetic stirrers or manually) and placed on a hot plate at $100^{\circ} \mathrm{C}$ to ensure samples were fully in solution, which typically took 1015 min.

\section{Cation column separation of REE and $H f$}

Cation exchange columns are first used to remove the majority of the unwanted matrix elements (e.g. Li, B, Si, Mg, Al, Na etc.) from fluxed samples (Figure A1.4). Biorad columns with the large extension inserted (taking the loadable acid volume to $30 \mathrm{~mL}$ ) are rinsed 3 times with $\mathrm{MQ}_{2} \mathrm{O}$, then ca. $2.5 \mathrm{~mL}$ Biorad cation exchange resin (AG50 W-X8) is added to create a $60 \mathrm{~mm}$ resin bed (up to the base of the bevelled neck of the column). Columns were cleaned with one column 
load (ca. $27 \mathrm{~mL}$ ) of $7 \mathrm{M} \mathrm{HNO}_{3}+2-3$ drops $(<0.1 \mathrm{~mL})$ of $\mathrm{HF}$ followed by 3 column loads of $\mathrm{MQ} \mathrm{H}_{2} \mathrm{O}$. Columns were then pre-treated with a half column load of 1.5 $\mathrm{M} \mathrm{HCl}$. The $14 \mathrm{~mL}$ of $1.5 \mathrm{M} \mathrm{HCl}$ from the flux fusion is then loaded onto the cation column through quantitative filter paper (Labserv $125 \mathrm{~mm}$ x $40 \mu \mathrm{m}$ ) that has been folded 3 times and opened out to create a funnel. This prevents any solid or graphite particles from the flux fusion being loaded onto the column. The funnel was then washed twice with $1.5 \mathrm{M} \mathrm{HCl}$, which ensures all the sample has been added to the column. Matrix elements are eluted in $27 \mathrm{~mL}$ of $1.5 \mathrm{M} \mathrm{HCl}$ and then $20 \mathrm{~mL}$ of $7 \mathrm{M} \mathrm{HNO}_{3}$ was collected in cleaned savillex beakers. This solution was then evaporated immediately on a hot plate in the laminar flow hood.

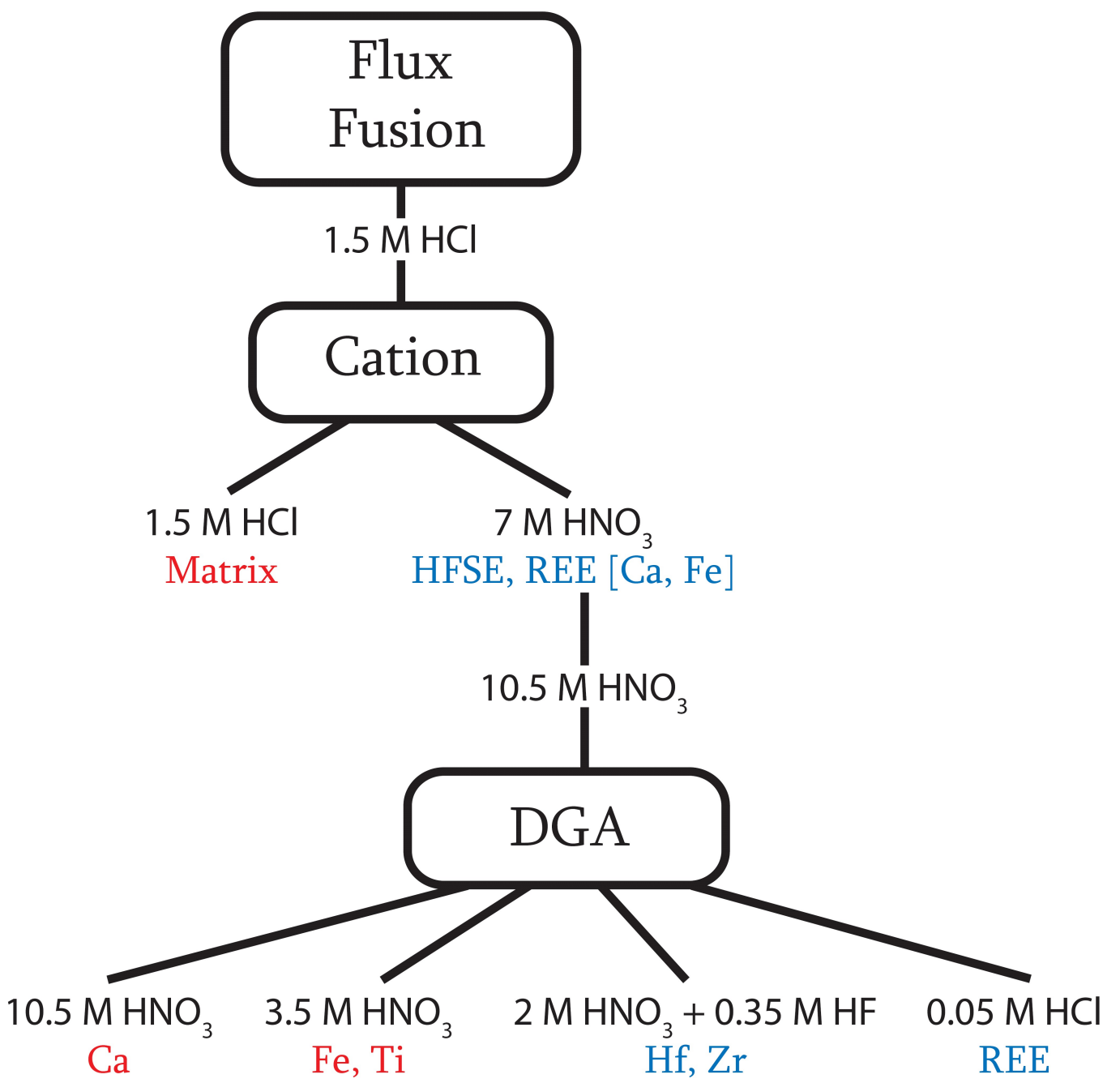

Figure A1.4: Flow chart showing the method for Hf and REE separation. Red cuts are discarded and blue cuts are retained for further chemistry or isotopic analysis. Modified after Connelly et al. (2006). 


\section{$\underline{D A}$ A column separation of $H f$}

Columns were prepared from $1 \mathrm{~mL}$ disposable pipettes by chopping off both ends and placing a $3.2 \mathrm{~mm}$ frit at the base of the columns neck (e.g. Figure A1.5). A 30 mm resin bed was created through the addition of Eichrom DGA resin (normal). It is easier to add the resin when the column is completely filled with water to prevent the possibility of air bubbles forming in the column. The column is then cleaned with 1 column load of each of the following (in this order): $\mathrm{MQ}_{2} \mathrm{O}$, 10.5 $\mathrm{M} \mathrm{HNO}_{3}, \mathrm{MQH}_{2} \mathrm{O}, 0.05 \mathrm{M} \mathrm{HCl}$ and $\mathrm{MQH}_{2} \mathrm{O}$. The evaporated sample collected off the cation exchange column was brought into solution in $0.5 \mathrm{~mL}$ of $10.5 \mathrm{M} \mathrm{HNO}_{3}$. Solutions were then centrifuged for 5 minutes at $5000 \mathrm{rpm}$ to ensure any graphite particles in the solution were not added to the DGA column. The columns were pre-treated with $1 \mathrm{~mL}$ of $10.5 \mathrm{M} \mathrm{HNO}_{3}$ and then the sample was loaded. The remaining matrix elements in the sample (e.g. Ca, Fe, and Ti) were eluted in $8 \mathrm{~mL}$ of $10.5 \mathrm{M} \mathrm{HNO}_{3}$ and then $3.5 \mathrm{M} \mathrm{HNO}_{3}$. The Hf cut was then collected in $8 \mathrm{~mL}$ of $2 \mathrm{M} \mathrm{HNO}_{3}+0.35 \mathrm{M} \mathrm{HF}$ in cleaned beakers. This cut is then dried down in preparation for Hf isotopic analysis on the MC-ICP-MS. In another clean $7 \mathrm{~mL}$ savillex beaker $4.5 \mathrm{~mL}$ of $0.05 \mathrm{M} \mathrm{HCl}$ was collected off the DGA column and evaporated. This cut contains the rare earth elements (REE) on which further chemistry is performed to separate the $\mathrm{Nd}$.

\section{$\underline{\text { Ln-spec column separation of } N d}$}

Ln-spec columns were prepared in the same manner as those used for DGA chemistry, and then filled with $88 \mathrm{~mm}$ of Eichrom Ln resin. Ln-spec resin works through the chromatographic separation of elements allowing the effective isolation of individual light lanthanides (Pin \& Zalduegui, 1997; Figure A1.5). Twenty column loads of water were eluted to ensure the proper compaction of the resin bed and to allow reproducible elution profiles of the REE. The column is then cleaned with 1 column load ( $4 \mathrm{~mL}$ ) of $6 \mathrm{M} \mathrm{HCl}$ followed by $2 \mathrm{~mL}$ of MQ. The evaporated REE cut off the DGA column is brought into solution in $0.5 \mathrm{~mL}$ 
of $0.25 \mathrm{M} \mathrm{HCl}$. Ln-spec resin was pre-treated with $1 \mathrm{~mL}$ of $0.25 \mathrm{M} \mathrm{HCl}$ and then the sample was loaded. Depending on calibration in use $3-4 \mathrm{~mL}$ of $0.25 \mathrm{M} \mathrm{HCl}$ is eluted and then into cleaned savillex beakers $6 \mathrm{~mL}$ of $0.25 \mathrm{M} \mathrm{HCl}$ was collected (Figure A1.6). This cut was then evaporated to dryness in readiness for $\mathrm{Nd}$ isotopic analysis on the MC-ICP-MS.

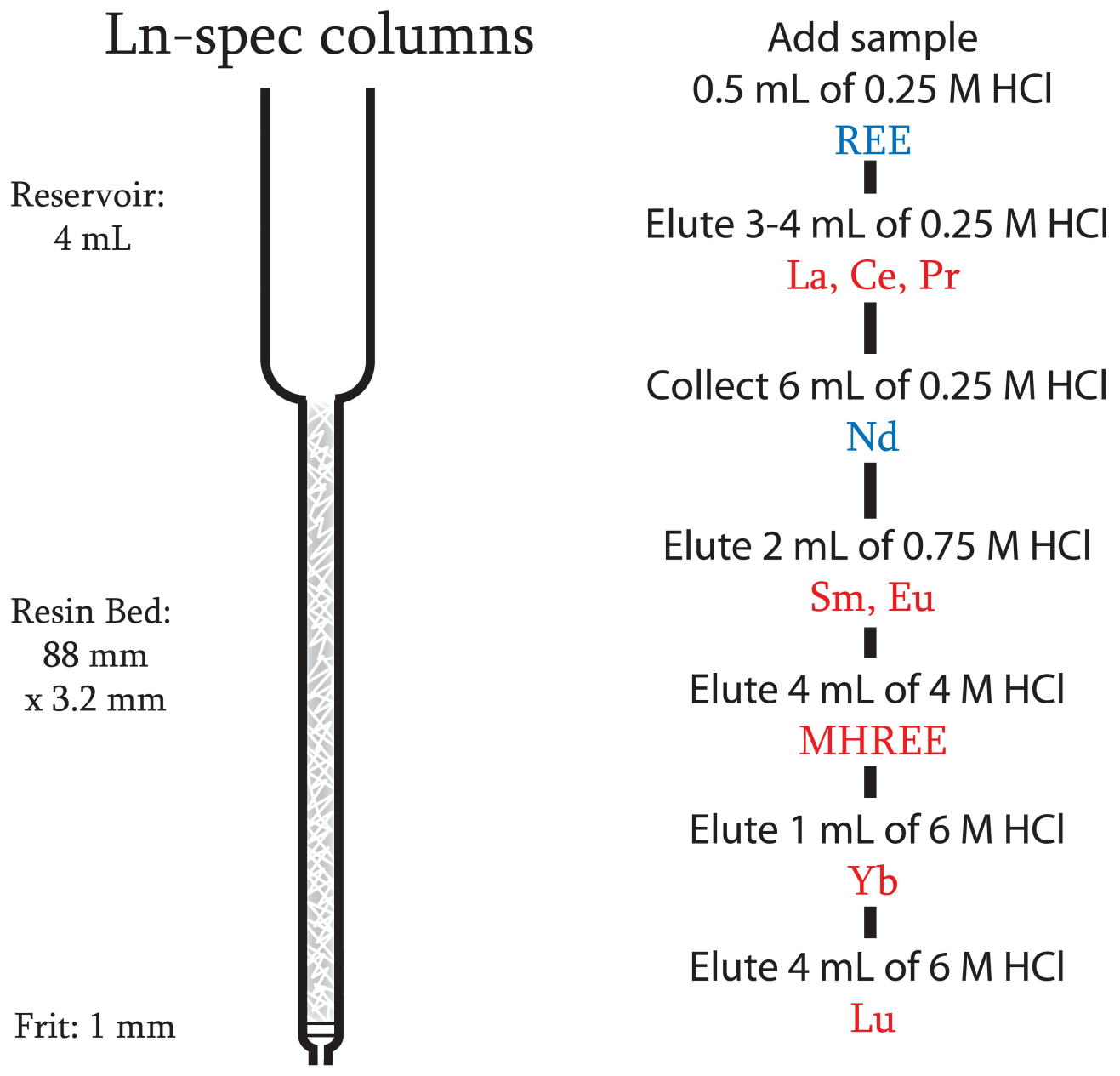

Figure A1.5: Ln-spec column elution procedure. Diagram is not to scale. Red cuts are discarded and blue cuts are kept for further chemistry or isotopic analysis. Figure illustrates the full REE separation potential of $\mathrm{Ln}-\mathrm{Spec}$ columns. In this study after collection of $\mathrm{Nd}$ the columns were cleaned repeatedly with $6 \mathrm{M} \mathrm{HCl}$ to remove all traces of REE from the column.

\section{Calibration of Ln-spec columns}

Using the correct calibration for Ln-spec columns is imperative to effectively isolate Nd from the adjacent REE. Figure A1.6 shows a comparison of elution curves for the light REE coming off used (multiple chemistries) and new (first 
chemistry) Ln-spec columns. The rate at which elements are liberated from the column changes with compaction (i.e. age of the column). Excellent Sm-Nd separation is always achieved with Ln-spec columns as Sm is not eluted from the column until the acid molarity is increased. Ce-Nd separation is more variable depending on the age of the columns.

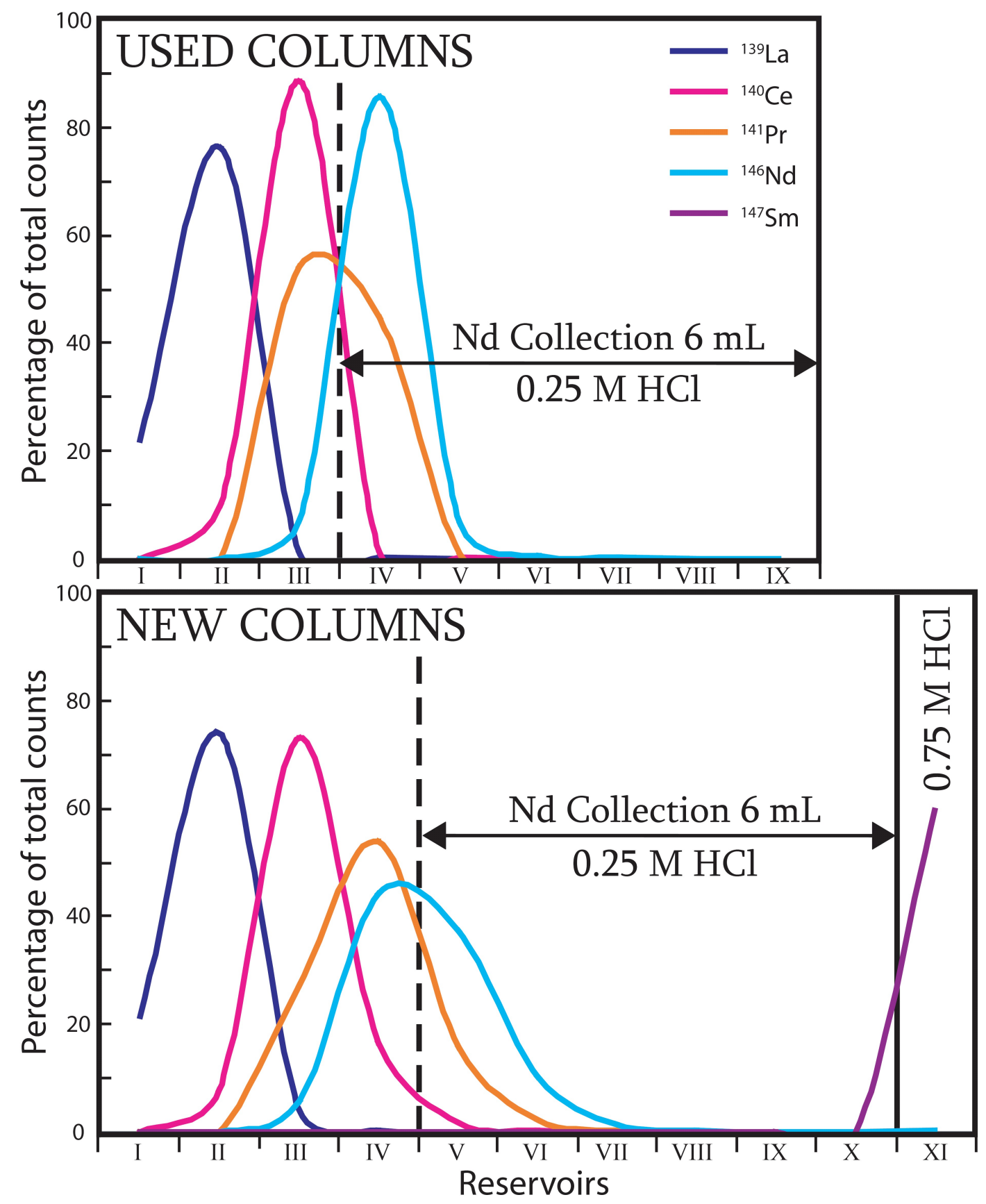

Figure A1.6: Comparison of the REE elution curves for used and new Ln-spec columns. Reservoirs consist of $1 \mathrm{~mL}$ of acid; all $0.25 \mathrm{M} \mathrm{HCl}$, except reservoir 11 which is $0.75 \mathrm{M} \mathrm{HCl}$. Graphs plot counts per second measured on individual $1 \mathrm{~mL}$ cuts, on 1:1000 dilutions using an ICP-MS as a percentage of the total counts over the sum of counts for all $1 \mathrm{~mL}$ cuts. 
In new columns, the elution curves have wider peaks and longer tails, thus to achieve sufficient Ce-Nd separation $4 \mathrm{~mL}$ is eluted off the column before collecting the Nd cut. However, as the columns age the initial elution can be shrunk towards $3 \mathrm{~mL}$ as the elution curves narrow. Older columns produce greater $\mathrm{Nd}$ yields due to the better separation of $\mathrm{Ce}-\mathrm{Nd}$ allowing more $\mathrm{Nd}$ to be collected. Pr does not directly interfere on the $\mathrm{Nd}$ isotopic array so separation of Pr is not critical to producing accurate results. Calibration of columns with a REE standard prior to the processing of samples is recommended because of the variability of elution curves with column age/compaction.

\section{A1.6.5 Lead separation}

All concentrated acids used for $\mathrm{Pb}$ separation in this study are Seastar and have $\mathrm{Pb}$ concentrations $<5 \mathrm{ppt}$. Chemical separation was undertaken in a Class 10 laminar flow hood.

\section{Lead beaker cleaning}

In addition to the general cleaning procedure, $7 \mathrm{~mL}$ savillex beakers for $\mathrm{Pb}$ separation were rinsed thoroughly with $\mathrm{MQ} \mathrm{H}_{2} \mathrm{O}$, and then $1 \mathrm{~mL}$ of $16 \mathrm{M} \mathrm{HNO}_{3}$ was added to the beakers and they were placed on the hotplate for 24 hours. This acid was discarded and the 24 hour flux repeated with clean acid. This acid was then discarded and the beaker was filled with $1 \mathrm{~mL} 6.5 \mathrm{M} \mathrm{HCl}$ and fluxed on the hotplate for a further 24 hours. The beakers were rinsed thoroughly with MQ $\mathrm{H}_{2} \mathrm{O}$ after these acid steps and shaken dry.

\section{Anion exchange column separation of $P b$}

$\mathrm{Pb}$ was separated by a double pass through a Biorad anion exchange resin. A representative sample of rock chips ( $<1 \mathrm{~mm}$ in size) was picked from sample material and beakers were filled with ca. $100 \mathrm{mg}$ of rock chips. Acid leaching was undertaken in hot $2 \mathrm{M} \mathrm{HCl}$ for two periods of 30 minutes, with a $\mathrm{MQH}_{2} \mathrm{O}$ rinse in between. Following the removal of the leachate and repeated rinses with MQ 
$\mathrm{H}_{2} \mathrm{O}$, the samples were digested in concentrated $\mathrm{HF}$ (ca. $\left.1.3 \mathrm{~mL}\right)$ and $\mathrm{HNO}_{3}(<0.2$ $\mathrm{mL}$ ) for 72 hours. After digestion, samples were evaporated, then fluxed in ca. 6.5 $\mathrm{M} \mathrm{HCl}$ for 1 hour, evaporated and then dried down in $1 \mathrm{~mL}$ of $1 \mathrm{M}$ hydrobromic acid $(\mathrm{HBr})$. Columns were created from acid leached $(6 \mathrm{M} \mathrm{HCl})$ polypropylene 1 $\mathrm{mL}$ pipette tips loaded with $5 \mathrm{~mm}$ (ca. $0.2 \mathrm{~mL}$ ) of Biorad anion exchange resin (AG-1X8). Columns were cleaned with 3 times with a reservoir of $6.5 \mathrm{M} \mathrm{HCl}$ followed by $1 \mathrm{~mL}$ of $\mathrm{MQ} \mathrm{H}_{2} \mathrm{O}$ and then pre-treated with 1 reservoir of $1 \mathrm{M} \mathrm{HBr}$. Samples were brought into solution in $1.5 \mathrm{~mL}$ of $1 \mathrm{M} \mathrm{HBr}$ and then loaded onto the column and one full and two half column loads of $1 \mathrm{M} \mathrm{HBr}$ were eluted to remove the matrix of the sample. The $\mathrm{Pb}$ in the sample was collected off the column in $3 \mathrm{~mL}$ of $6.5 \mathrm{M} \mathrm{HCl}$. While the sample was evaporating the column was cleaned with $6.5 \mathrm{M} \mathrm{HCl}$ and $\mathrm{MQ}_{2} \mathrm{O}$ before a second column pass was completed. After evaporation the $\mathrm{Pb}$ cut was evaporated in $0.5 \mathrm{~mL}$ concentrated $\mathrm{HNO}_{3}$ to remove any traces of bromide and convert the $\mathrm{Pb}$ to nitrate form.

\section{A1.6.6 Mineral Sr $(\mathrm{Nd})$ isotope analyses}

Green and brown clinopyroxene (10-20 mg) was separated using a binocular microscope. Clinopyroxenes were placed in $7 \mathrm{~mL}$ savillex beakers and leached in hot $6 \mathrm{M} \mathrm{HCl}$ for 1 hour to remove any surficial contamination on the crystals. The leachate was removed and the crystals were thoroughly rinsed in $\mathrm{MQ} \mathrm{H}_{2} \mathrm{O}$, and samples were then digested in concentrated $\mathrm{HF}(1.5 \mathrm{~mL})$ and $\mathrm{HNO}_{3}(0.3 \mathrm{~mL})$ for 48 hours. After drying down the digestion, $0.5 \mathrm{~mL}$ of concentrated $\mathrm{HNO}_{3}$ was evaporated. Samples were then brought into solution in $1 \mathrm{~mL}$ of $6 \mathrm{M} \mathrm{HCl}$ and left on the hot plate for 24 hours. If the sample was fully in solution it was dried down and converted to nitrates in preparation for Sr chemistry. However, the majority of samples required repetition of the $\mathrm{HF}$ digestion before beginning $\mathrm{Sr}$ chemistry. The waste off the Sr columns was collected during the chemistry and in selected samples this waste was passed through Ln-spec columns to separate the Nd. 
Plagioclase was separated using a binocular microscope but due to the high $\mathrm{Sr}$ concentration of plagioclase only $1 \mathrm{mg}$ of material was required. Plagioclase separates were acid leached in hot $2 \mathrm{M} \mathrm{HCl}$ for 1 hour and then digested as described above and put through Sr chemistry.

\section{A1.6.7 Mass spectrometry and isotopic analysis}

The accuracy and external reproducibility of international standards digested in conjunction with sample batches during this study and analysed by multicollector inductively coupled plasma mass spectrometry (MC-ICP-MS) at VUW are shown in Table A1.9.

\section{$\underline{\text { Strontium and neodymium }}$}

Analytical procedures for Nd and Sr are described by Luais et al. (1997) and Waight et al. (2002), respectively. Waight et al. (2002) demonstrated that replicate analysis of standards and aqueous solutions for $\mathrm{Sr}$ are comparable to the external reproducibilities given by conventional thermal ionisation mass spectrometry (TIMS) analyses. This result is confirmed by Sr isotopic analyses in this study of BHVO-2 (0.703467). Similarly, Nd isotopic analyses of BCR-2 (0.512643) and BHVO-2 (0.512982) by MC-ICP-MS at VUW are within error of published TIMS analyses. Internal precision (2 SE) was typically better than \pm 0.000015 for ${ }^{87} \mathrm{Sr} /{ }^{86} \mathrm{Sr}$ and \pm 0.000008 for ${ }^{143} \mathrm{Nd} /{ }^{144} \mathrm{Nd}$. External reproducibility of Sr and Nd isotope ratios was better than 0.000018 and 0.000028 (2 SD for BHVO$2 ; \mathrm{n}=4$ and 5), respectively. ${ }^{87} \mathrm{Sr} /{ }^{86} \mathrm{Sr}$ is reported relative to a value of 0.710248 for SRM987 and ${ }^{143} \mathrm{Nd} /{ }^{144} \mathrm{Nd}$ is reported relative to 0.512260 for the $\mathrm{Nd}$ standard Alfa Aesar. This Nd isotope ratio corresponds to a value of 0.51186 for La Jolla. Data were carefully monitored for interferences on the $\mathrm{Nd}$ isotopic array, i.e. Ce and Sm. ${ }^{142} \mathrm{Ce}$ and ${ }^{144} \mathrm{Sm}$ isobaric interferences were minimised as a result of excellent separation of $\mathrm{Nd}$ from these elements. It is imperative to achieve excellent Sm-Nd separation as ${ }^{144} \mathrm{Sm}$ interferes directly on an isotope $\left({ }^{144} \mathrm{Nd}\right)$ in 
the ratio of interest. Procedural blanks were $<1.1 \mathrm{ng}$ and $0.3 \mathrm{ng}$ for $\mathrm{Sr}$ and $\mathrm{Nd}$, respectively, and are insignificant to this study.

\section{$\underline{\text { Hafnium }}$}

Mass spectrometric procedures for Hf are outlined by Ulfbeck et al. (2002) and Bizzarro et al. (2003). Internal precision (2 SE) for samples was better than \pm 0.000007 for ${ }^{176} \mathrm{Hf} /{ }^{177} \mathrm{Hf}$. External reproducibility for ${ }^{176} \mathrm{Hf} /{ }^{177} \mathrm{Hf}$ is better than \pm $0.000010(2 \mathrm{SD})(\mathrm{n}=5)$ measured relative to a value of 0.282160 for the international standard JMC475.

Table A1 9: External reproducibility of international standards during MC-ICP-MS analyses.

\begin{tabular}{lccc}
\hline BHVO-2 & ${ }^{87} \mathrm{Sr} /{ }^{86} \mathrm{Sr}$ & ${ }^{143} \mathrm{Nd} /{ }^{144} \mathrm{Nd}$ & ${ }^{176} \mathrm{Hf} /{ }^{177} \mathrm{Hf}$ \\
\hline $\mathrm{A}$ & $0.703457 \pm 10$ & $0.512978 \pm 6$ & $0.283096 \pm 6$ \\
$\mathrm{~A}^{*}$ & $0.703467 \pm 10$ & $0.512972 \pm 7$ & - \\
$\mathrm{B}$ & $0.703464 \pm 13$ & $0.513005 \pm 6$ & $0.283101 \pm 4$ \\
$\mathrm{C}$ & $0.703479 \pm 8$ & $0.512985 \pm 5$ & $0.283097 \pm 5$ \\
$\mathrm{C}^{*}$ & - & $0.512970 \pm 5$ & - \\
Mean & 0.703467 & 0.512982 & 0.283098 \\
Georem & $0.703469 \pm 17$ & $0.512980 \pm 12$ & $0.283109 \pm 12$ \\
2 SD & 0.000018 & 0.000028 & 0.000005
\end{tabular}

\begin{tabular}{lcc}
\hline \hline BCR-2 & ${ }^{143} \mathrm{Nd} /{ }^{144} \mathrm{Nd}$ & ${ }^{176} \mathrm{Hf} /{ }^{177} \mathrm{Hf}$ \\
\hline $\mathrm{A}$ & $0.512649 \pm 5$ & $0.282858 \pm 6$ \\
$\mathrm{~A}^{*}$ & $0.512656 \pm 5$ & - \\
$\mathrm{B}$ & $0.512625 \pm 6$ & $0.282853 \pm 4$ \\
Mean & 0.512643 & 0.282855 \\
Georem & $0.512636 \pm 12$ & $0.282878 \pm 7$ \\
2 SD & 0.000033 & 0.000007 \\
\hline
\end{tabular}

\begin{tabular}{lccc}
\hline \hline JB-2 & ${ }^{206} \mathrm{~Pb} /{ }^{204} \mathrm{~Pb}$ & ${ }^{207} \mathrm{~Pb} /{ }^{204} \mathrm{~Pb}$ & ${ }^{208} \mathrm{~Pb} /{ }^{204} \mathrm{~Pb}$ \\
\hline $\mathrm{A}$ & $18.3439 \pm 11$ & $15.5631 \pm 10$ & $38.2819 \pm 25$ \\
$\mathrm{~B}$ & $18.3433 \pm 10$ & $15.5617 \pm 10$ & $38.2784 \pm 25$ \\
$\mathrm{C}$ & $18.3417 \pm 13$ & $15.5607 \pm 12$ & $38.2746 \pm 30$ \\
$\mathrm{D}$ & $18.3440 \pm 14$ & $15.5636 \pm 13$ & $38.2828 \pm 32$ \\
$\mathrm{E}$ & $18.3435 \pm 12$ & $15.5621 \pm 11$ & $38.2758 \pm 27$ \\
$\mathrm{~F}$ & $18.3406 \pm 12$ & $15.5590 \pm 10$ & $38.2693 \pm 26$ \\
$\mathrm{G}$ & $18.3406 \pm 11$ & $15.5593 \pm 10$ & $38.2718 \pm 24$ \\
$\mathrm{H}$ & $18.3424 \pm 10$ & $15.5617 \pm 10$ & $38.2752 \pm 30$ \\
$\mathrm{I}$ & $18.3404 \pm 9$ & $15.5590 \pm 8$ & $38.2682 \pm 21$ \\
Mean & 18.3423 & 15.5611 & 38.2753 \\
Preferred & $18.3435 \pm 17$ & $15.5619 \pm 16$ & $38.2784 \pm 50$ \\
2 SD & 0.0030 & 0.0035 & 0.0102 \\
2 SD (ppm) & $162 \mathrm{ppm}$ & $223 \mathrm{ppm}$ & $266 \mathrm{ppm}$ \\
\hline Prefered
\end{tabular}

Preferred values for the $\mathrm{Pb}$ isotopic ratios of JB-2 are those of Baker et al. (2004) $\mathrm{n}=14$. 
Data were carefully monitored for interferences on the Hf isotopic array, i.e. $\mathrm{Lu}$ and $\mathrm{Yb} .{ }^{176} \mathrm{Lu}$ and ${ }^{176} \mathrm{Yb}$ isobaric interferences were minimised as a result of excellent separation of $\mathrm{Hf}$ from these elements. Yb isobaric interferences were corrected during data acquisition using the stable ratio ${ }^{176} \mathrm{Yb} /{ }^{173} \mathrm{Yb}=0.79323 . \mathrm{Lu}$ isobaric interferences on ${ }^{176} \mathrm{Hf}$ were corrected using the stable ratio ${ }^{176} \mathrm{Lu} /{ }^{175} \mathrm{Lu}=$ 0.026525. The standard JMC475 was doped with Yb and Lu separately to check these isobaric corrections were working properly. Procedural blanks for this study were $<100 \mathrm{pg}$ for $\mathrm{Hf}$ and are neglible.

$\underline{\text { Lead }}$

$\mathrm{Pb}$ isotopes were corrected for instrumental mass bias by sample standard bracketing using SRM981. Internal precisions (2 SE) of ${ }^{206} \mathrm{~Pb} /{ }^{204} \mathrm{~Pb},{ }^{207} \mathrm{~Pb} /{ }^{204} \mathrm{~Pb}$ and ${ }^{208} \mathrm{~Pb} /{ }^{204} \mathrm{~Pb}$ were better than $\pm 0.0005, \pm 0.0004$ and \pm 0.0013 respectively. $\mathrm{Pb}$ isotope ratios are reported relative to ${ }^{206} \mathrm{~Pb} /{ }^{204} \mathrm{~Pb}=16.9416,{ }^{207} \mathrm{~Pb} /{ }^{204} \mathrm{~Pb}=15.5000$ and ${ }^{208} \mathrm{~Pb} /{ }^{204} \mathrm{~Pb}=36.7262$ for SRM 981 (Baker et al., 2004). External reproducibility from replicate digestions of JB-2 a basaltic standard from the Geological Survey of Japan is ${ }^{206} \mathrm{~Pb} /{ }^{204} \mathrm{~Pb} \pm 0.0030,{ }^{207} \mathrm{~Pb} /{ }^{204} \mathrm{~Pb} \pm 0.0035$ and ${ }^{208} \mathrm{~Pb} /{ }^{204} \mathrm{~Pb} \pm 0.0102(2 \mathrm{SD} ; \mathrm{n}=9$ ), this corresponds to errors of $\pm 162,223$ and 266 ppm, respectively. Total procedural $\mathrm{Pb}$ blanks in this study were typically $<10$ pg and are insignificant.

\section{A1.7 SAMPLE LEACHING}

Whole rock powders for Sr isotopic analyses were acid leached using ca. $6 \mathrm{M} \mathrm{HCl}$ on a hot plate at $110^{\circ} \mathrm{C}$ for 2 hours, to remove any non-magmatic (i.e. fluid related calcite amygdule) signature from the rock powders. However, prior to adopting this acid leaching procedure, tests where undertaken to assess if variations in the severity of this leaching resulted in differences in the ${ }^{87} \mathrm{Sr} /{ }^{86} \mathrm{Sr}$ 
isotopic ratio of the samples or the leachate (Table A1.9). Tests were conducted in hot $6 \mathrm{M} \mathrm{HCl}$ and samples were either gently (1 hour), moderately (2 hours) or severely (4 hours) leached before digestion and separation of Sr. Leaching of the more evolved/weathered samples (e.g. AMG-10 and AMB-52, respectively) produced leachates that varied significantly $\left({ }^{87} \mathrm{Sr} /{ }^{86} \mathrm{Sr}> \pm 0.0003\right)$ from the whole rock ratio, thus sufficient acid leaching to remove this non-magmatic signature is imperative considering the small ${ }^{87} \mathrm{Sr} /{ }^{86} \mathrm{Sr}$ variability in the rocks of the Lookout Volcanics $\left(\Delta^{87} \mathrm{Sr} /{ }^{86} \mathrm{Sr}=0.00013\right)$. Variation in the length of leaching experienced by the unweathered and primitive sample AMG-8 produced no systematic variation in the ${ }^{87} \mathrm{Sr} /{ }^{86} \mathrm{Sr}$ ratio of the sample, thus it was deemed sensible to be consistent and undertake a 2 hour leaching on every sample. The ${ }^{87} \mathrm{Sr} /{ }^{86} \mathrm{Sr}$ ratios for digestion of rock chips and powder are in excellent agreement for AMG-8.

Table A1.10: ${ }^{87} \mathrm{Sr} /{ }^{86} \mathrm{Sr}$ isotopic ratios of variably acid leached samples.

\begin{tabular}{ccccccc}
\hline & \multicolumn{2}{c}{ 1 hour } & \multicolumn{2}{c}{ 2 hour } & \multicolumn{2}{c}{ 4 hour } \\
& Sample & Leachate & Sample & Leachate & Sample & Leachate \\
\hline Powders & & & & & & \\
AMB-52 & 0.703179 & - & 0.703188 & 0.703611 & - & - \\
AMG-8 & 0.703136 & - & 0.703183 & 0.703195 & 0.703157 & 0.703101 \\
AMG-10 & 0.704326 & 0.704047 & 0.704293 & - & - & - \\
BHVO-2 & - & - & 0.703459 & 0.703465 & - & - \\
Rock Chips & & - & & & - & - \\
\hline AMG-8 & - & - & 0.703177 & - & - & - \\
\hline
\end{tabular}

\section{A1.8 AGE CORRECTIONS}

Age corrections were undertaken on $\mathrm{Sr}, \mathrm{Nd}, \mathrm{Hf}$ and $\mathrm{Pb}$ isotopic data to account for the radiogenic ingrowth of daughter nuclides with time. These corrections are necessary due the age of the Lookout Volcanics (i.e. ca. $96 \mathrm{Ma}$ ), and the evolved nature of some of the samples which have undergone significant radiogenic ingrowth (e.g. $\mathrm{AMG}-10 ; \mathrm{Rb} / \mathrm{Sr}=0.115$ ). 


\section{A1.8.1 Initial isotopic ratios}

The initial isotopic compositions of the Lookout Volcanics were calculated using an eruptive age of $96 \mathrm{Ma}$. Using the principle of constant radioactive decay the measured isotopic ratio (e.g. ${ }^{176} \mathrm{Hf} /{ }^{177} \mathrm{Hf}$ ) and the parent/daughter ratio (e.g. Lu/Hf) of the sample allow the initial isotopic composition of the sample to be calculated using the isochron (age) equation. Shown below is an example of the calculations required to calculate the initial ${ }^{87} \mathrm{Sr} /{ }^{86} \mathrm{Sr}$ ratio of a sample:

$$
{ }^{87} \mathrm{Sr} /{ }^{86} \mathrm{Sr}_{\mathrm{i}}={ }^{87} \mathrm{Sr} /{ }^{86} \mathrm{Sr}_{\mathrm{m}}-\left({ }^{87} \mathrm{Rb} /{ }^{86} \mathrm{Sr} \times\left(\mathrm{e}^{(\lambda \mathrm{Rb} x \mathrm{t})}-1\right)\right)
$$

${ }^{87} \mathrm{Sr} /{ }^{86} \mathrm{Sr}_{\mathrm{i}}=$ the calculated initial isotopic composition of the sample.

${ }^{87} \mathrm{Sr} /{ }^{86} \mathrm{Sr}_{\mathrm{m}}=$ the present day ${ }^{87} \mathrm{Sr} /{ }^{86} \mathrm{Sr}$ ratio of the sample measured by MC-ICP-MS.

$\lambda \mathrm{Rb}=$ the decay constant of ${ }^{87} \mathrm{Rb}\left(1.42 \times 10^{-11} \mathrm{yr}^{-1}\right.$; Steiger \& Jäger, 1977).

$\mathrm{t}=$ the age of the Lookout Volcanics $(96,000,000 \mathrm{yr})$.

The ${ }^{87} \mathrm{Rb} /{ }^{86} \mathrm{Sr}$ of a sample is calculated as follows:

$$
{ }^{87} \mathrm{Rb} /{ }^{86} \mathrm{Sr}=\mathrm{Rb} / \mathrm{Sr}_{\mathrm{m}} \times\left(\frac{\left(\mathrm{P}^{87 \mathrm{Rb}} \times \mathrm{A}^{\mathrm{Sr}}\right)}{\left(\mathrm{P}^{86 \mathrm{Sr}} \times \mathrm{A}^{\mathrm{Rb}}\right)}\right)
$$

$\mathrm{Rb} / \mathrm{Sr}_{\mathrm{m}}=\mathrm{Rb} / \mathrm{Sr}$ derived from trace element concentrations measured by ICP-MS. $\mathrm{A}^{\mathrm{Rb}} ; \mathrm{A}^{\mathrm{Sr}}=$ the atomic weight of $\mathrm{Rb}$ and $\mathrm{Sr}$ in the sample, respectively. $\mathrm{P}^{87 \mathrm{Rb}} ; \mathrm{P}^{86 \mathrm{Sr}}=$ the atomic proportion of ${ }^{87} \mathrm{Rb}$ and ${ }^{86} \mathrm{Sr}$ in the sample, respectively.

Equations of the same format were used to calculate the initial isotopic composition in the other isotopic systems (e.g. $\mathrm{Nd}, \mathrm{Hf}$ and $\mathrm{Pb}$ ). The systematics of the isotopic systems used in this study are shown in Table A1.11. Using these parameters and the equations above age corrected initial isotopic values were calculated for the samples of the Lookout Volcanics. The magnitudes of calculated age corrections for a selection of samples are shown in Table A1.12. $\mathrm{Nd}$ and $\mathrm{Hf}$ isotope age corrections are small and reasonably consistent across the 
samples of this study $\left(\Delta^{143} \mathrm{Nd} /{ }^{144} \mathrm{Nd}=0.000073-0.000082\right)$. However, Sr isotope age corrections vary considerable between primitive (low $\mathrm{Rb} / \mathrm{Sr} ; \Delta^{87} \mathrm{Sr} /{ }^{86} \mathrm{Sr}=$ 0.00012 ) and evolved (high $\mathrm{Rb} / \mathrm{Sr} ; \Delta^{87} \mathrm{Sr} /{ }^{86} \mathrm{Sr}=0.00046$ ) samples.

Age corrections for $\mathrm{Pb}$ isotopes vary considerably depending on the $\mathrm{U} / \mathrm{Pb}$ and $\mathrm{Th} /$ $\mathrm{Pb}$ ratios of the samples (e.g. $\left.\Delta^{208} \mathrm{~Pb} /{ }^{204} \mathrm{~Pb}=0.267-0.656\right)$. The most evolved sample (AMG-10) has a high $\mathrm{Pb}$ concentration relative to the other samples (i.e. low $\mathrm{U} / \mathrm{Pb}$ and $\mathrm{Th} / \mathrm{Pb}$ ratios) resulting in a smaller $\mathrm{Pb}$ isotope age corrections.

Table A1.11: Parameters of the isotopic systems used in this study.

\begin{tabular}{lccccc}
\hline System & Parent & Daughter & Ratio & $\lambda$ & $\mathrm{t}^{1 / 2}$ \\
\hline $\mathrm{Rb}-\mathrm{Sr}$ & ${ }^{87} \mathrm{Rb}$ & ${ }^{87} \mathrm{Sr}$ & ${ }^{87} \mathrm{Sr} /{ }^{86} \mathrm{Sr}$ & $1.42 \times 10^{-11} \mathrm{yr}^{-1}$ & $48 \mathrm{Gyr}$ \\
$\mathrm{Sm}-\mathrm{Nd}$ & ${ }^{147} \mathrm{Sm}$ & ${ }^{143} \mathrm{Nd}$ & ${ }^{143} \mathrm{Nd} /{ }^{144} \mathrm{Nd}$ & $6.54 \times 10^{-12} \mathrm{yr}^{-1}$ & $106 \mathrm{Gyr}$ \\
$\mathrm{Lu}-\mathrm{Hf}$ & ${ }^{176} \mathrm{Lu}$ & ${ }^{176} \mathrm{Hf}$ & ${ }^{176} \mathrm{Hf} /{ }^{177} \mathrm{Hf}$ & $1.94 \times 10^{-11} \mathrm{yr}^{-1}$ & $36 \mathrm{Gyr}$ \\
$\mathrm{U}-\mathrm{Pb}$ & ${ }^{238} \mathrm{U}$ & ${ }^{206} \mathrm{~Pb}$ & ${ }^{206} \mathrm{~Pb} /{ }^{204} \mathrm{~Pb}$ & $1.551 \times 10^{-10} \mathrm{yr}^{-1}$ & $4.47 \mathrm{Gyr}$ \\
$\mathrm{U}-\mathrm{Pb}$ & ${ }^{235} \mathrm{U}$ & ${ }^{207} \mathrm{~Pb}$ & ${ }^{207} \mathrm{~Pb} /{ }^{204} \mathrm{~Pb}$ & $9.849 \times 10^{-10} \mathrm{yr}^{-1}$ & $0.707 \mathrm{Gyr}$ \\
$\mathrm{Th}-\mathrm{Pb}$ & ${ }^{232} \mathrm{Th}$ & ${ }^{208} \mathrm{~Pb}$ & ${ }^{208} \mathrm{~Pb} /{ }^{204} \mathrm{~Pb}$ & $4.948 \times 10^{-11} \mathrm{yr}^{-1}$ & $14 \mathrm{Gyr}$ \\
\hline
\end{tabular}

Ratio $=$ the ratio measured during MC-ICP-MS; $\lambda$ = decay constant; $\mathrm{t}^{1 / 2} / 2$ half-life: the time for half the parent nuclides to decay to daughter nuclides.

Table A1.12: Calculated age corrections for selected samples from the Lookout Volcanics.

\begin{tabular}{lccc|cc}
\hline System & AMB-10 & AMC-5 & AMG-8 & AMB-54 & AMG-10 \\
\hline${ }^{87} \mathrm{Sr} /{ }^{86} \mathrm{Sr}$ & 0.00012 & 0.00008 & 0.00014 & 0.00037 & 0.00046 \\
${ }^{143} \mathrm{Nd} /{ }^{144} \mathrm{Nd}$ & 0.000082 & 0.000075 & 0.000080 & 0.000074 & 0.000073 \\
${ }^{176} \mathrm{Hf} /{ }^{177} \mathrm{Hf}$ & 0.000011 & 0.000010 & 0.000010 & 0.000011 & 0.000012 \\
${ }^{206} \mathrm{~Pb} /{ }^{204} \mathrm{~Pb}$ & 0.334 & 0.584 & 0.430 & 0.457 & 0.203 \\
${ }^{207} \mathrm{~Pb} /{ }^{204} \mathrm{~Pb}$ & 0.0160 & 0.0280 & 0.0206 & 0.0219 & 0.0097 \\
${ }^{208} \mathrm{~Pb} /{ }^{204} \mathrm{~Pb}$ & 0.450 & 0.656 & 0.518 & 0.594 & 0.267 \\
\hline
\end{tabular}

The vertical line divides primitive samples (left hand side) from those classed as evolved. Sample lithologies: picrobasalt (AMB-10); basalt (AMC-5; AMG-8); basaltic trachyandesite (AMB-54; AMG-10).

\section{A1.8.2 Modelled mantle source ratios}

Model present-day source values for the mantle that generated the Lookout Volcanics have been calculated to allow comparison to other well characterised mantle sources. Partial melting generates a different parent/daughter ratio in the melt than that possessed by its mantle source (Table A1.13) due to the variable enrichment of elements in a melt depending on their incompatibility. Thus the 
isotopic evolution of the mantle that created the Lookout Volcanics evolves at a different rate to that in the sampled lava flows. Sr, $\mathrm{Nd}$ and $\mathrm{Hf}$ mantle source ratios have been calculated by modelling the evolution with time of mixes of two reservoirs that encompass the variability of the Lookout Volcanics (i.e. chondritic uniform reservoir (CHUR) and depleted MORB mantle (DMM)). Isotopic compositions of CHUR and DMM are back calculated using the age equation to $96 \mathrm{Ma}$ (Table A1.14). These reservoirs in combination with the erupted lavas of the Lookout Volcanics of known isotopic composition allow the calculation of the mantle source parent/daughter ratio. Shown here is the equation required to calculate the model mantle source ${ }^{87} \mathrm{Rb} /{ }^{86} \mathrm{Sr}$ ratio:

${ }^{87} \mathrm{Rb} /{ }^{86} \mathrm{Sr}_{\text {Mantle }}=\left(\frac{\left({ }^{87} \mathrm{Sr} /{ }^{86} \mathrm{Sr}_{\text {LKV }}-{ }^{87} \mathrm{Sr}^{86} \mathrm{Sr}_{\mathrm{CHUR}}\right)}{\left({ }^{87} \mathrm{Sr} /{ }^{86} \mathrm{Sr}_{\mathrm{DMM}}-{ }^{87} \mathrm{Sr} /{ }^{86} \mathrm{Sr}_{\mathrm{CHUR}}\right.} \times\left({ }^{87} \mathrm{Rb} /{ }^{86} \mathrm{Sr}_{\mathrm{DMM}}-{ }^{87} \mathrm{Rb} /{ }^{86} \mathrm{Sr}_{\mathrm{CHUR}}\right)\right)+{ }^{87} \mathrm{Rb} /{ }^{86} \mathrm{Sr}_{\mathrm{CHUR}}$ ${ }^{87} \mathrm{Rb} /{ }^{86} \mathrm{Sr}_{\text {Mantle }}=$ calculated ${ }^{87} \mathrm{Rb} /{ }^{86} \mathrm{Sr}$ ratio of the model mantle source.

${ }^{87} \mathrm{Sr} /{ }^{86} \mathrm{Sr}_{\mathrm{CHUR}}$; DMM $=$ initial $(96 \mathrm{Ma}){ }^{87} \mathrm{Sr} /{ }^{86} \mathrm{Sr}$ ratio of CHUR and DMM, respectively.

${ }^{87} \mathrm{Rb} /{ }^{86} \mathrm{Sr}_{\mathrm{CHUR}}$ DMM $={ }^{87} \mathrm{Rb} /{ }^{86} \mathrm{Sr}$ ratio of CHUR and DMM, respectively.

${ }^{87} \mathrm{Sr} /{ }^{86} \mathrm{Sr}_{\mathrm{LKV}}=$ average initial ${ }^{87} \mathrm{Sr} /{ }^{86} \mathrm{Sr}$ ratio of the primitive lavas of the Lookout

Volcanics (classification of primitive compositions is explained in Table A1.13).

Table A1.13: Lookout Volcanics primitive average and calculated mantle source composition.

\begin{tabular}{lcc}
\hline Isotopic ratios & Lookout Volcanics ${ }^{96 \mathrm{Ma}}$ & Mantle Source \\
\hline${ }^{87} \mathrm{Rb} /{ }^{86} \mathrm{Sr}$ & $(0.0954)$ & 0.0360 \\
${ }^{87} \mathrm{Sr} /{ }^{86} \mathrm{Sr}$ & $\underline{0.703040}$ & \\
${ }^{147} \mathrm{Sm} /{ }^{144} \mathrm{Nd}$ & $(0.1258)$ & 0.2054 \\
${ }^{143} \mathrm{Nd} /{ }^{144} \mathrm{Nd}$ & 0.512711 & \\
${ }^{176} \mathrm{Lu} /{ }^{177} \mathrm{Hf}$ & $(0.0057)$ & 0.0350 \\
${ }^{176} \mathrm{Hf} /{ }^{177} \mathrm{Hf}$ & 0.282818 & \\
\hline
\end{tabular}

Lookout Volcanics ${ }^{96 \mathrm{Ma}}$ : The average composition of primitive samples from the Lookout Volcanics at $96 \mathrm{Ma}$ (initial). Primitive samples are those with ${ }^{87} \mathrm{Sr} /{ }^{86} \mathrm{Sr}<0.7031 ;{ }^{143} \mathrm{Nd} /{ }^{144} \mathrm{Nd}>0.5127$;

${ }^{176} \mathrm{Hf} /{ }^{177} \mathrm{Hf}>0.28281$. The value underlined and the value in bold were used and are the answer (i.e. parent/daughter ratio), respectively, of the example equation above. The parent/daughter ratios in brackets were not used for the calculation of mantle source values but are shown for comparison. Mantle source shows the calculated parent/daughter ratio of the mantle source of the Lookout Volcanics. 
Table A1.14: The isotopic compositions of reservoirs used for mantle source modelling.

\begin{tabular}{lcccc}
\hline Isotopic ratios & CHUR & CHUR $^{96 \mathrm{Ma}}$ & DMM & DMM $^{96 \mathrm{Ma}}$ \\
\hline${ }^{87} \mathrm{Rb} /{ }^{86} \mathrm{Sr}$ & $\underline{0.0889}$ & & $\underline{0.0188}$ & \\
${ }^{87} \mathrm{Sr} /{ }^{86} \mathrm{Sr}$ & 0.7045 & $\underline{0.704379}$ & 0.70263 & $\underline{0.702604}$ \\
${ }^{147} \mathrm{Sm} /{ }^{144} \mathrm{Nd}$ & 0.1967 & & 0.2481 & \\
${ }^{143} \mathrm{Nd} /{ }^{144} \mathrm{Nd}$ & 0.51263 & 0.512506 & 0.51313 & 0.512974 \\
${ }^{176} \mathrm{Lu} /{ }^{177} \mathrm{Hf}$ & 0.0336 & & 0.0520 & \\
${ }^{176} \mathrm{Hf} /{ }^{177} \mathrm{Hf}$ & 0.282785 & 0.282722 & 0.28326 & 0.283163 \\
\hline
\end{tabular}

Present day values are taken and calculated from values in Workman \& Hart (2005) and Bouvier et al. (2008). Values underlined are those used in the calculation of the parent/daughter ratio of the mantle source in the example equation given.

The Lookout Volcanics posses a HIMU-like signature $\left({ }^{206} \mathrm{~Pb} /{ }^{204} \mathrm{~Pb}>20\right)$. To generate this signature requires a mantle with high $\mathrm{U} / \mathrm{Pb}$ and $\mathrm{Th} / \mathrm{Pb}$ ratios, therefore DMM ratios were not used in this study. Instead the mantle source was assumed to be HIMU $(\mathrm{Pb}=0.170 \mathrm{ppm}$; $\mathrm{Th}=0.176 \mathrm{ppm}$; $\mathrm{U}=0.044 \mathrm{ppm})$ with $\mathrm{U} / \mathrm{Pb}=0.2588$ and $\mathrm{Th} / \mathrm{Pb}=1.035$. These values are derived from taking averages of published data from the Geochemical Earth reference model (GERM) website $(\mathrm{Pb}=0.170 \mathrm{ppm}(\mathrm{n}=3) ; \mathrm{Th}=0.081 \mathrm{ppm}(\mathrm{n}=3) ; \mathrm{U}=0.022 \mathrm{ppm}(\mathrm{n}=5))$ and increasing the $\mathrm{U}$ concentration so that the $\mathrm{U} / \mathrm{Pb}$ ratio is similar to that of HIMU (Chauvel et al., 1992) and the Th concentration to be consistent with regular mantle $\mathrm{Th} / \mathrm{U} \approx 4$ (McDonough \& Sun, 1995). ${ }^{238} \mathrm{U} /{ }^{204} \mathrm{~Pb}(16.5-17.2),{ }^{235} \mathrm{U} /{ }^{204} \mathrm{~Pb}$ $(0.120-0.125)$ and ${ }^{232} \mathrm{Th} /{ }^{204} \mathrm{~Pb}(68.4-71.1)$ ratios were calculated for each sample using the initial atomic weight of $\mathrm{Pb}$ in the sample. The ${ }^{238} \mathrm{U} /{ }^{204} \mathrm{~Pb}(\mu)$ values in this study are broadly consistent with those reported by Panter et al. (2006) (15.616.5).

$\mathrm{Sr}, \mathrm{Nd}, \mathrm{Hf}$ and $\mathrm{Pb}$ model mantle source isotopic ratios are 'aged' forward to the present day using the age equation by inputting the initial isotopic composition of the samples and the calculated parent/daughter ratio of the mantle 


\section{A1.9 OXYGEN ISOTOPE ANALYSES}

Oxygen isotope analyses were conducted by Kevin Faure at the Stable Isotope Laboratory, Institute of Geological and Nuclear Sciences, Lower Hutt, New Zealand. Pristine mineral grains of olivine and clinopyroxene (green and brown) were selected for analysis. Oxygen was extracted from the minerals for isotope analyses using a $10.3 \mu \mathrm{m} \mathrm{CO}$-laser and bromine pentafluoride $\left(\mathrm{BrF}_{5}\right.$; Sharp, 1990). Samples were evacuated for ca. 24 hours and left overnight in a vapour of $\mathrm{BrF}_{5}$. Blank $\mathrm{BrF}_{5}$ runs were done until the oxygen yield was $<0.1 \mu \mathrm{mol}$. Oxygen extracted from the samples was passed through a fluorine-getter before it was converted to $\mathrm{CO}_{2}$ by a graphite furnace, yields were recorded, and the gas was analysed on a Geo20-20 stable isotope mass spectrometer. Oxygen isotope values are reported in the familiar $\delta^{18} \mathrm{O}$ notation, relative to $\mathrm{V}_{\text {SMOW. }}$. Samples were normalised to the garnet standard UWG-2 using a value of 5.8\%o (Valley et al., 1995). Values for four UWG-2 standards analysed with the samples had values that varied by $<0.1 \%$. 


\section{APPENDIX 2: SAMPLE INFORMATION}

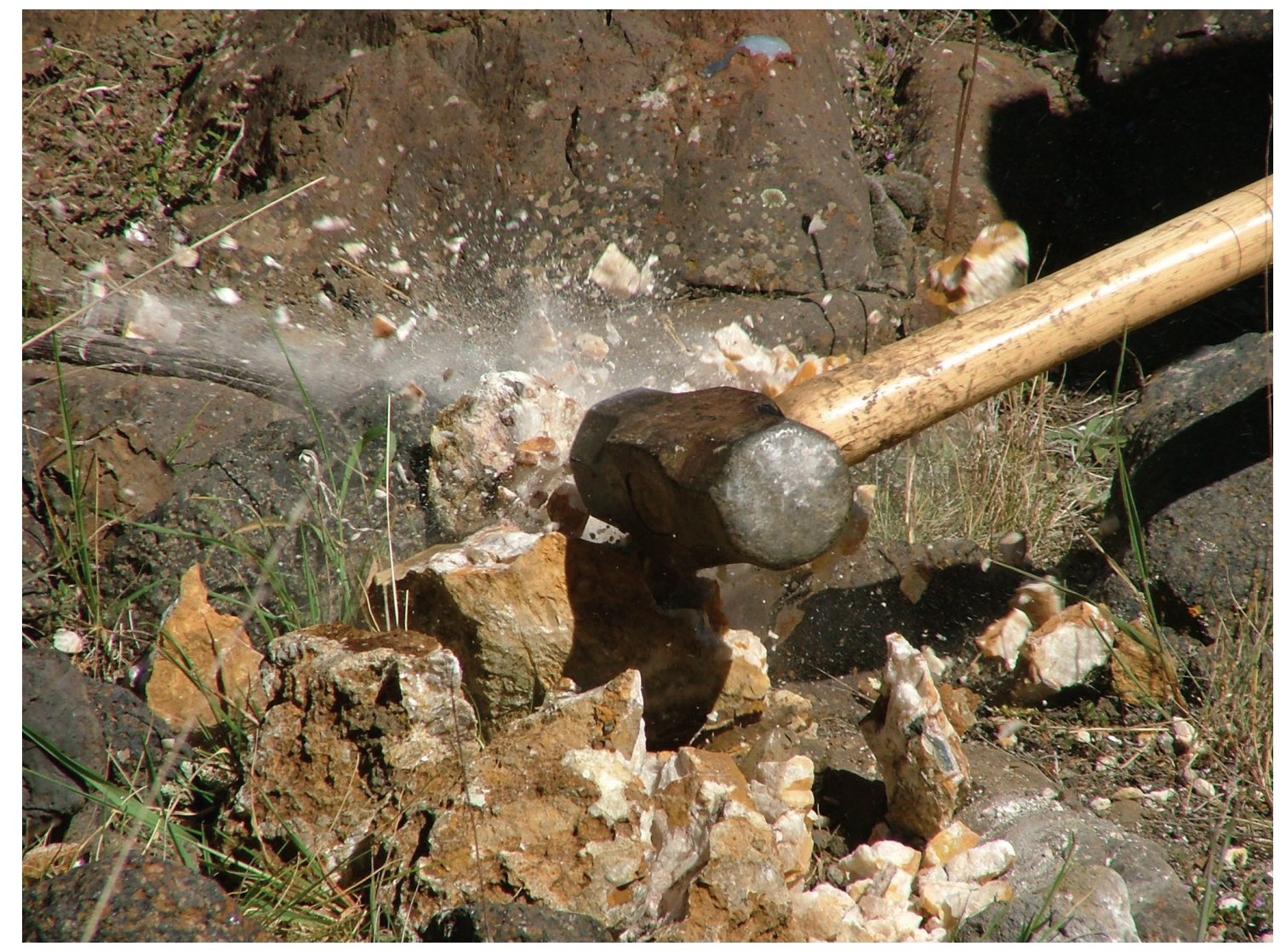

Plate 9: Tribute to the trusty sledge: an explosive impact with a large calcite amygdule on the banks of Middlehurst Stream. 


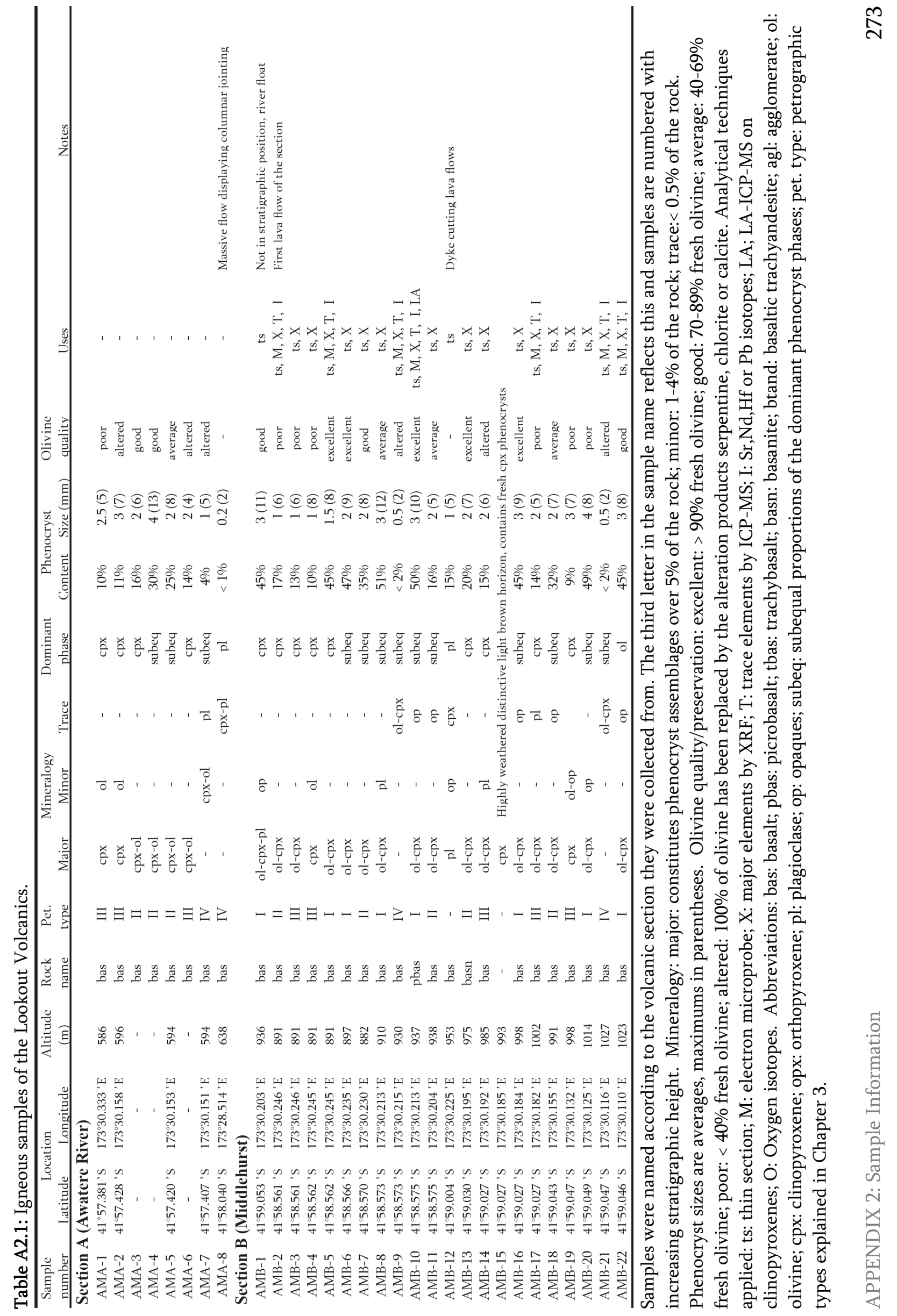




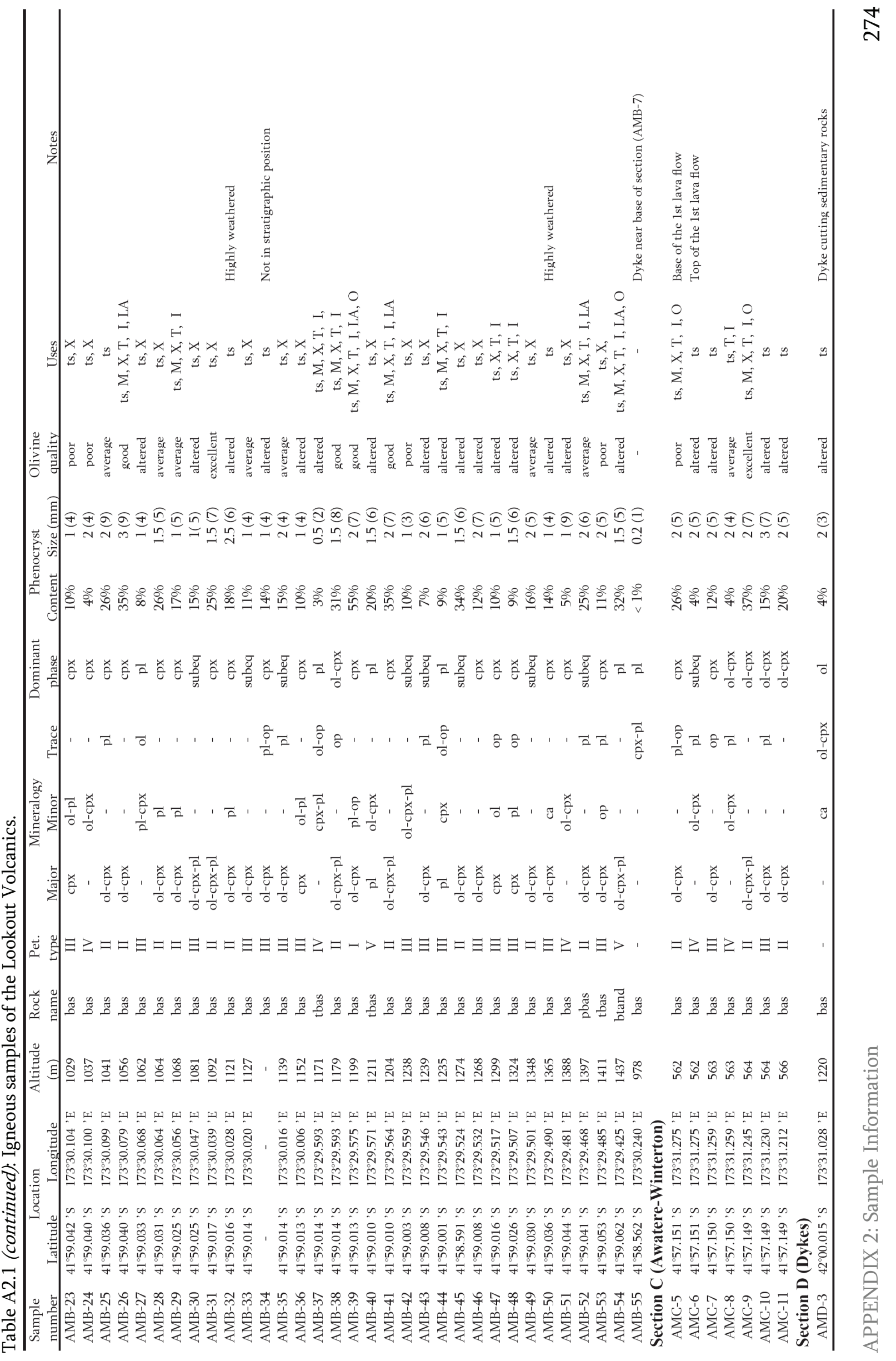




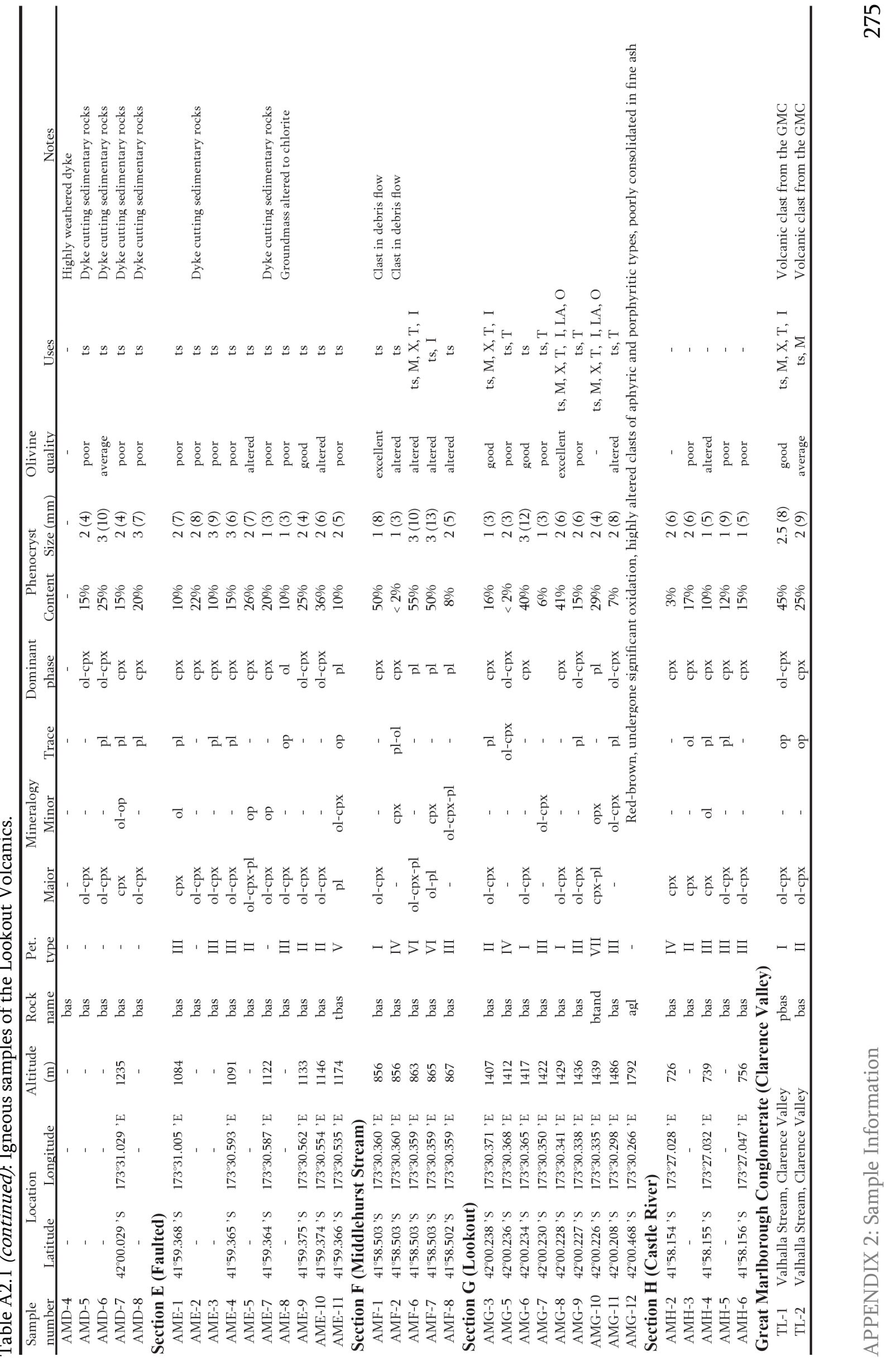




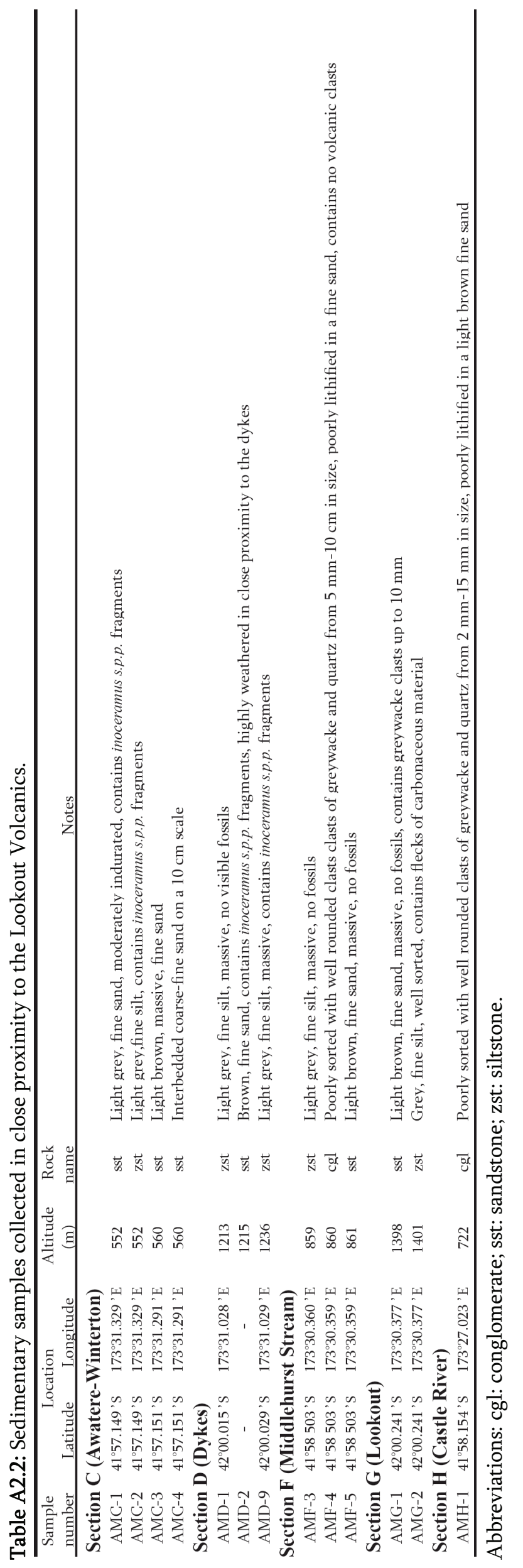




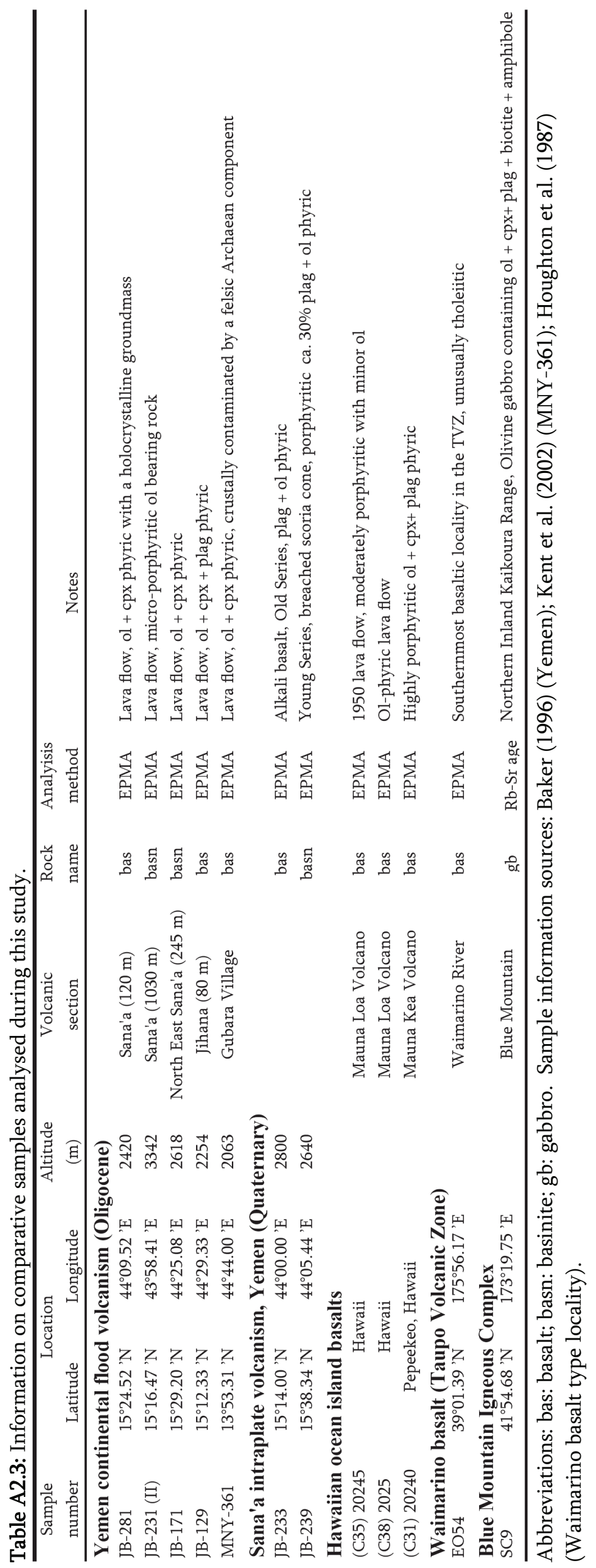




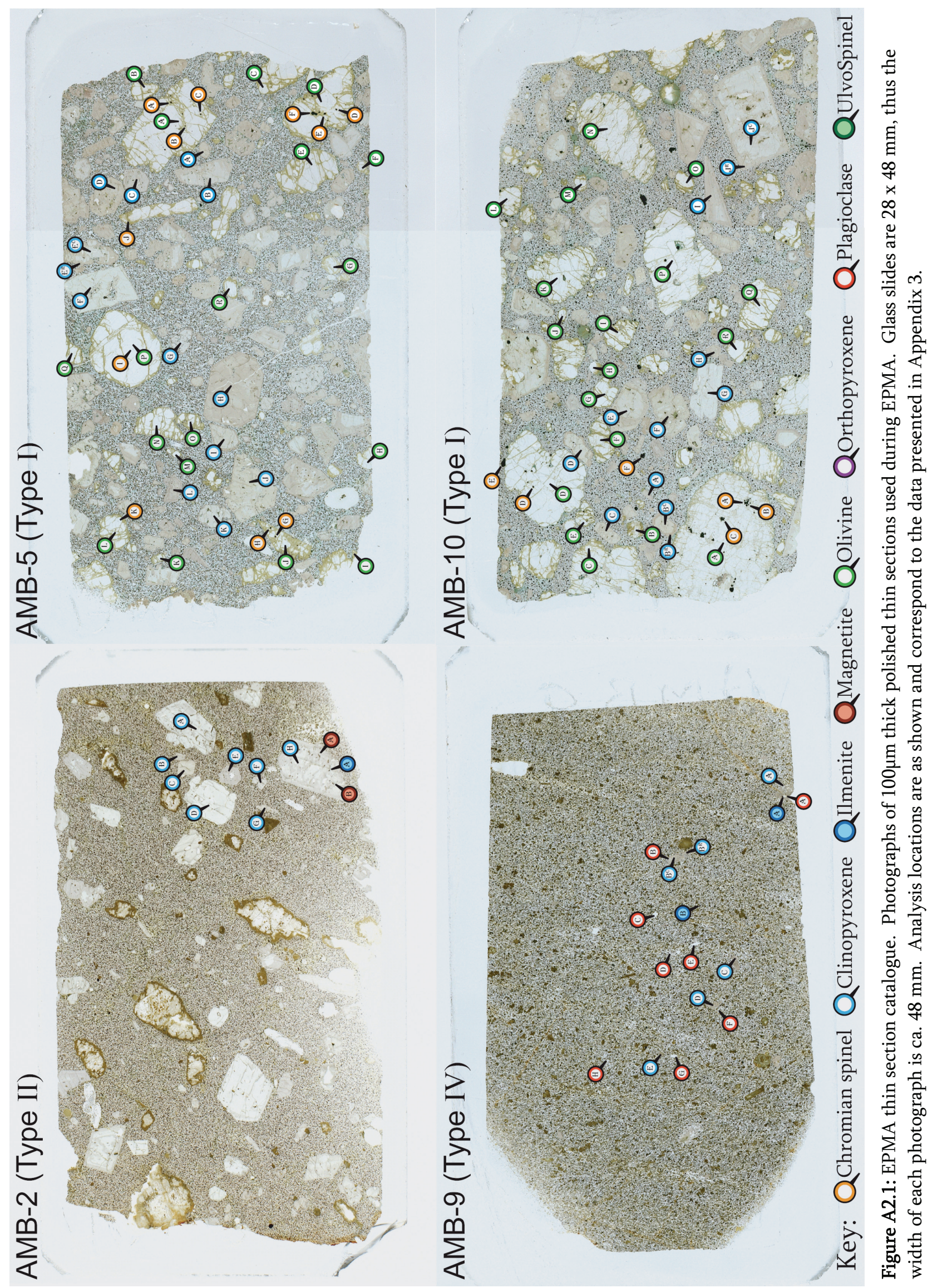



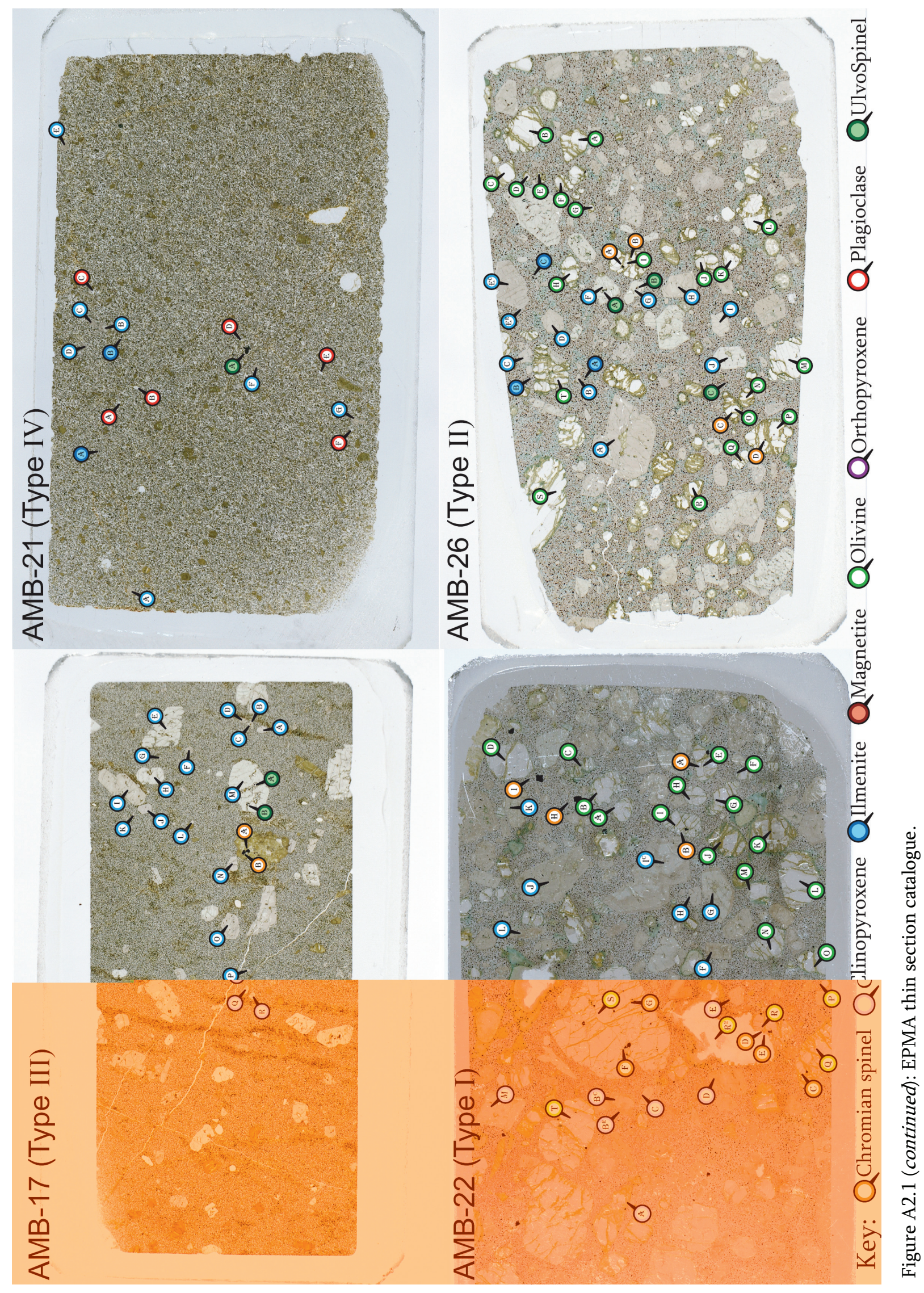


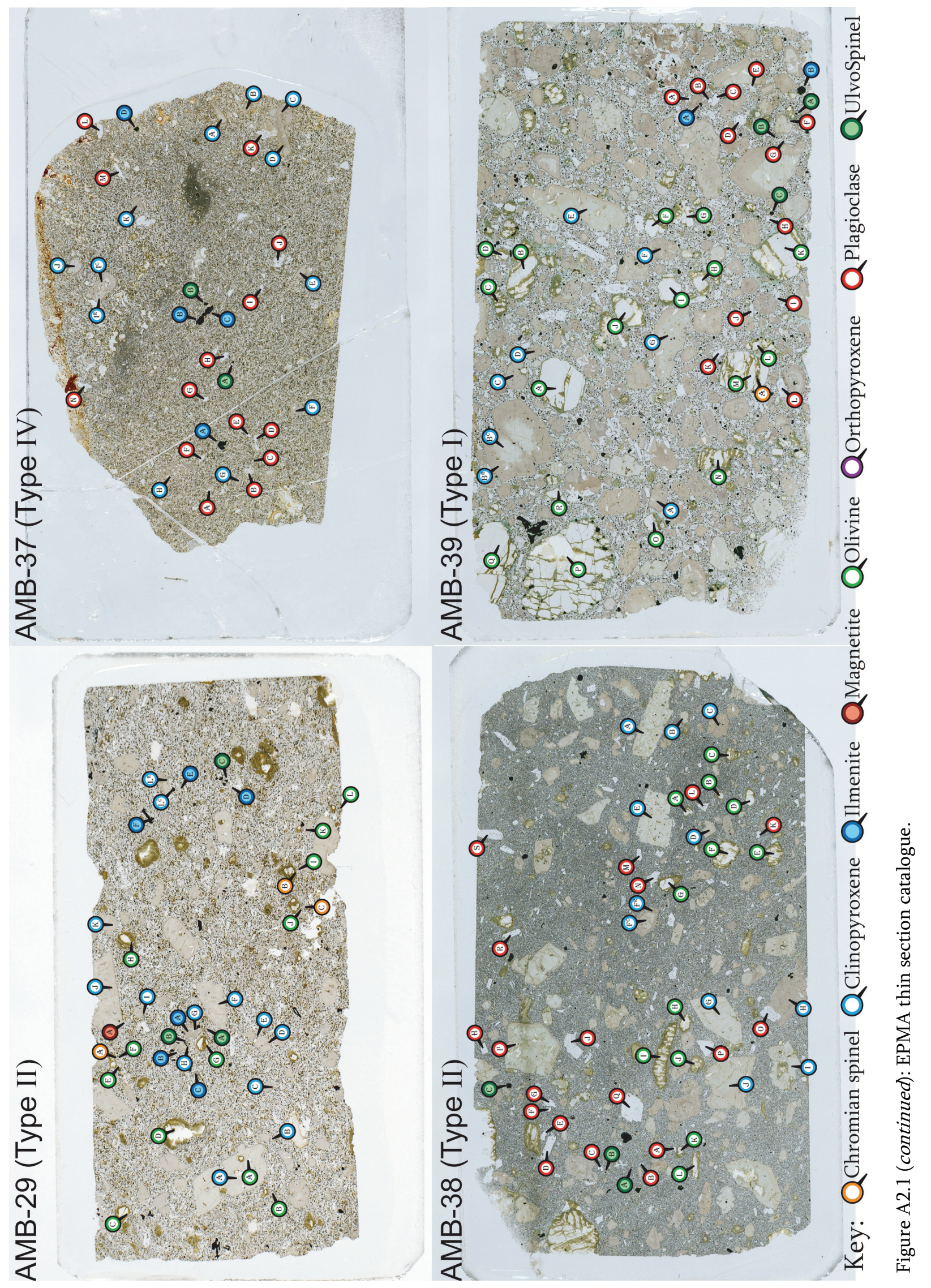




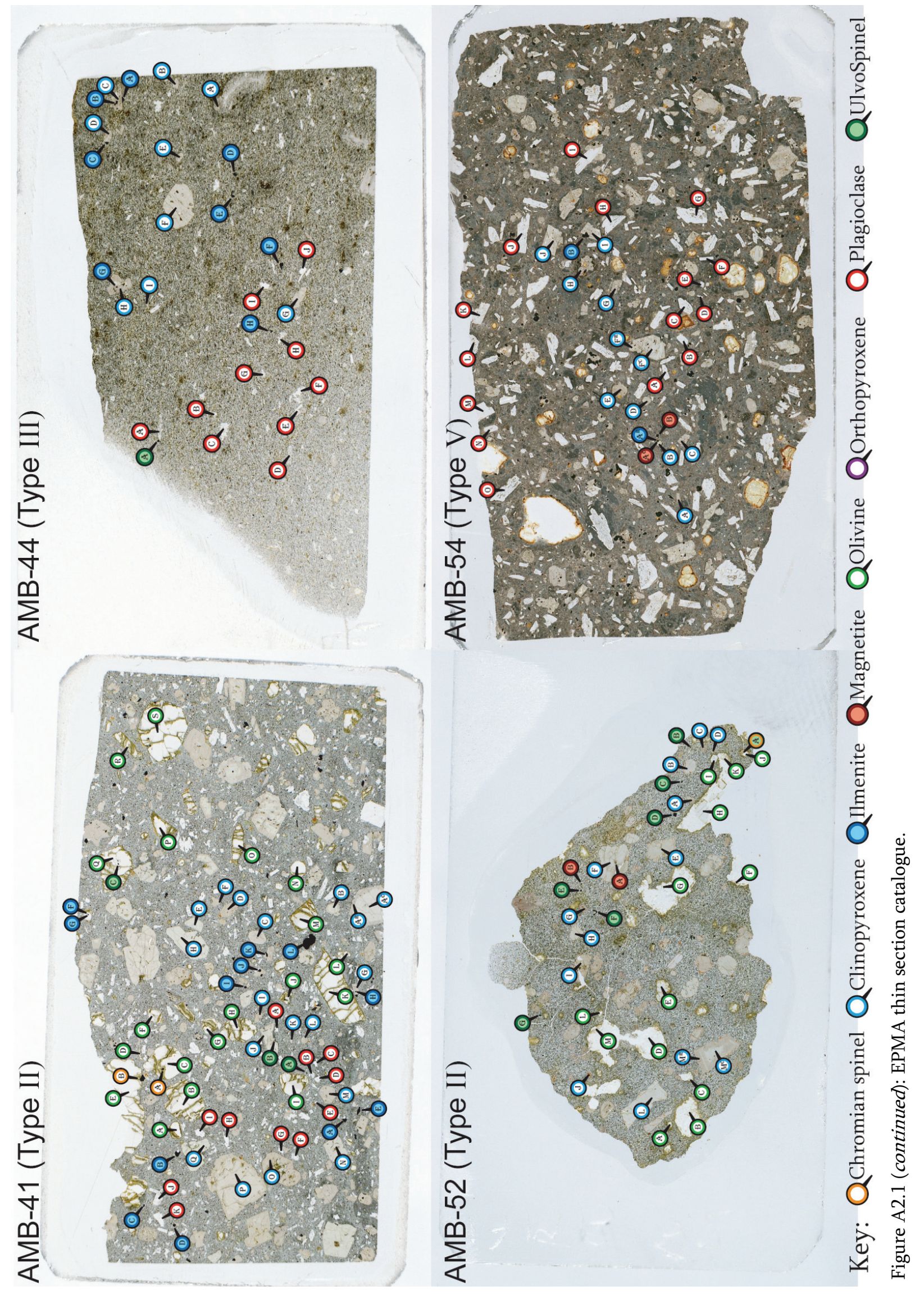




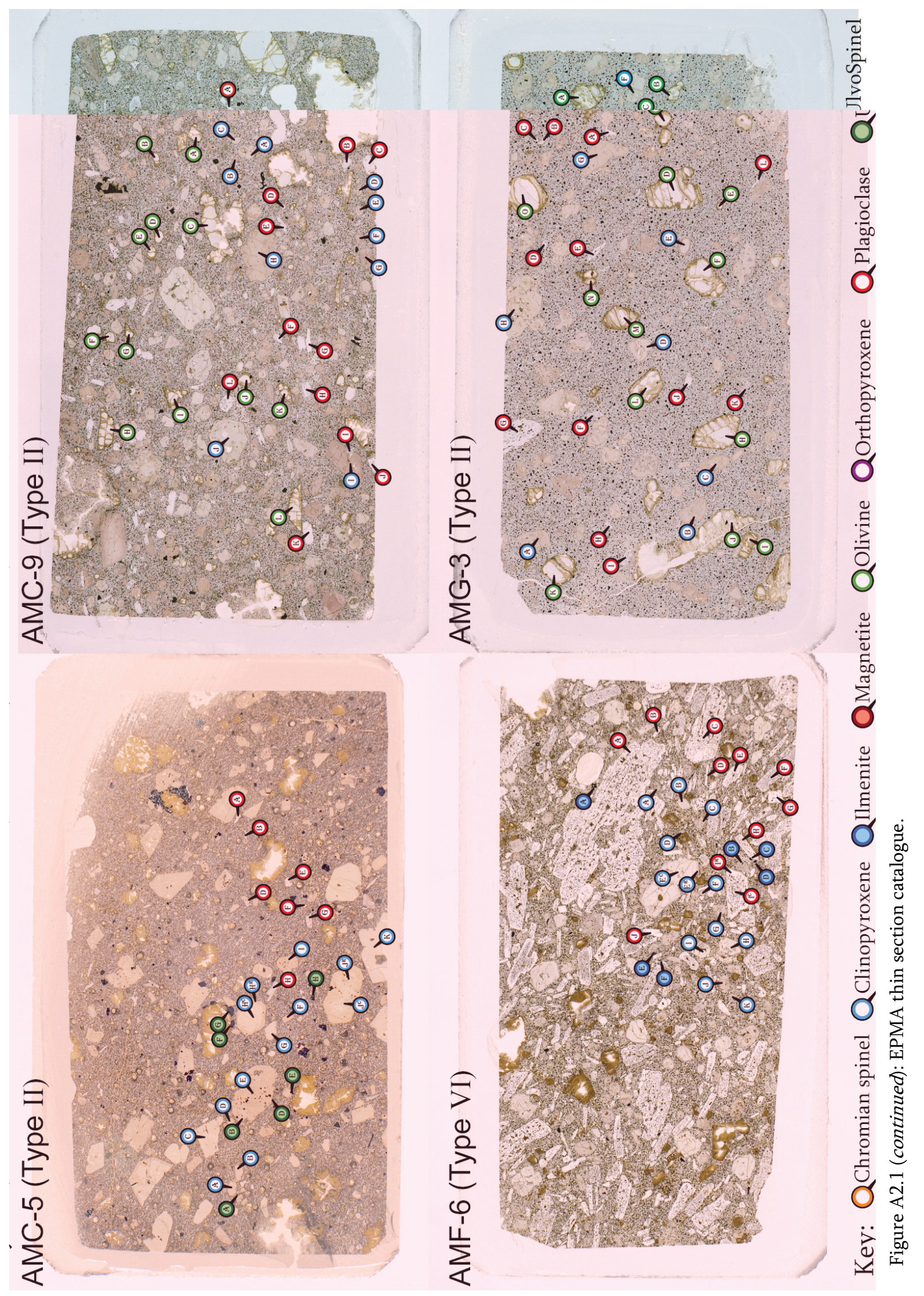




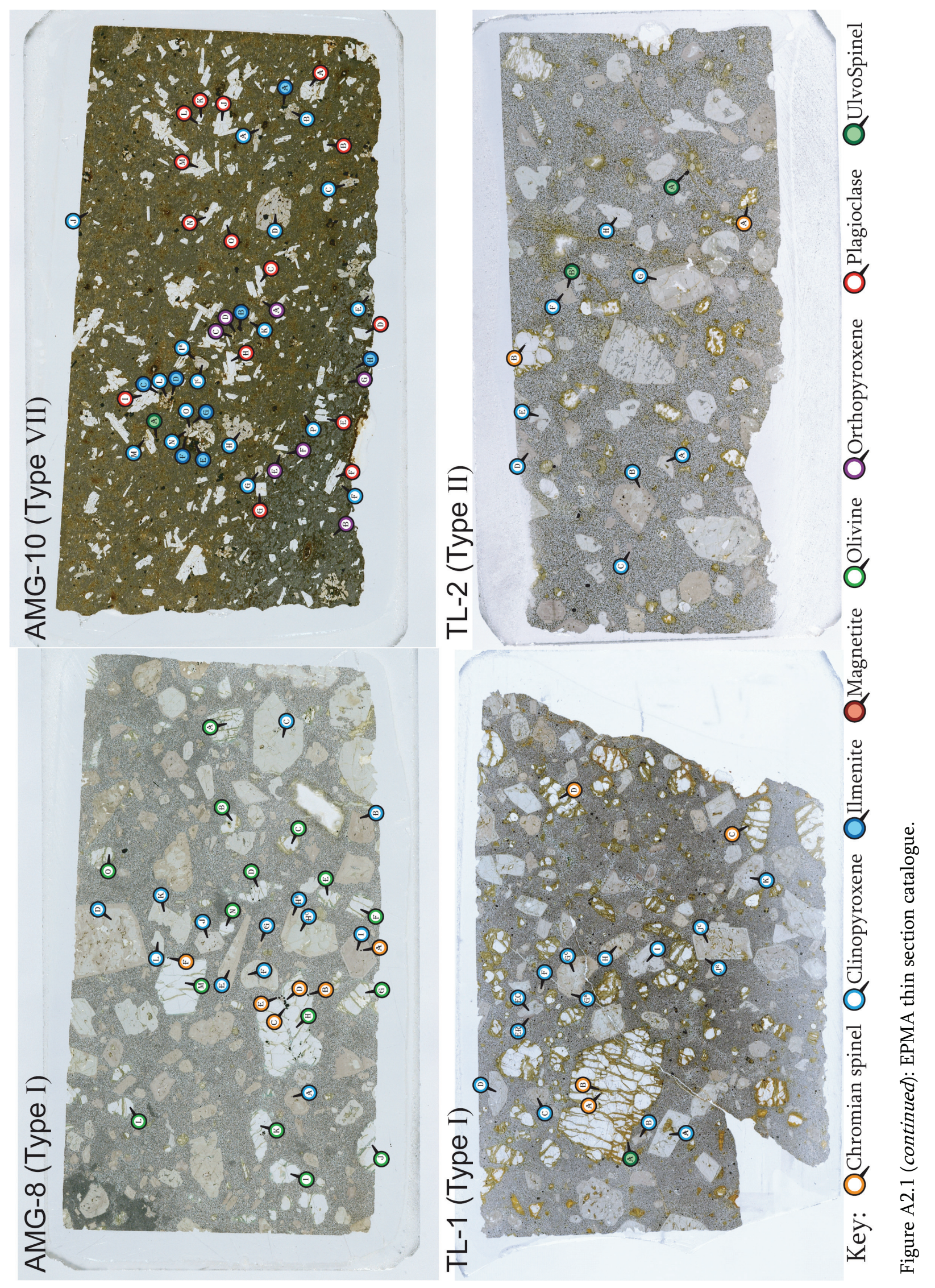




\section{APPENDIX 3: EPMA DATA}

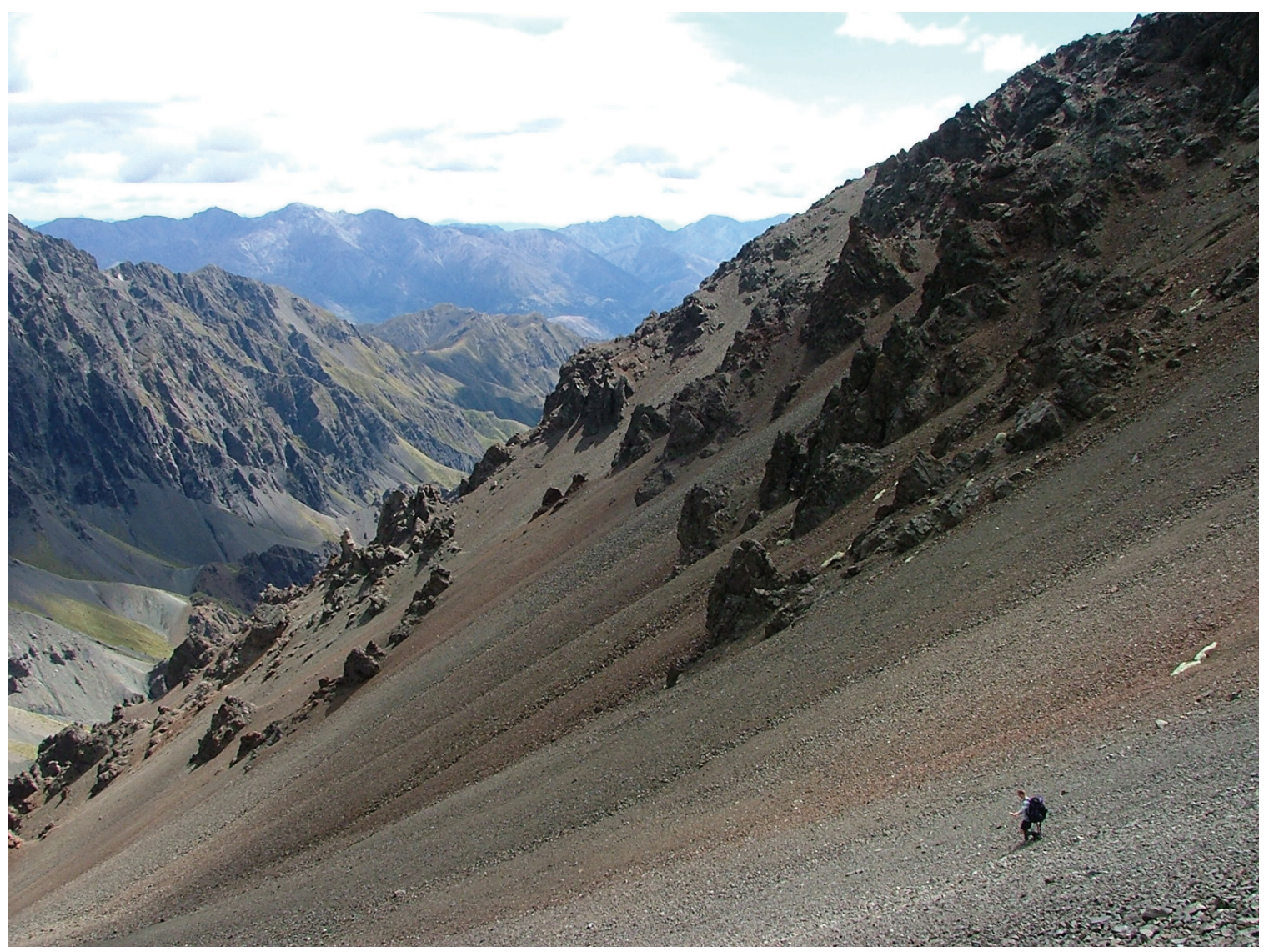

Plate 10: The descent into Trail Stream on the western side of the Red Hills via a massive scree slope (ca. $350 \mathrm{~m}$ ).

Table A3.1: Olivine phenocryst data (12 samples; 311 analyses)

Table A3.2: Clinopyroxene phenocryst data (24 samples; 327 analyses)

Table A3.3: Orthopyroxene data (2 samples; 7 analyses)

Table A3.4: Feldspar data (15 samples; 228 analyses)

Table A3.5: Ilmenite data (12 samples; 59 analyses)

Table A3.6: Ulvöspinel data (15 samples; 49 analyses)

Table A3.7: Magnetite data (4 samples; 7 analyses)

Table A3.8: Chromian spinel data (11 samples; 55 analyses) 


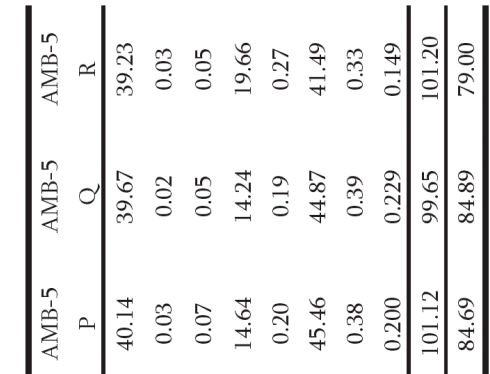

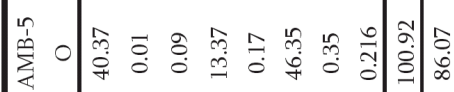

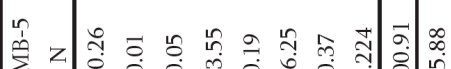

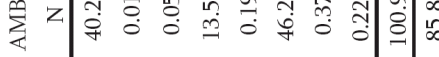

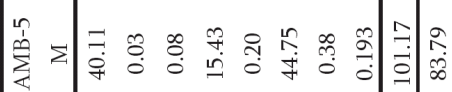

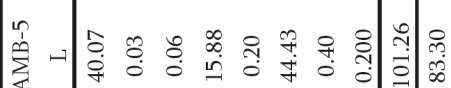

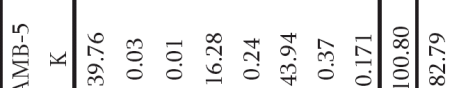

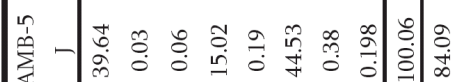

(8)

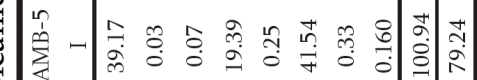

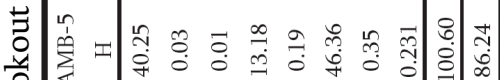

잉

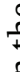

.

空

के

莺

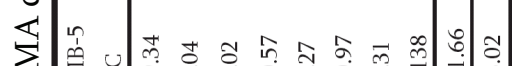

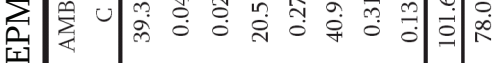

:

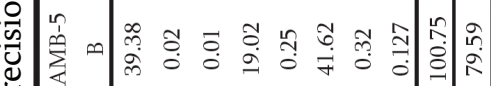

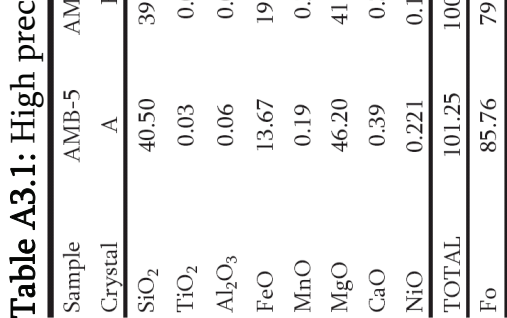

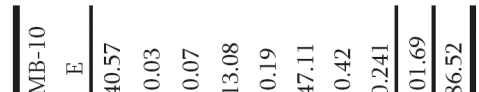

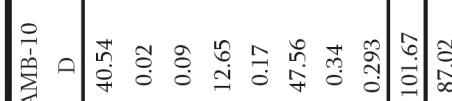

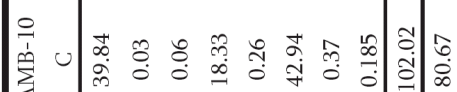

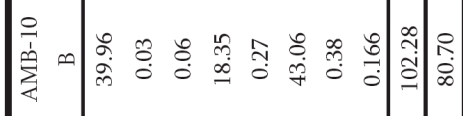

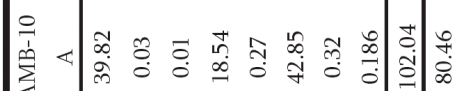

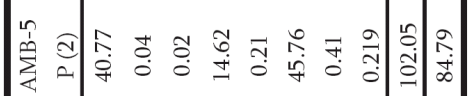

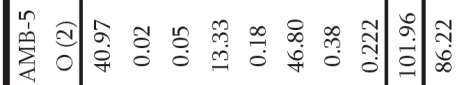

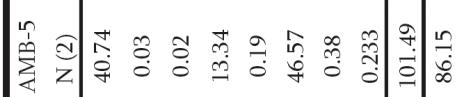

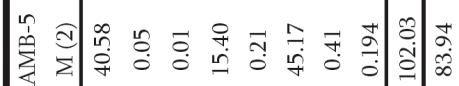

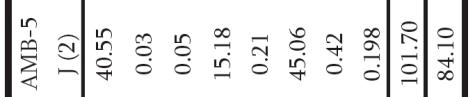

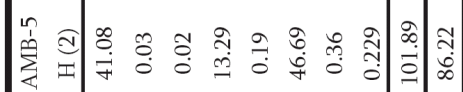

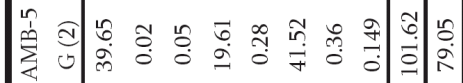

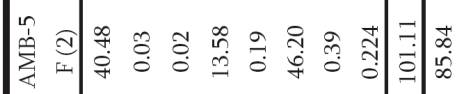

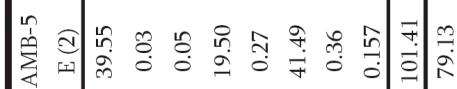

等等

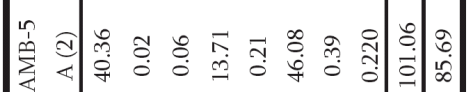

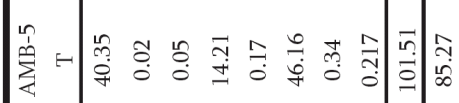

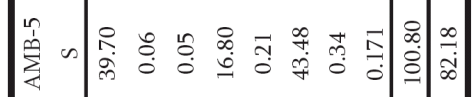

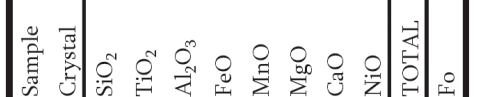

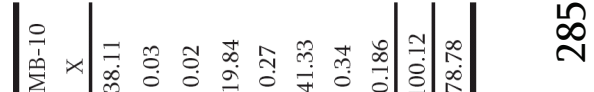

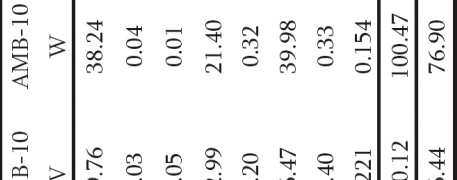

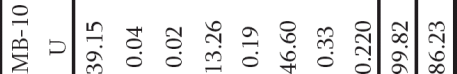

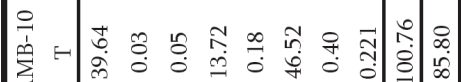

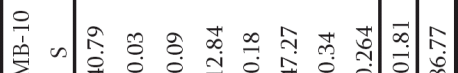

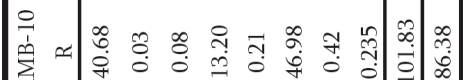

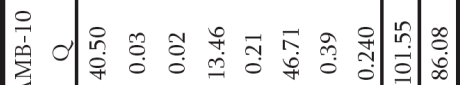

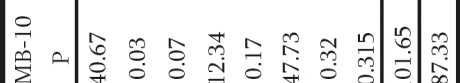

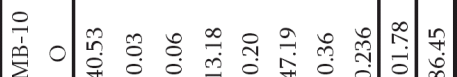

商

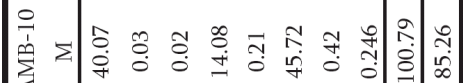

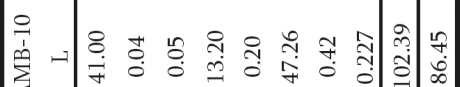

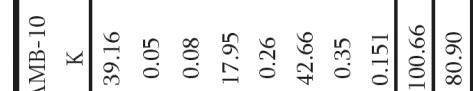

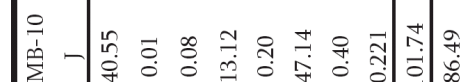

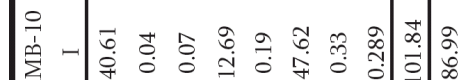

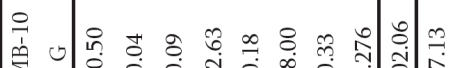

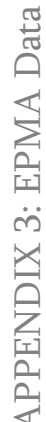




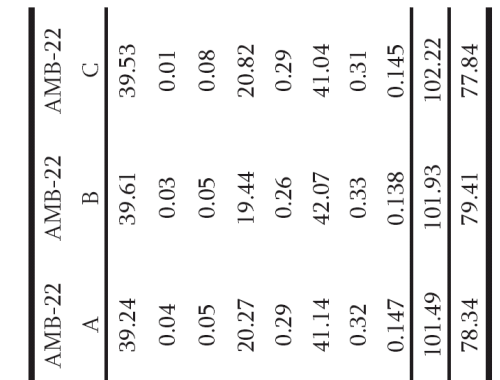

商

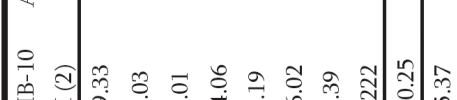

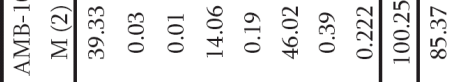

每

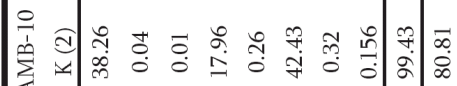

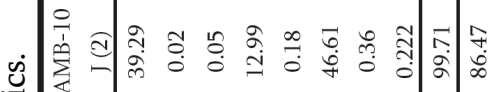

क्ष

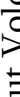

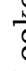

ฐี

.

.

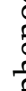

.

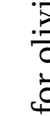$$
\text { 音 }
$$$$
\sum_{i=1}^{5}
$$$$
\text { : }
$$$$
\text { 耀 }
$$$$
\text { 童 }
$$

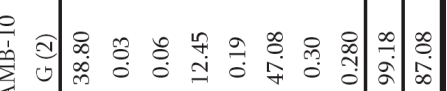

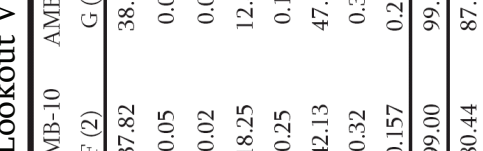

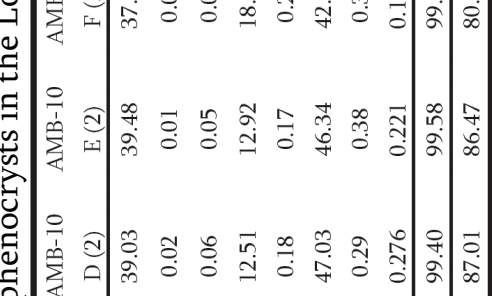

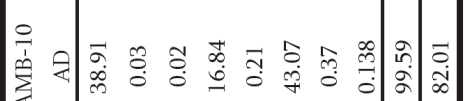

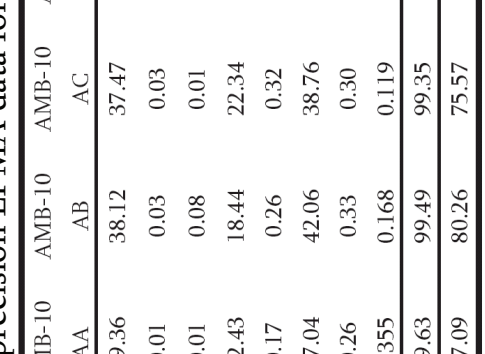

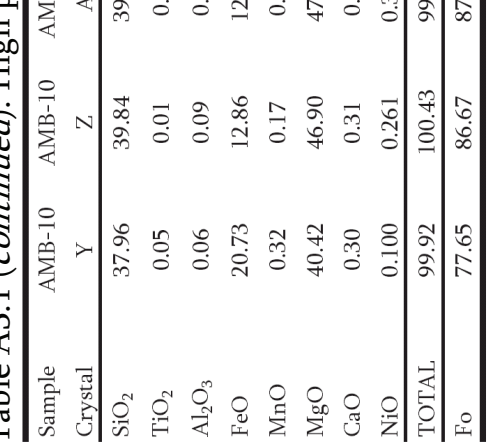

等

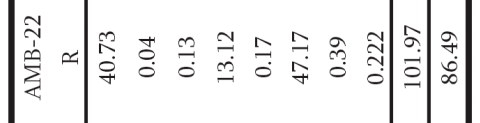

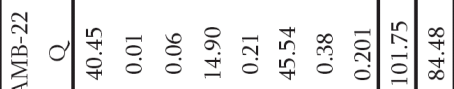

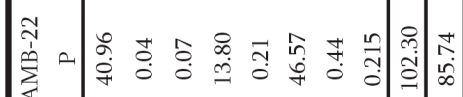

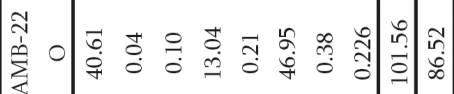

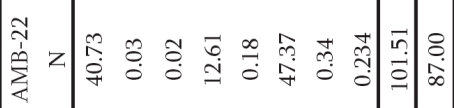

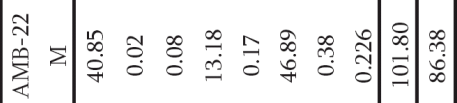

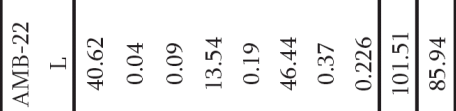

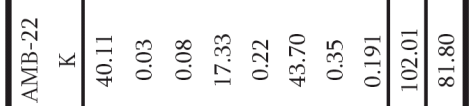

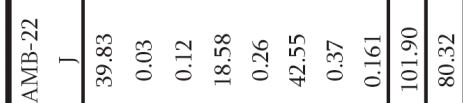

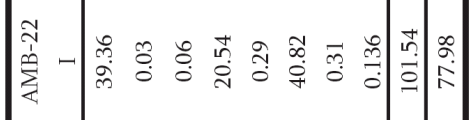

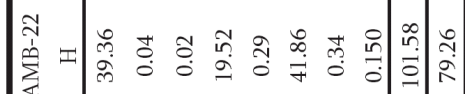

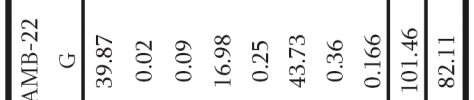

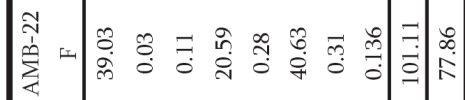

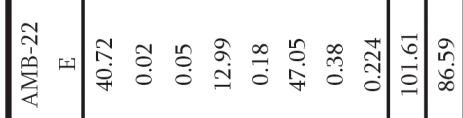

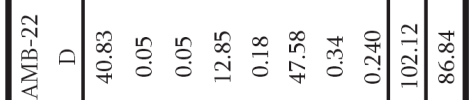

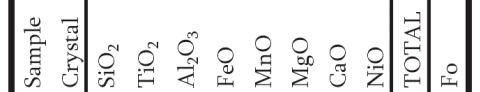

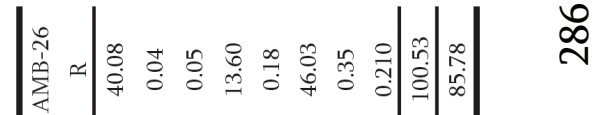

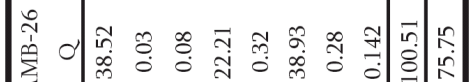

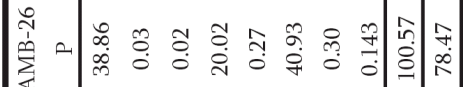

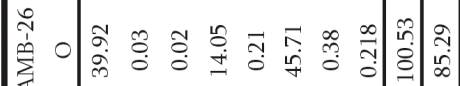

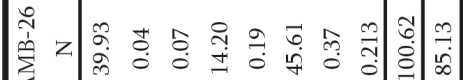

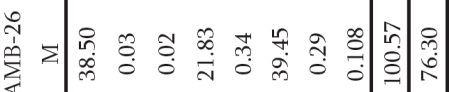

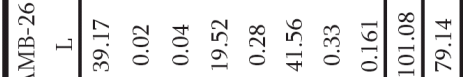
离

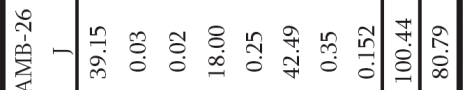
岁

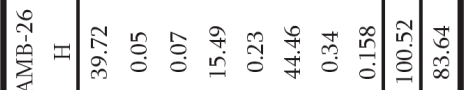
等 热

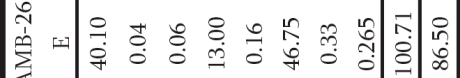
望 每

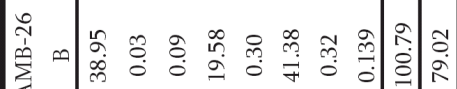

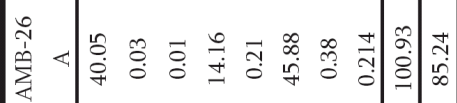

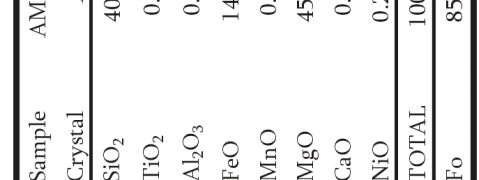




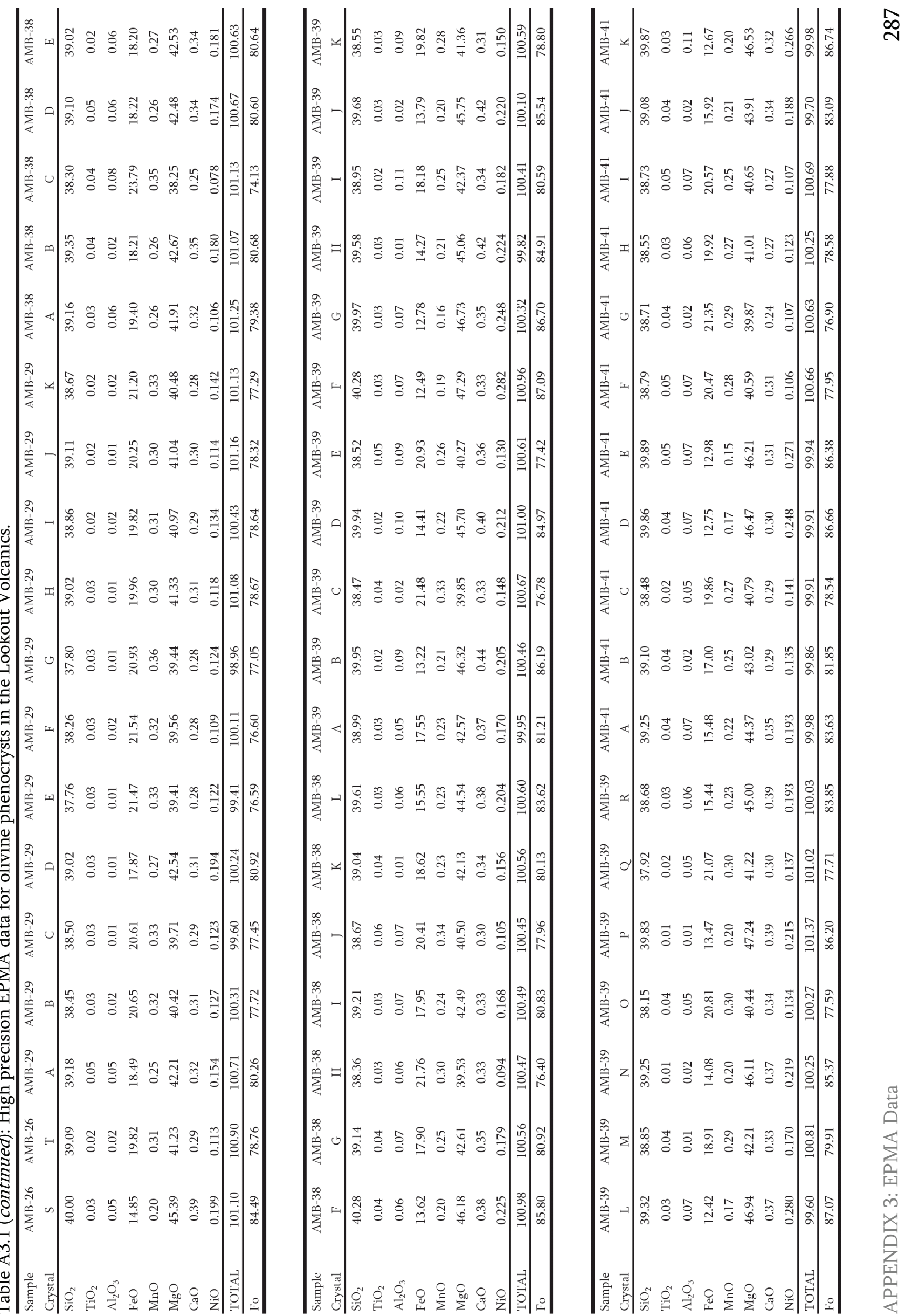




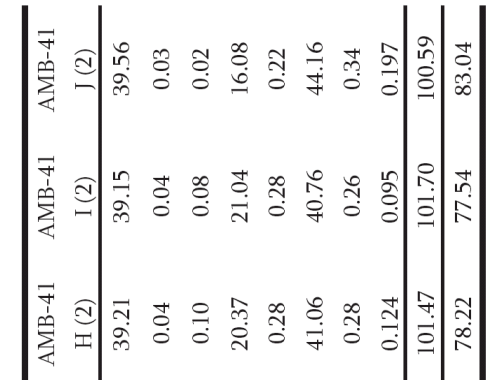

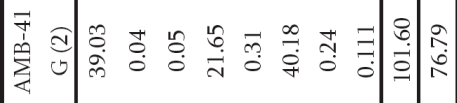

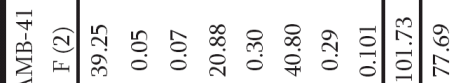

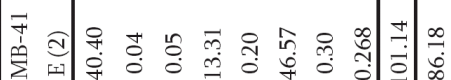

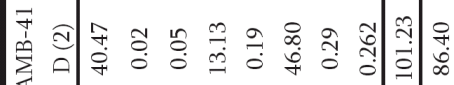

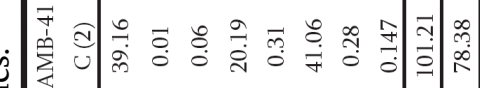
s.

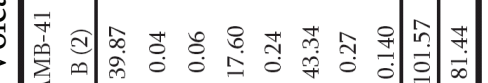
部

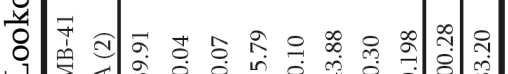
을 ,

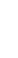
列

\section{制}

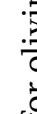

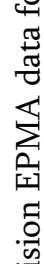

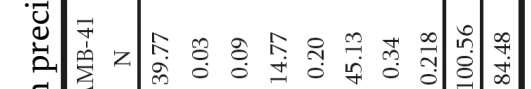

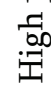

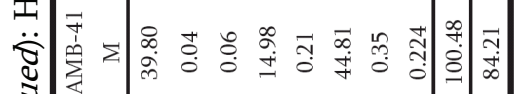

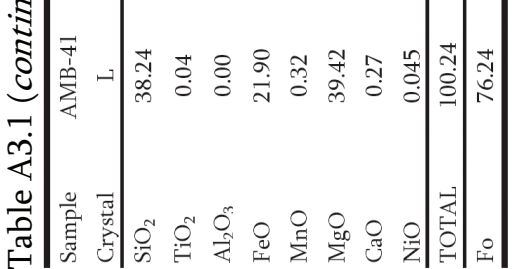

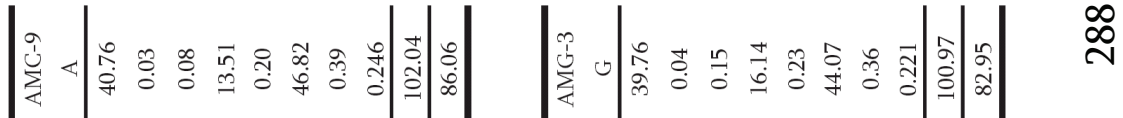

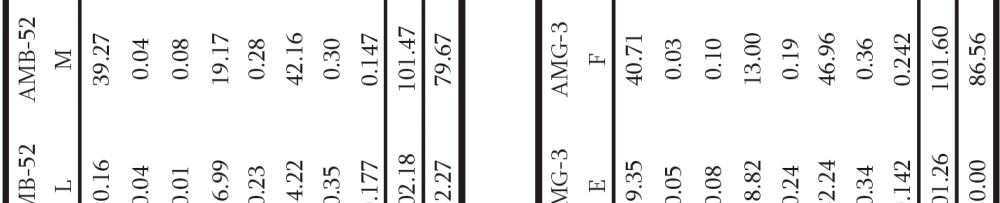

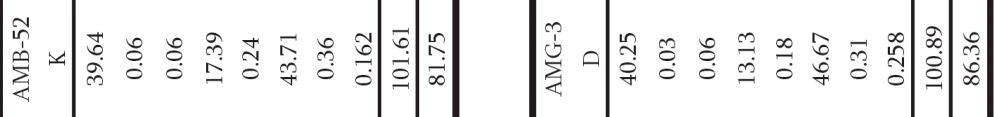

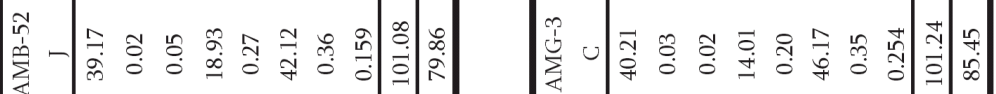
等 等 倠

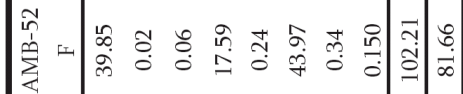
倠 隹 倠 等

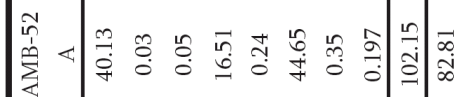

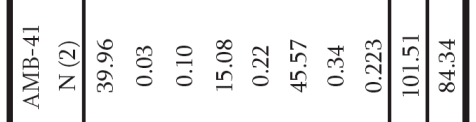

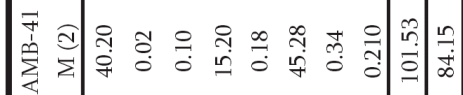

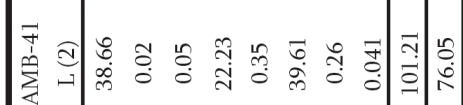

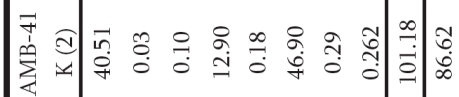

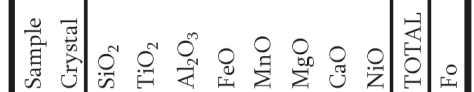

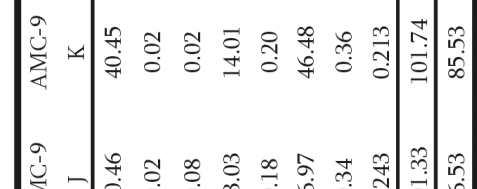

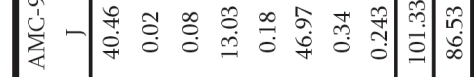

䒺-

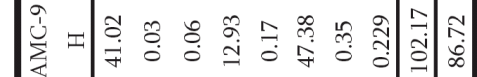

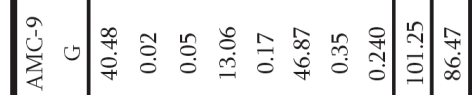

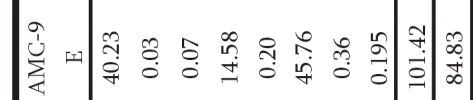

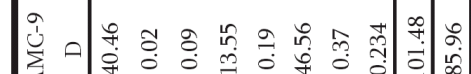

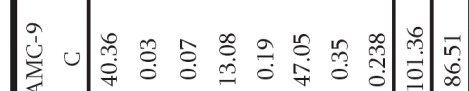

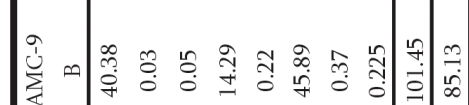

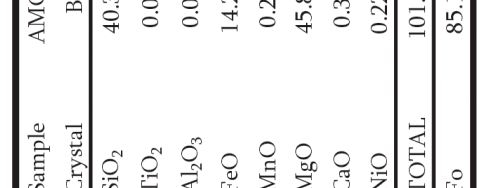

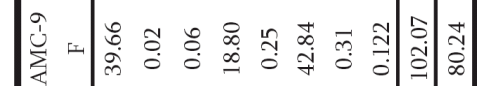

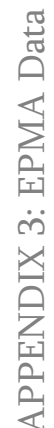




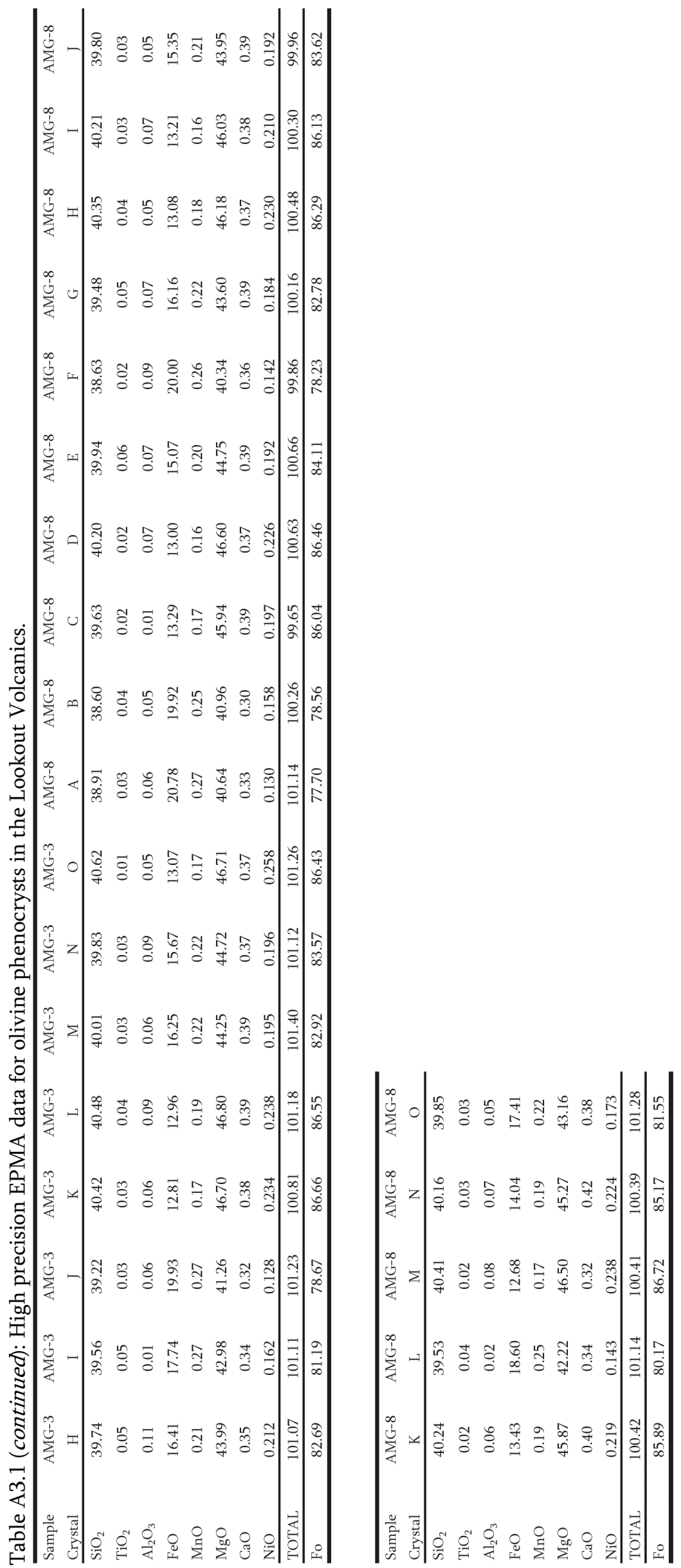




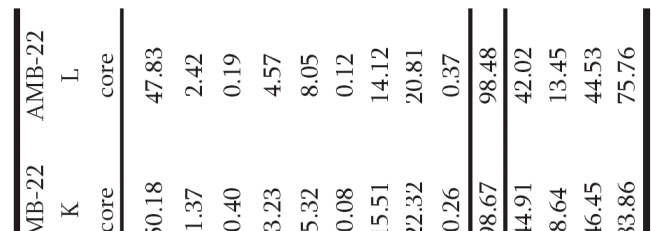

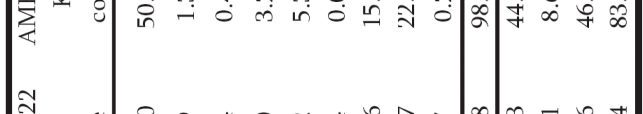

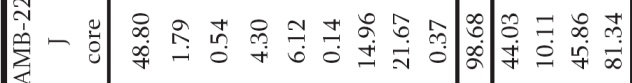

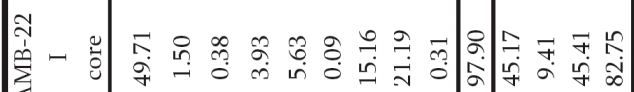

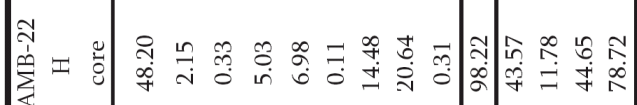

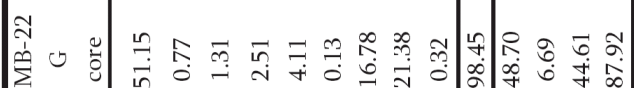

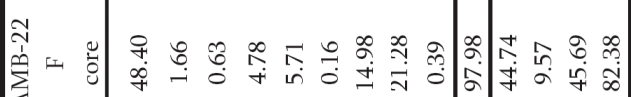

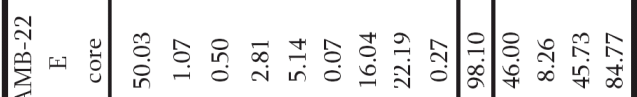

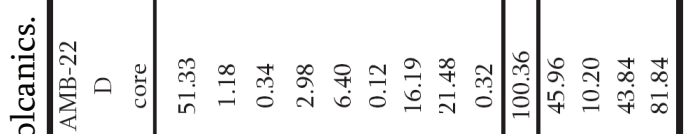

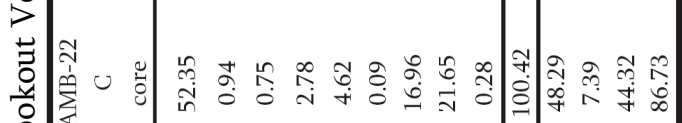

胥

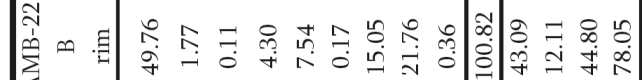

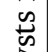

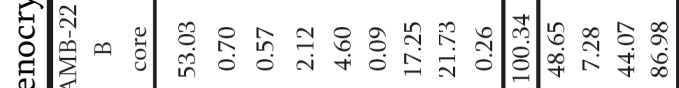

궁

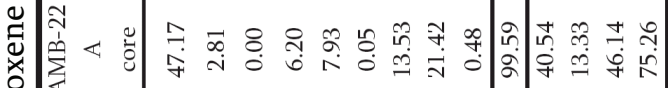

ô

:

嗬

$\sum_{\substack{1 \\ \text { I }}}^{\}$

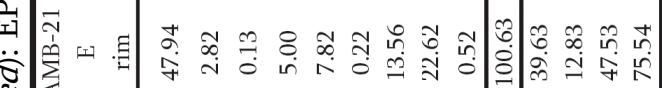

:

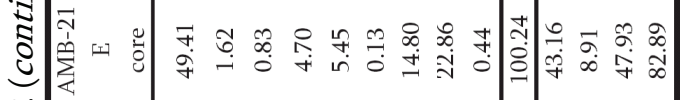

?ำ

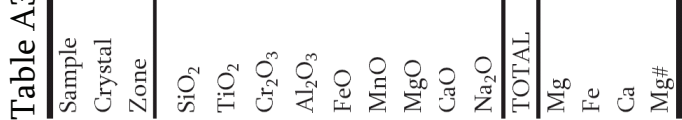

ำ

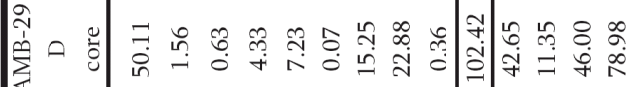

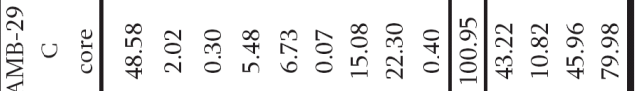

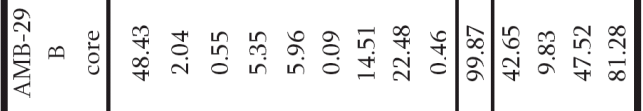

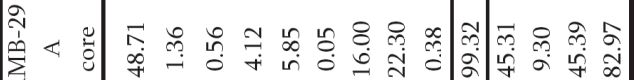

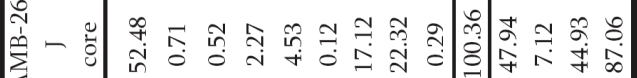

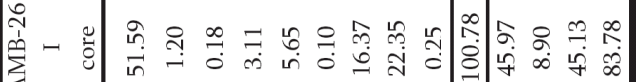

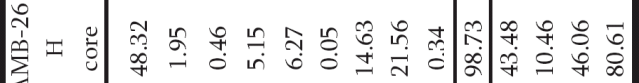

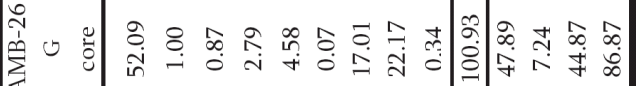

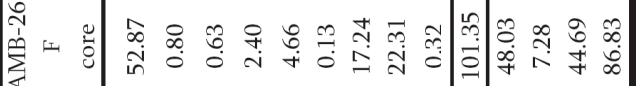

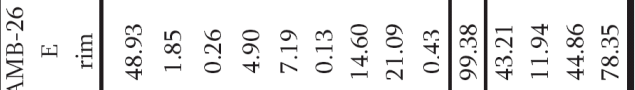

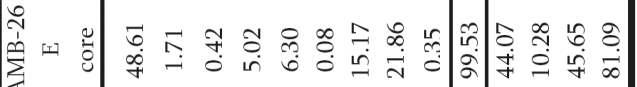

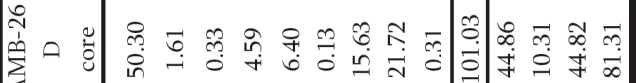

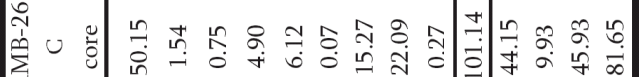

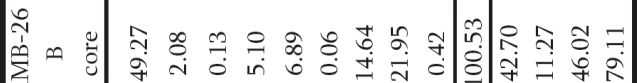

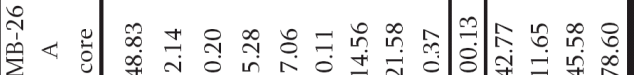

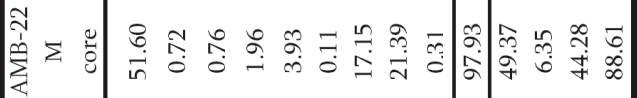

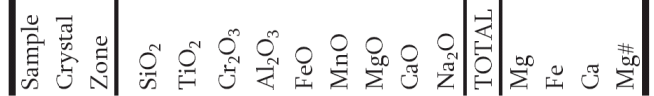




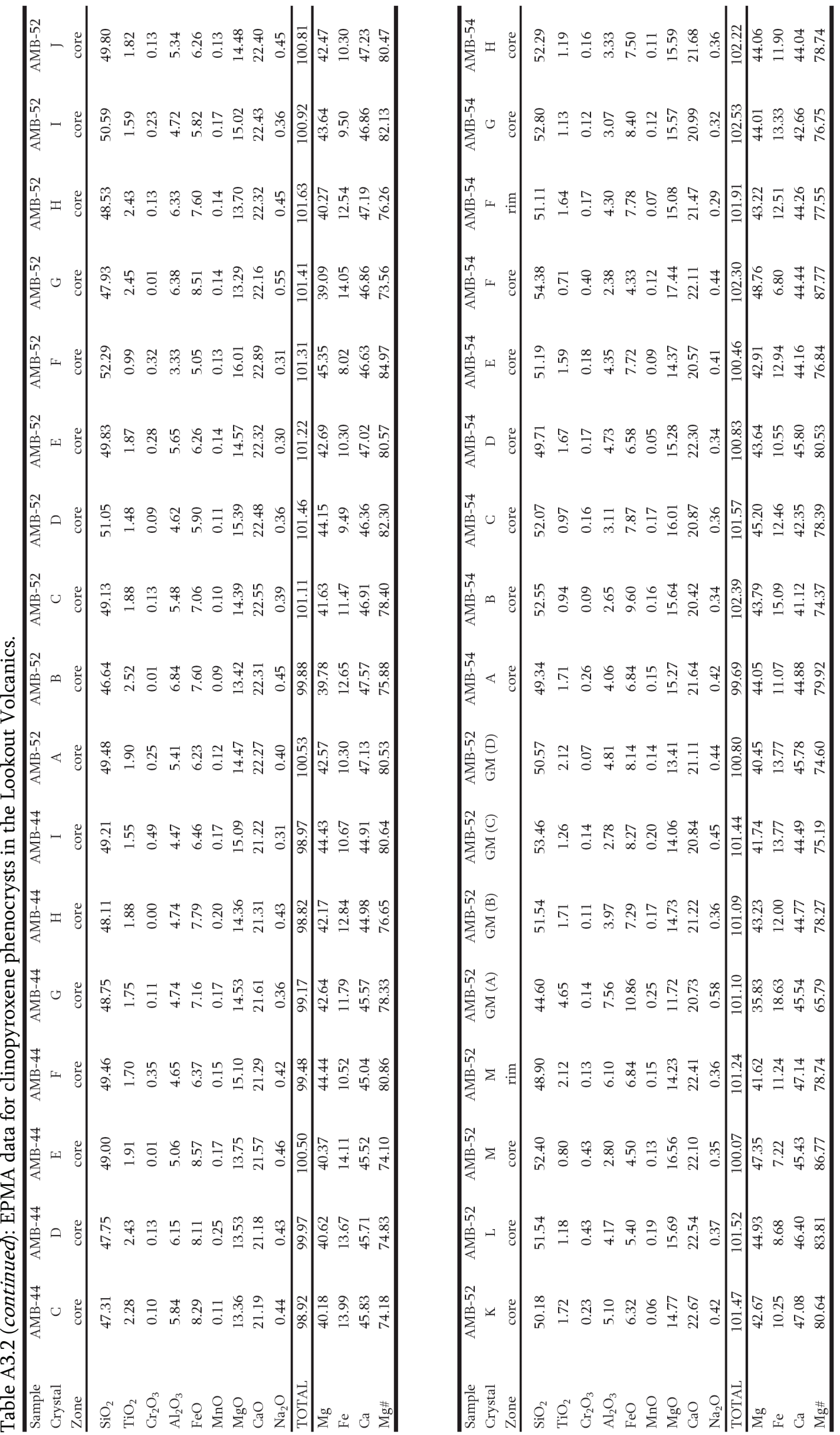

ลิ 


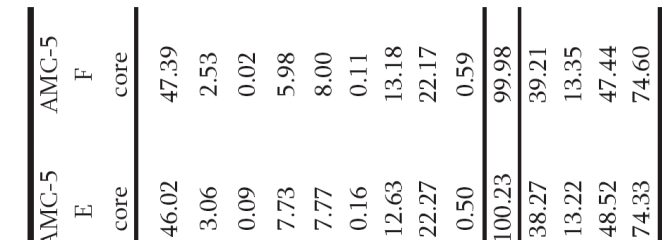

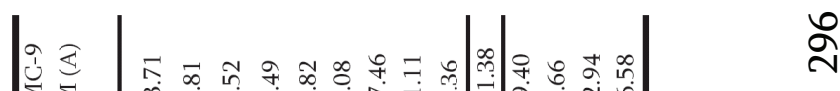

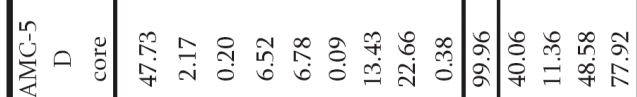

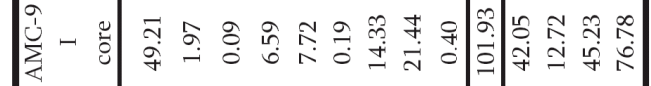

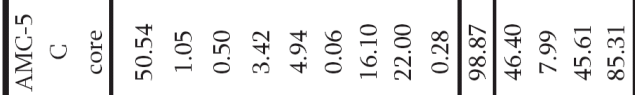

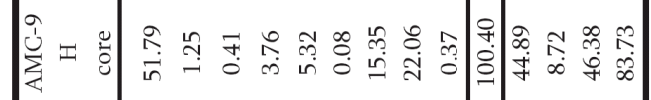

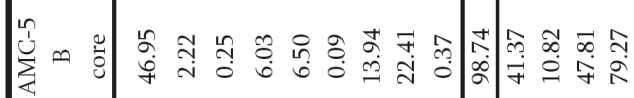

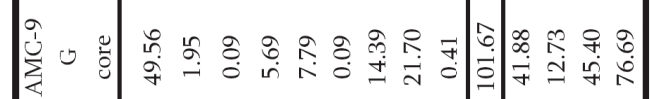

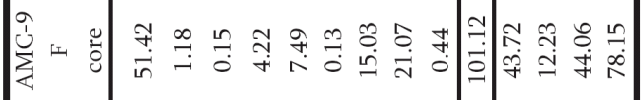

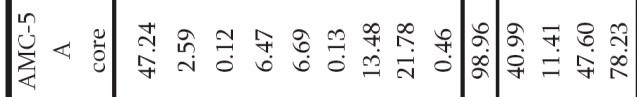

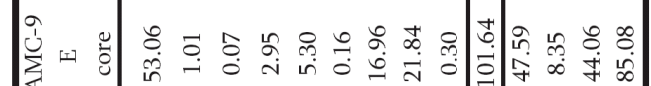

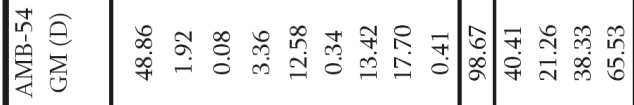

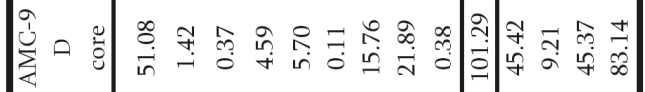

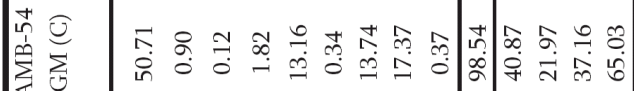

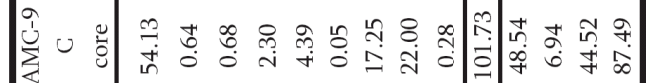

.

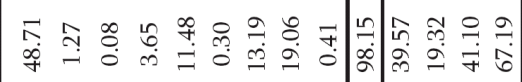

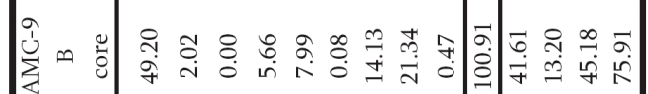

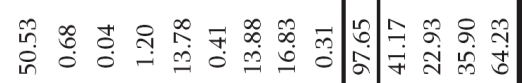

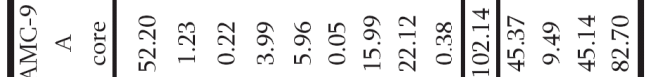




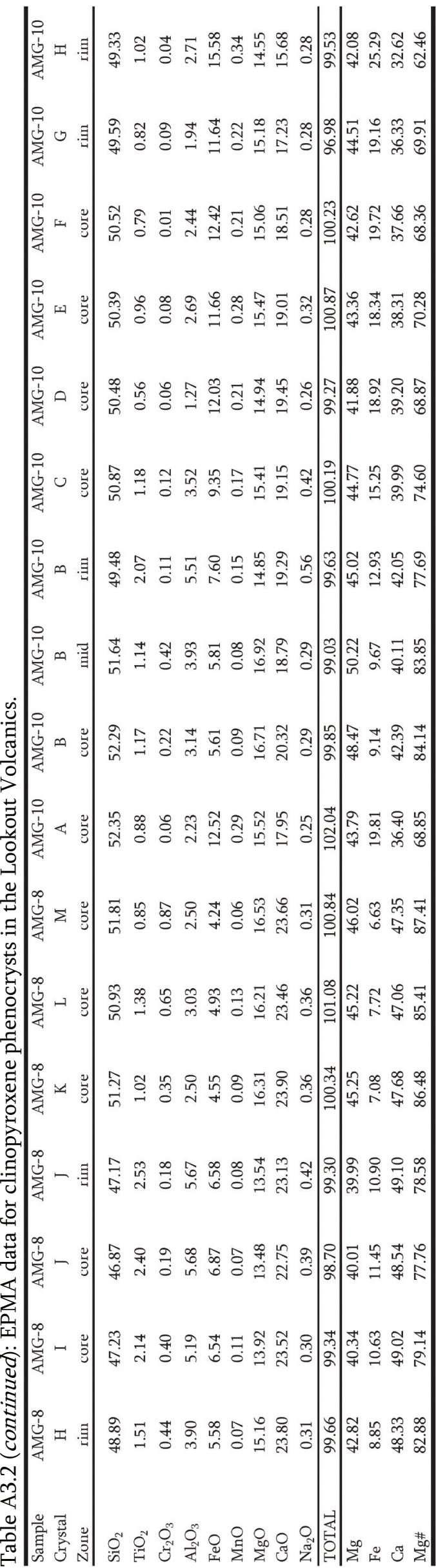

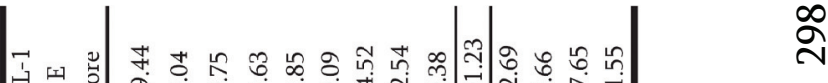

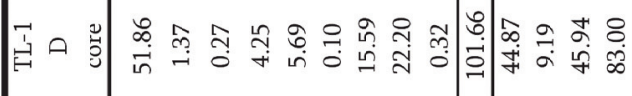

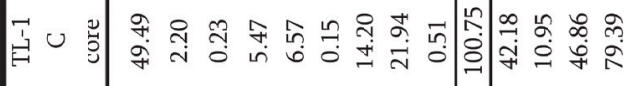

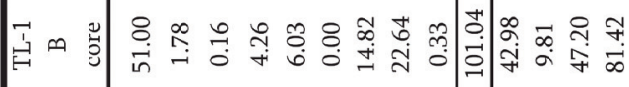

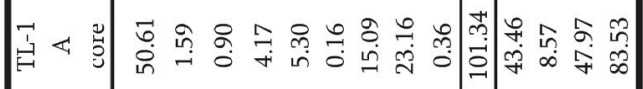

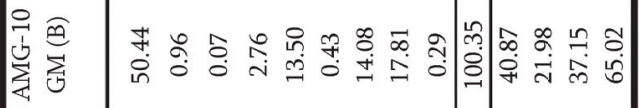

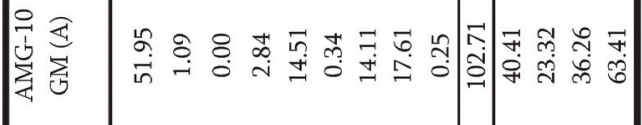

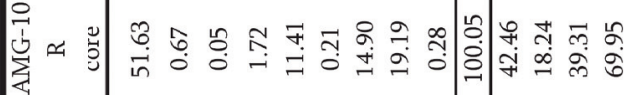

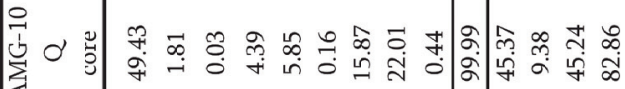

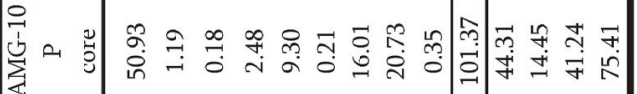

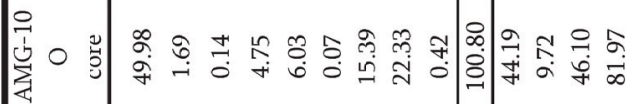

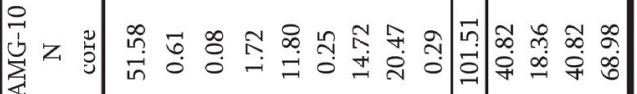

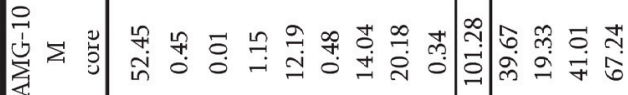

尊

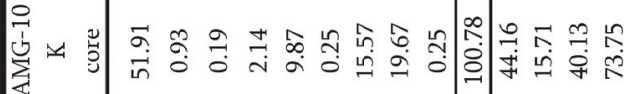

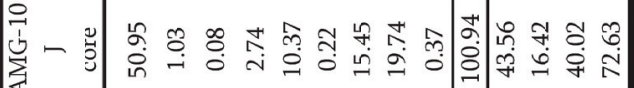

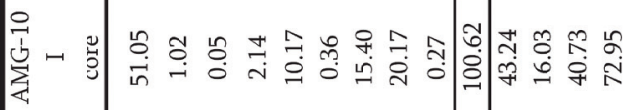

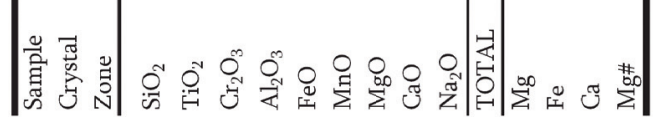




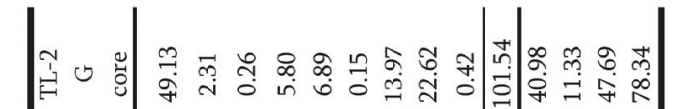

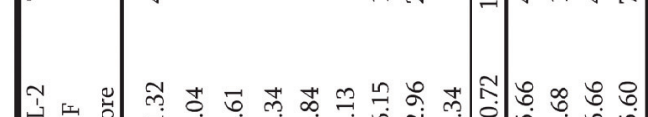

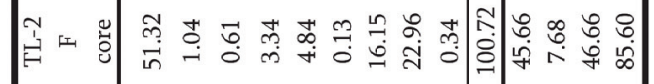
ง 베

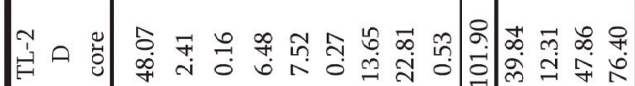

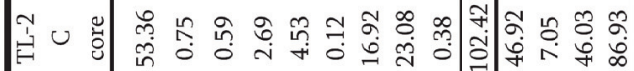

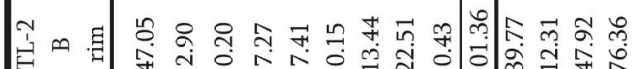

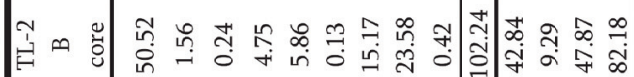

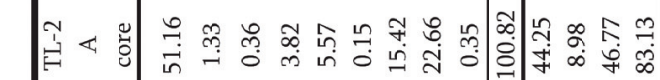

$$
\text { . }
$$$$
\text { . }
$$$$
\text { 결 }
$$

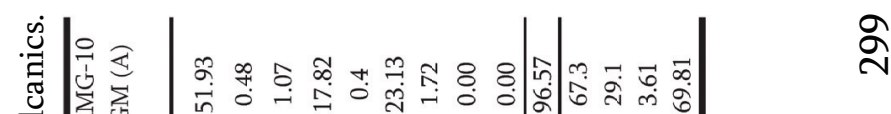

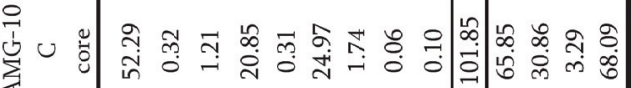

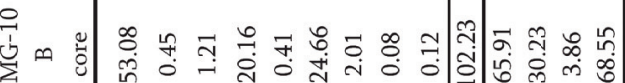

势

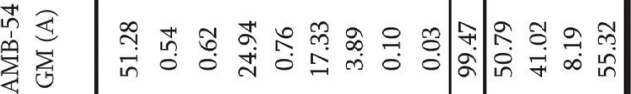

造

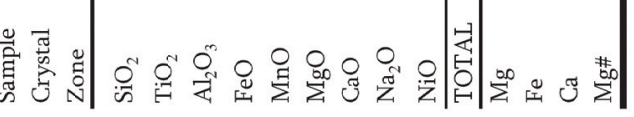

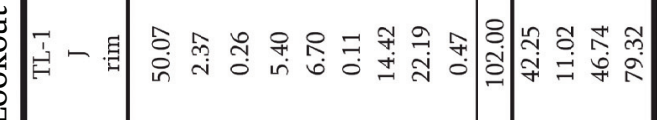

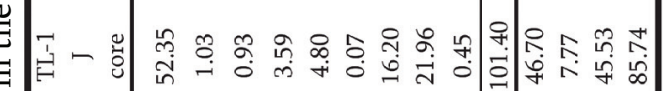

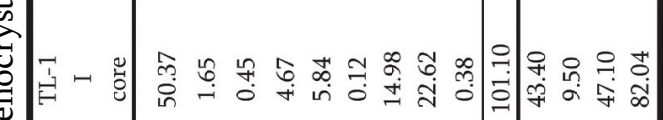

直壮

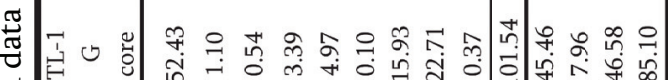

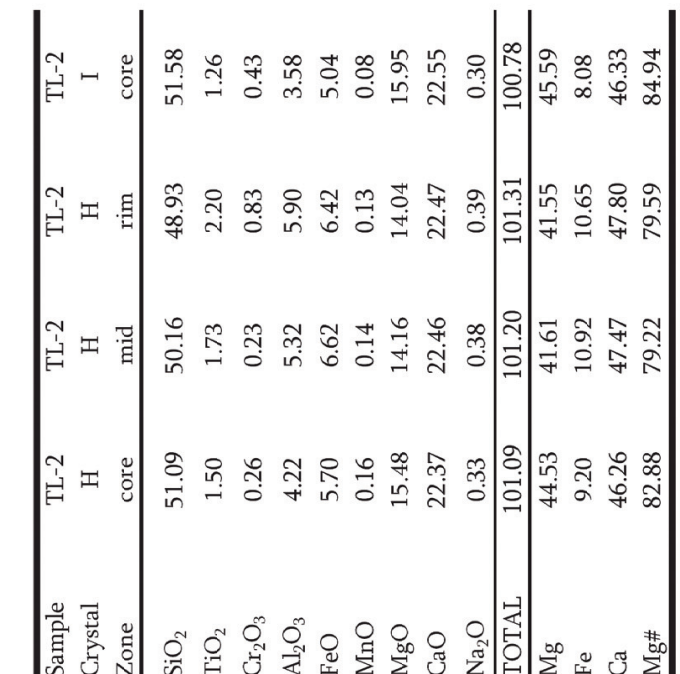

吾 


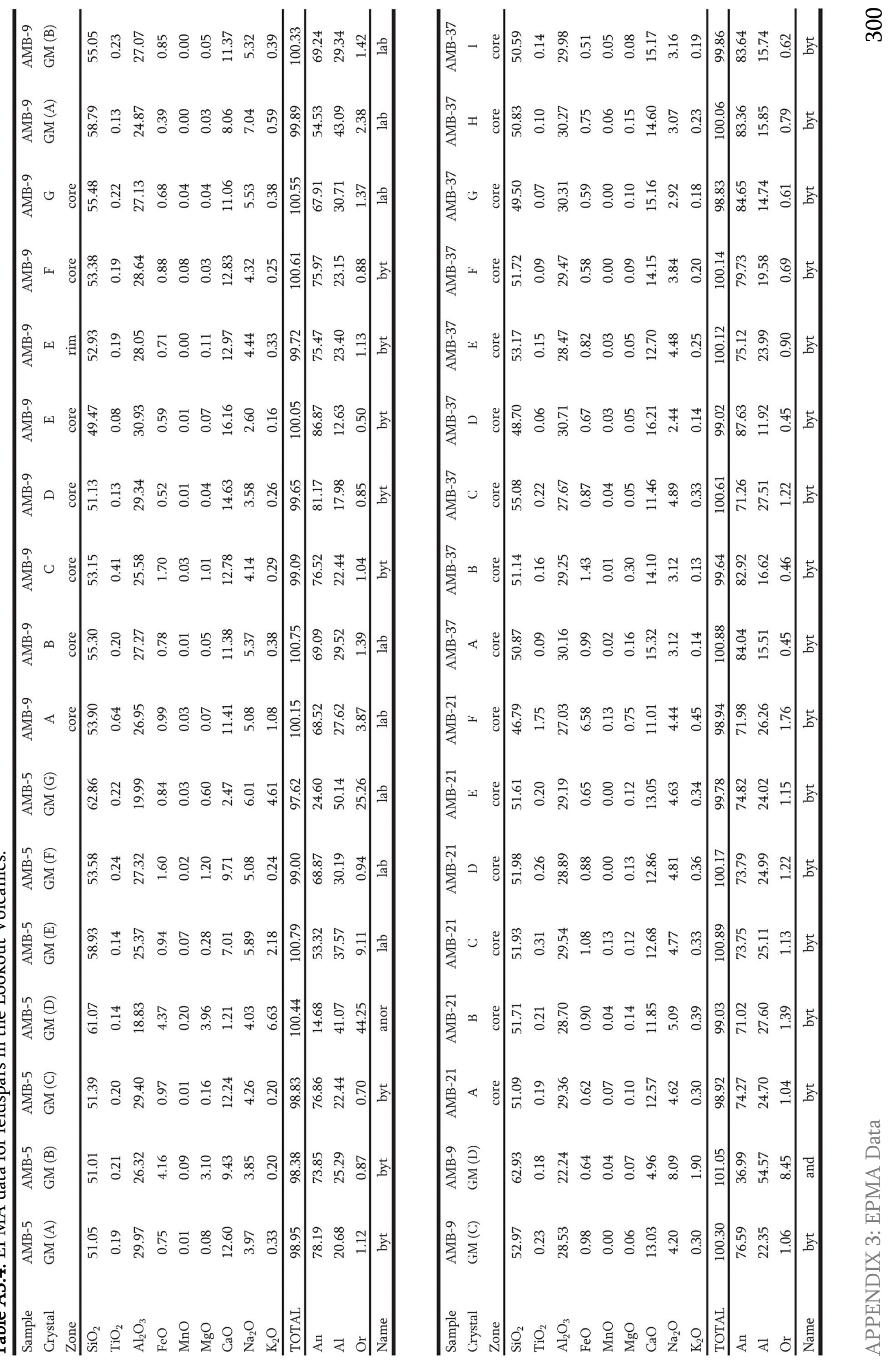




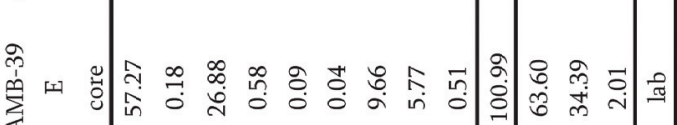

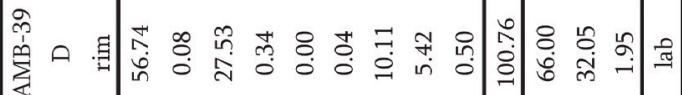
舟

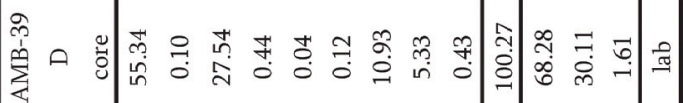
管 U 管 管

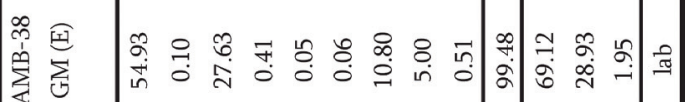

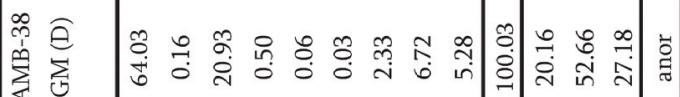

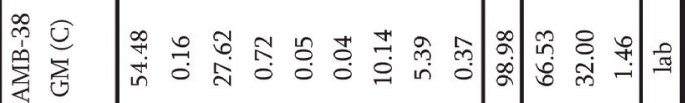

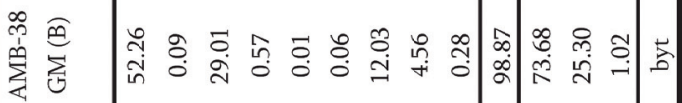

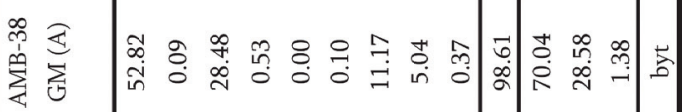

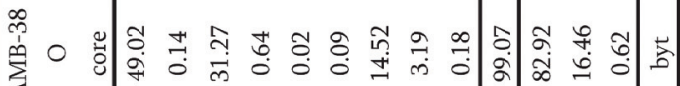
象 z

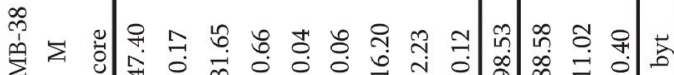

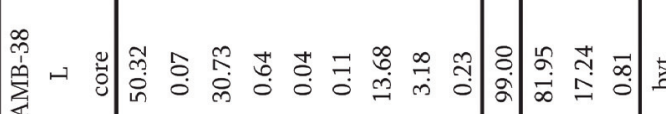

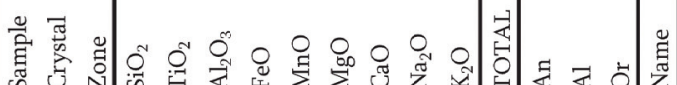




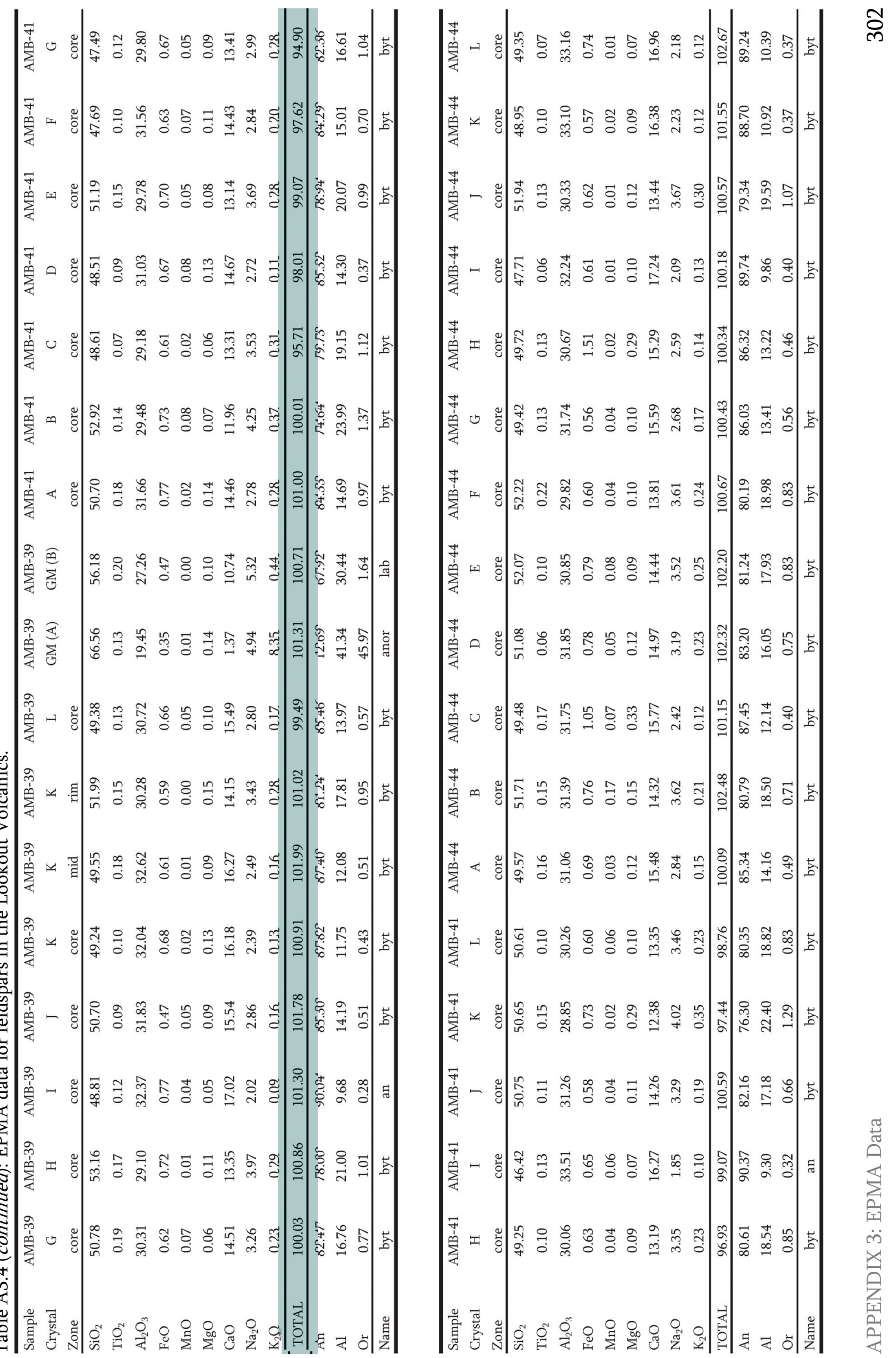




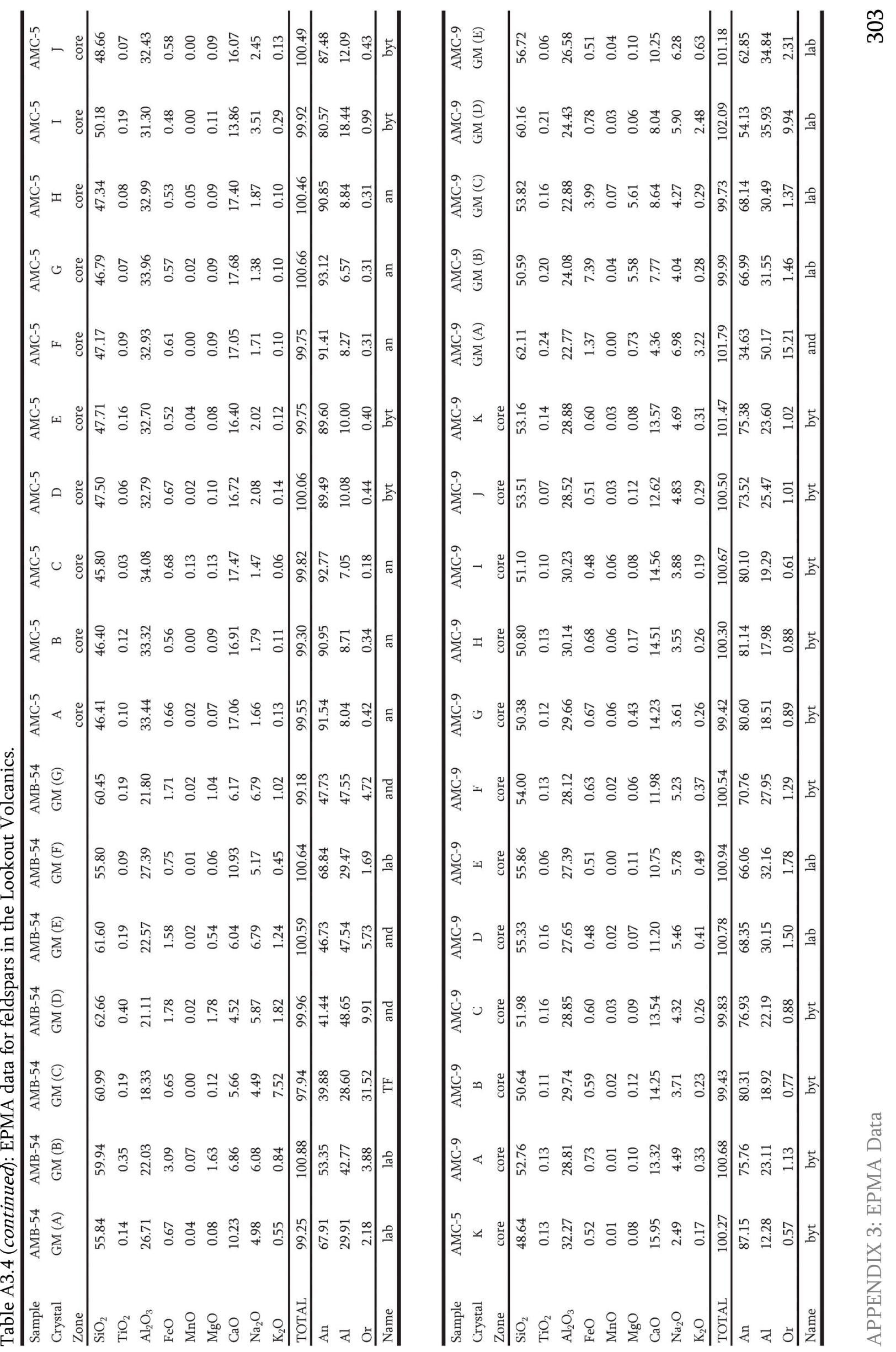




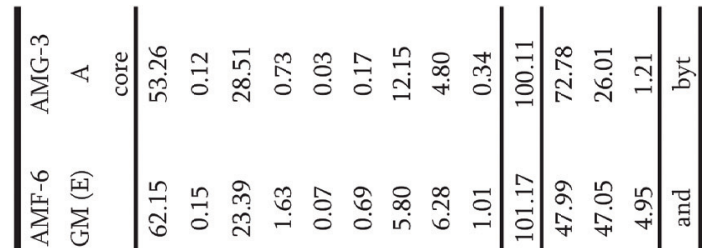

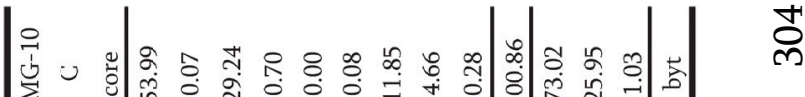

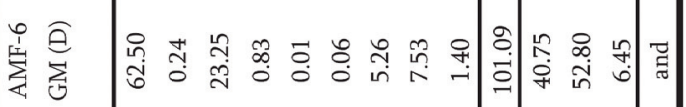

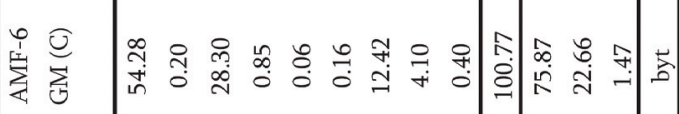

算

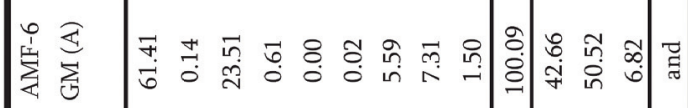

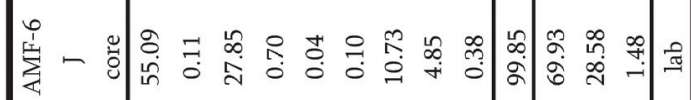

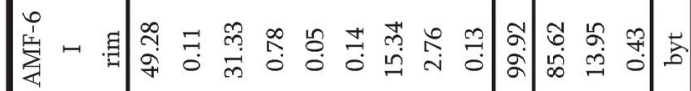

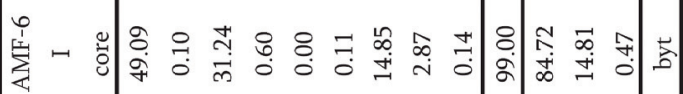

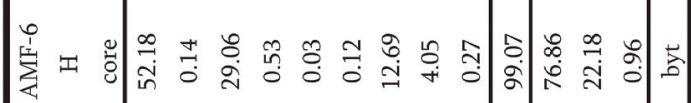

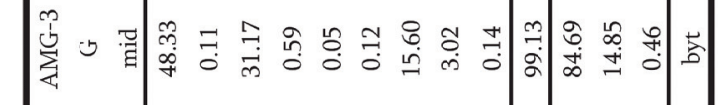

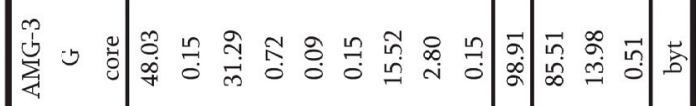

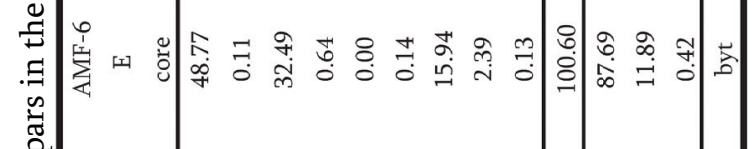

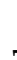

\section{列}

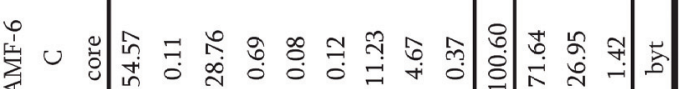

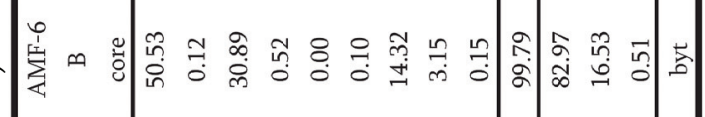

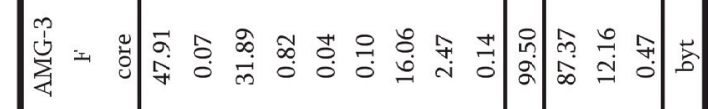

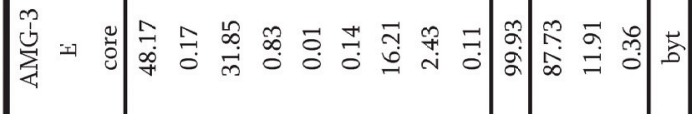

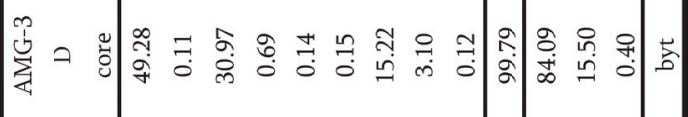

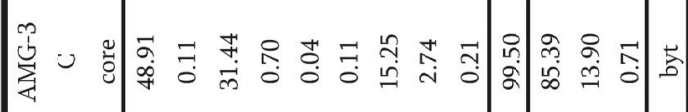

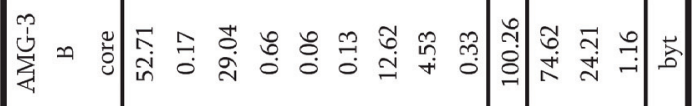

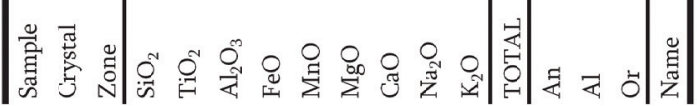




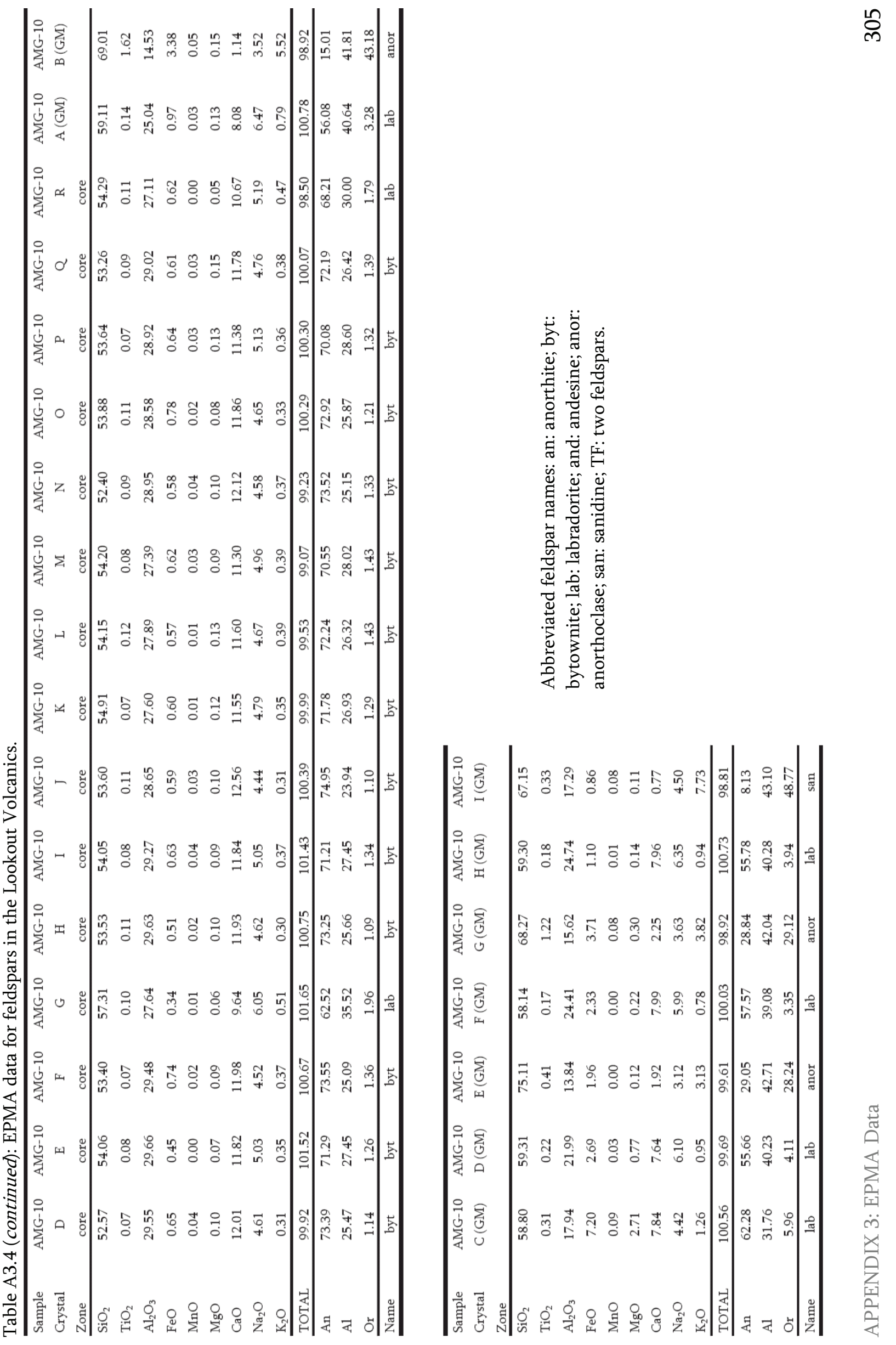




$$
\text { (1) }
$$




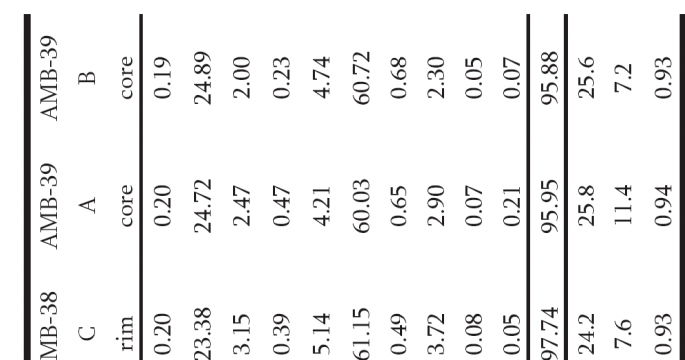

舟

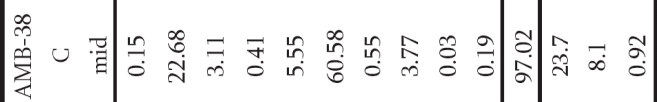

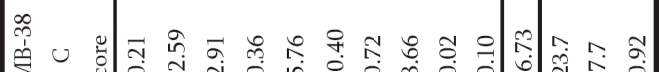

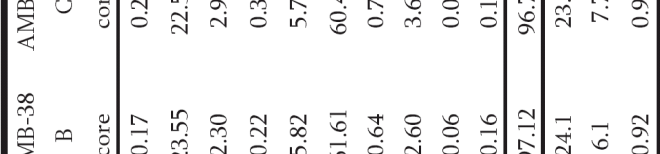

先

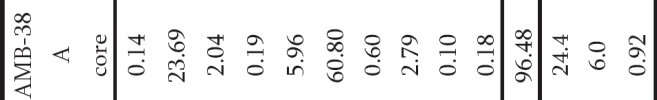

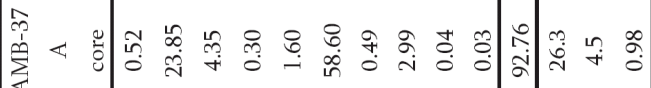

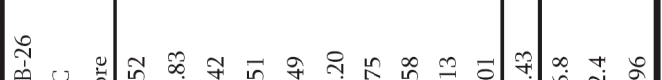

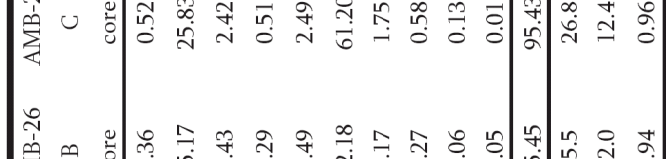

敢

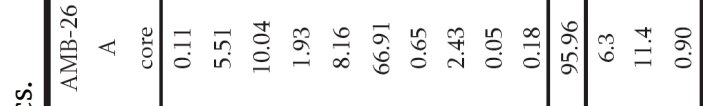

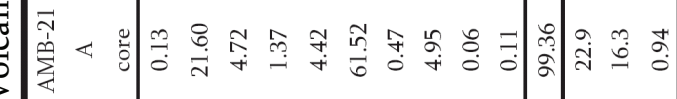

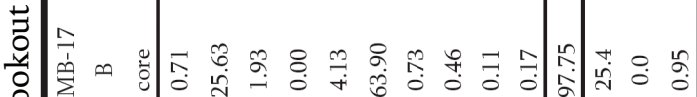

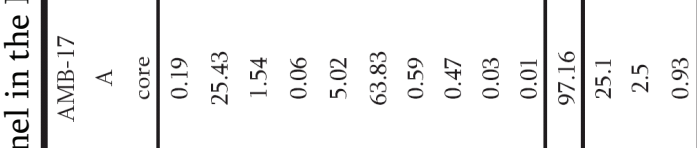

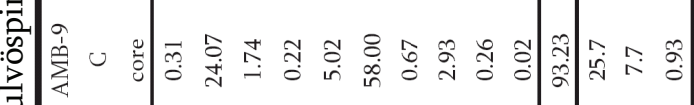

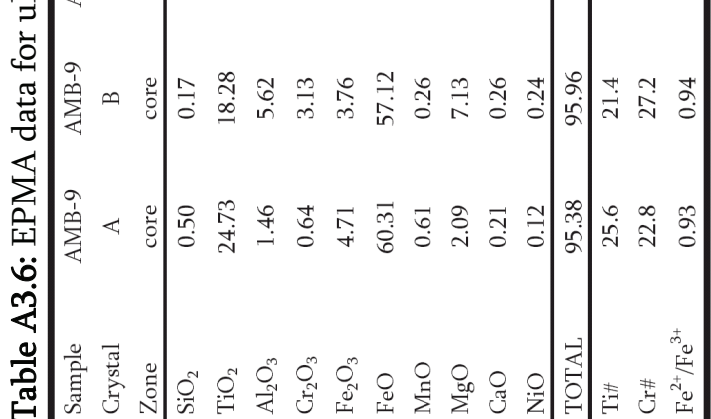

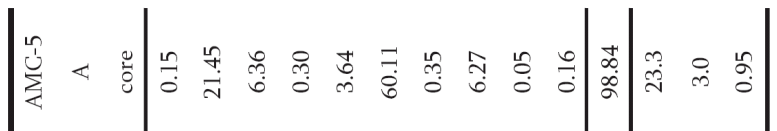

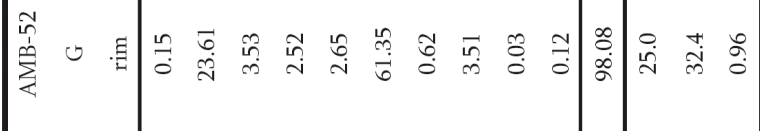

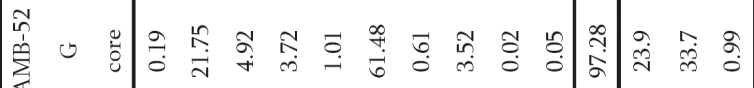

岱

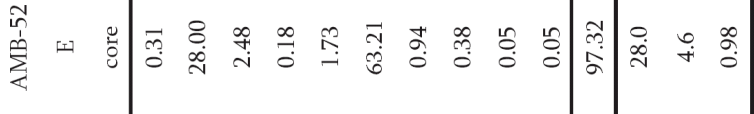

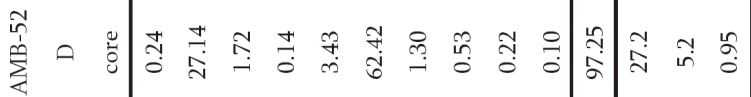

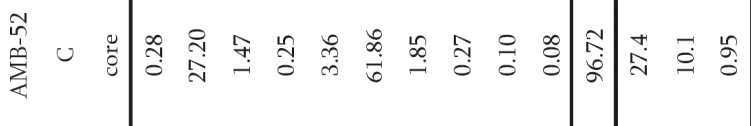

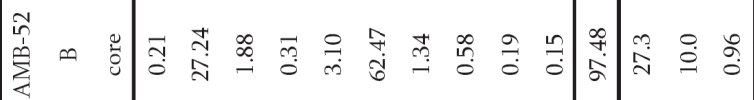

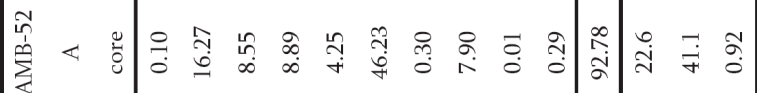

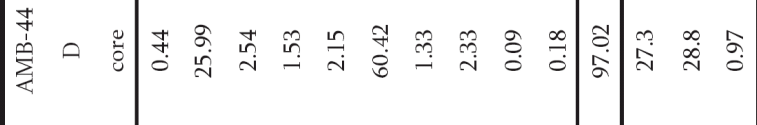

贲 $U$ 苦

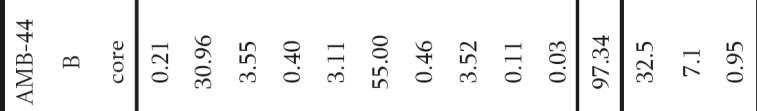

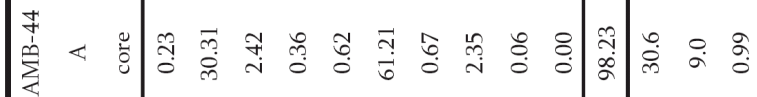

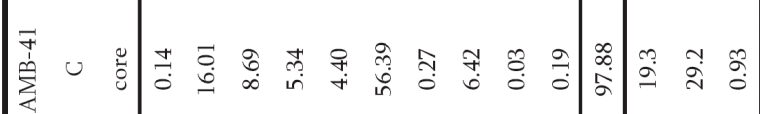

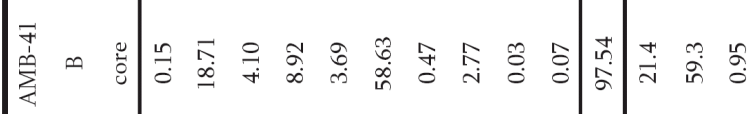

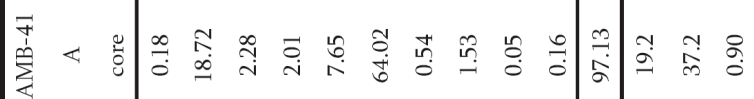

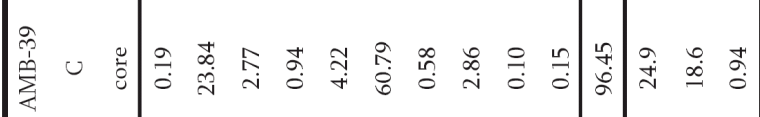

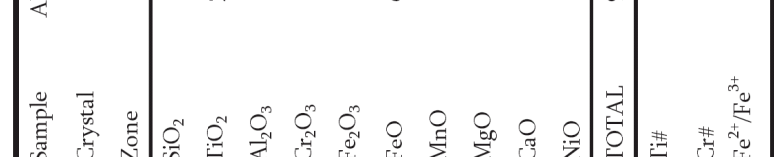

恶 


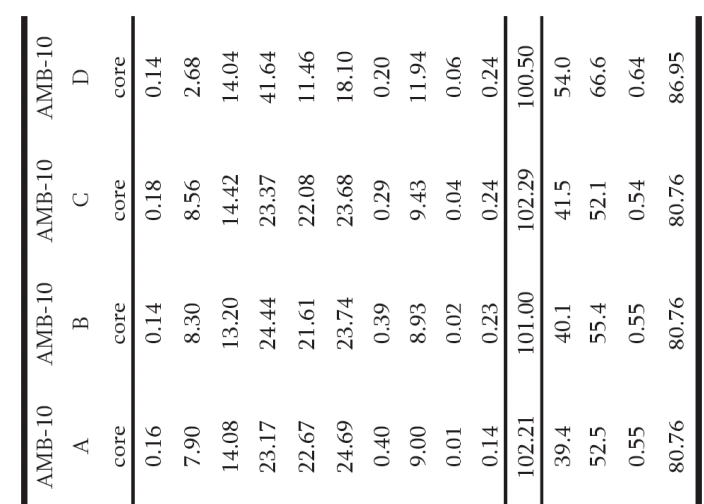

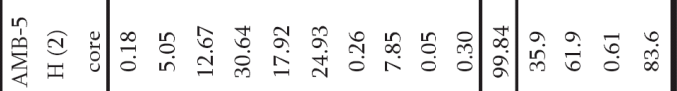

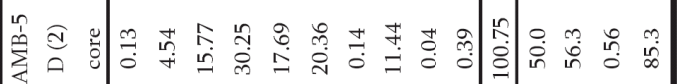

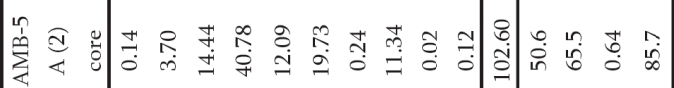

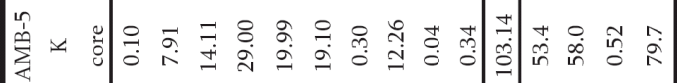

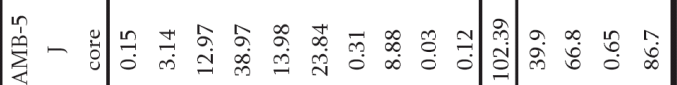
每

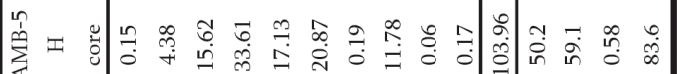
.

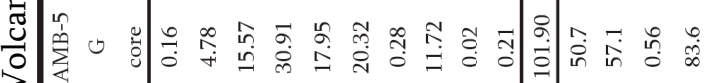

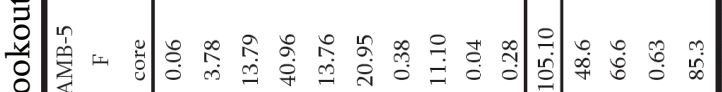
تี⿻ 我 की 린

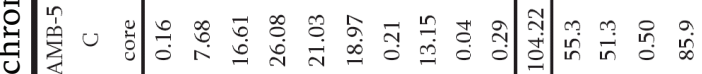
ชั้

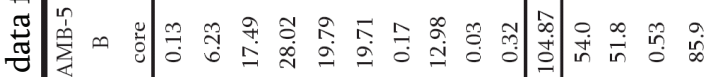

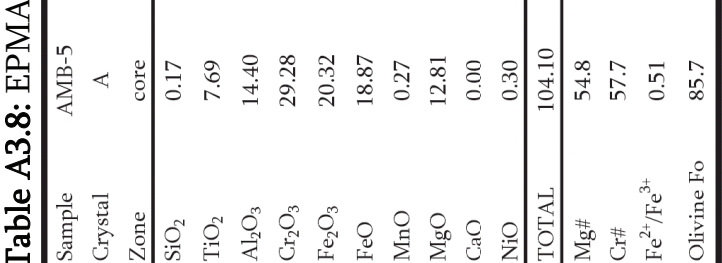

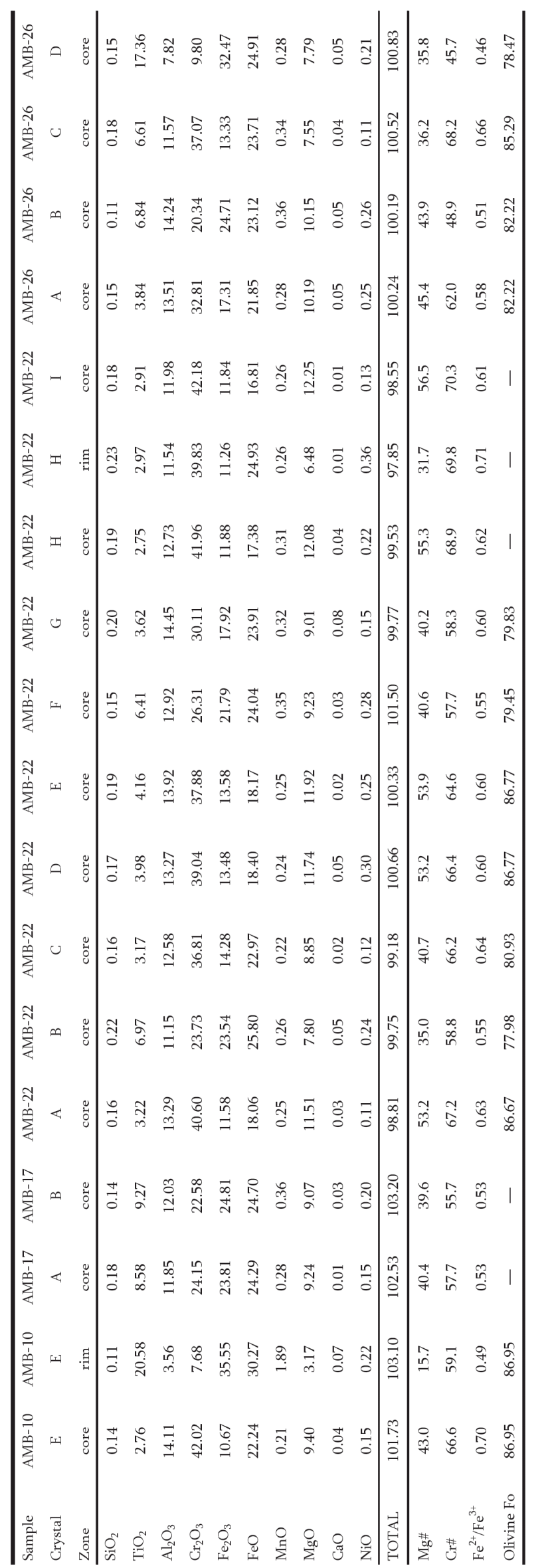

焉 


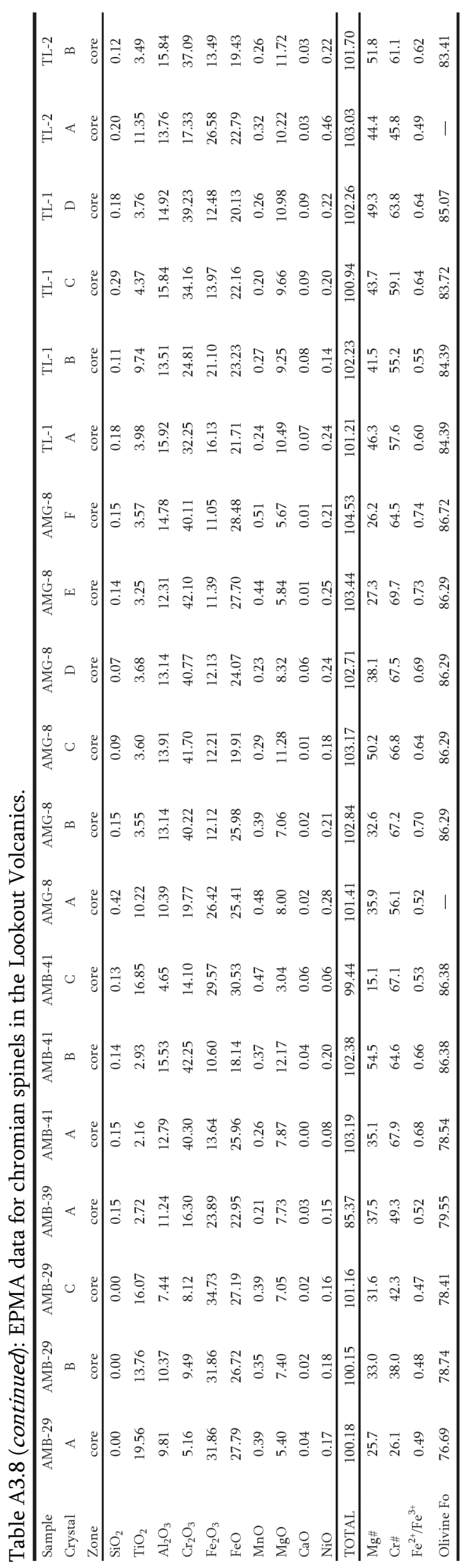




\section{APPENDIX 4: COMPARATIVE OLIVINE DATA}

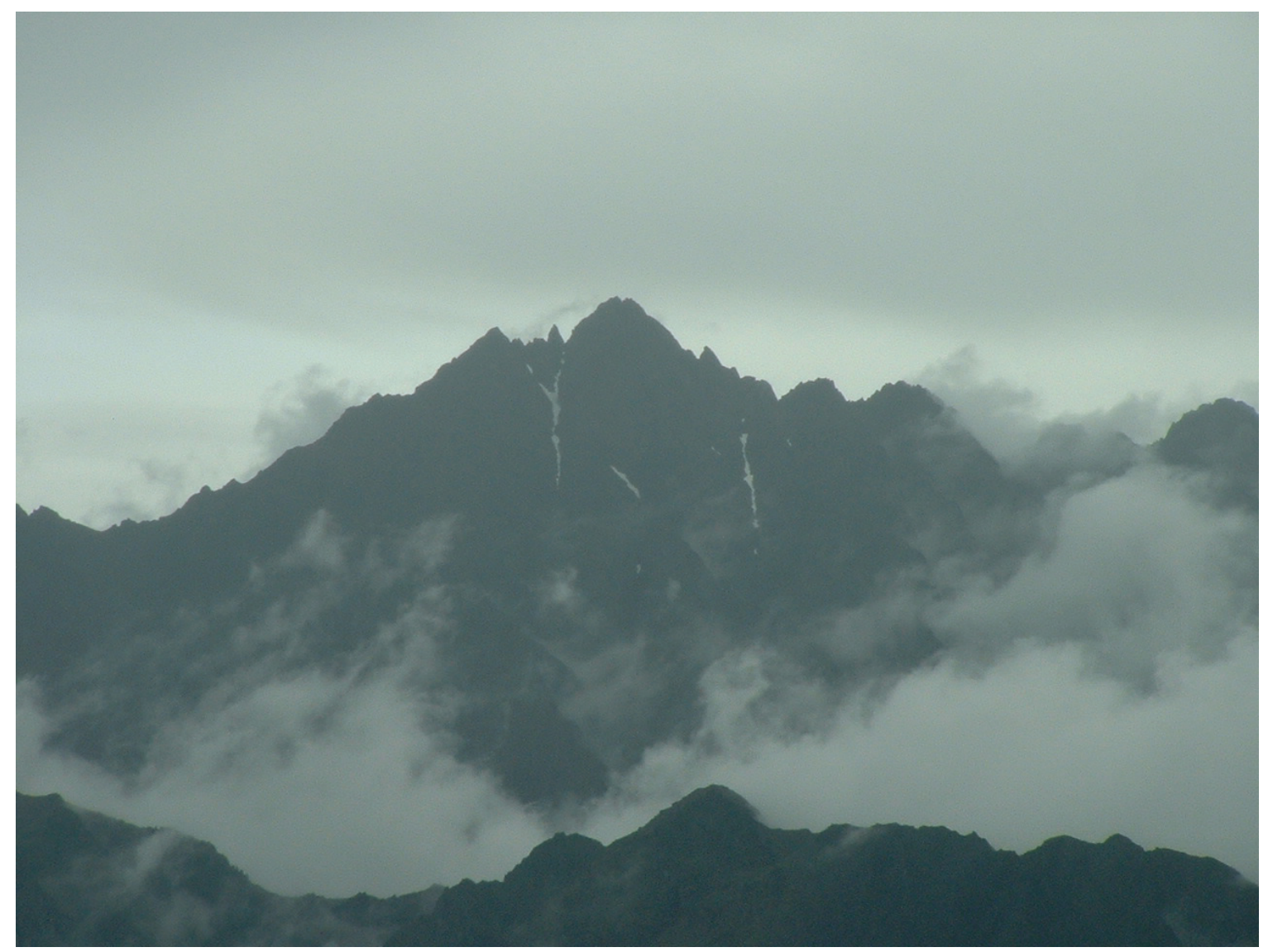

Plate 11: The hazardous ridgeline of Mitre Peak $(2621 \mathrm{~m})$ stands tall above the clouds in the heart of the Inland Kaikoura Range.

Table A4.1: EPMA data for basaltic samples from Yemen (6 samples; 592 analyses)

Table A4.2: EPMA data for basaltic samples from Hawaii (3 samples; 76 analyses)

Table A4.3: EPMA data for the Waimarino basalt (41 analyses) 
1

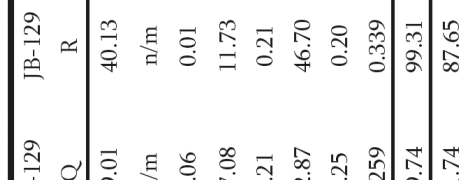

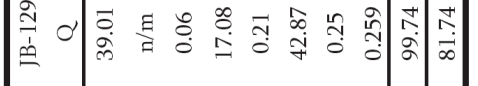

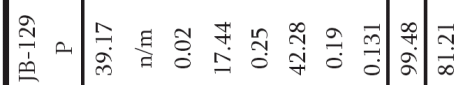

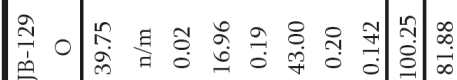

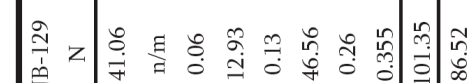

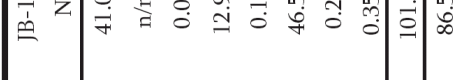

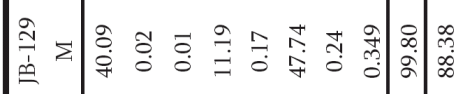
热

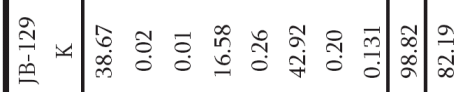

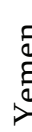

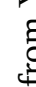$$
\text { हี }
$$

ปิ

$$
\text { (3) }
$$

\section{家}

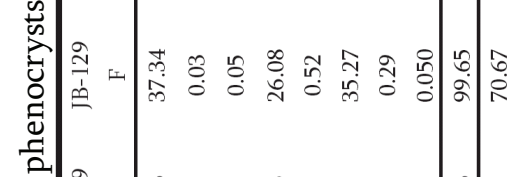

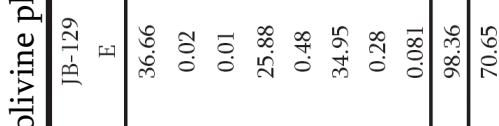

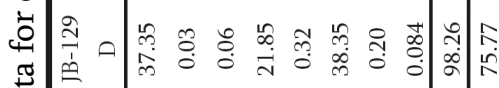

䒕

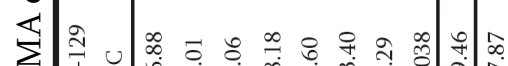

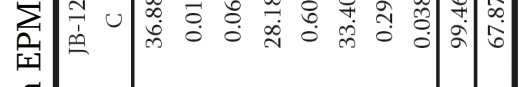

. .

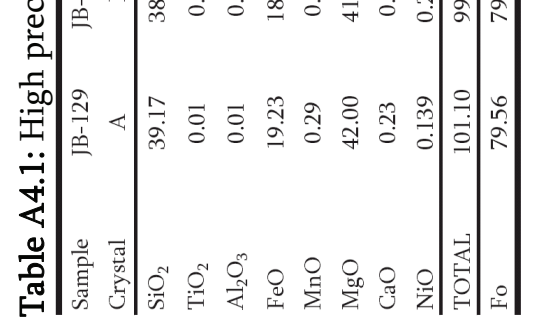

Iิ

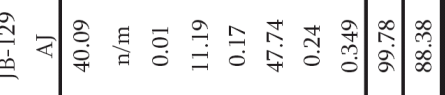
唁

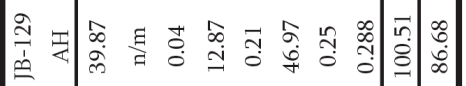

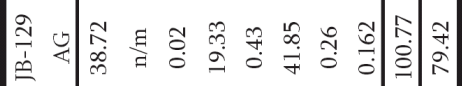

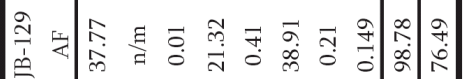
空

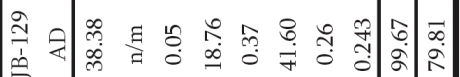
商 귀ำ

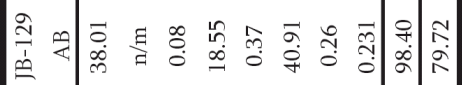

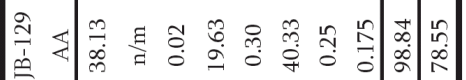

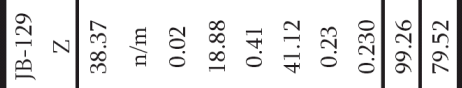

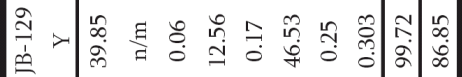

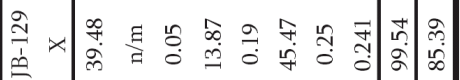

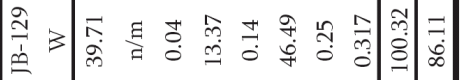

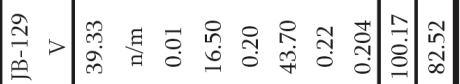
光

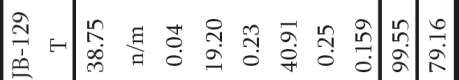

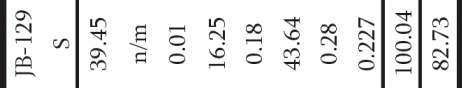

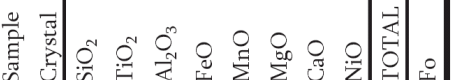

ㄷ. 可

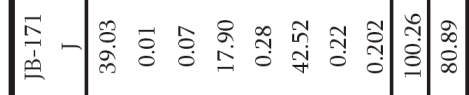
)

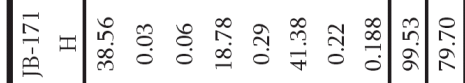
霄

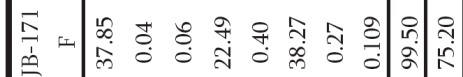

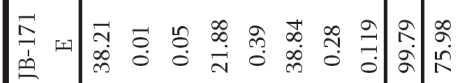

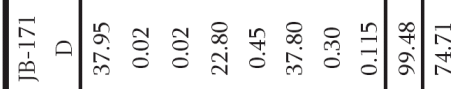
可 U

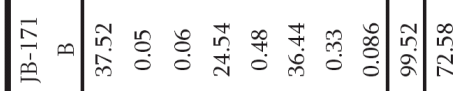

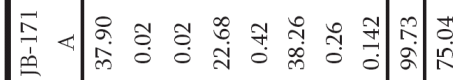

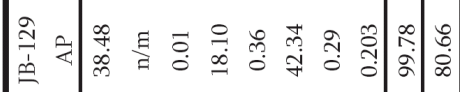
商 毛藏青

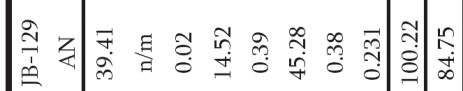
证

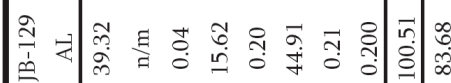
商

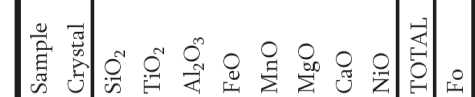




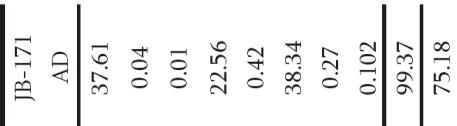

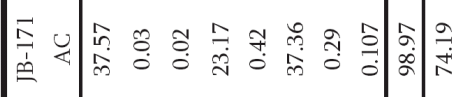

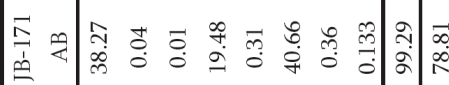

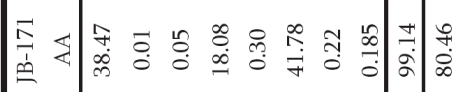

式 N N

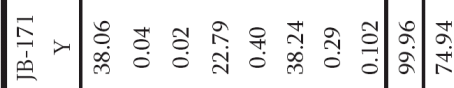

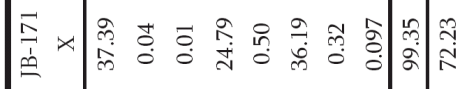

छี้

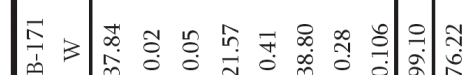

实

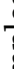

.

ปี

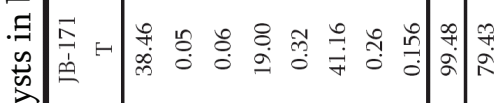

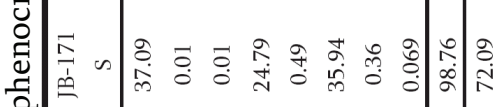

.

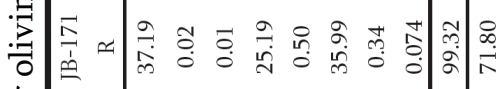

ธै

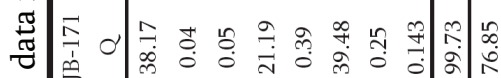

$\sum_{\infty}$

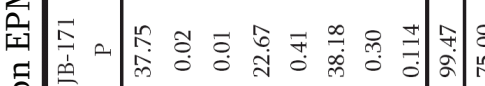

ป

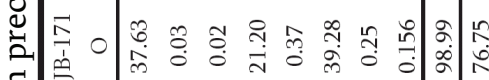

点

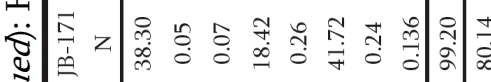

:

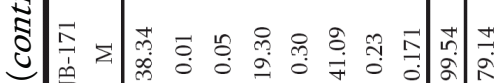

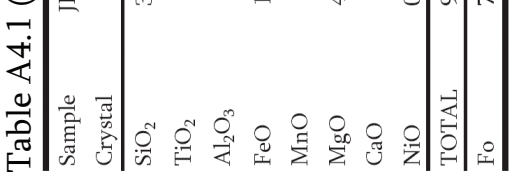

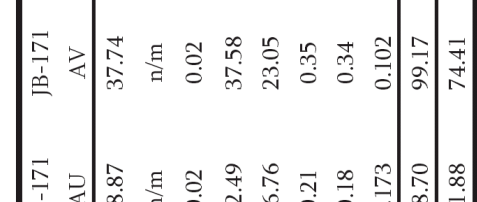

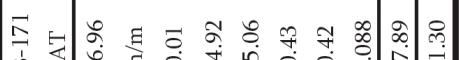

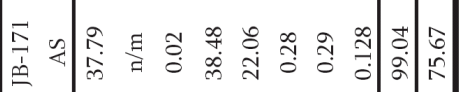

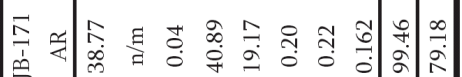

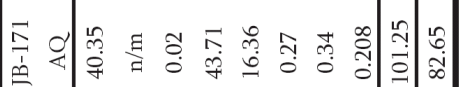

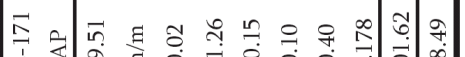

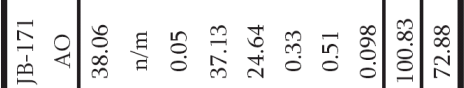

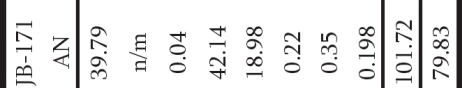

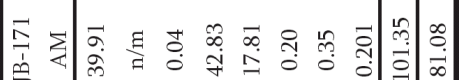

들

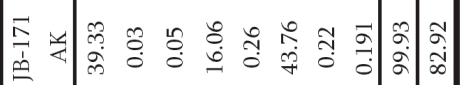

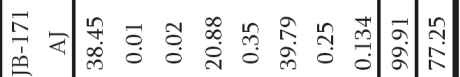

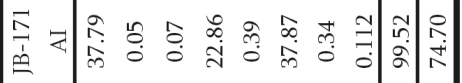

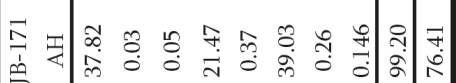

동

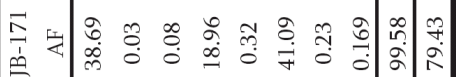

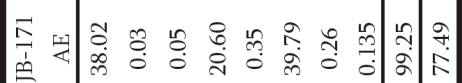

至

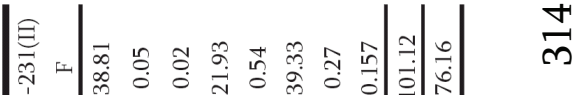

承

羞

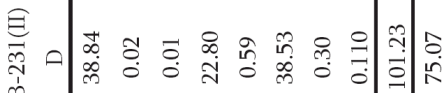

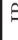

釷

武

$\cong$

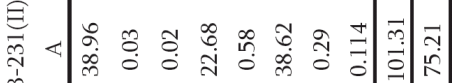

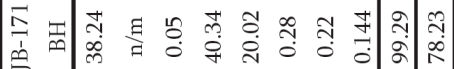

产

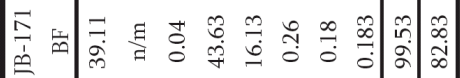

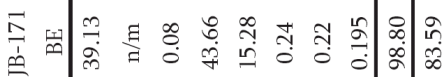

产

茼

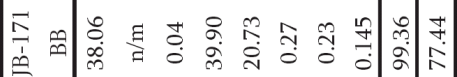

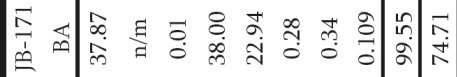

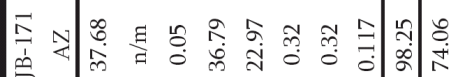

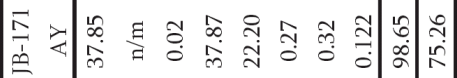

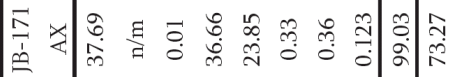

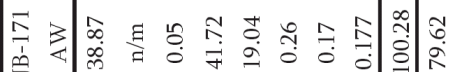

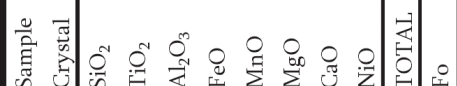

 


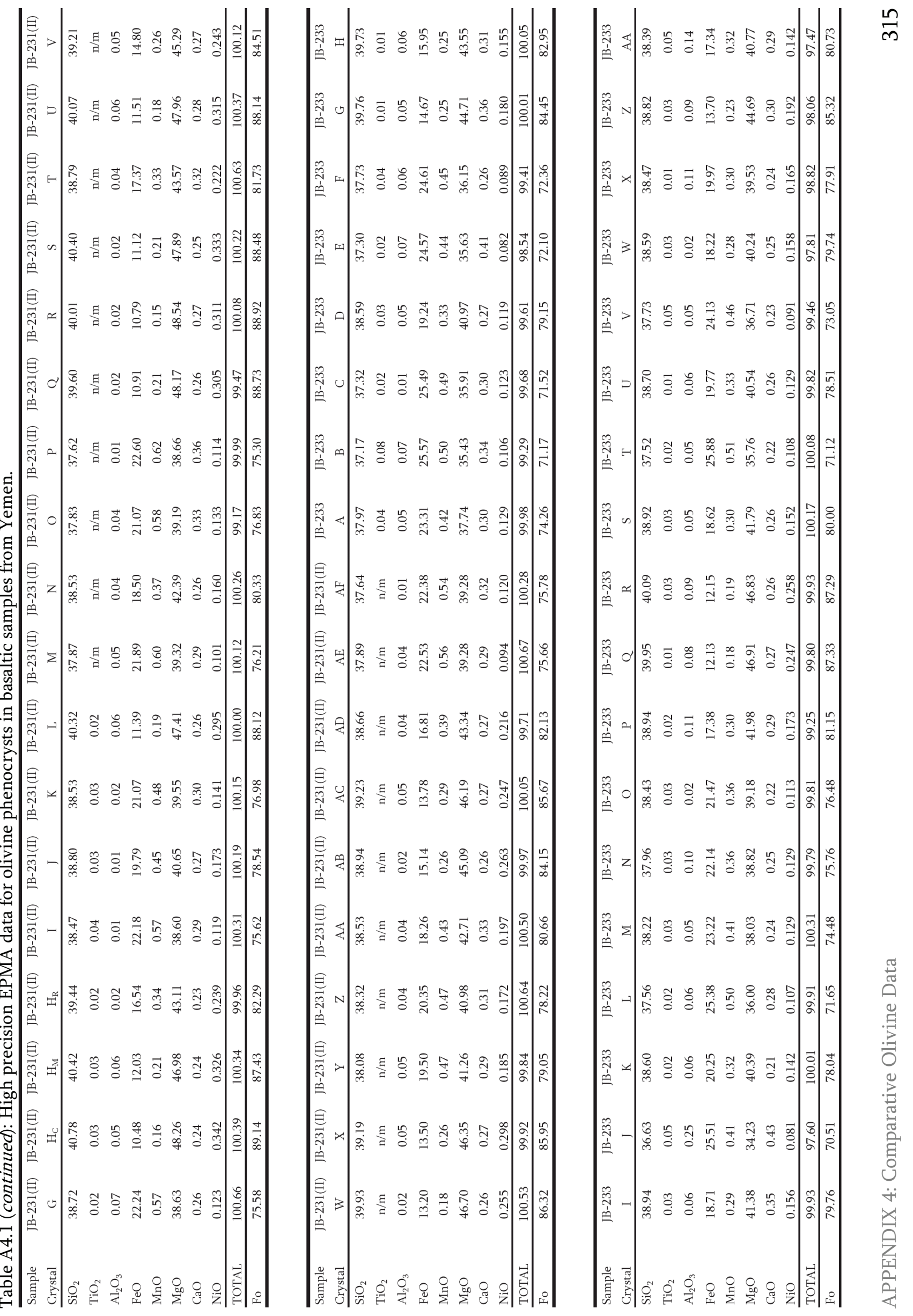




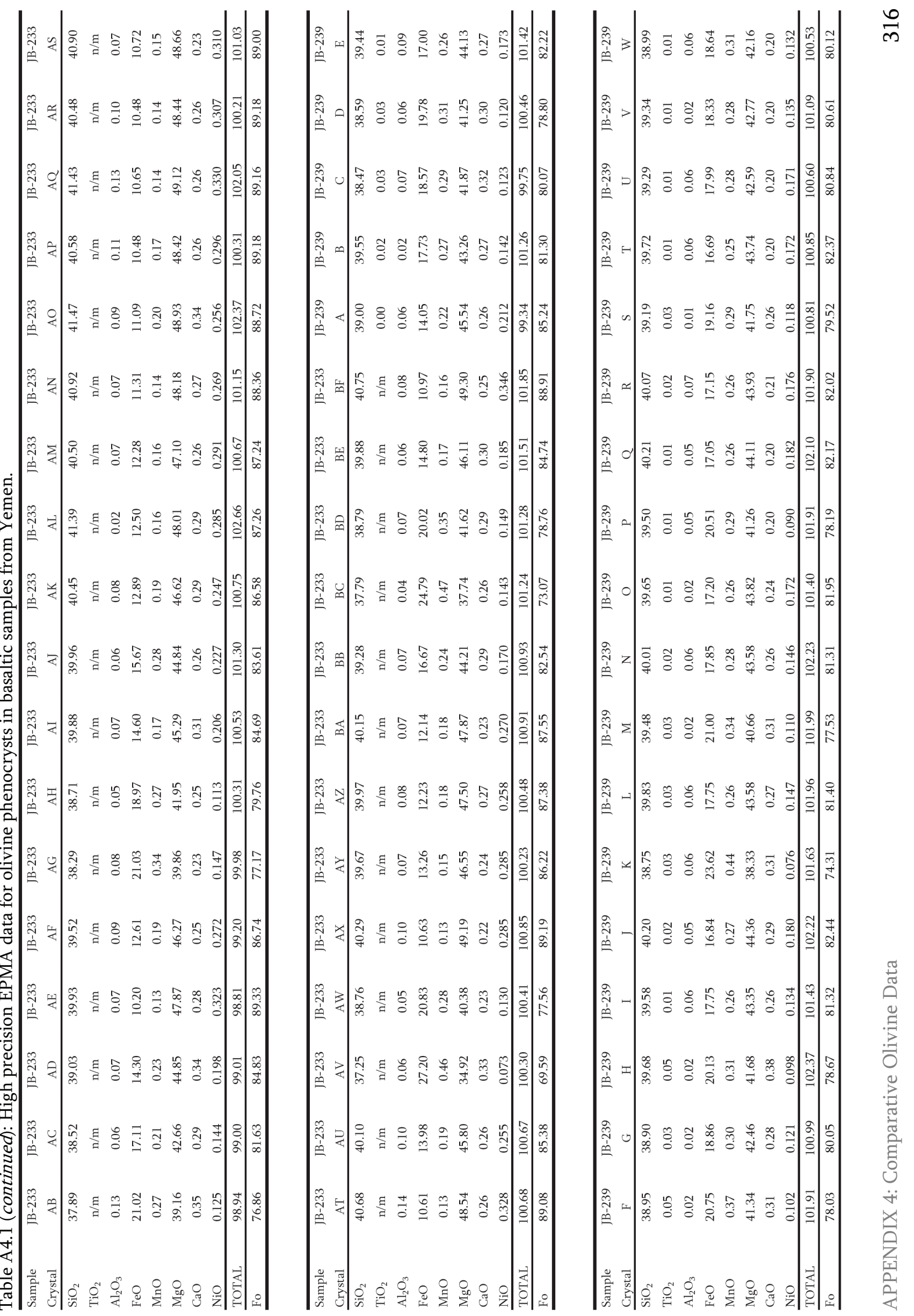




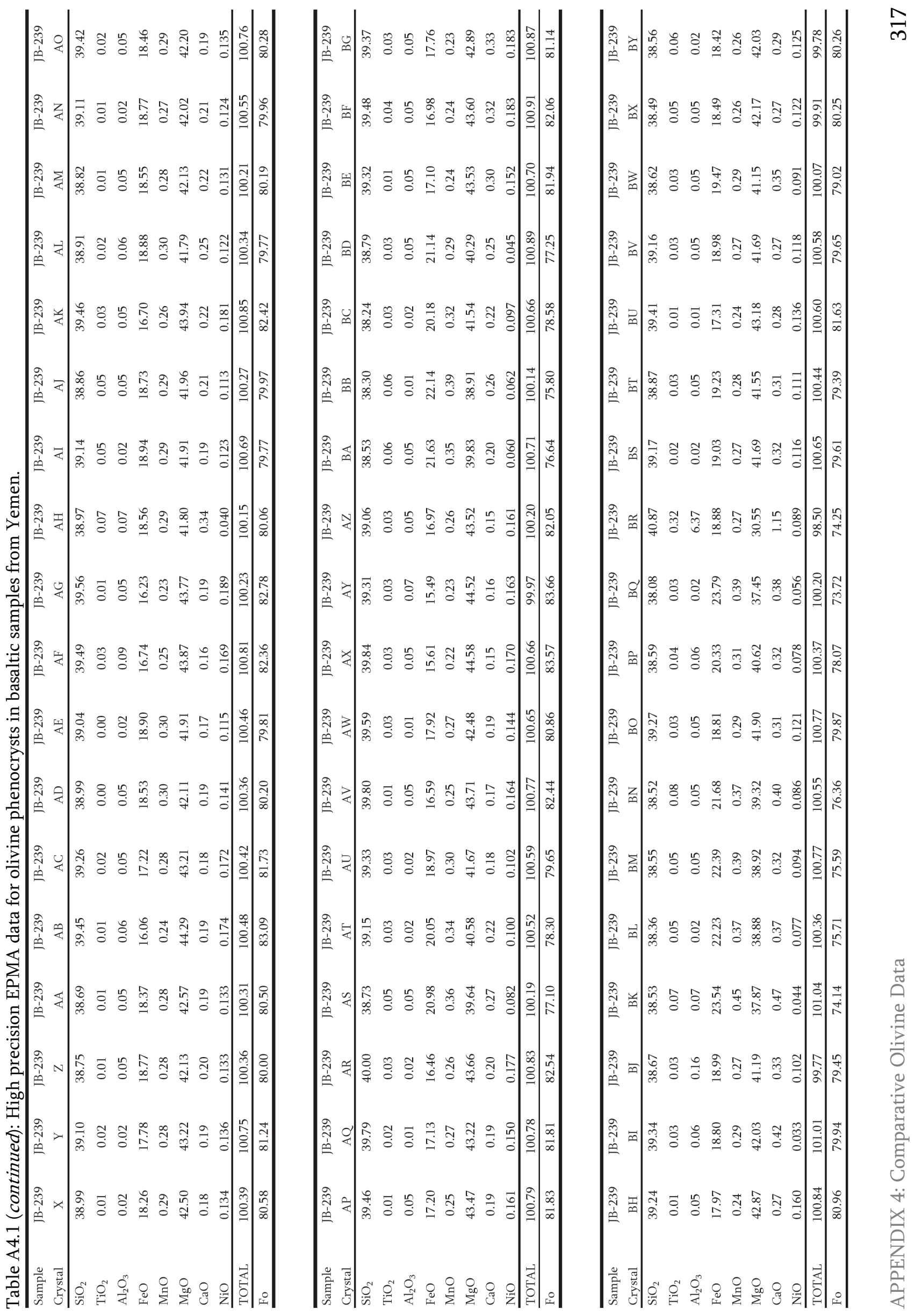




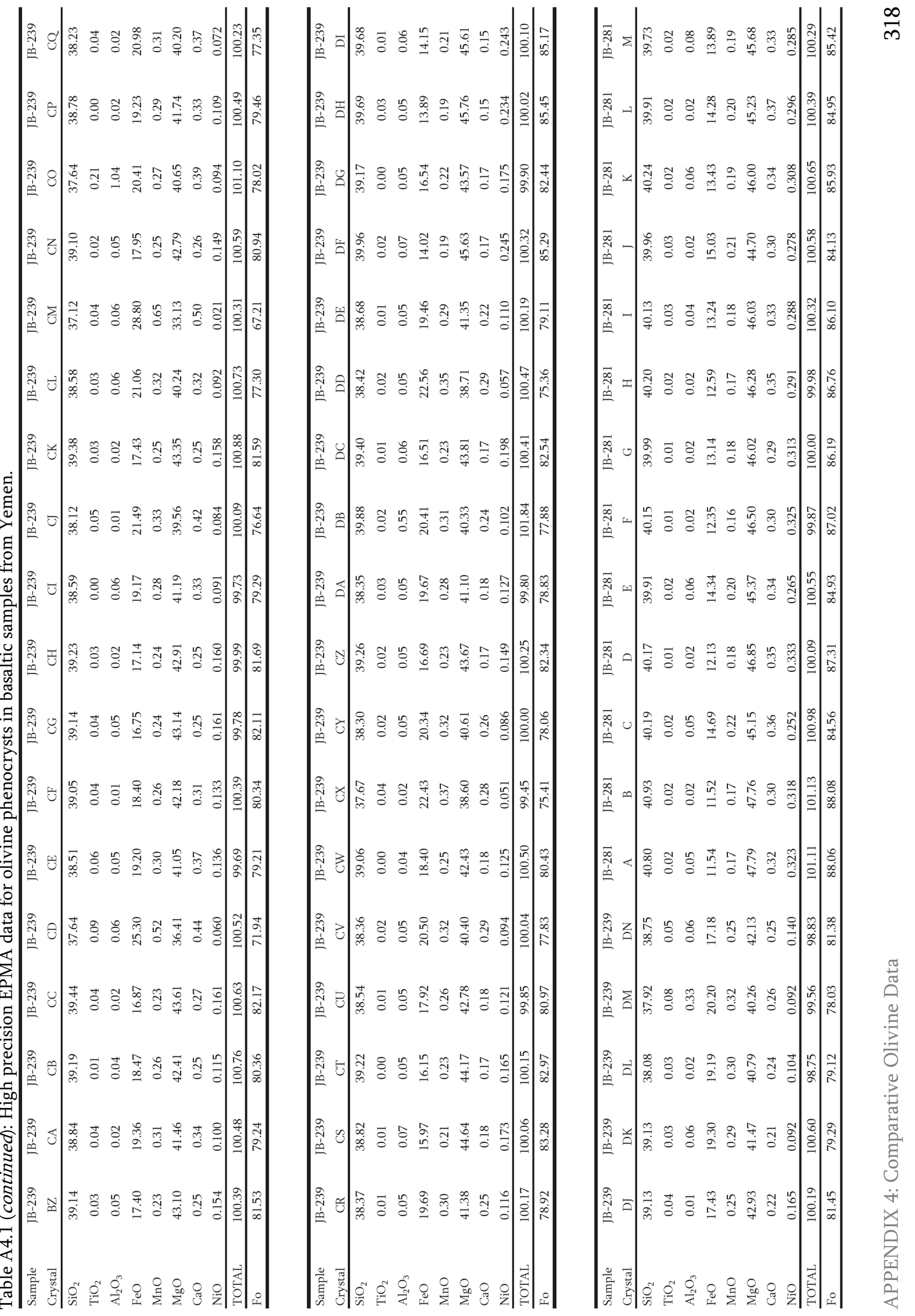




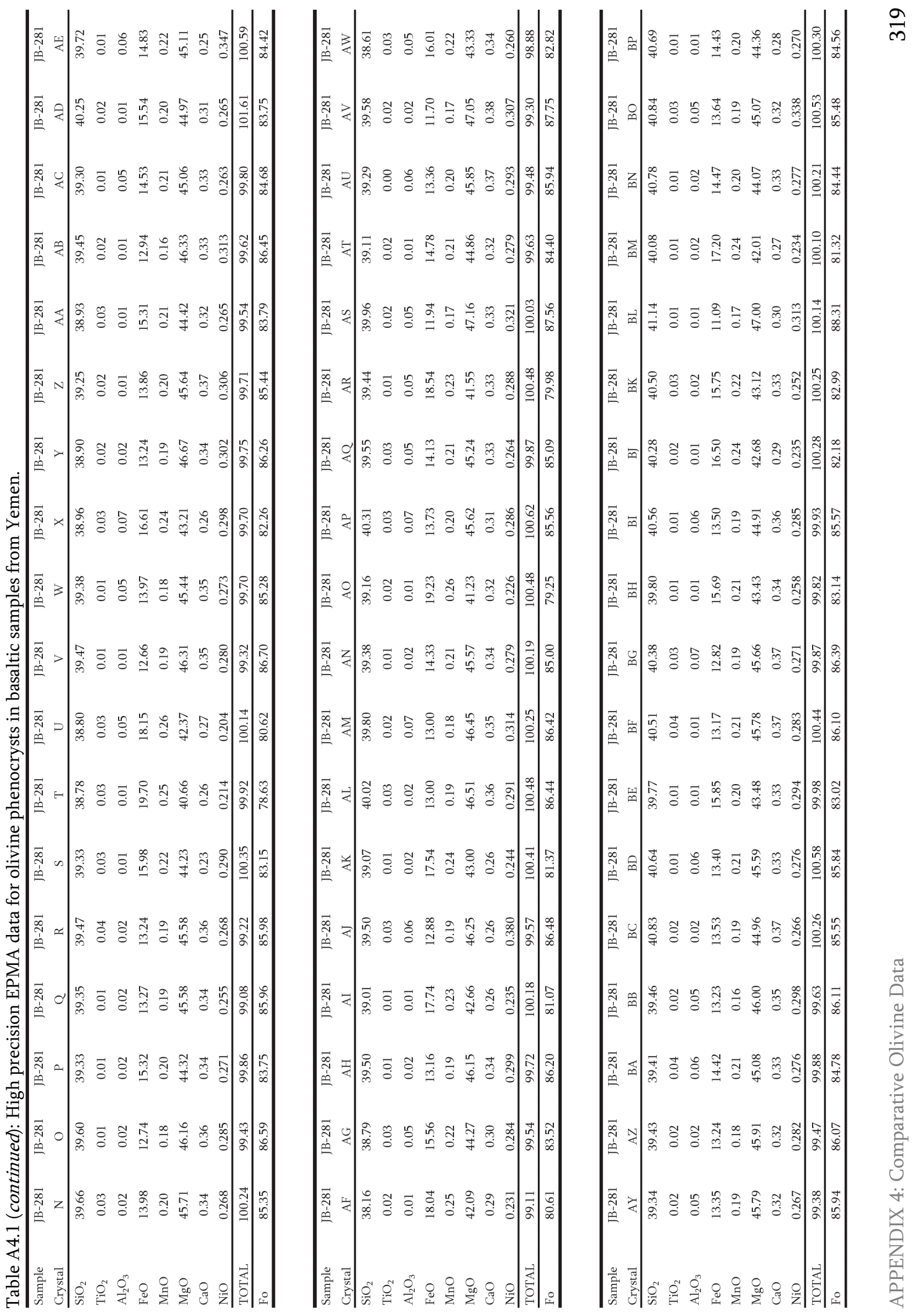




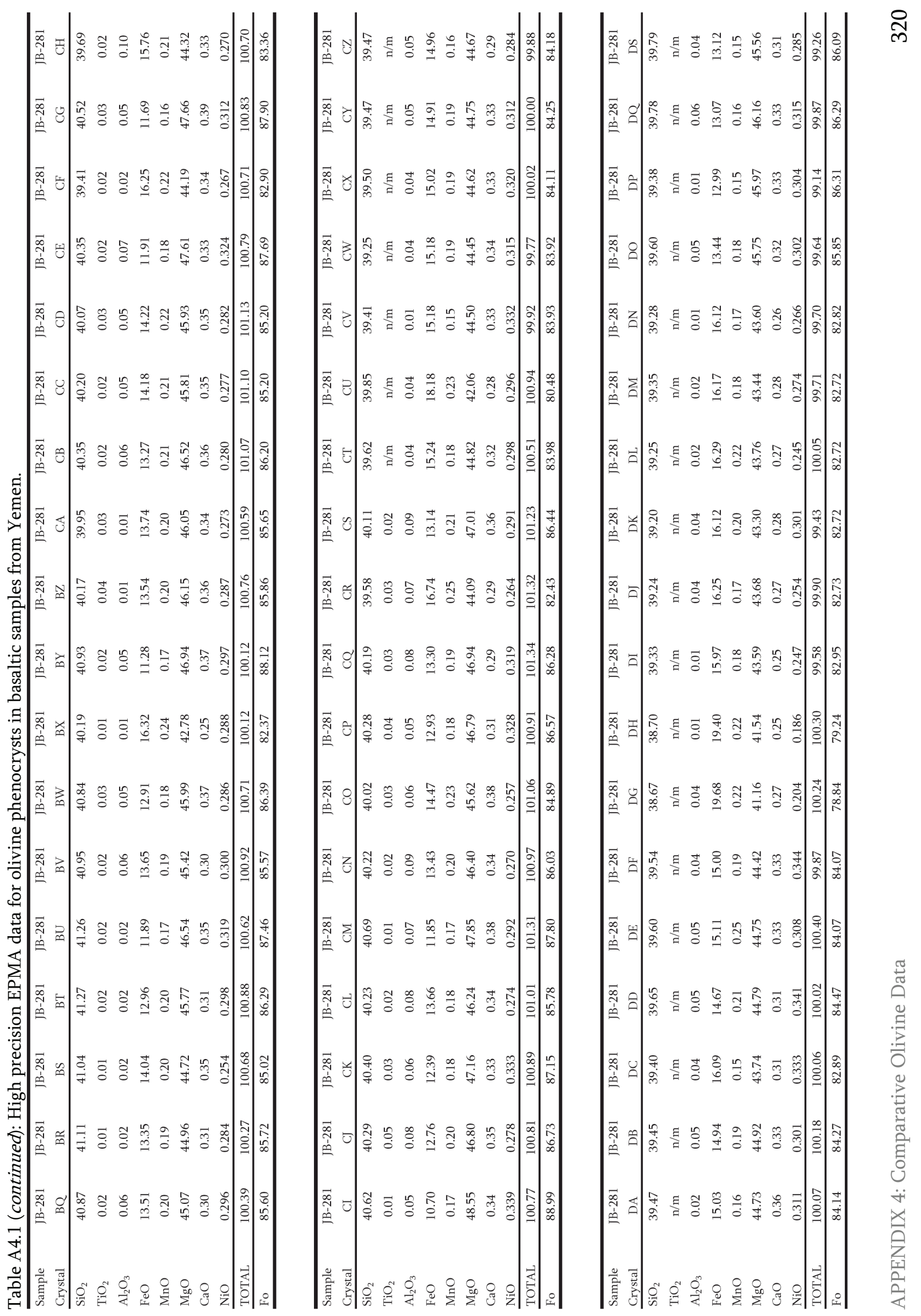




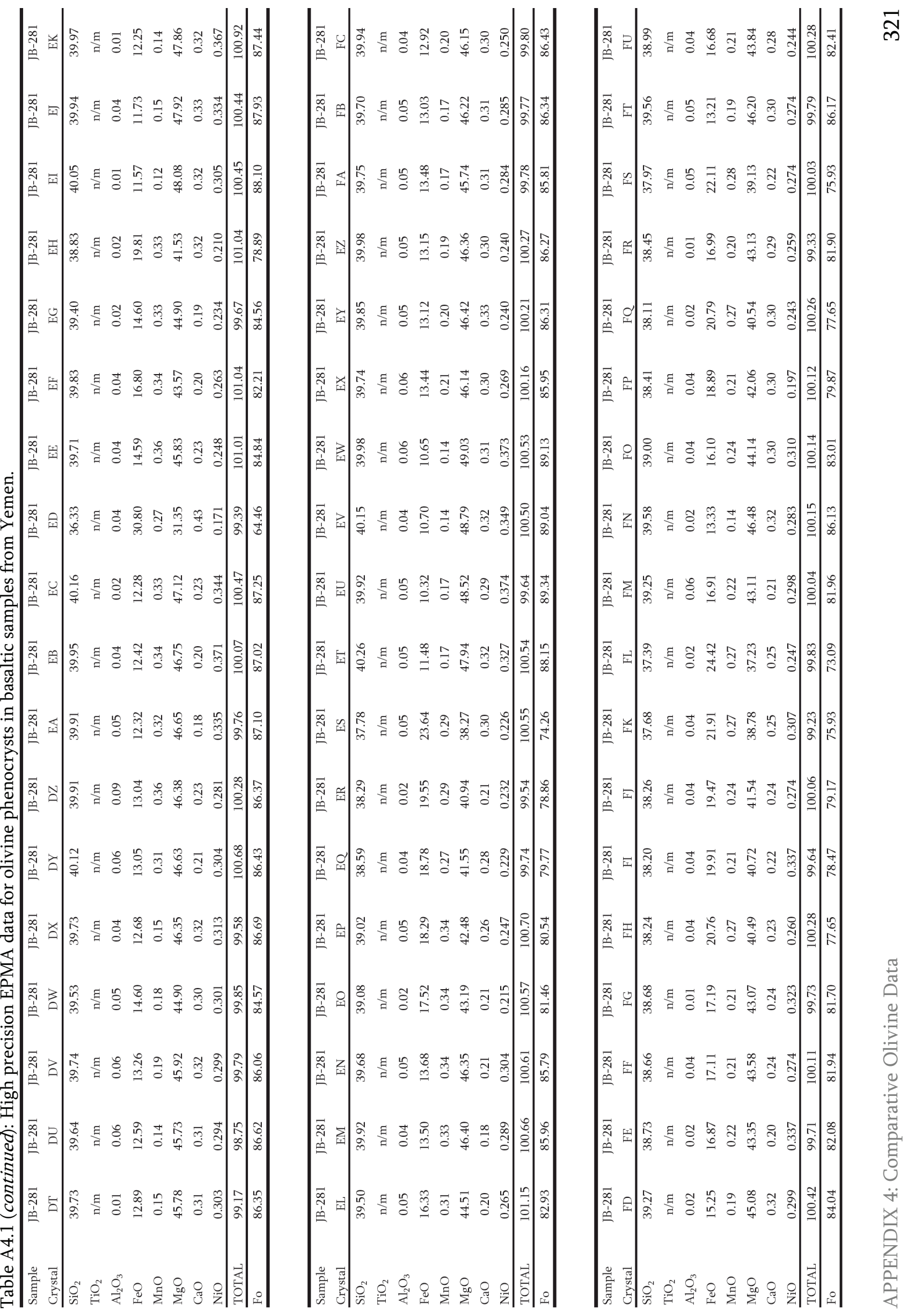




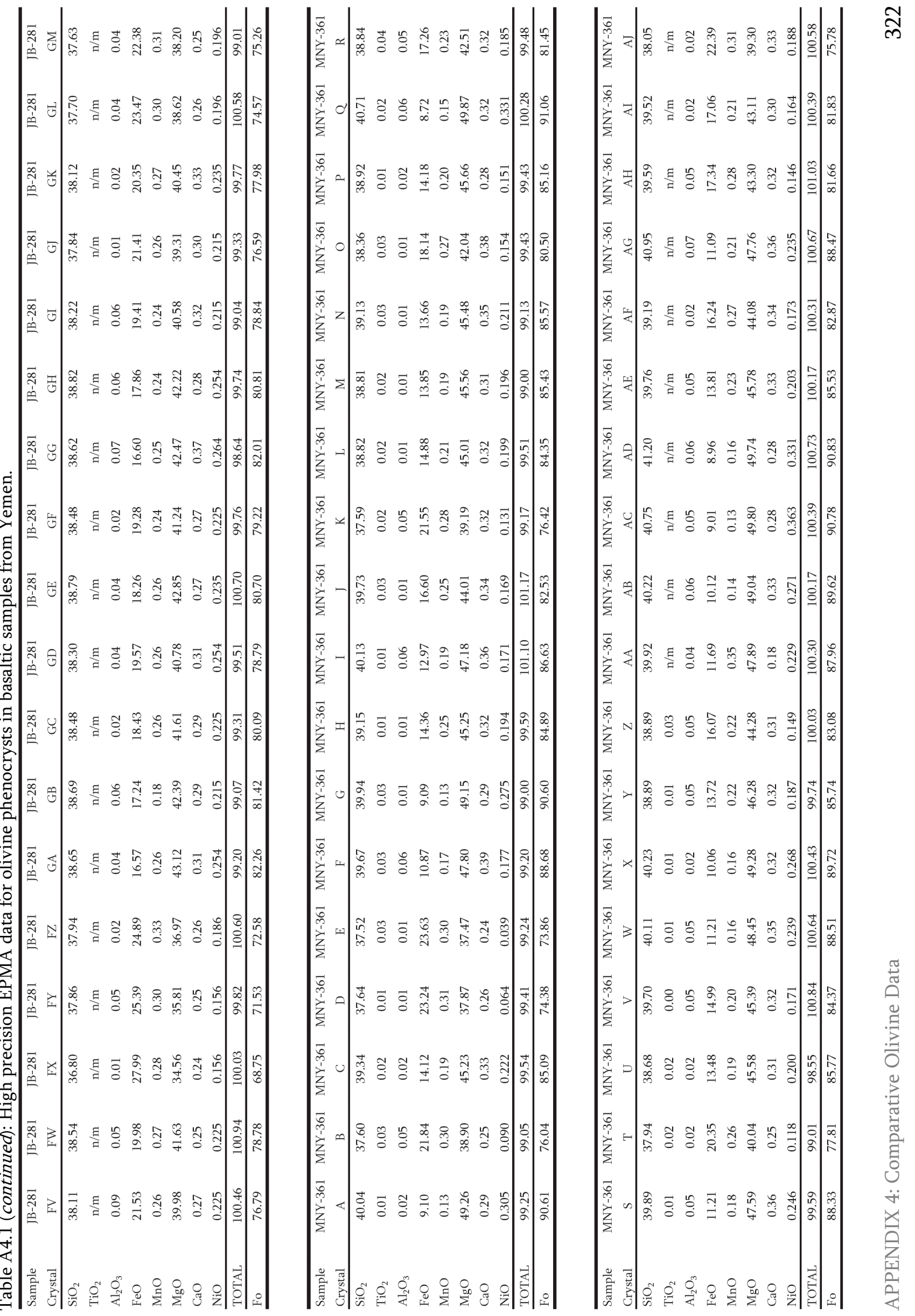




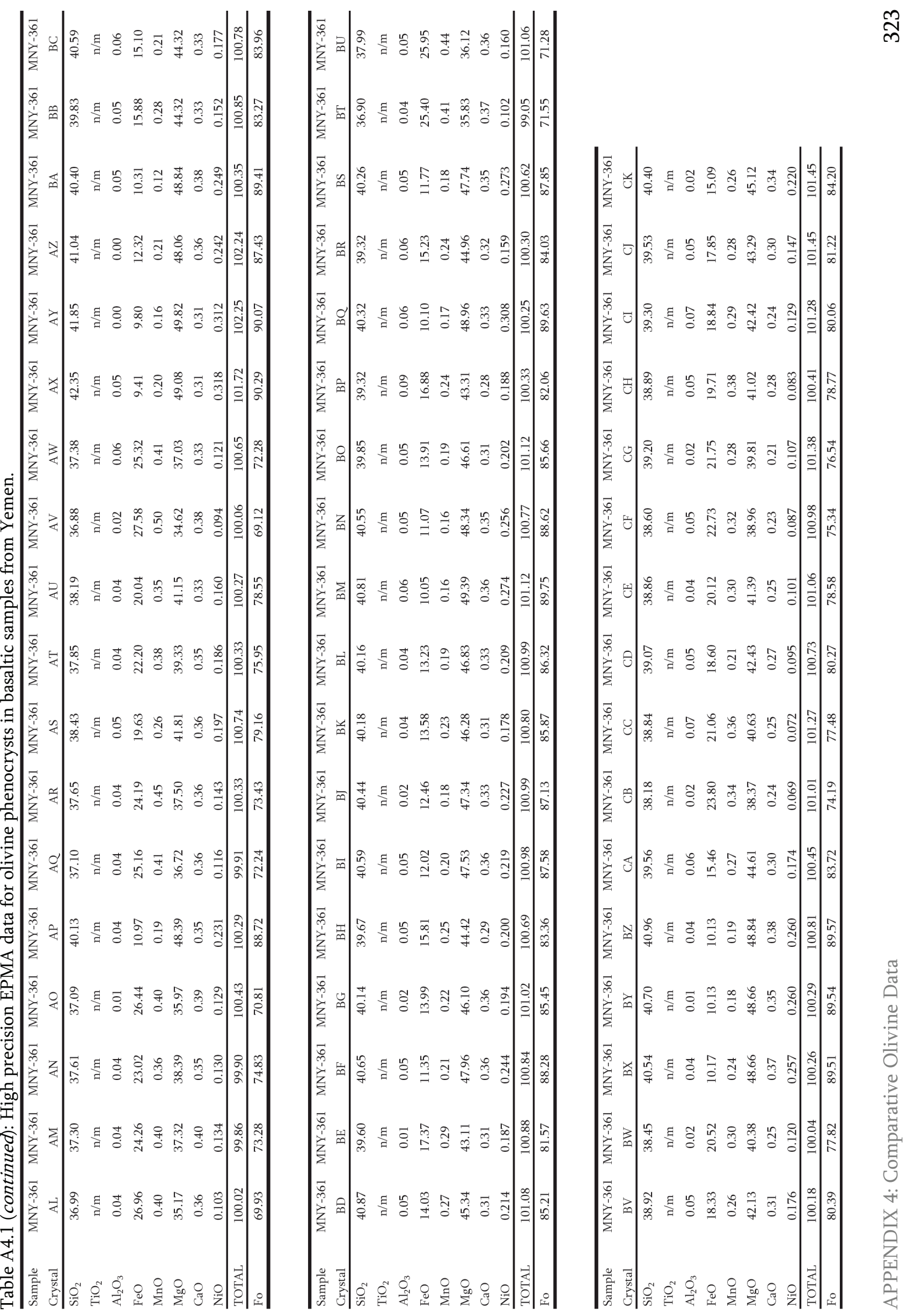




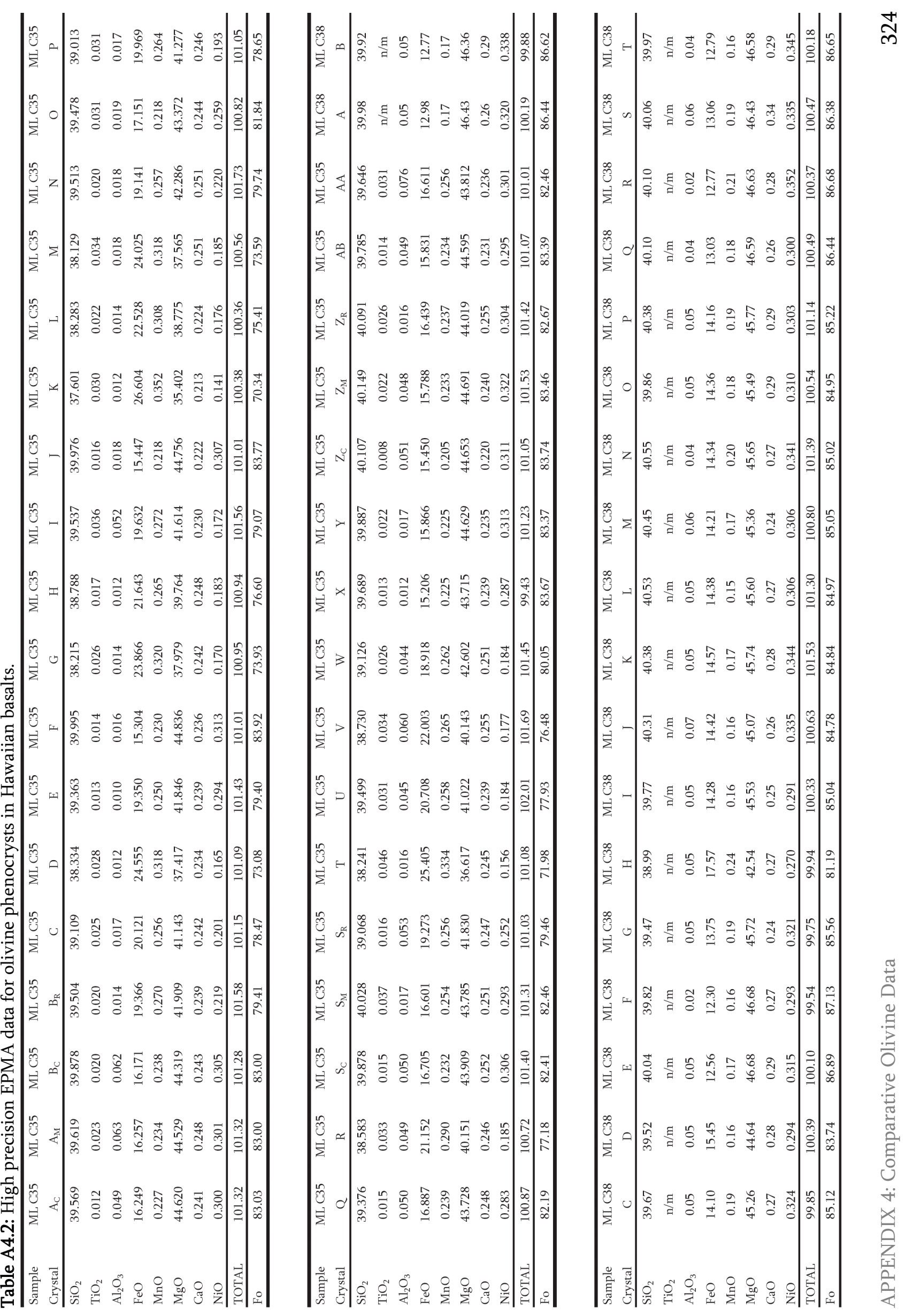




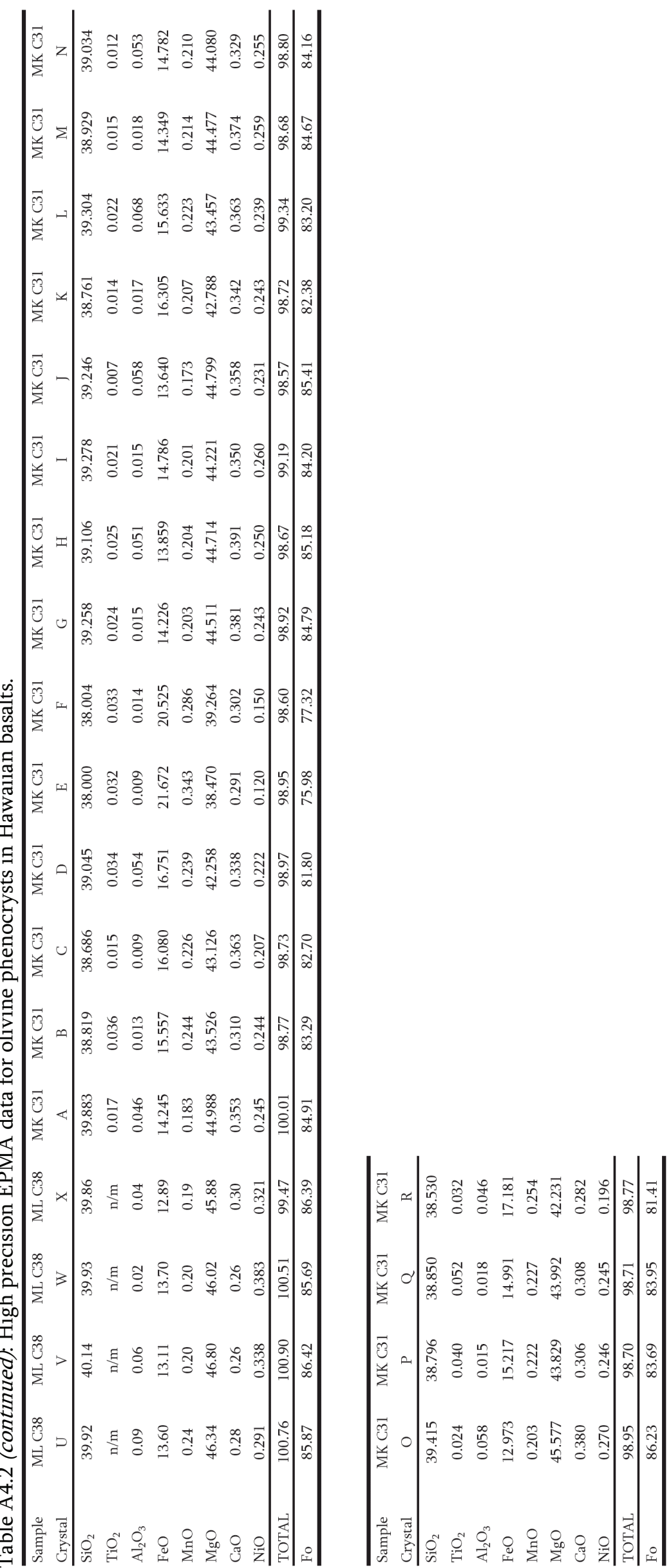




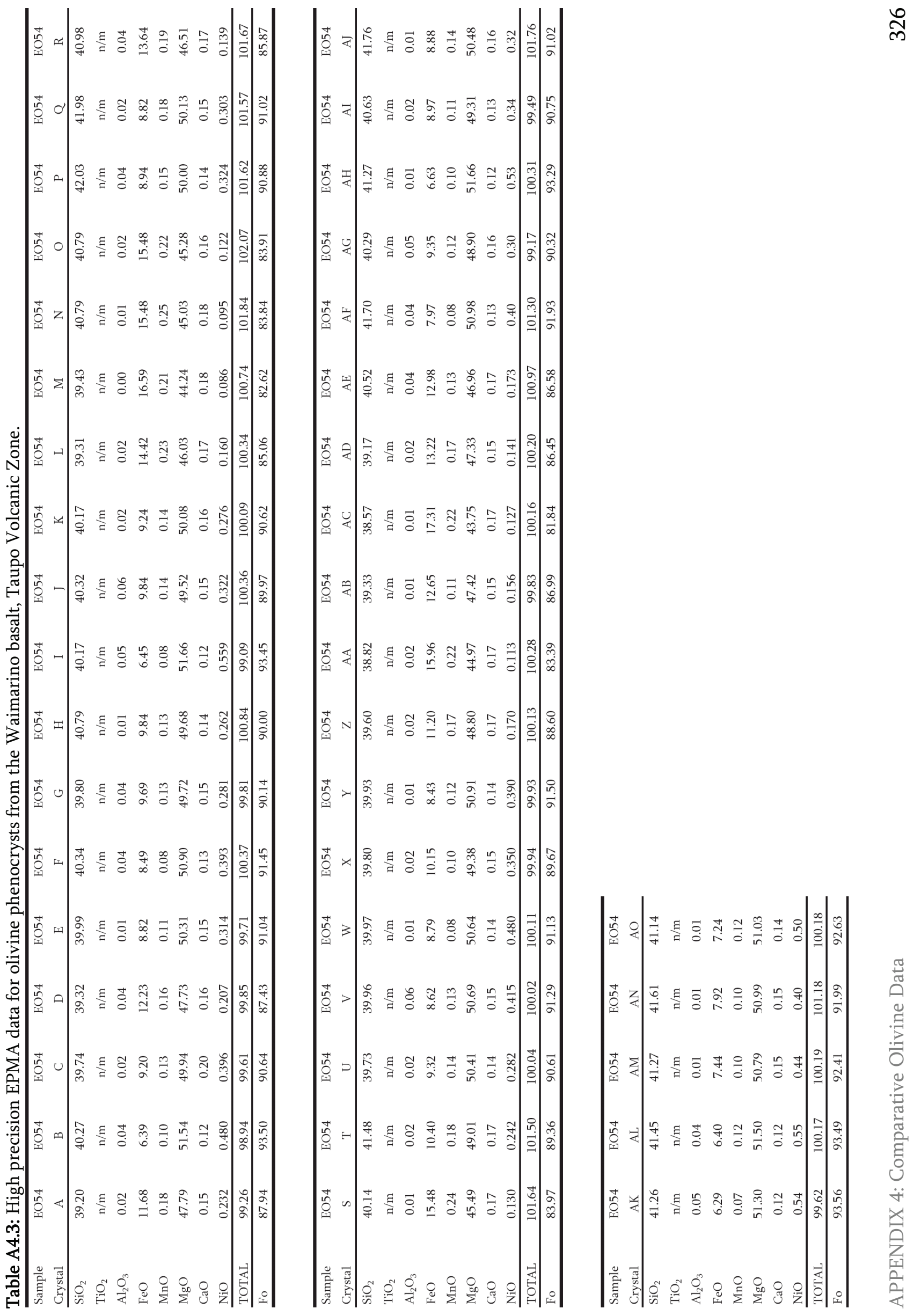




\section{APPENDIX 5: \\ CHEMICAL \& ISOTOPIC DATA}

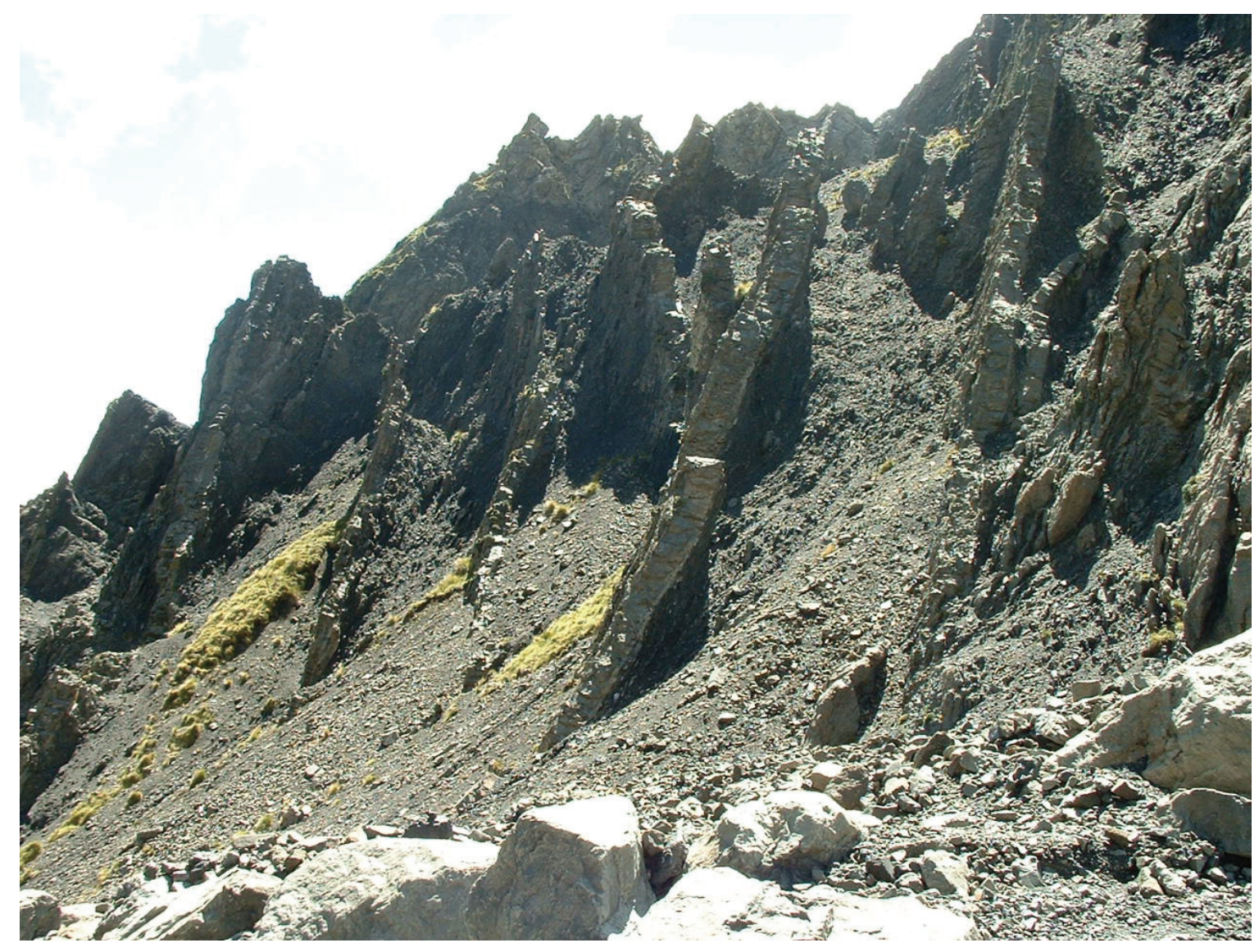

Plate 12: Basement greywacke intensively intruded by dykes of the regional swarm in the headwaters of Totara Stream, just below the summit of Mount Gladstone.

Table A5.1: X-ray fluorescence major element data (53 samples)

Table A5.2: Solution ICP-MS trace element data (35 samples)

Table A5.3: Sr-Nd-Hf-Pb whole rock isotopic data (26 samples)

Table A5.4: Mineral Sr-Nd-O isotope data (6 samples)

Table A5.5: Clinopyroxene LA-ICP-MS data (7 samples; 101 analyses) 


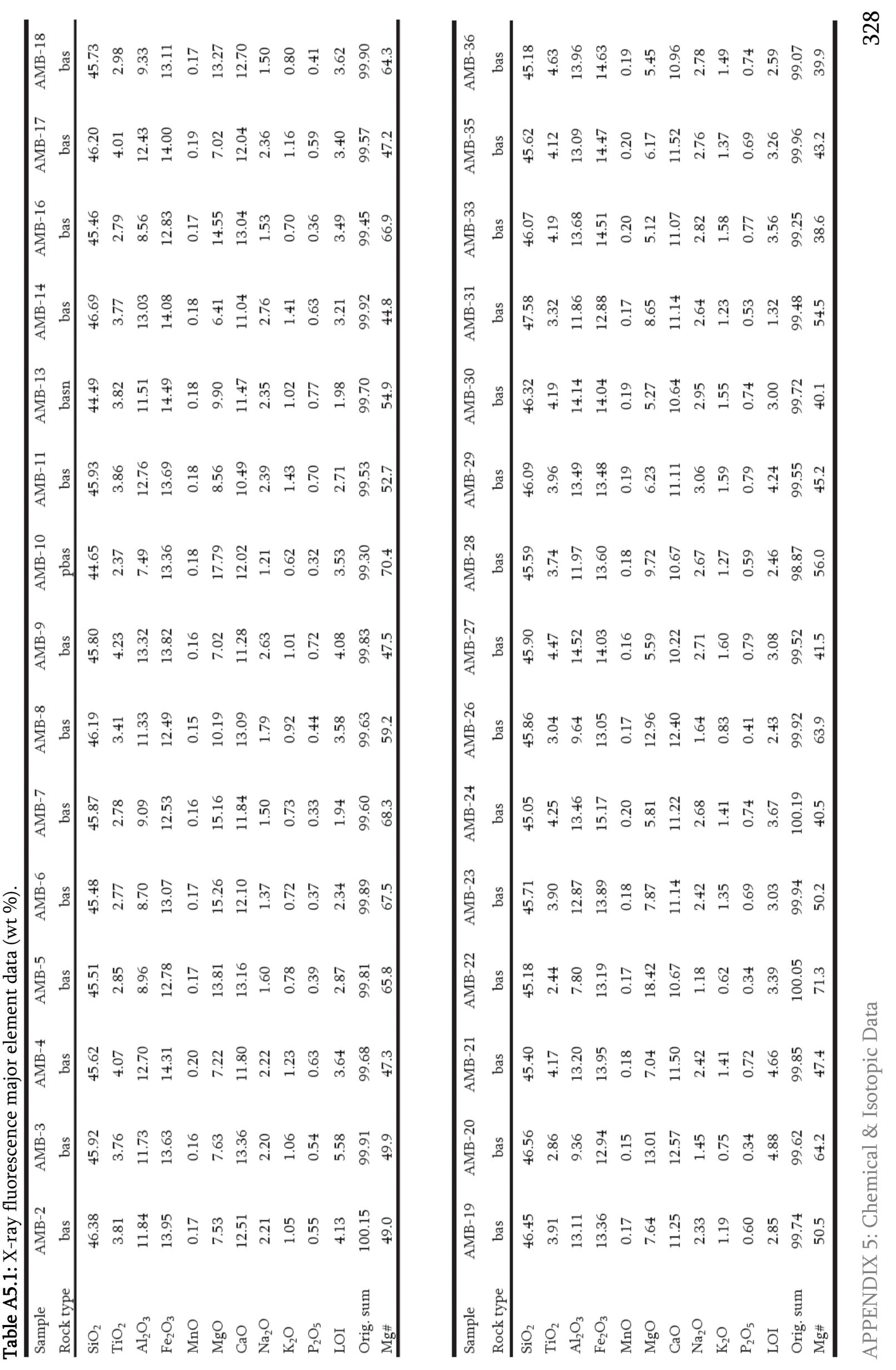




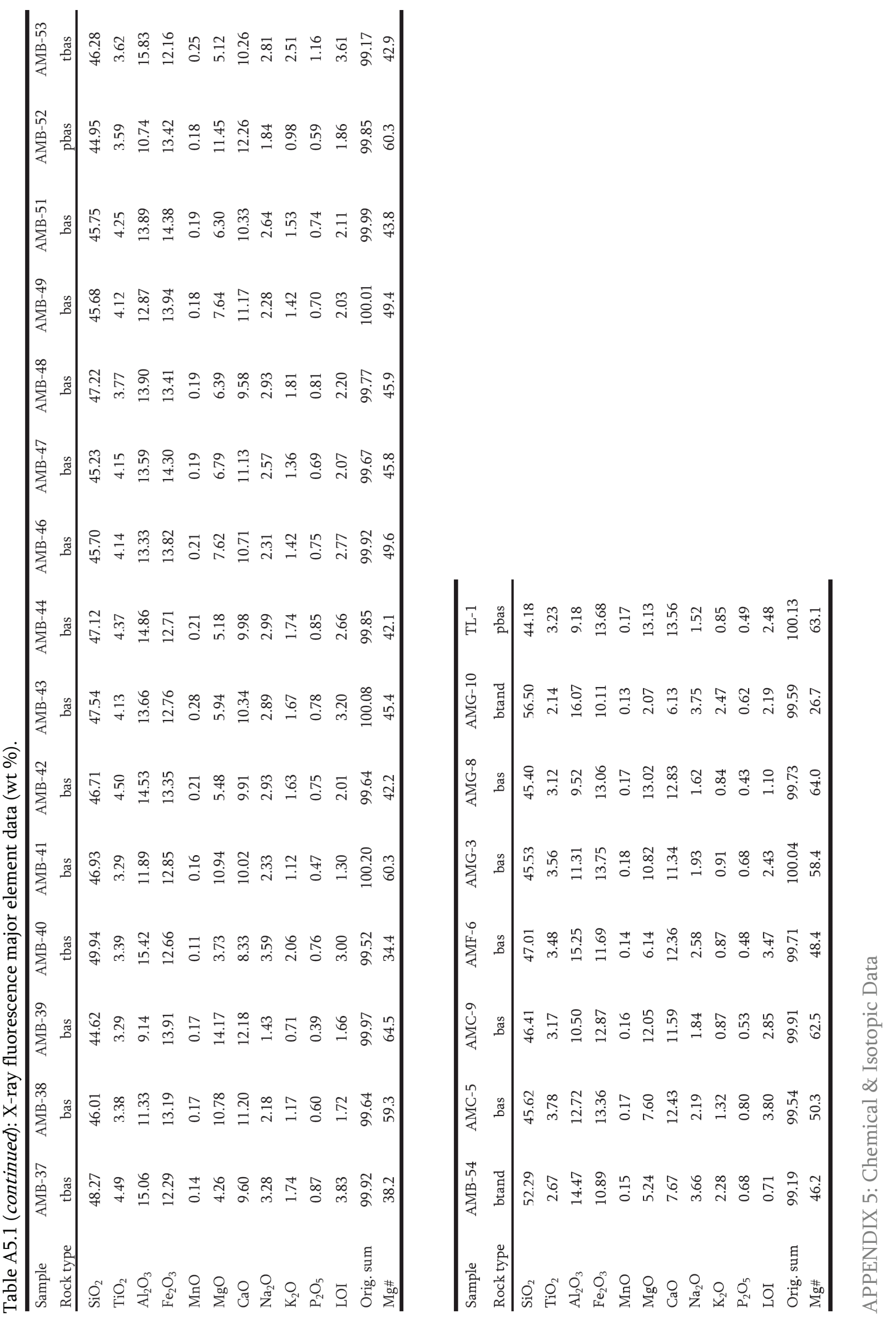




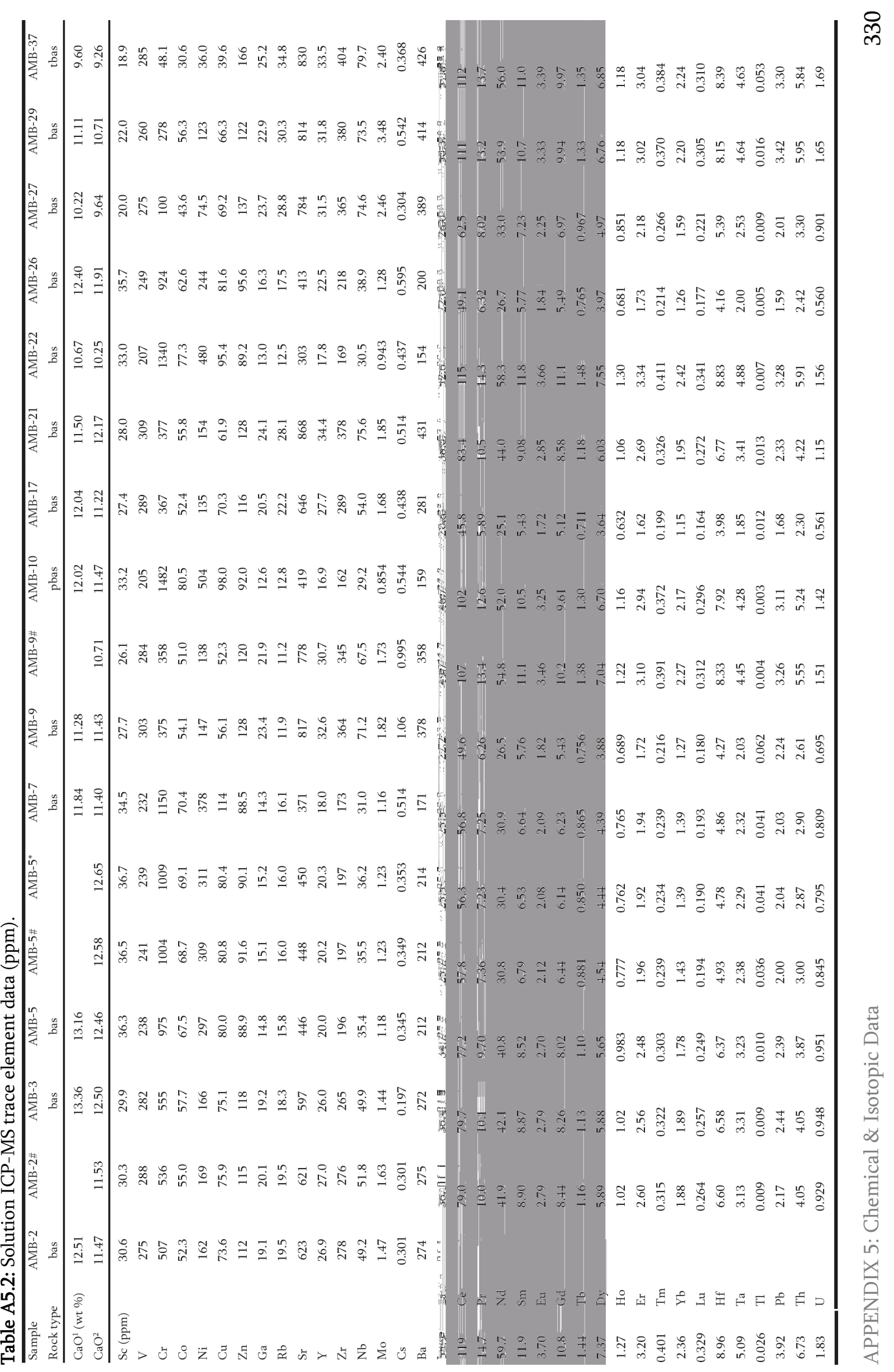




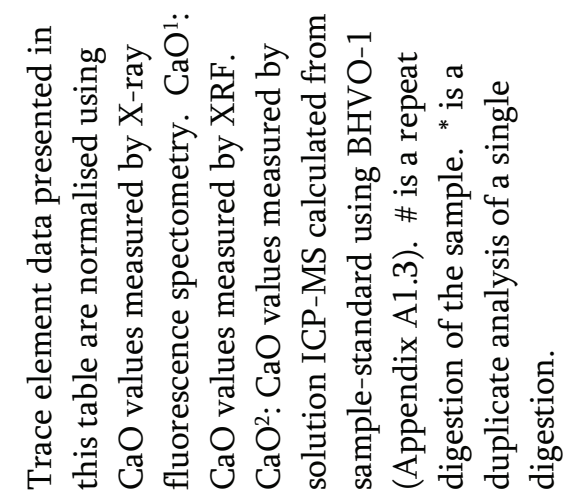

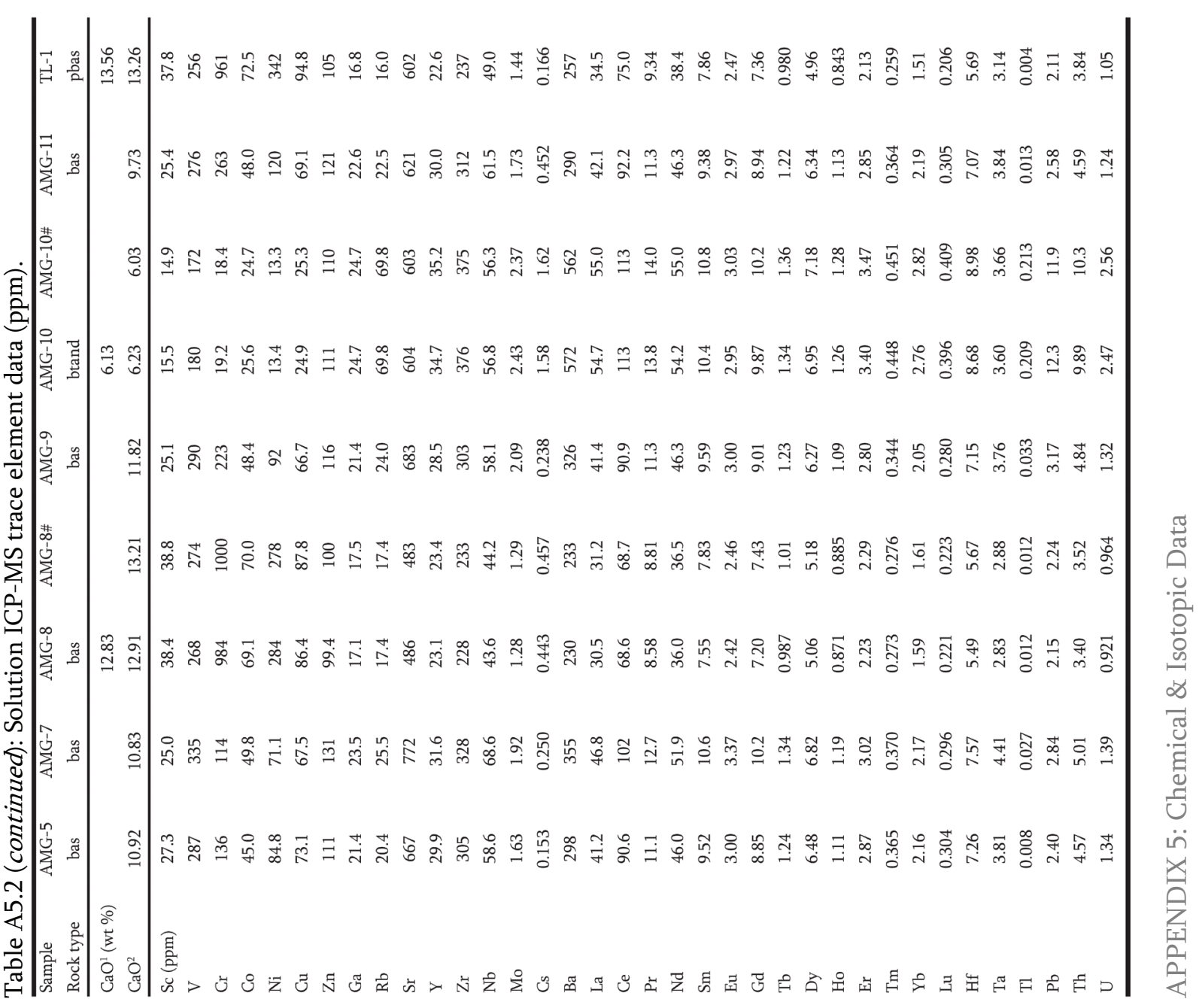




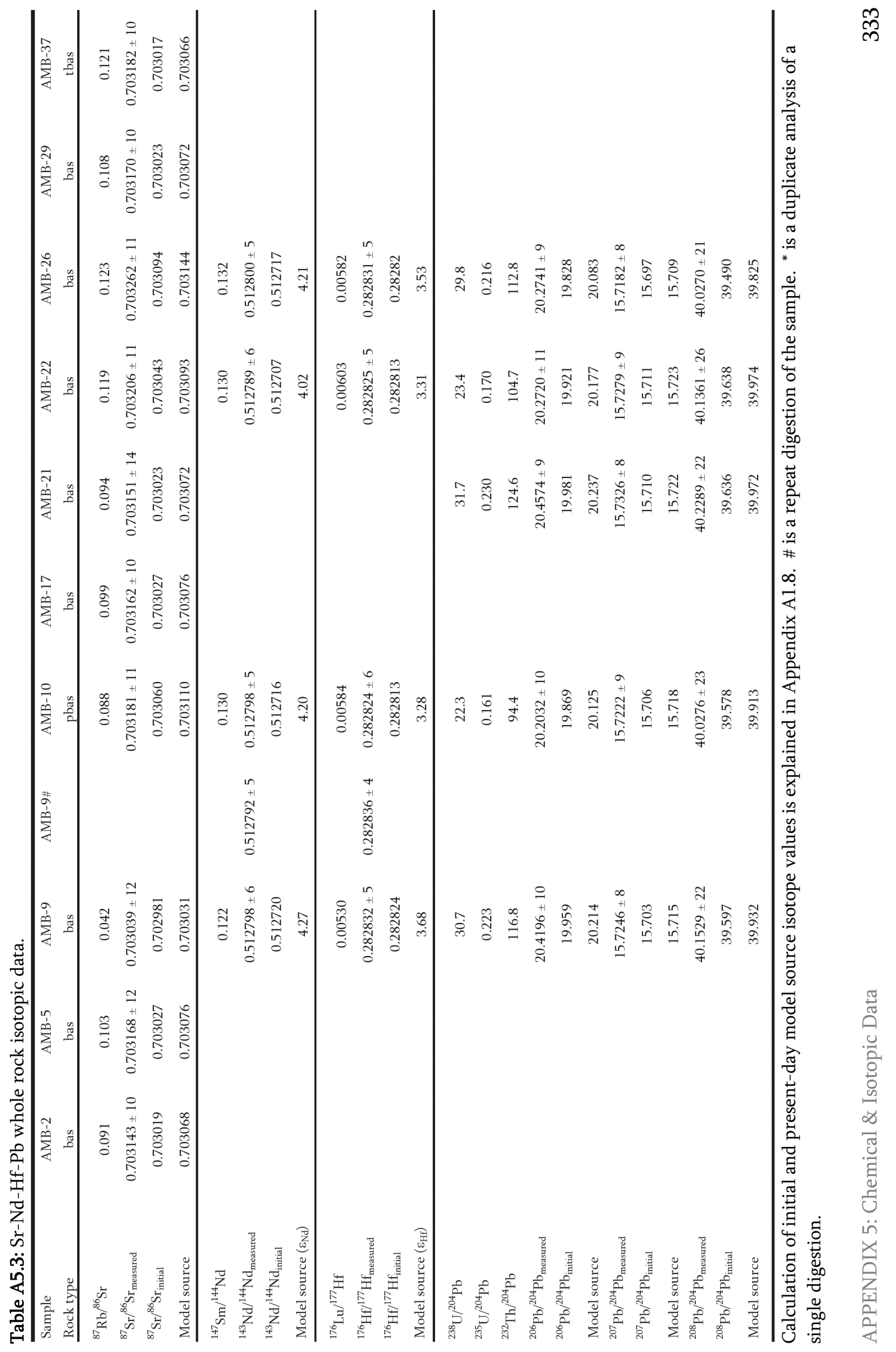




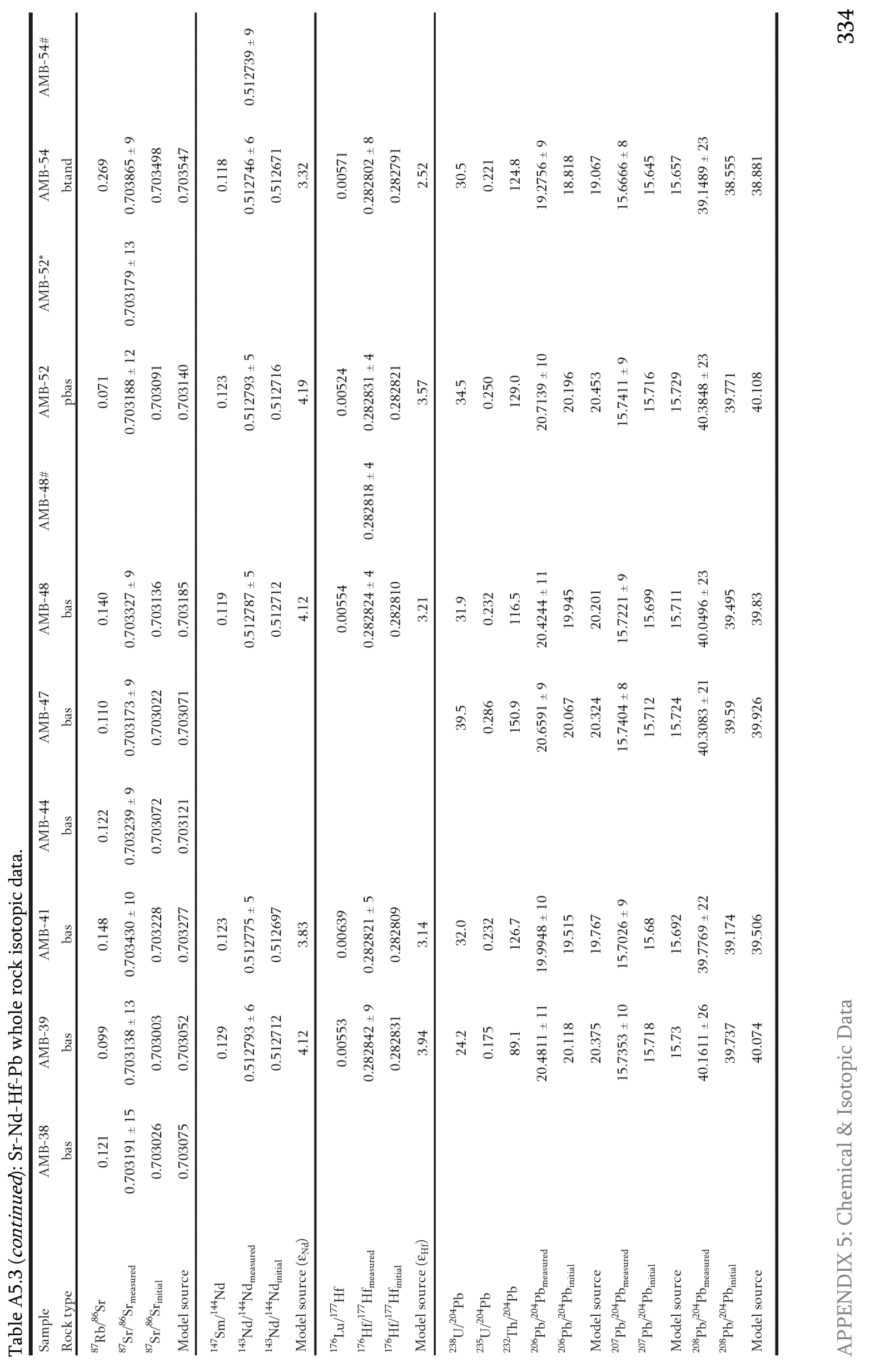




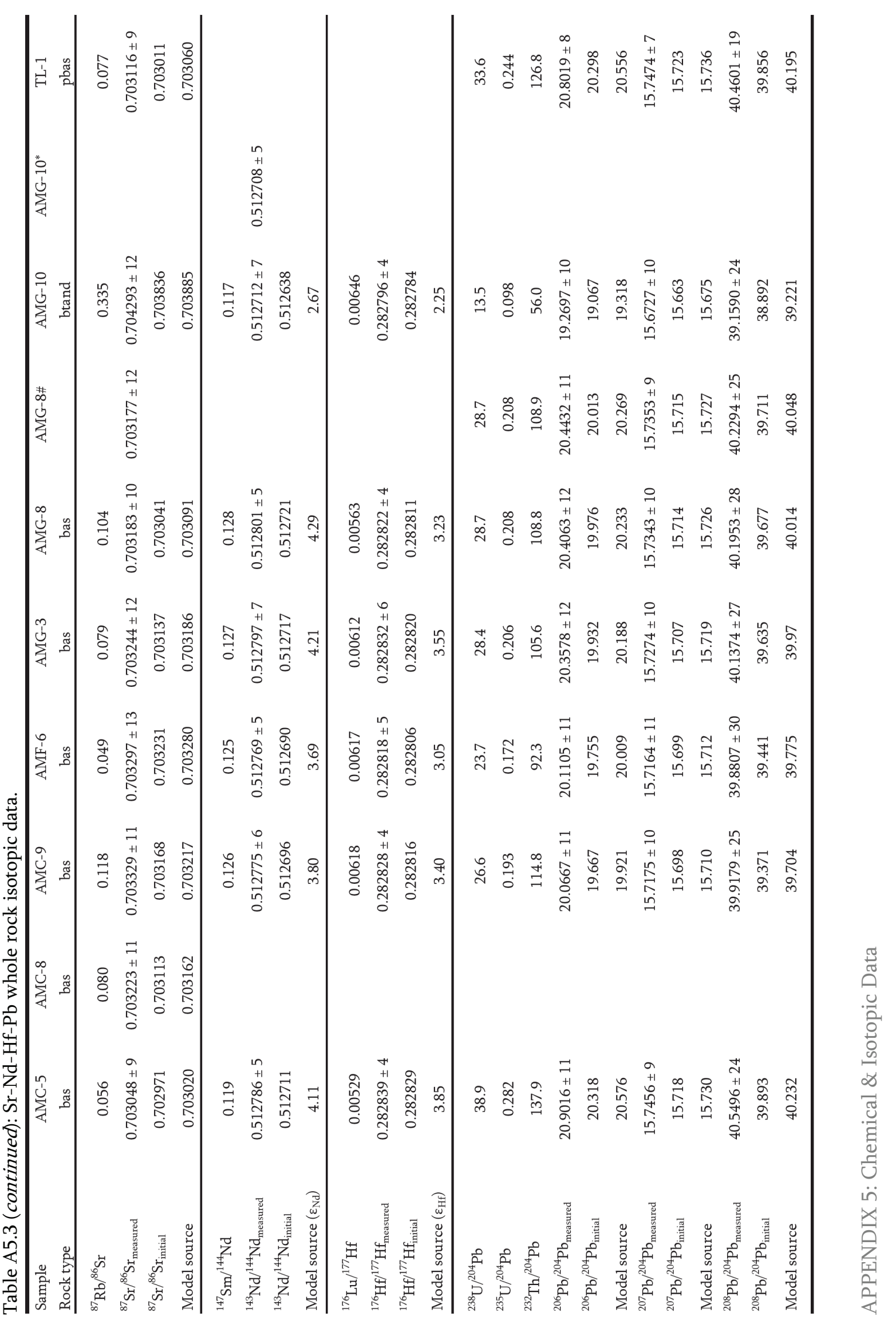


Table A5.4: Mineral Sr-Nd-O isotope data.

\begin{tabular}{|c|c|c|c|c|c|c|}
\hline Sample & Mineral & $\delta^{18} \mathrm{O}(\% 0)$ & ${ }^{87} \mathrm{Rb} /{ }^{86} \mathrm{Sr}$ & ${ }^{87} \mathrm{Sr} /{ }^{86} \mathrm{Sr}$ & ${ }^{147} \mathrm{Sm} /{ }^{144} \mathrm{Nd}$ & ${ }^{143} \mathrm{Nd} /{ }^{144} \mathrm{Nd}$ \\
\hline \multirow[t]{5}{*}{ AMB-39 } & green cpx & 4.78 & 0.0003 & $0.703021 \pm 12$ & 0.1735 & $0.512838 \pm 12$ \\
\hline & brown cpx & 4.80 & 0.0009 & $0.703047 \pm 10$ & 0.1818 & $0.512831 \pm 11$ \\
\hline & brown cpx\# & & & $0.703092 \pm 8$ & & \\
\hline & olivine & 4.78 & & & & \\
\hline & olivine\# & 4.78 & & & & \\
\hline \multirow[t]{3}{*}{ AMB-54 } & green cpx & 5.38 & 0.0004 & $0.703240 \pm 14$ & & \\
\hline & brown cpx & 4.91 & 0.0012 & $0.703532 \pm 10$ & & \\
\hline & plagioclase & 7.74 & & $0.703522 \pm 19$ & & \\
\hline \multirow[t]{3}{*}{ AMC-5 } & green cpx & 5.05 & 0.0003 & $0.703022 \pm 14$ & & \\
\hline & brown cpx & 4.45 & 0.0006 & $0.703026 \pm 9$ & & \\
\hline & brown cpx\# & 4.30 & & & & \\
\hline \multirow[t]{3}{*}{ AMC-9 } & green cpx & 5.00 & 0.0003 & $0.703013 \pm 9$ & & \\
\hline & brown cpx & 5.30 & 0.0029 & $0.703129 \pm 9$ & & \\
\hline & olivine & 4.86 & & & & \\
\hline \multirow[t]{5}{*}{ AMG-8 } & green cpx & 5.29 & 0.0005 & $0.703007 \pm 13$ & & \\
\hline & brown cpx & 3.93 & 0.0023 & $0.703022 \pm 9$ & & \\
\hline & olivine & 4.78 & & & & \\
\hline & olivine\# & 4.72 & & & & \\
\hline & olivine\# & 4.97 & & & & \\
\hline \multirow[t]{2}{*}{ AMG-10 } & brown cpx & 5.47 & 0.0069 & $0.703839 \pm 8$ & 0.1929 & $0.512775 \pm 10$ \\
\hline & plagioclase & 22.2 & & $0.703522 \pm 19$ & & \\
\hline
\end{tabular}

Note: The $\delta^{18} \mathrm{O}$ value measured on plagioclase from AMG-10 is considered erroneous due to a significant proportion of calcite within the mineral separate. \# is a repeat digestion. 
